FLÁVIA ULIAN

\title{
Sistemas de Transportes Terrestres de Passageiros em Tempos de Reestruturação Produtiva na Região Metropolitana de São Paulo
}

Tese apresentada ao Departamento de Geografia da Faculdade de Filosofia, Letras e Ciências Humanas da Universidade de São Paulo para obtenção do título de Doutor em Geografia.

Área de Concentração: Geografia Humana Orientador: Prof. Dr. Francisco Capuano Scarlato 
AUTORIZO A REPRODUÇÃO E DIVULGAÇÃO TOTAL OU PARCIAL DESTE TRABALHO, POR QUALQUER MEIO CONVENCIONAL OU ELETRÔNICO, PARA FINS DE ESTUDO E PESQUISA, DESDE QUE CITADA A FONTE.

\section{Catalogação da Publicação}

Faculdade de Filosofia, Letras e Ciências Humanas

Ulian, Flávia.

Sistemas de transportes terrestres de passageiros em tempos de reestruturação produtiva na Região Metropolitana de São Paulo / Flávia Ulian; orientador Francisco Capuano Scarlato. São Paulo, 2008. 320pp.

Tese (Doutorado - Programa de Pós-Graduação em Geografia Humana. Área de Concentração: Geografia Urbana) - Faculdade de Filosofia, Letras e Ciências Humanas da Universidade de São Paulo.

1. Transporte urbano. 2. Reestruturação produtiva. 3. Metrópole. 4. Circulação. 5. São Paulo. 


\section{FOLHA DE APROVAÇÃ̃O}

\section{Flávia Ulian}

Sistemas de transportes terrestres de passageiros em tempos de reestruturação produtiva na Região Metropolitana de São Paulo.

Tese apresentada ao Departamento de Geografia da Faculdade de Filosofia, Letras e Ciências Humanas da Universidade de São Paulo para obtenção do título de Doutor em Geografia.

Aprovada em:

\section{Banca Examinadora}

Prof. Dr.

Instituição:

Assinatura:

Prof. Dr.

Instituição:

Assinatura:

Prof. Dr.

Instituição:

Assinatura:

Prof. Dr.

Instituição:

Assinatura:

Prof. Dr.

Instituição:

Assinatura: 


\section{DEDICATÓRIA}

A todos os cidadãos que circulam incansavelmente pela Metrópole Paulistana. 


\section{AGRADECIMENTOS}

Ao meu orientador, Prof. Dr. Francisco Capuano Scarlato, por confiar tanto em mim e me transmitir segurança e autoconfiança. Por acreditar em mim e me ensinar a pesquisar.

À minha mãe Gilda Beltramelli Ulian, pelo exemplo acadêmico e pelo amor ao trabalho.

Ao meu pai Sérgio Ulian, que sempre me incentivou e interessou-se pelo andamento da pesquisa.

Ao meu companheiro Flávio Macedo, porque soube compreender o quanto esta pesquisa era importante para mim, me incentivando nos momentos de cansaço com muito amor.

À minha filha Déborah Ulian Mendes, por compreender minha ausência em tantos passeios e adiamento de viagens tão sonhadas.

À minha irmã Paula, às sobrinhas Marina e Fernanda, ao cunhado Tércio, à minha tia Irene Cipparullo e tantos outros que amo e sempre me apoiaram.

Aos meus sogros Luíza e Geraldo e toda a família, por compreenderem minha ausência nos encontros familiares.

A Isabel Alvarez, Cecília Almeida, Thaís Benfatti, Rosalia, Cíntia Michelini, Ana Cláudia Mendes, Raul Arraigada, Juliana Rodrigues, Lina Mendes e a todas as minhas amigas e amigos aqui não nomeados, porém lembrados, pelo interesse, amizade e dicas.

Ao meu primo André Luis de Paula e à equipe da Atera que sempre me socorreram no desvairado mundo da informática.

À Emília Hiroi - Cia. do Metropolitano de São Paulo, responsável pela Coordenação da Pesquisa O-D; ao Gerson Faria - Cia. Paulista de Trens Metropolitanos, Departamento de Marketing; ao Eng. Luciano Ferreira Luz - Cia. Paulista de Trens Metropolitanos, Departamento de Planejamento; à Érica Brandão - Assessoria de Imprensa da Metra; ao Claudinei Pereira- Vice-Secretário da Secretaria Municipal de Trânsito e Transportes de Taboão da Serra, meus sinceros agradecimentos pelas valiosas informações que vieram engrandecer esta pesquisa.

Ao meu aluno Osvaldo Bruno Meca pelas incríveis fotografias no sistema do Metrô.

A todos que me concederam entrevistas.

Aos professores do Departamento de Geografia da FFLCH-USP, em especial a Glória Anunciação Alves e Mônica Arroyo, pela leitura do Relatório de Qualificação e pela orientação; Amália Inês Geraiges Lemos e Mario de Biasi, pelas conversas que muito me orientaram na conclusão da Tese; e a todos meus mestres que me acompanharam desde meu ingresso nesta Faculdade.

Aos funcionários do Departamento de Geografia, em especial, à Ana e Orlando, pelo constante incentivo e confiança. 
“As várias iniqüidades referentes às condições de transporte e trânsito nos países em desenvolvimento podem ser atribuídas a muitos fatores, ligados ao processo de desenvolvimento social, político e econômico destes países, bem como às políticas urbanas e de transporte adotadas. Dentre estes fatores, dois se destacam: a adaptação do espaço para o automóvel e a adoção do enfoque de mercado para o sistema de transporte público."

Eduardo A. Vasconcellos 


\section{RESUMO}

ULIAN, Flávia. Sistemas de transportes terrestres de passageiros em tempos de reestruturação produtiva na Região Metropolitana de São Paulo. Tese (Doutorado) - Departamento de Geografia, Faculdade de Filosofia, Letras e Ciências Humanas da Universidade de São Paulo. Orientador: Prof. Dr. Francisco Capuano Scarlato. São Paulo, 2008. 314 pp.

Esta Tese foi formulada buscando responder a uma problemática central: a reestruturação produtiva induz a uma redefinição do sistema de transportes terrestres, tanto no que se refere à infra-estrutura quanto aos deslocamentos realizados por passageiros. $\mathrm{O}$ objetivo geral desta pesquisa é o estudo da configuração da rede de transporte e dos ritmos dos fluxos urbanos na Região Metropolitana de São Paulo (RMSP), observando que a reengenharia da produção a partir da década de 1990 alterou os fluxos e provocou novas demandas por transportes, configurando novos arranjos espaciais na metrópole.

Sob a linha metodológica de análise da realidade pautada sobre os fenômenos empíricos, de dados estatísticos e conhecimento teórico dos fatos que ocorrem na RMSP, no que tange às suas atividades econômicas, utilizamo-nos das quatro categorias do método geográfico de análise do espaço: forma, função, estrutura e processo. A pesquisa nos proporcionou, através do estudo das infra-estruturas de transporte ferroviário, metroviário e rodoviário, o conhecimento da forma. A análise dos fluxos realizados nos proporcionou o entendimento da função. As políticas que determinam a infra-estrutura viária e influem na qualidade dos fluxos de passageiros compuseram a dimensão da categoria de análise estrutura, fundamental para que pudéssemos fazer a crítica ao sistema de transporte de passageiros da RMSP. O processo histórico permeou toda a pesquisa. À luz da subjetividade expressa nas entrevistas que realizamos, foi possível construir uma nova visão de nosso problema de pesquisa. Fazendo uso dessas categorias analíticas, procuramos compreender a nova organização do espaço metropolitano sob o viés das infra-estruturas de transporte e dos deslocamentos dos passageiros.

A reestruturação produtiva significou nada mais do que a incorporação de novas técnicas ao trabalho e à gerência, que engendraram alterações na organização do espaço. Em tempos de reestruturação produtiva, verificamos a diminuição das atividades industriais e o crescimento de novas modalidades de serviços. Isto significa que, com a terceirização de tantas atividades que, em tempos fordistas, se concentravam na fábrica, multiplicaram-se as empresas prestadoras de serviços produtivos. Além disto, muitos outros serviços distributivos e sociais aumentaram e se disseminaram pelo espaço urbano.

Através do estudo das vias férreas, metroviárias e rodoviárias, das modalidades de transporte que circulam por estas vias na RMSP, e ainda dos deslocamentos de passageiros, concluímos que desde a origem da estruturação da metrópole paulistana, a mobilidade e a acessibilidade foram ao mesmo tempo princípios e resultantes do processo de metropolização, fato que pode ser verificado pelo estudo histórico da relação entre a expansão da mancha urbana e a estrutura viária. Tendo importante participação em todas as etapas do processo de estruturação da metrópole, a mobilidade teve um papel indutor tanto no início da metropolização quanto no atual período, quando a RMSP passa por intensas transformações decorrentes do processo de reestruturação da produção.

Os resultados de nossa pesquisa nos fizeram concluir que, notadamente em meados dos anos 1990, os sistemas de transportes metropolitanos iniciaram um processo de reorganização e modernização, acelerados nos anos 2000. A Tese apresenta dados que demonstram que a redefinição do padrão produtivo também redefiniu o padrão da circulação de passageiros na RMSP.

Palavras-chave: Transporte urbano. Reestruturação produtiva. Metrópole. Circulação. São Paulo. 


\begin{abstract}
ULIAN, Flávia. Terrestrial Passengers Transport System in Productive Restructuration times in São Paulo Metropolitan Area. Thesis (Doctoral) - Departamento de Geografia, Faculdade de Filosofia, Letras e Ciências Humanas da Universidade de São Paulo. Orientador: Prof. Dr. Francisco Capuano Scarlato. São Paulo, 2008. 314 pp.
\end{abstract}

This Thesis was formulated trying to answer to a central problem: the productive restructuration leads on a redefinition of the terrestrial transport system, concerning the infrastructure and the passengers' displacements. The research general objective is the study of the shape transport network and the urban fluxes rhythmic in São Paulo Metropolitan Area, observing that the production reengineering after 1990 changed the fluxes and stimulated new transport demands, configuring new metropolis spatial arrangements.

Under the methodological line of the reality analysis based on the empirical phenomena, statistical data and theoretical knowledge of the facts that occur in São Paulo Metropolitan Area, concerning to its economic activities, we use the four categories of the geographic analysis of the space method: form, function, structure and process. The research that we realized supplied, through the rail, underground and road infra-structure study, the knowledge of the form. The fluxes analysis supplied the function understanding. The politics that define the infra-structure and influence the passengers' fluxes quality made up the analysis category of the structure, important to the passengers' transport system critic that we have done. The historical process interposed all the research. The subjectivity expressed on the interviews we realized made a new vision of our research problem possible. Using the four analysis categories, we tried to understand a new metropolitan space organization under the obliquity of the transport infra-structure and the passengers' displacements.

The productive restructuration meant more than new techniques incorporation to labor and management, which expressed spatial organization changes. In productive restructuration times, we noticed a minimization of the industrial activities and the growth of some other services modalities. This means that, with so many activities that were transferred to a third company, which in "Ford" period were concentrated in the plant, the rendering companies of productive services had been multiplied. Moreover, many other distributive and social services had increased and had spread through the urban area.

Through the study of the railway, subway and road, of the transport modalities that circulate in São Paulo Metropolitan Area, and still of the passengers' displacements, we conclude that since São Paulo metropolis structural origin, mobility and accessibility had been, at the same time, principles and resultants of the metropolis formation process, fact that can be verified by the historical study of the urban area expansion and the road structure. Mobility had an inductive paper at the beginning of the metropolis formation and in the current period, when São Paulo Metropolitan Area passes for intense transformations decurrently of the process of production reorganization, having important participation in all the stages of the process of metropolis structural organization.

The results of our research had shown that, in middle of years 1990, the metropolitan transport systems initiated a reorganization and modernization process, sped up in the 2000 . We believe that the redefinition of the productive standard also redefined the standard of the passengers' circulation in the São Paulo Metropolitan Area. 


\section{LISTA DE ILUSTRAÇÕES}

Figura 1 - Região Metropolitana de São Paulo - Sub-regiões e Municípios.................. 41

Figura 2 - Linhas de Trem da CPTM, Metro e Corredor Metropolitano da EMTU.... 127

Figura 3 - Plano da Linha Expresso Aeroporto/Trem de Guarulhos........................... 156

Figura 4 - Município de São Paulo - Mini-Anel Viário Metropolitano......................... 197

Figura 5 - Trajeto atual do Corredor Expresso Tiradentes.......................................... 210

Figura 6 - Rede de Corredores Metropolitanos EMTU - São Mateus - Jabaquara /

Diadema /Brooklin...................................................................................... 212

Figura 7 - Subsistema Estrutural e Subsistema Local do Sistema Interligado................ 231

Figura 8 - Município de São Paulo - Áreas de Divisão para Operação do Sistema

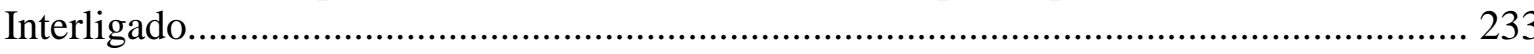

Mapa 1 - Região Metropolitana de São Paulo - Estrutura Viária de Acesso à RMSP...... 45

Mapa 2 - Região Metropolitana de São Paulo - Redes Ferroviária, Metroviária e de Corredores Metropolitanos de Ônibus......................................................................... 47

Mapa 3 - Região Metropolitana de São Paulo - Rede de Trens da CPTM........................ 126

Mapa 4 - Região Metropolitana de São Paulo - Rede de Linhas de Metrô....................... 164

Mapa 5 - Região Metropolitana de São Paulo - Densidade Populacional e de Empregos em 1997

Mapa 6 - Região Metropolitana de São Paulo - Rodoanel

Fotografia 1 - Município de Carapicuíba - Encostas cobertas de casas. .52

Fotografia 2 - Município de Diadema - Corredor Metropolitano São MateusJabaquara.....

Fotografia 3 - Município de Biritiba-Mirim................................................................ 57

Fotografia 4 - Estação de trem do Município de Mogi das Cruzes................................... 57

Fotografia 5 - Centro do município de Mogi das Cruzes.....................................................58

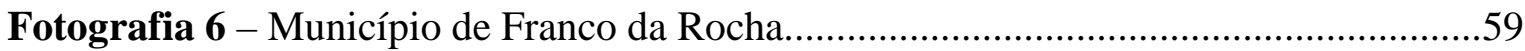

Fotografia 7 - Município de Taboão da Serra - Rodovia Régis Bittencourt.......................62

Fotografia 8 - Município de Jandira - Colinas com casas autoconstruídas...................... 63

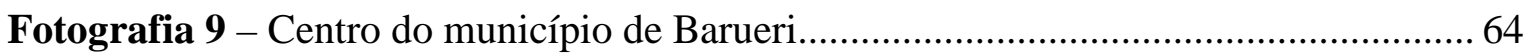

Fotografia 10 - Estação de trem metropolitano do município de Osasco...........................65 
Fotografia 11 - Município de Osasco - Ponto de ônibus intermunicipais, onde ambulante vende passes de ônibus.

Fotografia 12- Município de São Paulo - Terminal Jabaquara.

Fotografia 13 - Município de São Paulo - Ponto de ônibus no entorno da Estação de Metrô Clínicas (Linha 2 - Verde), onde há concentração de linhas intermunicipais para diversos municípios do arco sul-sudoeste-oeste da RMSP.

Fotografia 14 - Município de São Paulo - Estação Berrini (Linha C da CPTM) - ao fundo,

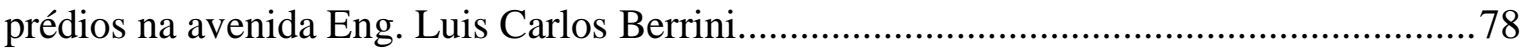

Fotografias 15 e 16 - Município de Francisco Morato - Ambulantes na avenida Gerônimo da Veiga.

Fotografias 17 - 18 - Município de Franco da Rocha - Jardim Montreal.

Fotografia 19 - Município de São Paulo - Plataforma da Estação Brás.

Fotografia 20 - Município de Franco da Rocha - Trem passa paralelo à avenida Dr. Mário Seltin.

Fotografia 21 - Município de Caieiras - Estação de Trem da CPTM.....

Fotografia 22 - Município de Caieiras - Estacionamento para bicicletas junto à Estação Caieiras

Fotografia 23 - Município de São Paulo - Terminal de Trem, Metrô e Ônibus da Barra Funda.

Fotografias 24 e 25 - Sequiência de desembarque na Estação da Luz em horário fora do pico.

Fotografia 26 - Interior de trem francês que trafega na Linha B.

Fotografias 27 e 28 - Embarque em trem da CPTM - A condições gerais do transporte permaneceram precárias, inseguras e desconfortáveis para os usuários durante todas estas décadas.

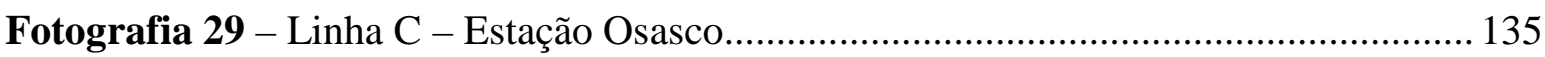

Fotografia 30 - Linha C - Estação Santo Amaro.......................................................... 135

Fotografia 31 - Linha C - Vista da Estação Socorro.................................................... 135

Fotografia 32 - Linha C - Estação Vila Olímpia.........................................................135

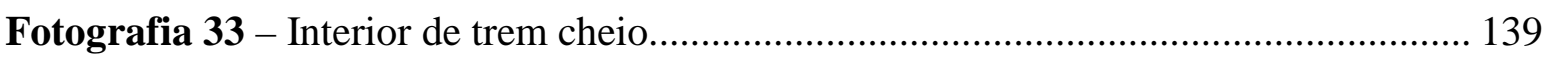

Fotografias 34 e 35 - No entorno da estação Mogi das Cruzes, observamos que o trânsito pára para o trem passar e os seguranças da CPTM impedem a entrada de transeuntes na estação pela linha, que é no nível da rua...

Fotografias 36 - 37 - Linha F - Estação Itaquaquecetuba............................................ 142

Fotografias 38 e 39 - Linha F - Estação Calmon Viana................................................142

Fotografia 40 - Linha 1 - Azul - Plataforma da Estação Paraíso..................................... 159

Fotografias 41 - 42 - 43 - Seqüência de imagens retratando a chegada do metrô da Linha 3 - Vermelha na Plataforma da Estação Sé. O jovem de blusa azul demonstra cansaço

Fotografia 44 - Linha 2 - Verde - Plataforma da Estação Alto do Ipiranga. 
Fotografia 45 - A Estação Santo Amaro fica suspensa em uma ponte sobre o rio Pinheiros.

Fotografia 46 - Linha 5 - Lilás - Plataforma da Estação Santo Amaro. 163

Fotografia 47 - Ponto de Parada da Ponte Orca na Estação Cidade Universitária, da Linha C da CPTM.

Fotografias 48 - 49 - 50 - 51 - 52 - Linha 3 - Vermelha - Embarque na Plataforma da Estação Barra Funda

Fotografia 53 - Município de São Paulo - Antiga indústria abandonada, às margens de ferrovia. 180

Fotografia 54 - Município de São Paulo - Ponte Estaiada Octavio Frias. 202

Fotografias 55 e 56 - Município de São Paulo - Trechos do Expresso Tiradentes 211

Fotografia 57 - Município de Diadema - Terminal Diadema. .213

Fotografia 58 - Município de São Bernardo do Campo - Terminal Ferrazópolis. 213

Fotografias 59 e 60 - Município de Diadema - Terminal Piraporinha. 213

Fotografia 61- Município de São Bernardo do Campo - Terminal Ferrazópolis 213

Fotografia 62 - Terminal São Bernardo. .213

Fotografia 63 - Município de Santo André Terminal Santo André Oeste - Vista

Geral. 214

Fotografia 64 - Terminal Santo André Oeste - Catracas localizam-se no subsolo. 214

Fotografia 65 - Trólebus da concessionária Metra 215

Fotografia 66 - Ônibus à diesel da Metra. 215

Fotografias 67 e 68 - Município de Itaquaquecetuba - Terminal urbano de ônibus no centro

Fotografia 69 - Município de São Paulo - Ônibus fretado e intermunicipal da EMTU disputam espaço na rua Teodoro Sampaio. 258

Fotografia 70 - Município de São Paulo - Ônibus fretados e automóveis disputam espaço na avenida Dr. Arnaldo.

Fotografia 71 - Município de São Paulo - Interior de ônibus novo a diesel da Viasul..... 278 


\section{LISTA DE TABELAS E QUADROS}

Tabela 1 - Região Metropolitana de São Paulo - Sub-Regiões e Municípios Área, Grau de Urbanização, População, Taxa Geométrica de Crescimento Anual (TGCA), Densidade Demográfica, PIB per capita, Participação no PIB Estadual e IDH............... 48

Tabela 2 - Estado de São Paulo - Participação das Regiões Paulistas no PIB Estadual2005.

Tabela 3 - Região Metropolitana de São Paulo - Viagens Diárias por Motivos - 1987 $-1997-2002$.

Tabela 4 - Região Metropolitana de São Paulo - Participação dos Empregos Ocupados segundo Setor de Atividade Econômica do Trabalho Principal (porcentagem).

Tabela 5 - Região Metropolitana de São Paulo - Viagens Diárias por Sub-Região em 1987-1997 e 2002 (em milhares e percentual)...

Tabela 6 - Região Metropolitana de São Paulo - Taxa de desemprego total, em anos escolhidos e em percentuais.

Tabela 7 - Região Metropolitana de São Paulo - Distribuição dos Ocupados, segundo Posição na Ocupação no Trabalho Principal - em anos escolhidos, em percentuais. 93

Tabela 8 - Região Metropolitana de São Paulo - Rendimento Médio Real dos Ocupados no Trabalho Principal, segundo Posição na Ocupação, em anos escolhidos.

Tabela 9 - Município de São Paulo - Rendimento Médio Real dos Ocupados no Trabalho Principal, segundo Posição na Ocupação, em anos escolhidos.

Tabela 10 - Região Metropolitana de São Paulo - Matriz de origem e destino de viagens diárias produzidas por sub-regiões -1997.

Tabela 11 - Região Metropolitana de São Paulo - Empregos por Sub-Região - 1987 $1997-2002$..

Tabela 12 - Região Metropolitana de São Paulo - Distribuição dos Ocupados, segundo Município onde Trabalha - em anos escolhidos e em percentuais.....

Tabela 13 - Região Metropolitana de São Paulo - Número de passageiros transportados no serviço de subúrbios (em milhares/dia).

Tabela 14 - PITU (Plano Integrado de Transportes Urbanos) - Investimentos realizados

e previstos $-1995-2025$.

Tabela 15 - Trens metropolitanos - Demanda atual e previsão de demanda após Implementação do Plano de Expansão 2007-2010 - em milhares/dia útil.

Tabela 16 - Município De São Paulo - Dados gerais do metrô - 2007.

Tabela 17 - Região Metropolitana de São Paulo - Número de passageiros transportados no serviço de Metrô (em milhares/dia).

Tabela 18 - Município de São Paulo - Evolução dos passageiros transportados pelo sistema de ônibus municipal - Anos escolhidos.

Tabela 19 - Região Metropolitana de São Paulo - Evolução das viagens motorizadas diárias em Ônibus - 1977-1987-1997-2002. 
Tabela 20 - Região Metropolitana de São Paulo - Sistema de ônibus municipal em 1997 e 2003

Tabela 21 - Região Metropolitana de São Paulo - Dados sobre o sistema de ônibus EMTUSP, 2006.

Tabela 22 - Região Metropolitana de São Paulo - Frota cadastrada de fretamento - Evolução anual - anos escolhidos. 257

Tabela 23 - Municípios e sub regiões da RMSP - Serviço de Lotação 1997 e 2003 264

Tabela 24 - Sub-Regiões da Região Metropolitana de São Paulo - Evolução das viagens diárias em Lotação - 1987-1997-2002

Tabela 25 - Região Metropolitana de São Paulo - Percentual de Viagens Diárias a Pé por Renda Familiar Mensal - 1987 e 1997 268

Tabela 26 - Região Metropolitana de São Paulo - Número de passageiros transportados a pé (em milhares/dia).

Tabela 27 - Região Metropolitana de São Paulo - Índice de mobilidade por renda familiar mensal, em 1987 e 1997 276

Tabela 28 - Região Metropolitana de São Paulo - Índice de mobilidade por modo principal e renda familiar mensal, em 2002 276

Tabela 29 - Região Metropolitana de São Paulo - Número de viagens diárias produzidas por modo principal e sua duração por motivo de trabalho, em 1997.

Tabela 30 - Região Metropolitana de São Paulo - Percentual de viagens diárias produzidas por modo principal e sua duração por motivo de trabalho, em 1997. 281

Tabela 31 - Região Metropolitana de São Paulo - Sub- Regiões e Municípios

Vínculos Empregatícios por Setor - 2005

$$
-x-
$$

Quadro 1 - Sistema de Trens Metropolitanos - Denominações das linhas. 128

Quadro 2 - Município de São Paulo - Corredores com Canaleta Exclusiva para Ônibus/Trolebus e Corredores com Faixas Exclusivas - 1995.

Quadro 3 - Município de São Paulo - Passa-Rápidos inaugurados na gestão 20012004.

Quadro 4 - Município de São Paulo - Corredores de ônibus previstos e inaugurados na gestão 2005-2008 208

Quadro 5 - Município de São Paulo - Terminais de ônibus e sua localização 236 


\section{LISTA DE SIGLAS}

AD - Pesquisa de Acesso e Difusão da CPTM

ANTP - Associação Nacional de

Transportes Públicos

BNDES - Banco Nacional de

Desenvolvimento

BOM - Bilhete Ônibus Metropolitano

CBTU - Companhia Brasileira de

Transportes Urbanos

CCQs - Círculos de Controle de Qualidade

Cepacs - Certificados de Potencial

Adicional de Construção

CET - Companhia de Engenharia de

Tráfego

CMSP - Companhia do Metropolitano de

São Paulo

CMTC - Cia. Municipal de Transportes

Coletivos

COCs - Centrais de Operação das

Concessionárias

COSIPA - Companhia Siderúrgica Paulista

CPTM - Companhia Paulista de Trens

Metropolitanos

DER - Departamento de Estradas de

Rodagem

DST - Departamento de Serviços de

Trânsito

DSV - Departamento do Sistema Viário

DTP - Departamento de Transporte

Público da SMT

EAOSA - Empresa de Auto-Ônibus Santo

André

EBTU - Empresa Brasileira de Transportes

Urbanos

EFSJ - Estrada de Ferro Santos-Jundiaí

Emplasa - Empresa Paulista de

Planejamento Metropolitano S.A.

EMTU - Empresa Metropolitana de

Transportes Urbanos

FEPASA - Ferrovias Paulistas S.A.

FMI - Fundo Monetário Internacional

GSP - Grande São Paulo

IBGE - Instituto Brasileiro de Geografia e

Estatística

IDH - Índice de Desenvolvimento

Humano
IPEA - Instituto de Pesquisa Econômica

Aplicada

IPI - Imposto sobre Produtos

Industrializados

Mafersa - Material Ferroviário S.A.

Orca - Operador Regional de Coletivo

Autônomo

Paep - Pesquisa da Atividade Econômica

Paulista

PBQP - Programa Brasileiro de Qualidade

e Produtividade

PEA - População Economicamente Ativa

PED - Pesquisa de Emprego e

Desemprego

Pesquisa O-D - Pesquisa Origem-Destino

PIA - População em Idade Ativa

PIB - Produto Interno Bruto

PITU - Plano Integrado de Transportes

Urbanos

PMDI - Plano Metropolitano de

Desenvolvimento Integrado

PMGSP - Plano Metropolitano da Grande

São Paulo 1994-2010

PND - Plano Nacional de

Desenvolvimento

PPP - Parceria Público Privada

PTTT - Plano Trienal de Tráfego e

Trânsito

RFFSA - Rede Ferroviária Federal S.A.

RMSP - Região Metropolitana de São

Paulo

SEMUTRANS - Secretaria Municipal de

Trânsito e Transportes

SIVIM - Sistema Viário de Interesse

Metropolitano

SMT - Secretaria Municipal dos

Transportes

SPTrans - São Paulo Transportes S.A.

TGCA - Taxa Geométrica de Crescimento

Anual

UITP - União Internacional de Transporte

Público

USP - Universidade de São Paulo

VLPs - Veículos Leves sobre Pneus 


\section{SUMÁRIO}

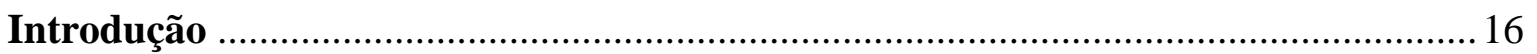

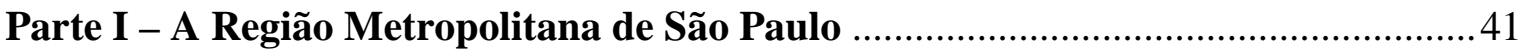

1 - A Reestruturação Produtiva na Metrópole Paulistana.......................................... 80

2 - O Emprego na RMSP e a Mobilidade Intra-Metropolitana .............................. 91

Parte II - Sistemas de Transporte Urbano de Passageiros na RMSP ....................... 106

3 - Infra-Estrutura e Políticas nos Modos de Transporte de Passageiros da RMSP ..119

3.1 - No Modo Ferroviário ................................................................................... 119

3.1.1 - Breves Notas sobre a Implantação e Início do

Desenvolvimento da Ferrovia em São Paulo.................................. 119

3.1.2 - Características da Rede do Trem Metropolitano da RMSP.......... 125

3.1.3 - Políticas de Transporte e o Trem Metropolitano......................... 145

3.2 - No Modo Metroviário............................................................................... 157

3.2.1 - Breves Notas sobre a Implantação do Metrô em São Paulo e

Características da Rede............................................................................ 157

3.2.2 - Políticas de Transporte e o Metrô................................................ 172

3.3 - No Modo Rodoviário................................................................................ 179

3.3.1 - Breves Notas sobre o Papel da Infra-Estrutura Rodoviária na Estruturação da Metrópole Paulistana no Passado e no Presente.......... 181

3.3.2 - Políticas para o Sistema Viário e Trânsito................................... 222

3.3.3 - Políticas de Transporte Coletivo Rodoviário: Ônibus e Lotação.. 225

4 - Transporte Não-Motorizado: o Modo a Pé........................................................... 268

Parte III - A Mobilidade dos Passageiros na RMSP em Tempos de Reestruturação

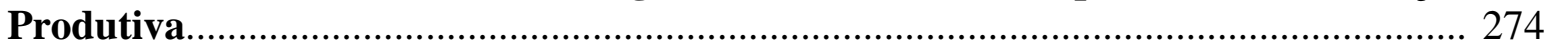

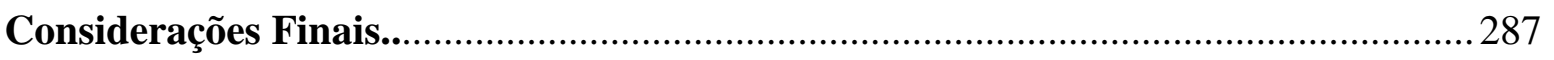

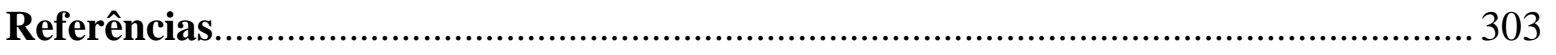

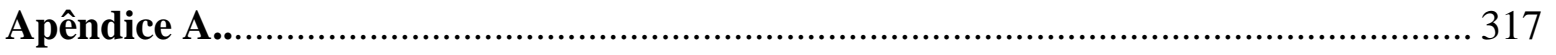




\section{Introdução}

O estudo da vida cotidiana e suas conexões com o mundo do trabalho e da reprodução social são os fatores mais importantes para o conhecimento das dimensões do ser social. Da esfera do trabalho origina-se o fundamento do ser social, pois, pelo trabalho, o homem produz-se a si mesmo como gênero humano, abandonando sua origem natural baseada nos instintos por uma produção e reprodução de si como gênero humano, que vem a ser o caminho para a realização de sua liberdade ${ }^{1}$.

A invenção do trabalho ${ }^{2}$, ao que parece, passa na atualidade por uma reinvenção. Muitas pesquisas têm sido realizadas acerca deste tema e, mais especificamente, da situação da força de trabalho a partir do fenômeno da reestruturação produtiva. A reestruturação produtiva da Região Metropolitana de São Paulo (RMSP) no final do século XX e início do século XXI é um tema bastante explorado pela Geografia. Com o intuito de abarcar uma parte de cada um destes dois grandes temas, o cotidiano do trabalhador e a reestruturação da RMSP, esta Tese traduz uma tentativa de investigar como se encontra o sistema de transporte metropolitano de passageiros em tempos de reestruturação produtiva na Região Metropolitana de São Paulo.

Neste contexto, ampliando o escopo das pesquisas que tratam da reestruturação produtiva na RMSP, inserimos o tema da circulação de passageiros. A partir do conhecimento já produzido sobre a reestruturação produtiva no Brasil, a desconcentração industrial, a terceirização e a terciarização na RMSP, estudamos a circulação de pessoas nesta região, permitindo a ampliação da compreensão das metamorfoses que vêm ocorrendo na metrópole.

\footnotetext{
${ }^{1}$ ANTUNES, 2003.

2 “Assim, a racionalização econômica do trabalho não consistiu simplesmente em tornar mais metódicas e melhor adaptadas a seus objetivos as atividades produtivas já existentes. Foi uma revolução, uma subversão do modo de vida, dos valores, das relações sociais e das relações com a natureza, uma invenção, no sentido pleno do termo, de algo que jamais existira antes." (GORZ, 2003, p.30, grifo do autor).
} 
O tema desta Tese é investigar os deslocamentos e a rede de transportes de passageiros na metrópole paulistana no período de 1987 a 2007. A Tese contempla os estudos da configuração da rede de transportes (fixos) e os deslocamentos (fluxos) dos passageiros.

Esta Tese foi formulada buscando responder a uma problemática central: a reestruturação produtiva induz a uma redefinição do sistema de transportes terrestres, tanto no que se refere à infra-estrutura quanto aos deslocamentos realizados por passageiros. Acreditamos que esse fenômeno também redefiniu o padrão da circulação de passageiros na RMSP.

Este processo não se deu por si só. Enquanto a circulação de trabalhadores redefiniu-se em grande parte por um processo de terceirização das unidades de produção, que significou uma realocação dos fluxos da força de trabalho no espaço da metrópole, a rede de transportes vem passando por grandes transformações, para dar suporte aos intensos fluxos metropolitanos.

A dispersão geográfica da produção, acompanhada da subcontratação de empresas para a realização de serviços ligados à produção e até mesmo de etapas da produção, faz com que os deslocamentos dos trabalhadores na RMSP adquiram uma nova configuração.

O poder público e as forças a ele atreladas propõem infra-estruturas urbanas de ordenamento e provimento de serviços sociais, entre elas as redes de transportes, para atender à sociedade, mesmo que de forma desigual. Esta infra-estrutura forma e transforma o espaço urbano. O ritmo just in time assumido pelas formações sociais na atualidade reflete-se nos espaços urbanos. As transformações da forma social da produção industrial dão origem a uma transmutação da forma espacial da cidade $^{3}$. Pode-se afirmar, ainda, que nos circuitos industriais brasileiros não há infra-estrutura urbana recentemente construída para atender a

\footnotetext{
${ }^{3}$ LENCIONI, 2005.
} 
esse ritmo $^{4}$. O território se reorganiza para atender, prioritariamente, à circulação do capital, em detrimento da circulação dos trabalhadores, mormente aqueles que se utilizam do transporte coletivo. Esta pesquisa procura desvendar o que ocorreu no território da metrópole paulistana entre 1987 e 2007 no que diz respeito tanto aos fluxos das pessoas como à infraestrutura de transportes a eles atrelada, o que entendemos como "fixos".

O objetivo desta pesquisa é, assim, verificar como a reestruturação produtiva redefiniu, a partir da década de 1990, os deslocamentos e a rede de transportes de passageiros na metrópole paulistana contemporânea. Trata-se tanto de um desafio teórico como empírico, visto que, apesar das exaustivas pesquisas realizadas sobre o fenômeno da reestruturação produtiva na $\mathrm{RMSP}^{5}$, não se encontram estudos sobre a reestruturação da mobilidade de passageiros.

A gestão territorial da metrópole paulistana, no que tange às políticas de transporte, tem sido responsável por um novo ordenamento urbano observado na paisagem metropolitana pela ampliação do sistema viário, construção de corredores de ônibus, linhas de metrô, entre outros, configurando uma aglomeração pautada na intensificação dos fluxos de mercadorias e de passageiros. A sociedade industrial está passando por um momento de mutação engendrado por forças inerentes ao modo de produção capitalista, que se rearranja de forma que o território, intermediado por técnicas informacionais cada vez mais abrangentes, reflete esta transição social no espaço urbano.

O objetivo geral desta pesquisa é o estudo da configuração da rede de transporte e dos ritmos dos fluxos urbanos de passageiros na RMSP, observando que a reengenharia da produção, a partir da década de 1990, alterou os fluxos e provocou novas demandas por transportes, configurando novos arranjos espaciais na metrópole.

\footnotetext{
${ }^{4}$ FERRARI, 2003.

5 ACCA, R.S., 2004; ARAÚJO, M.F.I., 2001; CARLOS, 2001; COMIN, A. \& AMITRANO, C., 2003; FERRARI, T., 2003; JANNUZZI, P. M.; MATTOS, F. A. M. \& PAULINO, L. A., 2005; KLINK, J.J., 2001; LENCIONI, S., 2005; PERO, V., 1995; POCHMANN, 2002; PRATES, R.C, 2001, entre outros.
} 
Através do estudo do sistema metropolitano de transportes terrestres, entendemos que a Geografia pode apreender as novas configurações e as dinâmicas territoriais que vêm ocorrendo na RMSP em um momento em que acontece uma "interpenetração" entre as atividades produtivas e improdutivas. O sistema de transportes de passageiros sofre transformações para garantir a mobilidade da população trabalhadora do crescente setor terciário da metrópole. O cotidiano da vida metropolitana nos revela transformações nos seus fluxos e fixos, ou ainda, no seu sistema de objetos e de ações. Verifica-se o crescimento do trabalho informal e das mais variadas formas de se ganhar a vida encontradas pelas pessoas para garantir sua reprodução. Essas formas de "trabalho" acarretam transformações territoriais. Diariamente, estes e os demais trabalhadores preenchem elevadas estatísticas de deslocamentos realizados no interior da metrópole.

\section{Mobilidade e Acessibilidade}

De acordo com Vasconcellos ${ }^{6}$, o transporte

representa a necessidade de deslocamento de pessoas e mercadorias no espaço, entre uma origem e um destino, implicando uma relação fundamental entre demanda e oferta e nas tecnologias disponíveis para o atendimento das necessidades. [Já o trânsito] [...] reflete apenas as consequiências do atendimento da necessidade, ou seja, reflete o ato de circular no espaço escasso, que deve ser dividido entre todos e tudo o que circula.

O autor explica que as discussões referentes à oferta, frequiência, confiabilidade, tarifa etc. do transporte público são pertinentes à área de transportes, bem como tudo aquilo que se refere ao atendimento da necessidade básica de deslocamento de pessoas e cargas. A discussão do trânsito, por outro lado, é necessariamente posterior à do transporte e "começa quando entra em consideração a disputa pelo espaço de circulação no ambiente urbano

\footnotetext{
${ }^{6}$ VASCONCELLOS, 1999, p.89.
} 
dado."7. Esta Tese prioriza o debate acerca do sistema de transportes terrestres de passageiros e, quando necessário, aborda a questão do trânsito, por este influenciar o deslocamento das pessoas.

Entendemos por mobilidade a capacidade dos indivíduos realizarem deslocamentos, constituindo-se em atributo social. O indivíduo faz-se movimentar pelo espaço à pé ou através de algum meio de transporte, o que é influenciado pela acessibilidade, "que retrata as condições de serviço ofertadas pelo sistema de transporte público" ${ }^{\text {. }}$. Do ponto de vista do planejamento em transportes, acessibilidade é a facilidade de um indivíduo, em uma localidade específica, para deslocar-se e participar de uma atividade, como o trabalho, a educação, o lazer etc., usando um modo de transporte ${ }^{9}$. Se não há acessibilidade satisfatória, o indivíduo tem limitadas suas oportunidades de tomar parte em um conjunto de atividades. Verifica-se, portanto, que "a capacidade de mobilidade é uma condicionante da participação no meio urbano" ${ }^{10}$. A acessibilidade está relacionada não só aos meios de transporte disponíveis, como também à localização do indivíduo e das atividades no espaço. Rosa ${ }^{11}$ acrescenta que "No conceito de acessibilidade [...] [há] uma conexão importante entre o local de onde o indivíduo parte (eventualmente o domicílio) com destino à oportunidade de seu interesse e o meio de ligação entre origem e destino proporcionado pelo sistema de transporte". A acessibilidade não deve ser pensada, no entanto, apenas no sentido de "alcançar pontos distantes, mas, sobretudo, de alcançar lugares específicos, centrais ou periféricos"12. Ressaltamos que a mobilidade, ou seja, os deslocamentos dos habitantes de uma cidade com a finalidade de vencer as distâncias, é não apenas produtora como também resultado de relações de produção desta espacialidade.

\footnotetext{
${ }^{7}$ VASCONCELLOS, 1999, p.89.

${ }^{8}$ ROSA, 2006, p. 25.

${ }^{9}$ Ibidem.

${ }^{10}$ RÉMY \& VOYÉ, 1994, p.74.

${ }^{11}$ ROSA, 2006, p.13.

${ }^{12}$ MEYER et alli, 2004, p. 29.
} 
Cremos que a cidade e o urbano podem proporcionar a ampliação da circulação espacial. A mobilidade como possibilidade de realizar deslocamentos necessários à manutenção da sobrevivência, bem como a mobilidade de boa qualidade nos espaços públicos são mais do que direitos do cidadão: são condição para sua inclusão no espaço urbano ${ }^{13}$. Entendemos, assim, que "a capacidade de mobilidade é uma condicionante da participação no meio urbano"14. A mobilidade, no entanto, não é uma capacidade que pertence a toda a população de forma igual: há diferenças ligadas à idade, à saúde e também à capacidade financeira dos indivíduos. Estas diferenças levam os grupos sociais desfavorecidos de mobilidade a assentarem sua segurança nas relações de vizinhança e no conhecimento pessoal. Já os grupos sociais dominantes, que apresentam índices maiores de mobilidade, podem usufruir de uma rede de relações que não se baseia na proximidade espacial ${ }^{15}$.

Podemos relacionar esta discussão com a "urbanização crítica", que Damiani ${ }^{16}$ define como a impossibilidade do urbano para todos. A autora afirma que não há urbano para todos, tampouco moradia e emprego para toda a população urbana. Apesar da metropolização ser constantemente associada à maior mobilidade, não há mobilidade para todos. A circulação intra-metropolitana torna-se uma condição inatingível para largas camadas de população em estado de pobreza, haja vista os grupos dominantes disporem de poder de escolha de localização na cidade, restando aos outros residirem onde sobra espaço. A livre circulação parece, verdadeiramente, não estar disponível para todos.

A mobilidade e a acessibilidade são elementos centrais nas análises urbanas, são as "funções urbanas que colocam em correspondência, da maneira mais decisiva, as duas dimensões materiais da sociedade contemporânea, que são o tempo e o espaço."17 Os autores

\footnotetext{
${ }^{13}$ ULIAN, 1999.

${ }^{14}$ RÉMY \& VOYÉ, 1994, p.74.

${ }^{15}$ Ibidem.

${ }^{16}$ DAMIANI, 2004.

${ }^{17}$ MEYER et alli, 2004, p.29, grifo dos autores.
} 
explicam que a realização destas duas funções urbanas, a mobilidade e a acessibilidade, tem por base três elementos principais: o sistema viário (elemento fixo), os percursos (fluxos) e os veículos (meio de transporte público). Esta Tese dedica-se a analisar estes três elementos.

De acordo com Vasconcellos ${ }^{18}$, para que a circulação urbana configure-se como um meio de consumo coletivo, torna-se fundamental que nela ocorra a intervenção do Estado. As vias constituem um caso especial de equipamento coletivo porque "podem servir tanto ao transporte de mercadorias (nelas incluída a própria força de trabalho) quanto ao deslocamento individual, para atendimento de necessidades individuais"19.

Vasconcellos $^{20}$ apresenta a discussão que Lojkine realiza sobre a definição do termo transporte, que "pode ser visto como um 'prolongamento do processo de produção no processo de circulação' [...] feito através do sistema viário." ${ }^{21} 22$. Sendo assim, a circulação propriamente dita seria "o conjunto das práticas de consumo do espaço viário, com todas as variações relacionadas às características sociais, econômicas e políticas dos usuários [...].”23. O autor baliza o consumo da via como essencialmente público, realizado através do processo de negociação de um espaço escasso, que precisa ser dividido entre aqueles que desejam utilizá-lo, daí a necessidade de regulamentação. Há ainda várias formas de se consumir este espaço da circulação, dados os meios de transporte disponíveis. O acesso aos vários meios de transporte é socialmente distinto e, portanto, o consumo do espaço viário é altamente diferenciado de acordo com o acesso que se possa dele fazer, tanto em função da renda da pessoa, quanto em função da condição física (como no caso de crianças, idosos e portadores

\footnotetext{
${ }^{18}$ VASCONCELLOS, 1999.

${ }^{19}$ Ibidem, p.61.

${ }^{20}$ Idem.

${ }^{21}$ LOJKINE, 1979, p.32, apud VASCONCELLOS, 1999, p.62.

${ }^{22}$ LOJKINE, Jean. O papel do estado na urbanização capitalista. In: FORTI, Reginaldo (org.). Marxismo e urbanismo capitalista. São Paulo: Ciências Humanas, 1979. 166 p.

${ }^{23}$ VASCONCELLOS, op. cit., p. 62.
} 
de deficiências físicas). Esta pesquisa examina, prioritariamente, as diferenças de mobilidade e acessibilidade em função da renda, como explicaremos a partir de agora.

\section{Renda e Mobilidade}

Quando os indivíduos não têm recursos financeiros para tomar uma decisão quanto à localização mais acessível de sua moradia, "são impelidos a uma segregação espacial"24, cujos principais efeitos são a favelização, o encortiçamento, os loteamentos clandestinos e outras formas informais de ocupação e uso do solo. Esta segregação espacial limita as condições de mobilidade da população metropolitana, caracterizada pela ocupação das periferias e, conseqüentemente, mais distante da localização de postos de trabalho. Maricato ${ }^{25}$ lembra que

\footnotetext{
Na história da política habitacional brasileira, a má localização (segregação ambiental) dos conjuntos habitacionais tem sido mais regra esmagadora do que exceção [...], uma política que, além de demagógica, dispendiosa e ineficaz para a solução de problemas sociais resultaram, ao contrário, em espaços segregados que contribuíram, ao lado de outros, para a geração de conflitos e violência.
}

A eqüidade espacial, entendida como a distribuição balanceada dos benefícios da urbanização em toda a área urbana, "pode refletir o grau de mobilidade e acessibilidade dos indivíduos, dada a distribuição espacial das oportunidades da área." ${ }^{26}$. Quanto mais eqüidade espacial, menos necessidade de longos deslocamentos, já que haveria uma distribuição equilibrada das oportunidades na cidade. A eqüidade espacial deve levar em consideração não só a distribuição balanceada das moradias e das oportunidades, como também a acessibilidade e a mobilidade do indivíduo. Apesar de entendermos que há segregação sócio-espacial também nas áreas centrais urbanas, nestas, a existência de infra-estrutura e de transporte

\footnotetext{
${ }^{24}$ ROSA, 2006, p.14.

${ }^{25}$ MARICATO, 1996, p.92.

${ }^{26}$ ROSA, op. cit., p.40
} 
público minimiza o problema do não-acesso às oportunidades. Há relações muito claras entre a segregação espacial, a acessibilidade e a mobilidade. Maricato ${ }^{27}$ afirma que a periferia da cidade de São Paulo expandiu-se horizontalmente nas décadas de 1940 a 1970 através do "binômio loteamento clandestino e ônibus urbano." ${ }^{28}$. A autora ainda aborda as relações calcadas no favor, no privilégio e na arbitrariedade que caracterizam a formação da sociedade brasileira, evidenciados em nossos estudos sobre os deslocamentos da população dependente do transporte coletivo versus a população que dele não depende. Verifica-se, em São Paulo, uma alta dispersão das atividades nas áreas urbanas, com grande dificuldade de acessibilidade em relação aos destinos desejados ${ }^{29}$. Uma ampla parcela populacional desgasta-se em horas de deslocamento entre a moradia, na periferia, e os distantes locais de trabalho.

As relações entre estas camadas pobres da população metropolitana - que, nas palavras de Maricato $^{30}$, habitam a "cidade oculta, disfarçada e dissimulada"- e as camadas dominantes - habitantes, de acordo com a autora, da cidade hegemônica ou virtual - são calcadas no favor, que "constitui a negação da universalidade dos direitos [...] ou a negação da cidadania e da dignidade" ${ }^{, 31}$.

O fordismo periférico, iniciado no Brasil após a Segunda Guerra Mundial, desenvolveu-se a partir da exclusão social, configurando uma modernização excludente. $\mathrm{O}$ crescimento urbano foi "marcado pela dinâmica expressa no binômio 'crescimento e pobreza', [que deixou uma grave herança para os anos 1980, agravada] pelo fim do desenvolvimentismo e pela emergência de novo arranjo internacional"32, que teria acarretado a ampliação da desigualdade.

\footnotetext{
${ }^{27}$ MARICATO, 1996, p.12.

${ }^{28}$ Ibidem.

${ }^{29}$ ROSA, 2006.

${ }^{30}$ MARICATO, op.cit., p. 14.

${ }^{31}$ Ibidem.

${ }^{32}$ Ibidem, p. 15.
} 
Segundo a autora, as classes médias e dominantes da sociedade desconhecem a cidade real, estão confinadas a uma área de circulação restrita, onde se concentram a infra-estrutura e os equipamentos urbanos. O mau funcionamento dos transportes públicos determina a ocupação densa da cidade hegemônica.

Sobre a urbanização brasileira, $\operatorname{Santos}^{33}$ afirma que

A partir dos anos 70, o processo de urbanização alcança novo patamar, tanto do ponto de vista quantitativo, quanto do ponto de vista qualitativo. Desde a revolução urbana brasileira, consecutiva à revolução demográfica dos anos 50, tivemos, primeiro, uma urbanização aglomerada, com o aumento do número - e da população respectiva - dos núcleos com mais de 20.000 habitantes e, em seguida, uma urbanização concentrada, com a multiplicação de cidades de tamanho intermediário, para alcançarmos, depois, o estágio da metropolização, com o aumento considerável do número de cidades milionárias e de grandes cidades médias (em torno do meio milhão de habitantes.).

Para este autor, a metropolização corresponde, no Brasil, à concentração da população e da pobreza ${ }^{34}$, das atividades modernas, dos meios de difusão das idéias, mensagens e ordens, construção da materialidade adequada à realização de objetivos econômicos e socioculturais.

Geiger $^{35}$ complementa:

Há algumas décadas, a pobreza no Brasil se concentrava no campo e em pequenas e médias cidades desprovidas de iniciativas empresariais. Atualmente, ela se concentra em grandes cidades, onde se acentuaram os contrastes sociais.

As promessas do emprego pleno, da assistência social providenciada pelo Estado, do lazer etc. não foram plenamente realizadas, como podemos aferir pelas palavras de Maricato $^{36}$ : "No final do século XX, [...] a imagem das cidades brasileiras parece estar

\footnotetext{
${ }^{33}$ SANTOS, 1993, p.69.

34 Santos (2000) nos ensina que há pelo menos três formas de pobreza que existem concomitantemente na segunda metade do século XX: a pobreza incluída, a marginalidade e a pobreza estrutural. O autor explica que a primeira seria aquela pobreza sazonal, que ocorre em certos momentos do ano. A segunda, que ele chamou marginalidade, "era produzida pelo processo econômico da divisão do trabalho, internacional ou interna" (ibidem, p.69). Segundo o autor, a marginalidade poderia ser corrigida pelos governantes. A terceira forma, a pobreza estrutural equivale a uma dívida social. Sendo ela estrutural, não é mais local e nem nacional: "torna-se globalizada, presente em toda parte do mundo" (ibidem).

35 GEIGER, 1995, p.33.

${ }^{36}$ MARICATO, 2003.
} 
associada à violência, poluição das águas e do ar, criança desamparada, tráfego caótico, enchentes, entre outros inúmeros males.” A autora chama a atenção para a dificuldade de acesso aos serviços e infra-estrutura urbanos, como a precariedade dos transportes, além da deficiência do saneamento, da inexistência de rede de drenagem, da dificuldade de abastecimento, do difícil acesso aos serviços de saúde, educação e creches, da maior exposição às enchentes e desmoronamentos, às menores oportunidades de emprego, principalmente formal e de profissionalização, entre muitos outros fatores.

Nas palavras de Milton Santos, "Quem mais ganha, mais viaja. Quem ganha pouco quase não se locomove. ${ }^{, 37}$ Renda e mobilidade são, assim, interdependentes, já que quem tem mais renda, tem também maior mobilidade. Quem tem maior mobilidade, pode, portanto, ter mais oportunidades de ampliar sua renda.

De acordo com Vasconcellos ${ }^{38}$, “A reorganização do espaço correspondeu a um novo estilo de vida, caracterizado por padrões de consumo e de relacionamento social crescentemente mercantilizados e complexos." O autor comenta que o aumento e a diversificação das redes de deslocamento das pessoas são fenômenos que afetaram a vida de todos, independentemente da sua condição social e econômica. Ele afirma que "o maior crescimento ocorreu nas viagens por automóvel, cuja participação no total quase triplicou $[\ldots]^{339}$. Este aumento nas viagens por automóvel, realizadas por setores limitados da população, estaria relacionado a mudanças econômicas e urbanas mais amplas, como a rede diária de atividades da classe média que, "apesar de diferenças entre subgrupos específicos, incorporou novos destinos e motivos, principalmente ligados à educação privada, medicina

\footnotetext{
${ }^{37}$ SANTOS, 1990, p.86.

${ }^{38}$ VASCONCELLOS, 2000, p.112.

${ }^{39}$ Ibidem.
} 
privada, esporte, lazer e compras, com impactos profundos nas suas necessidades de transporte" ${ }^{, 40}$. Antes da metropolização,

\begin{abstract}
essas atividades eram feitas com freqüência menor, muitas vezes gratuitamente, e na maioria das vezes dentro de distâncias que podiam ser percorridas a pé. A maioria das crianças da classe média freqüentava escolas públicas do bairro, usava serviços locais de saúde (públicos) e brincava nas ruas ou em lotes vazios das proximidades. As compras eram feitas em pequenos estabelecimentos locais e viagens de longa distância para fora da cidade eram feitas em ocasiões especiais (férias), frequientemente de trem ou ônibus ${ }^{41}$.
\end{abstract}

No cotidiano da metrópole paulistana é difícil usufruir das ruas por onde se anda, uma vez que a mobilidade é podada pela violência, pelo trânsito intenso de veículos automotores, pelo sistema de transportes inadequado, insuficiente, insultante, e até pelas características físicas das ruas e calçadas: esburacadas, sujas, com carros estacionados, com barracas de ambulantes e outros. Estamos tratando, então, da não realização do modo de vida urbano na cidade $^{42}$.

\title{
Considerações sobre a importância do tema de pesquisa para a Geografia
}

Compreendemos a Geografia como uma ciência que busca o conhecimento da espacialidade, ou seja, de um espaço socialmente produzido, sendo que, para entendê-lo, temos de partir para a observação do seu movimento, dos eventos que nele acontecem e que, ao mesmo tempo, o fazem existir ${ }^{43}$.

$\operatorname{Carlos}^{44}$ observa que "o espaço contempla dupla dimensão: de um lado é localização; de outro, encerra, em sua natureza, um conteúdo social, dado pelas relações sociais que se realizam em um espaço-tempo determinado, aquele de sua reprodução na sociedade.”. Não

\footnotetext{
${ }^{40}$ VASCONCELLOS, 2000, p.112.

41 Ibidem.

${ }^{42}$ ULIAN, 1999.

${ }^{43}$ DEUS, 2002.

${ }^{44}$ CARLOS, 2001, p.12.
} 
podemos pensar a existência de relações entre os seres sociais fora do espaço, e também nunca haverá um espaço sem a existência de relações sociais.

O sistema de objetos que compõe o espaço é altamente artificial. Composto por objetos técnicos, como hidrelétricas, fábricas, estradas de rodagem e de ferro, cidades, bem como o sistema de ações que "povoa" o espaço, é também imbuído de artificialidade ${ }^{45}$. O sistema de objetos é o conjunto de fixos, elementos "fixados em cada lugar [que] permitem ações que modificam o próprio lugar" ${ }^{\prime 46}$. As ações resultam direta ou indiretamente nos fluxos, “modificando a sua significação e o seu valor, ao mesmo tempo em que, também, se modificam" $"$. O autor considera que os fixos e os fluxos interagem e expressam a realidade geográfica.

Quanto ao sistema de ações, A. Moles ${ }^{48} 49$ define como ação "um deslocamento visível do ser no espaço, criando uma alteração, uma modificação do meio. Um dos resultados da ação é, pois, alterar, modificar a situação em que se insere." Segundo o autor, através do trabalho, o ser humano exerce ação sobre a natureza, alterando o meio exterior e a si mesmo.

No período técnico científico-informacional ${ }^{50}$, os objetos nascem praticamente predestinados a certos tipos de ações, que definem os objetos, dando-lhes sentido. O conteúdo técnico dos objetos "valoriza” as ações. A realidade histórica atual não nos permite considerar nem as ações nem os objetos separadamente ${ }^{51}$.

\footnotetext{
${ }^{45}$ SANTOS, 1997.

${ }^{46}$ Ibidem, p. 50.

47 Ibidem.

48 MOLES, A., 1974, p.264 apud Santos, 1997, p.64.

${ }^{49}$ MOLES, Abraham. Phénoménologie de l'action, in Les sciences de l'action, CEPL, Paris, 1974.

${ }^{50}$ O período técnico-científico pós-Segunda Guerra Mundial foi marcado pelas inovações técnicas que, nos vinte anos de pós-guerra,"se espalharam duas vezes mais rapidamente do que aquelas introduzidas depois da primeira guerra mundial e três vezes mais do que as introduzidas entre 1890 e 1919." (idem, 1997, p.143). O período técnico-científico informacional se distingue dos outros pela profunda interação da ciência e da técnica, sob a égide do mercado global. Neste período, os objetos técnicos são também informacionais, já que surgem como informação. Este período afirmou-se ao incluir os países de Terceiro Mundo nos anos 70 (ibidem).

${ }^{51}$ SANTOS, 1997.
} 
Nossa pesquisa visa a estudar uma porção e um momento desta realidade geográfica, tendo como recorte espacial a Região Metropolitana de São Paulo, e como recorte temporal o período compreendido entre 1987 e 2007.

A realidade geográfica, entendida como espaço geográfico, é o produto social criado na relação entre a sociedade e a natureza. $\mathrm{O}$ espaço "é formado à medida que o homem intervém sobre o meio natural, através de sua experiência acumulada ao longo do tempo"52. Sob este enfoque, concordamos com o autor ao afirmar que o espaço tem o trabalho humano como categoria principal.

O trabalho é ação humana realizada sobre o meio para suprir as condições necessárias à manutenção da espécie humana ${ }^{53}$. Toda ação humana é trabalho e todo trabalho é trabalho geográfico, já que a produção do espaço se dá pelo trabalho ${ }^{54}$.

O espaço, considerado aqui como objeto de estudo da ciência geográfica, é criado e recriado pelo trabalho humano. "A forma de vida do homem é o processo de criação do espaço." ${ }^{55}$. Segundo o autor, não há produção que não seja produção do espaço. Sua transformação se dá através do uso dos instrumentos de trabalho. A natureza modificada pelo trabalho humano resulta no espaço humano, e a produção deste é feita com meios de trabalho, em sociedade, e com divisão social do trabalho ${ }^{56}$.

Desde o início da ação humana na Terra até os dias de hoje, a produção impõe formas e ritmos à vida e às atividades humanas, ocasionando a utilização disciplinada do tempo e do espaço. O trabalho social é a atividade humana que transforma objetos da natureza em mercadorias produzidas com o objetivo de reprodução dos seres humanos com divisão de tarefas. A organização do espaço é, então, alterada sempre que as maneiras de produzir

\footnotetext{
${ }^{52}$ DEUS, 2002, p.31.

${ }^{53}$ SANTOS, 1996.

${ }^{54}$ Idem, 1980.

55 Idem, 1996, p.88.

${ }^{56}$ Idem, 1980.
} 
mudam. A incorporação de novas técnicas ao trabalho e o aumento da produtividade refletem alterações na organização do espaço.

De um estágio da produção a um outro, de um comando do tempo a um outro, de uma organização do espaço a uma outra, o homem está cada dia e permanentemente escrevendo sua História, que é, ao mesmo tempo, a história do trabalho produtivo e a história do espaço ${ }^{57}$.

Podemos dizer, então, que o trabalho, atividade que transforma objetos da natureza em mercadorias, é materializado no espaço como objetos fixos "os quais particularizam os lugares terrestres ao dar-lhes a marca da temporalidade dos usos sociais ali praticados." 58 Sendo assim, a paisagem nos mostra diversos estágios da produção humana. Carlos ${ }^{59}$ observa que "a produção da vida não envolve apenas a produção de bens para a satisfação das necessidades materiais: é também a produção da humanidade do homem"; o autor afirma, ainda, que "A noção de produção se vincula à produção do homem."

Os objetos geográficos que interessam à Geografia são tanto móveis, como imóveis. São contínuos, e ao geógrafo caberia estudá-los apenas como um sistema, e não separadamente, já que "sua utilidade atual, passada, ou futura vem, exatamente, do seu uso combinado pelos grupos humanos que os criaram ou que os herdaram das gerações anteriores" ${ }^{60}$, tendo papel simbólico e/ou funcional. O objeto é, para o geógrafo, um testemunho atual da ação. Cada objeto estudado não é necessariamente exclusivo da Geografia, mas como geógrafos, deveremos tratá-los geograficamente e, para tanto, buscamos categorias analíticas que nos permitam estudá-lo como tal ${ }^{61}$.

A Geografia, seria, portanto, uma ciência de certa forma "instrumentalizada" para o estudo do espaço. Soja ${ }^{62}$ justifica a utilização do termo espacialidade, ao invés de espaço, que

\footnotetext{
${ }^{57}$ SANTOS, 1980, p.163.

${ }^{58}$ MORAES, 2002, p.64.

${ }^{59}$ CARLOS, 2003, p.13.

${ }^{60}$ SANTOS, 1997, p.60.

${ }^{61}$ Ibidem.

${ }^{62}$ SOJA, 1993.
} 
evocaria uma imagem física ou geométrica. A espacialidade especificaria esse espaço socialmente produzido. Nesta concepção de Geografia e de seu objeto, a metrópole paulistana constitui-se em espaço produzido socialmente. A espacialidade da metrópole é o resultado dos processos produtivos que se acumularam através do tempo. A intencionalidade dos grupos sociais produz ininterruptamente seu sistema de objetos e seu sistema de ação.

Para o entendimento da metrópole paulistana, decidimos estudá-la por inteiro, como um objeto teórico. Apreender o real em sua integralidade, nesta pesquisa, será "propor uma visão totalizante [...] a partir de sua [do geógrafo] própria província do saber, isto é, de um aspecto da realidade global" ${ }^{\prime 63}$. Pretendemos contribuir, sob o aspecto do transporte de passageiros, para o entendimento totalizante da RMSP.

O todo somente pode ser conhecido através do conhecimento das partes e as partes somente podem ser conhecidas através do conhecimento do todo. Essas duas verdades são, porém, parciais. Para alcançar a verdade total, é necessário reconhecer o movimento conjunto do todo e das partes, através do processo de totalização ${ }^{64}$.

Não poderíamos, por essa razão, isolar as partes da RMSP (suas sub-regiões e municípios) neste momento em que a interpenetração dessas unidades é tão grande no aspecto dos fluxos de passageiros, pois correríamos o risco de não alcançar nosso objetivo geral: estudar a configuração da rede de transportes e os ritmos dos fluxos urbanos na RMSP. Carlos ${ }^{65}$ afirma que a localização das atividades deve ser apreendida no contexto urbano como um todo na metrópole. Daí a importância de se pensar a metrópole em sua totalidade, quando se pretende estudar os fluxos urbanos.

As moradias, por vezes tão distantes das atividades econômicas, sentenciam aos trabalhadores viagens longas, intermináveis. O preço do solo urbano coloca os indivíduos em áreas mais ou menos acessíveis em relação a lugares ditos privilegiados, em áreas com ou sem

\footnotetext{
${ }^{63}$ SANTOS, 1996, p.92.

${ }^{64}$ Ibidem, p.96.

${ }^{65}$ CARLOS, 2001.
} 
acesso à infra-estrutura de água, luz, esgoto, asfalto, telefone, vias de circulação, transporte, entre outros. A sociedade se apropria, assim, de forma diferenciada da metrópole em sua totalidade e a própria percepção total do espaço metropolitano é tantas vezes inacessível aos seus habitantes.

A partir das reflexões aqui expostas, entendemos, a princípio, que a grande relevância do tema desta pesquisa para a Geografia está na contribuição que ela pode dar para a melhor compreensão da metrópole paulistana como espacialidade formada e em constante transformação em função de sua própria condição de metrópole. Esta discussão já se faz na Geografia e a realização desta pesquisa possibilita ampliar o debate, acrescentando novas descobertas acerca da circulação de passageiros, uma dimensão em transformação a partir dos anos 1990, em virtude da reestruturação produtiva.

A metrópole paulistana desempenha vários papéis na formação sócio-espacial brasileira: centro de serviços e comércio, produção industrial, centro administrador da produção industrial, centro de negócios, de eventos culturais e científicos, além de papéis no âmbito da produção científica e tecnológica, entre muitos outros. Essa imensa variedade de atividades engendra fluxos e transformação dos fixos, ou seja, a metrópole está em constante formação e transformação.

A análise da circulação através do estudo específico da rede de transportes desta metrópole, levando-se em consideração que houve intensas transformações nestes aspectos a partir da reestruturação produtiva, é aqui realizada através do estudo das vias férreas, metroviárias e rodoviárias, bem como das modalidades que circulam por estas vias na região metropolitana.

Verificamos, enfim, que tanto em relação à área urbanizada, como no que diz respeito à população urbana, densidade demográfica, pessoal ocupado na indústria, comércio e 
serviços, os dados analisados nesta pesquisa acompanham a afirmação de Arroyo ${ }^{66}$ : “a aglomeração paulistana continua sendo um centro importante da atividade fabril”. Esta atividade e todas as outras dela decorrentes fazem com que a RMSP ocupe uma posição de destaque no crescimento econômico do país ${ }^{67}$. A qualidade ruim dos deslocamentos da população trabalhadora na metrópole tem sido divulgada pela imprensa e debatida no cotidiano, embora não haja nenhum movimento popular organizado, nem sequer sindical, que se preocupe com este tema. É considerada como pior e mais desgastante do que as horas em que o trabalhador realiza seu próprio trabalho, como demonstraram muitas das entrevistas efetuadas.

Realizamos nossa pesquisa sobre o período da reestruturação produtiva a partir da década de 1990 e seus reflexos na rede de transporte e acessibilidade da Região Metropolitana de São Paulo. Estes fenômenos constituem aspectos de uma realidade geográfica constituída por sistemas de objetos materializados no urbano, como vias, terminais e meios de transporte, mesclando rugosidades ${ }^{68}$ obtidas a partir de técnicas menos modernas, até os novos objetos produzidos no meio técnico-científico informacional, portanto, sistema de objetos indissociável de um sistema de ações que dão sentido a estes objetos, e que produzem fluxos. O termo fluxo, neste caso, aproxima-se bastante do significado de mobilidade, deslocamento, acessibilidade, já que o ponto de partida de nossas análises está fundamentado na mobilidade espacial. A mobilidade de pessoas, bens e informações repercute de várias maneiras na estruturação e no uso do espaço. Na paisagem metropolitana evidencia-se a valorização da mobilidade espacial, e a circulação torna-se uma exigência da estrutura metropolitana.

\footnotetext{
${ }^{66}$ ARROYO, 2004, p.92.

${ }^{67}$ Entendemos que o crescimento econômico não é acompanhado, via de regra, pelo desenvolvimento social, sendo este mais um foco de interesse da ciência geográfica.

${ }^{68}$ Entendemos por rugosidades as formas e relações sociais presentes no espaço sobreviventes de épocas anteriores.
} 
De acordo com Carlos ${ }^{69}$,

a cidade se reproduz, continuamente, como condição geral do processo de valorização gerado no capitalismo no sentido de viabilizar os processos de produção, distribuição, circulação, troca e consumo e, com isso, permitir que o ciclo do capital se desenvolva e possibilite a continuidade da produção, logo, sua reprodução.

Para a autora, ao realizarmos qualquer estudo urbano, devemos levar em conta dois aspectos interdependentes que seriam a base da análise urbana: "a necessidade de reprodução ampliada do capital e a crescente especialização decorrente do aprofundamento da divisão social, técnica e espacial do trabalho, que exige novas condições espaciais para sua realização." ${ }^{, 70}$. Entendemos que o estudo urbano realizado nesta Tese deve ser examinado sob a ótica de que o sistema de transportes metropolitano está a serviço da reprodução do capital e que, se são introduzidas melhorias na infra-estrutura de transportes, é porque elas servirão ao sistema do capital em primeira instância. Se não fosse isso, como poderíamos explicar que, sob tão avançada tecnologia, na maior metrópole da América do Sul, ainda se convive com meios de transporte tão desconfortáveis e morosos, como diversas linhas de trem metropolitano e de ônibus? A melhoria do transporte da classe trabalhadora é certamente uma demanda do capital, e finalmente o Estado parece reconhecer isso.

\section{Metodologia}

"Ultrapassar o fenômeno e atingir a essência é o objeto da reflexão no processo de conhecimento." ${ }^{71}$ Constatamos o fenômeno dos crescentes fluxos de pessoas que se faz cotidianamente na metrópole. Para encontrarmos o cerne, a essência deste acréscimo de deslocamentos, precisamos não só conhecer os dados que nos são apresentados através das

\footnotetext{
${ }^{69}$ CARLOS, 2001, p.15.

${ }^{70}$ Ibidem.

${ }^{71}$ DEUS, 2002, p.34.
} 
pesquisas estatísticas, mas também vivenciar a circulação na metrópole paulistana através de pesquisas de campo, estudar teoricamente os fenômenos que ocorrem na RMSP no que tange às suas atividades econômicas, ultrapassando suas externalidades e penetrando no âmago das problemáticas para, a partir destas reflexões, produzir um conhecimento sobre tal realidade geográfica.

Percebemos a importância da observação e da análise das contradições existentes no espaço metropolitano. Quando nos propusemos a ultrapassar as externalidades, pensamos em ir além do que se vê, daquilo que aparentemente está estável. A espacialidade metropolitana está plena de contradições, as quais precisamos conhecer para compreender a dinâmica metropolitana em sua totalidade.

Produzido para atender às necessidades da produção e da circulação dos bens, o espaço constitui-se uma unidade dos contrários, mas não de forma absoluta, pois as contradições são temporárias e existem até que outra realidade substitua a anterior. "Esse último antagonismo vai existir em um certo tempo até ser substituído por um outro, e assim, sucessivamente, até o infinito, fazendo do espaço algo sempre mutável."72

Nesta perspectiva, procuramos fazer, no decorrer de nossa pesquisa, um exercício constante de co-relação dos fenômenos empíricos e dos dados estatísticos, com a tentativa de produção de um conhecimento sustentado teórica e metodologicamente na ciência geográfica. À Geografia "cabe estudar o conjunto indissociável de sistemas de objetos e sistemas de ação que formam o espaço." ${ }^{, 73}$ Entendendo por sistema de objetos o conjunto de fixos, e por sistemas de ações os fluxos, nesta Tese, as vias, terminais e meios de transporte configuramse como fixos, e os deslocamentos de passageiros de seu domicílio a seu trabalho, como fluxos. Os fixos e os fluxos interagem e expressam a realidade geográfica, entendida como espaço.

\footnotetext{
${ }^{72}$ DEUS, 2002, p.36.

${ }^{73}$ SANTOS, 1997, p.51.
} 
De acordo com Santos ${ }^{74}$, há quatro categorias do método geográfico de análise do espaço: forma, função, estrutura e processo. A forma é componente da paisagem, ou seja, aquilo que se vê no espaço, seu aspecto visível, exterior. Um conjunto de formas compõe a paisagem. Entendemos a paisagem como "o conjunto de formas que, num dado momento, exprimem as heranças que representam as sucessivas relações localizadas entre o homem e natureza" ${ }^{, 75}$.

A função refere-se às atividades da sociedade, já que o espaço contém, além do sistema de objetos, também o sistema de ações. A função implica o papel desempenhado pela forma.

A estrutura diz respeito à inter-relação das partes do todo, à natureza social e econômica da sociedade em um dado momento do tempo. A estrutura é "a matriz social onde as formas e funções são criadas e justificadas." ${ }^{, 76}$ A estrutura contém as instituições sociais e as políticas por elas realizadas.

O processo remete à dimensão histórica do espaço, uma estrutura em seu movimento de transformação. Nas palavras de Santos,

Forma, função, estrutura e processo são quatro termos disjuntivos, mas associados, a empregar segundo um contexto do mundo de todo dia. Tomados individualmente, representam apenas realidades parciais, limitadas do mundo. Considerados em conjunto, porém, e relacionados entre si, eles constroem uma base teórica e metodológica a partir da qual podemos discutir os fenômenos espaciais em totalidade $^{77}$.

Nossa análise previu, metodologicamente, analisar a espacialidade metropolitana contemporânea a partir de sua forma, neste caso, sua infra-estrutura de transportes compreendendo vias, terminais e meios. Estes objetos inter relacionam-se, formando um sistema. Nesta pesquisa, as formas têm uma importância peculiar e procuramos enfatizá-la

\footnotetext{
${ }^{74}$ SANTOS, 1985.

${ }^{75}$ Idem, 1997, p.83, grifo nosso.

${ }^{76}$ CORREA, 2004, p.29.

${ }^{77}$ SANTOS, 1985, p.52.
} 
bastante, já que são estes objetos que possibilitam, adequadamente ou não, os deslocamentos dos passageiros, fundamento desta Tese.

A função da forma que estudamos é prover os fluxos dos indivíduos. As ações de deslocamento realizam-se a partir do sistema de objetos, existentes para suprir este sistema de ações.

A estrutura, a formação social brasileira e, em particular, a formação sócio-espacial da metrópole paulistana, decide sobre as vias, terminais, meios de transporte e fluxos. São as políticas que determinam a infra-estrutura viária, que escolhem a localização das formas no espaço urbano, e influem nos fluxos de pessoas. A estrutura é incondicionalmente responsável pelas agruras do cotidiano desordenado do transporte urbano metropolitano.

O processo da construção da metrópole permeia a pesquisa, especialmente o período a partir da reestruturação produtiva da década de 1990, na RMSP. A dimensão histórica é uma constante na análise dos fenômenos estudados.

\section{Métodos de Pesquisa}

Inicialmente, realizamos uma ampla pesquisa bibliográfica que se estendeu ao longo de todo o processo de pesquisa.

Efetuamos, paralelamente, a pesquisa de dados estatísticos, através da leitura, consulta e interpretação dos dados da Pesquisa Origem-Destino (O-D) 1997 e Aferição da Pesquisa Origem-Destino 2002, que nos foi fornecida pela Cia. Do Metropolitano de São Paulo em forma de CD-Rom. Também consultamos dados referentes às Pesquisas O-D anteriores, de 1967, 1977 e 1987. Todos estes dados referem-se à circulação diária na RMSP nos anos de 1967, 1977, 1987, 1997 e 2002. Do material oferecido pela Cia. Do Metrô, tivemos acesso também aos Relatórios Operacionais e a vários documentos disponibilizados no sítio da 
empresa. Obtivemos especialmente para esta pesquisa, sob encomenda, uma série de dados da Pesquisa O-D 1997 que não são de domínio público, fornecidos apenas para pesquisadores.

Também conseguimos dados acerca dos embarques nas estações da CPTM (Companhia Paulista de Trens Metropolitanos), fornecidos pela empresa a nosso pedido. O sítio da CPTM nos possibilitou a coleta de tantos outros dados e informações.

Os Sumários de Dados da Grande São Paulo, da EMPLASA (Empresa Paulista de Planejamento Metropolitano S.A.), nos foram disponibilizados na biblioteca e no sítio da empresa, bem como várias outras informações.

Realizamos, ainda, busca de dados estatísticos relacionados à atividade econômica das regiões do Estado de São Paulo, inclusive da RMSP e da metrópole expandida, nas Pesquisas Paep (Pesquisa da Atividade Econômica Paulista) de 1996 e 2001, disponíveis no sítio da Fundação Seade.

Além de todos os recursos técnicos já citados, realizamos muitas pesquisas de campo. Visitamos as seguintes sub-regiões e municípios da RMSP: Centro (São Paulo), Oeste (Barueri, Carapicuíba, Itapevi, Jandira, Osasco), Sudoeste (Embu e Taboão da Serra), Sudeste (Diadema Mauá, Ribeirão Pires, Rio Grande da Serra, Santo André, São Bernardo do Campo e São Caetano do Sul), Leste (Biritiba Mirim, Ferraz de Vasconcelos, Itaquaquecetuba, Mogi das Cruzes, Poá e Suzano), e Norte (Caieiras, Francisco Morato e Franco da Rocha).

A cada visita, usamos meios de transporte coletivos para acesso à sub-região e deslocamento dentro dela; realizamos observação e descrição da paisagem, além de análise do sistema de transporte coletivo: infra-estrutura e meios de transporte. Fizemos cerca de oitenta entrevistas abertas com usuários dos sistemas de transportes. Estas entrevistas versaram sobre seu cotidiano no transporte coletivo para o trabalho, sua opinião sobre este sistema de transportes quanto à eficiência, segurança, condições de limpeza e conforto, tempo dos 
deslocamentos, e sobre seu desgaste físico e mental como usuários do transporte coletivo. As entrevistas se restringiram aos usuários que usavam o meio de transporte para seu deslocamento por motivo de trabalho.

A pesquisa empírica nos proporcionou uma nova visão do problema, pois, em meio à metrópole, cujo sistema viário está permanentemente em obras, sujeito a inundações constantes e a congestionamentos diários, colhemos dados não só objetivos, mas, principalmente, subjetivos. Vivenciamos o cotidiano dos deslocamentos destes trabalhadores, o que nos proporcionou uma visão muito mais ampla dos dados objetivos estudados na pesquisa documental.

Marcelino $^{78}$ observa que foi à luz da subjetividade, expressa nas entrevistas que realizou, que conseguiu construir o entendimento da realidade estudada:

Entendemos que a realidade possui duas faces concomitantes e indissolúveis, ambas permeadas das contradições inerentes ao capitalismo: a material e a subjetiva. É essa subjetividade, ainda que fragmentada e não desenvolvida em todas as suas potencialidades humanas, que irá se manifestar no cotidiano dos homens, em sua compreensão e atuação sobre o processo de trabalho. Por meio dela é que os homens podem interagir, adaptar-se ou questionar de alguma forma a realidade. Nesse sentido, a subjetividade é construída a partir das relações sociais, mas delas também é constituidora.

Pareceu-nos impossível compreender a vastidão do sistema de transportes de passageiros da RMSP apenas pela bibliografia e pelos números. A vivência do cotidiano dos deslocamentos se faz fundamental para o entendimento da realidade geográfica por nós estudada. Compreender alguns aspectos da subjetividade que os passageiros vivenciam em seus deslocamentos pôde contribuir para a compreensão da realidade sócio-espacial metropolitana.

Muito contribuiu também a referência de $\operatorname{Carlos}^{79}$, já que nesta obra a autora realizou muitas entrevistas com os moradores das áreas por ela pesquisadas. Verificamos que, ao

\footnotetext{
${ }^{78}$ MARCELINO, 2004, p. 12.

${ }^{79}$ CARLOS, 2001.
} 
apresentar as entrevistas, a pesquisadora as mescla, fazendo considerações acerca de várias delas, permitindo, assim, reflexões norteadas a partir de seus objetivos. Procuramos proceder do mesmo modo neste texto. Ao tratar sobre os deslocamentos nos diversos modos de transporte, bem como em outros momentos, inserimos as entrevistas, já que os depoimentos dos sujeitos nos ajudam a interpretar a realidade por eles vivida.

$$
-\mathrm{x}-
$$

Iniciamos a Tese explicando nossa área de pesquisa, a Região Metropolitana de São Paulo (RMSP). O primeiro capítulo versa sobre esta vasta região. Procuramos caracterizá-la quanto à sua estruturação com base no sistema viário, sua população e outros dados a ela relacionados, explicando cada sub-região e suas inter-relações. Abordamos duas questões fundamentais para o entendimento desta que é a maior região metropolitana brasileira: a desconcentração industrial e a questão das centralidades metropolitanas. O capítulo apresenta também dois sub-itens que tratam, respectivamente, da reestruturação produtiva na metrópole paulistana e do emprego na RMSP e suas relações com a mobilidade intra-metropolitana.

Trata-se, portanto, de um capítulo que aprofundará a análise da realidade geográfica através da categoria "função". 


\section{Parte I - A Região Metropolitana de São Paulo}

A Região Metropolitana de São Paulo (RMSP), nossa área de estudo, foi constituída pela Lei Complementar Federal $n^{\circ} 14$, de 8/6/73 e Lei Complementar Estadual $n^{\circ}$ 94, de 29/5/74. É formada por trinta e nove municípios, sendo o de São Paulo o maior e principal indutor do crescimento da região metropolitana. Para melhor estudarmos esta vasta região, que hoje abrange $8.051^{80} \mathrm{~km}^{2}$ e é habitada por 19.608.281 habitantes (www.emplasa.sp.gov.br - 21.02.2008), vamos nos utilizar de sua divisão em sub-regiões adotada pela Secretaria dos Transportes Metropolitanos (STM-SP), a fim de sermos coerentes com os dados relativos aos transportes das sub-regiões a serem posteriormente analisados:

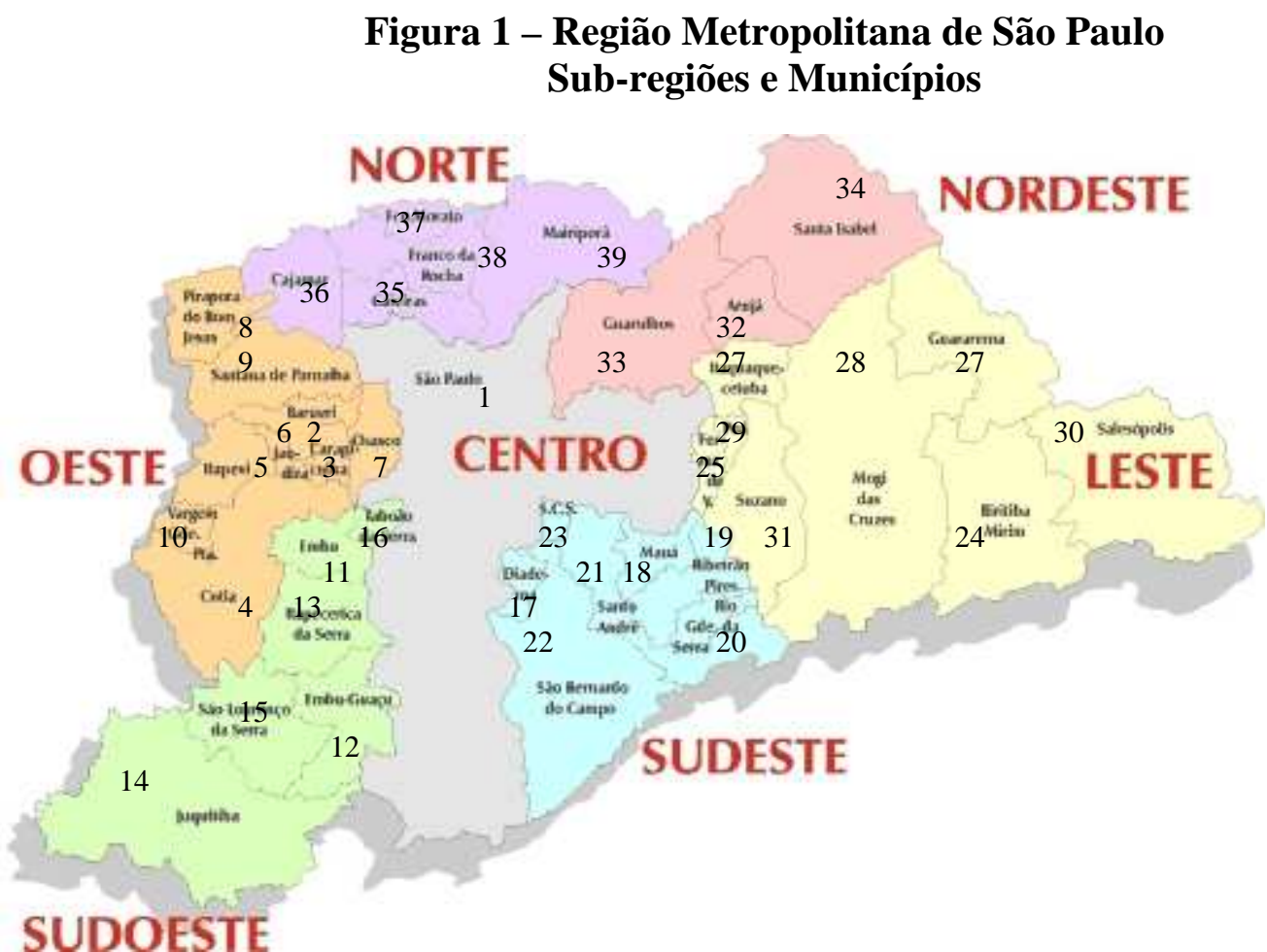

Fonte: http://www.stm.sp.gov.br/cam-rmspbs.gif - acesso em 21.02.2008

\footnotetext{
${ }^{80}$ A área da RMSP, de acordo com a Emplasa, seria de $7.947 \mathrm{~km}^{2}$; no entanto, este número não coincide com a soma das áreas de cada município da metrópole separadamente. A área correta é, então, $8.051 \mathrm{~km}^{2}$, apresentada pela Fundação Seade.
} 


\begin{tabular}{|c|c|}
\hline \multicolumn{2}{|r|}{ Legenda } \\
\hline SUB-REGIÕ̃ES & MUNICÍPIOS \\
\hline CENTRO & 1. São Paulo \\
\hline \multirow[t]{9}{*}{ OESTE } & 2. Barueri \\
\hline & 3. Carapicuíba \\
\hline & 4. $\quad$ Cotia \\
\hline & 5. Itapevi \\
\hline & 6. Jandira \\
\hline & 7. Osasco \\
\hline & 8. Pirapora do Bom Jesus \\
\hline & 9. $\quad$ Santana do Parnaíba \\
\hline & 10. Vargem Grande Paulista \\
\hline \multirow[t]{6}{*}{ SUDOESTE } & 11. Embu \\
\hline & 12. Embu-Guaçu \\
\hline & 13. Itapecerica da Serra \\
\hline & 14. Juquitiba \\
\hline & 15. São Lourenço da Serra \\
\hline & 16. Taboão da Serra \\
\hline \multirow[t]{7}{*}{ SUDESTE } & 17. Diadema \\
\hline & 18. Mauá \\
\hline & 19. Ribeirão Pires \\
\hline & 20. Rio Grande da Serra \\
\hline & 21. Santo André \\
\hline & 22. São Bernardo do Campo \\
\hline & 23. São Caetano do Sul \\
\hline \multirow[t]{8}{*}{ LESTE } & 24. Biritiba Mirim \\
\hline & 25. Ferraz de Vasconcelos \\
\hline & 26. Guararema \\
\hline & 27. Itaquaquecetuba \\
\hline & 28. Mogi das Cruzes \\
\hline & 29. Poá \\
\hline & 30. Salesópolis \\
\hline & 31. Suzano \\
\hline \multirow[t]{3}{*}{ NORDESTE } & 32. Arujá \\
\hline & 33. Guarulhos \\
\hline & 34. Santa Isabel \\
\hline \multirow[t]{5}{*}{ NORTE } & 35. Caieiras \\
\hline & 36. Cajamar \\
\hline & 37. Francisco Morato \\
\hline & 38. Franco da Rocha \\
\hline & 39. Mairiporã \\
\hline
\end{tabular}

Em sua formação, a RMSP foi, aos poucos, agrupando muitos municípios localizados nos arredores. Os municípios iniciais se desmembraram, totalizando trinta e cinco em 1964 . O último município a se desmembrar foi São Lourenço da Serra, em 1992.

De acordo com Comin \& Amitrano ${ }^{81}$, a "centralidade da metrópole paulista se exprime antes de tudo pela sua intensa imantação demográfica sobre o restante do país ao longo de 
todo o século XX”. Somente a população da cidade de São Paulo cresceu cinco vezes de 1950 a 2000, passando de pouco mais de dois milhões de habitantes em 1950 para 10 milhões em 2000, embora este crescimento tenha sido mais intenso entre 1950 e 1980.

Para os autores,

o crescimento industrial foi o vetor por excelência de acomodação dessa imensa concentração populacional na RMSP, não apenas em virtude do volume extraordinário de postos de trabalho gerados diretamente pelos setores industriais, mas também dos efeitos de encadeamento sobre as mais diversas atividades em serviços ${ }^{82}$.

Primeiramente, a estruturação urbana metropolitana ocorreu a partir da rede ferroviária, que ordenou o assentamento industrial. A expansão da Capital direcionou-se para leste, oeste e sudeste. Após os anos 1950, com o desenvolvimento da indústria automobilística, os vetores nordeste e sudeste sediaram os parques industriais mais importantes, na direção das rodovias Presidente Dutra e Via Anchieta. A metrópole passou a ter uma intensificação na sua expansão em direção ao oeste a partir da década de 1960, impulsionada pela oferta de terras para o assentamento residencial das classes média-alta e alta. Esta expansão foi catalizada pelas rodovias Raposo Tavares e Régis Bittencourt e, posteriormente, pela rodovia Castelo Branco. O vetor norte não teve grande expansão devido à barreira física constituída pela Serra da Cantareira. A RMSP é servida de malha rodoviária de estrutura tipicamente radial, centrada no município de São Paulo, caracterizando a função polarizadora da Capital. Esse formato de irradiação é semelhante ao dos primeiros caminhos que se articulavam no Estado ${ }^{83}$.

Atualmente, a RMSP é provida de cerca de $900 \mathrm{~km}$ de rodovias estaduais e de $160 \mathrm{~km}$ de rodovias federais. O território metropolitano é definido pelos eixos ferroviários e rodoviários que convergem para o município de São Paulo. São dez os eixos rodoviários

\footnotetext{
${ }^{82}$ COMIN \& AMITRANO, 2003, p.54,

${ }^{83}$ SÃO PAULO, 1994a.
} 
regionais, articulados nos complexos viários do Sistema Anhangüera-Bandeirantes (SP-330 e SP-332), atendendo a região nordeste do Estado de São Paulo provenientes do triângulo mineiro e Goiás; Dutra-Airton Senna (BR-116 e SP-70), atendendo a região do Vale do Paraíba e o tráfego proveniente do sul de Minas e Rio de Janeiro; Anchieta-Imigrantes (SP150 e SP-160), ligando a região da Baixada Santista, porto de Santos e o tráfego proveniente do sul do Estado de São Paulo; e Fernão Dias (BR-381), dando acesso ao oeste de Minas Gerais e Belo Horizonte. As rodovias Raposo Tavares (SP-270), Castelo Branco (SP-280) e Marechal Rondon (SP-300), também radiais, atendem a região oeste do Estado e o tráfego proveniente do Mato Grosso do Sul e norte do Paraná. A Régis Bittencourt (BR-116) atende o sul do Estado e o tráfego proveniente do sul do país ${ }^{84}$. O escoamento da produção industrial desenvolvida na RMSP apóia-se neste sistema rodoviário. Estes eixos "alcançam o sistema viário urbano no circuito formado pelas avenidas marginais aos rios Tietê e Pinheiros e pelas avenidas que compõem o minianel viário e o anel viário metropolitano" ${ }^{\text {" }}$. O minianel é interno ao município de São Paulo. Já o anel viário metropolitano tem raio mais amplo e estende-se para os municípios do ABC Paulista.

O mercado imobiliário tem se apropriado dos trechos lindeiros às rodovias que alcançam o município de São Paulo desde os anos 1990, com edifícios residenciais para a população de renda média e média-baixa ${ }^{86}$. Os autores opinam que, em decorrência dos planos do poder público de transformar esses trechos rodoviários em vias expressas, com acessos locais, deverão ampliar a oferta habitacional nessas áreas. Um exemplo seria a área urbana junto ao quilômetro 15 da rodovia Raposo Tavares.

\footnotetext{
${ }^{84}$ SÃO PAULO, 1994a.

${ }^{85}$ MEYER et alli, 2004, p.74, grifos dos autores.

${ }^{86}$ Ibidem.
} 
As pistas de padrão internacional que confluem para a RMSP integram o território paulista, diluem as distâncias e distendem o espaço metropolitano ${ }^{87}$. Apresentamos a seguir, nos Mapas 1 e 2, o sistema viário de acesso à RMSP e as redes ferroviária, metroviária e de corredores metropolitanos de ônibus.

\section{Mapa 1 - Região Metropolitana de São Paulo Estrutura Viária de Acesso à RMSP}

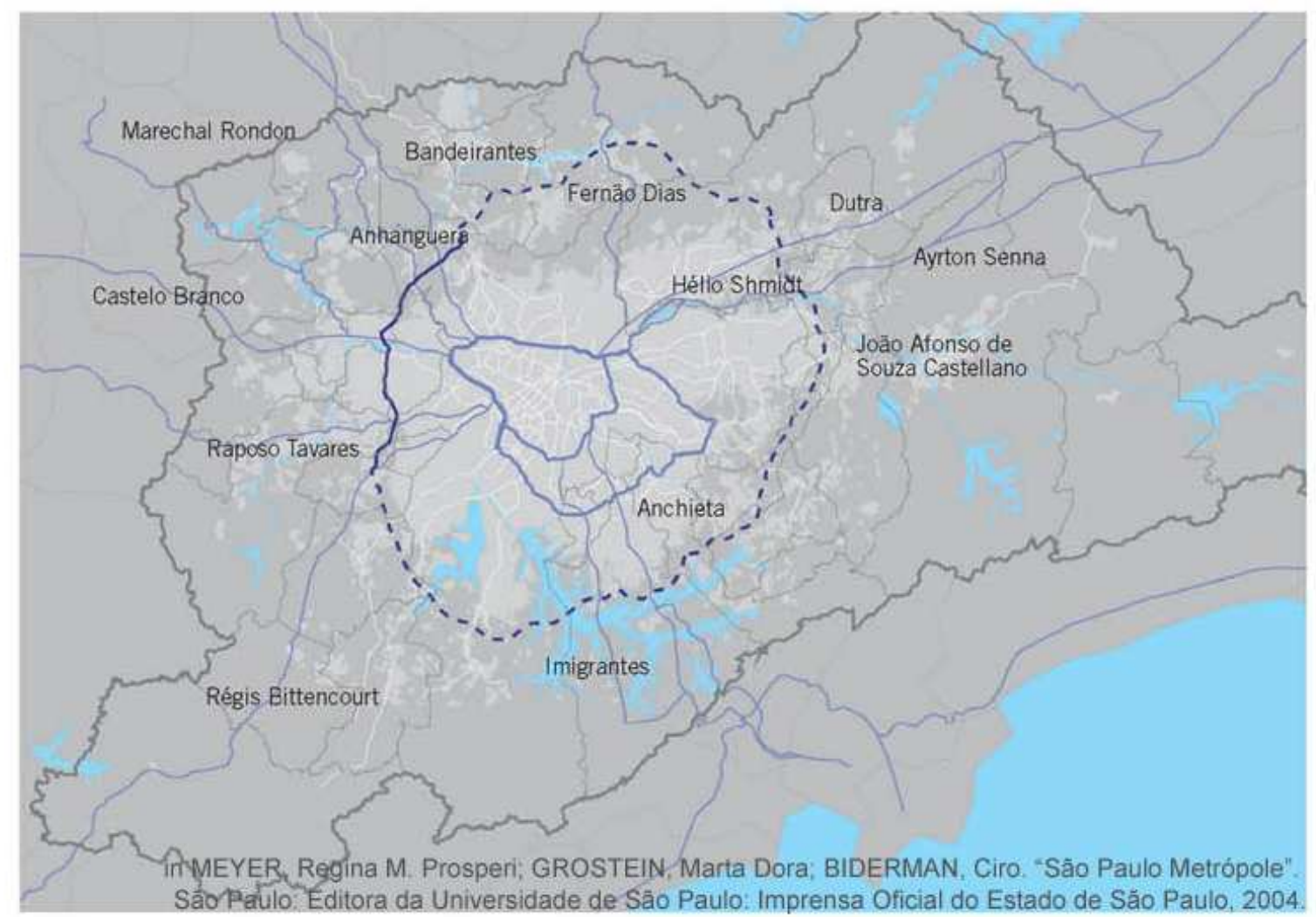

${ }^{87}$ LENCIONI, 1991. 


\section{SISTEMA VIÁRIO REGIONAL E PRINCIPAL}

2001

- Rodovias

Rodoanel

- trecho oeste - executado

-..- trechos norte, leste e sul projetados

- Primeiro e segundo anéis viários

FONTE, Laboratärio de Uirbaniseno da Metudocie- LUME

FONTES BASICAS:

siabima viśrio principal LOCT, ad, 340 PAULD (ESTADO), EMPLASA 1994 MAPOGRAE. 1998

Grea urbanizada 1997, SHO PALLO (ESTADO) EMPLACA; 2001

rios e istresas SAD PAULO (ESTADO), EMPIASA, 1994; LOGIT; s, d: LUME 2002, SAOO PALCO (ESTADO), SMA, IPT, ZDOO:

limites administrativo $10 Q 1$, sd - BAO PAULO IESTADO), EMPLASA. 1994

corredoles de Conibus SAD PAULO (ESTADO). STM, 1996

rodomel SAO PALULO (ESTADO), 3TM, OERSA, PROTRAV, 2009

$10 \quad 20$ Quilómetros

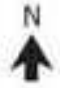

http://lume.fau.usp.br/tikiwiki/tiki-

index.php?page=São\%20Paulo\%20Metrópole\#attachments - acesso em 18.06.2008 - Organização da autora. 
Mapa 2 - Região Metropolitana de São Paulo Redes Ferroviária, Metroviária e de Corredores Metropolitanos de Ônibus
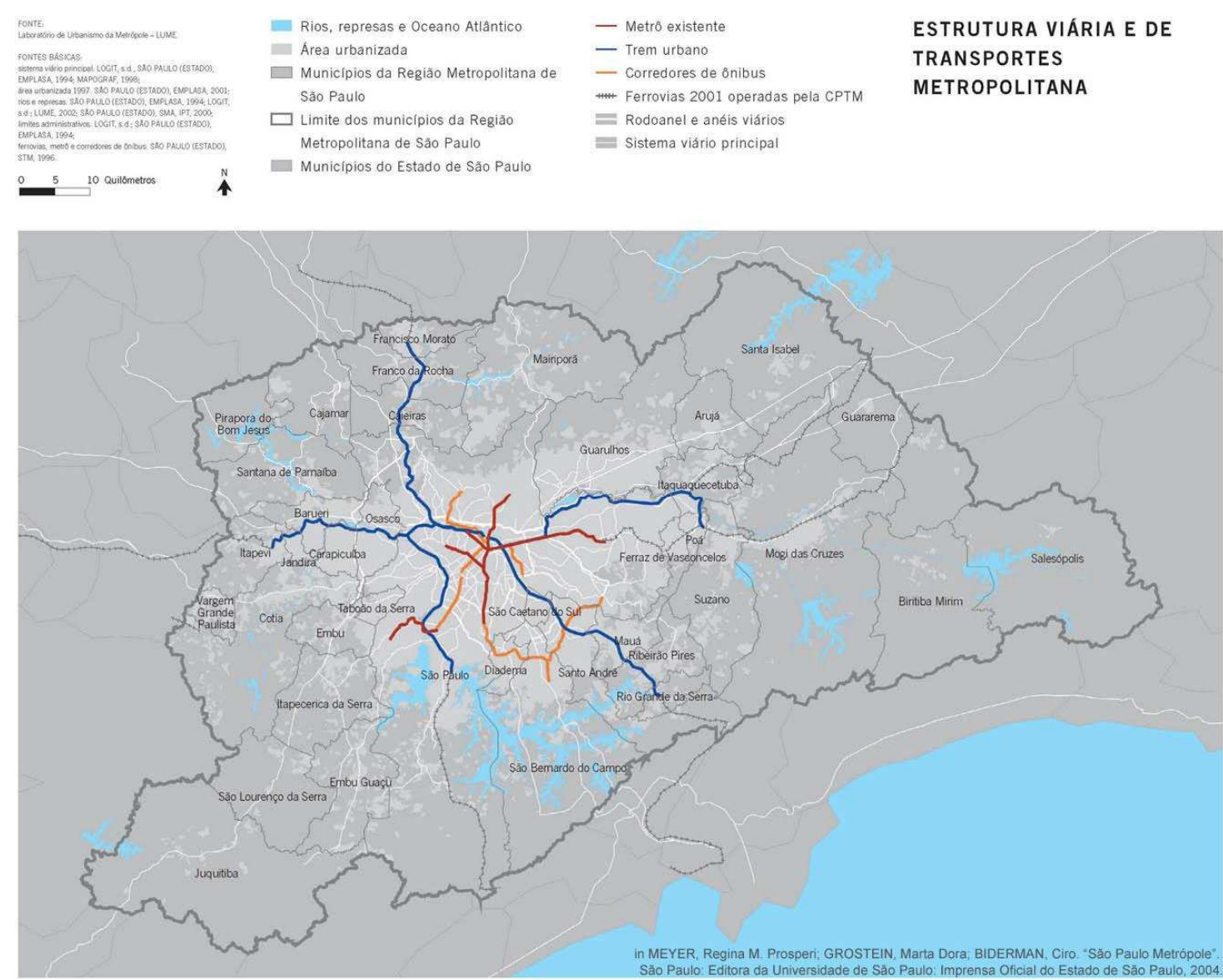

Fonte: http://lume.fau.usp.br/tikiwiki/tiki-index.php?page=São\%20Paulo\%20Metrópole\#attachments acesso em 18.06.2008

O sistema viário da metrópole é composto ainda por uma rede ferroviária e metroviária implantada no formato radial, que vem sendo reestruturada, notadamente a partir dos anos 1990, de forma a tornar-se efetivamente uma rede sobre trilhos. Até o momento, somando-se o sistema de trens metropolitanos e o sistema do metrô, há 318,8 km de vias sobre trilhos na cidade.

As informações da Tabela 1 referem-se a dados gerais sobre os municípios da RMSP: 
Tabela 1 - Região Metropolitana de São Paulo - Sub-Regiões e Municípios Área, Grau de Urbanização, População, Taxa Geométrica de Crescimento Anual (TGCA), Densidade Demográfica, PIB per capita, Participação no PIB Estadual e IDH

\begin{tabular}{|c|c|c|c|c|c|c|c|c|c|c|c|}
\hline $\begin{array}{c}\text { MUNICÍPIOS } \\
\text { E } \\
\text { SUB-REGIÕES }\end{array}$ & $\begin{array}{c}\text { ÁREA } \\
\text { TOTAL } \\
\mathrm{Km}^{2} \\
(2007)\end{array}$ & $\begin{array}{c}\text { GRAU DE } \\
\text { URBANIZAÇÃO } \\
(\%) \\
(2007)\end{array}$ & $\begin{array}{l}\text { POPULAÇÃO } \\
\text { RESIDENTE } \\
(2007)\end{array}$ & $\begin{array}{c}\text { POPULAÇÃO } \\
\text { URBANA } \\
(2007)\end{array}$ & $\begin{array}{l}\text { POPULAÇÃO } \\
\text { RURAL } \\
(2007)\end{array}$ & $\begin{array}{c}\text { TGCA(\%) } \\
(2000- \\
2007)\end{array}$ & $\begin{array}{c}\text { DENSIDADE } \\
\text { DEMOGRÁFICA } \\
\text { Hab./km }{ }^{2} \\
(2002)\end{array}$ & $\begin{array}{c}\text { PARTICIPAÇÃO } \\
\text { NO PIB DO } \\
\text { ESTADO DE } \\
\text { SÃO PAULO } \\
(2005) \\
\end{array}$ & $\begin{array}{c}\text { PIB per } \\
\text { capita } \\
(2005) \\
\text { Em reais } \\
\text { correntes }\end{array}$ & $\begin{array}{l}\text { (IDH) } \\
(1991)\end{array}$ & $\begin{array}{l}\text { (IDH) } \\
\text { (2000) }\end{array}$ \\
\hline CENTRO & 1.509 & 92,0 & 10.834 .244 & 9.967 .061 & 867.183 & $\mathbf{0 , 5 5}$ & $6.992,92$ & 36,19 & $24.082,86$ & 0,805 & 0,841 \\
\hline São Paulo & 1.509 & 92,0 & 10.834 .244 & 9.967 .061 & 867.183 & 0,55 & $6.992,92$ & 36,19 & $24.082,86$ & 0,805 & 0,841 \\
\hline OESTE & 904 & 100,0 & 2.055 .063 & 2.055 .056 & 7 & 3,68 & $\mathbf{3 . 5 7 4 , 5 7}$ & 7,07 & NA & NA & NA \\
\hline Barueri & 61 & 100,0 & 273.016 & 273.016 & - & 4,01 & $3.691,74$ & 3,08 & $87.337,92$ & 0,779 & 0,826 \\
\hline Carapicuíba & 36 & 100,0 & 389.118 & 389.118 & - & 1,78 & $9.914,25$ & 0,26 & $5.003,72$ & 0,764 & 0,793 \\
\hline Cotia & 325 & 100,0 & 184.719 & 184.719 & - & 3,17 & 487,48 & 0,47 & $19.840,13$ & 0,787 & 0,826 \\
\hline Itapevi & 79 & 100,0 & 206.374 & 206.374 & - & 3,54 & $2.200,76$ & 0,24 & $9.205,39$ & 0,717 & 0,759 \\
\hline Jandira & 22 & 100,0 & 116.724 & 116.724 & - & 3,54 & $4.472,82$ & 0,15 & $9.916,52$ & 0,742 & 0,801 \\
\hline Osasco & 68 & 100,0 & 710.984 & 710.984 & - & 1,25 & $9.833,13$ & 2,51 & $25.955,70$ & 0,783 & 0,818 \\
\hline $\begin{array}{c}\text { Pirapora do } \\
\text { Bom Jesus } \\
\end{array}$ & 99 & 99,96 & 16.639 & 16.632 & 7 & 4,36 & 135,91 & 0,01 & $7.274,36$ & 0,708 & 0,767 \\
\hline $\begin{array}{c}\text { Santana do } \\
\text { Parnaíba }\end{array}$ & 176 & 100,0 & 109.081 & 109.081 & - & 5,63 & 473,04 & 0,30 & $22.906,62$ & 0,79 & 0,853 \\
\hline $\begin{array}{c}\text { Vargem Grande } \\
\text { Paulista }\end{array}$ & 38 & 100,0 & 48.408 & 48.408 & - & 5,87 & 962,08 & 0,05 & $9.758,28$ & 0,738 & 0,802 \\
\hline SUDOESTE & 1.137 & 93,36 & 781.034 & 767.727 & 13.307 & 3,59 & $2.509,98$ & 1,01 & NA & NA & NA \\
\hline Embu & 68 & 100,0 & 250.532 & 250.532 & - & 2,76 & $3.224,66$ & 0,25 & $7.641,57$ & 0,749 & 0,772 \\
\hline Embu-Guaçu & 171 & 98,56 & 76.639 & 75.532 & 1.107 & 4,41 & 361,58 & 0,05 & $5.252,10$ & 0,73 & 0,811 \\
\hline $\begin{array}{c}\text { Itapecerica da } \\
\text { Serra }\end{array}$ & 136 & 99,21 & 175.864 & 174.467 & 1.397 & 4,51 & $1.041,04$ & 0,26 & $12.240,28$ & 0,747 & 0,783 \\
\hline Juquitiba & 550 & 71,05 & 32.274 & 22.930 & 9.344 & 2,92 & 50,84 & 0,02 & $5.774,54$ & 0,668 & 0,754 \\
\hline $\begin{array}{c}\text { São Lourenço } \\
\text { da Serra }\end{array}$ & 192 & 91,35 & 16.876 & 15.417 & 1.459 & 4,81 & 69,58 & 0,01 & $7.976,06$ & NA & 0,771 \\
\hline Taboão da Serra & 20 & 100,0 & 228.849 & 228.849 & - & 2,15 & $10.312,20$ & 0,42 & $13.969,84$ & 0,767 & 0,809 \\
\hline SUDESTE & 841 & 100,0 & 2.569 .208 & 2.556 .572 & 12.636 & 1,29 & $5.188,01$ & 7,19 & NA & NA & NA \\
\hline Diadema & 32 & 100,0 & 389.271 & 389.271 & - & 1,26 & $11.439,50$ & 1,01 & $18.856,26$ & 0,746 & 0,790 \\
\hline Mauá & 67 & 100,0 & 411.844 & 411.844 & - & 1,83 & $5.620,04$ & 0,66 & $11.966,40$ & 0,754 & $\begin{array}{c}0,781 \\
\text { continua }\end{array}$ \\
\hline
\end{tabular}


continuação

\begin{tabular}{|c|c|c|c|c|c|c|c|c|c|c|c|}
\hline $\begin{array}{l}\text { MUNICÍPIOS } \\
\text { E } \\
\text { SUB-REGIÕES }\end{array}$ & $\begin{array}{l}\text { ÁREA } \\
\text { TOTAL } \\
\mathrm{Km}^{2} \\
(2007)\end{array}$ & $\begin{array}{c}\text { GRAU DE } \\
\text { URBANIZAÇÃO } \\
(\%) \\
(2007)\end{array}$ & $\begin{array}{l}\text { POPULAÇÃO } \\
\text { RESIDENTE } \\
\text { (2007) }\end{array}$ & $\begin{array}{l}\text { POPULAÇÃO } \\
\text { URBANA } \\
(2007)\end{array}$ & $\begin{array}{l}\text { POPULAÇÃO } \\
\text { RURAL } \\
(2007)\end{array}$ & $\begin{array}{c}\text { TGCA(\%) } \\
(2000- \\
2007)\end{array}$ & $\begin{array}{c}\text { DENSIDADE } \\
\text { DEMOGRÁFICA } \\
\text { Hab./km² } \\
(2002)\end{array}$ & $\begin{array}{c}\text { PARTICIPAÇÃO } \\
\text { NO PIB DO } \\
\text { ESTADO DE } \\
\text { SÃO PAULO } \\
(2005) \\
\end{array}$ & $\begin{array}{l}\text { PIB per } \\
\text { capita } \\
(2005) \\
\text { Em reais } \\
\text { correntes }\end{array}$ & $\begin{array}{l}\text { (IDH) } \\
(1991)\end{array}$ & $\begin{array}{l}\text { (IDH) } \\
(2000)\end{array}$ \\
\hline Ribeirão Pires & 107 & 100,0 & 119.180 & 119.180 & - & 1,92 & $1.014,32$ & 0,15 & $9.779,22$ & 0,776 & 0,807 \\
\hline $\begin{array}{l}\text { Rio Grande da } \\
\text { Serra }\end{array}$ & 31 & 100,0 & 42.601 & 42.601 & - & 2,03 & $1.244,39$ & 0,03 & $5.755,12$ & 0,727 & 0,764 \\
\hline Santo André & 181 & 100,0 & 676.723 & 676.723 & - & 0,60 & $3.629,59$ & 1,57 & $17.065,58$ & 0,808 & 0,835 \\
\hline $\begin{array}{c}\text { São Bernardo } \\
\text { do Campo }\end{array}$ & 411 & 98,41 & 792.617 & 779.981 & 12.636 & 1,75 & $1.770,71$ & 2,67 & $24.662,70$ & 0,806 & 0,834 \\
\hline $\begin{array}{l}\text { São Caetano do } \\
\text { Sul }\end{array}$ & 12 & 100,0 & 136.972 & 136.972 & - & $-0,34$ & $11.597,58$ & 1,1 & $59.596,34$ & 0,842 & 0,919 \\
\hline LESTE & 2.135 & 90,36 & 1.392 .634 & 1.339 .693 & 52.941 & 2,81 & $2.181,65$ & 1,79 & NA & NA & NA \\
\hline Biritiba Mirim & 414 & 86,97 & 30.625 & 26.635 & 3.990 & 3,19 & 63,22 & 0,02 & $5.691,55$ & 0,7 & 0,750 \\
\hline $\begin{array}{c}\text { Ferraz de } \\
\text { Vasconcelos }\end{array}$ & 25 & 99,34 & 182.898 & 181.695 & 1.203 & 3,7 & $6.118,48$ & 0,10 & $4.628,99$ & 0,713 & 0,772 \\
\hline Guararema & 262 & 82,75 & 25.064 & 20.741 & 4.323 & 1,97 & 86,78 & 0,05 & $14.940,66$ & 0,705 & 0,798 \\
\hline Itaquaquecetuba & 83 & 100,0 & 367.042 & 367.042 & - & 4,39 & $3.583,99$ & 0,23 & $5.090,08$ & 0,704 & 0,744 \\
\hline $\begin{array}{c}\text { Mogi das } \\
\text { Cruzes }\end{array}$ & 721 & 92,25 & 374.168 & 345.174 & 28.994 & 1,83 & 474,32 & 0,60 & $12.091,80$ & 0,763 & 0,801 \\
\hline Poá & 17 & 98,93 & 108.651 & 107.487 & 1.164 & 1,85 & $5.838,82$ & 0,20 & $15.744,25$ & 0,765 & 0,806 \\
\hline Salesópolis & 418 & 65,28 & 16.672 & 10.884 & 5.788 & 2,19 & 35,78 & 0,01 & $8.474,29$ & 0,695 & 0,758 \\
\hline Suzano & 195 & 97,40 & 287.514 & 280.035 & 7.479 & 3,37 & $1.251,82$ & 0,58 & $15.744,25$ & 0,734 & 0,775 \\
\hline NORDESTE & 709 & 90,58 & 1.413.831 & 1.376.405 & 37.426 & 2,78 & $1.393,51$ & 3,13 & NA & NA & NA \\
\hline Arujá & 96 & 96,69 & 79.364 & 76.736 & 2.628 & 4,34 & 669,14 & 0,12 & $12.862,02$ & 0,745 & 0,788 \\
\hline Guarulhos & 334 & 98,16 & 1.286 .523 & 1.262 .788 & 23.735 & 2,67 & $3.387,06$ & 2,97 & $17.275,96$ & 0,762 & 0,798 \\
\hline Santa Isabel & 361 & 76,93 & 47.944 & 36.881 & 11.063 & 1,34 & 124,35 & 0,04 & $7.586,09$ & 0,701 & 0,766 \\
\hline NORTE & 734 & 95,09 & 540.251 & 520.372 & 19.879 & 3,68 & $1.070,84$ & $\mathbf{0 , 7 1}$ & NA & NA & NA \\
\hline Caieiras & 104 & 97,14 & 98.485 & 95.671 & 2.814 & 4,82 & 751,52 & 0,14 & $11.390,94$ & 0,762 & 0,813 \\
\hline Cajamar & 135 & 95,77 & 65.050 & 62.296 & 2.754 & 3,66 & 403,25 & 0,26 & $31.184,82$ & 0,735 & 0,786 \\
\hline $\begin{array}{c}\text { Francisco } \\
\text { Morato }\end{array}$ & 45 & 99,90 & 172.872 & 172.705 & 167 & 3,8 & $3.199,22$ & 0,07 & $3.108,56$ & 0,713 & 0,738 \\
\hline $\begin{array}{c}\text { Franco da } \\
\text { Rocha }\end{array}$ & 143 & 98,60 & 126.286 & 124.523 & 1.763 & 2,38 & 789,92 & 0,16 & $9.705,96$ & 0,736 & 0,778 \\
\hline Mairiporã & 307 & 84,04 & 77.558 & 65.177 & 12.381 & 3,76 & 210,31 & 0,08 & $8.335,77$ & 0,761 & $\begin{array}{c}0,803 \\
\text { continua }\end{array}$ \\
\hline
\end{tabular}




\begin{tabular}{|c|c|c|c|c|c|c|c|c|c|c|c|}
\hline $\begin{array}{l}\text { MUNICÍPIOS } \\
\text { E } \\
\text { SUB-REGIÕES }\end{array}$ & \begin{tabular}{|c|} 
ÁREA \\
TOTAL \\
$\mathrm{Km}^{2}$ \\
$(2007)$
\end{tabular} & $\begin{array}{c}\text { GRAU DE } \\
\text { URBANIZAÇÃO } \\
(\%) \\
(2007)\end{array}$ & \begin{tabular}{|} 
POPULAÇÃO \\
RESIDENTE \\
(2007)
\end{tabular} & $\begin{array}{c}\text { POPULAÇÃO } \\
\text { URBANA } \\
(2007)\end{array}$ & \begin{tabular}{|c} 
POPULAÇÃO \\
RURAL \\
(2007)
\end{tabular} & $\begin{array}{c}\text { TGCA(\%) } \\
(2000- \\
2007)\end{array}$ & \begin{tabular}{|} 
DENSIDADE \\
DEMOGRÁFICA \\
Hab./km² $^{2}$ \\
$(2002)$
\end{tabular} & \begin{tabular}{|} 
PARTICIPAÇÃO \\
NO PIB DO \\
ESTADO DE \\
SÃO PAULO \\
$(2005)$
\end{tabular} & $\begin{array}{c}\text { PIB per } \\
\text { capita } \\
(2005) \\
\text { Em reais } \\
\text { correntes }\end{array}$ & $\begin{array}{l}\text { (IDH) } \\
\text { (1991) }\end{array}$ & $\begin{array}{c}\text { (IDH) } \\
(2000)\end{array}$ \\
\hline
\end{tabular}

Fonte: http://www.emplasa.sp.gov.br/portalemplasa/infometropolitana/rmsp/rmsp.asp - acesso em 21.02.2008

NA : não se aplica

- : dado inexistente

Organização da autora. 
Observando-se a Tabela 1, podemos verificar que o grau de urbanização da RMSP é bastante alto, com média de 94,88\%, variando entre os menores percentuais, de $65,28 \%$, em Salesópolis, e 71,05\%, em Juquitiba, até 100,0\% em dezessete dos municípios. Assim, no total da região, a diferença entre a população urbana e a rural é muito grande: há cerca de dezoito vezes mais população residindo na área urbana do que na área rural. As sub-regiões Sudeste (Diadema, Mauá, Ribeirão Pires, Rio Grande da Serra, Santo André, São Bernardo do Campo, São Caetano do Sul) e Oeste (Barueri, Carapicuíba, Cotia, Itapevi, Jandira, Osasco, Pirapora do Bom Jesus, Santana do Parnaíba, Vargem Grande Paulista) são as mais urbanizadas, com praticamente toda a população vivendo na área urbana.

Entendemos que ter uma população rural em uma metrópole como São Paulo talvez não seja exatamente ter uma população que viva um modo de vida rural. Quanto à população urbana, também é uma classificação discutível, ou seja, até que ponto esta população urbana realmente usufrui o modo de vida urbano? Questionamos ainda até que ponto são confiáveis os dados sobre grau de urbanização de $100 \%$ de municípios como Cotia, Santana do Parnaíba, Embu, Ribeirão Pires, Rio Grande da Serra e Itaquaquecetuba.

O município de São Paulo é o mais populoso, com 10.834.244 habitantes, sendo seguido pelos municípios de Guarulhos, com 1.286.523 habitantes, São Bernardo do Campo, com 792.617 habitantes, Osasco, com 710.984 habitantes e Santo André, com 676.723 habitantes. Os demais municípios da RMSP apresentam população bem menor.

Reportagem da Folha de São Paulo de 18.02.2007 informou que 441 mil moradores mudaram-se do centro expandido da Capital para outras áreas da RMSP, e a periferia apresentava, em 2007, 1,23 milhão de moradores a mais do que em 1996. Além do crescimento de distritos da Capital, como o Grajaú e Anhanguera, com moradias de baixo padrão, a reportagem mostra o crescimento de outros municípios, como Barueri, Vargem 
Grande Paulista e Santana do Parnaíba, com concentração de condomínios de luxo ${ }^{88}$. De fato, observando-se a Tabela 1, verificamos que a Taxa Geométrica de Crescimento Anual (TGCA) de Barueri é de 4,01\%, para o período de 2000-2007; Santana do Parnaíba, 5,63\% e Vargem Grande Paulista, 5,87\%, sobressaindo-se ainda Pirapora do Bom Jesus, com 4,36\%. Outros municípios periféricos também apresentam taxas razoáveis de crescimento, como EmbuGuaçu (4,41\%), Itapecerica da Serra (4,51\%), São Lourenço da Serra (4,81\%), Itaquaquecetuba (4,39\%), Arujá (4,34\%) e Caieiras (4,82\%), mas não concentram condomínios de luxo. Ao invés disso, aglomeram-se, nestas periferias, bolsões de pobreza.

Tal aglomeração populacional é bastante observada em municípios carentes de emprego, como Ferraz de Vasconcelos e Carapicuíba (Fotografia 1). Por outro lado, há municípios com baixa densidade demográfica, mas também desprovidos de empregos. Em ambos os casos, os moradores precisam viajar diariamente para seu trabalho em municípios mais desenvolvidos da região, como São Paulo, Osasco, Guarulhos e ABC Paulista. Voltaremos a este tema no decorrer do trabalho.

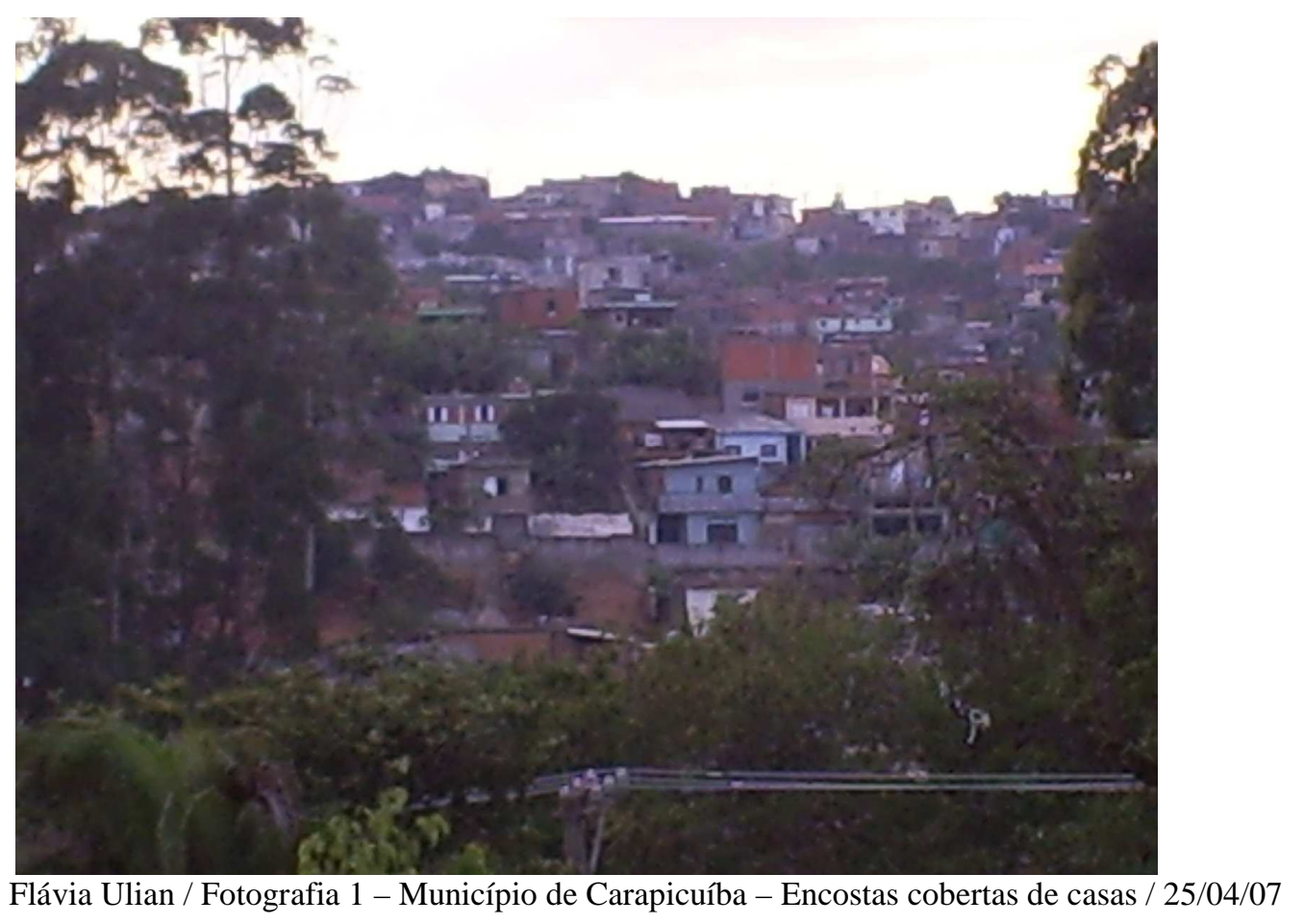

${ }^{88}$ GALVÃO \& GALLO, 2008. 
A metrópole paulistana teve o crescimento acelerado da população no decorrer do século XX, notadamente nas décadas de 1960 e 1970. Entre 1960 e 1970, a TGCA foi, em média, na RMSP, de 5,44\%. Alguns municípios tiveram taxas muito elevadas, como por exemplo Diadema, com 20,42\% de TGCA, e Taboão da Serra, com 19,03\% naquele período. Entre 1970 e 1980, a média da TGCA na RMSP caiu para 4,46\%. Entre 1980 e 1987, a TGCA média na RMSP foi de 1,39\%, ou seja, houve grande diminuição do crescimento populacional. Entre 2000 e 2007, a taxa caiu mais ainda, para 1,33\%, como mostrou a Tabela 1.

Informações do início da década de 1990 apontam que os vetores metropolitanos consolidados eram aqueles com crescimento negativo da população, isto é, com crescimento inferior ao da média da Metrópole. São os lugares mais antigos do município de São Paulo, com níveis de saturação do padrão de assentamento atual, destacando-se o Centro da Capital, que chegou a perder, na década de 1980, 150 mil habitantes ${ }^{89}$. Atualmente, verifica-se que esse processo não foi revertido, apesar das vantagens de infra-estrutura disponíveis nesse vetor. A Tabela 1 nos mostra que a TGCA 2000-2007, para o município de São Paulo foi de apenas 0,55 , confirmando a consolidação desse vetor.

No início do período em análise (década de 1990), os vetores considerados como em processo de consolidação compreendiam os municípios do ABC Paulista, cujo crescimento apresentava taxas decrescentes, mas, apesar disso, permaneciam ainda acima da média metropolitana ${ }^{90}$. No final do período em análise, conforme podemos aferir pela Tabela 1, apenas a sub-região Sudeste, que engloba os municípios do ABC Paulista, chegou a ter a TGCA entre 2000 e 2007 ligeiramente inferior à média da RMSP. As taxas de Santo André e São Caetano do Sul foram menores que 1\%, sendo, inclusive, negativa neste município,

\footnotetext{
${ }^{89}$ SÃO PAULO, 1994a.

${ }^{90}$ Ibidem.
} 
confirmando assim a tendência acenada no início dos anos 90 de consolidação desse vetor. Faremos uma apreciação detalhada sobre esta sub-região da RMSP, apoiada pelos dados da Tabela 1:

\section{Sub-região Sudeste: Diadema, Mauá, Ribeirão Pires, Rio Grande da Serra, Santo André, São Bernardo do Campo, São Caetano do Sul}

Diferentemente das outras sub-regiões da RMSP, a sub-região Sudeste é altamente densa, com uma média de 5.188,01 hab./ $\mathrm{km}^{2}$ (dados de 2002), sendo os municípios mais densamente ocupados Diadema (11.439,50 hab./ $\left.\mathrm{km}^{2}\right)$ e São Caetano do Sul $(11.597,58$ hab. $/ \mathrm{km}^{2}$ ). Sobressai-se a presença da atividade industrial e mais recentemente de serviços. O padrão de ocupação está relativamente estabilizado em São Caetano do Sul, São Bernardo do Campo, Diadema e grande parte de Santo André, com um ritmo elevado de ocupação recente na porção sul de Santo André e municípios de Mauá, Ribeirão Pires e Rio Grande da Serra ${ }^{91}$.

Os PIB per capita de alguns municípios desta sub-região sofreram grande aumento entre 2002 e 2005, como o do município de São Caetano do Sul, com aumento de $\mathrm{R} \$ 29.100,00$, passando para $\mathrm{R} \$ 59.596,34$ em 2005; o de São Bernardo do Campo, com aumento de $\mathrm{R} \$ 7.300,00$, passando para $\mathrm{R} \$ 24.662,70$ em 2005; e o de Diadema, com aumento de $\mathrm{R} \$ 7.000,00$, elevando-se para $\mathrm{R} \$ 18.856,26$.

Por possuir um sistema de transporte metropolitano estruturado no trem metropolitano e no corredor São Mateus-Jabaquara ${ }^{92}$ (Fotografia 2), a região tem o trem como estruturador de seu transporte coletivo. O Corredor Metropolitano - com canaleta exclusiva na maior parte de seu percurso, operado por linhas estruturais e adotando veículos de grande capacidade liga São Mateus, na Capital, a Ferrazópolis, em São Bernardo do Campo, passando por Santo André e Jabaquara, em São Paulo, e depois por Diadema.

\footnotetext{
${ }^{91}$ SÃO PAULO, 1999.

${ }^{92}$ Ibidem.
} 
O sistema de transporte coletivo sobre pneus da sub-região Sudeste é voltado para ligações internas, para o centro metropolitano, para a zona Leste da Capital, para os terminais de metrô Saúde e São Judas, em São Paulo, e para ligações inter-regionais com a sub-região Leste (Ferraz de Vasconcelos, Itaquaquecetuba, Mogi das Cruzes, Poá e Suzano) ${ }^{93}$.

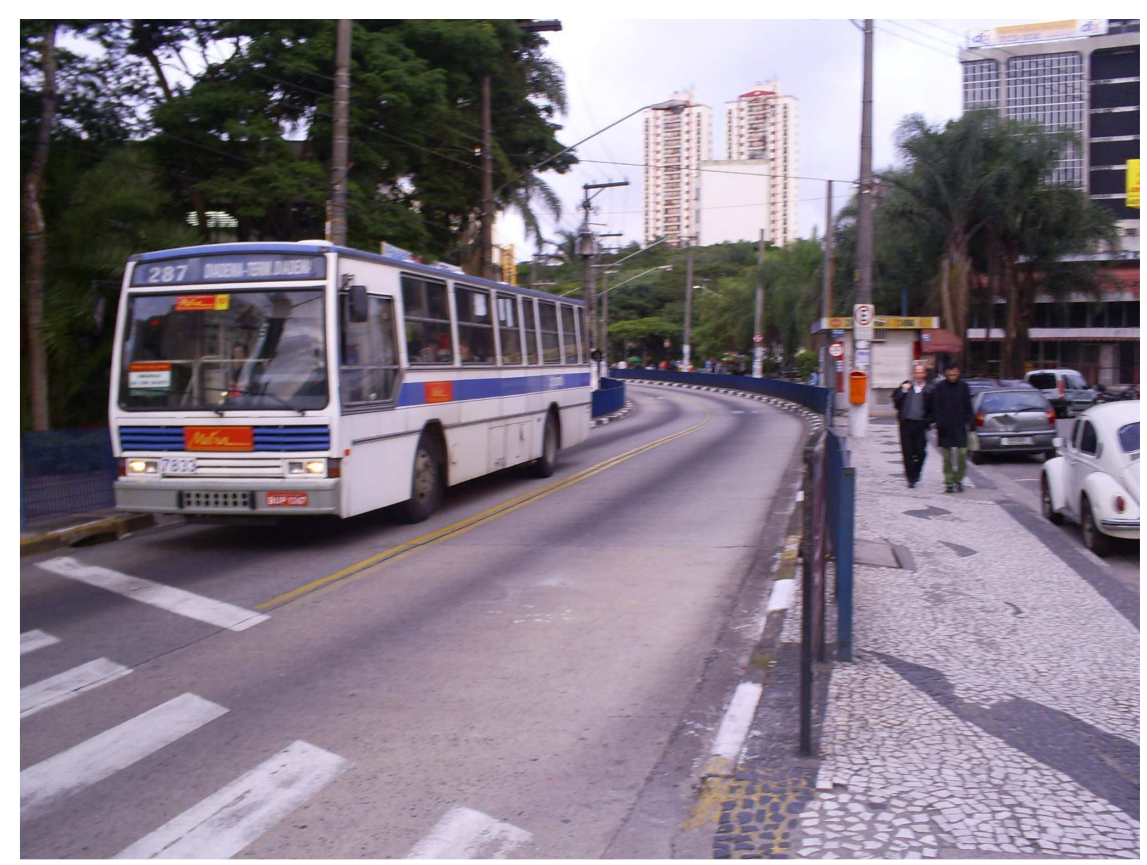

Autoria: Flávia Ulian

Fotografia 2 - Município de Diadema - Corredor Metropolitano São Mateus-Jabaquara / 30/05/07

Quanto aos vetores da RMSP em processo de expansão no início da década de 1990, consistiam naqueles cuja população vinha crescendo a taxas bastante superiores à média metropolitana. Eram as áreas do extremo Leste da Capital e parte da sub-região Leste (Ferraz de Vasconcelos, Itaquaquecetuba, Mogi das Cruzes, Poá e Suzano), da sub-região Norte (Caieiras, Cajamar, Francisco Morato, Franco da Rocha), da sub-região Nordeste (Arujá e Guarulhos), da sub-região Sudoeste (Embu, Embu-Guaçu, São Lourenço da Serra e Taboão da Serra) e da sub-região Oeste, apenas excetuando-se Pirapora do Bom Jesus (Barueri, Carapicuíba, Cotia, Itapevi, Jandira, Osasco, Santana do Parnaíba e Vargem Grande

\footnotetext{
${ }^{93}$ SÃO PAULO, 1999.
} 
Paulista) ${ }^{94}$. Na década de 2000, verificou-se que este crescimento continuou, como mostra a Tabela 1. Notamos apenas algumas diferenças, que são dignas de nota: na sub-região Oeste, Osasco e Carapicuíba tiveram incremento populacional bastante diminuído, sendo que o crescimento de Osasco foi inferior à média da RMSP; além, disso, houve a entrada de Pirapora do Bom Jesus para o vetor de expansão. Na sub-região Sudoeste, além dos municípios citados, que já tinham forte expansão populacional no início dos anos 1990, acrescentamos Itapecerica da Serra e Juquitiba, com incremento populacional nos anos 2000. Na sub-região Leste, diminuiu o crescimento de Mogi das Cruzes e Poá. O crescimento das demais sub-regiões mencionadas permaneceu nos anos 2000. Faremos um exame destas subregiões, amparado pelos dados da Tabela 1:

\section{Sub-região Leste: Biritiba Mirim, Ferraz de Vasconcelos, Guararema, Itaquaquecetuba, Mogi das Cruzes, Poá, Salesópolis, Suzano}

Verificamos a existência de extensas áreas desocupadas, com padrão heterogêneo de ocupação urbana, em que coexistem áreas de alta densidade demográfica, como Ferraz de Vasconcelos $\left(6.118,48\right.$ hab. $\left./ \mathrm{km}^{2}\right)$, Itaquaquecetuba $(3.583,99$ hab./km²), Poá $(5.838,82$ hab./ $\mathrm{km}^{2}$ ) e alguns bairros de Suzano e Mogi das Cruzes, e outras de baixa densidade, como parcelas do município de Mogi das Cruzes e os municípios de Biritiba Mirim (63,22 hab./km²) (Fotografia 3), Guararema (86,78 hab./km²) e Salesópolis (35,78hab./km²).

Cabe também, aqui, uma referência quanto ao PIB de alguns municípios da sub-região Leste por serem extremamente baixos, como é o caso de Ferraz de Vasconcelos e Itaquaquecetuba, que giram em torno de $\mathrm{R} \$ 5.000,00$.

${ }^{94}$ SÃO PAULO, 1999. 


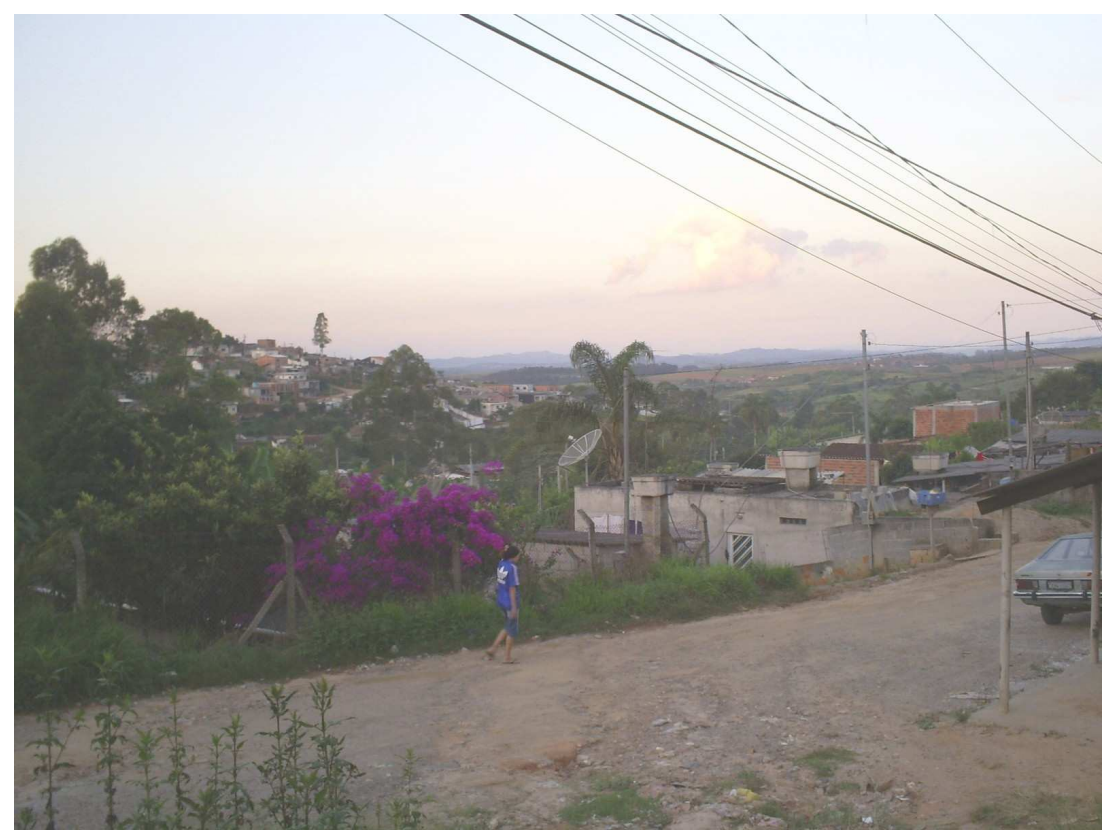

Autoria: Flávia Ulian

Fotografia 3 - Município de Biritiba-Mirim / 11/04/07

A presença do trem metropolitano é marcante na sub-região (Fotografia 4).

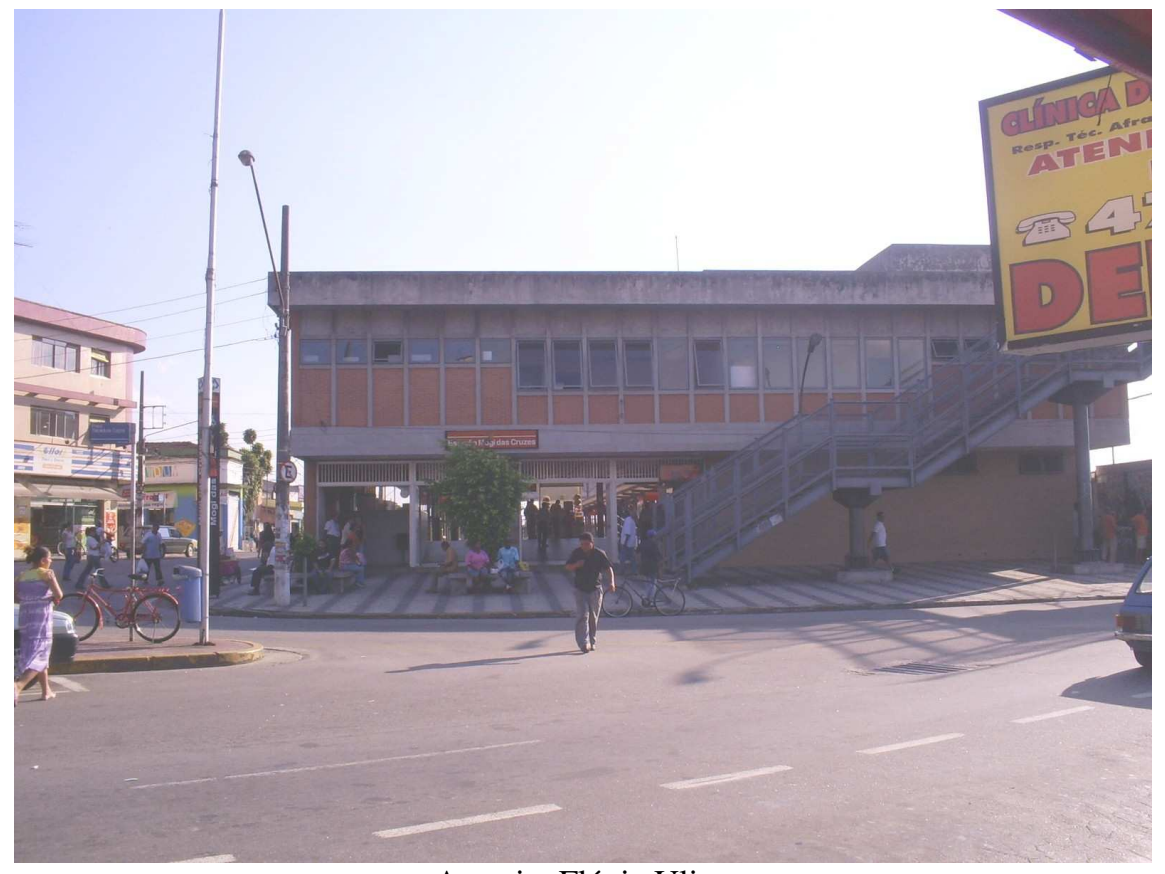

Autoria: Flávia Ulian

Fotografia 4 - Estação de trem do Município de Mogi das Cruzes / 11/04/07 
Já o sistema de transporte coletivo metropolitano sobre pneus é voltado para os pólos locais de Mogi das Cruzes (Fotografia 5), São Miguel Paulista (São Paulo) e Itaquera (São Paulo). Há ligações também internas e para o pólo do Brás e centro da Capital, além de ligações inter-regionais com as sub-regiões Nordeste (Arujá, Guarulhos e Santa Isabel) e Sudeste (Diadema, Mauá, Ribeirão Pires, Rio Grande da Serra, Santo André, São Bernardo do Campo e São Caetano do Sul $)^{95}$.

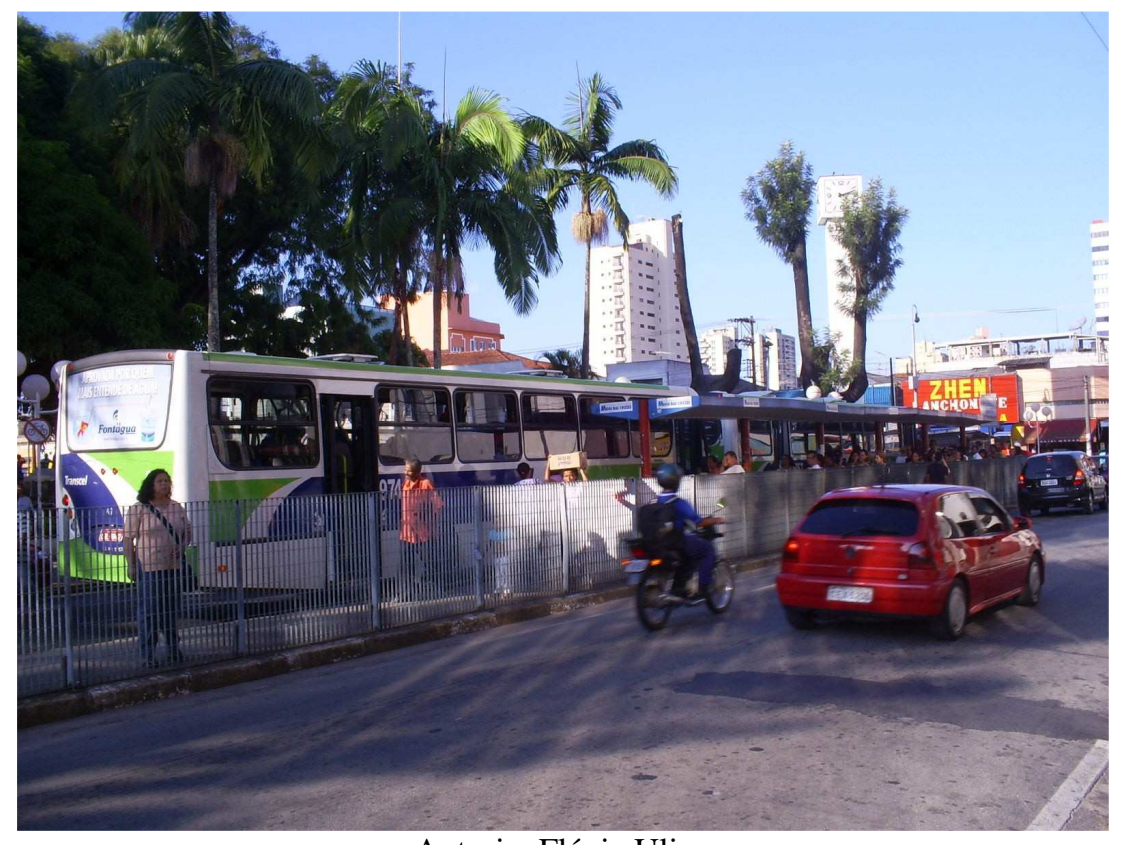

Autoria: Flávia Ulian

Fotografia 5 - Centro do município de Mogi das Cruzes / 11/04/07

\section{Sub-região Norte: Caieiras, Cajamar, Francisco Morato, Franco da Rocha, Mairiporã}

No final dos anos 1990, predominava o padrão de baixa densidade populacional com população de baixa renda, o que pode ser comprovado ainda nos anos 2000 pelos dados da Tabela 1, que indicam densidade demográfica média de $1.070,84$ hab. $/ \mathrm{km}^{2}$, principalmente porque Francisco Morato contribuiu para o aumento da média, com 3.199,22 hab./km², enquanto Mairiporã tinha 210,31 hab./ $/ \mathrm{km}^{2}$, em 2002. Quanto ao PIB per capita, o mais alto é 
o de Cajamar, de $\mathrm{R} \$ 31.184,22$ per capita, tendo sofrido aumento de $\mathrm{R} \$ 6.800,00$ entre 2002 e 2005; e o mais baixo, de Francisco Morato, de R\$3.108,56 per capita, em $2005^{96}$.

O trem metropolitano estrutura o sistema de transportes coletivos desta sub-região. $\mathrm{O}$ sistema de ônibus dos municípios de Caieiras, Franco da Rocha (Fotografia 6) e Francisco Morato é voltado para as ligações da sub-região com os pólos regionais da Lapa e Barra Funda e utilização da estrada velha de Campinas e avenida Raimundo Pereira de Magalhães. O uso da rodovia Anhangüera para o pólo regional da Lapa também é feito por estes municípios, bem como por Cajamar. Mairiporã liga-se à zona Norte do município de São Paulo pela rodovia Fernão Dias ${ }^{97}$. Há, ainda, ligações rodoviárias internas.

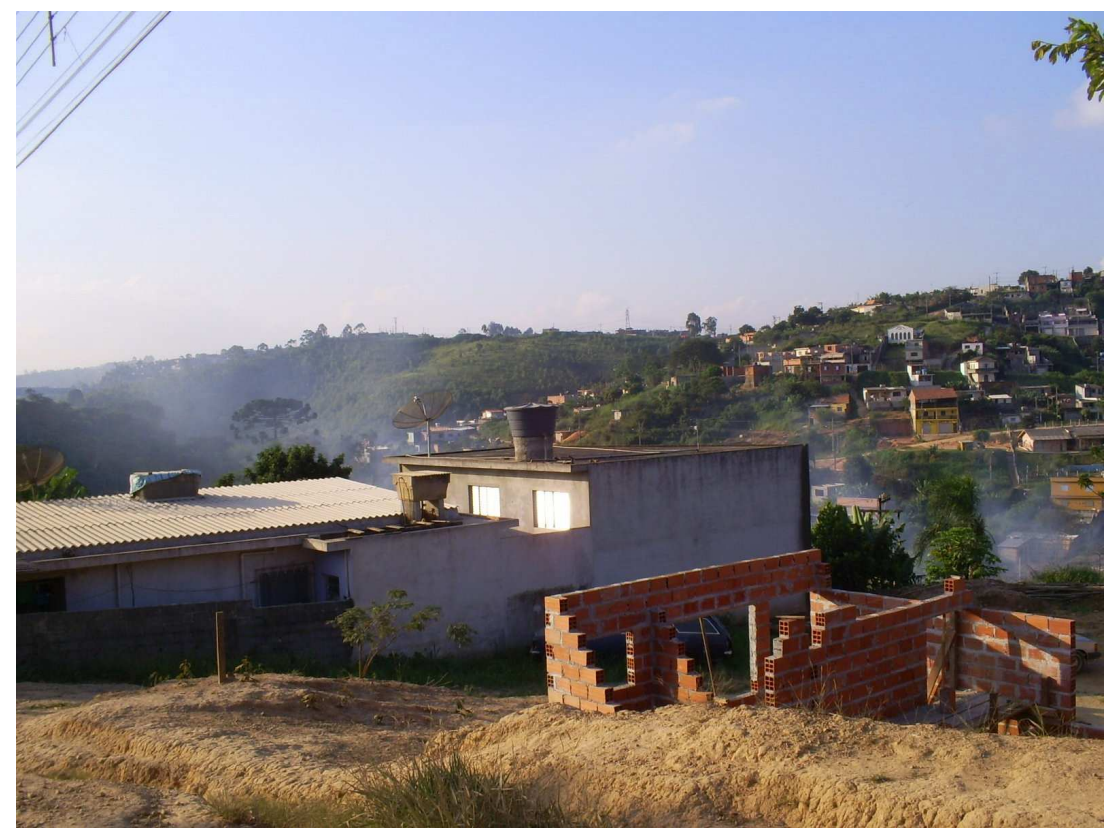

Autoria: Flávia Ulian

Fotografia 6 - Município de Franco da Rocha / 18/04/07

\footnotetext{
${ }^{96}$ SÃO PAULO, 1999.

${ }^{97}$ Ibidem.
} 


\section{Sub-região Nordeste: Arujá, Guarulhos e Santa Isabel}

Do mesmo modo que as anteriores, apresentava padrão heterogêneo de ocupação urbana no final da década de $1990^{98}$, com uma área de alta densidade, constituída pelo município de Guarulhos (3.387,06 hab./ $\mathrm{km}^{2}$ ) e áreas de baixa densidade nos municípios de Arujá e Santa Isabel $\left(669,14\right.$ hab./ $\mathrm{km}^{2}$ e 124,35 hab. $/ \mathrm{km}^{2}$, respectivamente). O município de Guarulhos era, em 1999, a segunda maior população do Estado de São Paulo. Em 2007, Guarulhos tinha 1.286.523 habitantes.

O perfil dos municípios de Arujá e Santa Isabel, diferentemente do de Guarulhos, demonstra o predomínio de imóveis rurais para a produção e o lazer. Alguns bairros destes municípios são dormitórios para população de baixa renda dependente de transporte coletivo que procura emprego nos municípios de Guarulhos e São Paulo. As viagens internas nesta sub-região, como também aquelas com o município de São Paulo, são em número bastante expressivo.

O sistema de transporte coletivo metropolitano está voltado para o centro do município de Guarulhos; para os pólos regionais de Itaim Paulista, São Miguel Paulista, Penha e Brás, na zona Leste do município de São Paulo; para as estações de metrô Armênia e Tietê, além de ligações para o centro da Capital e com municípios da sub-região Leste (Biritiba Mirim, Ferraz de Vasconcelos, Guararema, Itaquaquecetuba, Mogi das Cruzes, Poá, Salesópolis, Suzano $)^{99}$.

\footnotetext{
${ }^{98}$ SÃO PAULO, 1999.

${ }^{99}$ Ibidem.
} 


\section{Sub-região Sudoeste: Embu, Embu-Guaçu, Itapecerica da Serra, Juquitiba, São Lourenço da Serra, Taboão da Serra}

No final da década de 1990, verificava-se, na sub-região Sudoeste, a existência de vazios urbanos e regiões rarefeitas, com padrão heterogêneo de ocupação. A ocupação mais densa encontra-se no município de Taboão da Serra, na porção sudeste do município de Embu e alguns bairros do município de Itapecerica da Serra. A Tabela 1, mostra que as densidades demográficas de Taboão da Serra (10.312,20 hab./km²), Embu (3.224,66 hab./km²) e Itapecerica da Serra $\left(1.041,04 \mathrm{hab} . / \mathrm{km}^{2}\right)$ conviviam com as baixas densidades demográficas dos demais municípios, como por exemplo São Lourenço da Serra (69,58 hab./km²), em 2002.

Alguns municípios estão entre os que possuem os mais baixos PIB per capita da RMSP, como é o caso de Embu-Guaçu e Juquitiba, em torno de R \$5.000,00 per capita em 2005. Já Itapecerica da Serra teve um crescimento de $\mathrm{R} \$ 6.300,00$ de seu PIB per capita, passando para $\mathrm{R} \$ 12.240,28$.

No final da década de 1990, 47\% das linhas de ônibus tinham como destino o pólo regional de Pinheiros, no município de São Paulo. Verificava-se que praticamente a metade dos serviços de transportes públicos e da demanda dirigia-se a Pinheiros pela rodovia Régis Bittencourt (Fotografia 7) e avenida Francisco Morato ${ }^{100}$.

${ }^{100}$ SÃO PAULO, 1999. 


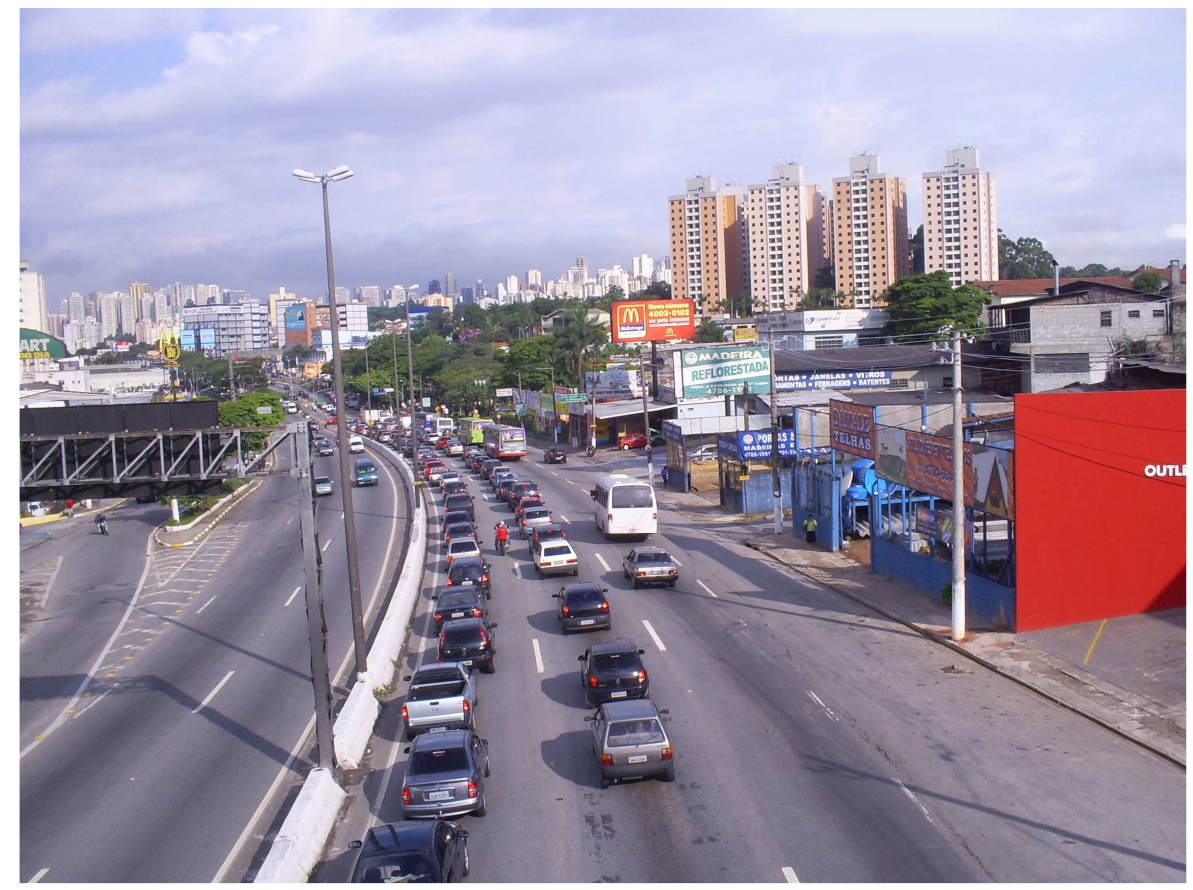

Autoria: Flávia Ulian

Fotografia 7 - Município de Taboão da Serra - Rodovia Régis Bittencourt / 31/01/07

Para o pólo regional de Santo Amaro dirigia-se 30\% dos passageiros, em 35\% das linhas de ônibus. A ligação com Santo Amaro dá-se pela estrada de Itapecerica e estrada de Campo Limpo. Especialmente o município de Embu-Guaçu liga-se apenas com o pólo regional de Santo Amaro por dois eixos viários principais: a estrada do M'Boi Mirim e a estrada de Parelheiros-avenida Teotônio Vilela ${ }^{101}$.

Verifica-se que, além do município de São Paulo, outra sub-região para onde a subregião Sudoeste produz mais deslocamentos é a Oeste, a ser analisada na seqüência.

\section{Sub-região Oeste: Barueri, Carapicuíba, Cotia, Itapevi, Jandira, Osasco, Pirapora do Bom Jesus, Santana do Parnaíba, Vargem Grande Paulista}

No final da década de 1990, verificava-se, nesta sub-região também um padrão heterogêneo de ocupação urbana. Dados da Tabela 1, referentes ao ano de 2002, atestam que áreas de alta densidade, como os municípios de Osasco $(9.833,13$ hab./km²) e Carapicuíba

${ }^{101}$ SÃO PAULO, 1999. 
(9.914,25 hab./ $\left./ \mathrm{km}^{2}\right)$, e alguns bairros de Barueri (3.691,74 hab./ $\left./ \mathrm{km}^{2}\right)$ e Jandira $(4.472,82$ hab./km²) (Fotografia 8), combinavam-se com áreas de baixa densidade de ocupação, como por exemplo o município de Pirapora do Bom Jesus (135,91 hab./km²).

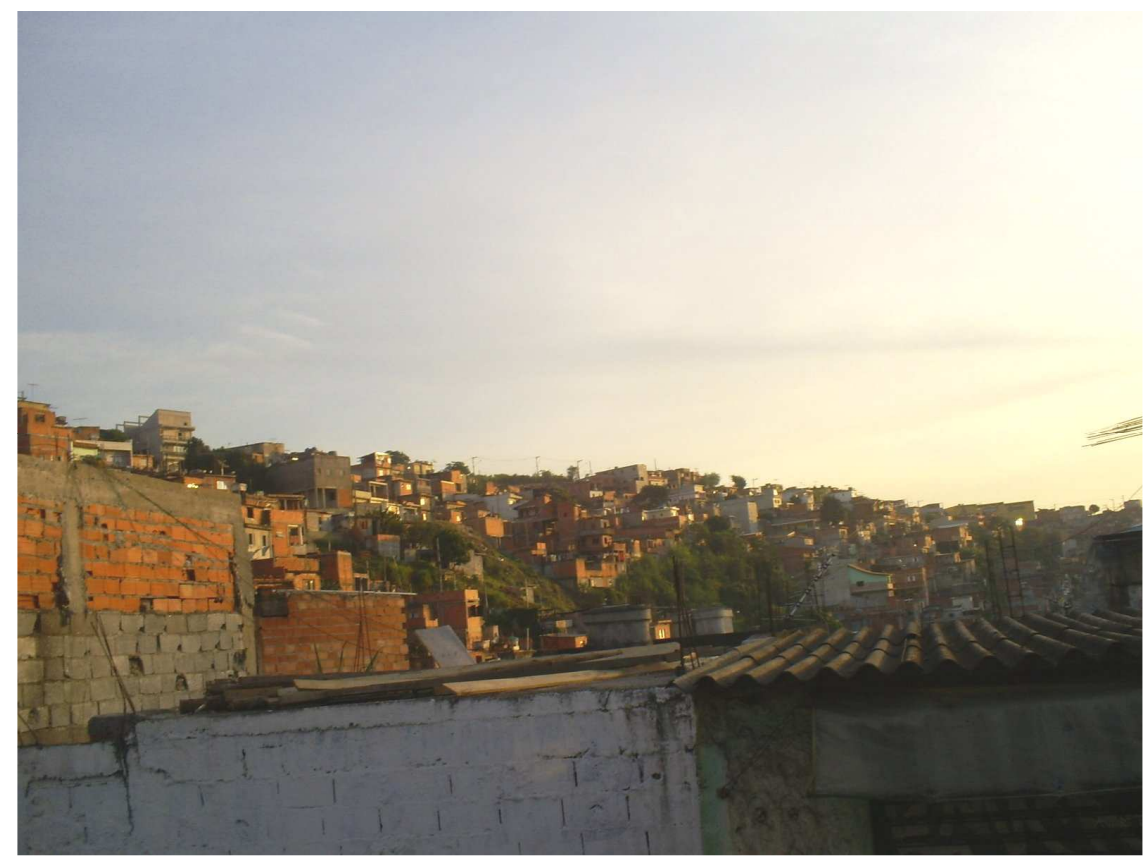

Autoria: Flávia Ulian

Fotografia 8 - Município de Jandira - Colinas com casas autoconstruídas / 02/05/07

Nesta sub-região, destaca-se a heterogeneidade da renda da população, havendo regiões de baixa renda nos municípios de Carapicuíba, Barueri, Jandira, Itapevi e Cotia, e alguns bairros de Osasco; renda média em Osasco; renda alta nos condomínios fechados de Barueri e Santana do Parnaíba (Alphaville e Tamboré), com uso intenso da rodovia Castelo Branco, e em Carapicuíba e Cotia (Granja Viana), com uso intenso da rodovia Raposo Tavares $^{102}$. Esta heterogeneidade de renda pode ser comprovada com os dados de 2005 da Tabela 1, que apresentam o PIB per capita da população dos municípios da RMSP: do mais elevado, $\mathrm{R} \$ 87.337,92$ per capita, em Barueri (Fotografia 9), ao mais baixo da sub-região, em Pirapora do Bom Jesus, de R\$7.274,36 per capita, passando pelos municípios de Osasco, 
com $\mathrm{R} \$ 25.955,70$ per capita e de Santana do Parnaíba, com $\mathrm{R} \$ 22.906,62$ per capita. Houve substancial incremento dos PIB per capita de alguns municípios desta sub-região, como é o caso de Barueri, com aumento, entre 2002 e 2005, de R\$36.000,00; Santana do Parnaíba, com aumento de $\mathrm{R} \$$ 9.600,00; Osasco, com aumento de $\mathrm{R} \$ 9.000,00$ do PIB per capita, e Cotia, com aumento de $\mathrm{R} \$ 7.500,00$ do PIB per capita.

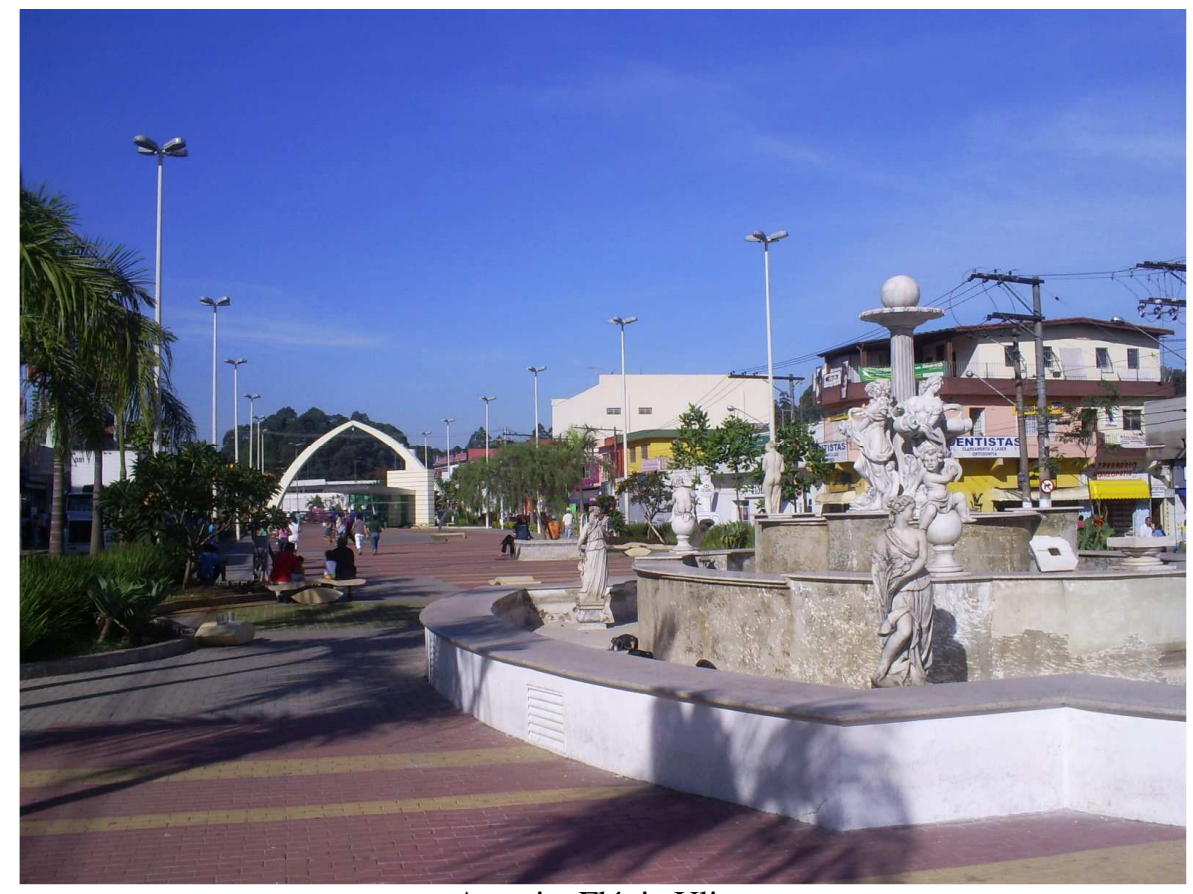

Autoria: Flávia Ulian

Fotografia 9 - Centro do município de Barueri / 02/05/07

A principal característica do sistema de transporte desta sub-região é o trem metropolitano, que estrutura o transporte coletivo nos municípios de Osasco (Fotografia 10), Carapicuíba, Barueri, Jandira e Itapevi ${ }^{103}$. 


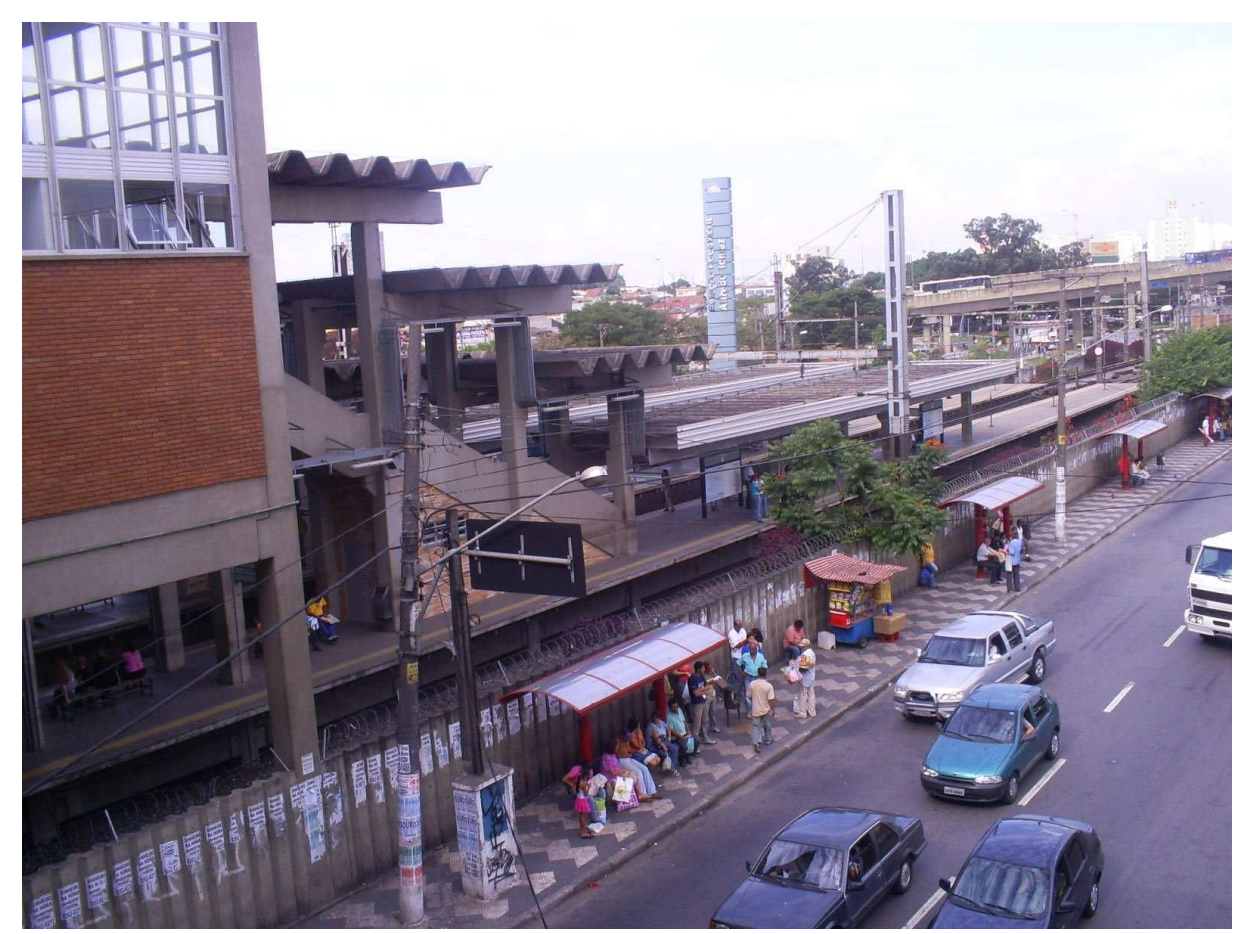

Autoria: Flávia Ulian

Fotografia 10 - Estação de trem metropolitano do município de Osasco / 25/04/07

Os municípios de Osasco (Fotografia 11), Carapicuíba, Barueri, Jandira, Itapevi, Santana do Parnaíba e Pirapora do Bom Jesus têm sistema de transporte coletivo metropolitano por ônibus até os pólos regionais paulistanos da Lapa e Pinheiros ${ }^{104}$. 


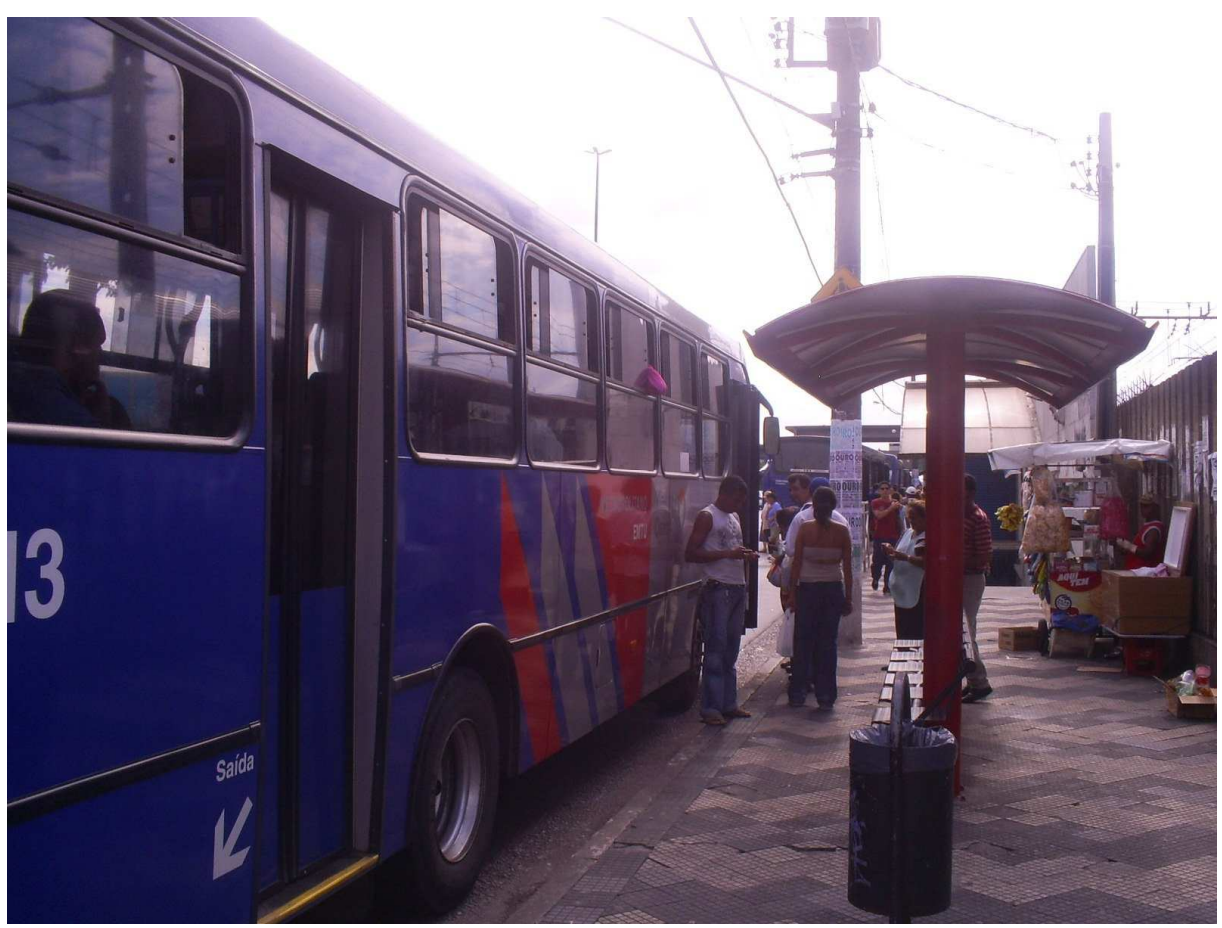

Autoria: Flávia Ulian

Fotografia 11 - Município de Osasco - Ponto de ônibus intermunicipais, onde ambulante vende passes de ônibus 25/04/07

Há, ainda, ligações internas intensas com mais duas sub-regiões da RMSP, além do município de São Paulo: a sub-região Sudoeste (Embu, Embu-Guaçu, Itapecerica da Serra, Juquitiba, São Lourenço da Serra, Taboão da Serra) e a sub-região Sudeste (Diadema, Mauá, Ribeirão Pires, Rio Grande da Serra, Santo André, São Bernardo do Campo, São Caetano do Sul).

Com relação ao $\mathrm{IDH}^{105}$, verificamos que também houve crescimento do índice em absolutamente todos os municípios da RMSP entre 1991 e 2000. Neste ano, não havia mais nenhum índice abaixo de 0,7 , sendo que 17 municípios apresentavam índices acima de 0,8, considerado alto, e São Caetano do Sul apresentava índice de 0,919, o mais alto do país.

105 O IDH, Índice de Desenvolvimento Humano, é uma medida comparativa de riqueza, alfabetização, saúde, esperança de vida, natalidade, entre outros fatores. O índice varia de zero, quando não há nenhum desenvolvimento humano, até 1, que seria o desenvolvimento humano total. Quando o IDH está entre 0 e 0,499, é considerado baixo. Quando está entre 0,5 e 0,799 é considerado médio. Quando está entre 0,8 e 1 , é considerado alto. O IDH do Brasil, 0,8, é o septuagésimo no ranking mundial. (http://pt.wikipedia.org/wiki/\%C3\%8Dndice_de_Desenvolvimento_Humano - acesso em 23.02.2008). 
Por fim, a Tabela 1 apresenta a participação de cada município da RMSP no PIB do Estado de São Paulo. A Capital sozinha participava, em 2005, com 36,19\% do PIB paulista, tendo havido uma ligeira queda em relação a 2002, quando contribuía com 36,94\% do PIB paulista. As demais sub-regiões da RMSP que mais participam no PIB do Estado de São Paulo são a Oeste (Barueri, Carapicuíba, Cotia, Itapevi, Jandira, Osasco, Pirapora do Bom Jesus, Santana do Parnaíba, Vargem Grande Paulista), que contribuía, em 2005, com 7,07\%, principalmente por causa dos municípios de Barueri, que, sozinho, contribuía com 3,08\% do PIB do Estado, e Osasco, com 2,51\%; e a sub-região Sudeste (Diadema, Mauá, Ribeirão Pires, Rio Grande da Serra, Santo André, São Bernardo do Campo, São Caetano do Sul), que contribuía, em 2005, com 7,19\% do PIB do Estado de São Paulo, principalmente por causa dos municípios de São Bernardo do Campo (2,67\%), Santo André (1,57\%) e Diadema $(1,01 \%)$

No total, a participação de toda a RMSP no PIB paulista é bastante elevada: 57,28\%. A título de comparação com as regiões administrativas do Estado de São Paulo, apresentamos na Tabela 2 suas participações no PIB estadual.

Tabela 2 - Estado de São Paulo Participação das Regiões Paulistas no PIB Estadual- 2005

\begin{tabular}{|l|c|}
\hline \multicolumn{1}{|c|}{ REGIÕES ADMINISTRATIVAS } & $\%$ \\
\hline Registro & 0,24 \\
\hline Santos & 3,01 \\
\hline São José dos Campos & 5,18 \\
\hline Sorocaba & 4,72 \\
\hline Campinas & 15,27 \\
\hline Ribeirão Preto & 2,53 \\
\hline Bauru & 1,68 \\
\hline São José do Rio Preto & 2,32 \\
\hline Araçatuba & 1,34 \\
\hline Presidente Prudente & 1,25 \\
\hline Marília & 1,37 \\
\hline Central & 1,86 \\
\hline Barretos & 0,77 \\
\hline Franca & 1,11 \\
\hline RMSP & $\mathbf{5 7 , 2 8}$ \\
\hline TOTAL & 100,0 \\
\hline
\end{tabular}

Fonte: Fundação Seade - Informações dos Municípios Paulistas http://www.seade.gov.br/produtos/imp/index.php - acesso em 12.01.2008 - Organização da autora. 
Como podemos verificar, o PIB da RMSP participava com mais da metade do PIB paulista. O segundo maior participante é a Região Administrativa de Campinas, com 15,27\% de participação, e em terceiro lugar, com um percentual já bastante inferior, a Região Administrativa de São José dos Campos (5,18\%). Nenhuma Região Administrativa do Estado tem participação igual ao percentual da Capital, de 36,19\%.

Cabe discutir, porém, que riqueza em produção econômica não quer dizer absolutamente boa qualidade de vida. Não compete a esta pesquisa avaliar itens relativos a atendimento nos hospitais públicos, abastecimento de água, atendimento em escolas, criminalidade, entre dezenas de outros que caberiam para conhecermos, efetivamente, a qualidade de vida na metrópole. O objetivo deste trabalho é a análise da circulação das pessoas. A partir deste viés, esperamos contribuir para o debate sobre a acumulação da riqueza e a qualidade nos deslocamentos das pessoas que produzem essa riqueza na metrópole. Para produzir-se como ser humano, o trabalhador usa, em seu cotidiano, um tempo que estende sua jornada de trabalho em duas, quatro horas ou mais, sob condições, grande parte das vezes, desconfortáveis e até mesmo humilhantes.

Uma série de depoimentos que colhemos no decorrer da realização de nossos trabalhos de campo contribuiu para esta conclusão. Um trabalhador do setor da indústria nos relatou que pega três conduções para se deslocar de sua casa, em Santo André, até o local de trabalho, em Diadema. Primeiramente, toma um ônibus de sua casa até o Terminal Santo André, onde pega o trólebus até o Terminal Piraporinha, em Diadema. Dali, toma um outro ônibus do sistema municipal de Diadema. O trajeto demora uma hora, sem levar em conta o tempo de espera pelos ônibus. Ele nos informa que não considera que o trajeto seja longo, mas: "o que mais é ruim (sic) é que a primeira condução demora para passar, a segunda é muito lotada, embora 
tenha bastante ônibus na linha, e a terceira condução reúne todas as condições negativas das outras: demora para passar, é muito cheio e a organização das filas é precária."106.

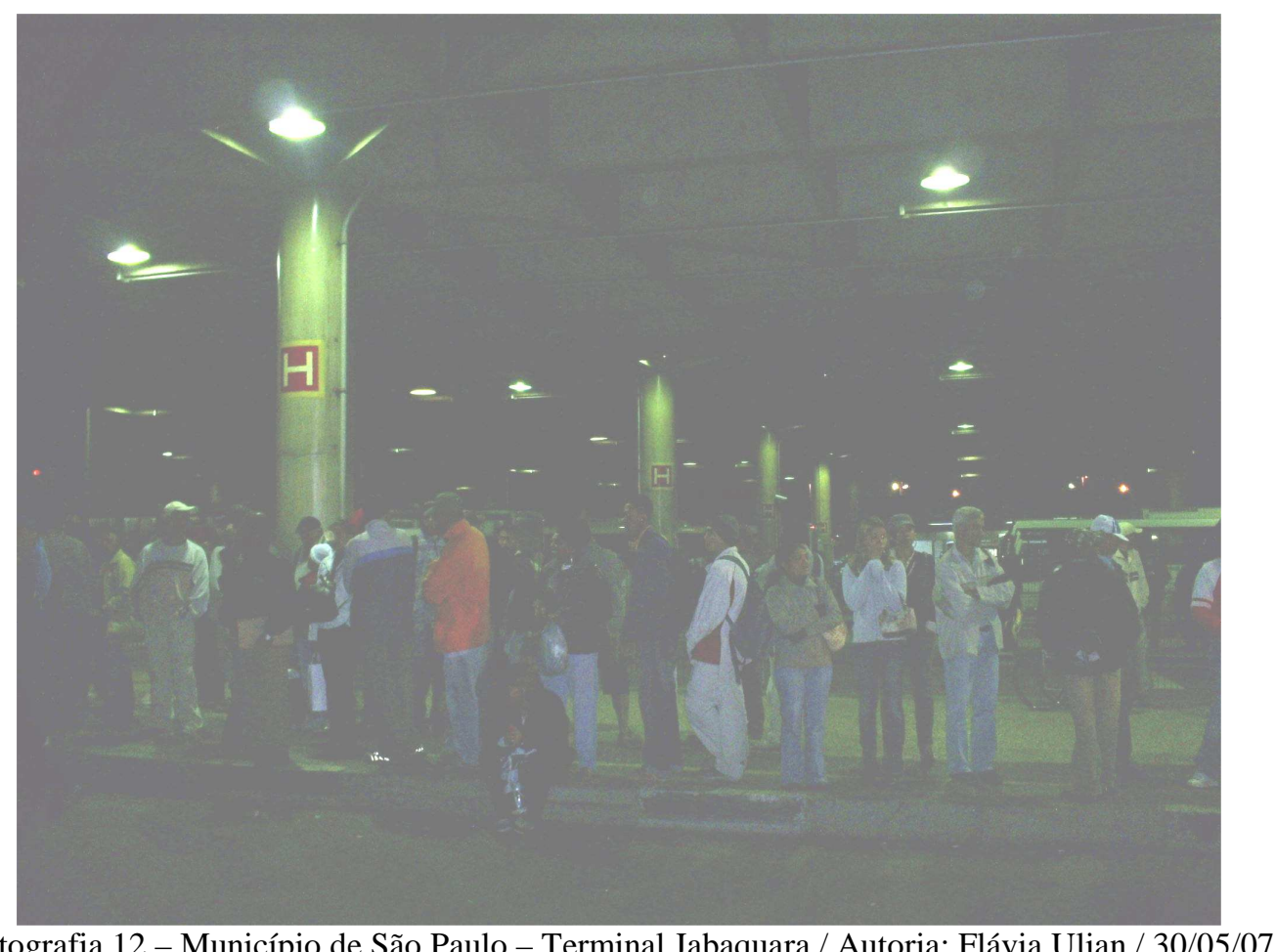

A experiência mais estarrecedora que ouvimos foi a de um trabalhador de indústria localizada em Guarulhos, que nos contou seu cotidiano. Ele mora em Cipó-Guaçu, próximo ao município de Embu-Guaçu. Sai às 4 h30 de seu bairro e, sem trânsito, demora 1 h40 até o Terminal Jabaquara. Entre o Terminal Jabaquara e a indústria onde trabalha, em Guarulhos, usa ônibus fretado da empresa, de $2^{\mathrm{a}}$. a $6^{\mathrm{a}}$. feira. Entre a saída de casa e a chegada ao trabalho, e também no deslocamento de volta, este entrevistado gasta de seis horas e meia a sete horas no transporte. Somando mais suas oito horas de trabalho, resta a ele pouco para conviver com sua família durante a semana. O trajeto de volta, do Terminal Jabaquara até Cipó-Guaçu, por causa do trânsito característico das 18 horas, demora duas horas e meia. Estes ônibus são, apesar de limpos, extremamente velhos e o intervalo entre eles é de uma hora. O usuário

\footnotetext{
${ }^{106}$ Informação pessoal, 30/05/07.
} 
afirmou que: "Se quebrar no caminho, é muito inseguro." 107. Trata-se da única linha que vai do Terminal Jabaquara para o município de Embu-Guaçu. São poucos ônibus, e andam sempre superlotados, pois esta linha passa por lugares muito populosos, como Parelheiros, por exemplo. Outra reclamação é quanto aos motoristas que não seriam credenciados: são funcionários da Prefeitura de Embu-Guaçu que fazem este trabalho "como um bico, não têm experiência, não pegam todo dia a linha." ${ }^{108}$. Embu-Guaçu é uma "cidade rural" e, não havendo empregos, as pessoas precisam vir para São Paulo para trabalhar. O entrevistado comenta que: "Em Parelheiros e Varginha está muito melhor, pois houve investimento no governo da Marta Suplicy. Mas em Embu, como é intermunicipal, é muito ruim."109. Quanto ao fretado, a empresa paga tudo, ele pode ir dormindo e descansando. Nos plantões que dá nos finais de semana, pois precisa fazer horas extras quando a produção sobe ${ }^{110}$, não há o transporte fretado e, então, precisa pegar quatro conduções: inicialmente, pega o ônibus em Embu-Guaçu e desce no Aeroporto de Congonhas; depois, pega o ônibus Tremembé que, nos finais de semana, é rápido até Santana. Aí toma uma lotação e usando o Bilhete Único ${ }^{111}$ vai até Guarulhos. Deste ponto, onde desce, até a empresa, pega mais uma lotação, mas nela não pode usar o bilhete único, aumentando, assim, seus gastos com condução. São depoimentos como esse que nos fizeram entender como é, na essência, o cotidiano de muitos trabalhadores desta cidade.

\footnotetext{
${ }^{107}$ Informação pessoal, 30/05/07.

108 Informação pessoal, 30/05/07.

${ }^{109}$ Informação pessoal, 30/05/07.

${ }^{110}$ Típico exemplo do ritmo just in time, e a cidade não está preparada para atender o trabalhador fora dos dias úteis!

${ }^{111} \mathrm{O}$ Bilhete Único permite a utilização de até quatro ônibus no período de duas horas no município de São Paulo.
} 


\section{A Desconcentração Industrial na RMSP}

Entendemos que a metrópole paulistana vive um momento de mutação engendrada por forças inerentes ao modo de produção capitalista que se rearranja de forma que o território, intermediado por técnicas informacionais cada vez mais abrangentes, reflete esta transição social no espaço urbano.

Lencioni $^{112}$ faz uma reflexão acerca do processo de reestruturação produtiva. Ela argumenta que essa terminologia indica que há um fenômeno de estruturação nova (reestruturação), que se impõe à antiga estruturação, e possui, ao mesmo tempo, "germes de um futuro", uma totalidade dialética em processo, não acabada. Esta nova estruturação é adjetivada como 'produtiva', "que indica que se está falando da produção como elemento determinante da reestruturação e não há dúvidas de que vimos assistindo a uma reestruturação do processo de reprodução capitalista."113. Para a autora, o "substrato comum" às interpretações de que um processo novo e uma nova forma de produção do espaço esteja ocorrendo se deve, "ora mais ora menos, à reestruturação produtiva"114.

Dentro deste processo de reestruturação produtiva está inserido o fenômeno da desconcentração industrial da RMSP e, para melhor compreendê-lo, recuamos até os anos 1970, quando se iniciaram os esforços de abertura de indústrias fora da metrópole paulistana.

As economias de aglomeração ${ }^{115}$ que trouxeram a indústria a São Paulo transformaram-se em deseconomias de aglomeração ${ }^{116}$ que, entre outros fatores, estimulariam

\footnotetext{
${ }^{112}$ LENCIONI, 2005, p. 47.

113 Ibidem, p.46.

114 Ibidem, p.45.

${ }^{115}$ Existência de mão-de-obra abundante, mercado de consumo, meios de transporte, infra-estrutura urbanoindustrial.

${ }^{116}$ Congestionamentos das vias urbanas de transporte, precariedade das redes de energia e de telecomunicações, pequena oferta de áreas para o assentamento industrial, zoneamento industrial e lei de mananciais, bem como demais restrições ambientais, e maior custo de reprodução da força de trabalho.
} 
a desconcentração das indústrias. Planos governamentais de âmbito federal ${ }^{117}$ e estadual procuraram incentivar o deslocamento de indústria para outras regiões do país e do Estado de São Paulo. A conjuntura nacional contribuiu para que houvesse diminuição do PIB e do mercado de trabalho em sub-regiões da RMSP, como é o caso do ABC Paulista. Por outro lado, esta região passava, através do processo de reestruturação da produção, a adotar a terceirização na indústria e isso ampliou as possibilidades das empresas prestadoras de serviços da região, trazendo a falsa impressão de ter havido um processo de desindustrialização ${ }^{118}$.

Não objetivamos aqui refazer o debate acerca da desconcentração industrial que estava ocorrendo na RMSP, cuja bibliografia é abundante. Cabe ressaltar, porém, que ocorreu, na realidade, uma dispersão territorial da indústria metropolitana, engendrada pela mobilidade espacial do Capital, que redefiniu a primazia da capital como gestora da produção industrial espraiada pela metrópole paulistana e seu entorno ${ }^{119}$.

$\mathrm{Na}$ virada do século XXI, a paisagem urbana reflete rugosidades dos tempos da indústria fordista em galpões de indústrias que hoje se transformaram em supermercados, shopping centers, igrejas e universidades. Grande parte da desconcentração industrial se deu, assim, dentro da própria RMSP.

A concentração industrial estruturou a metrópole e a desconcentração industrial estaria cumprindo o papel de reestruturação metropolitana ${ }^{120}$. Cumpre, no entanto, assinalar que a

\footnotetext{
${ }^{117}$ I e II Plano Nacional de Desenvolvimento (PND), da década de 1970.

${ }^{118} \mathrm{Na}$ década de 1980, o país precisou gerar saldos positivos na balança comercial, e necessitou incrementar as exportações. Isto foi mais fácil para as regiões Norte, Nordeste e Centro-Oeste, que, segundo Klink (2001), conseguiram tornar viável o aumento nos saldos exportáveis exigido pelo ajuste macroeconômico do momento e, portanto, aproveitaram melhor os programas do PND II. Já o Estado de São Paulo e, no caso específico da região estudada por Klink (ibidem, p.103), a região do ABC Paulista, "com uma pauta de exportação intensiva no uso de capital, reduziram a sua participação no PIB e no emprego nacional no referido período", ou seja, diferentemente do restante do país, o ABC Paulista teve diminuição do PIB e do mercado de trabalho nos anos 1980, refletindo a diminuição de sua produção industrial.

${ }^{119}$ LENCIONI, 2002.

${ }^{120}$ Ibidem.
} 
RMSP não estaria passando por um processo de sucessão setorial, mas de reorganização territorial pela reconfiguração da produção industrial ${ }^{121}$.

O fenômeno da terciarização ${ }^{122}$ da RMSP está ligado à ampliação da terceirização de serviços produtivos, distributivos e sociais ${ }^{123}$. Os deslocamentos por motivo de trabalho na indústria diminuíram no período analisado, conforme poderemos ver mais adiante, refletindo a diminuição do emprego industrial.

Verifica-se, portanto, que vivenciamos um momento em que as transformações da forma social da produção industrial dão origem a uma transmutação da forma espacial da cidade. Lencioni $^{124}$ (2005) explica que, em tempos anteriores, havia uma relação entre a forma social da produção industrial, no caso, a fábrica, e a forma espacial da cidade, pela concentração territorial da indústria, modelo do capitalismo industrial. A autora também observa que houve tempos em que a emergência das multinacionais estava intimamente relacionada ao crescimento de subúrbios nas grandes metrópoles “trazendo à luz a questão da região metropolitana policêntrica que se relaciona à rede urbana regional e nacional."125 .

A autora $^{126}$ destaca, porém, que, no momento atual, os grupos econômicos são elementos essenciais do processo produtivo e da disputa e estímulo à desconcentração territorial das atividades produtivas, o que configuraria a reestruturação produtiva. A centralização do capital se dá, assim, através de fusões de empresas, da internacionalização e ampliação dos mercados, acompanhados "de uma nova forma urbana relativa à expansão territorial metropolitana: metamorfoseia-se o urbano pelo desenvolvimento da região

\footnotetext{
${ }^{121}$ PRATES, 2001.

${ }^{122}$ Crescimento do setor terciário (serviços e comércio).

123 Serviços distributivos: comércio e armazenagem, transporte e comunicações; serviços pessoais: hotelaria, alojamento, higiene pessoal, confecção e conservação de vestuário, recuperação e conservação de aparelhos e veículos, manutenção e conservação de edifícios, esportes, cultura, diversão, rádio e TV; serviços sociais: saúde pública e particular, previdência, ensino público e particular, administração pública (CARLOS, 2001).

${ }^{124}$ LENCIONI, 2005.

125 Ibidem, p.47.

126 Ibidem.
} 
metropolitana associada ao processo de reestruturação produtiva." ${ }^{127}$. A autora ${ }^{128}$ conclui que, neste momento, “já não são mais a multinacional, nem a metrópole, as formas sócio-espaciais estruturantes [...]". A metrópole não se dissolve nesse processo de reestruturação produtiva, mas desempenharia algumas funções na nova estrutura. Além disso, ela modifica-se pela teia de relações em movimento, tornando-se forma subordinada "face ao desenvolvimento dessas novas formas que reestruturam tanto a sociedade como o espaço." ${ }^{129}$. Os movimentos de desintegração vertical da indústria e de produção de condições gerais condicionam a dispersão territorial da produção nas franjas da região metropolitana ${ }^{130}$.

Neste contexto, resgatamos que a problemática aqui pesquisada é que a reestruturação produtiva, a partir da década de 1990, induziu uma redefinição do sistema de transportes terrestres, tanto no que se refere à infra-estrutura quanto aos deslocamentos realizados por passageiros na RMSP. Inerente ao processo da reestruturação produtiva, a terceirização de atividades nas unidades de produção determinou a redefinição dos fluxos da força de trabalho no espaço da metrópole.

O ordenamento urbano que se dá em função da redefinição do sistema de transportes é inerente a esta nova formação sócio-espacial, a RMSP, que, em tempos de reestruturação produtiva, torna-se, nas palavras de Lencioni ${ }^{131}$, um "novo fato urbano metropolitano".

\section{A Questão das Centralidades Metropolitanas}

Aos objetivos de nossa pesquisa interessa a discussão sobre as centralidades metropolitanas, pois entendemos que são irradiadoras e atrativas de fluxos, e também pontos

\footnotetext{
${ }^{127}$ LENCIONI, 2005, p.48.

128 Ibidem.

${ }^{129}$ Ibidem, p.48.

${ }^{130}$ Ibidem.

${ }^{131}$ Ibidem.
} 
de convergência (hubs) de transportes. A metrópole paulistana é polinucleada, isto é, apresenta uma série de centros desiguais, ou seja, há centros mais novos e mais atrativos de fluxos, do que outros. Os fluxos também são diferenciados: eventualmente, alguns atraem determinados movimentos de pessoas com propósitos distintos daqueles que atraem outras pessoas a outros centros.

O termo centralidade remete à dupla escala: o centro urbano e a metrópole como centro. Para Carlos ${ }^{132}$, a centralidade, hoje, contém uma nova capacidade de concentração: “[...] o conteúdo do centro transformou-se, a polinucleação da metrópole, como consequiência da extensão do processo de urbanização, pulverizou o centro, criou subcentros especializados - monofuncionais [...]". A autora complementa que o deslocamento das atividades econômicas no espaço metropolitano em função da diminuição de custos gera a convergência e a freqüência de algumas atividades econômicas em determinados lugares.

Os atributos das centralidades - a concentração, a mono ou multifuncionalidade, acessibilidade, malha viária densa - relacionam-se com sua função de atraentes e/ou irradiadores de deslocamentos.

De acordo com Lemos e Scarlato ${ }^{133}$, São Paulo teria assumido rapidamente uma estrutura policêntrica de cidade globalizada a partir da década de 1970. A área urbana, entre 1930 e 1950, possuía entre 180 e $420 \mathrm{~km}^{2}$, chegando atualmente em uma região metropolitana de $8.051 \mathrm{~km}^{2}$, com uma população estimada de 19,5 milhões de habitantes distribuídos em 39 municípios. A metrópole polinucleada é revelada pela constituição de uma pluralidade de centros, sejam eles culturais, religiosos, simbólicos, de mercado, administrativos, de decisão política, financeiros etc. As periferias, que se estendem a perder de vista, englobam novas áreas e extensões fragmentadas que coexistem com o centro urbano principal da metrópole,

\footnotetext{
${ }^{132}$ CARLOS, 2001, p. 178.

${ }^{133}$ LEMOS \&SCARLATO, 2007.
} 
que é "aquele da decisão, que concentra informação e conhecimento [...] mantendo seu conteúdo simbólico"134.

O município de São Paulo é o município central da RMSP, possuindo, ele próprio, muitos centros que foram se multiplicando no decorrer da metropolização da cidade. Carlos ${ }^{135}$ explica que, no processo reprodutivo do espaço urbano da metrópole paulistana, profundas mudanças apresentam-se, "algumas muito bruscas, outras mais lentas, redefinindo usos e funções dos lugares, o que se traduz pela divisão da atividade no espaço urbano, produzindo rupturas." Os demais municípios da RMSP também apresentam centros, criando-se muitas redes de articulação entre si e com o município de São Paulo. As ações dos promotores imobiliários, das estratégias do sistema financeiro e da gestão política orientam e reorganizam “o processo de reprodução espacial por meio da realização da divisão socioespacial do trabalho, da hierarquização dos lugares e da fragmentação dos espaços vendidos e comprados no mercado." ${ }^{136}$. Logicamente, estes processos engendram deslocamentos, pois é a partir destes agentes que a distribuição dos locais de residência, de negócios, de comércio, de serviços e de indústrias se dá. A autora também adverte que o Estado, por intermédio do poder local, intervém na produção urbana, reforçando "a hierarquia de lugares, criando novas centralidades e expulsando para a periferia os antigos habitantes, criando um espaço de dominação"137 do capital, para onde devem convergir aqueles que o produzem. O espaço produzido torna-se, então, fragmentado e hierarquizado pela divisão espacial do trabalho.

A partir das décadas de 1950 e 1960, muitos bairros da Capital tornaram-se subcentros, recebendo e sendo ponto de origem de um crescente volume de ônibus que ligam os municípios da metrópole; isso ocorria em terminais improvisados que ocupavam praças e

\footnotetext{
${ }^{134}$ CARLOS, 2001, p. 177.

135 Ibidem, p.86.

${ }^{136}$ Ibidem, p. 15.

${ }^{137}$ Ibidem.
} 
calçadas, como no Largo da Batata, em Pinheiros; no Largo 13, em Santo Amaro, no Largo da Concórdia, no Brás, ou em terminais de trem e de metrô ${ }^{138}$.

Os terminais de ônibus intermunicipais - de onde partem e aonde chegam os passageiros que se deslocam diariamente da Capital em direção aos demais municípios da região metropolitana - chamam a atenção na paisagem urbana. A maior densidade de terminais está situada no arco sul-sudoeste-oeste, mostrando a intensidade de relações da capital com os municípios de Itapecerica da Serra, Embu, Taboão da Serra, Cotia, Osasco, Carapicuíba, Barueri, Jandira e Itapevi. A convergência de passageiros acarreta a concentração de atividades comerciais formais e informais no local ${ }^{139}$.

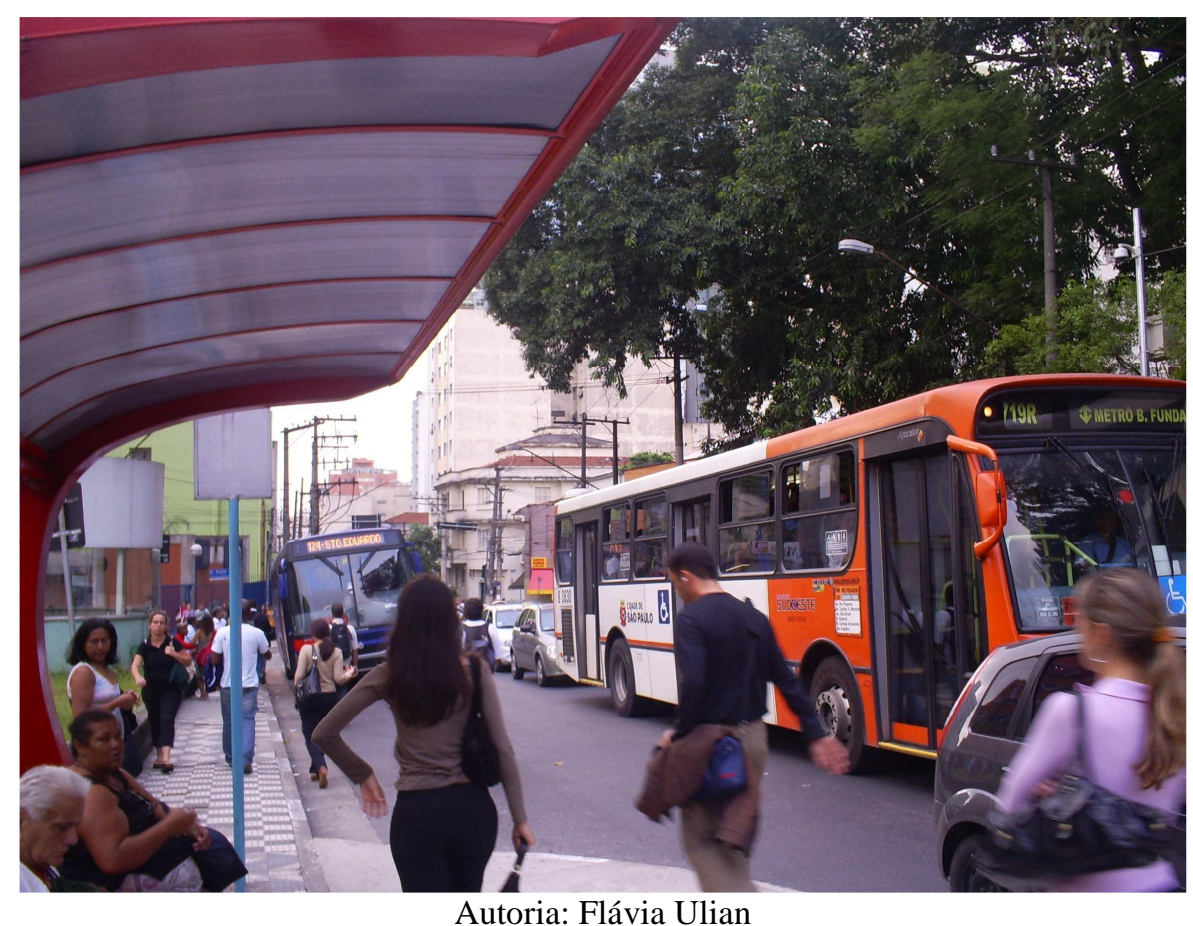

Fotografia 13 - Município de São Paulo - Ponto de ônibus no entorno da Estação de Metrô Clínicas (Linha 2 Verde), onde há concentração de linhas intermunicipais para diversos municípios do arco sul-sudoeste-oeste da RMSP / 31/01/08

Um dos focos de planejamento e projeto urbanos é reconhecer a existência dos “pólos de convergência", tendo em vista que "O novo padrão de organização do território

\footnotetext{
${ }^{138}$ MEYER et alli, 2004.

${ }^{139}$ Ibidem.
} 
metropolitano está intrinsecamente associado à mobilidade e é comandado, em grande parte,

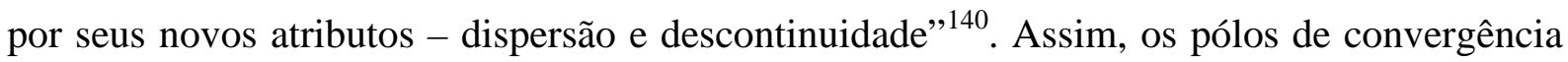
são aqueles articuladores dos fluxos dos passageiros e dos meios de transporte, como por exemplo, o Pólo Luz, na Capital.

Entendemos que isto mostra que a criação de novos pólos, ou novas centralidades, na RMSP, dá-se pela racionalidade econômica, na apropriação de espaços em função das necessidades econômicas e políticas em primeiro plano. Neste sentido, $\operatorname{Carlos}^{141}$ afirma que a metrópole se metamorfoseia com base na mercantilização do solo urbano. Na metrópole polinucleada, as funções especializam-se espacialmente, o que aprofunda a divisão espacial do trabalho na metrópole. Tal aprofundamento, acrescido da amplitude da área urbanizada e conurbada, é responsável pela má qualidade dos deslocamentos que vêm sendo realizados na RMSP, notadamente pela população que depende do transporte coletivo, mas também por aquela que se utiliza de transporte individual, neste caso devido aos congestionamentos.

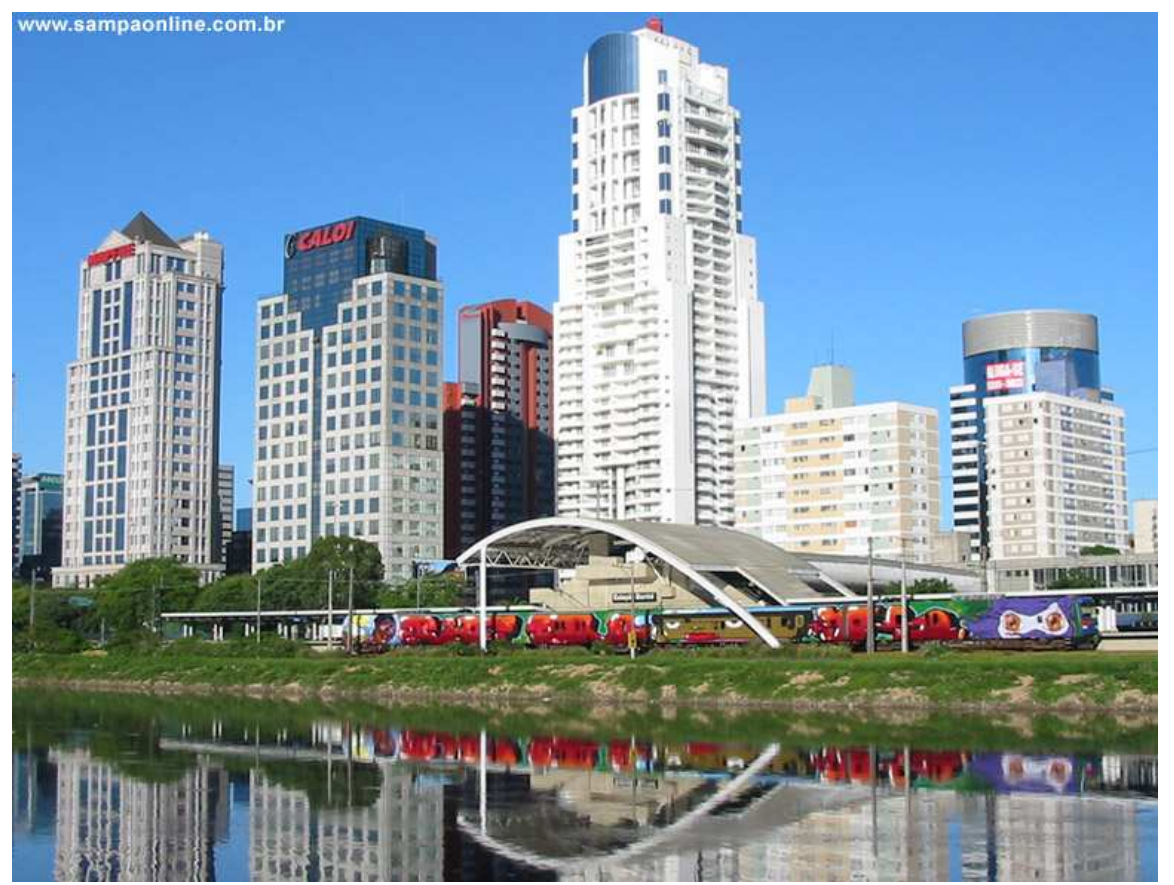

Fonte: http://www.sampaonline.com.br/postais/estacaoberrini.jpg - acesso em 24.06.2008

Fotografia 14: Município de São Paulo - Estação Berrini (Linha C da CPTM) - ao fundo, prédios na avenida Eng. Luis Carlos Berrini

\footnotetext{
${ }^{140}$ MEYER et alli, 2004, p.242.

${ }^{141}$ CARLOS, 2001.
} 
Novos centros, ou pólos, podem ser encontrados tanto no interior da RMSP, como em seu entorno, juntamente com o espraiamento da indústria, haja vista São Paulo ser a área mais industrializada do país, ampliando-se, assim, cada vez mais, com novos investimentos e desenvolvimento tecnológico. A localização do eixo empresarial com modernos escritórios na cidade de São Paulo também configura a produção de uma nova centralidade na metrópole, com tecnologia moderna, "densa rede viária, ligando pontos-chave da metrópole, como a proximidade com o aeroporto e serviços novos."142. Há concentração do setor financeiro, serviços, sedes de indústrias descontíguas das plantas industriais, que se desconcentraram em outros pontos da metrópole e seu entorno. Este novo centro, localizado no eixo Berrini-Faria Lima (Fotografia 14) configura, para Carlos ${ }^{143}$, uma movimentação de expansão dos centros tradicionais - centro histórico e da região da avenida Paulista.

$-\mathrm{x}-$

Fizemos o debate acerca de todos os aspectos referentes à área de estudo, ou seja: sobre a população da RMSP; os vetores urbanos consolidados, em consolidação e em expansão de acordo com a taxa geométrica de crescimento anual; informações quanto ao PIB per capita dos municípios integrantes desta região; as respectivas densidades demográficas; IDH. Do mesmo modo, foi posta em prática uma resumida abordagem acerca da desconcentração industrial da RMSP, bem como das novas centralidades metropolitanas, sobre as quais já existe uma ampla bibliografia, não cabendo aqui uma análise mais detalhada.

É premente, contudo, que conheçamos, ainda neste primeiro capítulo, o modo como se deu a inserção do Brasil nos tempos da reestruturação produtiva e as conseqüências deste fenômeno para a formação sócio-espacial da metrópole paulistana. Destarte, no item subseqüente, daremos prosseguimento ao entendimento deste fato no âmbito da conjuntura nacional e, em particular, no que tange ao processo de reestruturação produtiva da RMSP.

\footnotetext{
${ }^{142}$ CARLOS, 2001, p.27.

${ }^{143}$ Ibidem.
} 


\section{1 - A Reestruturação Produtiva na Metrópole Paulistana}

$\mathrm{Na}$ segunda divisão internacional do trabalho, o Brasil atingiu um desempenho econômico acima da média mundial, inclusive daquela dos países centrais, fato verificado nos anos de 1950 e 1980, quando houve forte impulso à industrialização nacional ${ }^{144}$. Tendo acabado de sair do período chamado de "milagre econômico", vivido entre 1968 e 1973, iniciou-se, na década de 1980, um período de desaceleração econômica, voltado para o crescimento interno, quando a evolução da economia brasileira esteve abaixo do comportamento da economia mundial ${ }^{145}$. Na passagem da década de 1980 para a de 1990 , em um contexto econômico recessivo, a política econômica brasileira voltou-se para uma maior integração internacional. Muitas empresas brasileiras adotaram medidas que visavam a estimular a competição, como privatizações, liberalização comercial e também medidas de concorrência, como os programas de apoio à capacidade tecnológica, de produtividade e qualidade $^{146}$. Estas medidas, juntamente com a queda do nível de atividade, provocaram diminuição do emprego industrial. Sob o discurso da modernização do país, praticado no início nos anos 1990, a busca por maior competitividade e produtividade exigia mudanças nas formas de gestão e organização do trabalho, além da adoção de novas tecnologias. Foi lançado, em 1990, o Programa Brasileiro da Qualidade e Produtividade, (PBQP) que visava a inserir o país na nova ordem mundial, fazendo parte do projeto neoliberal ${ }^{147}$, já em curso mundialmente, afinado com as recomendações do Fundo Monetário Internacional (FMI) e do Banco Mundial.

\footnotetext{
${ }^{144}$ POCHMANN, 2002.

145 MARCELINO, 2004.

${ }^{146}$ PERO, 1995.

${ }^{147}$ Estabilização monetária, diminuição das barreiras alfandegárias, fim das barreiras não tarifárias, privatização de grande parte das empresas estatais, tanto dos setores industriais como de serviços, o que criou condições favoráveis à elevação dos investimentos do setor privado e possibilidade de ampliação dos negócios (PRATES, 2001).
} 
Práticas japonesas de gestão do trabalho foram sendo implantadas de forma heterogênea setorial e regionalmente, sendo sua difusão realizada de forma gradual ${ }^{148}$. As primeiras iniciativas de introdução dos métodos japoneses ou "toyotistas" como os CCQs (Círculos de Controle de Qualidade) e o just in time (produção em tempo real), bem como o discurso da qualidade, respondem à situação econômica recessiva do início dos anos 1980. Com as primeiras iniciativas "alterou-se apenas a organização do processo de produção e do trabalho de maneira adaptada às condições especificamente brasileiras de exploração da força de trabalho." ${ }^{150}$. Apesar de, no decorrer da década de 1980, haver ocorrido processos de "transformação do aparato e da organização produtiva",151, o "toyotismo" não era um sistema dominante na produção, muito menos havia desbancado os princípios fordistas/tayloristas ${ }^{152}$, com padronização e rígida divisão do trabalho.

A crise econômica nacional ocorrida durante boa parte da década de 1980, chamada de “década perdida”, e parte dos anos 1990, com arrefecimento da atividade industrial, mostrava

\footnotetext{
${ }^{148}$ DRUCK, 2001.

${ }^{149}$ De acordo com Marcelino (2004), o surgimento do "toyotismo" deveu-se à grave crise econômica japonesa no pós-Guerra Mundial. Nesta época, o Japão apresentava escassez de força de trabalho, de matérias-primas e de desenvolvimento tecnológico. Verificava-se serem necessárias respostas rápidas e eficientes às demandas do mercado de produtos diferenciados. Neste contexto, a indústria japonesa reestruturou sua organização do trabalho para responder às necessidades de maximização dos lucros ao mesmo tempo em que se adaptava às condições de produção dadas. As primeiras iniciativas modernizadoras ocorreram no decorrer da década de 1940 e a pioneira foi a de um engenheiro da empresa automobilística Toyota Motor Co., Taiichi Ohno. "Suas propostas ofereciam soluções para a necessidade do capital de aumentar seus lucros por meio da diminuição gradativa da força de trabalho, da reorganização do espaço produtivo, da desconstrução da autonomia sindical e dos direitos dos trabalhadores." (Ibidem, pp.79-80).

${ }^{150}$ MARCELINO, 2004, p.107.

${ }^{151}$ Ibidem, p. 108 .

152 O fordismo pode ser caracterizado pela familiarização do trabalhador com longas horas de trabalho rotinizado, que exige poucas habilidades manuais e com controle quase inexistente do trabalhador sobre o projeto, o ritmo e a organização do processo produtivo. No início do século XX, o taylorismo, sistema de trabalho que separa a gerência, a concepção, o controle e a execução de tarefas na fábrica, transformou-se em um estilo de vida com o fordismo: "O que havia de especial em Ford (e que, em última análise, distingue o fordismo do taylorismo) era a sua visão, seu reconhecimento explícito de que produção de massa significava consumo de massa, um novo sistema de reprodução da força de trabalho, uma nova política de controle e gerência do trabalho, uma nova estética e uma nova psicologia, em suma, um novo tipo de sociedade democrática, racionalizada, modernista e populista." (HARVEY, 2005a, p. 121). Para maiores detalhes sobre o taylorismo e o fordismo, recorrer às leituras de Braverman (1987), Druck (2001), Harvey (2005a), Marcelino (2004).
} 
que o sistema do capital passava por um período crítico, tal qual os países centrais haviam sentido décadas atrás ${ }^{153154}$.

Klink $^{155}$ explica que os empresários brasileiros, no decorrer da década de 1990, vinham "enfrentando um quadro de muitas incertezas macroeconômicas que os induziu a implementar uma série de estratégias defensivas de reestruturação produtiva."156 , das quais destacamos a descentralização dos custos fixos para outras unidades da cadeia produtiva, intensificando a subcontratação ou terceirização de atividades ${ }^{157}$.

153 Analisando o período técnico-científico, verificamos que mudanças significativas encerraram o prolongado período de crescimento econômico e o pleno emprego nos países avançados, que vigorava na era fordista. Nesta era, a ativa intervenção dos Estados nacionais sustentava, em grande parte, o crescimento econômico. O início da crise deu-se sob "Os efeitos do colapso do sistema de Bretton Woods e da crise do petróleo da OPEP [Organização dos Países Produtores e Exportadores de Petróleo] na produção da turbulência e da volatilidade em todas as principais economias da década de 70 ao início da de 80.” (HIRST \& THOMPSON, 1998, p.19). Outros fatores que contribuíram para o enfraquecimento dos regimes anteriores podem ser citados, como inflação nos países avançados, impacto internacional do envolvimento dos Estados Unidos na guerra do Vietnã e aumento do preço do petróleo de 1973 a 1979. Uma das formas de descompensar esta crise deu-se com o crescimento do mercado de eurodólares proporcionado pelos empréstimos das instituições financeiras dos países ricos aos do Terceiro Mundo. A aceleração da internacionalização dos mercados financeiros, a desregulamentação de outros mercados no final da década de 70 e no início dos anos 80, o desenvolvimento do Sistema Monetário Europeu, em 1979, toda esta internacionalização do capital e o avanço do capitalismo financeiro são traços marcantes para a realização da reestruturação produtiva nos países capitalistas avançados (no Brasil ocorreria apenas a partir dos anos 1990). Deve-se acrescentar a esta conjuntura "A tendência à 'desindustrialização' na Inglaterra e nos Estados Unidos e o crescimento a longo prazo do desemprego na Europa, suscitando medo da competição estrangeira, especialmente do Japão.” (ibidem). A intensificação da competição internacional entre estas potências e vários outros países recém-industrializados do Terceiro Mundo acirrava a crise do sistema fordista. Já entre 1965 e 1973, evidenciava-se a incapacidade do fordismo e do keynesianismo de conter as contradições inerentes do capitalismo (HARVEY, 2005a). Para o autor, a rigidez dos investimentos de capital fixo de larga escala e de longo prazo em sistemas de produção em massa estava na tona das dificuldades. Esta rigidez impedia flexibilidade de planejamento, presumindo mercados e consumo rígidos. A rigidez estava se mostrando problemática nos mercados, na alocação e nos contratos de trabalho. O Estado de bem-estar social tinha compromissos rígidos em um momento em que a rigidez da produção restringia expansões na base fiscal para gastos públicos. Para manter sua política rígida, uma onda inflacionária foi iniciada, interrompendo a expansão do pós-guerra. O aumento dos insumos de energia levou "[...] todos os segmentos da economia a buscarem modos de economizar energia através da mudança tecnológica e organizacional [...]” (ibidem, p.136). Verificamos aqui as raízes da flexibilização. Entre 1973 e 1975 ocorreram forte deflação e crise fiscal, e então as corporações viram-se com muita capacidade excedente inutilizável, principalmente no que se refere a fábricas e equipamentos ociosos, em um período de intensificação da competição, até mesmo por fábricas localizadas no Terceiro Mundo. Estes fatores engendraram, aos poucos, a busca pela racionalização, reestruturação e aumento do controle do trabalho, intensificando-se as mudanças tecnológicas, automação e busca de novas linhas de produtos e nichos de mercado, bem como a dispersão geográfica da produção para zonas de controle do trabalho "mais fácil", menos especializado e mais barato.

${ }^{154}$ PRATES, 2001.

155 KLINK, 2001.

${ }^{156}$ Ibidem, p.149, grifo do autor.

157 A subcontratação, também denominada de terceirização, é um fenômeno que remonta aos tempos da Revolução Industrial. Na atualidade, sob novas bases, coloca-se de forma inteiramente diferente (LENCIONI, 2005). Terceirizar é passar para outra empresa a responsabilidade de realização de determinada tarefa. A Terceirização generalizou-se rapidamente por todas as atividades da economia, na produção industrial, nos 
O fenômeno da terciarização da metrópole, que significa o crescimento das atividades do setor terciário e o aumento da quantidade de empresas do setor de comércio e de serviços, é particularmente significativo para nosso estudo, que objetiva compreender a mobilidade de pessoas na RMSP. O crescimento do setor de serviços ou terciário é um fenômeno intrínseco à reestruturação produtiva e ao entendimento do trabalho no mundo contemporâneo, conforme podemos aferir através da afirmação de Antunes ${ }^{158}$ :

A expansão do trabalho em serviços, em esferas não diretamente produtivas mas que muitas vezes desempenham atividades imbricadas com o trabalho produtivo, mostra-se como outra característica importante da noção ampliada de trabalho, quando se quer compreender o seu significado no mundo contemporâneo.

A ampliação do setor terciário da economia está intimamente ligada à ampliação da terceirização, já que muitos prestadores de serviços surgiram a partir desse processo, como, por exemplo, empresas de manutenção industrial, empresas de consultoria, empresas de agenciamento de terceirização, entre outras. A RMSP tornou-se o grande pólo científico e

serviços, no comércio, em empresas de porte pequeno, médio e grande (DRUCK, 2001). A terceirização assume formas diferenciadas, como o trabalho doméstico ou domiciliar, quando as tarefas são realizadas nas casas dos trabalhadores, usando suas ferramentas e máquinas próprias ou alugadas. O trabalhador domiciliar data do período da Revolução Industrial, permanecendo presente até os dias de hoje, principalmente nas indústrias de microeletrônica e calçados. Geralmente, os trabalhadores são pagos por peças ou por encomenda realizada (MARCELINO, 2004). A rede de fábricas fornecedoras é uma outra forma de terceirização, bastante comum na indústria automobilística. Uma terceira forma é a terceirização dos serviços de limpeza, manutenção, segurança, alimentação etc., chamados de serviços de apoio ou periférico. A quarta forma, que tem deixado os pesquisadores surpresos, é a terceirização da própria área produtiva, ou atividade-fim, tanto fora quanto dentro da planta fabril principal (externalização e internalização, respectivamente). Por último, há a quarteirização, quando há a contratação de uma empresa para gerir os contratos das principais com as terceiras (DRUCK, 1999; MARCELINO, 2004). O princípio de que tudo o que não é vocação da empresa deve ser entregue a especialistas cai por terra quando a própria atividade nuclear da empresa é terceirizada. Pode-se aferir que o principal objetivo da empresa é desvencilhar-se dos encargos trabalhistas, tanto quanto dos impostos em relação aos salários. Encoberto pelo discurso de "que a terceirização pode abrir novas portas da economia e de empregos, bem como oferecendo a oportunidade aos trabalhadores de tornarem-se empresários" (MARCELINO, op.cit., p.140), na realidade, o intuito da terceirização é a redução de custos. No entanto, para o trabalhador, os autores consultados (DRUCK, 1999; MARCELINO, 2004, ANTUNES, 2003) enumeram diversos aspectos negativos da terceirização: redução dos empregos, já que há uma racionalização da organização do trabalho para reduzir o número de trabalhadores na empresa terceirizada, degradação das condições de trabalho na empresa terceirizada, com salários menores, redução ou inexistência de benefícios, "falta de políticas de treinamento, ritmo de trabalho mais intenso e dificuldade de organização dos sindicatos" (MARCELINO, op.cit., p.143); realização de trabalho diferente daquele para os quais os trabalhadores foram contratados, sem correspondência salarial; discriminação dos trabalhadores efetivos em relação aos das terceiras. Percebemos que a lógica da subcontratação é terceirizar as perdas para os trabalhadores, já que "as empresas principais buscam superar a crise transferindo o ônus para os parceiros, que, em última instância, recai sobre os ombros da classe trabalhadora." (Ibidem).

${ }^{158}$ ANTUNES, 2003, p.125, grifo do autor. 
informacional brasileiro e as indústrias nela instaladas tornaram-se seus próprios clientes por serviços desta magnitude ${ }^{159}$.

Observemos como a população se desloca na metrópole, de acordo com os motivos e sua relação com a ocupação, segundo o setor de atividade econômica na RMSP.

Tabela 3 - Região Metropolitana de São Paulo Viagens Diárias por Motivos - 1987 - 1997 - 2002

\begin{tabular}{|c|c|c|c|c|c|c|c|c|c|c|c|c|}
\hline \multirow[t]{2}{*}{ ANO } & \multicolumn{2}{|c|}{$\begin{array}{l}\text { TRABALHO } \\
\text { INDÚSTRIA }\end{array}$} & \multicolumn{2}{|c|}{$\begin{array}{l}\text { TRABALHO } \\
\text { COMÉRCIO }\end{array}$} & \multicolumn{2}{|c|}{$\begin{array}{l}\text { TRABALHO } \\
\text { SERVIÇOS }\end{array}$} & \multicolumn{2}{|c|}{$\begin{array}{c}\text { TOTAL } \\
\text { TRABALHO }\end{array}$} & \multicolumn{2}{|c|}{$\begin{array}{c}\text { OUTROS } \\
\text { MOTIVOS } \\
\text { EDUCAÇÃO- } \\
\text { SAÚDE- } \\
\text { LAZER- } \\
\text { OUTROS }\end{array}$} & \multicolumn{2}{|c|}{ TOTAL } \\
\hline & milhares & $\%$ & milhares & $\%$ & milhares & $\%$ & milhares & $\%$ & milhares & $\%$ & milhares & $\%$ \\
\hline 1987 & 3.885 & 13,35 & 2.495 & 8,48 & 5.910 & 20,10 & 12.290 & 41,80 & 17.110 & 58,20 & 29.400 & 100,0 \\
\hline 1997 & 2.279 & 7,35 & 2.807 & 8,93 & 7.776 & 24,73 & 12.862 & 41,01 & 18.570 & 59,07 & 31.432 & 100,0 \\
\hline 2002 & - & - & - & - & - & - & 15.230 & 39,39 & 23.430 & 60,61 & 38.660 & 100,0 \\
\hline
\end{tabular}

Fonte: CIA. DO METROPOLITANO DE SÃO PAULO. Aferição da Pesquisa O-D 1997, 2002. - $\quad$ : informação não disponível Elaboração da autora.

Entre 1987 e 1997, verificamos diminuição nos deslocamentos pelo motivo trabalho na indústria, aumento inexpressivo nos deslocamentos por trabalho no motivo comércio e aumento de 4,63\% nos deslocamentos por motivo de trabalho nos serviços. Verifica-se que os deslocamentos por motivo trabalho, no total, na RMSP decresceram quase $1 \%$ entre 1987 e 1997. No entanto, entre 1997 e 2002 houve uma diminuição maior, de 1,62\%. Estes dados refletem as análises que os autores pesquisados fizeram em relação à diminuição do emprego industrial e ao crescimento da terceirização e terciarização, que pode ser verificado na Tabela 3.

Dados da população empregada em diferentes setores da economia mostram que o emprego industrial sofreu uma forte diminuição. A Pesquisa de Emprego e Desemprego (PED) na Grande São Paulo, realizada pela Fundação Seade, mostra que, em 1987, 31,26\% dos ocupados estavam empregados no setor industrial; $14,43 \%$ no setor do comércio; e 
39,7\%, no de serviços. Dez anos depois, em 1997, o percentual de pessoas ocupadas empregadas no setor industrial caiu para 21,15\%; o de pessoas empregadas no comércio subiu para 17,01\%; e no setor de serviços subiu para 50,12\% (http://www.seade.gov.br - acesso em 29.03.08). Estes valores sofreram novas alterações em 2003 e 2007, quando os empregos ocupados na indústria representavam 18,96\%; no comércio, 16,23\%; e, nos serviços, 53,78\%. Esses dados podem ser observados na Tabela 4.

Tabela 4 - Região Metropolitana de São Paulo Participação dos Empregos Ocupados segundo Setor de Atividade Econômica do Trabalho Principal (porcentagem)

\begin{tabular}{|c|c|c|c|c|c|c|c|}
\hline $\begin{array}{c}\text { RMSP } \\
\text { Anos }\end{array}$ & $\begin{array}{c}\text { Indústria de } \\
\text { transformação }\end{array}$ & $\begin{array}{c}\text { Construção } \\
\text { Civil }\end{array}$ & Comércio & Serviços & $\begin{array}{c}\text { Serviços } \\
\text { domésticos }\end{array}$ & Outros & Total \\
\hline $\mathbf{1 9 8 7}$ & 31,26 & 4,05 & 14,43 & 39,7 & 6,86 & 0,72 & 97,02 \\
\hline $\mathbf{1 9 9 7}$ & 21,15 & 2,76 & 17,01 & 50,12 & 8,35 & 0,45 & 99,84 \\
\hline $\mathbf{2 0 0 3}$ & 19,19 & 2,5 & 16,17 & 52,55 & 8,85 & 0,42 & 99,68 \\
\hline $\mathbf{2 0 0 7}$ & 18,96 & 2,37 & 16,23 & 53,78 & 8,1 & 0,40 & 99,84 \\
\hline
\end{tabular}

Fonte: Fundação SEADE. Pesquisa de Emprego e Desemprego da Grande São Paulo. (http://www.seade.gov.br - acesso em 29.03.08). Organização da autora.

Comin \& Amitrano ${ }^{160}$ balizam que aspectos como a reestruturação das empresas mediante terceirizações e a diminuição da atividade industrial em decorrência da abertura comercial e crescimento das importações durante o ciclo de valorização do real (1994 e 1999) estão entre as causas da diminuição do emprego industrial da RMSP.

A crescente concentração do setor financeiro no município de São Paulo deu-se, principalmente, com a desregulamentação do setor a partir de meados dos anos $1990^{161}$. Quanto ao crescimento do setor comercial e de serviços que servem diretamente sua população, enormes redes de supermercados e shopping centers espalharam-se pela paisagem metropolitana, incrementando ainda mais os fluxos de distribuidores, consumidores e trabalhadores. Para tanto, houve a construção de dezenas de novas vias e o aumento de $31 \%$

\footnotetext{
${ }^{160}$ COMIN \& AMITRANO, 2003.

161 ACCA, 2004.
} 
na quantidade de deslocamentos entre 1987 e $2002^{162}$. Em 2008, a RMSP atingiu uma das maiores frotas de automóveis do mundo, com 2,4 habitantes por carro ${ }^{163}$. Do mesmo modo, o desenvolvimento tecnológico nos quais se apóiam os serviços terciários modernos vem construindo um novo espaço urbano. A centralidade da região metropolitana não pode, contudo, ser negligenciada.

Lencioni $^{164}$ reitera a importância da Capital, São Paulo, de maneira nova, "promovendo uma nova terciarização - superior -, decorrente da concentração cada vez maior dos mecanismos de controle e decisão da produção."

Comin \& Amitrano ${ }^{165}$ afirmam que

Com a expulsão do interior das empresas industriais de inúmeras atividades - desde serviços de baixa complexidade, como alimentação, limpeza, zeladoria, manutenção e segurança patrimonial, até os mais complexos, como serviços jurídicos, publicidade e marketing, atendimento ao consumidor, design, análise e suporte de informática -, essas ocupações desapareceram das estatísticas do setor industrial e reapareceram nas dos setores de serviços, mas sem que sua funcionalidade com o setor secundário tenha se alterado.

Grande parte do crescimento do setor de serviços deve-se, assim, à reengenharia da produção: a terceirização de atividades outrora desenvolvida na indústria fordista passou a ser realizada por empresas contratadas pela fábrica "enxuta". Desse modo, muitos trabalhadores que antes faziam parte das estatísticas do setor secundário, encontram-se, agora, no setor terciário.

A passagem do trabalhador do setor industrial para o de serviços - e que está associada à destruição de postos de trabalho - acontece quando o trabalhador perde o posto de trabalho na indústria, mas é readmitido cumprindo outro tipo de função em uma empresa terceira. Estatisticamente, este indivíduo saiu do setor secundário e passou a exercer atividades terciárias, mas prestando serviço para a empresa industrial. Ele pode, ainda, ser efetivamente

\footnotetext{
162 CIA. DO METROPOLITANO DE SÃO PAULO, 2002.

${ }^{163}$ SANGIOVANNI \& PINHO, 2008.

${ }^{164}$ LENCIONI, 1991, p. 270.

${ }^{165}$ COMIN \& AMITRANO, 2003, p.57.
} 
demitido, com a destruição de seu posto de trabalho na indústria, e como alternativa ao desemprego tentar uma ocupação no setor informal ${ }^{166}$.

Houve um acréscimo generalizado da quantidade de motocicletas em todos os municípios da RMSP entre 2002 e 2006 que se deveu, em grande parte, diretamente à terceirização. Documentos e informações necessitam ser rapidamente levados, e, sendo a motocicleta um meio de transporte ágil dentro da metrópole, o serviço de entregas realizado pelos motoboys torna-se cada vez mais utilizado, o que explica o aumento da frota deste tipo de veículo na RMSP.

Tal fenômeno é particularmente relevante para o período aqui analisado. A acumulação flexível sobrevive da produção em tempo real e a rede de entregas rápidas realizadas pelos motoboys é parte intrínseca desse processo. Aliamos a essa demanda o próprio excedente de mão-de-obra, visto que a produção "enxuta" minimiza, cada vez mais o contingente de trabalhadores. Há, assim, um incrível exército de reservas disponível para ocupar a demanda pelo transporte de todos os tipos de documentos e pequenas mercadorias realizado pelas motocicletas. Conversamos com alguns destes trabalhadores; um deles considera os deslocamentos que realiza com sua motocicleta desgastantes mentalmente: "Como um típico paulista, a pressa e o stress vivem lado a lado comigo. Sem mencionar o perigo, que é constante pela falta de atenção e cuidado dos outros motoristas."167.

Lencioni $^{168}$ observa que a exigência de condições gerais de produção faz parte do processo da reestruturação produtiva subjacente à dispersão territorial da indústria. Estas condições seriam "de grande diversidade: desde equipamentos e serviços para o atendimento da reprodução da força de trabalho, bolsas e bancos para realizar a circulação comercial e

\footnotetext{
${ }^{166}$ PERO, 1995.

${ }^{167}$ Informação pessoal, 31.01.08.

${ }^{168}$ LENCIONI, 2005.
} 
financeira ou aeroportos e estradas para a circulação das mercadorias e das pessoas."169. Podemos afirmar que a RMSP concentra estas condições gerais de produção, fato que explicaria a afirmação de que a metrópole paulistana está terciarizada, ou seja, desempenha atualmente mais a função de serviços (terciária) do que a produção industrial, ao mesmo tempo em que teria a função de um centro a partir do qual orbitam cidades recentemente industrializadas. A autora ${ }^{170}$ observa, porém, que há outras condições que não estão distribuídas homogeneamente fora da metrópole, sendo estas um limite para a dispersão territorial da indústria. Tais condições estariam relacionadas à existência de

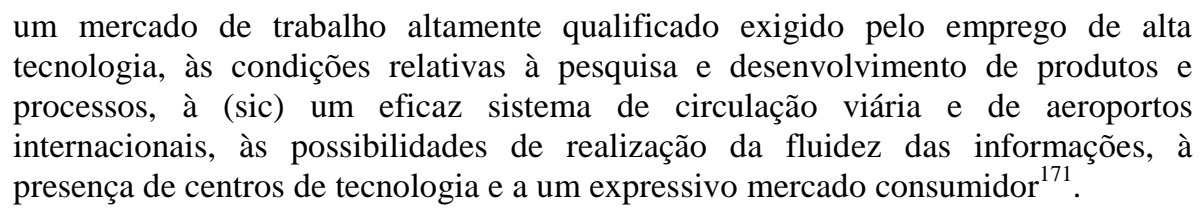

Acrescenta, ainda, que outros serviços como hotéis, consultoria, assessoria, auditoria, bolsas, seguradoras, relações públicas, imobiliárias e propaganda e marketing, por exemplo, são também desejáveis.

Comin \& Amitrano ${ }^{172}$ são enfáticos ao afirmar que na RMSP “os serviços cresceram porque a indústria se manteve vigorosa". Os autores acrescentam que "boa parte da atividade industrial que se desconcentra o faz de forma concentrada [...] num movimento de alargamento do tradicional cinturão industrial metropolitano em direção ao interior do Estado $[\ldots] "$

Buscando apreender o conhecimento já produzido sobre esta questão, bem como as informações estatísticas disponíveis, nossa análise ocorre em função das transformações que esses fenômenos realizaram nos fluxos dos trabalhadores na RMSP, conjuntamente com as mudanças na configuração territorial da região.

\footnotetext{
${ }^{169}$ LENCIONI, 2005, p.50.

${ }^{170}$ Ibidem.

${ }^{171}$ Ibidem, p.51.

${ }^{172}$ COMIN \& AMITRANO, 2003, p.74.
} 
O crescimento das atividades do setor terciário tem contribuído para a ampliação dos deslocamentos na metrópole no decorrer das décadas de 1990 e 2000. O aumento do consumo, das entregas em domicílio, das prestações de serviços, tudo isso está relacionado ao aumento de 29.400 mil deslocamentos em 1987 para 38.660 mil em 2002, conforme pode ser aferido na Tabela 5, que apresenta as viagens diárias realizadas na RMSP e em suas subregiões:

Tabela 5 - Região Metropolitana de São Paulo Viagens Diárias por Sub-Região em 1987-1997 e 2002 (em milhares e percentual)

\begin{tabular}{|l|c|c|c|c|c|c|}
\hline SUB-REGIÃO & $\mathbf{1 9 8 7}(\mathbf{x 1 . 0 0 0 )}$ & $\mathbf{1 9 8 7}(\mathbf{\%})$ & $\mathbf{1 9 9 7}(\mathbf{x 1 . 0 0 0})$ & $\mathbf{1 9 9 7}(\mathbf{\%})$ & $\mathbf{2 0 0 2}(\mathbf{x 1 . 0 0 0})$ & $\mathbf{2 0 0 2}(\mathbf{\%})$ \\
\hline SUDOESTE & 565 & 1,92 & 869 & 2,76 & 1.108 & 2,86 \\
\hline OESTE & 1.897 & 6,45 & 2.737 & 8,70 & 3.230 & 8,35 \\
\hline NORTE & 383 & 1,30 & 565 & 1,79 & 681 & 1,76 \\
\hline NORDESTE & 1.375 & 4,67 & 1.894 & 6,02 & 2.322 & 6,00 \\
\hline LESTE & 1.206 & 4,10 & 1.656 & 5,26 & 2.181 & 5,64 \\
\hline SUDESTE & 3.948 & 13,42 & 4.094 & 13,02 & 5.696 & 14,73 \\
\hline CENTRO & 20.024 & 68,11 & 19.617 & 62,41 & 23.442 & 60,63 \\
\hline TOTAL - RMSP & $\mathbf{2 9 . 3 9 8}$ & $\mathbf{1 0 0 , 0}$ & $\mathbf{3 1 . 4 3 2}$ & $\mathbf{1 0 0 , 0}$ & $\mathbf{3 8 . 6 6 0}$ & $\mathbf{1 0 0 , 0}$ \\
\hline
\end{tabular}

Fonte: CIA. DO METROPOLITANO DE SÃO PAULO. Aferição Pesquisa O-D 1997, 2002.

Elaboração da autora.

Os dados acima mostram uma evolução positiva do número de viagens diárias entre 1987 e 2002. Mesmo sem ter acesso aos resultados da Pesquisa O-D 2007, em fase de execução, dados divulgados separadamente pela EMTU (Empresa Metropolitana de Transportes Urbanos), CPTM (Cia. Paulista de Trens Metropolitanos), Metrô (Cia. Do Metropolitano de São Paulo) e SPTrans (São Paulo Transportes) mostram um grande aumento de deslocamentos entre 2002 e 2007, principalmente após a entrada do Bilhete Único em 2005. Analisaremos estes dados com mais atenção no capítulo subseqüente. No momento, apenas apreendemos, através da Tabela 5, um crescimento dos deslocamentos, em números absolutos, em todas as sub-regiões da RMSP, e em números relativos, também em todas, exceto na sub-região Centro (município de São Paulo), onde teria havido uma queda relativa em relação às outras sub-regiões, mas não absoluta. Este aspecto, aliás, reforça a questão das novas centralidades metropolitanas, já aferida anteriormente. 
De acordo com Antunes ${ }^{173}$,

as empresas do complexo produtivo toyotista, inclusive as terceirizadas, têm estrutura horizontalizada, ao contrário da verticalidade fordista. Enquanto na fábrica fordista aproximadamente $75 \%$ da produção era realizada no seu interior, a fábrica toyotista é responsável por somente $25 \%$ da produção, tendência que vem se intensificando ainda mais. Essa última prioriza o que é central em sua especialidade no processo produtivo (a chamada "teoria do foco") e transfere a "terceiros" grande parte do que antes era produzido dentro de seu espaço produtivo. Essa horizontalização estende-se às subcontratadas, às firmas "terceirizadas", acarretando a expansão dos métodos e procedimentos para toda a rede de fornecedores.

Esta afirmação corrobora o entendimento do fato de que a terceirização acarreta mais transporte de pessoas e de produtos nos tempos de reestruturação produtiva, conforme atestaram os dados da Tabela 5.

Para conhecer mais de perto a distribuição dos empregos na RMSP e a mobilidade de passageiros relacionada a esta distribuição, versaremos no próximo item a respeito do emprego na RMSP e da mobilidade intra-metropolitana.

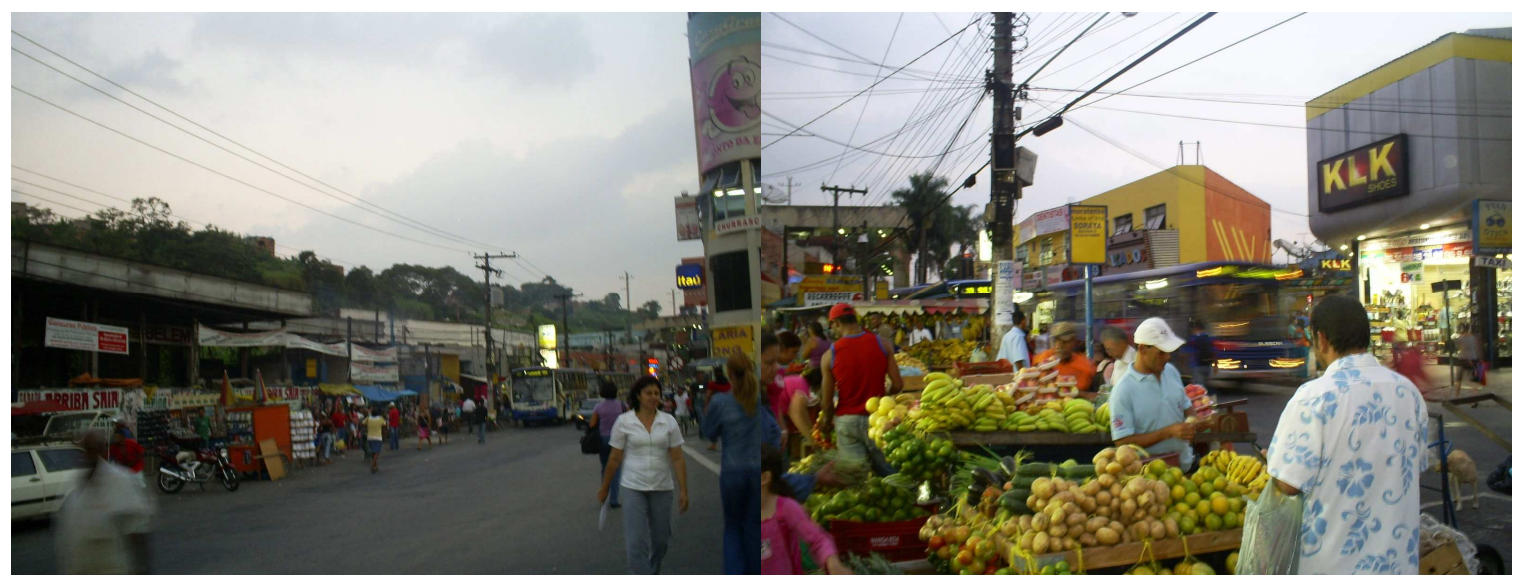

Autoria: Flávia Ulian

Fotografias 15 e 16 - Município de Francisco Morato - Ambulantes na avenida Gerônimo da Veiga $18 / 04 / 07$

${ }^{173}$ ANTUNES, 2003, pp. 54-55, grifo do autor. 


\section{2 - O Emprego na RMSP e a Mobilidade Intra-Metropolitana}

No decorrer da década de 1990, na RMSP, a População Economicamente Ativa manteve-se em torno de $61,3 \%$ a 61,7\% da População em Idade Ativa ${ }^{174}$; na década de 2000, aumentou para $63,5 \%$ e $63,6 \%$. Destes economicamente ativos, os ocupados tiveram o percentual em queda entre 1987 a 2002, momento em que aumentavam os desempregados; a partir de 2005 até 2007, houve aumento do percentual de ocupados e diminuição dos desempregados, sem chegar, contudo, aos patamares de 1987, ou seja, ainda havia mais desempregados em 2007 do que em 1987. Assim, no período de nossa pesquisa, observamos queda dos ocupados na década de 1990 e a reversão relativa deste quadro nos anos após $2002^{175}$.

A mídia tem divulgado informações sobre o aumento dos empregos no Estado e na RMSP. A Folha de São Paulo noticiou em 06.01.2008 que houve alta do emprego de baixa escolaridade entre 2003 e 2006. O mesmo jornal também divulgou, em 17.01.2008, que a indústria do Estado de São Paulo fechou o ano de 2007 com a criação de 104 mil vagas, o que equivaleu à expansão de 5,01\% na oferta de emprego ${ }^{176}$.

Analisamos, na Tabela 6, a evolução da taxa total de desemprego do total da RMSP, do município de São Paulo e dos demais municípios da RMSP:

\footnotetext{
174 A População em Idade Ativa (PIA) é conceituada pela Fundação Seade (http://www.seade.sp.gov.br/produtos/ped/pedv98/jan08/janeiro2008.pdf - acesso em 27.02.2008) como a população com 10 anos e mais, conceito aliás extremamente discutível, tendo em vista que no país só se permite o trabalho, e ainda assim como aprendiz, a partir dos 14 anos. A População Economicamente Ativa (PEA) é a parcela da PIA que está ocupada ou desempregada. Os “Ocupados são os indivíduos que nos 7 dias anteriores ao da entrevista: a) possuem trabalho remunerado exercido regularmente; b) possuem trabalho remunerado exercido de forma irregular, desde que não estejam procurando trabalho diferente do atual; c) possuem trabalho nãoremunerado de ajuda em negócios de parentes, ou remunerado em espécie/benefício, sem procura de trabalho; d) excluem-se as pessoas que de forma bastante excepcional fizeram algum trabalho nesse período."

${ }^{175}$ www.seade.gov.br - acesso em 27.02.2008

176 SALLES, 2008; SOFIA, 2008.
} 
Tabela 6 - Região Metropolitana de São Paulo Taxa de desemprego total, em anos escolhidos e em percentuais

\begin{tabular}{|c|c|c|c|}
\hline Anos & RMSP & Município de São Paulo & Demais municípios da RMSP \\
\hline 1987 & 9,2 & 8,75 & 9,7 \\
\hline 1991 & 11,7 & 10,68 & 13,4 \\
\hline 1997 & 16,0 & 13,38 & 18,2 \\
\hline 2002 & 19,0 & 17,78 & 20,6 \\
\hline 2005 & 16,9 & 15,83 & 18,5 \\
\hline 2007 & $(-)$ & 14,05 & $(-)$ \\
\hline
\end{tabular}

Fonte: SEP. Convênio SEADE - DIEESE. Pesquisa de Emprego e Desemprego. http://www.seade.gov.br/produtos/ped/ - 27.02.2008

(-) dado não disponível

Organização da autora.

A taxa de desemprego, aberto e oculto ${ }^{177}$ total da RMSP, sofreu forte aumento entre 1987 e 2002, tanto no município de São Paulo, quanto nos demais municípios da RMSP. Em 2005, o percentual de desempregados caiu, e no município de São Paulo os dados de 2007 atestam que a taxa continua em queda. É importante ressaltar que as taxas de desemprego do município de São Paulo, no período estudado, foram inferiores às dos demais municípios da RMSP, o que nos faz inferir que a Capital se torna mais atraente na medida em que oferece mais postos de trabalho.

Observemos agora se o incremento aferido de ocupados deve-se à maior quantidade de postos de trabalho no mercado formal ou no informal:

\footnotetext{
177 De acordo com a Fundação Seade ((http://www.seade.sp.gov.br/produtos/ped/pedv98/jan08/ janeiro2008.pdf - acesso em 27.02.2008), desempregados são os "indivíduos que se encontram em uma das seguintes situações: a) Desemprego Aberto: pessoas que procuraram trabalho de maneira efetiva nos 30 dias anteriores ao da entrevista e não exerceram nenhum trabalho nos 7 últimos dias; b) Desemprego Oculto pelo Trabalho Precário: pessoas que realizam algum trabalho remunerado eventual de auto-ocupação, ou seja, sem qualquer perspectiva de continuidade e previsibilidade, ou realizam trabalho não-remunerado em ajuda de negócios de parentes e que procuraram mudar de trabalho nos 30 dias anteriores ao da entrevista ou que, não tendo procurado neste período, o fizeram sem êxito até 12 meses atrás; c) Desemprego Oculto pelo Desalento e Outros: pessoas que não possuem trabalho e nem procuraram nos últimos 30 dias, por desestímulo do mercado de trabalho ou por circunstâncias fortuitas, mas apresentaram procura efetiva de trabalho nos últimos 12 meses.
} 
Tabela 7 - Região Metropolitana de São Paulo Distribuição dos Ocupados, segundo Posição na Ocupação no Trabalho Principal - em anos escolhidos, em percentuais

\begin{tabular}{|c|c|c|c|c|c|c|c|c|c|}
\hline \multirow[t]{3}{*}{ Anos } & \multirow[t]{3}{*}{ Total } & \multicolumn{5}{|c|}{ Assalariados } & \multirow[t]{3}{*}{ Autônomos } & \multirow[t]{3}{*}{ Empregador } & \multirow{3}{*}{$\begin{array}{c}\text { Empregado } \\
\text { Doméstico }\end{array}$} \\
\hline & & Total & \multicolumn{3}{|c|}{ Setor Privado } & Setor & & & \\
\hline & & & Total & $\begin{array}{c}\text { Com } \\
\text { carteira } \\
\text { assinada }\end{array}$ & $\begin{array}{c}\text { Sem } \\
\text { carteira } \\
\text { assinada }\end{array}$ & & & & \\
\hline 1987 & 97,7 & 70,7 & 61,3 & 53,2 & 8,1 & 9,3 & 15,7 & 4,5 & 6,9 \\
\hline 1991 & 97,4 & 67,4 & 57,4 & 48,2 & 9,2 & 9,9 & 18,1 & 5,0 & 6,9 \\
\hline 1997 & 96,5 & 61,6 & 53,2 & 41,3 & 11,9 & 8,3 & 20,5 & 6,0 & 8,4 \\
\hline 2002 & 97,3 & 62,4 & 54,1 & 40,2 & 14,0 & 8,2 & 21,6 & 4,7 & 8,6 \\
\hline 2005 & 97,5 & 63,4 & 55,3 & 41,6 & 13,8 & 8,0 & 21,0 & 4,5 & 8,6 \\
\hline Dez.2007 & 99,9 & 65,9 & 58,2 & 45,0 & 13,2 & 7,7 & 19,9 & $*$ & $*$ \\
\hline
\end{tabular}

Fonte: SEP. Convênio SEADE - DIEESE. Pesquisa de Emprego e Desemprego.

Obs. A soma total não dá 100,0 porque optamos por excluir dados referentes a Trabalhadores Familiares e Outros, cujos dados são inexpressivos. Em 2007, os dados de empregadores, empregados domésticos, trabalhadores familiares e outros foram reunidos em um número apenas: $14,10 \%\left(^{*}\right)$ http://www.seade.gov.br/produtos/ped/ - 27.02.2008 http://www.seade.sp.gov.br/produtos/ped/pedv98/jan08/janeiro2008.pdf - 27.02.2008 Organização da autora.

Na RMSP, em 1987, os assalariados compunham 70,7\% do total de ocupados. Destes, $61,3 \%$ trabalhavam no setor privado, sendo $53,2 \%$ com carteira assinada, e apenas $8,1 \%$ sem carteira assinada. No decorrer da década de 1990, houve queda no percentual de assalariados, e também nos trabalhadores com carteira assinada, que chegaram a 40,2\% em 2002, enquanto o percentual de assalariados do setor privado sem carteira assinada aumentava. A partir de 2005, os dados mostram um tênue reverso desta situação, com aumento dos trabalhadores assalariados com carteira assinada, mas não chegando ainda nos patamares da década de 1980. O movimento de queda do percentual de trabalhadores formais, isto é, com carteira assinada e setor público, é reflexo, em grande parte, da terceirização de atividades seguida de flexibilização das relações de trabalho, levada a cabo pela reestruturação produtiva realizada no período, conforme já foi discutido neste trabalho. 
A terceirização "é vista como inevitável, na medida em que se relaciona com uma transformação do sistema produtivo." ${ }^{178}$ Cabe lembrar que a crítica feita a ela relaciona-se à chamada "terceirização à brasileira", que deformaria, segundo a autora, o verdadeiro caráter da terceirização. No caso do Brasil, mais especificamente, tal caráter ocorre numa tentativa de acompanhar as tendências da economia mundial, procurando responder às exigências de maior produtividade e qualidade com custos mais baixos e visando, assim, a garantir maior competitividade para os produtos brasileiros no mercado. No país, a terceirização assume dimensões perversas até mesmo pela nossa própria história de exploração ${ }^{179}$.

A flexibilização dos contratos de trabalho não leva a uma expansão do número de vagas no mercado de trabalho, esta só seria possível com o aumento da demanda efetiva ${ }^{180}$. Dentre as causas que podemos apontar para o crescimento da informalidade no Brasil estão o baixo crescimento econômico do país; a pressão demográfica, com a entrada no mercado de trabalho de jovens resultante da alta taxa de natalidade do passado; as "transformações tecnológicas poupadoras de mão-de-obra, decorrentes da abertura comercial; e uma força de trabalho com baixa escolaridade, obrigada a buscar ocupação numa situação de escassez das oportunidades de emprego"181 , além da razão mais comumente alegada pelas empresas para a utilização de modalidades alternativas de contrato de trabalho: a redução de custos.

Lencioni $^{182}$ observa que o número de trabalhadores regidos pela CLT entre 1996 e 2000 decresceu 20,8\% no Estado de São Paulo, tendo crescido as formas de vínculo empregatício temporário e avulso.

Entre 1990 e 1998, observou-se no país e na RMSP (que, por si só, já reflete a própria situação do Brasil) a diminuição dos postos de trabalho qualificados e o crescimento das

\footnotetext{
${ }^{178}$ MARTINS, 1994, p.18.

${ }^{179}$ MARCELINO, 2004.

${ }^{180}$ CACCIAMALI \& BRITO, 2003.

${ }^{181}$ Ibidem, pp.10-11.

${ }^{182}$ LENCIONI, 2005.
} 
ocupações não-qualificadas. Isto teria se dado devido, entre outros fatores, à ampliação das importações, ausência de novos investimentos e reformulação do setor público, juntamente com as baixas taxas de expansão do PIB. Comin \& Amitrano ${ }^{183}$ destacam duas tendências relacionadas à natureza e à qualidade das ocupações que se perderam e que se criaram ao longo da década de 1990: "a redução na faixa de assalariamento da economia metropolitana (tendência na verdade nacional) e a polarização da estrutura ocupacional" ${ }^{, 184}$, com inflexão do emprego formal e aprofundamento da heterogeneidade estrutural do mercado de trabalho brasileiro. Os autores observam que a informalidade "cresceu tanto nos setores modernos e dinâmicos (caso da indústria moderna e dos serviços produtivos) quanto nos setores tradicionais (como construção civil e o comércio)." ${ }^{185}$.

Pochmann ${ }^{186}$ observa que as

ocupações profissionais mais concorridas no Brasil durante os anos 90 não são aquelas que poderiam ser identificadas com as ocupações modernas (profissionais técnicos, técnicos superiores e direção). As atividades profissionais que mais recrutam trabalhadores não são aquelas associadas aos setores econômicos que poderiam ser objeto de mudança no conteúdo dos postos de trabalho e, por isso, estariam necessitando de trabalhadores mais qualificados.

Os estudos de Pochmann ${ }^{187}$ apontam que não assistimos, ao menos da década de 1990 , ao crescimento da importância dos cargos de administradores, técnicos e profissionais especializados, e ao decréscimo da proporção de cargos de artífices e operadores. Pesquisa recente do Instituto de Pesquisa Econômica Aplicada (IPEA) parece indicar que a tendência à oferta de trabalho por profissionais qualificados estaria se dando no final da primeira década do século $\mathrm{XXI}^{188}$. Isto explica o recente incremento observado em relação ao crescimento do

\footnotetext{
183 COMIN \& AMITRANO, 2003.

${ }^{184}$ Ibidem, p.67.

185 Ibidem.

${ }^{186}$ POCHMANN, 2002, p.68.

187 Ibidem.

${ }^{188}$ SALOMON, 2007.
} 
percentual de empregos com carteira assinada no município de São Paulo em 2007, como pudemos aferir pela Tabela 7.

Além disso, Pochmann ${ }^{189}$ afirma que durante os anos 1940 e 1970, de cada dez postos de trabalho criados, somente dois não eram assalariados, sendo sete com registro formal. Porém, na década de 1990, a cada dez empregos criados, somente dois eram assalariados, mas sem registro formal. Essas ocupações não-assalariadas representam "formas de produção e reprodução de estratégias de sobrevivência" ${ }^{190}$. O desemprego deixou de ser um fenômeno de camadas específicas da sociedade para se generalizar por quase toda a população ativa. Na RMSP houve, mais do que a criação de novos empregos "flexíveis", a substituição de empregos formais por ocupações informais ${ }^{191}$.

Nos países capitalistas centrais, o processo de acumulação é global. O capitalismo periférico tem outras especificidades ${ }^{192}$. A industrialização brasileira, firmada decisivamente a partir da década de 1930, não rompeu com os regimes arcaicos dos antigos proprietários rurais que fizeram um "pacto estrutural" com a burguesia urbano-industrial, garantindo "mudanças sem rupturas e a convivência de políticas contraditórias." ${ }^{193}$. O Estado brasileiro instituiu, juntamente com a legislação trabalhista, o protecionismo da acumulação urbano-industrial e a regulação do preço da força de trabalho que, com baixos salários, busca estratégias de sobrevivência, como a informalidade.

\footnotetext{
${ }^{189}$ POCHMANN, 2002.

${ }^{190}$ Ibidem, p. 99.

${ }^{191}$ COMIN \& AMITRANO, 2003.

${ }^{192}$ MARICATO, 1996.

${ }^{193}$ Ibidem, p.39.
} 
Tabela 8 - Região Metropolitana de São Paulo Rendimento $^{194}$ Médio Real dos Ocupados no Trabalho Principal (1), segundo Posição na Ocupação, em anos escolhidos (Valores em reais de dezembro de 2007)

\begin{tabular}{|c|c|c|c|c|c|c|c|c|c|}
\hline \multirow[t]{3}{*}{ Anos } & \multirow[t]{3}{*}{ Total } & \multicolumn{5}{|c|}{ Assalariados } & \multirow[t]{3}{*}{ Autônomos } & \multirow[t]{3}{*}{ Empregador } & \multirow{3}{*}{$\begin{array}{c}\text { Empregado } \\
\text { Doméstico }\end{array}$} \\
\hline & & Total & \multicolumn{3}{|c|}{ Setor Privado } & Setor & & & \\
\hline & & & Total & $\begin{array}{c}\text { Com } \\
\text { carteira } \\
\text { assinada }\end{array}$ & $\begin{array}{c}\text { Sem } \\
\text { carteira } \\
\text { assinada }\end{array}$ & & & & \\
\hline 1987 & 1.738 & 1.732 & 1.656 & 1.778 & 780 & 2.222 & 1.659 & 4.648 & 501 \\
\hline 1991 & 1.292 & 1.312 & 1.225 & 1.328 & 644 & 1.803 & 1.032 & 3.278 & 413 \\
\hline 1997 & 1.563 & 1.545 & 1.463 & 1.613 & 926 & 2.039 & 1.360 & 4.262 & 533 \\
\hline 2002 & 1.121 & 1.171 & 1.102 & 1.211 & 776 & 1.615 & 836 & 3.053 & 434 \\
\hline 2005 & 1.060 & 1.136 & 1.070 & 1.172 & 756 & 1.586 & 747 & 2.723 & 387 \\
\hline $\begin{array}{l}\text { Dez. } \\
2007\end{array}$ & 1.157 & 1.214 & 1.129 & 1.211 & 835 & - & 791 & - & - \\
\hline
\end{tabular}

Fonte: SEP. Convênio SEADE - DIEESE. Pesquisa de Emprego e Desemprego / Organização da autora. http://www.seade.gov.br/produtos/ped/ - 27.02.2008

Obs: (-) dado não disponível

A Tabela 8 mostra que os rendimentos dos trabalhadores assalariados na RMSP sofreram queda entre 1987 e 2005, apesar da alta de salários do ano de 1997. Os dados mostram ainda uma recuperação dos rendimentos em 2007. No entanto, fica claro, pelos dados apresentados, que os trabalhadores assalariados com carteira assinada percebem rendimentos superiores aos assalariados sem carteira assinada. A ocupação de Empregado Doméstico é a que recebe rendimentos mais baixos na região, seguida pelos assalariados do setor privado sem carteira assinada. Os autônomos tiveram seus rendimentos médios cortados praticamente pela metade entre 1987 e 2007.

Comparando-se os dados da Tabela 8 com a Tabela 9, que mostra os rendimentos dos trabalhadores do município de São Paulo, verificamos que a dinâmica acompanha os dados da

\footnotetext{
194 De acordo com a Fundação Seade (http://www.seade.sp.gov.br/produtos/ped/pedv98/jan08/janeiro2008.pdf acesso em 27.02.2008), "Rendimento do trabalho: rendimento monetário bruto (sem descontos de imposto de renda e previdência social) efetivamente recebido, referente ao trabalho realizado no mês imediatamente anterior ao da pesquisa. Para os assalariados, são considerados descontos por falta etc. ou acréscimos devidos a horas extras, gratificações etc. Não são computados o $13^{\circ}$ salário e os benefícios indiretos. Para os empregadores, os autônomos e as demais posições, é considerada a retirada mensal, não incluindo os lucros do trabalho, da empresa ou do negócio."
} 
RMSP, porém as médias de rendimentos são superiores às da metrópole como um todo. Assim, por exemplo, o rendimento médio real do assalariado sem carteira assinada em 2005 era, na RMSP, $\mathrm{R} \$ 756,00$, mas no município de São Paulo era $\mathrm{R} \$ 848,00$. Isto quer dizer que a Capital faz a média salarial subir na RMSP. Presumimos, então, que os rendimentos médios nos demais municípios, sem a Capital, devem ser ainda menores do que os apresentados na Tabela 8.

Tabela 9 - Município de São Paulo

Rendimento Médio Real dos Ocupados no Trabalho Principal, segundo Posição na Ocupação, em anos escolhidos (Valores em reais de novembro de 2005)

\begin{tabular}{|c|c|c|c|c|c|c|c|c|c|}
\hline \multirow[t]{3}{*}{ Anos } & \multirow[t]{3}{*}{ Total } & \multicolumn{5}{|c|}{ Assalariados } & \multirow[t]{3}{*}{ Autônomos } & \multirow[t]{3}{*}{ Empregador } & \multirow{3}{*}{$\begin{array}{l}\text { Empregado } \\
\text { Doméstico }\end{array}$} \\
\hline & & \multirow[t]{2}{*}{ Total } & \multicolumn{3}{|c|}{ Setor Privado } & \multirow{2}{*}{$\begin{array}{c}\text { Setor } \\
\text { Público }\end{array}$} & & & \\
\hline & & & Total & $\begin{array}{c}\text { Com } \\
\text { carteira } \\
\text { assinada }\end{array}$ & $\begin{array}{c}\text { Sem } \\
\text { carteira } \\
\text { assinada }\end{array}$ & & & & \\
\hline 1987 & 1.810 & 1.782 & 1.692 & 1.817 & 820 & 2.321 & 1.756 & 4.783 & 527 \\
\hline 1991 & 1.382 & 1.386 & 1.277 & 1.379 & 699 & 1.972 & 1.110 & 3.452 & 436 \\
\hline 1997 & 1.725 & 1.689 & 1.588 & 1.743 & 1.028 & 2.288 & 1.378 & 4.411 & 576 \\
\hline 2002 & 1.238 & 1.281 & 1.196 & 1.317 & 848 & 1.829 & 929 & 3.281 & 456 \\
\hline 2005 & 1.205 & 1.272 & 1.184 & 1.297 & 854 & 1.880 & 835 & 3.046 & 418 \\
\hline
\end{tabular}

Entendemos, assim, que a Capital torna-se mais atraente também sob este sentido, motivando que os moradores de outros municípios da RMSP desloquem-se para a Capital.

Podemos explicar, conforme mostrado na Tabela 10, parte do intenso fluxo de passageiros entre a sub-região Centro (município de São Paulo) e as demais sub-regiões: 
Tabela 10 - Região Metropolitana de São Paulo Matriz de origem e destino de viagens diárias produzidas por sub-regiões 1997

\begin{tabular}{|c|c|c|c|c|c|c|c|}
\hline $\begin{array}{c}\text { Sub-região de } \\
\text { origem }\end{array}$ & \multicolumn{7}{|c|}{ Sub-região de destino } \\
\hline & Sudoeste & Oeste & Norte & Nordeste & Leste & Sudeste & $\begin{array}{c}\text { Centro } \\
\text { (município de São Paulo) }\end{array}$ \\
\hline Sudoeste & $\mathbf{6 4 5 . 2 2 4}$ & 14.300 & 203 & 4.384 & 1.006 & 2.949 & 202.338 \\
\hline Oeste & 15.220 & $\mathbf{2 . 3 1 4 . 1 1 2}$ & 6.103 & 4.296 & 3.252 & 15.312 & 378.198 \\
\hline Norte & 219 & 6.418 & $\mathbf{4 6 7 . 6 9 6}$ & 3.160 & 1.257 & 1.571 & 85.897 \\
\hline Nordeste & 5.048 & 5.062 & 3.757 & $\mathbf{1 . 5 9 3 . 2 4 7}$ & 10.511 & 6.019 & 270.772 \\
\hline Leste & 756 & 3.656 & 1.236 & 11.945 & $\mathbf{1 . 4 6 4 . 0 6 6}$ & 11.109 & 163.833 \\
\hline Sudeste & 2.088 & 11.546 & 13.117 & 6.244 & 18.854 & $\mathbf{3 . 6 0 8 . 5 0 8}$ & 451.179 \\
\hline $\begin{array}{c}\text { Centro (município } \\
\text { de São Paulo) }\end{array}$ & 199.108 & 371.734 & 84.852 & 267.798 & 163.115 & 449.507 & $\mathbf{1 8 . 0 7 8 . 4 3 8}$ \\
\hline Total RMSP & 867.663 & 2.726 .609 & 565.418 & 1.891 .074 & 1.655 .817 & 4.094 .975 & 19.630 .655 \\
\hline
\end{tabular}
Fonte: CIA. DO METROPOLITANO DE SÃO PAULO. Pesquisa O-D 1997. Organização da autora.

A maior quantidade de deslocamentos é realizada internamente em cada sub-região, como mostram os números assinalados em negrito. Em segundo lugar, a maior quantidade de viagens realizada pelos habitantes de cada sub-região da RMSP é feita com o município de São Paulo, e isto está claro a partir da observação da última coluna da Tabela 10.

Conforme demonstrado nas Tabelas 6, 8 e 9, este fenômeno é, em grande medida, devido ao município de São Paulo possuir maior quantidade de vagas para trabalho, além de oferecer maior remuneração. Logicamente, outros fatores também corroboram para haver maior número de viagens entre as sub-regiões da RMSP e o município de São Paulo: a maior quantidade de serviços médicos e de saúde, serviços de lazer, de educação, de compras etc. locados nesta cidade.

A súmula de número de empregos por sub-região ${ }^{195}$ também pode nos ajudar a compreender este fenômeno, conforme podemos ver pela Tabela 11:

\footnotetext{
${ }^{195}$ O Apêndice1 apresenta detalhadamente a distribuição dos vínculos empregatícios dos municípios da RMSP na agropecuária, indústria, comércio, serviços e construção civil.
} 


\section{Tabela 11 - Região Metropolitana de São Paulo \\ Empregos por Sub-Região \\ $1987-1997-2002$}

\begin{tabular}{|c|c|c|c|c|c|c|}
\hline SUB-REGIÃO & $\mathbf{1 9 8 7}(\mathbf{x} \mathbf{1 . 0 0 0})$ & $\mathbf{1 9 8 7}(\boldsymbol{\%})$ & $\mathbf{1 9 9 7}(\mathbf{x} \mathbf{1 . 0 0 0})$ & $\mathbf{1 9 9 7}(\mathbf{\%})$ & $\mathbf{2 0 0 2}(\mathbf{x ~ 1 . 0 0 0 )}$ & $\mathbf{2 0 0 2}(\mathbf{\%})$ \\
\hline 1. SUDOESTE & 91 & 1,61 & 164 & 2,36 & 198 & 2,48 \\
\hline 2. OESTE & 310 & 5,49 & 532 & 7,64 & 599 & 7,51 \\
\hline 3. NORTE & 49 & 0,87 & 95 & 1,37 & 110 & 1,38 \\
\hline 4. NORDESTE & 277 & 4,91 & 399 & 5,73 & 464 & 5,81 \\
\hline 5. LESTE & 217 & 3,84 & 305 & 4,38 & 400 & 5,01 \\
\hline 6. SUDESTE & 701 & 12,41 & 837 & 12,03 & 988 & 12,37 \\
\hline 7. CENTRO & 4.022 & 70,87 & 4.627 & 66,49 & 5.224 & 65,45 \\
\hline TOTAL & 5.647 & 100,0 & 6.959 & 100,0 & 7.983 & 100,0 \\
\hline
\end{tabular}

Fonte: CIA. DO METROPOLITANO DE SÃO PAULO. Aferição da Pesquisa O-D 1997, 2002.

Elaboração da autora.

A Tabela 11 atesta que houve, no total da RMSP, aumento de 2.336 mil empregos (cerca de 41\%) entre 1987 e 2002 . Houve aumento relativo dos empregos das sub-regiões Sudoeste (Embu, Embu-Guaçu, Itapecerica da Serra, Juquitiba, São Lourenço da Serra, Taboão da Serra), Oeste (Barueri, Carapicuíba, Cotia, Itapevi, Jandira, Osasco, Pirapora do Bom Jesus, Santana do Parnaíba, Vargem Grande Paulista), Norte (Caieiras, Cajamar, Francisco Morato, Franco da Rocha, Mairiporã), Nordeste (Arujá, Guarulhos e Santa Isabel) e Leste (Biritiba Mirim, Ferraz de Vasconcelos, Guararema, Itaquaquecetuba, Mogi das Cruzes, Poá, Salesópolis, Suzano), mas diminuição do número relativo de empregos das sub-regiões Sudeste (Diadema, Mauá, Ribeirão Pires, Rio Grande da Serra, Santo André, São Bernardo do Campo, São Caetano do Sul) e Centro (São Paulo). Ressaltamos que a sub-região Centro, embora tenha queda relativa dos empregos, teve crescimento absoluto de 1.202 mil vagas, o que não contradiz nossa observação anterior de haver muitos fluxos intra-metropolitanos motivados pela maior empregabilidade do município de São Paulo.

Dados da Fundação Seade, obtidos através das Informações dos Municípios Paulistas e organizados por nós em tabela que se encontra no Apêndice A mostram que se sobressaíram, em 2005, os vínculos empregatícios no setor de serviços: 59,17\%. Em segundo lugar, constam os vínculos empregatícios no setor secundário, ou seja, na Indústria: 19,77\%. Em seguida, no 
Comércio: 17,32\% e, por último, verifica-se que havia 3,53\% de vínculos empregatícios na construção civil. Cabe lembrar que estes vínculos são formais.

Quanto às sub-regiões, é notório que os vínculos empregatícios na Agropecuária são marcantes na sub-região Leste, com 5.054 vínculos empregatícios, o que corresponde a quase 45\% dos vínculos na agropecuária da RMSP. Sobressaem-se, nesta sub-região, os municípios de Biritiba Mirim e Mogi das Cruzes, mas também são expressivos Guararema, Salesópolis e Suzano (Apêndice A).

Quanto ao setor secundário, 9,8\% dos vínculos empregatícios na Indústria da RMSP estão na sub-região Oeste (Barueri, Carapicuíba, Cotia, Itapevi, Jandira, Osasco, Pirapora do Bom Jesus, Santana do Parnaíba, Vargem Grande Paulista). Sobressai-se também a sub-região Sudeste, com 21,23\% dos empregos industriais da RMSP, na qual se destaca o município de São Bernardo do Campo. A sub-região Nordeste também merece ser citada, principalmente por causa do município de Guarulhos. Esta sub-região concentra quase $10 \%$ dos empregos industriais da RMSP. No entanto, ainda é a Capital que concentra a maior parte dos empregos industriais: 48,57\%, quase a metade dos empregos industriais da RMSP (Apêndice A).

Em relação aos vínculos empregatícios no Comércio, destacam-se novamente as subregiões Centro (Capital), Sudeste (Diadema, Mauá, Ribeirão Pires, Rio Grande da Serra, Santo André, São Bernardo do Campo, São Caetano do Sul) e Oeste (Barueri, Carapicuíba, Cotia, Itapevi, Jandira, Osasco, Pirapora do Bom Jesus, Santana do Parnaíba, Vargem Grande Paulista), com participação, em 2005, respectivamente, nos vínculos empregatícios deste setor na RMSP, de 68,3\%, 10,6\% e 8,84\% (Apêndice A).

O setor que mais emprega, o de Serviços, é também polarizado pela Capital, com 74\% dos vínculos empregatícios da RMSP, em 2005, neste setor. Em segundo lugar, aparece a subregião Oeste (Barueri, Carapicuíba, Cotia, Itapevi, Jandira, Osasco, Pirapora do Bom Jesus, Santana do Parnaíba, Vargem Grande Paulista), com 8,3\% e em terceiro, a sub-região Sudeste 
(Diadema, Mauá, Ribeirão Pires, Rio Grande da Serra, Santo André, São Bernardo do Campo, São Caetano do Sul) com 8,7\% dos vínculos empregatícios no setor de Serviços da RMSP (Apêndice A).

Sem dúvida, os municípios onde há maior disponibilidade de emprego são também aqueles que apresentam maior quantidade de deslocamentos. Assim sendo, se observarmos novamente a Tabela 10 e relacionarmos seus dados com as informações acima apresentadas sobre a distribuição dos empregos pelas sub-regiões metropolitanas, entenderemos a grande incidência de viagens internas das sub-regiões Oeste (Barueri, Carapicuíba, Cotia, Itapevi, Jandira, Osasco, Pirapora do Bom Jesus, Santana do Parnaíba, Vargem Grande Paulista), com 2.314.112 viagens internas; a Sudeste (Diadema, Mauá, Ribeirão Pires, Rio Grande da Serra, Santo André, São Bernardo do Campo, São Caetano do Sul), com 3.608.508 viagens internas; e por fim a sub-região Centro, município de São Paulo, com 18.078.438 viagens internas.

As viagens entre as sub-regiões e o município de São Paulo também são muito expressivas, notadamente entre o município de São Paulo e as sub-regiões Sudeste (449.507 viagens), Oeste (371.734 viagens) e Nordeste (Arujá, Guarulhos e Santa Isabel) (267.798 viagens), justamente as sub-regiões com maior quantidade de vínculos empregatícios formais nos setores secundário e terciário.

A Tabela 12 apresenta informações sobre os municípios de trabalho e residência dos ocupados da RMSP. Verifica-se que, durante a década de 1990, 81,1\% dos ocupados trabalhavam no mesmo município onde residiam. A partir de 2002, verificamos que esta porcentagem diminuiu, e em 2005 decresceu 3,3\% em relação a 1997, havendo 22,2\% de ocupados que residiam em municípios diferentes daquele em que trabalhavam. 


\section{Tabela 12 - Região Metropolitana de São Paulo \\ Distribuição dos Ocupados, segundo Município de Trabalho - em anos escolhidos e em percentuais}

\begin{tabular}{|c|c|c|c|}
\hline Anos & \multicolumn{3}{|c|}{ Município onde trabalha } \\
\hline & Total & É o mesmo onde reside & É diferente de onde reside \\
\hline 1988 & 100,0 & 81,4 & 18,6 \\
\hline 1991 & 100,0 & 81,1 & 18,9 \\
\hline 1997 & 100,0 & 81,1 & 18,9 \\
\hline 2002 & 100,0 & 79,2 & 20,8 \\
\hline 2005 & 100,0 & 77,8 & 22,2 \\
\hline
\end{tabular}

Fonte: SEP. Convênio Seade-Dieese. Pesquisa de Emprego e Desemprego - PED. http://www.seade.gov.br/produtos/ped/ - 27.02.2008

Organização da autora.

Este fato nos ajuda, igualmente, a compreender o aumento de fluxos nos meios de transporte intermunicipais da metrópole, já que, certamente, passaram a transportar mais pessoas em direção a outros municípios com destino ao trabalho.

O Censo Demográfico de 2000, do IBGE, aponta que "a capital recebia diariamente mais de 673 mil moradores de outros municípios do Estado para trabalhar ou estudar. Cerca de $87 \%$ desse contingente (591 mil habitantes) residia em outros municípios da Região Metropolitana de São Paulo.”196

A Fundação Seade realizou projeções preliminares sobre o deslocamento pendular no Estado de São Paulo, verificando seu aumento em cerca de $20 \%$ até 2010 (de 1,9 milhão para 2,3 milhões), fato que poderia elevar o número de pessoas que entram na Capital para 807,6 mil. Afirma-se que este é o deslocamento pendular mais significativo do país.

A atual fase de acumulação do capital dá-se através da reestruturação da produção na chamada Terceira Revolução Industrial. Procuramos identificar, de forma geral, que uma das estratégias tomadas por empresas brasileiras no período da reestruturação produtiva, que se

\footnotetext{
${ }^{196}$ http://www.seade.sp.gov.br - 21.02.2008.
} 
dava a partir da década de 1990 no Brasil, foi a terceirização, processo seguido da flexibilização e precarização das relações de trabalho.

A redefinição do processo produtivo redesenhou plantas e estruturas de produção, pois a competitividade entre as empresas, buscada através da flexibilização dos processos produtivos e dos contratos de trabalho, determinou novos modelos espaciais ${ }^{197}$. Este novo estágio do desenvolvimento do ciclo capitalista, portanto, tem acarretado grandes transformações na metrópole paulistana.

O conhecimento destes fenômenos nos possibilita compreender melhor aquilo que Lencioni $^{198}$ afirmou quanto à reestruturação produtiva ser um processo criador de um novo fato urbano, já que todas estas estratégias repercutem em uma nova organização do território. Visando a compreender este novo fato urbano que é a metrópole paulistana, prosseguimos com a análise desta fase de crescimento da atividade econômica industrial no Brasil, e constatamos a desconcentração industrial da RMSP, com abertura de filiais de empresas fora desta região e estímulo a outras atividades industriais que, por forças econômicas e políticas, localizaram-se no interior do Estado de São Paulo. Contudo, acompanhando a tendência mundial de diminuição do número de estabelecimentos industriais, averiguamos que a metrópole paulistana ainda centraliza os setores administrativo e financeiro da produção ${ }^{199}$.

Encerramos este primeiro capítulo com um resgate dos fenômenos ocorridos na RMSP no período entre 1987 e 2007 pertinentes à questão central de nossa Tese. A reestruturação produtiva, a desconcentração industrial, a terceirização e a flexibilização das relações de trabalho na RMSP são processos que estiveram presentes nessas duas últimas décadas, sendo indispensáveis para avaliarmos as transformações nos fluxos de passageiros na metrópole.

\footnotetext{
${ }^{197}$ CARLOS, 2001.

${ }^{198}$ LENCIONI, 2005.

${ }^{199}$ CARLOS, 2001; LENCIONI, 2005.
} 
Uma maior quantidade de centralidades implica em mais fluxos acontecendo no tempo e no espaço. A forma da metrópole tornou-se, no período estudado, dotada de mais vias e meios de transporte. A função, entendida aqui como os fluxos dos trabalhadores e sua articulação com a rede de transportes, também se tornou mais densa. As categorias do método geográfico estão sendo analisadas e pensadas, nos permitindo, com rigor metodológico, entender os anos após 1990 como anos de redefinição do padrão produtivo e de circulação de passageiros na RMSP.

Aliaremos todas estas reflexões ao que será apresentado no próximo capítulo, o sistema de transporte urbano de passageiros na RMSP. Faremos sua caracterização recuando algumas décadas antes do recorte temporal da pesquisa, para melhor compreender esse processo. Enfatizaremos o período de 1987-2007 no que se refere às transformações da paisagem a partir da implantação de infra-estruturas de transporte de passageiros em relação a suas vias, terminais e meios de transporte, passando pelas políticas de transportes instituídas pela estrutura no processo histórico até os dias atuais. 


\section{Parte II - Sistemas de Transporte Urbano de Passageiros na RMSP}

A rede de transportes é um dos fatores estruturadores mais importantes da urbanização. Através da construção de ruas, avenidas, linhas de bonde, ferrovias, rodovias, linhas de metrô e aeroportos, podemos verificar como a metrópole paulistana foi se estruturando e se metropolizando. A circulação intra-urbana, bem como a circulação entre o núcleo urbano e seu entorno, são, em grande medida, indutores do crescimento da cidade.

Conforme já foi visto no capítulo anterior, a metrópole paulistana teve o crescimento da população acelerado no decorrer do século XX, principalmente em sua segunda metade. Este é um fenômeno característico dos países capitalistas dependentes, que restringem os locais onde o trabalhador pode vender sua força de trabalho, ocasionando sua mobilidade em direção às grandes cidades. Esse fato ocorre no Brasil devido ao baixo poder aquisitivo da classe trabalhadora, população mais carente que veio se instalando em locais de baixa valorização fundiária, adquirindo lotes baratos e promovendo a auto-construção. Os locais periféricos não tinham muitas vezes a mínima infra-estrutura, inclusive no que se refere ao provimento de linhas de ônibus. Desse modo, a forma extensa do espaço urbano, conurbado a outros municípios e repleto de terrenos vazios que aguardam valorização é fator que dificulta

a mobilidade dessas camadas de população habitantes das periferias ${ }^{200}$. A distribuição desigual dos meios de transporte entre os grupos sociais de acordo com o seu lugar nas relações de produção e a distribuição desigual dos meios de transporte no espaço são problemas que levam à exclusão sócio-espacial dos indivíduos.

${ }^{200}$ ULIAN, 1999. 
Já havíamos aludido, anteriormente, ao crescimento dos deslocamentos por automóveis relacionado ao fenômeno de crescimento da classe média ocasionado, tanto em virtude de seu poder aquisitivo para a aquisição de automóveis, quanto pela rede de deslocamentos realizada por esta camada da população "principalmente ligados à educação privada, medicina privada, esporte, lazer e compras, com impactos profundos nas suas necessidades de transporte. ${ }^{201}$ Pelo peso que as classes médias possuem na estrutura social, a ação mais visível do Estado nas cidades brasileiras foi muito mais a elas direcionada ${ }^{202}$, sobretudo na RMSP. Somem-se a isso as camadas sociais ainda mais abastadas: entre 1960 e 1980 verificamos o crescimento da concentração de renda no país, quando "a participação dos $20 \%$ mais ricos da população brasileira cresce na renda global do país, em detrimento dos $80 \%$ mais pobres, cuja participação diminui” ${ }^{, 03}$. Neste período, a autora verificou que a frota de automóveis cresceu mais de cinco vezes.

Uma nova estrutura de classes formou-se no Brasil em um período muito curto, com a criação de um enorme exército industrial de reserva, um exército em atividade relativamente pequeno para o conjunto da população ativa, uma classe média também grande, sendo esta um reflexo do estilo de organização do capitalismo monopolista. Com a industrialização brasileira e o estabelecimento de inúmeras filiais de empresas transnacionais na RMSP, introduziram-se novos estilos de organização empresarial que se refletiam na divisão social do trabalho trazida pelo estilo de organização do capital monopolista, com a entrada de 'trabalhadores improdutivos', ou seja, executivos, gerentes, especialistas financeiros, mercadológicos, de recursos humanos, que vieram a engrandecer a classe média ${ }^{204}$.

O crescimento do setor de comércio e serviços é "a expressão urbana dessa nova estrutura de classe, onde o peso das classes médias emerge com enorme força, com enorme

\footnotetext{
${ }^{201}$ VASCONCELLOS, 2000, p.112.

${ }^{202}$ MELLO, 2000.

203 Ibidem, p.53.

${ }^{204}$ OLIVEIRA, 1982.
} 
gravitação, tendo em vista o tipo de organização que o capitalismo internacional criou ao projetar suas empresas dentro da sociedade brasileira."205.

A construção da cidade para a classe média deu-se, sobretudo, no período do autoritarismo, a partir do Golpe Militar de 1964. Neste período, foi retirada das classes populares a participação na estrutura política. O Estado utilizou-se de parte importante do excedente social para atender às demandas da classe média, sob o ponto de vista dos investimentos e dos gastos públicos. Ao agir assim, o Estado deixou de atender às solicitações das classes operárias ${ }^{206} 207$.

A intensificação das migrações para o Estado de São Paulo deu-se nos anos 1970, enfraquecendo as periferias nacionais, "enquanto o país parecia refluir para o seu centro: capitais privados, investimentos públicos, população, crescimento e pobreza." ${ }^{\text {208 }}$ A formação da Região Concentrada efetivava-se sobre uma urbanização excludente e contraditória.

Mello $^{209}$ observa que a ação do Estado nos países subdesenvolvidos tem ocorrido na indústria e infra-estrutura, criando as "condições de expansão e reprodução do capital, atuando com um papel complementar fundamental à inserção do país na divisão internacional do trabalho." Conseqüentemente, formou-se uma grande lacuna na atuação do Estado para a efetivação das condições de reprodução da força de trabalho, "significando as enormes disparidades de acesso dos trabalhadores aos serviços públicos essenciais." ${ }^{210}$. A autora realizou uma pesquisa sobre o transporte urbano de passageiros da cidade de São Paulo entre 1975 e 1995 e verificou que, em grande medida, o que se estabeleceu como uma política de prioridade ao transporte de massa nas metrópoles brasileiras, em meados da década de 70, não

\footnotetext{
${ }^{205}$ OLIVEIRA, 1982, p.48.

${ }^{206}$ Ibidem.

${ }^{207}$ Para maiores referências, Vasconcellos (1999) e Mello (2000) resumem o processo de despolitização da sociedade brasileira no período da ditadura militar.

${ }^{208}$ SANTOS, 2006, p.48.

${ }^{209}$ MELLO, 2000, p.11.

${ }^{210}$ Ibidem.
} 
se confirmou em São Paulo. Foram elaborados inúmeros planos que não conseguiram dotar a cidade de um sistema de transporte de massa estruturado e bem articulado.

Mello $^{211}$ concluiu, a partir de suas pesquisas, que "as políticas desenvolvidas para o transporte coletivo foram instrumentalizadas para apoiar, para auxiliar o desenvolvimento de atividades privadas envolvidas com o transporte de passageiros", envolvendo o financiamento de programas industriais relacionados à fabricação dos veículos (trens e ônibus) e de empreiteiras das obras públicas. Hoje, quando se noticia cotidianamente o caos no transporte urbano de passageiros na metrópole, quando ocorrem protestos nas periferias por um transporte digno ${ }^{212}$, quando se comenta no dia-a-dia sobre o estresse do trânsito, vê-se o quanto Mello ${ }^{213}$ acertou em suas conclusões.

O agravamento das condições de deslocamento da população periférica foi estudado por diversos autores, entre eles Kovarick $^{214}$, Mello $^{215}$, Vasconcellos ${ }^{216}$ e Ulian ${ }^{217}$. $\operatorname{Vasconcellos}^{218}$ ressalta que a expansão da indústria de habitação para a classe média e o aumento e concentração espacial da frota de veículos significou uma readaptação da cidade para a nova vida da classe média emergente, configurando a cidade da classe média ${ }^{219}$.

O que determina grande parte dos fluxos migratórios cotidianos entre o centro da RMSP e sua periferia, ou entre diferentes setores das periferias é a distribuição espacial dos empregos e das residências. Na cidade da classe média, o sistema coletivo de transportes de passageiros é fator de exclusão do cidadão no espaço urbano.

\footnotetext{
${ }^{211}$ MELLO, 2000, P. 231.

${ }^{212}$ No dia 07.03.2008, cerca de mil moradores dos distritos de Jardim Ângela e Jardim São Luís, pertencentes à subprefeitura de M'Boi Mirim, fizeram barricadas e depredaram vários ônibus em protesto contra os engarrafamentos no corredor de ônibus da avenida Guido Caloi até o terminal Jardim Ângela.

${ }^{213}$ Ibidem.

${ }^{214}$ KOVARICK, 1982.

${ }^{215}$ MELLO, op. cit.

${ }^{216}$ VASCONCELLOS, 1999.

${ }^{217}$ ULIAN, 1999.

${ }^{218}$ VASCONCELLOS, op. cit.

${ }^{219}$ Ibidem.
} 
Vasconcellos $^{220}$ salienta que, apesar da impossibilidade de resolução definitiva dos conflitos no trânsito, dado que as atividades e a circulação humana no ambiente urbano têm um caráter político, "isto não significa [...] que a forma de ocupação do espaço seja indiferente para a política da circulação.”. A ocupação e o uso do solo para finalidades de habitação, industriais, comerciais e institucionais se dá "por mecanismos do mercado imobiliário, ligados à expectativa de renda fundiária e à especulação com a posse da terra",221 . Os interesses imobiliários dos detentores da terra e do capital constróem, no sistema do capital, o espaço urbano. Na metrópole paulistana, nessas áreas mais dinâmicas, especialmente ao sul e sudoeste, localiza-se a maior parte das obras viárias, exatamente onde estão disponíveis as melhores condições para o consumo do espaço, com comércio e serviços diversificados e sofisticados. As regiões que circundam os shopping centers, construídos dentro da mesma lógica de formação de amplas camadas médias consumidoras, apresentam as maiores concentrações de renda e de veículos por quilômetro quadrado da cidade.

A partir de 2003, verificou-se forte crescimento em lançamentos imobiliários na cidade de São Paulo. A Zona Leste despontou com crescimento de 93\%, seguida da Zona Sul, com $46 \%^{222}$. As facilidades de aquisição do crédito imobiliário têm contribuído para a tendência de difusão de empreendimentos populares.

Quanto à RMSP como um todo, o total de unidades residenciais, entre casas e apartamentos lançados em 2007, cresceu 70\% sobre o total lançado em 2006. O município de São Paulo, com preços cerca de $8 \%$ maiores, teve $65 \%$ dos lançamentos imobiliários da $\mathrm{RMSP}^{223}$.

\footnotetext{
${ }^{220}$ VASCONCELLOS, 1999, p.54.

${ }^{221}$ Ibidem, p.54.

222 http://www.blogtecnisa.com.br/ - acesso em 24.09.2007.

${ }^{223}$ MARCHESINI, 2008a , 2008b.
} 
Estes números nos ajudam a explicar o crescimento das viagens intra-metropolitanas. A verticalização da cidade aumenta seu adensamento, que, por sua vez, está relacionado ao crescimento de pessoas circulando sobre o sistema viário, ou seja, implica em mais trânsito.

A lentidão na execução das obras viárias na RMSP as torna, via de regra, pouco eficazes aos fins a que se destinavam. Visando sempre a ampliar a fluidez e otimizar os fluxos circulantes, o poder público realiza, de modo praticamente ininterrupto, obras no sistema viário estrutural metropolitano. A paisagem é, dialeticamente, construída e destruída incessantemente. Após a construção do Mini-Anel Viário e do Anel Viário Metropolitano, por exemplo, encontra-se em construção o Rodoanel, tendo em vista que os anéis viários anteriormente construídos estão completamente internos à malha urbana metropolitana.

Para Vasconcellos ${ }^{224}$, à primeira vista, a ampliação do sistema viário efetivamente ampliou a fluidez e macroacessibilidade em São Paulo, tanto "as mercadorias transportadas por caminhões quanto as pessoas transportadas por automóveis, táxis e ônibus tiveram aumentadas suas possibilidades de circulação e sua velocidade média"225, e tem-se a impressão de "que o Estado interveio globalmente na fluidez, aumentando a velocidade média de todos os elementos envolvidos. ${ }^{, 226}$.

Ao crescer muito rapidamente, a "frota de automóveis em circulação começou a prejudicar a velocidade dos ônibus, apesar dos aumentos de capacidade viária. Isto significa que aquele ganho original de velocidade dos ônibus começou a ser perdido pelo efeito do enriquecimento parcial da classe média"227. Este fenômeno não foi acompanhado pela expansão suficiente da rede de ônibus para as periferias, que, justamente por não terem infraestrutura adequada, tornaram-se atraentes pelo seu baixo valor. A população da periferia, então, é quem vai enfrentar "problemas graves de acessibilidade e fluidez: ônibus

\footnotetext{
${ }^{224}$ VASCONCELLOS, 1999.

${ }^{225}$ Ibidem, p. 232.

${ }^{226}$ Ibidem, grifo do autor.

${ }^{227}$ Ibidem, p. 233.
} 
superlotados trafegam por vias precárias, de terra ou asfalto, mas em condições geométricas desfavoráveis para o desenvolvimento de velocidades razoáveis."228.

Esta citação refere-se à década de 1960, mas podemos assegurar que ainda se encaixa na metrópole contemporânea. Em 2007, ao empreendermos visita à sub-região norte da RMSP, tomamos um ônibus em Franco da Rocha para o Jardim Montreal, bairro daquele município. Ele estava vazio, era relativamente velho, com bancos duros e bastante empoeirados. Ao passar pela estação de trem, muitas pessoas entraram. O trajeto se fez em uma região montanhosa, com muitas casas espalhadas pelas encostas, porém não se tratava de região favelizada. Havia escadas para pedestres galgarem os morros, terrenos vazios e com construções de casas. A rua por onde o ônibus passava era asfaltada, mas as travessas eram de terra. No Jardim Montreal, o ônibus entrou em uma rua de terra muito íngreme. Havia bastante poeira proveniente da terra vermelha. Esta visita nos remete àquela realidade que Vasconcellos (1999) relatava. Verificamos que o local ainda permanece de difícil circulação em muitos enclaves na RMSP (Fotografias 17 e 18).

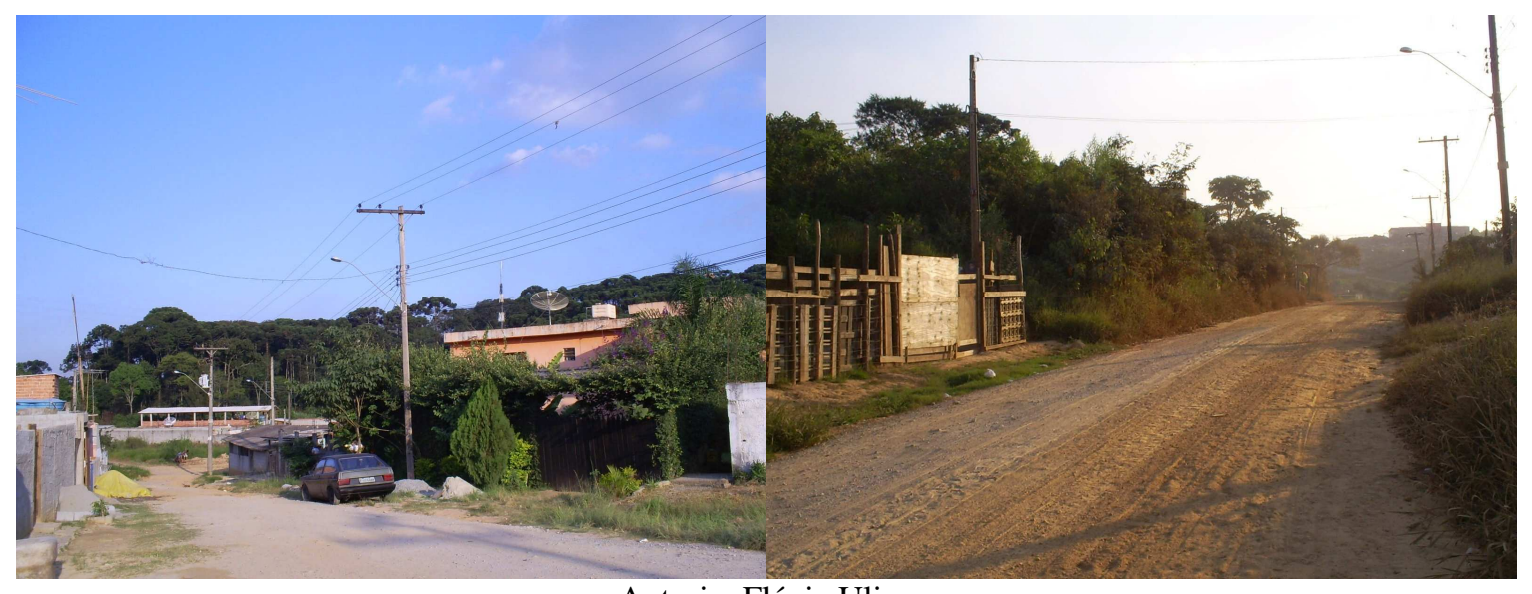

Autoria: Flávia Ulian

Fotografias 17 - 18 - Município de Franco da Rocha - Jardim Montreal 18/04/07

${ }^{228}$ VASCONCELLOS, 1999, pp.233-234. 
Apoiando-nos em alguns depoimentos colhidos em entrevistas realizadas com trabalhadores que usam o sistema de transporte coletivo da RMSP, verificamos que o desgaste do usuário deste sistema é gritante:

Eu considero meu cotidiano desgastante fisicamente e mentalmente. Porque o ônibus sempre está lotado, com muito aperto e empurra-empurra. Mentalmente cansa, pois tem sempre trânsito e o ônibus fica praticamente parado, com muito calor e muito aperto, com isso o nervosismo é muito grande ${ }^{229}$.

O deslocamento é desgastante pelo número de pessoas permitidas dentro do ônibus ser excessivo, pela velocidade e frenagem brusca dos motoristas e pelo espaço interno dos micro-ônibus. Como a distância é relativamente curta e fora dos horários de "rush", o percurso é feito de forma satisfatória e rápida. Um outro "porém" é o preço cobrado pelas conduções ${ }^{230}$.

Com certeza o deslocamento é mais desgastante que o próprio trabalho. Consome um tempo valioso, principalmente na vida de um trabalhador universitário. Além disso, o transporte, com exceção do trólebus, é precário, sujo, perigoso, pois literalmente o ônibus que utilizo está "caindo aos pedaços" ${ }^{231}$.

O deslocamento é muito desgastante, pois tenho que andar mais ou menos um quilômetro para pegar o ônibus no Paço Municipal de São Bernardo. O ônibus demora cerca de uma hora e meia, dependendo do trânsito, e tenho que descer no Aeroporto, que é o ponto final, e andar mais um quilômetro e meio para chegar ao trabalho. Do trabalho para a faculdade, o ônibus do caminho de volta pára na avenida Senador Vergueiro e tenho que andar mais um quilômetro até a faculdade $^{232}$.

O Estado brasileiro, portanto, optou por reproduzir a sociedade capitalista como estrutura de classes, atuando como motor de desigualdades, favorecendo concentração e marginalização ${ }^{233}$.

Logicamente, o Poder Público não pôde se abster totalmente de prover o mínimo de infra-estrutura às classes desfavorecidas que habitam as periferias, com forte demanda de transporte, pois destas áreas originam-se grandes contingentes de viagens por motivo de trabalho nas áreas centrais. Segundo Mello ${ }^{234}$, o investimento nas áreas em que reside a população de baixa renda é quase sempre o residual dos orçamentos públicos. Esta opção

\footnotetext{
${ }^{229}$ Informação pessoal, 20/04/07.

${ }^{230}$ Informação pessoal, 20/04/07.

${ }^{231}$ Informação pessoal, 20/04/07.

${ }^{232}$ Informação pessoal, 20/04/07.

${ }^{233}$ SANTOS, 1994.

${ }^{234}$ MELLO, 2000.
} 
mostra a conivência do Estado com a construção de um modelo econômico concentrador de renda e de um espaço segregador.

Para podermos entender as transformações da rede de transportes na RMSP, será necessário abordar como se deu a intervenção do Estado na circulação urbana, alterando as condições de circulação metropolitana. O planejamento e as políticas públicas têm caráter político e "um jogo complexo de interesses e ações"235 permeia todo o processo de planejamento dos transportes públicos urbanos. O planejamento urbano, que visa a propor regulamentação de uso do solo e da ordenação do espaço urbano é tão necessário no âmbito dos transportes, já que a circulação urbana, que hipoteticamente seria um resultado natural das atividades humanas ocorridas na cidade, acaba sendo submetida a opções quase sempre políticas $^{236}$.

O tratamento do trânsito apenas como uma questão técnica estaria visando à imposição de uma nova racionalidade à ação estatal sobre a circulação, no sentido de "viabilizar uma nova velocidade para a circulação do capital, obstaculizada pelo congestionamento crônico do trânsito. ${ }^{, 237}$. A análise realizada pelo autor, embora não reflita os tempos de reestruturação da produção, tendo em vista que seu estudo compreendeu o período entre 1960 e 1980, já retratava o Brasil moderno, inserido em um "novo padrão de desenvolvimento, que diversifica as atividades, aumenta os deslocamentos no espaço urbano e acelera a acumulação, [exigindo] [...] um nível compatível de velocidade de circulação [...]." ${ }^{\text {,238 }}$. Entre 1987 e 2007, período de análise desta pesquisa, poderíamos aferir que tal necessidade de velocidade de circulação foi potencializada incrivelmente; poderíamos afirmar, ainda, e sem nenhuma dúvida, que o Estado brasileiro não mudou de posição quanto a construir a cidade da classe média, mas, apesar desta opção, precisou dar uma certa atenção ao sistema de transporte público

\footnotetext{
${ }^{235}$ VASCONCELLOS, 1999, p.35.

236 Ibidem.

${ }^{237}$ Ibidem, p.238.

${ }^{238}$ Ibidem.
} 
metropolitano, porque, caso contrário, a própria classe para a qual a cidade foi construída estaria "imobilizada" pelos congestionamentos. No entanto, demorou-se demais para que isso começasse a acontecer e o transporte público, no final do período por nós estudado, ainda se encontra insuficiente e desorganizado. A insuficiência do transporte sobre trilhos acabou por sobrecarregar o sistema de ônibus e, conseqüentemente, o sistema viário, repercutindo na circulação dos automóveis. Esta demora não se deveu à falta de políticas, mas sim à sua implementação e à sua coerência.

Percebemos muito recentemente uma reorganização do sistema. As integrações físicas mais articuladas e até mesmo o início das integrações tarifárias vêm ocorrendo. Estas ações sinalizam para uma melhoria do sistema como um todo. Os terminais de integração para a interligação entre os sistemas de ônibus locais e os estruturais, no caso de muitos municípios da RMSP, são acompanhados de críticas relacionadas à demora que os passageiros enfrentam nas baldeações. Depoimento de passageira entrevistada no Terminal Vila Luzita, em Santo André, em 24.08.2007 revela esta insatisfação. Ela usa o terminal para realizar a baldeação do ônibus que vem do bairro onde mora e pegar outro ônibus para a Vila Pires, onde trabalha. O trajeto do ônibus é de meia hora, mas ela fica mais meia hora no terminal a espera do segundo ônibus. Não é cobrada a segunda passagem, mas o tempo de espera na baldeação atrapalha seu deslocamento. Os ônibus ficam estacionados no terminal aguardando por outros veículos para, então, fazerem uma nova viagem.

Vasconcelos $^{239}$ afirma que a modernização na área dos transportes públicos foi concentrada no metrô, "criando-se um hiato tecnológico entre o arcaico, representado pelo sistema de ônibus na sua configuração atual, e a moderna [tecnologia], representado (sic) pelo metrô" 240 . Para ele, a modernização realmente essencial sob o ponto de vista da massa dos

\footnotetext{
${ }^{239}$ VASCONCELLOS, 1999.

${ }^{240}$ Ibidem, p.243, grifo do autor.
} 
trabalhadores é a do sistema de ônibus, mas esta não interessa ao capital. A circulação generalizada no espaço urbano torna-se apenas virtual ao usuário do transporte coletivo.

Cabe à Geografia abordar a questão do uso seletivo do espaço urbano como substrato físico cortado por vias e meios de transporte em função da valorização de alguns espaços em detrimento da desvalorização de outros em decorrência, em grande parte, do mercado imobiliário. Este capítulo intenciona, portanto, dar um parâmetro geral da implantação da infra-estrutura e de políticas de transporte, principalmente das políticas estaduais em nível metropolitano, dos três modos de transporte: ferroviário, metroviário e rodoviário.

Procuramos relacionar a estruturação da metrópole ${ }^{241}$ com a implantação e o crescimento das infra-estruturas de cada modo, ao mesmo tempo em que as relacionamos com as políticas de transporte. Entendemos como políticas de transporte os planos do Governo relacionados à área. Dada a impossibilidade, neste texto, de abordar todas as políticas de todos os municípios integrantes da RMSP, versaremos sobre algumas mais significativas que abrangem toda a RMSP, e o município de São Paulo, já que é o maior da região e também o que apresenta maior importância em termos de viagens.

Sabemos que cada município possui, dependendo de seu tamanho, população e da quantidade de deslocamentos, políticas próprias de transporte e trânsito. Porém, nosso foco são as políticas metropolitanas, que pensam a região como um todo e que são realizadas pela STM, do governo estadual. Cabe observar que os planos e as políticas que serão apresentados, muitas vezes abarcam os três modos de transporte, pois são planos abrangentes. Procuramos

\footnotetext{
${ }^{241}$ A relação da construção da infra-estrutura de transportes com a estruturação da metrópole é evidente. No entanto, foge ao escopo desta pesquisa o aprofundamento da análise desta relação. Langenbuch (1971) o fez até o ano de 1970. Como sugestão, pensamos que valeria a pena empreender, para próximas pesquisas, os mesmos detalhes que este autor deu ao tema, para décadas posteriores.
} 
evidenciar cada modo separadamente para melhor compreendê-los. Iniciaremos com os modos ferroviário e metroviário, que pertencem aos modos sobre trilhos, passando depois ao modo rodoviário ou sobre pneus. Finalizamos com o modo não motorizado a pé.

Quanto ao enfoque temporal, apesar de nosso período de análise concentrar-se entre 1987 e 2007, foi necessário recuar um pouco mais no tempo para podermos entender o processo de metropolização que se deu a partir de 1950, quando "a industrialização brasileira ganha novo ímpeto e São Paulo se afirma como a grande metrópole fabril do país." ${ }^{242}$

O recuo no tempo nos permite a visão do processo. A estrutura nos proporciona o entendimento das escolhas realizadas na dimensão política, pela sociedade e seus representantes, quanto à implantação da infra-estrutura viária, que compõe a forma, o sistema de objetos, e que possibilitam os fluxos, ou sistema de ações (função).

Nesta segunda parte do texto, preocupamo-nos em mostrar a forma e a estrutura, no processo de desenvolvimento da infra-estrutura ferroviária, metroviária e rodoviária da metrópole paulista. Relatamos, em breves notas, o processo de implantação do sistema ferroviário, seguido da caracterização da rede ferroviária metropolitana e das políticas de recomposição do sistema ferroviário.

Procedemos da mesma forma quanto ao sistema metroviário, finalizando o modo "sobre trilhos" com as políticas de expansão do sistema metroviário.

Ao abordar o modo rodoviário, procuramos relacioná-lo com a metropolização de São Paulo. Evidenciamos, assim, as políticas de ampliação do sistema viário voltadas ao transporte individual e coletivo, retratando a lenta evolução dos corredores de ônibus. Discutimos ainda, neste item, o processo de implantação do Rodoanel, que já provoca intensas transformações no espaço urbano.

\footnotetext{
${ }^{242}$ SANTOS \& SILVEIRA, 2006, p.43.
} 
A análise do modo rodoviário contempla ainda as políticas para o sistema viário e de trânsito, porém de forma superficial, já que o trânsito não é exatamente nosso objeto de pesquisa.

Aprofundamos o tema das políticas ao abordar os sistemas de ônibus regular e de fretamento, e o sistema de lotações.

Finalizamos a segunda parte desta Tese com a abordagem do transporte não motorizado, o modo a pé. 


\section{3 - Infra-Estrutura e Políticas nos Modos de Transporte Terrestres de Passageiros da RMSP}

\section{1 - No Modo Ferroviário}

\subsection{1 - Breves notas sobre a implantação e início do desenvolvimento da ferrovia em São Paulo}

A implantação e desenvolvimento da ferrovia em São Paulo deram-se com a inauguração da São Paulo Railway, em 1867, da Sorocabana, em 1872, e da São Paulo-Rio de Janeiro (Dom Pedro II), futura Central do Brasil, em 1877. Estas estradas tiveram um importante papel haja vista que suas estações serviram como embriões dos atuais municípios que margeiam as linhas de trem. Tão importante quanto isso foi a concentração industrial que se deu em São Paulo no entorno das linhas férreas. Percebemos o papel estruturador dos transportes no parque industrial paulista, que só pôde crescer devido aos investimentos em transportes, e talvez não tenha crescido mais, com melhor qualidade nos deslocamentos dos trabalhadores, devido à sua não priorização no rateio dos investimentos do governo.

Os trens que transportavam também passageiros e paravam em muitas estações, os trens paradores, passaram a ser denominados trens de subúrbio e, posteriormente, trens metropolitanos, sendo essenciais para o transporte da mão-de-obra industrial. Bairros dormitórios cresciam no município de São Paulo e nos municípios vizinhos ${ }^{243}$.

As ferrovias sofreram competição das novas rodovias que vinham sendo construídas. Apesar disso, em meados do século XX, no fenômeno de metropolização que se dava em São Paulo, tiveram as ferrovias papel fundamental. A qualidade dos serviços, por sua vez, deixava

${ }^{243}$ LANGENBUCH, 1971; PASSARELLI, 1994. 
muito a desejar, tendo em vista que os maiores recursos foram destinados ao transporte rodoviário, mais interessante para as políticas nacional e internacional. O transporte de carga passou assim, e cada vez mais, a ocorrer por via rodoviária. Mesmo assim, o trem metropolitano, então conhecido como trem de subúrbio, ainda representava o principal meio de transporte das classes mais pobres que habitavam os demais municípios da metrópole, dando acesso à Capital. Com a opção do trem, a metropolização se acentuava, expandindo as localidades por ele atendidas ${ }^{244}$.

Em Itaquaquecetuba, deu-se exatamente este processo. Na década de 1940, este município começou a esboçar a função de "subúrbio dormitório" pelo aproveitamento da linha férrea da antiga Estrada de Ferro Central do Brasil, por onde se deslocavam diariamente as pessoas que trabalhavam nas fábricas da Capital ou da região de São Miguel e nos estabelecimentos comerciais do centro urbano ${ }^{245}$. Há três estações de trem em Itaquaquecetuba, no entanto, Lemos ${ }^{246}$ afirma que nenhuma delas trouxe um desenvolvimento muito grande ao município e que os bairros que surgiram ao seu redor não têm grande expressão.

A eletrificação da Santos-Jundiaí (antiga São Paulo Railway) a partir de 1950, entre as estações Jundiaí e Moóca, estendida a Santo André em 1951 e atingindo Paranapiacaba em 1959, beneficiou o transporte de passageiros. Este processo fortaleceu a expansão da metrópole, já que o novo serviço, “mais veloz, reduziu as distâncias e permitiu que as regiões mais periféricas assumissem mais fortemente o papel de cidades-dormitório"247. Podemos compreender o fenômeno de metropolização que se dava. Lemos ${ }^{248}$ salienta a importância da ferrovia neste processo, afirmando que estes eixos de circulação foram os responsáveis pela

\footnotetext{
${ }^{244}$ LANGENBUCH, 1971; PASSARELLI, 1994.

${ }^{245}$ LEMOS, 1980.

246 Ibidem.

${ }^{247}$ PASSARELLI, op. cit., p.42.

248 Op. cit.
} 
aglutinação que foi se instalando no território. As áreas de maior crescimento acompanhavam praticamente as estradas de ferro: a linha Sudeste, em direção a Santos-Jundiaí; as sub-regiões Nordeste e Oeste, que acompanham a estrada de ferro Sorocabana; e a Estrada de Ferro Central do Brasil, na qual uma aglutinação mais densa compacta e uniforme é observada ${ }^{249}$. A função de muitos municípios que sofreram efeitos da metropolização era, desse modo, abrigar mão-de-obra da Capital.

Entre 1950 e 1970, manteve-se o processo de modernização do serviço de trens de subúrbio. Foram adquiridos mais trens. Com a maior oferta do serviço de subúrbio e a expansão da região metropolitana, aumentou o número de passageiros atendidos. Os serviços de trem de subúrbio foram ampliados, atingindo de Paranapiacaba a Jundiaí em 1970. Com o intuito de possibilitar as comparações, a Tabela 13 compõe o número de passageiros diários entre 1950 e $2007:$

Tabela 13 - Região Metropolitana de São Paulo Número de passageiros transportados no serviço de subúrbios (em milhares/dia)

\begin{tabular}{l|c|c|c|c|c|c|c|}
\hline $\mathbf{1 9 5 0}$ & $\mathbf{1 9 6 0}$ & $\mathbf{1 9 7 0}$ & $\mathbf{1 9 7 7}$ & $\mathbf{1 9 8 7}$ & $\mathbf{1 9 9 7}$ & $\mathbf{2 0 0 2}$ & $\mathbf{2 0 0 7}$ \\
\hline 66 & 128 & 138 & 512 & 891 & 650 & 765 & 1.600 \\
\hline Fonte: PASSARELLI, 1994; CIA. DO METROPOLITANO DE SÃO PAULO.Aferição da Pesquisa O-D 1997, \\
2002; www.cptm.sp.gov.br - acesso em 03.04.2008. \\
Organização da autora.
\end{tabular}

A Tabela 13 indica incessante crescimento de usuários, embora, a oferta de trens tenha estagnado durante um longo período. As modificações eram realizadas em decorrência da expansão das localidades servidas pela estrada, que trazia um aumento da demanda não previsto nos planos e políticas nacionais ou regionais de transportes ${ }^{250}$.

Em 1957 foi criada a Rede Ferroviária Federal S/A (RFFSA), que unificou o sistema ferroviário nacional. No entanto, o estímulo ao desenvolvimento do transporte rodoviário, que interessava às políticas nacional e internacional, acirrou a competição entre o transporte

\footnotetext{
${ }^{249}$ LEMOS, 1980.

${ }^{250}$ PASSARELLI, 1994.
} 
ferroviário e o rodoviário e, rapidamente, "os trens perderam espaço para os caminhões, ônibus e automóveis e, mais recentemente, para o Metrô. ${ }^{, 251}$ Como os recursos arrecadados priorizavam o investimento nas rodovias, faltaram recursos em investimentos no transporte ferroviário. Logo, a RFFSA tornou-se uma empresa deficitária, "necessitando constantemente de recursos da União para saldar compromissos assumidos e ampliar a oferta de serviços." 252 . A autora observa que houve uma "total falta de programação dos recursos destinados ao transporte entre os governos do Estado e da União"253 , já que o Governo Federal inaugurou o moderno sistema cremalheira-aderência no trecho ferroviário da Serra do Mar em 1974, na mesma época em que o Estado de São Paulo construiu a Via Imigrantes, inaugurada em 1976. Quanto ao transporte na RMSP, a União apresentava planos para a modernização dos trens de subúrbio juntamente à construção da linha vermelha de Metrô, na segunda metade da década de 1970, paralela à linha de trem da então Central do Brasil, na zona leste do município de São Paulo. A perda de passageiros do transporte ferroviário para as modalidades rodoviária e metroviária se deu, também, pelo seu obsoletismo. Causa espanto que "somente em 1970, os vagões de madeira da antiga São Paulo Railway foram totalmente substituídos pelos trens metálicos" ${ }^{254}$, produzidos no Brasil pela Mafersa (Material Ferroviário S/A).

Em 1984, foi criada a Cia. Brasileira de Transportes Urbanos (CBTU), responsável pela administração do transporte suburbano das ferrovias federais. A nova empresa enfrentou a demanda crescente de transporte suburbano da RMSP, como pôde ser visto na Tabela 13.

Apesar do exposto, a melhoria do transporte rodoviário não reduziu o número de passageiros do trem, que ainda representava o principal meio de transporte das classes sociais mais pobres, dando acesso à Capital. No caso da EFSJ, que ligava Santo André, onde havia trabalho, comércio e educação, com os municípios de Mauá, Ribeirão Pires e Rio Grande da

\footnotetext{
${ }^{251}$ PASSARELLI, 1994, p.44.

252 Ibidem.

${ }^{253}$ Ibidem, p.45.

${ }^{254}$ Ibidem, p.43.
} 
Serra, verificou-se que estes municípios atingiram grande crescimento populacional, fornecendo mão-de-obra para Santo André, São Bernardo do Campo e São Caetano do Sul, assumindo a função de cidades dormitório do $\mathrm{ABC}^{255}$.

Com o início das operações do Metrô, na linha Norte-Sul (hoje linha 1 - Azul), a estação Luz, mesmo ainda não conectada com a estação de trem Luz, permitia a integração, ainda que cobrada, entre o trem e o metrô. Posteriormente, a estação Brás ligou a EFSJ com a linha Leste-Oeste (hoje linha 3 - Vermelha) de metrô. Num futuro próximo, a estação Barra Funda de metrô facilitaria a ligação de muitas áreas da RMSP atendidas pelo metrô e pelo trem. Estes fatores aumentaram a demanda das pessoas pelo uso do trem ${ }^{256}$.

O sistema metropolitano de ônibus também se interligou ao trem a partir de 1988. Em frente à estação Santo André foi inaugurado o Terminal Santo André do Corredor Metropolitano, ligando São Mateus, na Zona Leste do município de São Paulo, ao Jabaquara, na Zona Sul do município de São Paulo, passando pelos municípios de Santo André, São Bernardo do Campo e Diadema. Circulando em corredor exclusivo de trólebus ou ônibus a diesel, aproximou ainda mais as cidades ${ }^{257}$.

A falta de investimento na modernização tecnológica nos sistemas de trens metropolitanos pôs à mostra a fragilidade do sistema ferroviário. Com a redução do transporte de carga pela ferrovia - já que muitas indústrias instaladas ao longo da linha férrea reestruturaram suas produções e deixaram de operar com grandes estoques, o que necessitava mais agilidade nas entregas - os ramais ferroviários dentro das indústrias foram abandonados $^{258}$.

O descaso no atendimento dos usuários, o excesso de lotação, a demora entre as composições, o uso da ferrovia de passageiros concomitantemente ao transporte de carga:

\footnotetext{
${ }^{255}$ PASSARELLI, 1994.

${ }^{256}$ MELLO, 2000.

${ }^{257}$ PASSARELLI, op. cit.

${ }^{258}$ Ibidem.
} 
todos estes fatores tornaram o trem metropolitano decadente e desinteressante para os passageiros. Esta realidade veio mostrar sinais de transformação há muito pouco tempo, quase no final do período em análise por esta pesquisa. Voltaremos a este assunto oportunamente. 


\subsection{2 - Características da Rede do Trem Metropolitano da RMSP}

Os trens suburbanos, hoje chamados trens metropolitanos, transportavam diariamente uma porcentagem muito baixa de passageiros. Em 1997, a quantidade diária de deslocamentos realizados de metrô era mais do que o dobro daqueles realizados através de trem metropolitano. A desproporção tornava-se mais acentuada quando se sabe que o número de viagens a pé era pelo menos dezesseis vezes maior do que o dos deslocamentos pelos trens metropolitanos. Em 2007, o uso dos trens metropolitanos mais do que duplicou, registrandose uma média de 1,6 milhão de viagens nos dias úteis desse ano.

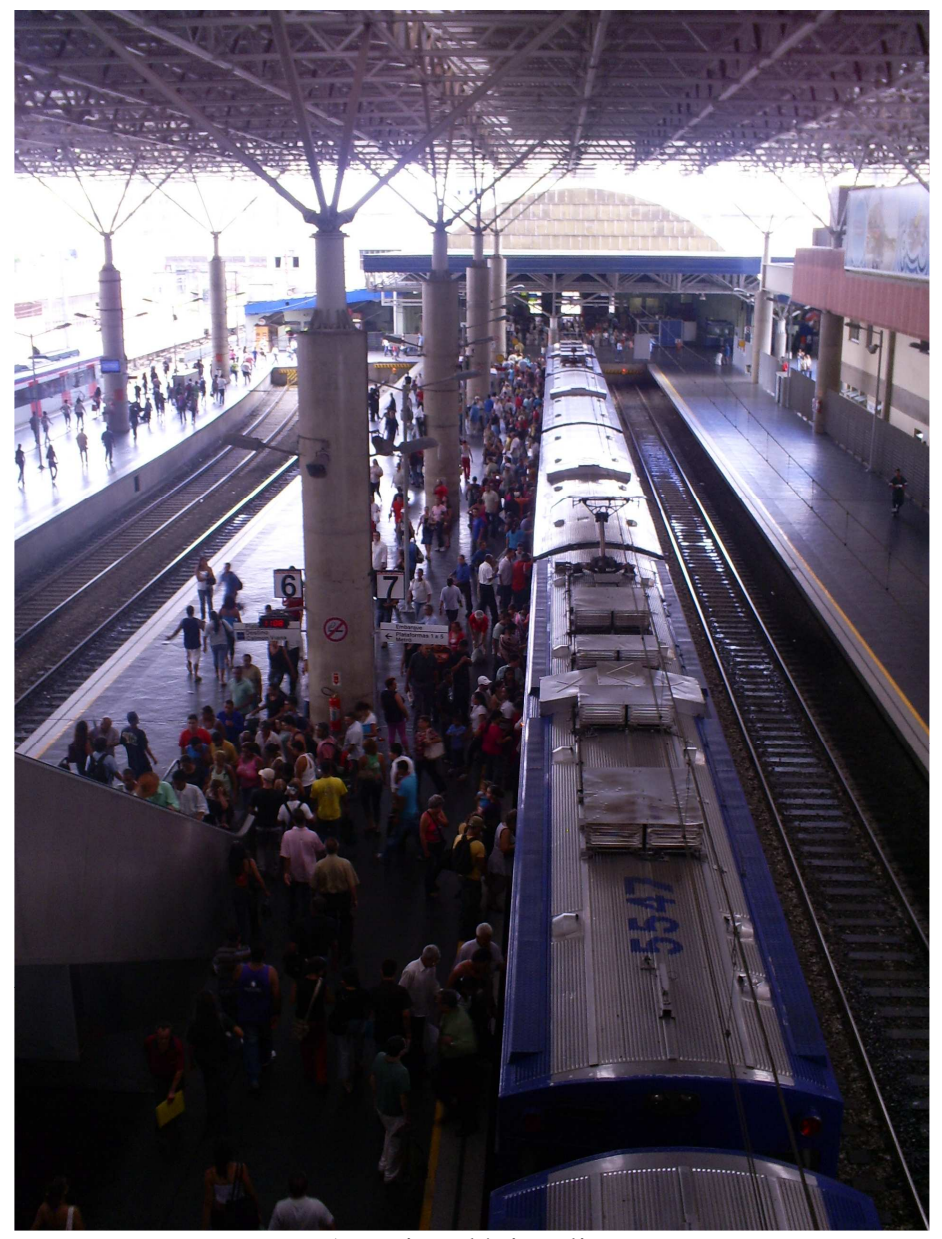

Autoria: Flávia Ulian

Fotografia 19 - Município de São Paulo - Plataforma da Estação Brás $12 / 03 / 08$ 


\section{Mapa 3 - Região Metropolitana de São Paulo Rede de Trens da CPTM}

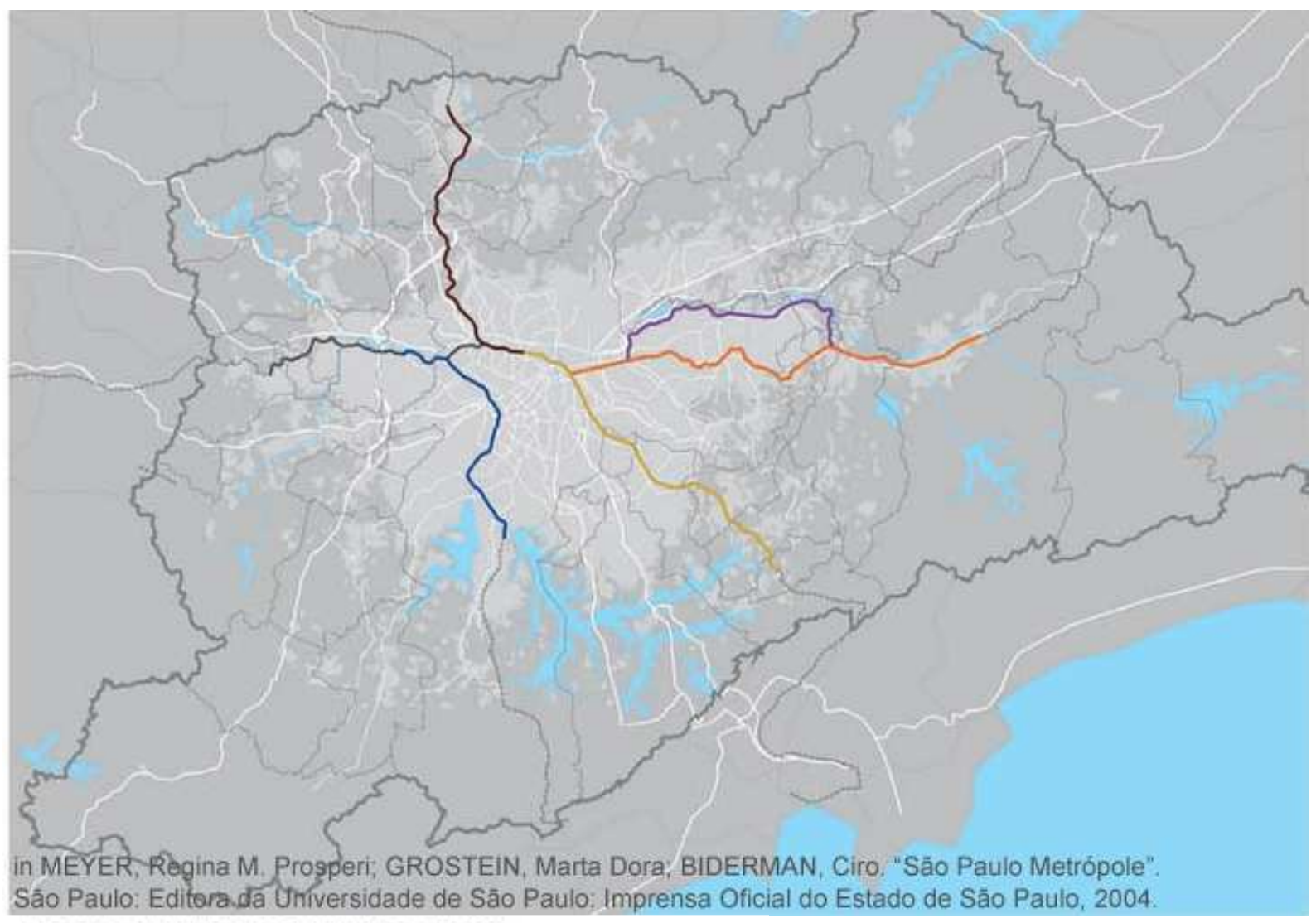

\section{TREM METROPOLITANO 2002}

- Linha A/ Barra Funda - Francisco Morato

- Linha B / Júlio Prestes - Itapevi

- Linha C / Osasco - Jurubatuba

- Linha D / Barra Funda - Rio Grande da Serra

- Linha E / Barra Funda - Estudantes

- Linha F/Brás - Calmon Viana

\#+m Ferrovias 2001 operadas pela CPTM

FONITE: Laboratscio de Uutanismo a Metrodocle - LUME

FONTES BASICAS

sesema vitro pincias LOBI, sd, SAO PAULO (ESTADO), EMPLASA, 1994, MAPOCRAF, 1998

tiea urtanizads 1997. SAO PACLLO (ESTADO) EMPLASA. 2001

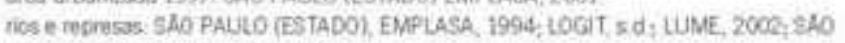
PAULO (ESTADO) SMA, IPT, 2000

Iimins adminictrativos LOGIT, sd; SAO PAULO (ESTADO), EMFIASA, 1994;

tetrovias, metis e estaçCES SAD PAULO (ESTADO). STM, 1996.

todosnet: SAO FALILO (ESTADO), STM, DEASA, PROTRAN, 2003 .

0

10

20 Quilâmetros
Fonte:http://lume.fau.usp.br/tikiwiki/tiki-

index.php?page=São\%20Paulo\%20Metrópole\#attachments - acesso em 20.06.2008 Organização da autora. 
Figura 2 - Linhas de Trem da CPTM, Metro e Corredor Metropolitano da EMTU

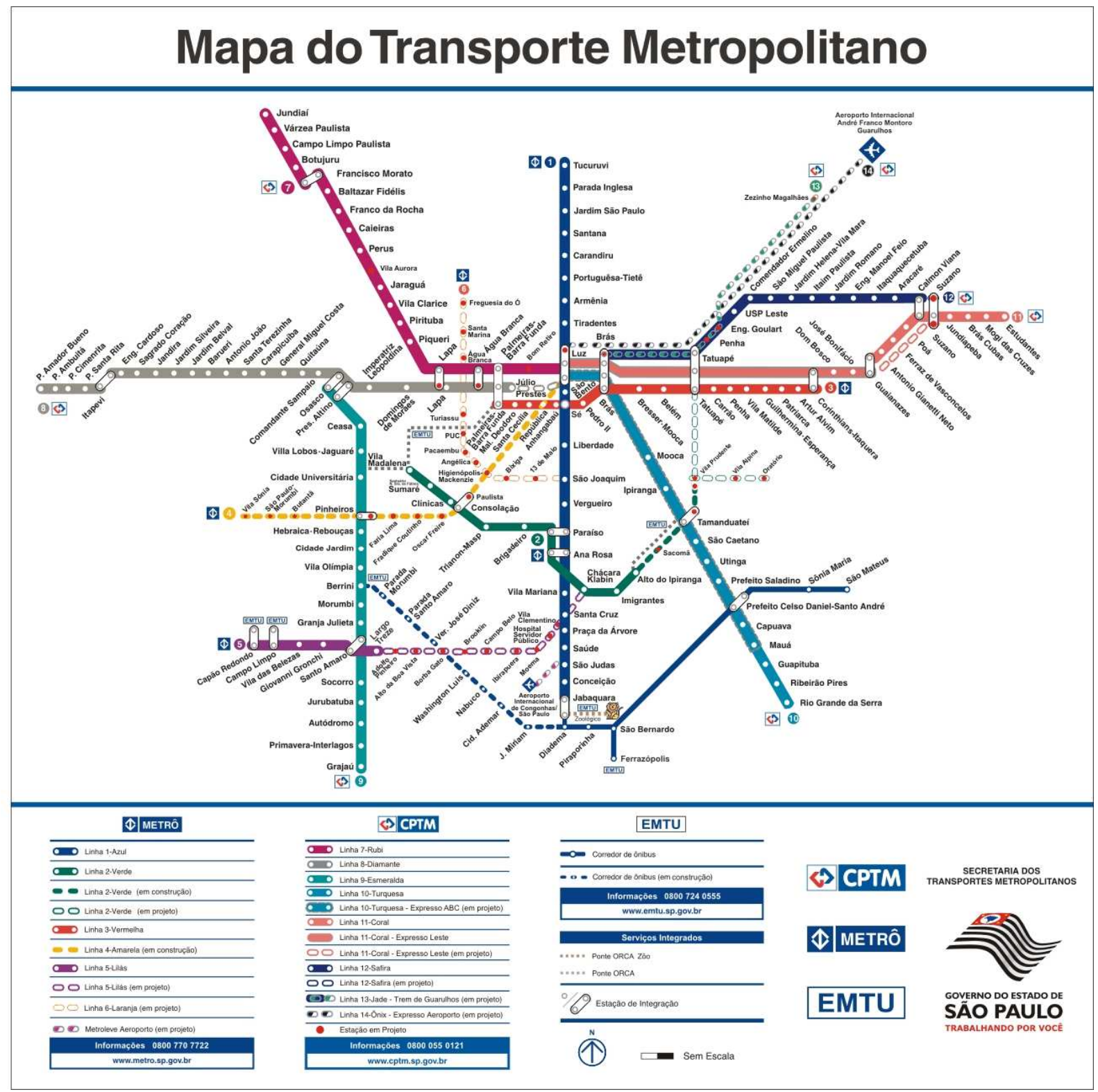

http://www.cptm.sp.gov.br/E_IMAGES/geral/Mapa_popup.asp - acesso em 20.06.2008

Os trens metropolitanos servem ao município de São Paulo e a mais outros 21 municípios da Grande São Paulo, fazendo sua interligação. Existem 6 linhas com 257,5 km de 
extensão total e $88^{259}$ estações que, interligadas aos ônibus e metrôs, proporcionam um sistema metropolitano de transportes razoavelmente eficiente.

Desde 1996, todo o sistema é operado pela CPTM, subordinada à STM ${ }^{260}$.

A integração com o metrô possibilita o alcance do transporte sobre trilhos em 318,8 km de linhas com o pagamento de uma única tarifa. Em 2004, o processo de integração tarifária entre o metrô e o trem teve início na estação Luz, estendendo-se nos anos seguintes para as estações Barra Funda, Luz, Brás, Tatuapé e Santo Amaro. O uso do Bilhete Único, que possibilita a integração também com os ônibus municipais de São Paulo, mediante pagamento da diferença da tarifa dos ônibus $(\mathrm{R} \$ 2,30)$ para o valor da integração $(\mathrm{R} \$ 3,50)^{261}$, foi implantado no sistema em $2005^{262}$.

Neste item, descreveremos as linhas do sistema de trens metropolitanos, que se traduz, metodologicamente, pela forma.

\section{Quadro 1 - Sistema de Trens Metropolitanos Denominações das linhas}

\begin{tabular}{|c|c|c|}
\hline $\begin{array}{c}\text { Nome anterior } \\
\text { (utilizado nesta Tese) }\end{array}$ & Nome atual & Trajeto \\
\hline Linha A & Linha 7 - Rubi & Luz-Francisco Morato-Jundiaí \\
\hline Linha B & Linha 8 - Diamante & Júlio Prestes-Itapevi-Amador Bueno \\
\hline Linha C & Linha 9 - Esmeralda & Osasco-Autódromo \\
\hline Linha D & Linha 10 - Turquesa & Luz-Rio Grande da Serra \\
\hline Linha E & Linha 11 - Coral & Expresso Leste-Luz-Guaianazes e \\
& Guaianazes-Estudantes \\
\hline Linha F & Linha 12 - Safira & Brás-Calmon Viana \\
\hline- & Linha 13 - Jade & Em projeto \\
\hline- & Linha 14 - Ônix & Em projeto \\
\hline
\end{tabular}

Fonte: http://www.cptm.sp.gov.br/e_noticias/webnoticias/one_news.asp?IDNews=4327 - acesso 03.04.2008 Organização da autora.

\footnotetext{
259 Serão inauguradas estações no primeiro semestre de 2008, de acordo com a CPTM (http://www.cptm.sp.gov.br/ - acesso em 06.02.2008)

${ }^{260} \mathrm{O}$ sistema de trens atual é composto por dois sistemas anteriores, o da Fepasa (Ferrovias Paulistas S.A.) e o da RFFSA, sendo que este último havia passado a ser gerenciado pela CBTU, federal.

${ }^{261}$ Valores de 2007.

262 www.cptm.sp.gov.br - acesso em 06.02.2008.

263 A CPTM tomou a iniciativa de nomear de forma diferente as linhas do sistema de trens. Neste trabalho estamos usando as denominações que vigoraram até março de 2008, nomeando as linhas de A a F. A partir de abril de 2008, elas passaram a ser denominadas por números e cores, assim como já são as do Metrô, com o objetivo de reafirmar a integração da rede metroferroviária na RMSP.
} 
A linha A opera entre as estações Barra Funda, na zona oeste de São Paulo e o município de Francisco Morato. Há um prolongamento até Jundiaí. No total, esta linha tem 60,5 km e 17 estações. O tempo de deslocamento do início ao final é de 53 minutos, mais 25 minutos até Jundiaí. Os intervalos entre os trens variam de acordo com o horário, podendo ser de 8 a 20 minutos. Já entre Francisco Morato e Jundiaí, pode haver intervalos de 22 a 30 $\operatorname{minutos}^{264265}$.

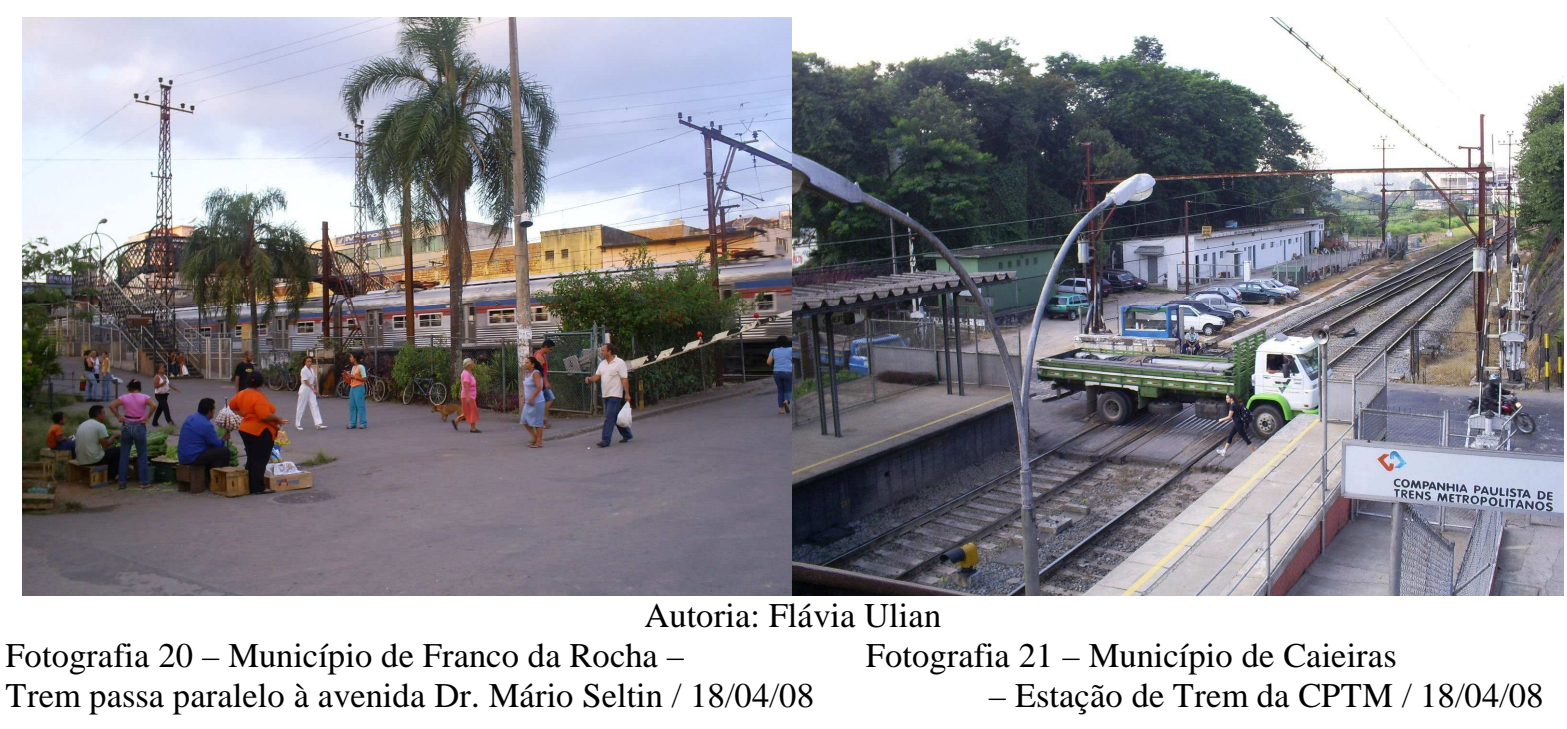

Trafegando pela linha A, entre as estações Barra Funda e Francisco Morato, em trabalho de campo realizado no dia 18.04.2007, verificamos que no entorno da estação Caieiras há dezenas de bicicletas estacionadas, provavelmente por usuários do trem que as usam para chegar à estação. No trecho entre as estações Francisco Morato e da Luz, o trem que circula é muito velho e desconfortável. Na Barra Funda, há acesso à linha B do metrô e ao Terminal Rodoviário. Às 19h20, ao chegar de Francisco Morato à Estação Luz, foi muito difícil sair do trem, pois muitas pessoas querem entrar. O trem lota nesta estação para voltar a Francisco Morato.

\footnotetext{
${ }^{264}$ Em todas as linhas serão divulgados dados sobre o intervalo entre os trens para o ano de 2007. Novos intervalos estão sendo implantados no Plano de Expansão da STM, a ser apresentado no próximo item. 265 www.cptm.gov.br - acesso em 06.02.2008.
} 


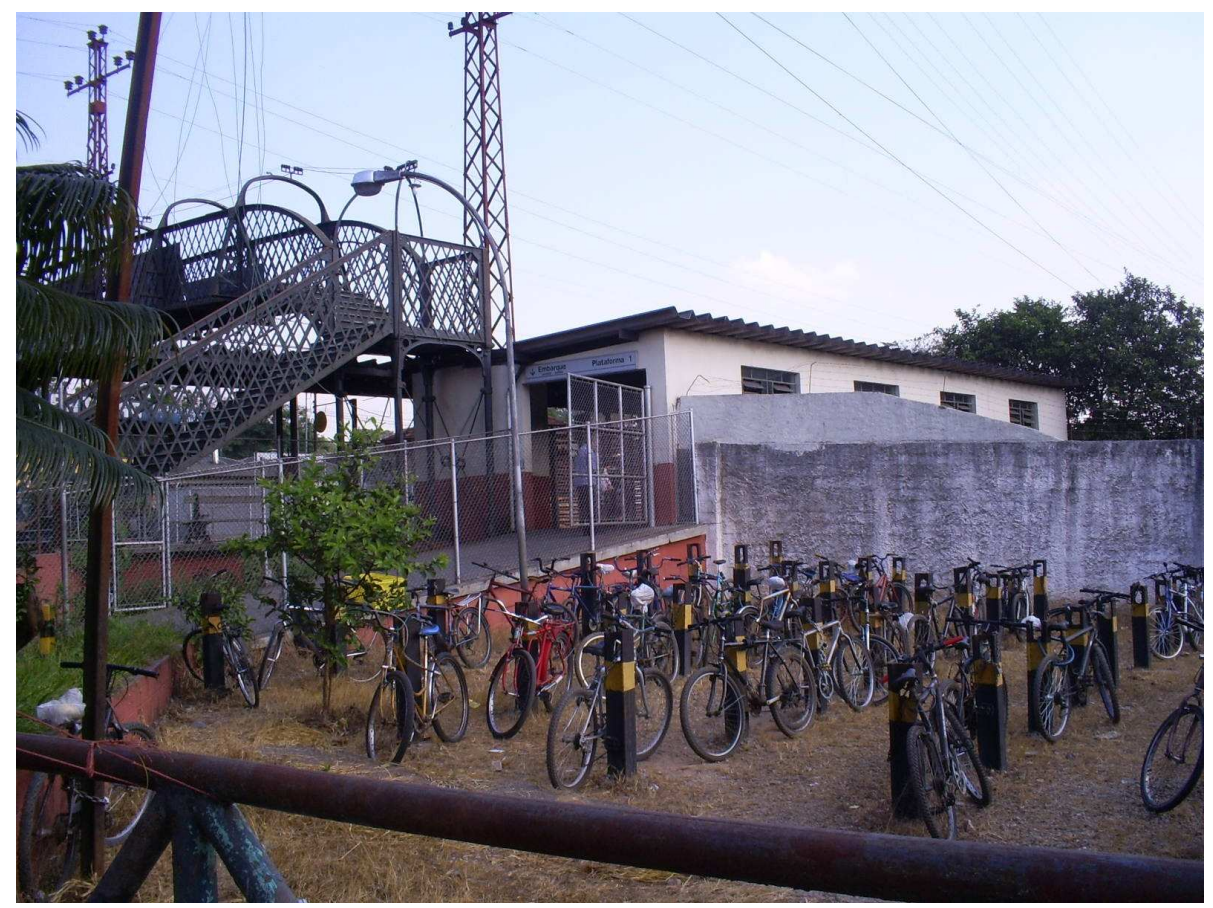

Autoria: Flávia Ulian

Fotografia 22 - Município de Caieiras - Estacionamento para bicicletas junto à Estação Caieiras / 18/04/08

Realizamos dezenas de entrevistas com os passageiros, buscando compreender alguns aspectos da subjetividade que esses trabalhadores vivenciam em seus deslocamentos para o trabalho, ajudando-nos, assim, a compreender a realidade sócio-espacial.

No cotidiano, os deslocamentos da população metropolitana são realizados, em grande parte, à revelia do desejo das pessoas. Ao conversar com a população durante seus deslocamentos de casa ao trabalho, percebemos que esses indivíduos almejam gastar menos tempo e passar por menos desconforto nestes trajetos.

Entrevistamos uma trabalhadora usuária desta linha de trem. Ela reside em Franco da Rocha e usa o trem diariamente para ir até seu trabalho, próximo à estação Barra Funda, em São Paulo. Ela confirmou que o trem é superlotado neste trecho. Por duas vezes, em 2007, a plataforma ficou lotada, mas o trem não veio, pois houve roubo de fios. Muitos passageiros voltaram para casa e outros tomaram ônibus para o trabalho. 


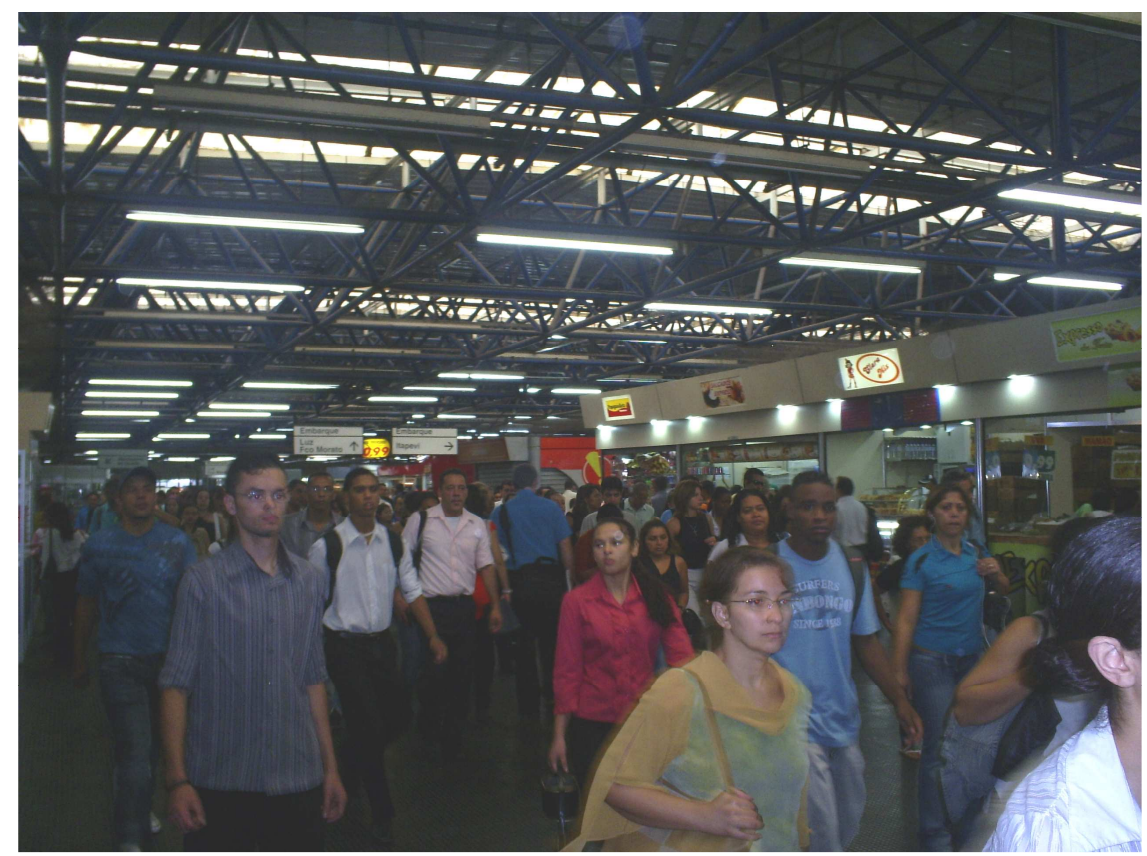

Autoria: Flávia Ulian

Fotografia 23 - Município de São Paulo - Terminal de Trem, Metrô e Ônibus da Barra Funda / 12/03/08

Outra entrevistada desta linha queixou-se da superlotação do trem no horário de pico da tarde. Se quiser se sentar, ela precisa voltar algumas estações. O único benefício deste meio de transporte, a seu ver, é que ele é rápido: o trajeto entre a Barra Funda e Francisco Morato leva 40 minutos, enquanto de ônibus, demora duas horas. Uma outra usuária desta linha, no trajeto entre Francisco Morato e Luz, reclamou muito do trem e disse que não sabe como agüenta ainda realizar este trajeto diariamente. Ela afirmou que já se queixou por carta, por $e$-mail e pessoalmente, mas ninguém toma providências, principalmente no que se refere ao fato de existirem apenas quatro escadas para a evacuação da plataforma na estação da Luz, o que torna a vazão da multidão que sai dos trens perigosa, podendo haver pisoteamento. Ela reconheceu, no entanto, que no passado já foi muito pior, quando o trem ia direto de Francisco Morato até Rio Grande da Serra. Como atualmente é obrigatória a baldeação na Luz, melhorou bastante o embarque. Vivenciando a péssima qualidade do deslocamento, custa-nos imaginar como seria pior do que isso. 


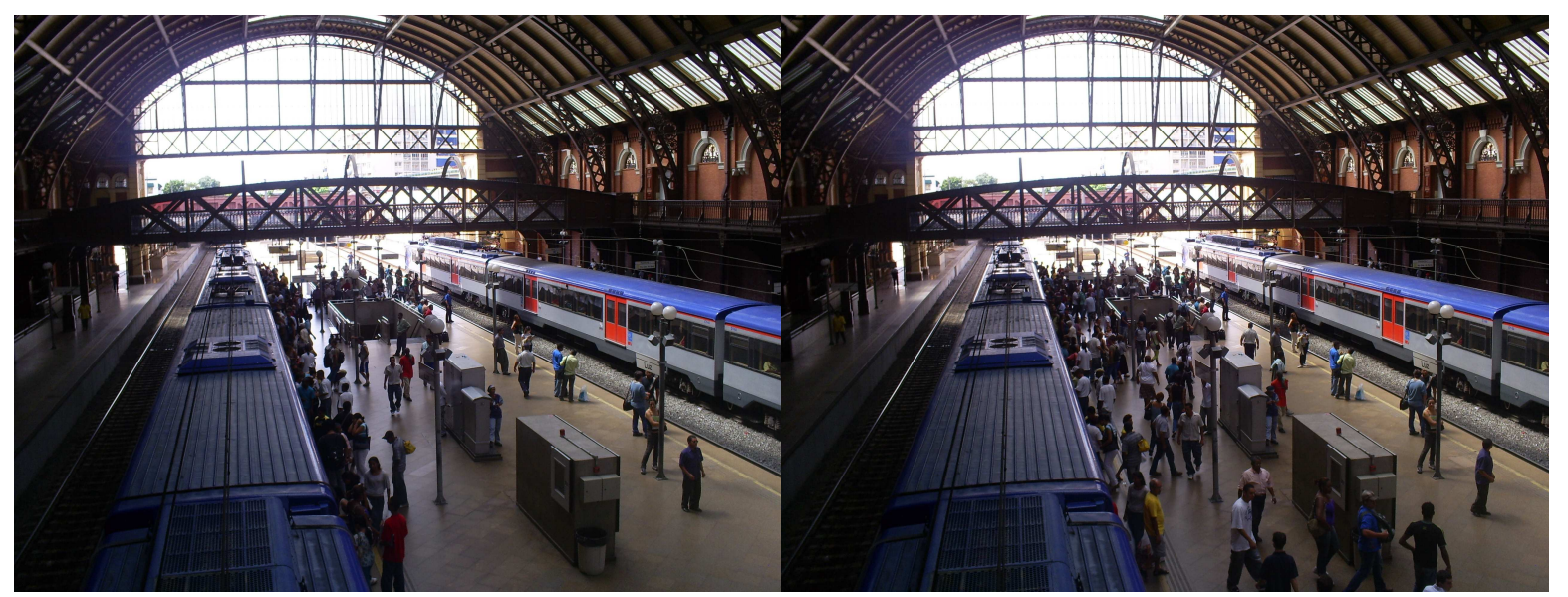

Autoria: Flávia Ulian

Fotografias 24 e 25 - Seqüência de desembarque na Estação da Luz em horário fora do pico / 12/03/08

A linha B liga as estações Júlio Prestes a Itapevi, havendo um prolongamento até Amador Bueno, no município de Itapevi. Esta linha tem 41,6 km e 24 estações. O tempo de deslocamento do início ao final da linha leva 59 minutos, mais 21 até Amador Bueno. Os intervalos entre os trens variam de acordo com o horário, podendo ser de 8 a 20 minutos. Já entre Itapevi e Amador Bueno, os intervalos são de 30 a 60 minutos ${ }^{266}$.

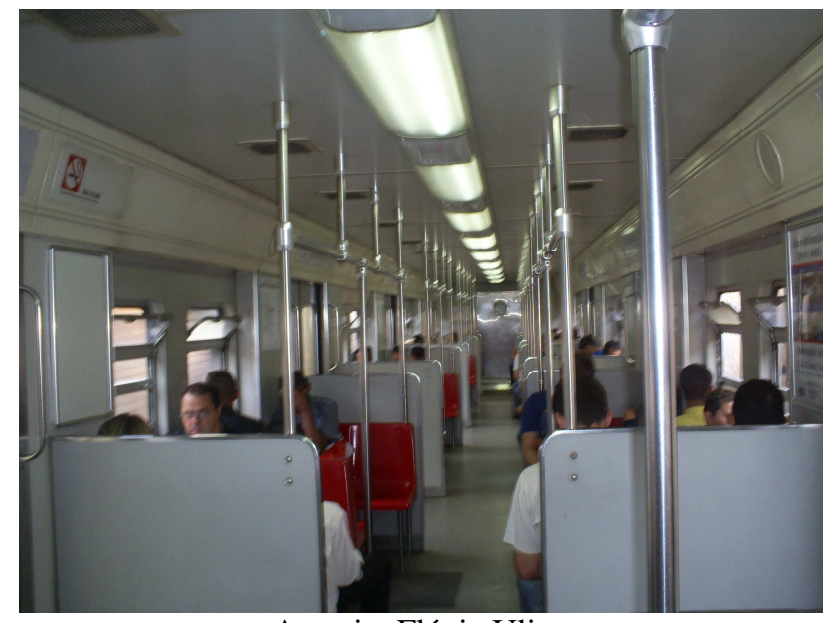

Autoria: Flávia Ulian

Fotografia 26 - Interior de trem francês que trafega na Linha B / 12/03/08

Trafegando pela linha B entre a estação Barra Funda e a estação Amador Bueno, em visita realizada no dia 02.05.2007, verificamos que, entre as estações Barra Funda e Itapevi, o

\footnotetext{
${ }^{266}$ www.cptm.gov.br - acesso em 06.02.2008.
} 
trem usado não é dos mais novos. Trata-se de um trem francês, importado há pelo menos 30 anos. Em algumas estações, como a Jd. Silveira, há muitas bicicletas penduradas na grade de ferro. Na estação Sagrado Coração, vimos um jovem pulando o muro para entrar na plataforma, sob as vistas de um policial, que nada fez. Observamos que o policiamento é menor nesta linha do que nas demais. Na estação Eng. Cardoso, apesar de ser quase a final, muitas pessoas entram. $\mathrm{O}$ trem estava cheio e seguiu lento até Itapevi. $\mathrm{O}$ auto-falante dentro do trem avisou a chegada à estação final e o acesso aos trens para Amador Bueno. A estação Itapevi ficou cheia com o desembarque. Uma parte dos passageiros foi para a plataforma de embarque para a estação Amador Bueno. Não há escada rolante, como em muitas estações desta linha. A ligação entre a estação Itapevi e a estação Amador Bueno é bastante precária e o trem sai de 30 em 30 minutos. Ambulantes circulam no trem parado na frente dos funcionários e guardas da estação. O trem é todo decorado, pintado por fora artisticamente. Trata-se de um trem japonês grafitado pelos artistas "Os Gêmeos" e "Ise". Por dentro, o trem é mais velho e não tem assento para passageiros especiais ${ }^{267}$; é riscado, não tem mapa da linha como os outros, e ainda leva a marca da Fepasa. Pessoas fumavam e também portavam bicicletas. Este trem tem apenas dois carros. Depois da estação Comenrita, o trem segue lento em trecho pouco urbanizado. Em Amador Bueno, no município de Itapevi, verificamos que não há cobrança de passagem para quem pega o trem nesta estação final com destino a Itapevi. No entanto, em Itapevi, para sair da estação, é necessário pagar a passagem, e também se quiser continuar no sistema é necessário passar pela catraca e pagar. Porém, se o usuário descer antes da estação Itapevi, não paga passagem.

$\mathrm{Na}$ volta para Itapevi, ao aproximar-se da estação, verificamos que o trem serve as cercanias do leito da ferrovia, e os ônibus sobem os morros para servir as residências, em sua maioria, autoconstrução.

\footnotetext{
${ }^{267}$ Idosos, portadores de deficiência, mulheres grávidas e pessoas com crianças de colo.
} 

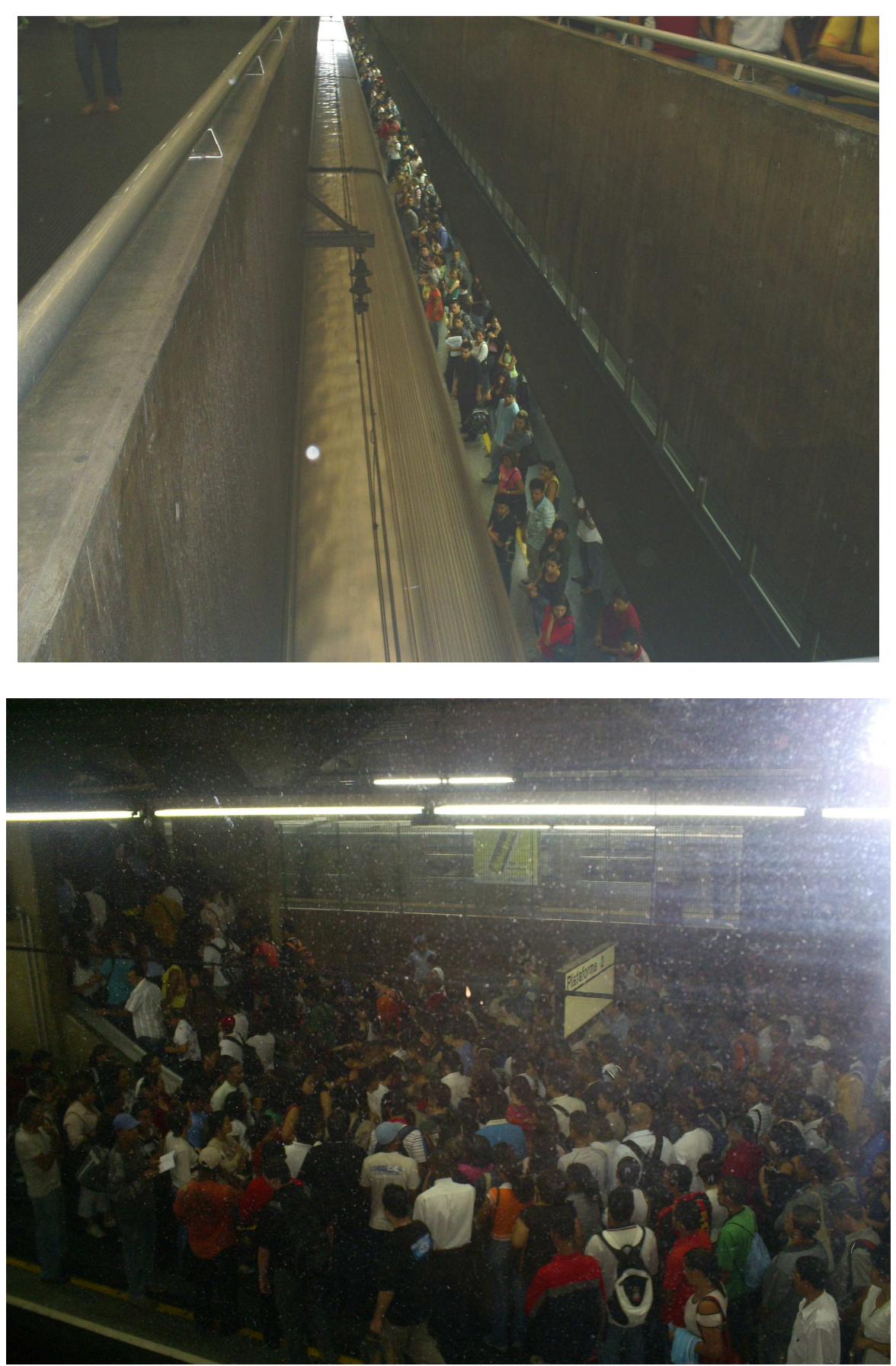

Autoria: Flávia Ulian

Fotografias 27 e 28 - Embarque em trem da CPTM - A condições gerais do transporte permaneceram precárias, inseguras e desconfortáveis para os usuários durante todas estas décadas/ 12/03/08

A linha C faz a ligação das estações Osasco (município de Osasco) a Autódromo (município de São Paulo), inaugurada em outubro de 2007. No total, esta linha tem $28,2 \mathrm{~km}$ e 
16 estações. O tempo de deslocamento do início ao final da linha é de 47 minutos. Os intervalos entre os trens variam de acordo com o horário, podendo ser de 6 a 16 minutos $^{268}$.

Em visita realizada nos dias 31.01 e 12.03.2008, verificamos que os trens que trafegam na linha $\mathrm{C}$ são novos, com ar condicionado e música ambiente. Além disso, não ficam muito tempo parados em nenhuma estação, não chacoalham e são muito silenciosos, mais até do que o metrô. Há uma grande diferença entre os usuários desta linha e os das demais linhas. Muitos são executivos. A demanda que ela atende é a de trabalhadores do setor sudoeste da Capital, dos escritórios da região da Vila Olímpia e Berrini.

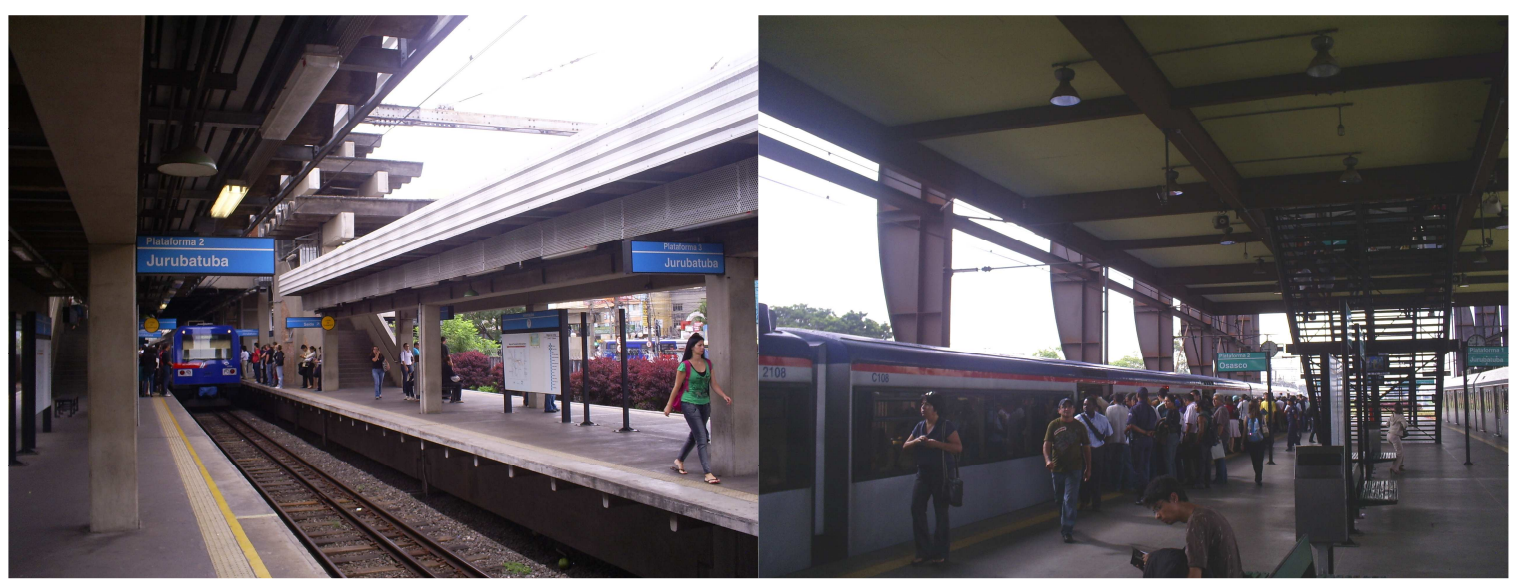

Autoria: Flávia Ulian

Fotografia 29 - Linha C - Est. Osasco / 12/03/08 Fotografia 30 - Linha C - Estação Santo Amaro / 12/03/08

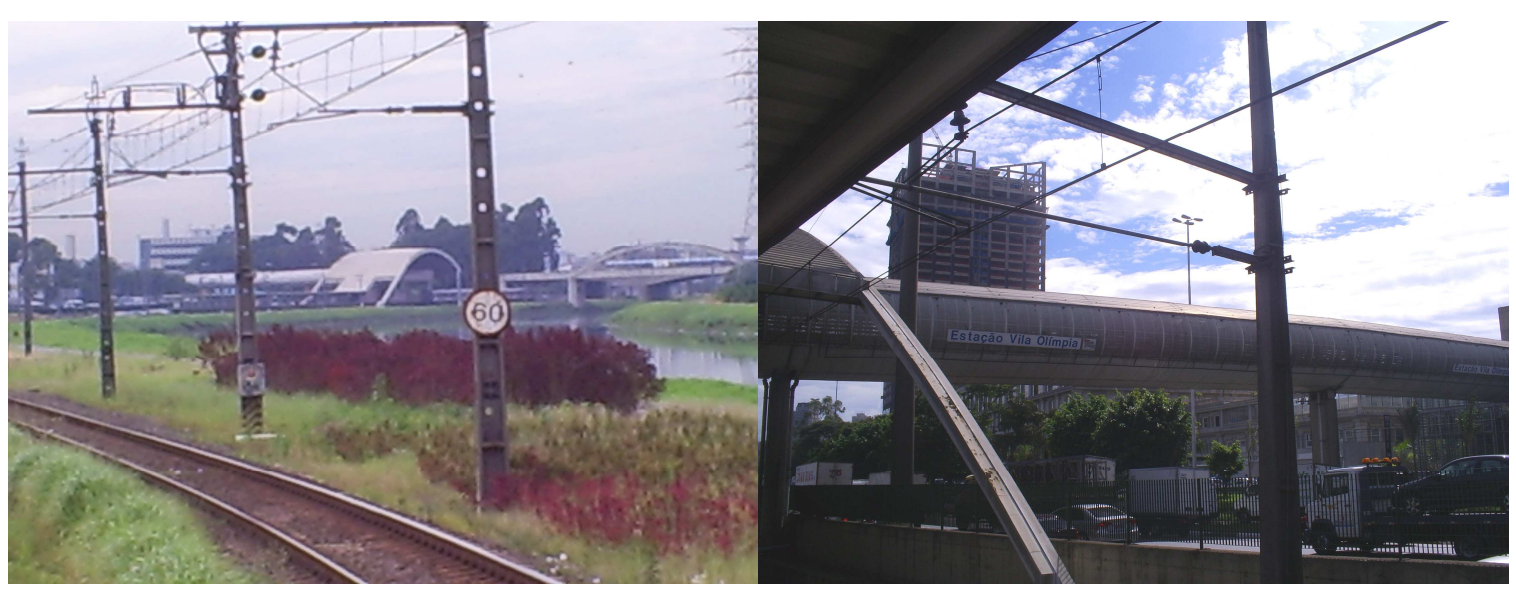

Autoria: Flávia Ulian

Fotografia 31 - Linha C - Vista da Est. Socorro /12/03/08 Fotografia 32 - Linha C - Est. Vila Olímpia/12/03/08

${ }^{268}$ www.cptm.gov.br - acesso em 06.02.2008. 
Os passageiros entrevistados que usam a linha $\mathrm{C}$ deram depoimentos positivos, elogiando os trens novos, com ar condicionado e música ambiente. Estes usuários também usam a linha B, mas esta última foi criticada pelo fato de nela circularem trens velhos e muito cheios. Um dos usuários pensa que o trem não é muito seguro, pois vê poucos seguranças na plataforma e teme por assaltos.

A linha D opera entre as estações Luz, no centro da Capital, e Rio Grande da Serra, no município do mesmo nome. Esta linha tem $37,2 \mathrm{~km}$ e 15 estações. O tempo de deslocamento do início ao final da linha leva 54 minutos. Os intervalos entre os trens variam de acordo com o horário, podendo ser de 8 a 20 minutos $^{269}$.

Trafegando pela linha D em 28.02 e 14.03.2007, notamos a má sinalização da estação Santo André no que concerne ao destino das vias de embarque no sentido Luz e no sentido Rio Grande da Serra. Há cinco plataformas, sendo que somente duas são usadas. As demais, apenas quando há problema nas linhas das outras plataformas, como um trem quebrado, por exemplo. Não há escadas rolantes. Fizemos o trajeto de trem de Santo André a Rio Grande da Serra, às $14 \mathrm{~h} 10$. O trem tem ar condicionado, é silencioso e razoavelmente limpo. Observa-se fábricas no leito da linha. A maior parte dos usuários do trem desce na estação Mauá. Conversamos com um usuário deste trecho, que usa o trem para voltar para casa, de Mauá até o Brás. Ele considera o trem rápido, confortável e seguro. Para ir a Mauá, ele pega carona no caminhão da empresa e economiza o dinheiro da passagem do trem, mas levam muito tempo no trânsito. "Seria menos cansativo se fosse de trem para o trabalho."270.

Conversando com outro trabalhador que usa o trem entre as estações Mauá e Santo André, ele comentou que o trem tem algum conforto e, o mais importante, é rápido. "Mas mesmo com ar condicionado, fica muito quente."271.

\footnotetext{
${ }^{269}$ www.cptm.gov.br - acesso em 06.02.2008.

270 Informação pessoal, 14/03/07.

${ }^{271}$ Informação pessoal, 28/02/07.
} 
Dono de banca de camelô do centro de Santo André, contou-nos que usa o trem para fazer compras em São Paulo pelo menos três vezes por semana. Ele acha a linha muito cheia e às vezes a lotação do trem amassa suas mercadorias. O intervalo entre os trens costuma ser de 20 minutos, mas às vezes atrasa e pode demorar de 30 a 40 minutos para o trem chegar. $\mathrm{O}$ trajeto é rápido entre a estação Santo André e o Brás. Acha o trem limpo e "quando consigo sentar, é até confortável, mas é quase impossível."272.

A partir da estação Guapituba, notamos que não há mais fábricas na paisagem. Entre Ribeirão Pires e Rio Grande da Serra, há pouca urbanização. Na chegada a Rio Grande da Serra o trem segue bem lento. Recentemente (no jornal Folha de São Paulo de 11.02.08), foi divulgado o atropelamento de uma mulher que atravessava a linha do trem em uma passagem clandestina $^{273}$.

A estação de Rio Grande da Serra é limpa, de construção antiga, mas bem conservada. Há muitos funcionários do setor de limpeza, o que chama a atenção. Há diversos carros estacionados nas proximidades da estação e em um estacionamento que também abriga diversas bicicletas, o que nos faz concluir que muitos usuários vão até a estação de carro ou bicicleta, para daí tomarem o trem para outros municípios. Um entrevistado que usa o trem entre as estações Utinga e Rio Grande da Serra diz estar bastante satisfeito com esta linha: o trem é limpo, confortável, muito eficiente e, no horário em que o usa, apresenta pouco movimento.

Na estação Mauá, do lado de fora, é evidente o comércio de Vales Transporte clandestinos, apesar da ilegalidade. Desde 30.04.2008, o Bilhete Único substituiu definitivamente os vales transporte em papel.

Também nos chamou a atenção, em várias estações da rede, como por exemplo a estação Guapituba, a existência de passarela com escadas para sair da estação e cruzar para o

\footnotetext{
${ }^{272}$ Informação pessoal, 14/03/07.

${ }^{273}$ MÃE ..., 2008.
} 
outro lado da linha, o que dificulta o acesso de deficientes e carrinhos de bebê. Em várias estações há elevadores que, contudo, não funcionam.

Um entrevistado revela que usa o trem na linha D para realizar seu próprio trabalho: é promotor comercial. Para ir para casa também se utiliza do transporte coletivo. Chega a pegar dez conduções por dia, entre trens e ônibus. Pensa que o trem seria até confortável, não fosse o excesso de pessoas. "Gostaria de ter uma motocicleta, pois gastaria menos e seria mais rápido, apesar de ter o problema do trânsito." ${ }^{274}$. Acha que o uso contínuo do transporte coletivo é bastante desgastante, afetando seu estado emocional e sua saúde.

Alguns outros usuários da linha D não reclamam do trem, elogiando seu conforto e rapidez. Os trens desta linha são os espanhóis, importados já usados que foram aqui reformados na década de 1990. No entanto, certa vez, em visita realizada em 04.04.2007, o trem parou várias vezes porque o ar condicionado parava de funcionar. Sem o ar funcionando, dentro do trem cheio, fica difícil de se respirar, pois não há circulação de ar, já que os vidros são vedados. Alguns usuários, neste dia, disseram que o problema é recorrente. Comentaram que costumam ligar de dentro do trem para o atendimento a clientes da CPTM informando do problema. Um passageiro entrevistado também mencionou que, dentre todos os meios de transporte que utiliza, ônibus, trólebus, metrô e trem, o seu maior problema é com o longo intervalo entre as composições da CPTM, no trecho Rio Grande da Serra até a estação da Luz.

\footnotetext{
${ }^{274}$ Informação pessoal, 28/02/07.
} 


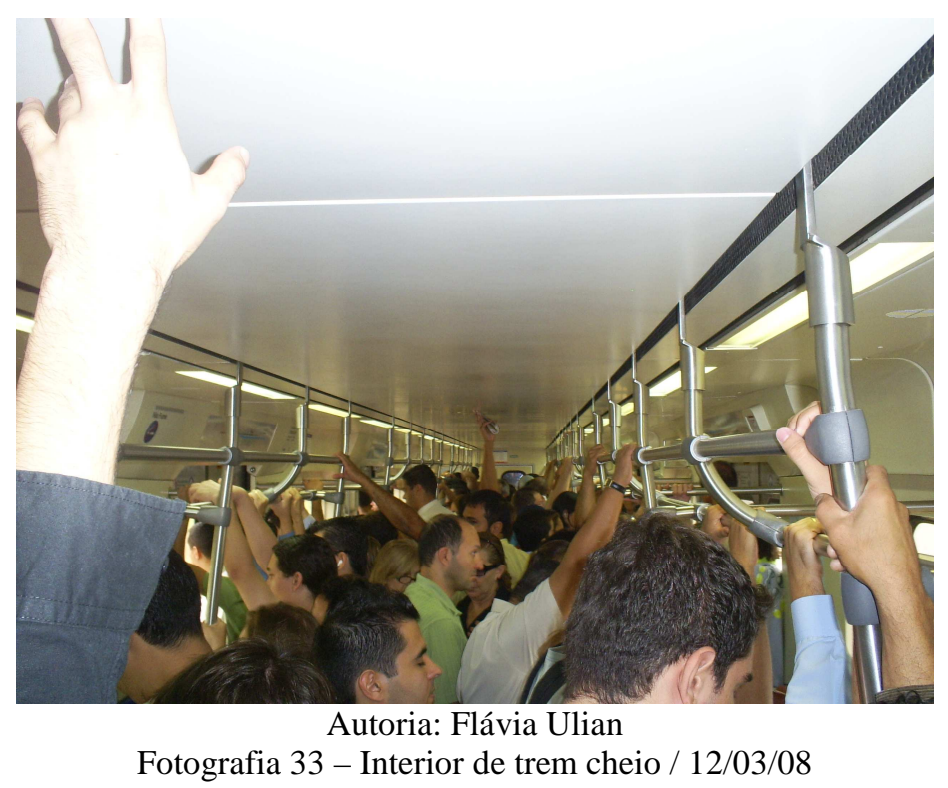

A linha E liga Luz a Estudantes, em Mogi das Cruzes. Esta linha tem 50,8 km e 16 estações. O tempo de deslocamento do início ao final da linha é de 36 minutos no trecho entre a Luz e Guaianazes, chamado Expresso Leste, mais 36 minutos até Estudantes. Os intervalos entre os trens variam de acordo com o horário, podendo ser de 6 a 20 minutos ${ }^{275}$. O Expresso Leste é o trecho da linha de trem que corre paralelamente ao Metrô, fazendo paradas apenas no Brás, Tatuapé, Corinthians-Itaquera, Dom Bosco, José Bonifácio e Guaianazes, ao passo que o metrô pára em todas as estações. Muitas estações de trem outrora utilizadas, antes da linha tornar-se "expressa", hoje estão abandonadas. O trem expresso passou a operar em 1995, reduzindo o tempo de trajeto entre seu extremo leste até o centro, melhorando a imagem dos serviços por trem ${ }^{276}$.

Em trabalho de campo realizado no dia 21.03.2007, fizemos a ida pela linha $\mathrm{F}$ e optamos por retornar pela linha E até o Brás, pois é expressa e não se paga baldeação entre as linhas de trem. Eram 17h20, o trem estava muito cheio, mas não lotado. No sentido contrário, avistamos um trem velho que vai para Mogi das Cruzes, muito cheio. As estações são próximas umas das outras. Na estação Guaianazes, muda-se de trem, mas não se paga nova

${ }_{276}^{275} \frac{\text { www.cptm.gov.br }}{\text { MELLO, 2000. }}$ acesso em 06.02.2008. 
passagem. Pega-se um outro trem, bem mais novo, com ar condicionado, que chega lotado da Luz. Este trem esvazia e seus usuários ocupam o trem em que estávamos.

A estação Guaianazes parece uma estação de metrô, com catracas e piso iguais aos do metrô, mas não há escada rolante, nem sanitários, o que evidencia que não estamos em uma estação do Metrô.

No subsolo da estação, há quiosques de venda de alimentos. Há também terminais de ônibus e placas indicativas para o embarque em quatro plataformas, que, contudo, não informam o destino. Uma luz acende indicando de qual plataforma vai sair o próximo trem para a estação da Luz, mas não há placas avisando sobre isso. Em todas as estações da linha E e F verifica-se a presença de muitos seguranças da CPTM.

Na estação Corinthians-Itaquera, a integração com o metrô não é gratuita, o que nos pareceu estranho, mas viemos a entender que isso acontece para que os usuários do trem não mudem para o metrô, visando a não sobrecarregá-lo. O trem passa ao lado de estações de metrô, mas não pára, pois é expresso neste trecho, apesar da velocidade baixa, efetuando sua parada apenas na estação Tatuapé por alguns minutos. Nesta estação há integração com o metrô, mas também não é gratuita. O trem fica lotado, com muitas pessoas viajando em pé. Ao chegar à estação Brás, o trem pára por 10 minutos e enche mais ainda. Na estação da Luz, final desta linha, uma multidão entrou empurrando-se ${ }^{277}$ uns aos outros, o trem ficou abarrotado de gente, parado por alguns minutos. Saiu muito lentamente, já em retorno para Guaianazes, parando várias vezes no meio da via. Voltando para o Brás, as pessoas não conseguem mais entrar no trem, pois poucos usuários descem. Eram 18h45. Uma grande parte dos passageiros, quase todos aqueles que estavam no trem entre a Estação Tatuapé e a Luz, estava andando no contra-fluxo para poderem voltar sentados, pois o mesmo trem que chegou na Luz volta para Guaianazes. Ele é lento e extremamente lotado. Grupos de evangélicos

\footnotetext{
${ }^{277}$ As pessoas entram se acotovelando e muitos dão gargalhadas, passando por cima dos outros. O espetáculo se assemelha a um evento surreal.
} 
cantam, apesar de ser proibido (informaram-me que ficam sempre no $2^{\circ}$. vagão). Os passageiros não têm onde se segurar, amparando-se nas luminárias do trem, que estão até se quebrando. Não é possível entrar no trem nem no Brás, nem no Tatuapé.

Esta população mora na periferia, nas cidades dormitórios e vem para São Paulo trabalhar, submetendo-se a esta situação desrespeitosa para com a sua (pretensa) cidadania diariamente em seus deslocamentos.

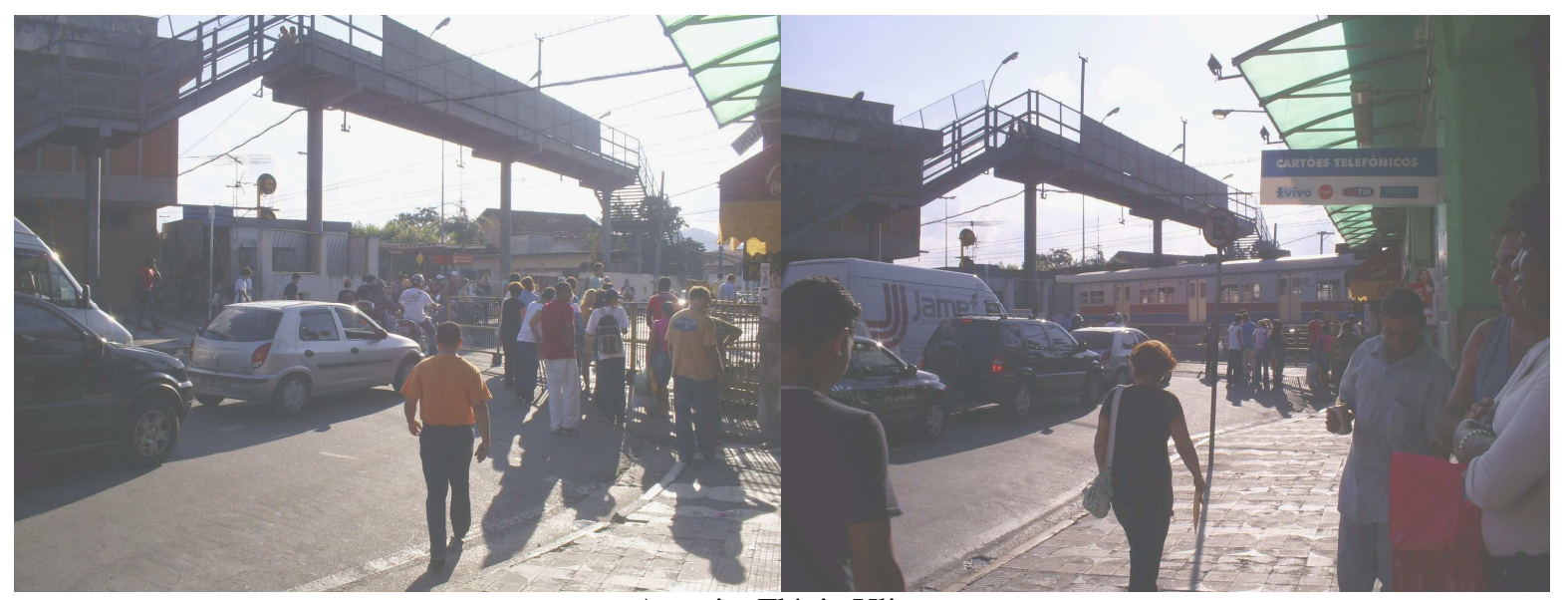

\section{Autoria: Flávia Ulian}

Fotografias 34 e 35 - No entorno da estação Mogi das Cruzes, observamos que o trânsito pára para o trem passar e os seguranças da CPTM impedem a entrada de transeuntes na estação pela linha, que é no nível da rua. $11 / 04 / 07$

A linha F liga as estações Brás, em São Paulo a Calmon Viana, no município de Poá. Duas estações foram inauguradas neste trecho, em janeiro de 2008, a estação USP Leste, nova, e a Comendador Ermelino, reconstruída. Esta linha tem 38,8 km e 11 estações. O tempo de deslocamento do início ao final da linha leva 59 minutos. Os intervalos entre os trens variam de acordo com o horário, podendo ser de 8 a 20 minutos $^{278}$.

Em 21.03.2007, realizamos trajetos nesta linha do sistema e observamos carcaças de trens antigos de passageiros no caminho. Na estação Itaquaquecetuba, há um elevador que não

${ }^{278}$ www.cptm.gov.br - acesso em 06.02.2008. 
está funcionando. Presenciamos uma senhora idosa carregando muitas sacolas pesadas com problemas para subir a escadaria de saída da estação.

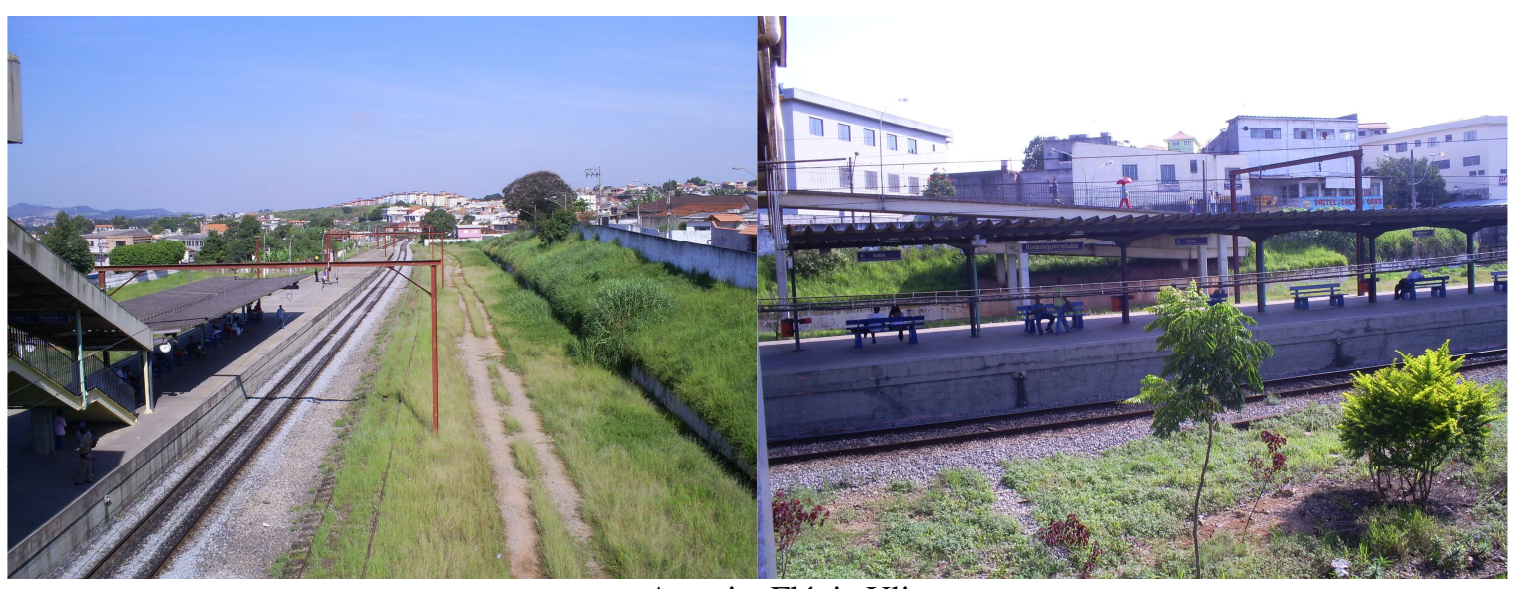

Autoria: Flávia Ulian

Fotografias 36 - 37 - Linha F - Estação Itaquaquecetuba / 21/03/07

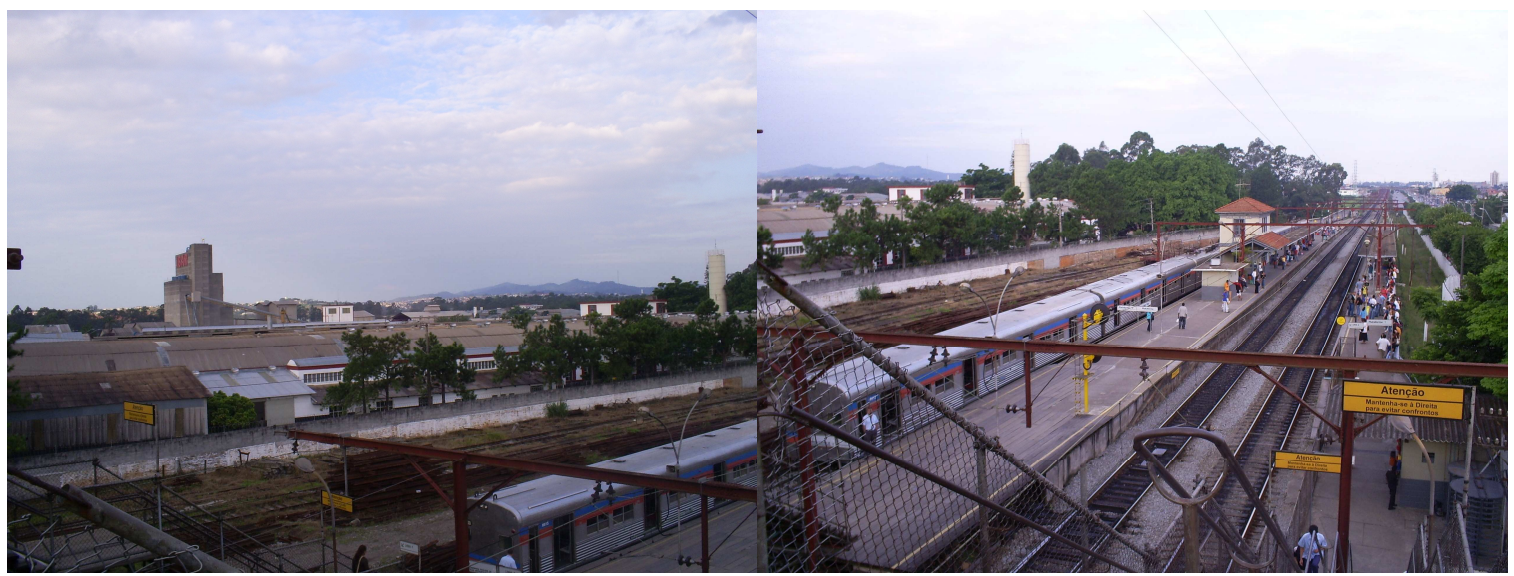

Autoria: Flávia Ulian

Fotografias 38 e 39 - Linha F - Estação Calmon Viana / 21/03/07

A reprodução do espaço urbano envolve o cotidiano dos deslocamentos e, ao mesmo tempo, dá-se por intermédio deles. Os longos deslocamentos desconfortáveis revelam uma prática urbana perversa. É o que percebemos ao conversar com usuários da linha F. Em um trem velho, uma passageira afirmou que há pouco tempo ${ }^{279}$, estes trens trafegavam com as portas abertas. Por causa do calor, os próprios usuários mantinham-nas abertas. Certa vez, o

\footnotetext{
${ }^{279}$ A partir do início do ano de 2007 os trens não circularam mais com portas abertas.
} 
maquinista ordenou, pelo auto-falante, que se fechassem as portas. Como uma das portas se mantivesse aberta, ele sugeriu que os demais usuários deveriam colocar aquele que mantinha a porta aberta para fora do trem, caso contrário, o trem não prosseguiria a viagem. $\mathrm{O}$ trem estava fora da estação e não havia seguranças no local. Foi uma situação constrangedora, conforme relatou a usuária. $\mathrm{Na}$ sua visão, o trem é lento, desconfortável e sem a mínima segurança. No entanto, ela não pode ir de ônibus, pois demoraria muito mais entre a estação Itaim Paulista e o Anhangabaú. De trem, o percurso demora uma hora e meia, fazendo baldeação com o metrô na estação Brás. Como há a construção de novas estações na linha F, como a estação USP Leste, a usuária teme que, havendo mais paradas, o trajeto fique ainda mais demorado.

Estes depoimentos nos suscitam diversas interpretações, já que os passageiros, sujeitos desse processo, também interpretam os meios de transporte de acordo com seus anseios e sua subjetividade. Contudo, podemos apreender, desses depoimentos, que há linhas da CPTM elogiáveis, como é o caso da linha C. A linha D aparece nos depoimentos como uma linha razoável, com aspectos tanto positivos como negativos. As demais linhas citadas são cheias de problemas, principalmente pela qualidade ruim das composições que por elas trafegam, e pelo imenso contingente de usuários. O intervalo longo entre as composições foi unanimemente criticado.

Neste item, ao descrever o sistema de trens metropolitano e conhecer o cotidiano de alguns de seus usuários, verificamos que, apesar de abrangência da infra-estrutura (forma), sua função não está se dando a contento em todas as linhas. 
No próximo item trataremos das políticas de transportes ligadas ao setor ferroviário, ou seja, da estrutura. Pela descrição que empreendemos acima, podemos adiantar que tais políticas foram inócuas na melhoria do sistema há décadas. As recentes propostas de melhoria ainda não foram capazes de reverter o quadro de abandono a que o sistema de trens foi submetido por décadas. 


\subsection{3 - Políticas de Transporte e o Trem Metropolitano}

Concentraremos a análise das políticas de transporte no que tange ao trem metropolitano no período estudado por nós nesta pesquisa - 1987 a $2007^{280}$. Passaremos a analisar como o sistema ferroviário da RMSP, altamente precário, vem se modernizando a partir de meados dos anos 90.

A partir das diretrizes dos Planos Nacionais de Desenvolvimento (PND I e II), iniciouse, na década de 1980, a estadualização do transporte de passageiros nas regiões metropolitanas atendidas pelas linhas da CBTU. Conforme já foi referido, a CBTU passou a operar as linhas de passageiros da RFFSA no início da década de 1990 na RMSP. Houve aumento das tarifas, que então correspondiam a 50\% do valor da passagem dos ônibus urbanos e, entre 1991 e 1992 igualaram-se aos ônibus. Mesmo assim, ainda neste período, o serviço convivia com atrasos e vagões lotados.

Em 1991 foi assinado um convênio entre o Governo do Estado e o Governo Federal visando ao processo de transferência dos serviços da CBTU para a esfera estadual, e em 1993 foi constituída a CPTM. A Fepasa foi incorporada pela CPTM em 1996. As atuais linhas B e C (então linhas Oeste e Sul) pertenciam à Fepasa. As demais pertenciam à CBTU. A CPTM é subordinada à STM.

A gestão do governo do Estado de São Paulo 1990-1993 idealizou, através da Secretaria de Estado de Planejamento e Gestão e da Emplasa (Empresa Metropolitana de Planejamento da Grande São Paulo S.A.), o “Plano Metropolitano da Grande São Paulo 1994 / 2010" (PMGSP). O ensejo do Plano era "investigar os riscos e as oportunidades que se

\footnotetext{
280 Para maiores detalhes em anos anteriores, consultar Mello (2000), que realizou ampla pesquisa sobre as políticas de transporte relativas ao trem entre 1975 e 1995.
} 
oferecem à Grande São Paulo nas atuais circunstâncias e, ao construir um cenário inovador do que a Metrópole poderá vir a ser no ano 2010, propõe conjuntos de ações necessárias para maximizar as vantagens comparativas."281 Este sucedeu o Plano Metropolitano de Desenvolvimento Integrado (PMDI), realizado 20 anos antes. Estabeleceu ainda diretrizes e ações em diversos âmbitos de atuação da política do Estado, instituiu a STM e promulgou o estatuto legal das parcerias e privatizações de atividades públicas estaduais. Assim, o Plano se autodenomina diferente dos anteriores porque busca maior equilíbrio, levando em conta "as decisões e o potencial do setor privado com atuação possível na Região."282.

Embora incorpore planos anteriores, acrescentou conteúdos inéditos, pois nesta época ocorria a consolidação do transporte ferroviário suburbano de passageiros sob a autoridade do Estado, a partir da criação da CPTM.

Entre os objetivos gerais do Plano, destacava-se o desenvolvimento de uma política regional, encarando a RMSP como principal pólo urbano do território estadual, entendendo que a RMSP passava por um incremento excepcional do setor de serviços, denominando-a "pólo de serviços" e "cidade mundial".

Com diretrizes amplas, no que tange aos transportes metropolitanos, ressaltamos a promoção de "maior eqüidade nas condições de localização intra-urbana na GSP, com ênfase para a homogeneização da acessibilidade pelo sistema de transporte público."283. Para esta diretriz, as ações correspondentes seriam a complementação da malha viária e de transportes regionais, modernização do sistema ferroviário de passageiros e ainda a complementação da integração do sistema sobre trilhos com o sistema sobre pneus. Propunha também expandir e adensar a Metrópole no sentido leste/nordeste e, para tanto, priorizar os "investimentos na

\footnotetext{
${ }^{281}$ SÃO PAULO, 1994a p.11.

282 Ibidem, p. 22.

${ }^{283}$ Ibidem, p. 183.
} 
melhoria do sistema de transporte que atende a zona leste da Metrópole"284 tanto no ramal ferroviário quanto na sua complementação com o sistema de ônibus.

No que se refere ao transporte ferroviário, o Plano definiu que iria "Implantar melhorias e consolidar, em bases infra-estruturais e de operação de alta qualidade técnica, o sistema ferroviário de cargas e passageiros" ${ }^{285}$, compatibilizando o transporte de passageiros metropolitanos com o transporte de média e longa distância. No entanto, este último veio a ser extinto, contrariando as premissas do Plano. Havia ainda propostas para a implantação de serviços de transportes de passageiros de média distância no espaço macrometropolitano, proposta esta incorporada pelo Plano Integrado de Transportes Urbanos (PITU), como veremos adiante. Propunha a segregação completa do transporte de carga e do transporte de passageiros, que está em contínuo avanço, mas até os dias de hoje não foi alcançada.

No PMGSP, estava incluído o programa TRANSPORTE - SIM: SISTEMA INTEGRADO METROPOLITANO ${ }^{286}$, que "perseguia a integração de todas as modalidades de transporte coletivo a cargo do Estado nos 39 municípios da Grande São Paulo e previa a integração da rede de metrô (Cia. Do Metropolitano), trens metropolitanos (CPTM) e dos corredores de ônibus da EMTU"287. A integração tarifária entre o Metrô e a CPTM se concretizou, mas não houve até hoje a integração tarifária com a EMTU.

Nos anos 90, foram lançados vários programas de recuperação do sistema, com verba estadual e federal, entre eles o Programa de Recuperação do Sistema Oeste, visando a minimizar a degradação do antigo sistema Fepasa, e o Projeto de Integração Física (Integração Centro), possibilitando, no terminal intermodal Barra Funda, a integração dos antigos sistemas Fepasa e CBTU, o que favoreceria a transposição dos usuários da região metropolitana de leste a oeste, passando por 10 municípios e alcançando a região central de

\footnotetext{
${ }^{284}$ SÃO PAULO, 1994a p.183.

${ }^{285}$ Ibidem, p. 194.

${ }^{286}$ Programa atualmente compreendido no Plano de Expansão 2007-2010.

${ }^{287}$ MELLO, 2000, p.181.
} 
São Paulo, sem a utilização de outro meio de transporte ${ }^{288}$. As estações da Luz de metrô e de trem, e ainda a estação Júlio Prestes, também se integrariam. O projeto de integração só seria completamente finalizado em novembro de 2004.

Em 1995, foi implementado o Projeto Leste, que consistiu na modernização da linha tronco da antiga CBTU, ampliando a capacidade leste do Corredor Leste Metrô/CBTU, o que deu origem ao Expresso Leste, já aludido anteriormente.

Na mesma época, foi lançado o Projeto Sul, que visava a dinamizar a Linha Sul HÁ e a implantar a linha Campo Limpo - Santo Amaro. De acordo com Mello ${ }^{289}$, a linha C operava com ociosidade, particularmente entre as estações Pinheiros, Largo 13 e Jurubatuba. Não havia estações que dessem acesso justamente às áreas que passavam por intensas transformações resultantes do processo de desconcentração das atividades terciárias: as regiões da avenida marginal do rio Pinheiros e das avenidas Luís Carlos Berrini, Morumbi e Faria Lima, “cujas acessibilidades poderiam ser grandemente favorecidas pela presença de transporte de alta capacidade, caso houvesse estações entre Pinheiros e Santo Amaro"290.

O trecho referido pela autora recebeu várias melhorias e, no ano de 2001, entraram em operação as novas estações no intervalo ressaltado por Mello ${ }^{291}$ entre as estações Pinheiros e Santo Amaro: estações Granja Julieta, Morumbi, Berrini, Vila Olímpia, Cidade Jardim e Hebraica-Rebouças e a estação Socorro, depois da Santo Amaro, antes de chegar na final Jurubatuba.

Em 2007, o trecho modernizado avançou para mais uma estação, a Autódromo. Estão previstas para 2008 as inaugurações das estações Interlagos e Grajaú ${ }^{292}$. Na realidade, este trecho já existia, fazendo parte do antigo ramal Varginha, mas estava inoperante.

\footnotetext{
${ }^{288}$ MELLO, 2000.

${ }^{289}$ Ibidem.

${ }^{290}$ Ibidem, p. 116.

${ }^{291}$ Ibidem.

292 www.sptm.sp.gov.br - acesso em 06.02.08.
} 
Quanto à nova linha, 5 - Lilás, prevista no Projeto Sul, foi inaugurada em 2002 e tem caráter metroviário, atendendo as viagens com origem nos bairros de Capão Redondo, Campo Limpo e parte dos municípios de Embu e Taboão da Serra. Voltaremos a falar dela no item referente ao transporte metroviário.

Apesar de todas as medidas acima referidas, em meados dos anos 90 o sistema de trens metropolitanos foi alvo de depredações por parte dos usuários, em virtude de revoltas por seu mau atendimento, constantes atrasos e falta de segurança. Denúncias de realização de tráfico de drogas dentro dos vagões, além do molestamento sexual de mulheres eram então freqüentes. Além disso, a entrada de passageiros nas composições sem pagar tarifa seria da ordem de $45 \%{ }^{293}$. A avaliação da autora é que no período por ela estudado, entre 1975 e 1995 , houve "políticas que ignoraram o caráter do transporte como serviço público e usaram-no como instrumento de promoção da acumulação capitalista inserida no contexto do modelo gestado para o País."294. De fato, melhorias efetivas no sistema ocorrem a partir de 1995, mas também a passos lentos.

No período entre 1987 e 2007, além do PMGSP/1994, destacou-se o PITU 2020, iniciado na gestão do governo estadual 1995-1998 que antevia coordenar o futuro dos transportes metropolitanos da RMSP, aumentando a acessibilidade e reduzindo os congestionamentos. As estratégias do PITU frisavam os investimentos em infra-estrutura, medidas de gestão em transportes que regulam o uso da infra-estrutura proposta, medidas de gestão no trânsito para controle do uso do automóvel e políticas de preços que regulam tarifas de estacionamento, pedágio, entre outros ${ }^{295}$. O PITU 2020 definiu as diretrizes para a expansão das linhas de transporte metropolitano para a RMSP, a serem implantadas até o ano de 2020 nas três categorias de serviços: linhas de trens metropolitanos, de competência da

\footnotetext{
${ }^{293}$ MELLO, 2000.

${ }^{294}$ Ibidem, p. 203.

${ }^{295}$ CIA. DO METROPOLITANO DE SÃO PAULO, 1998.
} 
CPTM, linhas metroviárias, de competência da Companhia do Metropolitano de São Paulo Metrô, e linhas de ônibus metropolitanos, de competência da Empresa Metropolitana de Transportes Urbanos - EMTU/SP ${ }^{296}$.

De acordo com as previsões realizadas pelo PITU 2020, se não forem tomadas medidas adequadas para conter o uso do transporte individual, em 2020 as viagens por automóvel crescerão $69 \%$ em relação aos dados de 1997, caindo para $46 \%$ a participação das viagens por transporte coletivo. Para os usuários de automóveis a mobilidade também decrescerá, já que o tempo gasto nos deslocamentos, mesmo em automóveis, cairá cerca de $20 \%$ com a diminuição da velocidade e aumento dos custos, maior concentração de poluentes e diminuição ainda maior do acesso a bens e serviços pelas camadas da população de renda inferior $^{297}$.

Depois de concluídas todas as medidas planejadas, esperava-se que a metrópole recuperasse a mobilidade da década de 1970, dobrando as facilidades de acesso aos bens e serviços, com crescimento da velocidade das viagens, diminuindo-se, assim, os congestionamentos. Os deslocamentos por modo coletivo atingiriam $60 \%$ das viagens motorizadas, com maior velocidade e raio de alcance, inclusive apresentando maior integração do sistema coletivo e dos automóveis. O plano pretendia estimular o uso do transporte coletivo, tornando-o competitivo do ponto de vista do conforto e mobilidade comparativamente com os veículos particulares, para que a classe média passasse a utilizá$10^{298}$. Em 2008, dez anos após o início da implantação deste Plano, portanto, verificamos que este grande objetivo ainda não foi atingido ${ }^{299}$.

\footnotetext{
${ }^{296}$ CIA. DO METROPOLITANO DE SÃO PAULO, 2006b, p.14.

${ }^{297}$ Idem, 1998.

298 Ibidem.

${ }^{299}$ Reportagem do Jornal da Tarde de 29.03.2008 aborda a questão da demora na espera e nos trajetos realizados por ônibus como fatores que pesam bastante na troca do automóvel pelo ônibus. Quanto ao trem, o sítio da CPTM divulgou notícia em 18.07.2006 comentando o uso da Linha $\mathrm{C}$ de trem por executivos, que preteriram o automóvel pelo trem.
} 
De acordo com a STM, o plano foi idealizado para viabilizar dois aspectos: primeiramente projetos que resultarão na implantação de novas linhas de transporte metropolitano, novos terminais de ônibus e estações de acesso aos subsistemas planejados, ampliação e construção de novas vias, novos sistemas de sinalização e controle do trânsito, ou seja, uma política de investimentos de cerca de $\mathrm{R} \$ 30.300 .000,00$ (trinta milhões e trezentos mil reais) no setor; o segundo aspecto enfatiza a operação dos subsistemas e sua inter-relação, configurando um novo padrão de gestão e preços no sistema de transporte e no trânsito. Previa retomar obras do metrô nas extensões leste, oeste e norte, bem como realizar

\begin{abstract}
um intenso processo de transformação do sistema ferroviário a cargo da Companhia Paulista de Trens Metropolitanos - CPTM, com investimentos em melhorias dos serviços e a introdução de trens novos e modernização da frota existente, novos serviços e possibilidades concretas de integração com o sistema metroviário ${ }^{300}$.
\end{abstract}

No que se refere ao transporte sobre trilhos ${ }^{301}$, as proposições mais concretas do PITU 2020 eram: trem especial de ligação dos aeroportos de Congonhas, Guarulhos e Campo de Marte, com a implantação de $44 \mathrm{~km}$ de trem especial; trem aproximador - melhoria do sistema de trens da CPTM utilizando via compartilhada nos trechos comuns à operação do metrô em nível, para atendimento às áreas periféricas internas à região; modernização das linhas, melhoria do material rodante, da via permanente, da rede aérea e dos sistemas de sinalização, totalizando $88 \mathrm{~km}$ da rede; trem regional - ligação da metrópole aos pólos de Campinas, Sorocaba e São José dos Campos, oferecendo percurso de $177 \mathrm{~km}$ em trem reformulado.

Em 1999, já eram evidentes os sinais de consolidação de inúmeras novas funções terciárias na metrópole, havendo grandes alterações nos perfis da população e dos deslocamentos metropolitanos. Projeções indicavam estagnação do crescimento demográfico

\footnotetext{
${ }^{300}$ CIA. DO METROPOLITANO DE SÃO PAULO, 2006b, pp.10-11.

${ }^{301}$ Optamos por dividir o PITU 2020 em relação às ações propostas para o transporte ferroviário, metroviário e rodoviário de acordo com os itens deste texto.
} 
no Centro da região metropolitana (município de São Paulo) e crescimento acima da média regional em áreas mais distantes, como Juquitiba e Barueri ${ }^{302}$. Osasco e Guarulhos tornaramse pólos urbanos de atração regional e até do município de São Paulo, dado o aumento de empregos nestes municípios. O crescimento de relações destes municípios em relação aos outros dentro de suas próprias sub-regiões e entre eles e municípios de outras sub-regiões, como por exemplo entre Guarulhos e municípios do ABC Paulista, suscitou a necessidade de revisões no PITU 2020. Os investimentos no sistema metroferroviário já haviam absorvido $72 \%$ do total dos investimentos previstos ${ }^{303}$.

Em 2001 foi promulgada a Lei Federal $n^{\circ}$. 10.257, de julho de 2001 - o Estatuto da Cidade, que trouxe novas diretrizes e instrumentos para a gestão das cidades e seu financiamento, além de dar obrigatoriedade à realização de planos diretores para os municípios das regiões metropolitanas. Estas questões impactaram sobre o serviço intermunicipal de transporte e suas conexões com os sistemas locais, bem como sua evolução. Desta forma, o PITU necessitou de ajustes, adequando suas propostas e explorando as novas possibilidades de intervenção propiciadas pelo Estatuto da Cidade e Planos Diretores. A STM criou, em 2005, o PITU 2025. A melhor garantia de qualidade das recomendações deste plano estaria na cooperação dos municípios integrantes da RMSP, através das agências de transportes. No PITU 2025, novos conceitos de rede, novas estratégias de infraestrutura, de administração da demanda, de tarifas e bilhetagem foram propostas.

Os planejadores entendem que o transporte influencia e é influenciado pelo desenvolvimento urbano e, assim, interfere na localização de moradias, comércio, empregos e escolas. O Censo de 2000 mostrou um agravamento das tendências de desenvolvimento da RMSP. O desequilíbrio do crescimento demográfico na metrópole, apontado pelo Censo 2000

\footnotetext{
${ }^{302}$ A Tabela 1 com dados referentes à TGCA pode ser consultada na Parte I - A Região Metropolitana de São Paulo, p.46.

${ }^{303}$ CIA. DO METROPOLITANO DE SÃO PAULO, $2006 \mathrm{~b}$.
} 
teve grande repercussão na demanda de transporte. Conforme já foi acenado no primeiro capítulo desta Tese, verificou-se que as zonas centrais de municípios perderam população, como as dos municípios de São Paulo, Guarulhos, Osasco e do ABC Paulista, e que entre o período 1991-2000 as franjas urbanas ou periferias, cresceram a taxas elevadas:

\begin{abstract}
A fração mais consolidada da metrópole cai de 6,7 milhões para 6,0 milhões de habitantes, enquanto que as demais áreas crescem de 7,7 milhões para 10,3 milhões. [...] E como a maior quantidade de empregos situa-se nas zonas centrais, fica fácil avaliar as grandes e crescentes pressões que se colocarão sobre os serviços de transportes, caso persistam essas tendências ${ }^{304}$.
\end{abstract}

A Tabela 14 mostra os investimentos realizados e previstos no PITU:

Tabela 14 - PITU - Investimentos realizados e previstos - 1995 - 2025

\begin{tabular}{|c|c|c|c|}
\hline PITU & Período & R\$ milhões & R\$ milhões/ano \\
\hline PITU & $1995-2003$ & 9.863 & 822 \\
\hline PITU 2015 & $2003-2006$ & 5.473 & 1.368 \\
\hline & $2007-2010$ & 16.313 & 4.078 \\
\hline & $2011-2014$ & 9.663 & 2.416 \\
\hline PITU 2025 & $2015-2025$ & 22.700 & 2.064 \\
\hline
\end{tabular}

Fonte: (www.pitu.stm.sp.gov.br/download.php?file=documentos/revisaodoplano.pdf - acesso em 24.02.2008) Organização da autora.

Alicerçado no PITU 2025, que consiste, portanto, em um processo contínuo de planejamento, a STM lançou o Plano de Expansão 2007-2010 que prevê investimentos entre 2007 e 2010 de R \$16.307,5 milhões, sendo esta Secretaria a que mais investimentos receberá do Estado de São Paulo. A Prefeitura do Município de São Paulo terá uma participação nestes investimentos. Os objetivos são acelerar o processo de modernização da malha da CPTM; expandir a rede de Metrô e racionalizar o transporte sobre pneus (EMTU) das três regiões metropolitanas do Estado ${ }^{305}$.

No que tange aos trens metropolitanos, o Plano de Expansão prevê modernização das Linhas A, C e F, com diminuição do intervalo entre os trens, o que, espera-se, tornará o

\footnotetext{
${ }^{304}$ www.pitu.stm.sp.gov.br /download.php?file=documentos/revisaodoplano.pdf - acesso em 24.02.2008.

305 www.metro.sp.gov.br/expansao/plano_expansao_2007_2010/plano_expansao_2007_2010.asp - acesso em 03.03 .2008
} 
sistema mais atraente. Conforme foi visto no item anterior, já houve alteração nos intervalos em 2007 e o Plano intenciona reduzi-los para 4 minutos nos horários de pico. Serão adquiridos 48 novos trens, sendo 20 para a Linha F, mais 20 para a Linha A e 8 para a Linha C. Haverá modernização do sistema de sinalização de controle, da rede aérea, da linha de alimentação auxiliar e do sistema de alimentação de energia. Estas medidas são prementes, tendo em vista que a demanda vem aumentando consideravelmente.

Na Linha C deverá ocorrer expansão, com a construção de trecho de $8,5 \mathrm{~km}$, entre Jurubatuba e Grajaú. Serão construídas 3 novas estações, a Autódromo (já inaugurada no final de 2007), Interlagos e Grajaú, e a estação Jurubatuba será reformada. O valor estipulado do projeto é de $\mathrm{R} \$ 744,3$ milhões. As demais estações desta linha serão modernizadas.

$\mathrm{Na}$ Linha B pretende-se diminuir o intervalo entre os trens para 5 minutos, com modernização da frota e manutenção a ser realizada num prazo de 20 a 25 anos. Serão adquiridos 25 trens. Nesta linha rodam trens com 30 anos de uso. Prevê-se também modernização no trecho Barra Funda / Itapevi.

A Linha D será modernizada e haverá a implantação do Expresso $\mathrm{ABC}$, trem que deverá seguir expresso entre a estação da Luz e a estação Mauá, com intervalo de 8 minutos entre as composições. Será, para isso, construída uma via expressa, com $25,2 \mathrm{~km}^{306}$. Haverá ainda modernização da linha entre as estações Luz e Rio Grande da Serra, com intervenções nas vias existentes, nos sistemas elétricos e oficinas, aquisição de 10 trens, modernização de 15 estações, incluindo adequações no entorno.

O Plano prevê ainda modernização da Linha E, ampliação do Expresso Leste até as estações Suzano e Mogi, bem como modernização das estações da linha, aquisição de novos trens, intervenção nas vias existentes e sistemas elétricos.

\footnotetext{
306 No mesmo sítio, informa-se que haverá apenas a implantação do serviço expresso, sem mencionar construção de via (http://www.metro.sp.gov.br/expansao/plano_expansao_2007_2010/plano expansao_2007_2010.asp - acesso em 03.03.2008).
} 
Em todas as linhas há perspectiva de aumento da demanda, conforme podemos ver pela Tabela 15:

Tabela 15 - Trens metropolitanos

Demanda atual e previsão de demanda após implementação do Plano de Expansão 2007-2010 - em milhares/dia útil

\begin{tabular}{|l|l|l|l|l|l|l|l|}
\hline & \multicolumn{1}{|c|}{ Linha A } & \multicolumn{1}{|c|}{ Linha B } & \multicolumn{1}{|c|}{ Linha C } & \multicolumn{1}{|c|}{ Linha D } & \multicolumn{1}{|c|}{ Linha E } & Linha F & TOTAL \\
\hline $\begin{array}{l}\text { Demanda } \\
\text { anterior }\end{array}$ & 341 & 334 & 124 & 264 & 100 & 137 & 1.300 \\
\hline $\begin{array}{l}\text { Demanda } \\
\text { prevista }\end{array}$ & 436 & 422 & 430 & 670 & 192 & 215 & 2.365 \\
\hline
\end{tabular}

Fonte:http://www.metro.sp.gov.br/expansao/plano_expansao_2007_2010/plano_expansao_2007_2010.asp acesso em 03.03.2008

Elaboração da autora.

A Tabela 15 mostra uma projeção total de aumento da demanda de cerca de $91 \%$. As linhas com previsão de maior aumento de demanda são a linha $\mathrm{C}$, que terá sua demanda praticamente quadruplicada, e a Linha $\mathrm{D}$, que terá sua demanda triplicada.

O Plano de Expansão prevê também a implantação do Expresso Aeroporto/Trem de Guarulhos, uma ligação ferroviária entre o centro de São Paulo, Aeroporto Internacional André Franco Montoro e Guarulhos. Serão construídos $28 \mathrm{~km}$ de via permanente para o Aeroporto e 20,5 km até Guarulhos. Haverá também a construção de Pátio e Oficina e aquisição de 14 trens. Este projeto será viabilizado através de concessões, e o Governo espera contar com a participação da Infraero para a construção dos terminais.

Cumpre assinalar que, quando o Plano fala em modernização, o objetivo é assegurar qualidade de metrô para toda a rede sobre trilhos. Além disso, a aquisição de trens ${ }^{307}$, desta vez, prevê veículos novos, e não usados ${ }^{308}$, em grande parte com ar condicionado e TV de plasma. A frota existente já está sendo reformada.

\footnotetext{
${ }^{307}$ O Plano prevê a aquisição de 100 trens de última geração para o Metrô e a CPTM.

${ }^{308}$ Em 1998 foram adquiridos 48 trens da empresa espanhola Red Nacional de los Ferrocarriles Españoles, que foram reformados para adaptação aos trilhos existentes em São Paulo. Os trens eram usados e sua aquisição, ao invés da encomenda de trens novos para a indústria ferroviária nacional, foi muito criticada.
} 
Figura 3 - Plano da Linha Expresso Aeroporto/Trem de Guarulhos

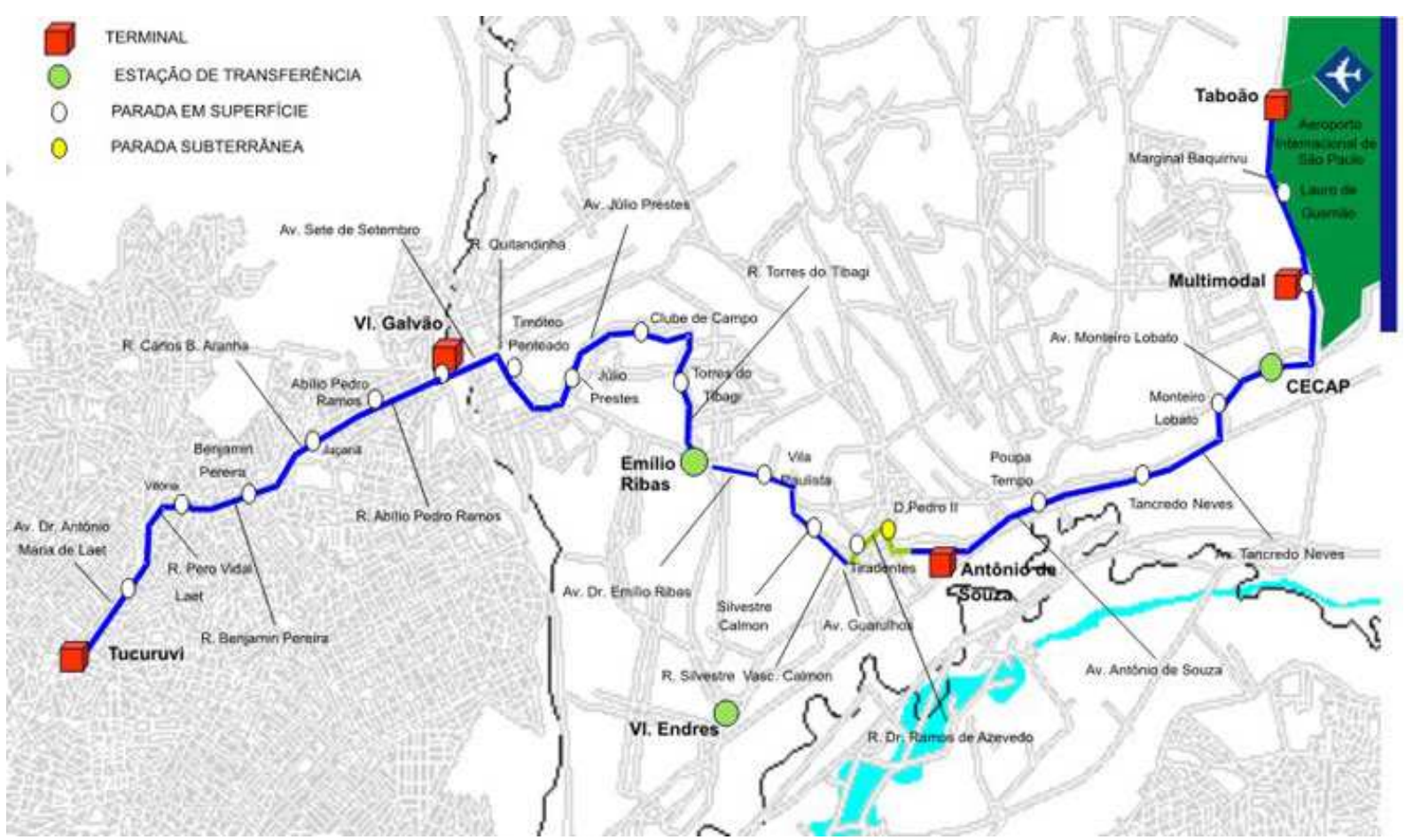

http://www.emtu.sp.gov.br/empreendimentos/sivimlmais.htm?m=9 - acesso em 03.03.2008

Para completarmos o debate acerca da rede sobre trilhos, delinearemos, no próximo item, notas sobre a implantação do metrô em São Paulo, características da rede metroviária e ainda sobre as políticas de expansão do metrô no período focado por esta pesquisa. 


\section{2 - No Modo Metroviário}

\subsection{1 - Breves Notas sobre a Implantação do Metrô em São Paulo e Características da Rede}

O sistema de metrô foi tardiamente empreendido em São Paulo e iniciou seu funcionamento no princípio dos anos 1970. O consórcio HMD, formado pelas empresas Montreal (nacional), Hochtief e Deconsult (alemãs), foi o responsável pelo empreendimento. Em 1968 foi criada a Companhia do Metropolitano de São Paulo (CMSP), empresa do Governo do Estado de São Paulo vinculada à STM que opera o sistema de Metrô ${ }^{309}$.

Inicialmente pertinente à esfera municipal, antes dos anos 80, a CMSP passou para o âmbito estadual, tendo em vista o ensejo de desenvolver projetos em conjunto com a linha de trem da Fepasa, companhia estadual. A construção do metrô mudou a aparência dos lugares. Os projetos do metrô incorporaram planos de urbanização e foram responsáveis por mudanças razoáveis nos hábitos e valores da população. Assistimos a uma valorização do novo, o metrô, e a uma degradação da velha ferrovia ${ }^{310}$.

Analisando-se a primeira fase de operação da primeira linha construída, a linha 1 Azul, verificou-se que o metrô só servia aos moradores próximos à linha. Os habitantes de áreas mais afastadas continuavam usando os ônibus para se dirigir ao centro. Assim, em 1975, foi criada a integração metrô-ônibus ${ }^{311}$, que ampliava a área de influência da linha de metrô.

\footnotetext{
${ }^{309}$ CIA. DO METROPOLITANO DE SÃO PAULO, 1991.

${ }^{310}$ SÃO PAULO, s.d.

${ }^{311}$ Esta integração era física e parcialmente tarifária, havendo algum desconto na tarifa do ônibus para o usuário do metrô, que adquiria nas bilheterias do metrô o bilhete "Integração metrô-ônibus", hoje já abolido.
} 
Além disso, neste ano foi formalizada a articulação com o transporte ferroviário de subúrbios $^{312}$.

A linha 1 - Azul compreende 23 estações, ligando a zona norte à zona sul da capital. Esta linha tem 20,1 km e foi a primeira linha de metrô construída em São Paulo. O início de suas obras ocorreu em dezembro de 1968. A primeira viagem oficial de trem aconteceu em setembro de 1972, entre as estações Jabaquara e Saúde. Em setembro de 1975, começou a fazer o percurso Jabaquara-Santana integralmente, das $6 \mathrm{~h} 30$ às 20h30, de segunda a sextafeira. Aos poucos, sua operação foi ampliada para os finais de semana e o seu horário para das 5 às 24 horas. Em dezembro de 1987, iniciaram-se as obras da extensão Norte, com 3,5 km de linha e três novas estações, até o Tucuruvi. Após paralisação de cinco anos, as obras foram retomadas em 1996 e as novas estações inauguradas em $1998^{313}$.

A questão da superlotação da linha 1 - Azul apareceu em algumas entrevistas realizadas. Trabalhador do setor de serviços que a utiliza entre as estações Jabaquara e Luz acha seu deslocamento muito desgastante "tanto fisicamente quanto mentalmente, pois os trens vão lotados todos os dias e horários. Há uns 8 anos atrás era o melhor meio de transporte público do mundo.”314. O tempo de deslocamento também não vai bem, de acordo com seu depoimento.

Passageira que trabalha no setor de serviços e usa a linha 1 - Azul entre as estações Jabaquara e Liberdade também acha o metrô desconfortável e muito apertado, um local onde as pessoas não se respeitam. Juntamente com o ônibus que toma, seu percurso entre casa e trabalho leva uma hora, o que é, em seu ponto de vista, um tempo muito longo.

\footnotetext{
312 SÃO PAULO, s.d.

${ }^{313}$ MELLO, 2000.

${ }^{314}$ Informação pessoal, 30/05/07.
} 


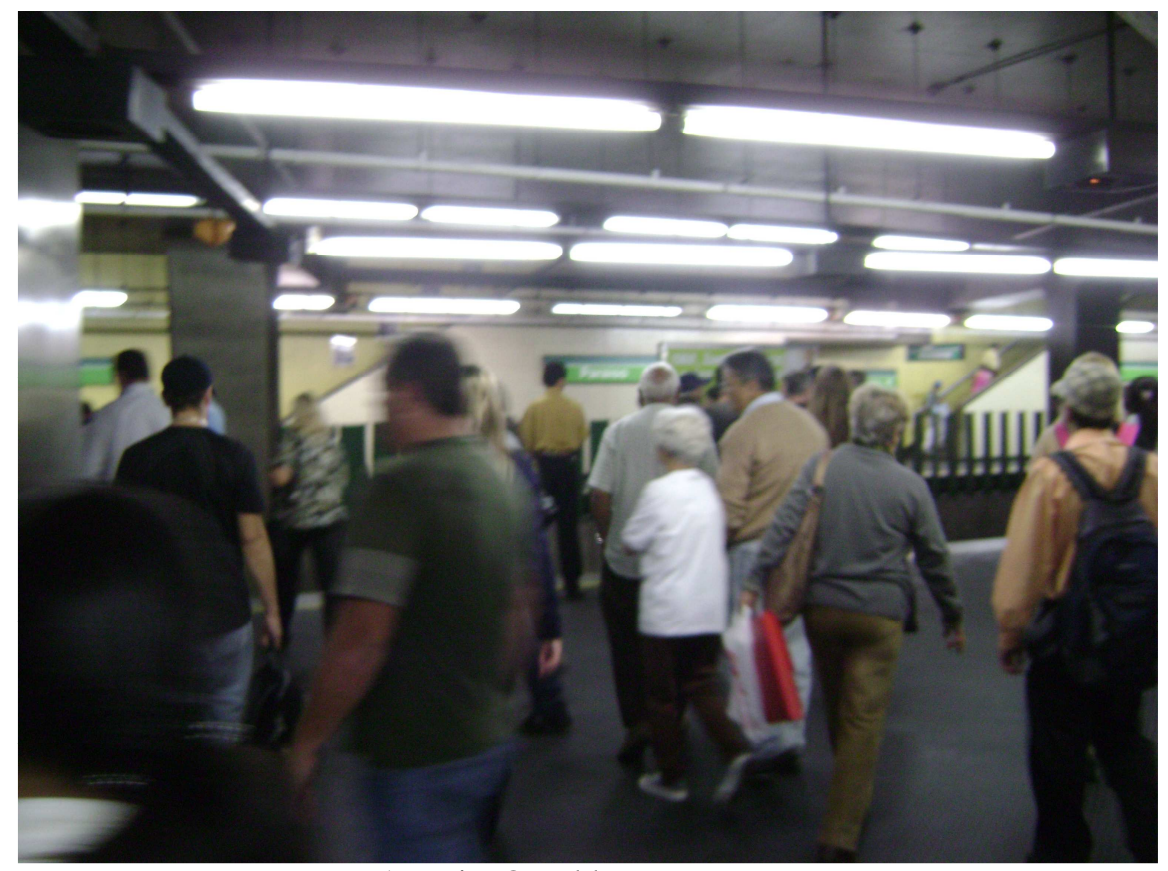

Autoria: Osvaldo Bruno Meca

Fotografia 40 - Linha 1 - Azul - Plataforma da Estação Paraíso / 19/05/08

Para a segunda linha, atualmente chamada linha 3 - Vermelha, privilegiou-se um projeto de custos reduzidos com trechos de superfície sempre que possível e utilizando corredores de transporte já existentes. Novos "viadutos [...] e passarelas para pedestres buscaram rearticular a estrutura urbana rompida pela ferrovia e pelas novas vias.",315

Os projetos das linhas Casa Verde-Vila Maria e Pinheiros-Via Anchieta, bem como os ramais Moema e Vila Bertioga, prognosticados pelo consórcio HMD, foram abandonados neste momento. Com a preocupação de reduzir custos, entre outros fatores, verificamos que até 1998, ou seja, em 30 anos, muito foi alterado do projeto inicial. Além disso, a evolução do metrô é muito lenta.

Mello ${ }^{316}$ discutiu em seu trabalho que representantes do sistema ferroviário defendiam que o Metrô deveria assumir uma configuração em forma de malha centralizada, ao invés de ter extensões periféricas. Nesta visão, o Metrô teria investido erradamente, no caso da linha 3 - Vermelha, que, ao acompanhar um bom trecho da Linha E da CPTM, vai até bairros

\footnotetext{
${ }^{315}$ MELLO, 2000.

${ }^{316}$ Ibidem.
} 
periféricos da Capital. Por outro lado, dada a alta densidade demográfica da Zona Leste, há quem defenda que tanto o trem quanto o metrô, e ainda os sistemas de ônibus, são necessários para atender àquela população. Não aprofundaremos o debate sobre esta polêmica no momento, tampouco sobre as questões relacionadas aos custos do Metrô e dificuldades de expansão do sistema. Para tanto, sugerimos a leitura da obra de Mello ${ }^{317}$, já que não está entre nossos objetivos adentrar esse mérito.

A linha 3 - Vermelha faz a ligação leste-oeste da capital, com 22,2 km de extensão e 18 estações. As obras iniciaram-se em março de 1975. Em março de 1979, entrou em operação comercial o primeiro trecho da linha 3, da estação Sé ao Brás. Em outubro de 1988, com a inauguração da estação Corínthians-Itaquera, foi concluído o lado leste desta linha. Do lado oeste, em dezembro de 1989, foram inauguradas as estações Marechal Deodoro e Barra Funda, completando os $22,2 \mathrm{~km}$ da linha. Sua integração com o trem metropolitano completou-se através das estações Palmeiras-Barra Funda, Brás, Tatuapé e CorínthiansItaquera $^{318}$.

Esta linha, então chamada linha Leste-Oeste, foi desenhada visando a servir à populosa $^{319}$ Zona Leste da Capital, principal aglomeração da área metropolitana de São Paulo. Nesta área, "que se distinguia pela deterioração das edificações e equipamentos urbanos e por extensas zonas de baixa ocupação, a Linha Leste-Oeste veio estimular o maior adensamento, a reurbanização e a reconstrução da rede de transporte, orientando o crescimento da cidade."320

\footnotetext{
${ }^{317}$ MELLO, 2000.

${ }^{318}$ Www.metro.sp.gov.br - acesso em 06.02.2008.

319 À época da construção, esta região englobava cerca de $43 \%$ da população da Capital.

${ }^{320}$ CIA. DO METROPOLITANO DE SÃO PAULO, 1991, p.48.
} 


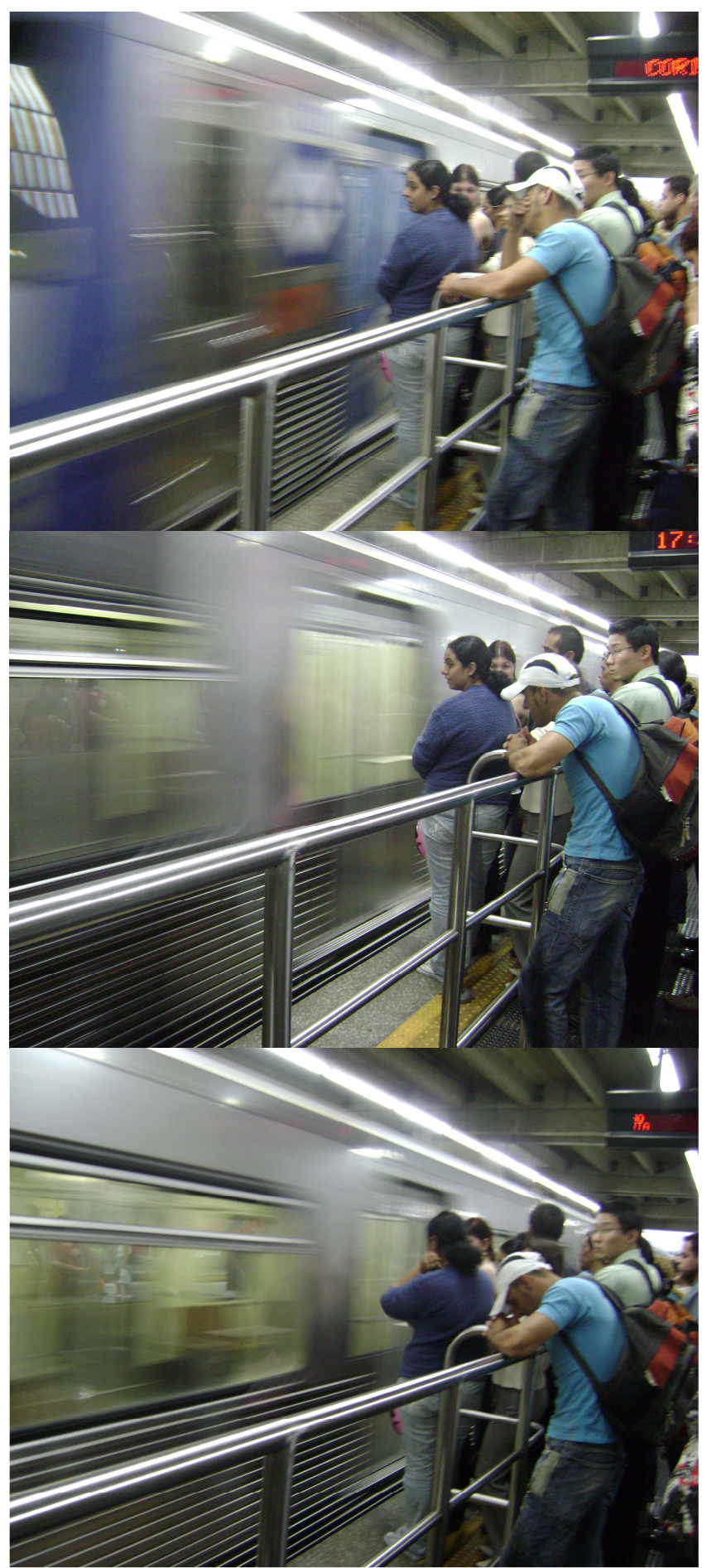

Autoria: Osvaldo Bruno Meca

Fotografias 41 - 42 - 43 - Sequiência de imagens retratando a chegada do metrô da Linha 3 - Vermelha na Plataforma da Estação Sé. O jovem de blusa azul demonstra cansaço / 05/06/08

Desejado por quem deixaria o carro apenas se tivesse como opção o metrô, mas severamente criticado por outros que reclamam da decadência de seus serviços, lembramos que em muitas outras metrópoles a lotação dos metrôs é um fato recorrente, pois os sistemas foram instalados nas áreas mais densas das aglomerações, com maior oferta de empregos, 
tendo, portanto, uma grande demanda. O intervalo entre as composições, no caso de São Paulo, já é bem reduzido, e diminui ainda mais nos horários de pico. Contudo, sua superlotação vem tornando os deslocamentos difíceis e desconfortáveis.

Reportagem da Folha de São Paulo do dia 21.04.2008 informou que o metrô de São Paulo é mais lotado que o de Tóquio. Em 2007, o metrô de São Paulo teve 10 milhões de passageiros por quilômetro; o de Tóquio, 8,3 milhões. Atribuindo a lotação exagerada ao Bilhete Único, na linha 3 - Vermelha, a superlotação chega a mais do que seis passageiros por metro quadrado, num limite considerado insuportável ${ }^{321}$.

A terceira linha construída, a linha 2 - Verde tem 10,7 km e 11 estações, ligando o Alto do Ipiranga até o bairro de Vila Madalena, cruzando toda a avenida Paulista. O primeiro trecho, que liga as estações Paraíso, da linha 1-Azul, e Consolação, foi inaugurado em 1991. No ano seguinte, inaugurou-se a estação Clínicas e ampliou-se a linha até a estação Ana Rosa, da linha 1-Azul. Em 1998, mais duas estações foram inauguradas no sentido oeste: Sumaré e Vila Madalena. Em 2006, foram inauguradas, no sentido leste, as estações Chácara Klabin e Imigrantes, e em 2007, também no eixo leste, a estação Alto do Ipiranga, aproximando-se mais do plano final, de chegar à Vila Prudente. A partir de janeiro de 2008, passaram a operar vans e miniônibus da Ponte Orca (Operador Regional de Coletivo Autônomo) entre a estação Alto do Ipiranga e a estação Tamanduateí, da linha D da CPTM, além da que já era operada anteriormente, que liga a estação Vila Madalena até a linha C da CPTM.

Conversamos com morador da região do ABC Paulista que trabalha em São Paulo e beneficiou-se com a ampliação da linha 2 - Verde do metrô até o Alto do Ipiranga. Ele vem do $\mathrm{ABC}$ de ônibus, mas para dirigir-se até seu emprego, na avenida Paulista, pode ir de metrô, encurtando o tempo do deslocamento.

${ }^{321}$ IZIDORO, 2008b. 


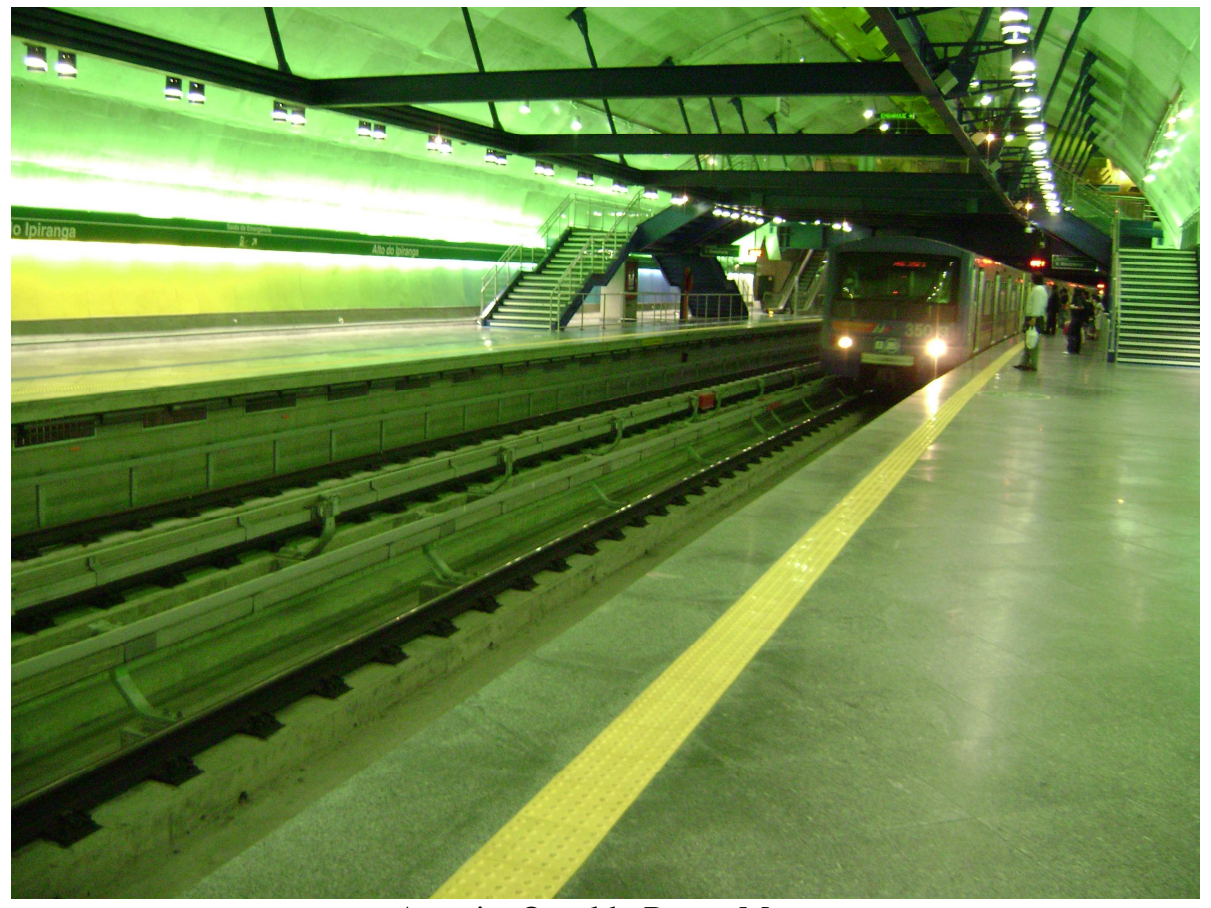

Autoria: Osvaldo Bruno Meca

Fotografia 44 - Linha 2 - Verde - Plataforma da Estação Alto do Ipiranga / 22/12/07

A quarta linha é a linha 5 - Lilás ${ }^{322}$; foi construída pela CPTM e inaugurada em 2002. Localizada na região de Santo Amaro, possui 8,4 km e 6 estações, sendo 5 delas com terminais de integração com ônibus urbano e uma, a estação Santo Amaro, interligada também à linha $\mathrm{C}$ da $\mathrm{CPTM}^{323}$.

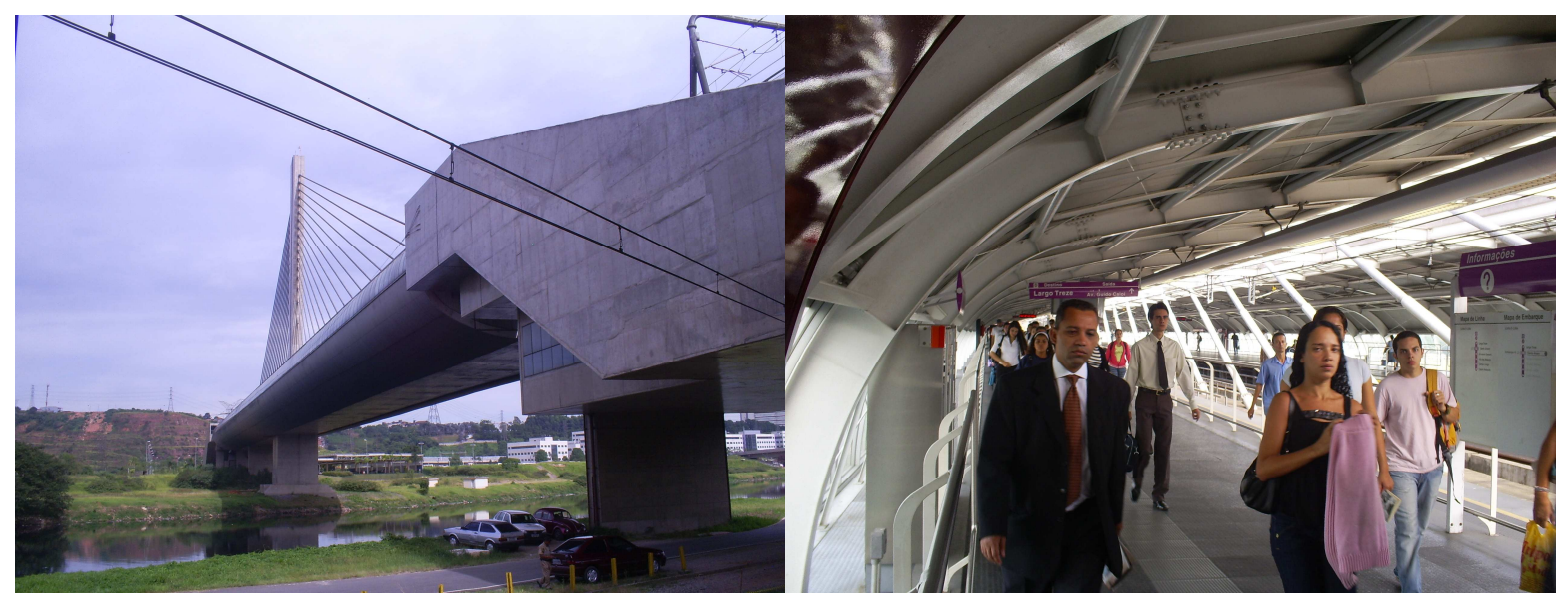

Autoria: Flávia Ulian

Fotografia 45 - Linha 5 - Lilás - A Estação Santo Amaro fica suspensa sobre o rio Pinheiros / 05/03/08
Fotografia 46 - Linha 5 - Lilás - Plataforma da Estação Santo Amaro / 05/03/08

${ }_{323}^{322}$ A linha 4 - Amarela ainda não está concluída.

${ }^{323}$ www.metro.sp.gov.br/ - acesso em 30.01.2008. 


\section{Mapa 4 - Região Metropolitana de São Paulo \\ Rede de Linhas de Metrô}

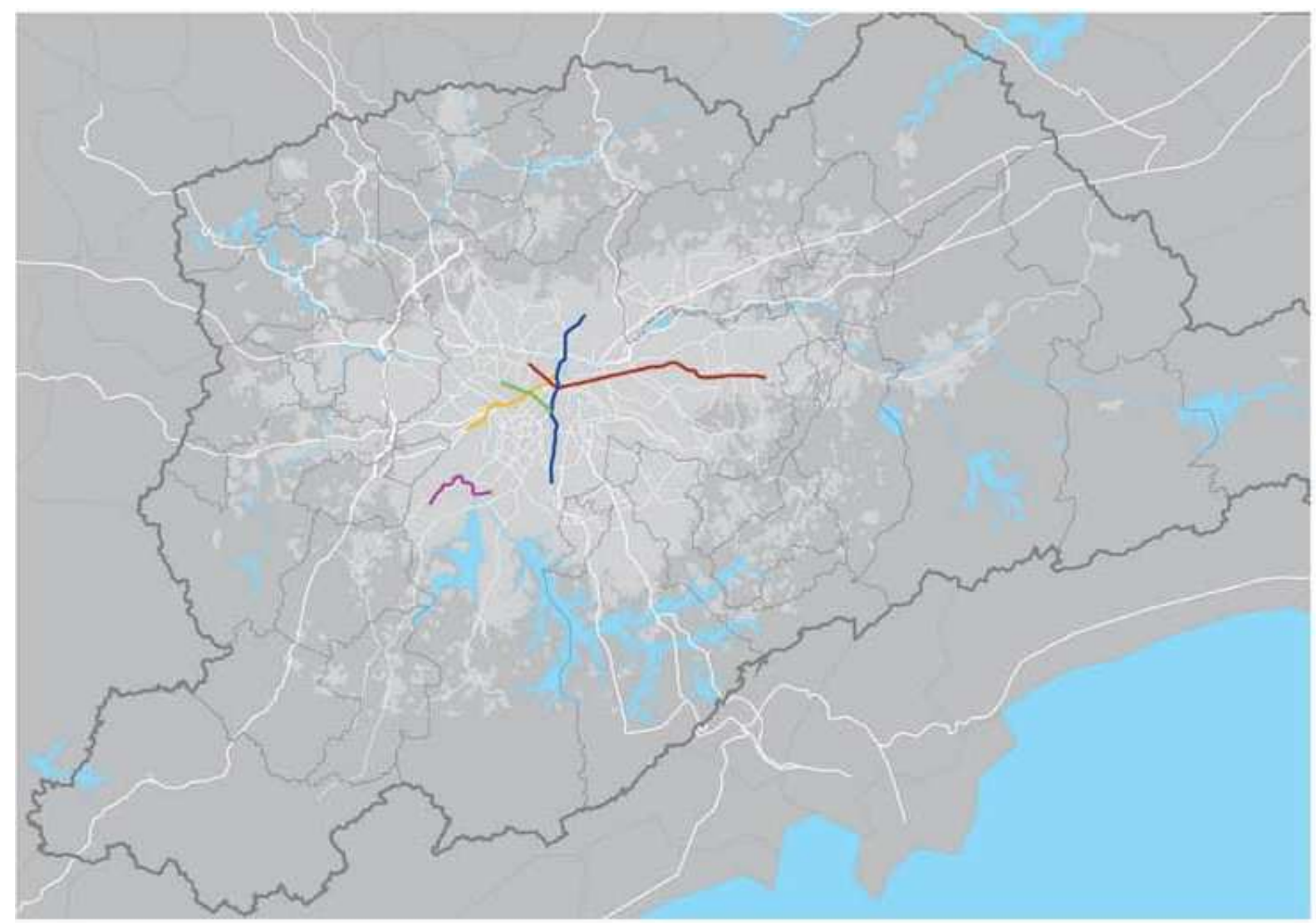

\section{METRÔ 2002}

- Linha 1 - Norte-Sul

- Linha 2 - Paulista

- Linha 3 - Leste-Oeste

- Linha 5 - Capão Redondo-Largo Treze

- Metró projetado - Linha 4

E Sistema viário principal

- Area urbanizada

Lios, represas e oceano Atlåntico

$\square$ Limite da Região Metropolitana de São Paulo

$\square$ Municípios da Regiāo Metropolitana de São Paulo

— Municípios do Estado de São Paulo 


\section{$0 \quad 10 \quad 20$ Quilơmetros}

index.php?page=São\%20Paulo\%20Metrópole\#attachments - acesso em 20.06.2008

Organização da autora.

A Tabela 16 mostra dados gerais de 2007 do metrô de São Paulo e o Mapa 4, a rede metroviária do município:

\section{Tabela 16 - Município de São Paulo Dados gerais do Metrô - 2007}

\begin{tabular}{|l|l|l|l|l|l|}
\hline Linhas & $\begin{array}{l}\text { Linha 1 } \\
\text { Azul }\end{array}$ & $\begin{array}{l}\text { Linha 2 } \\
\text { Verde }\end{array}$ & $\begin{array}{l}\text { Linha 3 } \\
\text { Vermelha }\end{array}$ & $\begin{array}{l}\text { Linha 5 } \\
\text { Lilás }\end{array}$ & Rede \\
\hline Início da operação comercial & 1974 & 1991 & 1979 & 2002 & \\
\hline Horário da operação comercial & $\begin{array}{l}4 \mathrm{~h} 40 \text { às } \\
0 \mathrm{~h} 20(5)\end{array}$ & $\begin{array}{l}4 \mathrm{~h} 40 \text { às } \\
0 \mathrm{~h} 20(5)\end{array}$ & $\begin{array}{l}4 \mathrm{~h} 40 \text { às } \\
0 \mathrm{~h} 20(5)\end{array}$ & $\begin{array}{l}4 \mathrm{~h} 40 \text { às } \\
24 \mathrm{~h}(6)\end{array}$ & - \\
\hline Extensão atual das linhas (km) & 20,2 & 10,7 & 22,2 & 8,4 & 61,3 \\
\hline Estações & 23 & 11 & 18 & 6 & $55(1)$ \\
\hline Estações de transferência & 3 & 2 & 1 & - & 3 \\
\hline Estações de integração com ferrovia & 1 & $2(2)$ & 4 & 1 & 8 \\
\hline Estações com terminais de ônibus urbanos & 6 & 1 & 10 & 5 & 22 \\
\hline Estações com terminais rodoviários & 2 & 0 & 1 & 0 & 3 \\
\hline Estações com estacionamento de automóveis & 3 & 0 & 4 & 0 & 7 \\
\hline Número de carros da frota (3) & 306 & 66 & 282 & 48 & 702 \\
\hline Número de carros utilizados nas horas de pico & 258 & 90 & 262 & 24 & 624 \\
\hline Intervalo mínimo entre trens / real (seg.) & 109 & 150 & 101 & 381 & - \\
\hline Velocidade máxima (km/h) & 87 & 87 & 87 & 68 & - \\
\hline Velocidade comercial (km/h) & 32 & 35 & 42 & 45 & - \\
\hline Passageiros transportados (milhões/ano) (4) & 227,1 & 55,2 & 262,8 & 18,5 & 563,6 \\
\hline Passageiros transportados/km de linha (milhões) (4) & 16,58 & 10,16 & 15,11 & 1,78 & 9,5 \\
\hline Passageiros transportados - média dia útil (mil) (4) & 775,8 & 226,4 & $1.026,8$ & 92,4 & $2.232,5$ \\
\hline Usuários que se utilizam da integração tarifária & $17 \%$ & $19 \%$ & $20 \%$ & $9 \%$ & - \\
\hline
\end{tabular}

Fonte: http://www.metro.sp.gov.br/empresa/relatorio/2006/rametro2006.pdf - acesso em 03.02.2008 Organização da autora.
(1) As estações de transferência foram computadas nas duas linhas que atendem - Sé (L1 e L3), Ana Rosa (L1 e L2) e Paraíso (L1 e L2) - porém uma só vez no total da rede.
(2) Feita através da Ponte Orca.
(3) Cada trem possui formação fixa de 6 carros.
(4) Dados relativos ao ano de 2006.
(5) As estações vão fechando conforme passa o último trem, em média, às 0h20.
(6) Funcionamento de $2^{\mathrm{a}}$. feira a sábado, exceto feriados. 
Conforme pode ser visto na Tabela 16, para o tamanho da RMSP, a rede de metrô é muito reduzida, principalmente por se concentrar apenas na Capital. No entanto, a sua integração física e tarifária com a ferrovia em 8 estações, minimiza sua pequena dimensão. A integração com lotações e ônibus municipais e intermunicipais da EMTU nos terminais de ônibus urbanos em 22 estações expande a ação do metrô para o restante da metrópole. Apesar desta integração, os dados mostram que, em termos percentuais, a integração tarifária chega a, no máximo, 20\% das entradas de passageiros, o que é um índice baixo. Este fato é mais marcante na linha 5 - Lilás, que se conecta somente com a ferrovia, e não com outras linhas de metrô. Mesmo sendo uma região bastante carente, apenas $9 \%$ dos passageiros fazem uso da integração tarifária e física com a linha C da CPTM. Além disso, esta linha também transporta apenas 1,78 passageiros por quilômetro de linha, o que é muito pouco para um modo de transporte com custos de implantação altíssimos.

Pensamos que, assim como nos foi explicado pelo subsecretário da Secretaria Municipal de Trânsito e Transportes (SEMUTRANS) de Taboão da Serra, Sr. Claudinei Pereira, em entrevista concedida em 31.01.2008, se houvesse integração tarifária entre os ônibus dos municípios vizinhos e esta região (Embu e Taboão da Serra), certamente esta linha de metrô seria mais utilizada. A integração física já existe, através de ônibus que saem das estações de metrô desta linha, mas ainda falta a integração tarifária, "que é a que mais pesa, tanto para o lucro dos operadores de ônibus, quanto para a melhoria dos deslocamentos para a população de baixa renda" ${ }^{324}$.

Para os empregadores do município de São Paulo, a integração tarifária também é um item importante na hora de empregar o indivíduo. De acordo com depoimento do empresário André de Paula, da área de informática, da Capital, há um gasto maior para a empresa se o funcionário reside em outro município e necessita pagar o ônibus intermunicipal, pois até o

\footnotetext{
${ }^{324}$ Informação pessoal, 31/01/08.
} 
momento, apenas os ônibus municipais possuem integração tarifária. No entanto, pensamos que pagar apenas a diferença de tarifa do ônibus intermunicipal, quando se utiliza o terminal de integração de ônibus intermunicipais, como a estação Campo Limpo, da linha 5 - Lilás, para quem usou o metrô, é um avanço em direção a uma integração tarifária completa. Na estação Capão Redondo desta linha, há total integração tarifária do metrô com algumas linhas da EMTU nas quais, pagando apenas uma tarifa, o passageiro que pegar o ônibus intermunicipal no município de Embu desembarca no terminal Capão Redondo, onde é possível fazer, sem custo adicional, transferência para a linha 5 - Lilás e, na estação Santo Amaro, para a linha C da CPTM. A partir desta linha, se o usuário precisar pegar novamente o sistema do Metrô, poderá fazê-lo tanto através da Ponte Orca, que sai da Estação Cidade Universitária (linha C CPTM) até a estação Vila Madalena (linha 2 - Verde), quanto pela utilização do trem na linha $\mathrm{C}$ até sua conexão com a linha $\mathrm{B}$ e, dela, até a estação Barra Funda, onde há conexão com o metrô, na linha 3 - Vermelha. É premente que esta integração tarifária entre os meios de transporte sobre trilhos e os ônibus seja ampliada.

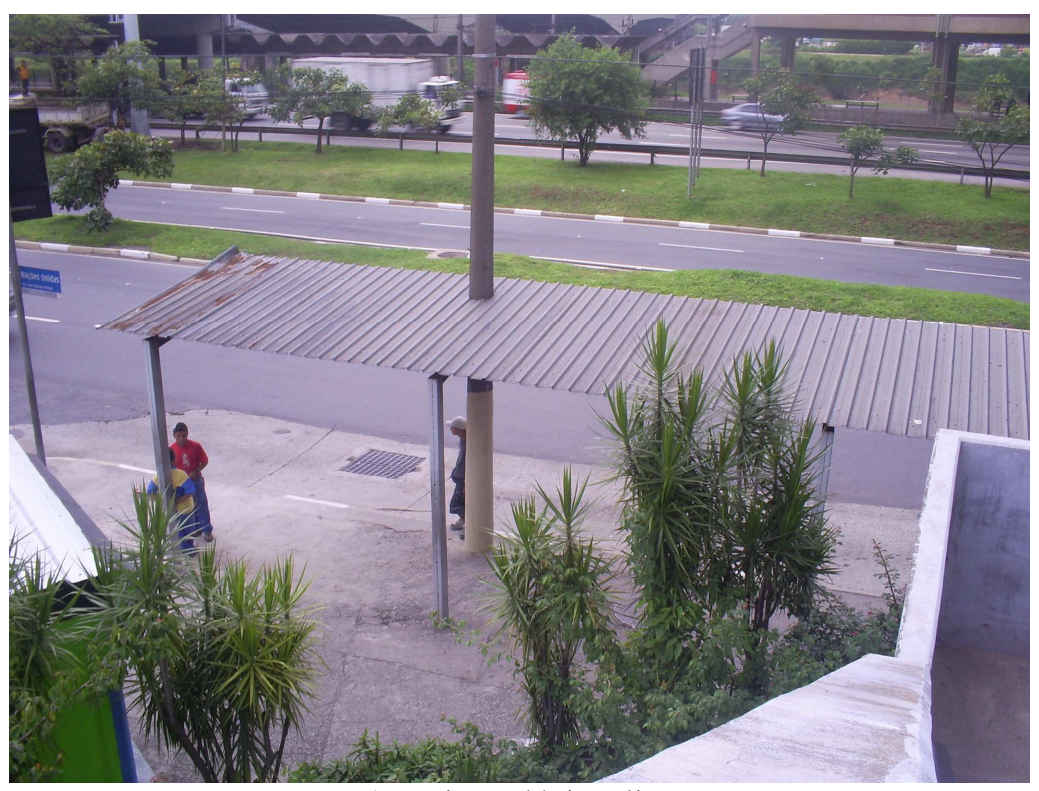

Autoria - Flávia Ulian

Fotografia 47 - Ponto de Parada da Ponte Orca na Estação Cidade Universitária, da Linha C da CPTM 31/01/08 
Considerado transporte de alta qualidade, principalmente por ser rápido e eficiente, além do ótimo padrão de qualidade no que se refere à limpeza e conservação dos seus trens, o metrô sempre foi e continua sendo o meio de transporte público melhor avaliado pela população. O tempo médio de espera, de 109 segundos nas linhas 1 e 3, de 150 segundos na linha 2 e 381 segundos na linha 5 é bastante razoável, sendo uma modalidade de transporte que apresenta pouca espera. No entanto, o Metrô sofreu queda em sua avaliação em 2007. Neste ano, o nível de satisfação dos clientes freqüentes passou para $87 \%$, contra $92 \%$ em 2006. O Metrô sempre fez campanhas para aumentar a demanda, mas quando ela efetivamente foi aumentada, com a implantação do Bilhete Único (31/12/05), a inauguração de três novas estações na Linha 2-Verde, Chácara Klabin (09/05/06), Imigrantes (15/04/06) e Alto do Ipiranga (30/06/07), além do aquecimento da economia, mostrou que ele não estava preparado para este crescimento, decaindo a qualidade de seus serviços e levando, assim, à queda do nível de satisfação dos usuários.

Na perspectiva de integrarmos todos estes dados objetivos com o cotidiano do usuário do metrô, coletamos, nas pesquisas de campo, alguns depoimentos, que aqui inserimos como contribuição para o entendimento do dia-a-dia do trabalhador usuário do sistema de metrô.

Entrevistamos uma trabalhadora do setor de serviços que se utiliza do metrô nas linhas 1 - Azul e 2 - Verde. Considera o metrô rápido, limpo, confortável, uma excelente alternativa para fugir do trânsito. Ela ressalta, porém, que usa o metrô fora do horário de pico e que por isso não há desgaste físico. Esta é exatamente a imagem que o metrô passa, e por isso a classe média pressiona por sua ampliação, mostrando ser uma opção de transporte que faria com que o usuário de automóvel abandonasse o carro em casa e passasse a usar o transporte coletivo. 
Em entrevista ao Jornal da Tarde de 25.03.2008, médico paulistano declarou que "não pensa duas vezes para deixar o carro na garagem, quando pode ir de metrô para os hospitais onde trabalha.",325

Ouvimos o depoimento de uma trabalhadora do setor de serviços que usa as linhas 1 Azul e 2 - Verde, além de ônibus. O trajeto de manhã, entre sua casa e o trabalho, é de uma hora e meia, e na volta, um pouco mais. Um dia, em uma ocasião em que o metrô parou de funcionar por motivos técnicos, precisou usar o ônibus também no trajeto pela Avenida Paulista e chegou muito mais tarde em sua casa, pois o metrô permite uma incrível economia de tempo. Pensamos que, pela forma da cidade e porque as pessoas necessitam residir tão longe de seus lugares de trabalho, o deslocamento torna-se uma imposição da metrópole. No entanto, se este deslocamento puder ser de boa qualidade e agilizado pelo uso de uma tecnologia tão moderna quanto à do metrô, o cotidiano dos trabalhadores tornar-se-á menos desgastante.

Para estimular a integração metrô-automóvel, há garagens subterrâneas nas estações Ana Rosa, Santa Cruz e Tietê, da linha 1 - Azul, e nas estações Corinthians-Itaquera, Palmeiras-Barra Funda, Penha e Tatuapé, da linha 3 - Vermelha, em um convênio chamado metrô-automóvel, no qual o usuário deixa seu carro e continua o trajeto de metrô. O preço do estacionamento é variável de acordo com a estação e os estacionamentos são operados pela iniciativa privada.

Há também, no sistema do metrô, 3 estações integradas com terminais de ônibus rodoviários (estações Tietê e Jabaquara, na linha 1 - Azul e estação Barra Funda, na linha 3 Vermelha). Até 2001 havia um quarto terminal rodoviário, junto à estação Bresser (linha 3Vermelha), que foi desativado. Os terminais rodoviários tiveram sua administração

\footnotetext{
${ }^{325}$ FRANÇA, 2008, p.3.
} 
terceirizada a partir de 1990, quando o consórcio Prima passou a operá-los comercialmente através da empresa Socicam Administração de Terminais Rodoviários.

A Tabela 17 mostra a quantidade de deslocamentos diários realizados pelo Metrô.

Observamos que, entre 1987 e 2007 , cresceram em $72 \%$.

Tabela 17 - Região Metropolitana de São Paulo Número de passageiros transportados no serviço de Metrô (em milhares/dia)

\begin{tabular}{|c|c|c|c|}
\hline $\mathbf{1 9 8 7}$ & $\mathbf{1 9 9 7}$ & $\mathbf{2 0 0 2}$ & $\mathbf{2 0 0 7}$ \\
\hline 1.462 & 1.696 & 1.803 & 2.110 \\
\hline
\end{tabular}
Fonte: CIA. DO METROPOLITANO DE SÃO PAULO.Aferição da Pesquisa O-D 1997, 2002;
www.metro.sp.gov.br - 27.05.2008 / Organização da autora




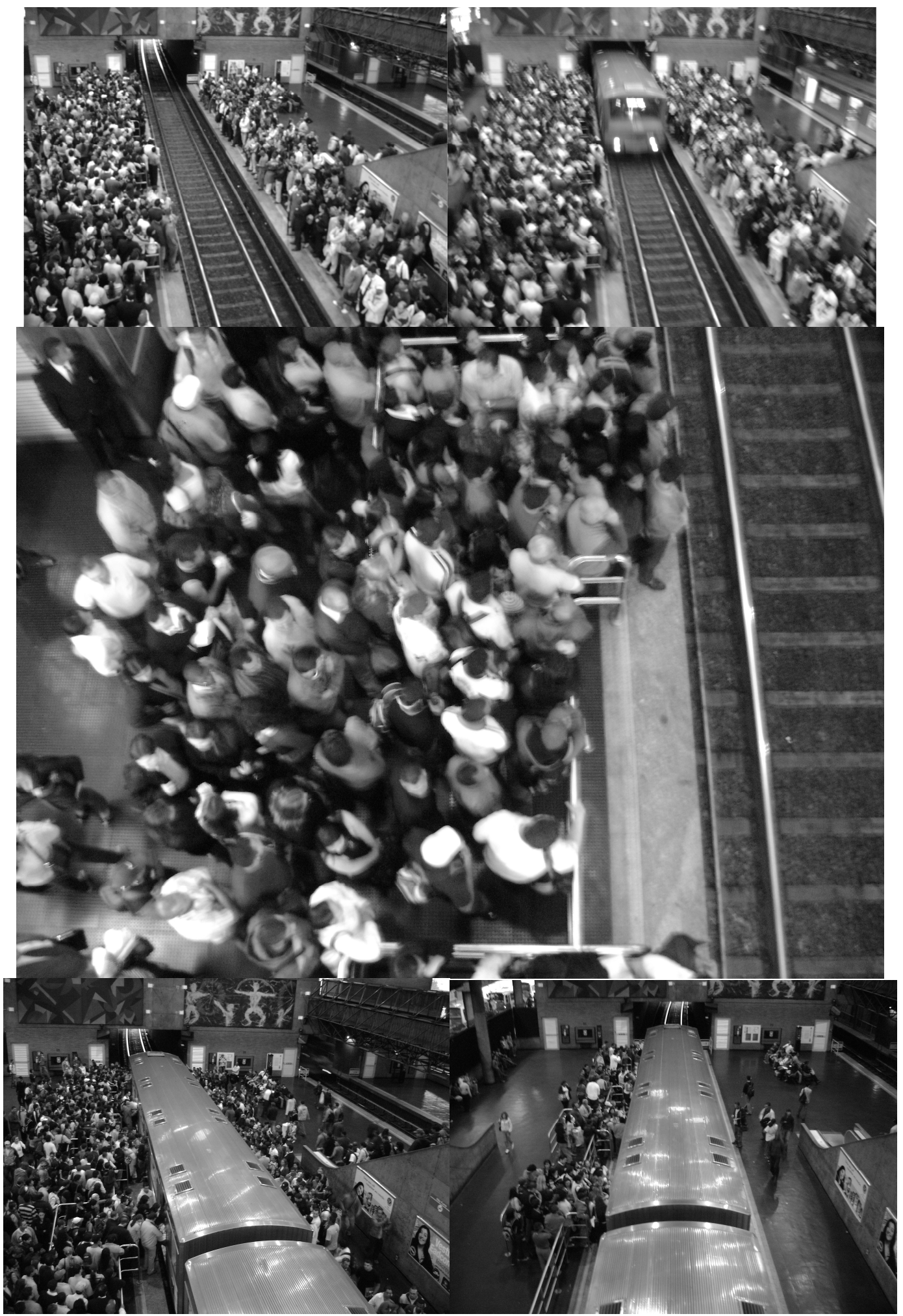

Autoria: Osvaldo Bruno Meca

Fotografias 48 - 49 - 50 - 51 - 52 - Linha 3 - Vermelha - Embarque na Plataforma da Estação Barra Funda $22 / 01 / 08$ 


\subsection{2 - Políticas de Transporte e o Metrô}

Ao comentar as políticas de transporte para o sistema de trens metropolitanos, abordamos o PMGSP/1994 e os Planos PITU 2020 e 2025. Neste item, apontaremos projetos de expansão da rede metroviária inseridos nos referidos planos.

Também será objeto de nossa análise neste item um documento bastante interessante, elaborado sobre a expansão da rede metroviária, denominado "Rede Essencial do Metrô".

O PMGSP de 1994 instituiu propostas para o metrô, através do estímulo ao processo de renovação urbana em conjunto com obras viárias e metroviárias, junto à avenida do Estado, associada a obras de canalização do rio Tamanduateí e Córrego dos Meninos, e ainda da linha Oratório (atual linha 2 - Verde) do metrô. O Plano propunha, além disso, a conclusão dos trechos do Metrô na extensão norte da linha 1 - Azul (concretizada em 1998, com a inauguração da estação Tucuruvi), extensão leste da linha 3 - Vermelha, que não foi cumprida, pois se optou posteriormente por realizar-se benfeitorias na linha E da CPTM; extensão oeste da linha 2 - Verde, concluída em 1998 com a inauguração da estação Vila Madalena; implantação dos seguintes trechos do Metrô: trecho Campo-Limpo-Santo Amaro da linha 5 - Lilás, concluído em 2002; trecho Santo Amaro-Emboaçu, que conectaria a linha 5 - Lilás com a linha 2 - Verde; trecho Ana Rosa-Oratório da linha 2 - Verde, que está em fase de construção; trecho Vila Sônia-Consolação da linha 4 - Amarela, também em fase de construção. Estes planos, já prognosticados na gestão do governo do Estado 1991-1994, foram incluídos no PITU 2020, proposto na gestão do governo estadual 1995-1998, como vimos anteriormente.

Como a extensão do Metrô é extremamente cara, os planos vão se arrastando por décadas, até serem vagarosamente implementados. Destarte, aparecem em grande parte no Plano que analisaremos a seguir. 
O Plano de Expansão $2007-2010^{326}$ prevê, para a rede metroviária, a modernização de suas linhas 1 - Azul e 3 - Vermelha.

Quanto às novas linhas e estações, o Plano calcula que sejam construídas mais três estações na linha 2 - Verde: as estações Sacomã, Tamanduateí e Vila Prudente, com a extensão da linha em mais $3,9 \mathrm{~km}$. Será construído também um pátio de manutenção e adquiridos 16 trens. Haverá integração com a linha D da CPTM, na qual circulará o Expresso ABC, já aludido em item anterior. Haverá integração com o Expresso Tiradentes, gerenciado pela SPTrans, que detalharemos posteriormente, o que possibilitará integração com o sistema de ônibus municipal e intermunicipal. A melhoria da regularidade da linha em operação está, igualmente, prevista. Esta linha será uma alternativa para os usuários de automóveis da região leste e dos municípios do ABC.

A linha 4 - Amarela, em construção desde maio de 2005, terá 12,8 km e 11 estações, conectando-se com as linhas 1- Azul, 2 - Verde e 3 - Vermelha. Era prevista para ser inaugurada em 2005, mas foi somente neste ano que as obras foram iniciadas. Houve um grave acidente em um dos pontos de construção em janeiro de 2006, com abertura de uma cratera e a queda de veículos com ocorrência de mortes no local. As obras, desde então, seguem desaceleradas $^{327}$. A linha 4 - Amarela será totalmente subterrânea, já que a superfície construída é muito adensada e seria muito caro pagar as desapropriações. Ela será operada pela iniciativa privada através da PPP (Parceria Público-Privada), que

\footnotetext{
prevê a concessão de sua operação comercial, pelo prazo de 30 anos, a um agente privado que terá também a responsabilidade pelo investimento na compra da frota de trens e de outros sistemas operacionais, como sinalização e controle; telecomunicações móveis e supervisão; e controle centralizado ${ }^{328}$.
}

\footnotetext{
${ }^{326}$ Conforme já foi referido em item anterior, o Plano de Expansão 2007-2010 integra o PITU 2025.

${ }^{327}$ www.metro.sp.gov.br/ - acesso em 30.01.2008.

328 www.metro.sp.gov.br/expansao/sumario/ppp/ppp.shtml - acesso em 06.04.2008.
} 
Apesar de a empresa privada ter captado recursos para a construção da linha, três esferas do governo ${ }^{329}$ estão participando do custeio das obras. Resta saber se o custo do empreendimento terá retorno aos cofres públicos a partir da operação da linha, ou se a PPP servirá para "favorecer" a empresa concessionária a partir dos lucros que poderá obter com a operação do sistema.

A construção da linha 4 - Amarela promoverá reorganização do transporte público na zona oeste e favorecerá o rápido deslocamento ao centro, a integração de sub-centros como Butantã, Pinheiros, região da Avenida Paulista, o centro histórico e grandes equipamentos urbanos como o Hospital das Clínicas, os campus da Cidade Universitária e do Mackenzie ${ }^{330}$. Uma linha intermunicipal integrará a estação Vila Sônia com o município de Taboão da Serra, sem a cobrança de tarifa ${ }^{331}$.

A expansão da linha 5 - Lilás será, dentro do período do Plano de Expansão 20012010, apenas iniciada. O trecho entre as estações Largo 13 desta linha, e a estação Chácara Klabin, da linha 2 - Verde, proporcionará a ligação do centro de Santo Amaro ao bairro da Vila Mariana. Serão construídas 11 estações e 11,4 km de linha, além da aquisição, para esta linha, de 26 novos trens, e a construção de um pátio de manutenção. Haverá integração com a linha 2 - Verde e com a linha 1 - Azul na estação Santa Cruz.

O estudo "Rede Essencial do Metrô", que tem como horizonte o período entre 2020 e 2025, analisou e comparou três propostas para expansão da rede metroviária. A primeira é a rede proposta pelo PITU 2020, desenvolvida pela STM em 1999, com cerca de $230 \mathrm{~km}$ de extensão. Esta se caracterizava por compor uma rede aberta e abrangente de linhas de metrô

\footnotetext{
329 Reportagem da Folha de São Paulo de 18.03.2008 divulgou que "O Governo do Estado e a Prefeitura de São Paulo começaram a negociar a injeção de recursos do governo federal para a expansão do metrô paulista", tendo em vista o alardeamento sobre o crescimento dos "recordes de trânsito" realizado pela mídia nos meses iniciais de 2008. A prefeitura repassará $\mathrm{R} \$ 1$ bilhão para o Metrô, e espera-se que o governo federal destine $\mathrm{R} \$ 150$ milhões por mês para as obras (UNIÃO..., 2008).

${ }^{330}$ www.metro.sp.gov.br/expansao/plano_expansao_2007_2010/plano_expansao_2007_2010.asp - acesso em 03.03.2008.

${ }^{331}$ CIA. DO METROPOLITANO DE SÃO PAULO, 2007.
} 
visando a captar a demanda o mais próximo possível das suas áreas de origem, inclusive se ela se originasse de regiões periféricas do município de São Paulo.

Em um detalhamento da rede proposta no PITU 2020, foi desenvolvida pelo Metrô uma segunda rede, em 2002, denominada rede azul, com cerca de 263 km de extensão.

A terceira rede foi concebida em consonância com a modernização de toda a malha da CPTM, e decresceu para $205 \mathrm{~km}$ de extensão. Esta rede, denominada posteriormente de essencial, "foi proposta com o objetivo de melhor distribuir a demanda nas áreas com características de centro metropolitano, integrada a um adequado sistema de ônibus, descongestionando seus corredores de tráfego., ${ }^{332}$

As chamadas áreas com características de centro metropolitano são privilegiadas em infra-estrutura, configurando-se como destino da maioria das viagens da metrópole, apresentando potencial para adensamento e abrigando as mais diversas funções. Assim, entendeu-se que o metrô deveria circunscrever-se a estas áreas, já que, a partir delas, haveria a distribuição dos passageiros para os modos trem e ônibus, encarregados de levar a população até as áreas periféricas da metrópole ${ }^{333}$. A rede resultante é de menor extensão, tendo sido denominada rede essencial. Ela é imprescindível para dar prosseguimento ao processo de implantação das linhas de metrô, e é essencial para garantir acessibilidade na metrópole, assegurando sua funcionalidade na dinâmica urbana. A Rede Essencial, ao ser implantada nas áreas já providas em grande parte de infra-estrutura urbana, visa a aliviar a pressão de urbanização na periferia, além da franja urbanizada ${ }^{334}$.

A preocupação com a otimização dos recursos investidos no metrô está inserida nesta lógica. Vasconcellos ${ }^{335}$ afirma que a construção de uma grande rede de metrô é um objetivo

\footnotetext{
332 http://www.metro.sp.gov.br/expansao /rede essencial/rede essencial 01.shtml - acesso em 02.03.2008.

333 A divergência sobre a construção do metrô até as periferias da metrópole ou a sua concentração no centro já existia desde sua implantação, nos anos 1970, e já foi referida neste texto no item 3.2.1.

334 Ibidem.

${ }^{335}$ VASCONCELLOS, 1999.
} 
inatingível no Brasil, frente aos seus custos, além de atender prioritariamente aos interesses dos setores da construção civil, das indústrias de base e dos trabalhadores ligados a este meio de transporte. Na visão do autor, e em consonância com o documento da Rede Essencial, o metrô vai se concentrar na área central metropolitana, cabendo aos sistemas de ônibus e trens metropolitanos o atendimento às periferias da Capital e aos demais municípios da metrópole. Concordamos com esta visão, tendo em vista que a modernização do sistema de trens metropolitanos, inicialmente chamados de trens de subúrbio, tem originariamente a função de ser um transporte de massa dos subúrbios, das periferias. Além disso, a construção de mais corredores metropolitanos como o São Mateus-Jabaquara viabilizaria, a um custo muito menor e com muito mais rapidez que a construção do metrô, a possibilidade de distribuição da população para as periferias da Capital e da metrópole. Haveria aumento da acessibilidade a empregos e serviços urbanos, redução dos congestionamentos de trânsito e diminuição do tempo médio das viagens.

Levando em conta que a reestruturação produtiva trouxe um novo padrão de produção, é importante ressaltar que o Plano entende a nova dinâmica no território metropolitano com novas centralidades que diluem a forma convencional de concentração urbana. As pesquisas mostraram que, na RMSP, no ciclo industrial fordista, predominava o padrão pendular de deslocamentos. Na nova ordem econômica, contudo, há dispersão das atividades e os fluxos distribuem-se de forma diferente pelo território.

A continuação da linha 5 - Lilás até a estação Chácara Klabin, na linha 2 - Verde, e desta até a Vila Prudente, além da implantação da linha 4 - Amarela (Vila-Sônia-Estação da Luz) "configuram a primeira etapa de uma verdadeira rede, interligando todas as linhas metroferroviárias existentes [...],336

\footnotetext{
${ }^{336}$ www.metro.sp.gov.br/expansao/rede_essencial/rede_essencial_01.shtml - acesso em 02.03.2008.
} 
O documento "Rede Essencial do Metrô" traz explicações detalhadas sobre a relação entre os resultados da Pesquisa O-D 1997 e a realização dos projetos de extensão das linhas de metrô, e também as operações urbanas definidas no Plano Diretor Estratégico Municipal de 2002, mas fugiria aos objetivos desta pesquisa detalhar estas metas. Enfatizamos a relação que o estudo fez entre a rede essencial e a concentração de empregos, que pode ser visualizada no mapa 5.

\section{Mapa 5 - Região Metropolitana de São Paulo \\ Densidade Populacional e de Empregos em 1997}

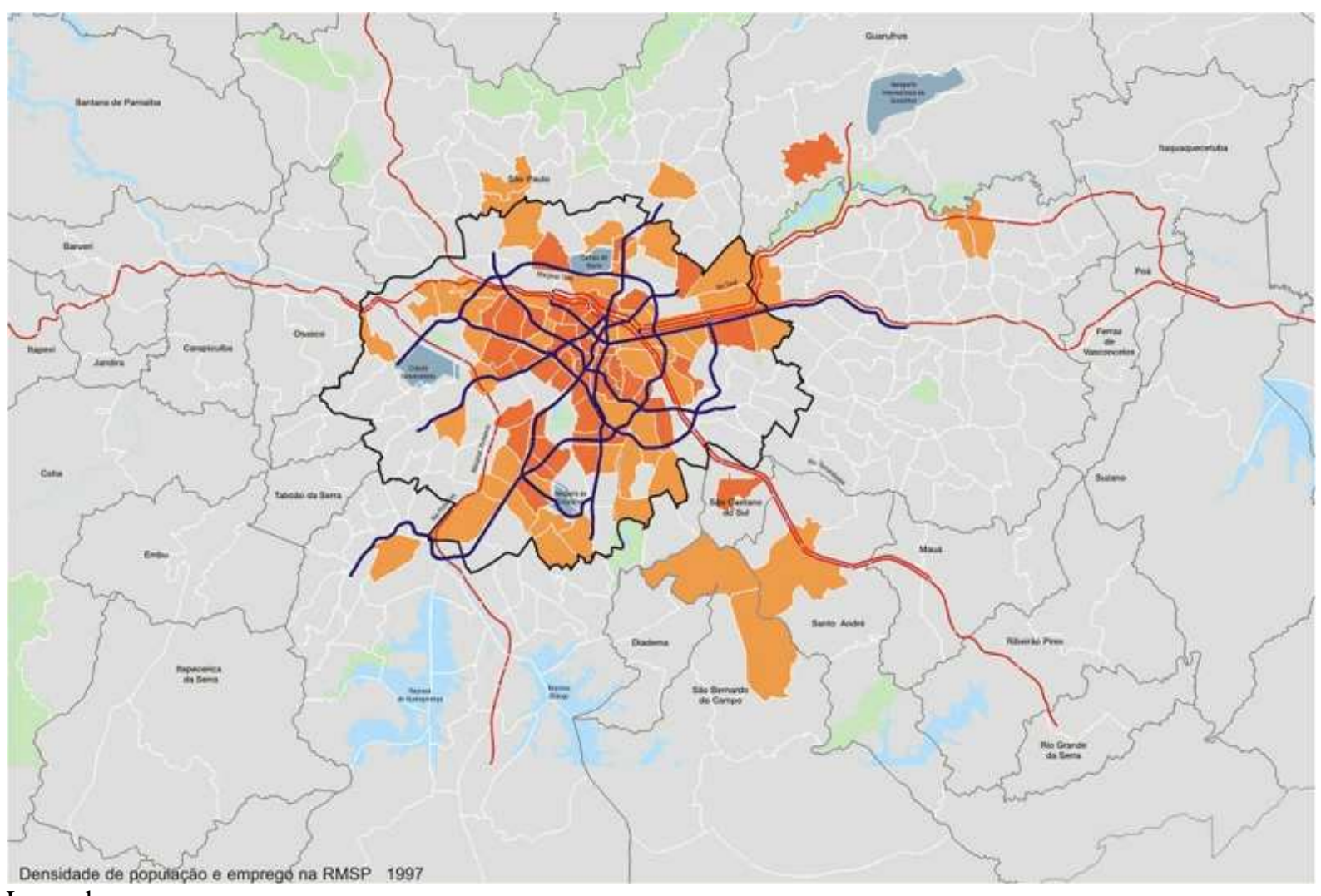

Legenda:

Acima de 75 empr/há e acima de 75 hab/há

Entre 50 e 75 empr/há e entre 50 e 75 hab/há

Abaixo de 50 empr/há e abaixo de 50 hab/há

Limite da área de expansão do Metrô na rede essencial 2025

Limite de municípios

Linhas de Metrô

Linhas da CPTM

http://www.metro.sp.gov.br/expansao/rede_essencial/rede essencial_06.shtml - 18.06.2008

Organização da autora. 
Passaremos, no próximo item, a analisar a estruturação da metrópole paulistana a partir da ampliação de seu sistema rodoviário, considerando as políticas de transporte deste setor e ao mesmo tempo avaliando o uso dos meios de transporte sobre pneus. 


\section{3 - No Modo Rodoviário}

O império do modo rodoviário como estruturador da metrópole paulistana no período estudado é incontestável. A paisagem da metrópole estrutura-se sobre ruas, avenidas, viadutos e túneis, em um conjunto de formas que moldam uma cidade veloz e a fazem funcionar em uma dinâmica de constantes sobressaltos em função de atrasos na espera pelos meios de transporte coletivo, de demora nos deslocamentos realizados sobre pneus, de mortes por acidentes no trânsito, de degradação da saúde física e mental causados pela poluição do ar e sonora e pelo estresse de passageiros em decorrência dos congestionamentos.

O aumento da mobilidade, acessibilidade e velocidade teoricamente proporcionado pelos meios de transporte sobre pneus, principalmente o automóvel, vem se esvaindo cotidianamente. A publicidade massiva impulsiona o consumo de automóveis e motocicletas, garantido pelo aumento do crédito que se verifica no período estudado.

O presente item apresentará, em breves notas, a estruturação da metrópole paulistana no decorrer do processo de crescimento do sistema viário. Entendemos que a estruturação da RMSP pautou-se, até determinado momento, sobre a ferrovia. A rede metroviária também participa da estruturação metropolitana, principalmente da Capital. Entretanto, a infraestrutura rodoviária, tanto no que se refere às vias, como também aos terminais de ônibus, praticamente fundamenta a estruturação do espaço metropolitano.

Langenbuch $^{337}$ ressalta que o desenvolvimento periférico que se verifica no domínio de estruturação urbana promovido pelo modo rodoviário em comparação àquele promovido pelo modo ferroviário é de pulverização da área edificada, ao passo que, no domínio da

\footnotetext{
${ }^{337}$ LANGENBUCH, 1971.
} 
ferrovia, havia polarização em torno da estação. O espraiamento da metrópole paulistana está, em grande parte, ligado à estruturação metropolitana sob o domínio rodoviário.

Procuramos destacar alguns momentos mais importantes do processo de estruturação metropolitana, notadamente a partir de 1950, quando a indústria fordista demandava soluções imediatas para a agilização do transporte de passageiros e de carga na RMSP. Porém, enfatizamos o período em exame nesta pesquisa, os tempos de reestruturação produtiva, nos quais a produção enxuta e o crescimento dos serviços impõem a circulação de mercadorias e pessoas no inebriante ritmo just in time. Nossa pesquisa diz respeito à estruturação da malha rodoviária e à formação da metrópole enquanto processos contínuos.

Tratamos ainda das políticas de expansão do sistema viário e das políticas de transporte coletivo sobre pneus que vêm acontecendo a partir da década de 1990. Cabe lembrar que o foco de nossas atenções se dá na interação das transformações do sistema de transportes terrestres e o processo de reestruturação da metrópole engendrados pela reestruturação da produção capitalista do espaço.

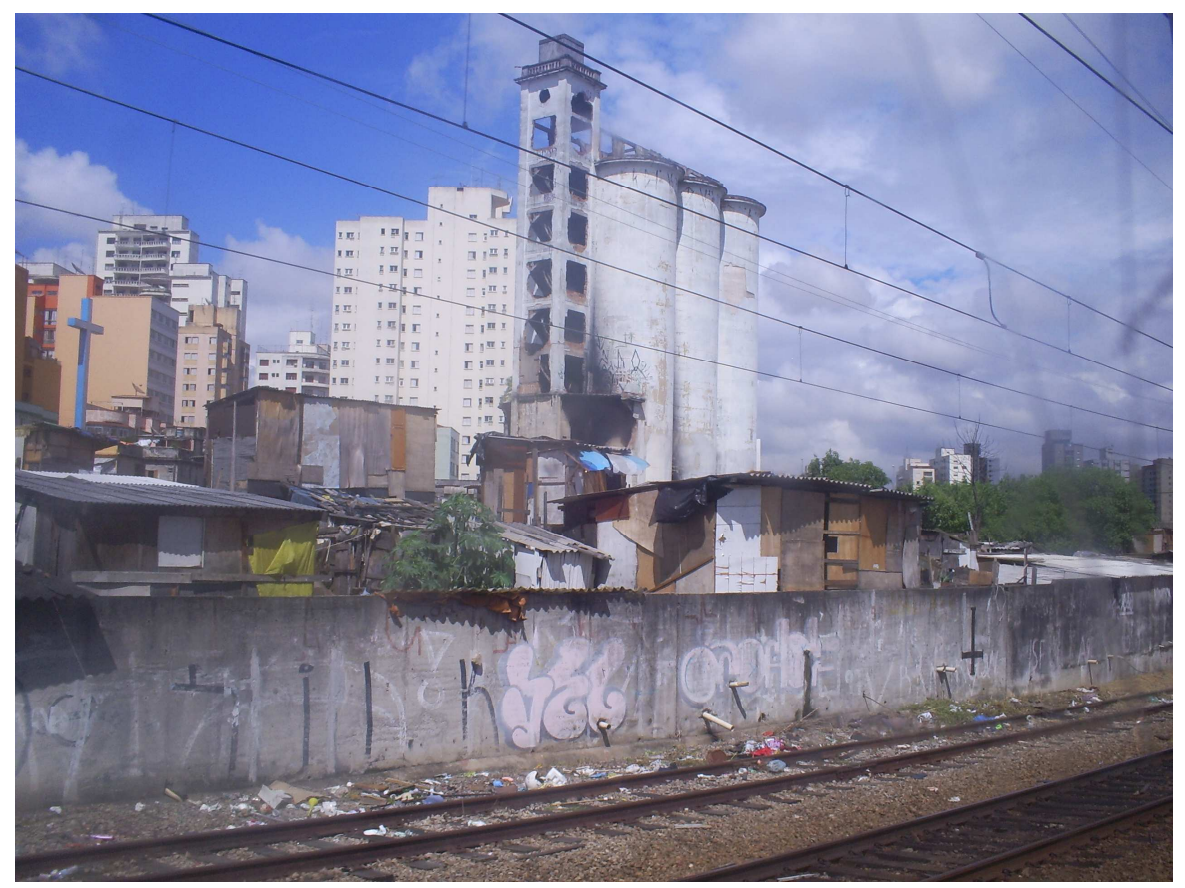

Autoria: Flávia Ulian

Fotografia 53 - Município de São Paulo - Antiga indústria abandonada, às margens de ferrovia. A indústria paulista dispôs-se às margens das ferrovias, notadamente na primeira metade do século XX. 05/03/08 


\subsection{1 - Breves Notas sobre o Papel da Infra-Estrutura Rodoviária na Estruturação da Metrópole Paulistana no Passado e no Presente}

Como uma via de mão dupla, as atividades econômicas que se instalaram em São Paulo induziram a configuração da rede de transportes rodoviária. Ao mesmo tempo em que se fez elemento indutor, a rede de transporte se estruturou produzida pelas atividades econômicas realizadas. Esta lógica persevera até os dias de hoje, mesmo com as mudanças ocorridas nas atividades econômicas existentes no início da estruturação da metrópole até os atuais tempos de reestruturação produtiva.

O papel da rede viária na metropolização paulistana foi fundamental. No que se refere à rede rodoviária, observa-se que, ao passo que eram construídas ruas dentro dos bairros, muitas vezes novos e distantes do centro, o papel de ligá-los à área compacta da cidade era feito pelos ônibus e bondes ${ }^{338}$.

O automóvel não participou, até os anos 1950, da expansão metropolitana. A suburbanização da população mais abastada não se verificou em São Paulo por vários fatores, entre eles pela impossibilidade de deslocamentos rodoviários diários, dada a má qualidade das $\operatorname{vias}^{339}$. A participação da rodovia teria se limitado aos ônibus. A circulação rodoviária funcionava predominantemente como meio de transporte complementar a ferrovia, com a criação de linhas de ônibus para as áreas residenciais (bairros ou vilas) mais afastados das estações ferroviárias $^{340}$.

As ligações por ônibus entre bairros e municípios tiveram um importante papel na estruturação metropolitana, já que os pontos de ônibus, diferentemente das estações

\footnotetext{
${ }^{338}$ LANGENBUCH, 1971

${ }^{339}$ Enquanto o subúrbio representa, nos Estados Unidos, reduto dos mais ricos, no Brasil significa dos mais carentes.

${ }^{340}$ Ibidem.
} 
ferroviárias, não se concentram em um único lugar, possibilitando a dispersão de estabelecimentos comerciais ao longo das ruas e avenidas por onde eles passam:

\begin{abstract}
Os pontos de parada são múltiplos. O equipamento comercial que surge tende a uma dispersão linear, ao longo do trecho da rua ou estrada que o ônibus percorre [...]. O ponto-final do ônibus constitui o maior pólo em potencial, pois a $\square$ us (sic) afluem os moradores de toda a porção mais afastada do subúrbio ${ }^{341}$, não alcançada pelo veículo. Uma certa concentração de comércio e serviços tende a se verificar ali; todavia, com o crescimento do subúrbio a linha de ônibus acaba por ser prolongada, surgindo semelhantes pólos mais para a frente, firmando-se assim a tendência à dispersão linear a que aludimos ${ }^{342}$.
\end{abstract}

Frisamos esta afirmação por acreditarmos ser de suma importância para entendermos os períodos posteriores da metropolização, quando a rede rodoviária e os meios de transporte rodoviários passaram a ser os estruturadores da metrópole, ou seja, participaram mais ativamente na estruturação da RMSP do que neste período inicial. No final do século XX, as transformações na metrópole foram induzidas em grande parte pela reestruturação da infraestrutura e dos meios de transporte rodoviários, engendradas pela reestruturação produtiva por que passa a economia brasileira neste período.

De 1940 a 1966, a população paulistana quase quadruplicou, exercendo enorme pressão sobre sua periferia. Houve também a compactação da área edificada, através da verticalização do centro e de vários bairros próximos.

Com o aumento da demanda pelos trens de subúrbio, o uso do ônibus tornou-se uma alternativa aos migrantes pendulares em seus deslocamentos. O ônibus também era usado pela classe média, ainda nesta fase não tão fidelizada ao automóvel, atraída a alguns municípios industrializados, como São Caetano do Sul e Santo André, por exemplo.

A intensificação do uso do automóvel requereu uma série de medidas de caráter técnico, como as propostas de

implantação de estacionamentos de curta duração nas vias (o atual sistema denominado 'zona azul'), o controle geral do problema de estacionamento e da

\footnotetext{
${ }^{341} \mathrm{O}$ conceito de subúrbio é utilizado por Langenbuch (ibidem) no sentido que conhecemos hoje por periferia.

${ }^{342}$ LANGENBUCH, 1971, p.159.
} 
carga/descarga, a sincronização dos semáforos, a construção de um 'anel periférico' (precursor da idéia do anel viário da década de 60), e a construção de passagens de nível nos cruzamentos principais ${ }^{343}$.

No final da década de 50, o sistema viário principal do município “já estava composto por dezenas de vias de grande porte, caracterizando o início de uma estrutura básica que se consolidaria a partir da década seguinte" ${ }^{344}$. De acordo com Scarlato ${ }^{345}$, o grande indicador do crescimento de São Paulo é o aumento da área de seu espaço urbano que, de $130 \mathrm{~km}^{2} \mathrm{em}$ 1940, passou para $420 \mathrm{~km}^{2}$ em 1954. Daí até os dias de hoje, a extensão desse espaço passou para um tamanho maior que o triplo de seu original. No ano de 1954, comemorou-se o quarto centenário da cidade. Neste período, ocorreria forte industrialização da região. Os limites da "urbanização passaram a integrar-se com os municípios vizinhos através de um complexo

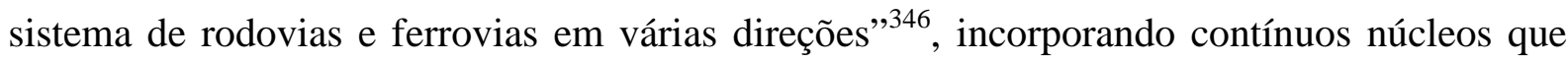
cresciam isoladamente, como os de Pinheiros, Lapa e Penha, cuja integração fortaleceu o plano viário radial concêntrico de expansão da cidade de São Paulo.

Em 1954, São Paulo concentrava 35,4\% dos investimentos do Brasil, crescendo para 62,2\% em 1958. Com o desenvolvimento industrial, nascia a metrópole econômica brasileira $^{347}$. Os transportes terrestres, sobretudo a partir da Segunda Guerra Mundial, beneficiaram São Paulo. Os investimentos em estradas reforçaram, assim, a posição de São Paulo como centro produtor e a implantação da indústria automobilística e de muitas outras indústrias de base abasteceria a demanda do vasto território nacional. Santos \& Silveira ${ }^{348}$ chamam este novo processo territorial de formação de uma região concentrada, um pólo, o fato paulista, "único em todo o mundo subdesenvolvido com a contigüidade entre a metrópole

\footnotetext{
${ }^{343}$ VASCONCELLOS, 1999, p.72.

${ }^{344}$ Ibidem, p. 151.

345 SCARLATO, 1998.

${ }^{346}$ Ibidem, p.444.

${ }^{347}$ SANTOS \& SILVEIRA, 2006, p.43.

${ }^{348}$ Ibidem.
} 
econômica e a área agrícola mais tecnificada e dinâmica, [que] ainda mais facilita o desenvolvimento do conjunto e aumenta ainda mais a força da cidade de São Paulo"349.

Até meados do século XX, as indústrias tradicionais locais existentes no Brasil eram restritas a pequenas regiões, pois não havia grandes facilidades de transporte, com a ausência de integração das ferrovias e a deterioração da navegação costeira. Além disso, o mercado regional era complementado por bens provenientes do exterior. Em contrapartida, a explosão da industrialização no eixo Rio-São Paulo, na segunda metade da década de 1950, rompeu com essa situação tradicional ${ }^{350}$.

Grande papel na metropolização dos arredores paulistanos desempenharam as rodovias. As primeiras a serem implantadas foram a Anchieta, a Anhangüera e a Dutra. Depois, a Raposo Tavares, a Fernão Dias e a Régis Bittencourt. Após melhoramentos, muitos estabelecimentos industriais foram atraídos para as margens das rodovias, como ocorreu ao longo da Via Raposo Tavares, no distrito de Cotia. Porém eram fábricas menores do que aquelas instaladas às margens da Via Anchieta e Via Dutra. Na rodovia Fernão Dias, a instalação de indústrias se daria entre os anos 1960 e 1970, quando o parque industrial paulistano começou a abandonar os tradicionais eixos de circulação e buscou outras áreas na BR-116, Raposo Tavares e Fernão Dias ${ }^{351}$.

A compreensão da configuração territorial e da circulação na RMSP perpassa por compreendermos que as rodovias passaram a desempenhar um fator locacional para as indústrias que, até 1940, tinha sido desempenhado pelas ferrovias. Havia espaços amplos e disponíveis para a instalação dos estabelecimentos industriais de grande porte às suas margens. No entanto, somente este fato não seria suficiente para explicar a transformação da configuração territorial da metrópole nos eixos rodoviários, já que ainda havia espaços

\footnotetext{
${ }^{349}$ SANTOS \& SILVEIRA, 2006, p.46.

${ }^{350}$ BARAT, 1978.

${ }^{351}$ LEMOS, 1972.
} 
disponíveis para as indústrias em determinados trechos ao longo das ferrovias, como na Lapa (Santos-Jundiaí), além de Engenheiro Goulart (Variante da Central do Brasil, atual linha F), providos de núcleos “dormitórios" que poderiam fornecer mão-de-obra ${ }^{352}$.

Langenbuch $^{353}$ pensa que, no Brasil, as ferrovias desempenham papel diferente das ferrovias em escala mundial, quer dizer, no Brasil, e mesmo no Estado de São Paulo, as ferrovias não lotavam seus vagões de carga a ser transportada para longas distâncias. Mesmo em localidades onde a ferrovia teria condições técnicas e funcionais para vencer a concorrência com o caminhão, perdiam fretes em favor do transporte rodoviário, pois muitos estabelecimentos industriais contíguos às linhas de trem não possuíam desvios ferroviários. As indústrias já encontravam condições satisfatórias de transporte junto às rodovias, que além de colocá-las em fácil comunicação com a metrópole também assegurava as relações extrametropolitanas. Mesmo se fosse necessária a utilização de uma estrada secundária, isso não diminuiria as boas condições de acessibilidade proporcionadas pelo transporte sobre pneus $^{354}$. Havia ainda, nas palavras do autor, o "fator psicológico", ligado ao que hoje chamamos de "marketing". A propaganda da localização, às margens ou na proximidade das rodovias, "pode constituir um elemento positivo junto ao mercado consumidor e creditício" ${ }^{355}$, traduzindo a "pujança da empresa, em local onde será visto por todos",356, o que se tornava um fator atraente para as empresas.

Barat $^{357}$ considera que, do ponto de vista dos transportes, o pós-guerra foi marcado pela deterioração física e obsoletismo das infra-estruturas ferroviária e portuária, além do forte declínio da navegação de cabotagem. Em função disso, o Governo Federal realizou o encampamento destas modalidades de transporte, procurando prover os recursos necessários à

\footnotetext{
${ }^{352}$ LANGENBUCH, 1971.

${ }^{353}$ Ibidem.

${ }^{354}$ Ibidem.

${ }^{355}$ Ibidem.

${ }^{356}$ Ibidem.

${ }^{357}$ BARAT, 1991.
} 
sua modernização e reequipamento. Contudo, é clara a prioridade dada à construção e pavimentação das estradas de rodagem troncais como forma de suplementar a capacidade ferroviária. Quanto ao tráfego ferroviário, a rentabilidade média sofreu rápido declínio a partir de 1945, último ano em que o conjunto das ferrovias brasileiras, ainda sob a jurisdição do Estado brasileiro, apresentou uma relação receita/despesa positiva. Na realidade, a concorrência com o transporte rodoviário acirrava-se neste período, conforme mostra a explicação dada por Langenbuch ${ }^{358}$ no parágrafo anterior. A incapacidade das ferrovias em atender às novas correntes de tráfego, que exigiam maior rapidez e regularidade no manuseio, estocagem e transporte, contrapôs-se ao dinamismo do transporte rodoviário ${ }^{359}$.

Meyer et alli $^{360}$ ressaltam que as rodovias inauguradas nos anos 40 e 50 na cidade de São Paulo encontraram-se com a malha viária urbana e geraram conflito de tráfego, pois aumentou o fluxo de veículos, evidenciando as carências na articulação dos dois sistemas. Os autores completam, afirmando que "Essa desarticulação se somou às novas questões introduzidas pelo rompimento da relação moradia/trabalho na cidade e na metrópole, com a

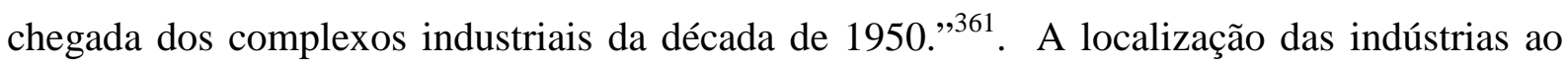
longo das rodovias acarretou grandes transformações na estrutura metropolitana.

A partir dos anos 1960, o sistema viário metropolitano principal foi ampliado e ganhou uma "estrutura com nível crescente de integração, abrangendo toda a região central da ‘mancha urbana' de São Paulo"362, ampliando, assim, a capacidade de escoamento do tráfego.

Nesta fase, igualmente se observa a intensificação das relações entre os municípios vizinhos e alguns bairros periféricos de São Paulo que se estruturaram como sub-centros e não eram atingidos pela ferrovia, como a ligação entre o bairro de Pinheiros, na Capital, e o

\footnotetext{
${ }^{358}$ LANGENBUCH, 1971.

${ }^{359}$ BARAT, 1991.

${ }^{360}$ MEYER et alli, 2004.

361 Ibidem, p.74.

${ }^{362}$ VASCONCELLOS, 1999, p. 152.
} 
município de Taboão da Serra. Intensificaram-se as ligações rodoviárias e os percursos a pé $^{363}$.

Os deslocamentos internos nos maiores municípios, mesmo sendo possível sua realização por trem, passaram a ser feitos por ônibus nesta fase, dada a pequena distância, bem como a grande freqüência destes meios de transporte, sobretudo em São Caetano do Sul, Santo André e Osasco. Mais um exemplo da influência da rede rodoviária na estruturação da metrópole neste período é a ligação São Paulo-Guarulhos. Langenbuch ${ }^{364}$ relata que "já na década de 1940 a ferrovia [então estrada da Cantareira] perdia sua importância” por ter traçado sinuoso e, portanto, moroso, o que provocou rapidamente a opção pelo transporte rodoviário através da avenida Guarulhos. O crescimento industrial de Guarulhos também se deveu muito mais à inauguração da rodovia Presidente Dutra, na década de 1950, do que correlacionado à antiga ferrovia.

A metrópole cresceu também a partir do loteamento de áreas situadas

fora dos principais eixos de circulação rodoviária, junto a estradas secundárias,
ainda não servidas por onibus. Os primeiros moradores, quase sempre pessoas
humildes, fazem papel de pioneiros. Por muito tempo deslocam-se a pé à estrada
transitada por ônibus. Estes apenas são estendidos ao lugar depois de já contar com
povoamento razoável, assegurando rentabilidade à linha ${ }^{365}$.

Um exemplo deste fenômeno foi dado pelo sub-secretário da Secretaria Municipal de Transportes e Trânsito de Taboão da Serra, Sr. Claudinei Pereira, em entrevista realizada conosco em 31.01.2008. Ele relatou que, em Taboão da Serra, chegaram muitos migrantes que não tinham condições de arcar com o preço da terra na Capital e então desbravavam terrenos nos arredores. A primeira coisa que faziam era abrir um poço, já que não havia nenhum equipamento nem infra-estrutura de água e esgoto. No caso de Taboão, ocuparam as áreas mais elevadas e, para pegar uma condução para ir ao trabalho, na Capital, desciam o

\footnotetext{
${ }^{363}$ SÃO PAULO, s.d.

${ }^{364}$ LANGENBUCH, 1971, p.193.

${ }^{365}$ Ibidem, p. 201.
} 
morro andando e sujavam os calçados nas ruas de terra. Grupos organizaram-se e reivindicaram o asfalto. A impermeabilização do solo acarretou enchentes, que são, até hoje, um grande problema neste município.

A paisagem é marcada profundamente sobre a estrutura rodoviária em todo o território metropolitano. $\mathrm{O}$ fator indutor da ocupação urbana no eixo da rodovia Castelo Branco nos anos 1970 foi o assentamento residencial das classes média-alta e alta. Meyer et alli ${ }^{366}$ observam que, com isso, a metrópole iniciou um novo ciclo de deslocamento e desconcentração de funções que, até então, localizavam-se no município de São Paulo. Nos anos 1980, este fenômeno ocorreria ao longo do complexo formado pelas rodovias Presidente Dutra e dos Trabalhadores.

O trânsito foi transformado em uma verdadeira "questão" na década de 1960, quando o aumento significativo da frota de veículos alterou "radicalmente as condições gerais de circulação, aumentando muito o número de acidentes de trânsito e transformando os congestionamentos em fatos diários, afetando principalmente a área central e o seu entorno.”367 Nesta década, o Departamento de Serviços de Trânsito (DST), órgão estadual encarregado do trânsito, envolveu-se em denúncias graves de corrupção no registro de veículos e habilitação de motoristas. Também ocorreu nesta mesma década o II Congresso de Trânsito da Cidade de São Paulo (o primeiro ocorreu no final da década de 1940). Houve grandes discussões sobre os problemas de circulação urbana da Capital. Em 1966 foi editado o novo Código Nacional de Trânsito. Um dado curioso sobre este período é sobre o tratamento dado aos veículos estacionados em locais proibidos: os pneus eram esvaziados ${ }^{368}$.

Até 1973, o trânsito era gerenciado pela Secretaria Estadual de Segurança Pública e seu Departamento de Trânsito, porém, a partir deste ano o controle do tráfego urbano foi

\footnotetext{
${ }^{366}$ MEYER et alli, 2004.

${ }^{367}$ VASCONCELLOS, 1999, p.77.

${ }^{368}$ Ibidem.
} 
municipalizado. Por meio de convênios, o Estado passou ao Município as atribuições de planejamento, operação e fiscalização do trânsito, incluindo a otimização da infra-estrutura viária $^{369}$.

A crise internacional do petróleo de 1973 repercutiu negativamente sobre a ampliação do sistema viário que era levada em curso, prejudicando os planos de construção de um anel rodoviário e de vias expressas. Matérias em defesa do transporte público passaram a ser veiculadas enfaticamente, ao mesmo tempo em que foram criadas instituições voltadas para o transporte coletivo: a Empresa Brasileira de Transportes Urbanos (EBTU), a EMTU e a Associação Nacional de Transportes Públicos (ANTP), entidade civil de âmbito nacional ${ }^{370}$. O transporte coletivo foi incentivado nas várias esferas do governo brasileiro, incentivo este contraditório com a crescente produção de automóveis e sua entrada no cotidiano das cidades do país ${ }^{371}$.

Em 1976, foi criada a Companhia de Engenharia de Tráfego (CET). Agência de economia mista ligada ao Departamento do Sistema Viário (DSV), sua função seria dar apoio à Secretaria Municipal dos Transportes (SMT) do município de São Paulo. Na época, emergiu a discussão sobre a privatização-estatização dos problemas de trânsito da cidade. Vasconcellos ${ }^{372}$ explica que a CET deu continuidade e expandiu “a intervenção técnica iniciada em 1973, seguindo os moldes tradicionais da engenharia de tráfego, através da modernização da sinalização, implantação de novos e extensos planos de circulação, alterações geométricas e coordenação de semáforos" visando a aumentar a velocidade média do tráfego ${ }^{373}$.

\footnotetext{
${ }^{369}$ MELLO, 2000.

${ }^{370}$ VASCONCELLOS, 1999.

${ }^{371}$ MELLO, 2000.

${ }^{372}$ VASCONCELLOS, op. cit. pp. 16-17.

${ }^{373}$ Ibidem, p. 17.
} 
Tendo analisado as intervenções no sistema viário e os planos de transporte e trânsito da Capital no período de 1960 a 1980, bem como as Pesquisas O-D do período, Vasconcellos ${ }^{374}$ acredita

que o impacto da política de circulação na macroacessibilidade foi positivo, no sentido de viabilizar o aumento de $120 \%$ verificado nas viagens internas à área de estudo. Este efeito pode ser creditado ao aumento da capacidade viária do sistema principal, da ordem de $200 \%$, auxiliado pelo aumento (impossível de calcular) da capacidade do sistema viário secundário propiciado por centenas de projetos de pavimentação e de pequenas alterações geométricas e de circulação. Paralelamente, as barreiras naturais, como os rios e as estradas de ferro, foram transpostas por um grande número de novas estruturas, tendo-se caracterizado a interligação generalizada de um sistema viário antes descontínuo, transformando capacidades potenciais em capacidades reais e ampliando as possibilidades de deslocamento no espaço.

O autor ${ }^{375}$ observa, porém, que este impacto positivo não foi sentido equiitativamente por toda a população do município, já que o acesso aos meios de transporte é diferenciado socialmente. Ampliaremos esta discussão a seguir.

\section{A Ampliação do Sistema Viário e a Supremacia do Automóvel}

A intensificação do uso do transporte sobre pneus cresceu a partir do período técnicocientífico. Com a aceleração da industrialização do país, na década de 1950, indústrias automobilísticas estrangeiras se interessaram em se instalarem aqui: a Mercedes Benz assumiu o compromisso de fabricar veículos comerciais e a Volkswagen começou a montar seus carros em São Paulo. “Assim sendo, em 1952, começou a haver uma limitação da concessão de licenças de importação para peças automotivas já produzidas no Brasil, pois já havia 350 fabricantes de autopeças." 376

\footnotetext{
${ }^{374}$ VASCONCELLOS, 1999, p. 191, grifo do autor.

${ }^{375}$ Ibidem.

${ }^{376}$ ULIAN, 1999, pp.21-22.
} 
Com a criação da Petrobrás (Petróleo Brasileiro S/A) e da COSIPA (Companhia Siderúrgica Paulista) em 1953, vetou-se a importação de veículos completos e montados. Este protecionismo viria incentivar a produção de veículos no país.

De acordo com Langenbuch ${ }^{377}$, ao final da década de 1960 o crescimento do número de automóveis superou o crescimento demográfico em São Paulo e seu entorno ${ }^{378}$. Em 1940, havia na região 23.902 automóveis (66,9 habitantes por auto); em 1960, 133.686 automóveis (36,5 habitantes por auto) e em 1965, 340.416 (19,2 habitantes por auto). Hoje são 2,4 habitantes por automóvel ${ }^{379}$.

Em 1967, 31,90\% das viagens eram realizadas diariamente de modo individual ${ }^{380}$ na RMSP. Em 1977, as viagens em modo individual totalizavam 39\% das viagens. Já em 1987, 44,24\%, e em 1997, 49,21\% das viagens foram realizadas em modo individual. A Aferição da Pesquisa O-D 1997, realizada em 2002, mostrou que este índice vem aumentando, com 12.958.000 viagens por modo individual, num total de 24.466 .000 viagens motorizadas, equivalendo a $52,96 \%$ destas viagens naquele ano ${ }^{381}$.

De acordo com Santos ${ }^{382}$,

A tendência à ascensão do transporte individual nos países subdesenvolvidos é mais forte em certas aglomerações que em outras, mas sempre se dá acompanhada da degradação da qualidade do transporte público. No caso de São Paulo, e limitandose ao período do "milagre econômico", enquanto a demanda por transporte em

\footnotetext{
${ }^{377}$ LANGENBUCH, 1971.

378 Arujá, Cotia, Itapevi, Guarulhos, Itapecerica da Serra, Embu, Taboão da Serra, Jundiaí, (em 1940 incluindo Vinhedo), Mairiporã, Caieiras, Franco da Rocha, Mogi das Cruzes, Ferraz de Vasconcelos, Poá, Suzano, Itaquaquecetuba, Santana do Parnaíba, Barueri, Cajamar, Santo André, São Caetano do Sul, São Bernardo do Campo, Diadema, Mauá, Ribeirão Pires, São Paulo, Osasco.

${ }^{379}$ No ano de 1967, havia 493.000 veículos licenciados na RMSP, número que passou para 1.384 .000 em 1977 , 2.014.000 em 1987, 3.092.000 em 1997 e 3.378.000 em 2002. A taxa de motorização, ou seja, o número de automóveis particulares por 1.000 habitantes passou de 70, em 1967, para 184 em 2002, significando mais do que o dobro em 35 anos. Em 1997, as sub-regiões com taxas de motorização acima da média da RMSP foram: Sudeste, composta pelos municípios de Santo André, São Bernardo do Campo, São Caetano do Sul, Diadema, Mauá, Ribeirão Pires e Rio Grande da Serra, e Centro, que constitui o município de São Paulo, com respectivamente 212 e 197 automóveis para cada 1.000 habitantes (CIA. DO METROPOLITANO DE SÃO PAULO, op. cit.).

${ }^{380} \mathrm{O}$ modo individual é representado pelo motorista de automóvel, passageiro de automóvel, táxi, caminhão, moto, bicicleta e outros (ibidem).

${ }^{381}$ CIA. DO METROPOLITANO DE SÃO PAULO, 2002.

${ }^{382}$ SANTOS, 1990, p.81.
} 
ônibus cresce $75 \%$ entre 1968 e 1974, o número desses veículos aumenta apenas $12 \%[\ldots]$.

A partir da década de 1970, houve forte desenvolvimento industrial fordista e crescimento populacional e da mancha urbana da metrópole paulistana. As avenidas 23 de Maio, Rebouças, Consolação, Brigadeiro Luís Antônio e Pacaembu, que são radiais perpendiculares à avenida Paulista, se constituíram em importantes eixos de comunicação deste novo centro com o velho centro e com as vias perimetrais das marginais dos rios Pinheiros e Tietê $\hat{~}^{383}$. Para o autor,

a construção de grandes avenidas perimetrais e radiais cortando a cidade em várias direções associou-se à criação de várias auto-estradas ligando a região metropolitana às várias regiões do Estado de São Paulo e transformou antigas avenidas que cortavam os bairros aristocráticos da zona sul da cidade em verdadeiros corredores de circulação ${ }^{384}$.

O autor acrescenta que estes bairros foram "invadidos" pelo automóvel, ocorrendo uma pressão sobre o território e gerando barulho e desconforto ambiental para os moradores.

Para Scarlato ${ }^{385}$, a indústria automobilística induziu importantes transformações no espaço geográfico paulistano. O automóvel modelou as cidades no século XX, reformulando a noção de espaço e distância e modificando os hábitos humanos. Em São Paulo, determinou a necessidade de uma rápida adaptação da cidade aos automóveis, o que redimensionou o espaço físico e social da cidade.

Quanto mais aumenta a quantidade de automóveis particulares, maior a necessidade de modificações no sistema viário. A maior parte das obras realizadas por diversas gestões das várias Prefeituras dos municípios da RMSP foi voltada para o transporte individual. As novas vias geraram novos deslocamentos e pioraram o tráfego a médio prazo. As obras voltadas para o transporte coletivo, por outro lado, geraram mais conforto para uma parcela maior da

\footnotetext{
${ }^{383}$ SCARLATO, 1998.

${ }^{384}$ Ibidem, p.447.

${ }^{385}$ Idem, 1981.
} 
população, já que os próprios motoristas de veículos particulares sentiram maior tranqüilidade nos deslocamentos quando havia menos carros nas ruas.

A principal característica da atual constituição do espaço metropolitano é a dissociação entre os processos de expansão urbana e a oferta de transporte público, conforme podemos entender através da explicação de Meyer et alli ${ }^{386}$ : “A extensão do território metropolitano, a baixa densidade e a estrutura radioconcêntrica, elementos organizadores do espaço físico da metrópole, geraram um espaço urbano pouco favorável a intervenções que visassem à racionalização viária." Soma-se a isso a questão da ênfase ao sistema de transporte de massa sobre pneus, em detrimento de um sistema sobre trilhos, que criou uma excessiva dependência da disponibilidade de vias, gerando conflitos na circulação no espaço metropolitano ${ }^{387}$.

Grandes vias de circulação rodoviária foram construídas nos fundos de vale, que foram terraceados e retificados, tornando as vias próximas aos rios propícias a alagamentos, intensificados com a impermeabilização das ruas e avenidas. As obras sempre procuravam unir a questão do tráfego com o saneamento, canalização de córregos e rios para resolver os problemas das inundações. A opção por construir vias de fundo de vale ${ }^{388}$ devia-se ao fato de serem aquelas que receberiam recursos federais em virtude do saneamento. O município de São Paulo, ao receber muitas intervenções para prover a cidade de circulação para a “arrancada modernizadora", teve sua urbanização acelerada ${ }^{389}$. Nas palavras da autora, foi promovida uma "política de macrodrenagem urbana, associada a uma política viária completamente desconectada de uma política de transporte público, porém fortemente conectada ao transporte individual”390. A população usuária de automóveis recebeu bem esta

\footnotetext{
${ }^{386}$ MEYER et alli, 2004, p.79.

${ }^{387}$ Ibidem.

${ }^{388}$ Marginais dos rios Pinheiros e Tietê, que se situam em um contexto de maior amplitude; outras avenidas de fundo de vale: Aricanduva, Eliseu de Almeida, do Estado, Inajar de Souza, Inácio de Anhaia Mello, Águas Espraiadas, Jaguaré, entre outras.

${ }^{389}$ MELLO, 2000.

${ }^{390}$ Ibidem, p.89.
} 
"política viária" de construção de vias de fundo de vale, que veio junto com a desfavelização de áreas junto a cursos d'água. Esta política de suprimir as várzeas desconsiderou "o que poderiam representar para a melhor qualidade do espaço urbano: áreas de não impermeabilização do solo, de redução das ilhas de calor, abertura para paisagens vegetadas, para espaços de lazer e práticas esportivas da população.”391 392.

As soluções para os problemas de circulação urbana parecem ser sempre a ampliação das vias para melhorar o trânsito, não havendo articulação com propostas consistentes de transporte coletivo: “As intervenções realizadas e novas vias abertas não contemplaram, nem conceitualmente nem praticamente, o transporte coletivo, que se fez presente apenas nas justificativas, nos discursos, quando muito." ${ }^{, 393}$. Verifica-se que, tão logo as obras são inauguradas, os veículos passam a utilizá-la e rapidamente a fluidez ali diminui, pois há uma saturação das novas vias. O ônibus não se beneficia igualmente dessa ampliação das vias porque se subordina ao automóvel, que tem mais mobilidade ${ }^{394}$.

Além disso, a autora aponta também a ineficiência dessas vias para o tráfego dos pedestres, já que muitas delas possuem faixas largas e insegurança nas travessias, com falta de semáforos e de passarelas. Acrescentamos a isso o tempo exíguo para a travessia nos semáforos de pedestres.

Outra questão apontada pela autora refere-se à qualidade de vida no que diz respeito a ruídos, fumaça e insegurança em áreas residenciais e indução à ocupação desordenada, bem

\footnotetext{
${ }^{391}$ MELLO, 2000, p.90.

$392 \mathrm{Na}$ atualidade, espaços adjacentes a "inúmeras avenidas de fundo de vale reúnem em pontos específicos condições propícias para a implantação de equipamentos urbanos de grande porte" (MEYER et alli, 2004, p.212), como shopping centers. As avenidas Aricanduva, Jacu-Pêssego/Nova Trabalhadores, Escola Politécnica são exemplos desse processo, onde se verifica a ocupação por população de baixa renda, promovendo mudanças no uso do solo e criando "formas embrionárias de novas centralidades, ancoradas em funções comerciais." (MEYER et alli, 2004, p.212, grifo dos autores). Até os anos 1990, grandes empreendimentos comerciais não existiam afastados do centro. Os autores observam, porém, que esta ocupação deve vir acompanhada de um aumento significativo de oferta habitacional para a população de renda média e baixa para evitar que se reforcem os processos de exclusão social.

393 Ibidem, p.92.

394 Ibidem.
} 
como à preservação da memória urbana. $\mathrm{O}$ alargamento de vias, construção de pontes e viadutos e outras intervenções no sistema viário, ao aumentar a capacidade das vias, aumentam também os fluxos e os fixos na paisagem.

Em tempos de reestruturação produtiva, grandes modificações foram sentidas com relação ao uso do transporte sobre pneus. Como um resultado das políticas de transporte de décadas anteriores, nos anos 1990 acirrava-se a concorrência transporte público versus transporte individual. Rosa ${ }^{395}$ explica o círculo vicioso da degradação do transporte urbano conforme análise da União Internacional de Transporte Público (UITP): a exigência de mais deslocamentos é induzida pelo crescimento desordenado da metrópole, contribuindo para deteriorar o transporte coletivo, aumentando a pressão por mais infra-estrutura e para o espraiamento da cidade. Aos que têm acesso, suprem suas necessidades de deslocamento, com o uso do automóvel, "o que aumenta a dependência por este modo e contribui para a inviabilidade do transporte público, segregando espacialmente os pobres e realimentando o círculo vicioso." ${ }^{396}$.

O estado crítico em que se encontra o trânsito na RMSP, os constantes congestionamentos enfrentados por todos que se deslocam pela metrópole devem-se não só à sua grande população e às imensas distâncias a serem percorridas, mas também ao uso do automóvel particular como opção em metade das viagens motorizadas realizadas para vencer as distâncias metropolitanas.

Vasconcellos $^{397}$ explica que o Estado fez um esforço significativo na ampliação do sistema viário principal, realizando altos investimentos nesta área a fim de ampliar a capacidade do sistema e integrar regiões desprovidas de ligações com as áreas centrais. No que se refere à ampliação do sistema viário, no período em estudo, seu detalhamento

\footnotetext{
${ }^{395}$ ROSA, 2006.

${ }^{396}$ Ibidem, p.32.

${ }^{397}$ VASCONCELLOS, 1999.
} 
extrapola nossos objetivos. Contudo, cabe destacar, neste item, algumas obras que consideramos aliadas à ampliação do sistema viário e convidativas ao maior uso do automóvel.

Neste contexto, pontuamos obras que, iniciadas bem antes de nosso período de análise, só foram concluídas durante ele, como a construção do Mini-Anel Viário, originado de propostas de modificação do traçado do Pequeno Anel Rodoviário, com vistas a minimizar custos, sendo seu traçado inteiramente interno ao território da Capital ${ }^{398}$. Seu objetivo era interligar as rodovias, utilizando-se das vias marginais dos rios Tietê e Pinheiros e de vias de fundo de vale. O percurso do Mini-Anel incorporou o traçado de algumas dessas obras sanitárias/viárias. Até o final da década de 1970, parte do traçado já era existente, como as avenidas marginais, a avenida dos Bandeirantes e a avenida Juntas Provisórias. Para a efetivação do Mini-Anel faltavam interligações e havia pontos críticos até mesmo onde elas existiam. Estas obras foram se desenrolando durante pelo menos duas décadas: o "cebolão", entroncamento das avenidas marginais dos rios Tietê e Pinheiros, com obras iniciadas em 1976; o viaduto sobre o rio Pinheiros próximo à Usina da Traição, atual Ponte Engenheiro Ary Torres; a canalização de córregos e construção de vias; a ligação entre a rodovia dos Imigrantes e a avenida Tancredo Neves; e a interligação das avenidas Prof. Anhaia Melo e Salim Farah Maluf, entregue ao tráfego parcialmente executada em setembro de 1990 e inaugurada em 1994 com o nome de Complexo Viário Maria Maluf. Os viadutos que faltavam foram inaugurados somente em 1995 e 1996. A inauguração de todo o conjunto foi feita em setembro de 1996 com o nome de Complexo Viário Escola de Engenharia Mackenzie, após a construção de um complexo de viadutos, passagem subterrânea e passarelas para pedestres. Finalmente concluiu-se o Mini-Anel Viário (em vinte anos). Mello ${ }^{399}$ explica que, desde a concepção do projeto, no Primeiro Seminário de Trânsito de São Paulo, em 1949, quando a

\footnotetext{
${ }^{398}$ MELLO, 2000.

${ }^{399}$ Ibidem.
} 
cidade tinha uma frota de 106 mil veículos, até a conclusão do Mini-Anel, em 1996, quando a frota era de mais de 4,4 milhões de veículos, o projeto já estaria “completamente ultrapassado, totalmente interno à malha urbana, com bastante lentidão de tráfego e 35 semáforos em seu percurso. $" 400$.

\section{Figura 4 - Município de São Paulo \\ Mini-Anel Viário Metropolitano}

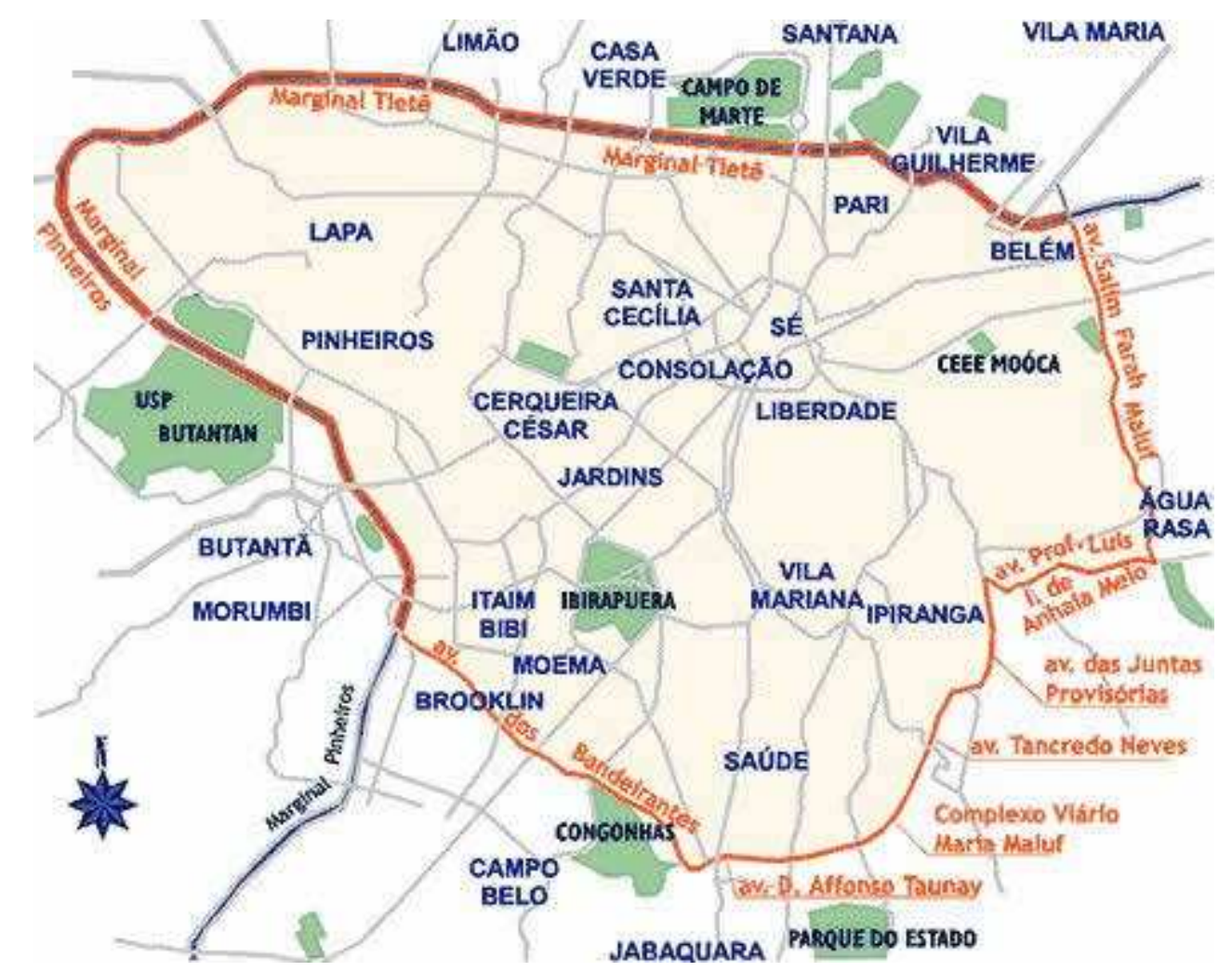

http://www.cetsp.com.br/internew/informativo/pico/reesinte.gif - 22.06.2008

O mesmo caso aconteceu com a construção do Segundo Anel Viário, o Anel Viário Metropolitano, concebido a partir do Pequeno Anel Viário ou Anel Rodoviário pelo governo do Estado, idealizado na década de 1970, cujo primeiro trecho começou a ser construído em 1986. Em dezembro de 1992, seis anos depois, portanto, do início da construção do primeiro 
trecho, nem sequer o pedaço dentro do município de São Paulo estava concluído, isso porque grande parte do percurso já existia. Em 1995, conseguiu-se concluir 50\% dos trabalhos do Anel Viário Metropolitano com a inauguração da duplicação do trecho da avenida Dr. Assis Ribeiro, ligando São Paulo a Guarulhos na altura do Parque Ecológico do Tietê sobre a Rodovia Ayrton Senna. Em 1996, houve a inauguração da avenida Nova Trabalhadores e canalização do córrego Jacu e a construção de "4,5 km de extensão das adaptações necessárias ao Corredor de ônibus Diadema-Brooklin" ${ }^{401}$. Neste ano, a inauguração do primeiro trecho deste complexo viário possibilitou uma importante conexão intermunicipal, ligando a região do ABC Paulista a Guarulhos, além de ter sido proporcionada uma nova alternativa de circulação entre os bairros do extremo leste, como a Vila Jacu, São Miguel, Itaquera, José Bonifácio, Parque do Carmo e São Mateus. Entre idas e vindas, as obras de construção da avenida Jacu-Pêssego tiveram início há pelo menos vinte anos, tendo sido retomadas na gestão da Prefeitura de São Paulo 2005-2008, em convênio com o governo do Estado. A obra em tela foi inaugurada no final de 2007 , uma extensão de $2,1 \mathrm{~km}$, uma alça que liga a rodovia Ayrton Senna à avenida Jacu-Pêssego. Quando o Complexo Viário todo estiver pronto, a marginal Tietê, as rodovias Ayrton Senna e Presidente Dutra se interligarão à Jacu-Pêssego, desafogando o trânsito da região, já que, até então, o acesso à Jacu-Pêssego só era possível pela avenida Assis Ribeiro.

Grandes investimentos ligados às empresas financeiras e serviços internacionais na década de 1990 determinaram o desenvolvimento de pólos terciários ao longo de vias de acesso estruturais da cidade de São Paulo ${ }^{402}$. Em se tratando de tratamento prioritário para o transporte individual, sobressai-se a gestão da Prefeitura do Município de São Paulo no período 1993-1996, quando se construiu uma vasta quilometragem de túneis e viadutos.

\footnotetext{
${ }^{401}$ MELLO, 2000, p.80.

${ }^{402}$ ACCA, 2004.
} 
Na década de 1990, novas articulações do sistema viário foram realizadas, ligando a avenida Eng. Luis Carlos Berrini ${ }^{403}$ aos bairros Jardim Paulista e Jardim América e à avenida Brigadeiro Faria Lima, o que melhorou o acesso a essas áreas. Os dois pólos econômicos importantes, a região da avenida Brigadeiro Faria Lima de um lado, e a região da avenida Eng. Luis Carlos Berrini, de outro, são áreas voltadas para atividades bancárias e de serviços que eram cortados pelos bairros Vila Olímpia e Itaim. A construção das avenidas Hélio Pelegrino e Nova Faria Lima, articulada à avenida Juscelino Kubitscheck e também a saída do túnel construído sob o leito do rio Pinheiros, permitiu acessibilidade aos bairros do Morumbi, ao sul; a ligação entre a avenida Uberaba e a avenida República do Líbano, juntamente com o novo complexo de túneis Ayrton Senna, ao norte, permitiu ainda a ligação da região dos pólos citados com os bairros do Ibirapuera, Vila Mariana e o aeroporto de Congonhas, tratando-se de um verdadeiro corredor viário que corta a Capital de Sudoeste ao Centro ${ }^{404}$.

A “operação urbana Água Espraiada”, canalizou o córrego do mesmo nome, removeu uma das favelas e construiu uma nova avenida perpendicular à avenida Engenheiro Luis Carlos Berrini. Esta operação criou terrenos passíveis de serem incorporados ao mercado imobiliário, bem como ampliaram a circulação de automóveis e ônibus.

Próximo à avenida Berrini, a pista da avenida marginal do rio Pinheiros foi alargada. Cabe lembrar que todas essas obras foram realizadas pela Prefeitura, na gestão 1993-1996. A hegemonia do automóvel é indiscutível nas construções das largas avenidas, pontes, túneis e viadutos mencionados. Carlos ${ }^{405}$ interpreta que o espaço da metrópole é tornado espaço de circulação. A autora informa que nos escritórios da avenida Berrini havia 32 mil pessoas

\footnotetext{
403 O deslocamento do centro econômico financeiro da antiga área central para as intermediações da avenida Paulista nos anos 70, e desta para os eixos das avenidas Faria Lima e Berrini nas duas décadas seguintes, foi incentivado pelas políticas públicas de infra-estrutura viária (Águas Espraiadas e a ligação JuscelinoBandeirantes-Berrini), pelo processo de valorização imobiliária em larga escala e contaram com alguns componentes derivados da própria inserção do município na cadeia de fluxos internacionais, que atingiu setores estratégicos do terciário (ACCA, 2004).

${ }^{404}$ CARLOS, 2001.

405 Ibidem.
} 
trabalhando em meados dos anos 1990, sendo que, em 2000 esta população teria chegado a 50 mil pessoas. A avenida, sempre congestionada de veículos, entre ônibus, automóveis e motocicletas, serve ainda de passagem por parte dos moradores da região do Campo Limpo em deslocamento ao centro da cidade ${ }^{406}$. Os ônibus que por ela circulam não têm corredor exclusivo, apenas faixa segregada.

Ainda na década de 1990, na gestão da prefeitura de 1993-1996, foram construídos os túneis: um sob o rio Pinheiros, ligando as duas margens, e os dois do Complexo Ayrton Senna, sendo um deles sob a avenida Santo Amaro e o outro sob o Parque do Ibirapuera. Cabe lembrar que os túneis não permitem o tráfego de ônibus, apenas de automóveis e motocicletas.

Outras alterações realizadas no seio do sistema viário da Capital paulistana durante a década de 1990 são decorrentes da formação do complexo Eusébio Matoso, em que obras de duplicação da avenida permitiram a ligação das rodovias Raposo Tavares e Régis Bittencourt à rua da Consolação e daí, ao centro da cidade por meio do eixo Rebouças ${ }^{407}$. A ponte Bernardo Goldfarb, construída junto à avenida Eusébio Matoso, na concepção de Carlos ${ }^{408}$, seria de uso exclusivo de ônibus, o que não se efetivou.

Nos anos 2000, nas gestões das prefeituras de São Paulo 2001-2004 e 2005-2008, enfatizamos a construção dos túneis da Rebouças e Cidade Jardim e de nova ponte sobre o rio Pinheiros.

Abordaremos a construção dos túneis adiante, quando analisarmos a construção de corredor de ônibus da avenida Rebouças.

Quanto à décima terceira ponte sobre o rio Pinheiros, localizada justamente no eixo sudoeste da cidade de São Paulo, próxima do novo centro financeiro, de grande valorização

\footnotetext{
${ }^{406}$ CARLOS, 2001 .

407 Ibidem.

${ }^{408}$ Ibidem.
} 
imobiliária, foi inaugurada no primeiro semestre de 2008. Compactuando com o processo, na gestão da prefeitura de 2001-2004 foi lançado o projeto da ponte com uma previsão de R\$ 233 milhões $^{409}$. O início da construção se deu em 2003.

Trata-se de uma ponte de arquitetura arrojada e monumental, com duas pistas estaiadas em curva, onde só poderão trafegar automóveis e motos, ligando a avenida Roberto Marinho com a avenida marginal Pinheiros.

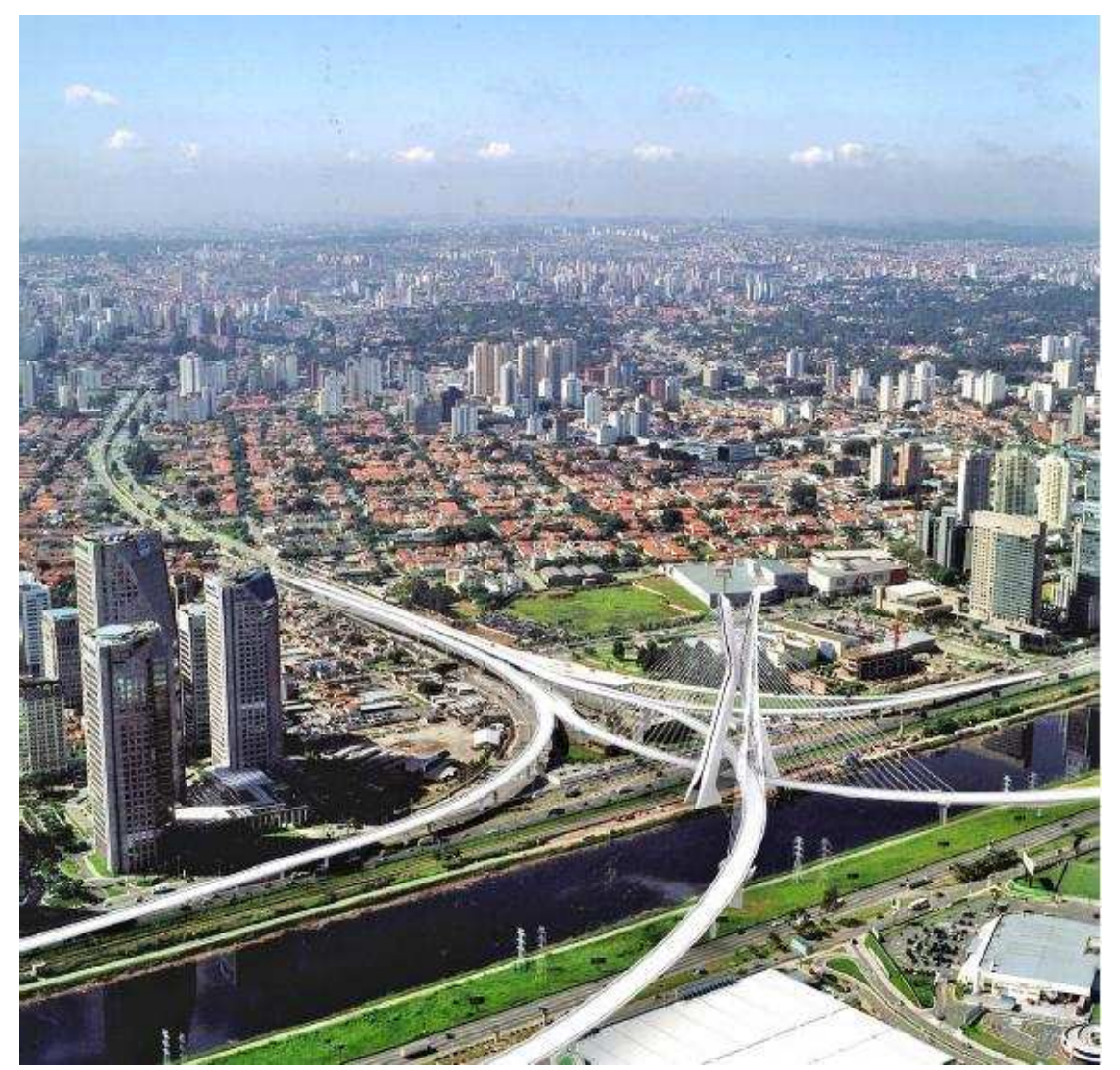

Fonte: http://elt0n.files.wordpress.com/2007/02/image004.jpg - acesso em 22.06.2008 Fotografia 54 - Município de São Paulo - Ponte Estaiada Octavio Frias

Com o corredor, o motorista terá a opção de, a partir da marginal Pinheiros, na zona oeste de São Paulo, prosseguir até o Jabaquara (bairro da zona sul) sem enfrentar o tráfego de ônibus e caminhões. Em 2010, quando o prolongamento da avenida estiver concluído, será possível chegar até a rodovia dos Imigrantes ${ }^{410}$.

${ }^{409}$ Reportagem da Revista Veja São Paulo de 18.10.2007 informou que parte deste valor seria financiado com a venda do Cepacs (Certificados de Potencial Adicional de Construção) pela Prefeitura. Estes certificados permitem que as construtoras ergam prédios acima da altura prevista para a região (BRISOLA, 2007).

${ }^{410}$ www1.folha.uol.com.br/folha /cotidiano/ult95u344648.shtml - acesso em 08.04.2008. 
Conforme se pode apreender pelo trecho acima, mais uma ampliação do sistema viário foi realizada no intuito de se promover maior fluidez aos veículos particulares. Para quem reside no Morumbi, a nova ponte possivelmente ajudará na diminuição dos engarrafamentos nos acessos ao bairro. Quem trafega pela avenida marginal Pinheiros no sentido Santo Amaro, seguindo pela avenida Jornalista Roberto Marinho (antiga avenida Águas Espraiadas), acessará o Aeroporto de Congonhas sem necessidade de usar a avenida dos Bandeirantes.

Logicamente, se os automóveis e motos que utilizam a avenida dos Bandeirantes forem por esta nova via alternativa, haverá um alívio para os caminhões e ônibus da avenida dos Bandeirantes. Sob este ponto de vista, a obra poderia até ser defendida. Mas por que um gasto tão elevado para uma ponte que não servirá ao transporte coletivo? Por que esta opção e não a de se priorizar a construção de uma ponte exclusiva para ônibus?

Daremos prosseguimento à análise referente à ampliação do sistema viário, a seguir, examinando a construção dos corredores de ônibus.

\title{
Infra-Estrutura de Transporte Coletivo: Os Corredores Exclusivos de Ônibus
}

\author{
Vasconcellos ${ }^{411}$ observa que \\ a ação técnica de implantar faixas exclusivas de ônibus representa uma ação na área \\ do trânsito, ou seja, da circulação de pessoas e veículos no sistema viário disponível. \\ [...] a autoridade está apenas redefinindo a utilização de um espaço viário já \\ existente, e que é disputado por vários tipos de usuários [...]
}

Portanto, implantar faixas exclusivas para os ônibus não traduz a discussão de oferta do transporte público, mas facilita a circulação dos ônibus existentes e, teoricamente, diminui seu tempo de percurso.

${ }^{411}$ VASCONCELLOS, 1999, p.149. 
Podemos aferir desta explicação que, ao tratar a prioridade dos ônibus nas vias apenas com o objetivo de melhorar sua fluidez e rapidez, os planejadores pecaram pela carência de um planejamento integrado com outros modos de transporte e com o entorno da Capital. $\mathrm{Na}$ realidade, "o fornecimento de meios públicos de transporte faz parte de uma política de planejamento de transportes [e deveria ser] anterior à política de circulação propriamente dita." ${ }^{412}$.

O autor realizou, entre 1979 e 1980, um estudo das velocidades desenvolvidas pelos ônibus nas avenidas Radial Leste e Brigadeiro Luís Antônio anteriormente e após a implantação das faixas exclusivas e concluiu que "as alterações de velocidade foram muito pequenas, resultando em ganhos reduzidos no tempo de viagem." ${ }^{\text {"13 }}$. Ele crê que isto se deve ao trecho percorrido na faixa exclusiva ser reduzido em relação ao percurso total da linha, além de falha na fiscalização quanto a estacionamentos irregulares ao longo da faixa. Este problema é recorrente na atualidade. Podemos assegurar que os estudos realizados pelo autor há praticamente 30 anos refletem as mesmas dificuldades nos dias de hoje, conforme podem atestar diversas reportagens atuais ${ }^{414}$.

No início de nosso período de análise, entre 1991 e 1992, foram construídas faixas exclusivas para ônibus nas avenidas Vereador José Diniz e Ibirapuera, e um corredor exclusivo entre a Vila Nova Cachoeirinha e o Largo Paissandu, no município de São Paulo.

Em 1993, paralelamente à "privatização" da Cia. Municipal de Transportes Coletivos (CMTC) e sua transformação em SPTrans, órgão gerenciador, o governo lançou o "Programa de Corredores e Terminais de Integração de Ônibus", prevendo-se "a construção de 240 km de corredores em 15 trechos de vias, com faixas segregadas preferencialmente à esquerda e

\footnotetext{
${ }^{412}$ VASCONCELLOS, 1999, p.157.

413 Ibidem, p. 198.

414 IZIDORO, Alencar; SEABRA, Cátia; SPINELLI, Evandro, 2008; IZIDORO, Alencar; SANGIOVANNI, Ricardo, 2008; SANGIOVANNI, Ricardo \& CREDENCIO, José Ernesto, 2008.
} 
reforma dos corredores existentes" ${ }^{\natural 15}$. Também foram propostos terminais de integração, estações de transferência, compra de 1.353 ônibus articulados a diesel e informatização do sistema com uso de bilhetagem automática.

No entanto, os empréstimos junto ao Banco Nacional de Desenvolvimento (BNDES) não foram liberados para as empreiteiras, havendo, então, “a redução do número de corredores de 15 para 5, que seriam feitos com recursos públicos apenas."416. O Quadro 2 apresenta os Corredores com Canaleta Exclusiva ${ }^{417}$ e Corredores com Faixas Exclusivas para Ônibus em 1995:

\section{Quadro 2 - Município de São Paulo Corredores com Canaleta Exclusiva para Ônibus/Trólebus e Corredores com Faixas Exclusivas - 1995}

\begin{tabular}{|l|l|l|}
\hline \multicolumn{4}{|l|}{ CANALETA EXCLUSIVA } \\
\hline TRECHO & OPERAÇÃO & TIPO DE VEÍCULO \\
\hline Santo Amaro-9 de Julho & SPTrans & Ônibus e trólebus \\
\hline Paes de Barros & SPTrans & Ônibus e trólebus \\
\hline São Mateus-Santo André & EMTU & Ônibus e trólebus \\
\hline Vila Nova Cachoeirinha & SPTrans & $\begin{array}{l}\text { Ônibus articulado } \\
\text { Porta esquerda }\end{array}$ \\
\hline Inajar de Souza & SPTrans & $\begin{array}{l}\text { Ônibus articulado } \\
\text { Porta esquerda }\end{array}$ \\
\hline FAIXA EXCLUSIVA & \multicolumn{2}{|l}{} \\
\hline TRECHO & TRECHO & \\
\hline Aricanduva & Brigadeiro Luís Antônio \\
\hline Cardeal Arcoverde & Celso Garcia \\
\hline Consolação & Av. do Estado \\
\hline Francisco Matarazzo & Francisco Morato \\
\hline Heitor Penteado & Luís Inácio de Anhaia Melo \\
\hline Mateo Bei & Nazaré \\
\hline Paulista & Rangel Pestana \\
\hline Radial Leste & Ragueb Chofhi \\
\hline Regente Feijó & São Miguel \\
\hline Silva Bueno & Teodoro Sampaio \\
\hline Vergueiro & \multicolumn{2}{|l}{} \\
\hline
\end{tabular}

\footnotetext{
${ }^{415}$ MELLO, 2000, p.155.

${ }^{416}$ Ibidem, p. 157.

${ }^{417}$ A canaleta exclusiva é a faixa de ônibus com uso exclusivo destes veículos, localizada à esquerda da via, onde é proibido qualquer uso por veículos particulares. As faixas exclusivas são localizadas à direita das vias e para realizar conversões ou entrar e sair de edificações e estacionamentos, os veículos particulares podem circular por elas.
} 
Os planos dos Corredores Exclusivos foram praticamente paralisados nas gestões das prefeituras de 1993-1996 e 1997-2000. Em 1996, o sistema viário de São Paulo cobria cerca de 18 mil km de vias com tratamento, dos quais cerca de 3 mil km correspondiam às vias estruturais, que são basicamente as vias por onde trafegam os ônibus. Dessas vias, apenas 98 $\mathrm{km}$ receberam algum tratamento diferenciado para o transporte coletivo ${ }^{418}$.

A partir de 2002, na gestão da prefeitura municipal de São Paulo de 2001-2004, entraram em operação os corredores de ônibus com a denominação de Passa-Rápido, fazendo parte de um sistema denominado Interligado, que será explicado adiante. Os Passa-Rápidos são corredores com canaleta exclusiva e propôs-se que fossem implantados nas principais avenidas da cidade, dando preferência às faixas de ônibus à esquerda e às paradas no canteiro central. Para utilizá-los, os coletivos devem ter portas à esquerda. O uso dos corredores centralizados facilita o deslocamento do veículo, que não é interrompido pelas manobras dos automóveis que saem das garagens ou fazem conversões à direita. Os Passa-Rápidos poderiam, igualmente, ocupar as faixas da direita das avenidas, caso não fosse possível a circulação na faixa central por algum motivo, como a existência de canteiros arborizados, por exemplo. Para assegurar o uso prioritário do coletivo, os Passa-Rápidos deveriam ser monitorados pela Operação Via Livre, com uso de fiscalização eletrônica por câmeras da CET. Na referida gestão da prefeitura, foram construídos e/ou reformados cerca de $100 \mathrm{~km}$ de corredores Passa-Rápido, conforme atesta o Quadro 3:

${ }^{418}$ ULIAN, 1999. 
Quadro 3 - Município de São Paulo

Passa-Rápidos inaugurados na gestão 2001-2004

\begin{tabular}{|l|l|l|}
\hline Passa-Rápido & Extensão em km & Ano de inauguração \\
\hline Lapa/Pirituba/Centro & 15 & Junho/2002 \\
\hline Parelheiros/Rio Bonito/Santo Amaro & 23,18 & Julho/2002 \\
\hline Jardim Ângela/Guarapiranga/Santo Amaro & 7,3 & Agosto/2002 \\
\hline Capelinha/Ibirapuera/Santa Cruz & 4,5 & Julho/2003 \\
\hline Santo Amaro/Nove de Julho/Centro & 14,8 & Setembro/2003 \\
\hline Campo Limpo/Rebouças/Centro & 10,3 & Março/2004 \\
\hline Inajar/Rio Branco/Centro & 14,5 & Abril/2004 \\
\hline Itapecerica/João Dias** & 7,0 & Abril/2004 \\
\hline Total & $\mathbf{9 6 , 5 8}$ & \\
\hline
\end{tabular}

Fonte: www.smt.sp.gov.br -27.05 .05$

Elaboração da autora.

** Este Passa-Rápido faz parte do eixo Capelinha/Ibirapuera/Santa Cruz.

Destes, o corredor Santo Amaro/Nove de Julho já existia, tendo sido apenas reformado. O corredor Inajar de Souza também já constava na lista do Quadro 2, apresentado por Mello ${ }^{419}$ para o ano de 1995.

O nome Passa-Rápido foi utilizado por esta gestão, mas rapidamente após a mudança de prefeito, perderam esta denominação e voltaram a ser chamados de corredores de ônibus. De acordo com o deputado federal Carlos Zaratini, ex-Secretário Municipal dos Transportes de São Paulo da gestão 2001-2004, em artigo publicado no jornal Folha de São Paulo de 20.03.2008, o plano daquela gestão era de que se construíssem 325 km de Passa-Rápidos e $204 \mathrm{~km}$ de vias com tratamento preferencial para os ônibus. O Quadro 3 mostra que foram inaugurados $96,58 \mathrm{~km}$, o que veio a reduzir "em $40 \%$ o tempo de viagem dos usuários das linhas que se utilizavam deles." 420

Foi bastante polêmica a construção do Passa-Rápido na avenida Rebouças/Eusébio Matoso, onde foi construído o túnel Fernando Vieira de Mello, sob a avenida Brigadeiro Faria Lima, para que os automóveis que circulam pela avenida Rebouças pudessem passar sob a avenida, eliminando, assim, este cruzamento. O Passa-Rápido e os ônibus passam sobre a

\footnotetext{
${ }^{419}$ MELLO, 2000.

${ }^{420}$ ZARATINI, 2008.
} 
avenida, bem como os automóveis que querem acessar a avenida Faria Lima. O túnel foi terminado "a toque de caixa", como se diz popularmente, e inaugurado em setembro de 2004, meses depois da inauguração do Passa-Rápido Campo Limpo/Rebouças/Centro e um ano após o início das obras. Os túneis teriam custado $\mathrm{R} \$ 97,4$ milhões $^{421}$, ou ainda $\mathrm{R} \$ 322$ milhões ${ }^{422}$ que seriam pagos pela Operação Faria Lima por meio de leilões de Cepacs, já referidos na nota de rodapé $n^{0}$ 175. A contratação da empresa, sem licitação, foi feita a partir do uso de um instrumento administrativo chamado de Ata de Registro de Preços, o que teria permitido a ela executar três contratos para aterrar os fios de energia e telecomunicações, remover a passarela em frente ao Shopping Eldorado e reformar o corredor de ônibus da avenida Rebouças até a Eusébio Matoso. Sob suspeita de favorecimento da empresa, a gestão da prefeitura seguinte pediu investigações. Reformas foram feitas, pois o túnel foi interditado várias vezes por problemas técnicos e alagamentos. Foram encontrados outros defeitos de construção, como remendos na tubulação e infiltrações.

Na mesma gestão (2001-2004), um segundo túnel, este na avenida Cidade Jardim, foi construído, também sob a avenida Faria Lima, o túnel Max Feffer. De acordo com reportagem do jornal O Estado de São Paulo, de 05.05.2005, o plano de transportes da região necessitaria das obras que foram realizadas em conjunto com os túneis para a execução da Estação Faria Lima do Metrô ${ }^{423}$. Além disso, segundo reportagem da Vejinha Online de 19.01.2005, “a passagem melhorou a vida de quem usa transporte público, mas não trouxe alívio para quem anda de carro"424. Tendo em vista que o foco da construção dos túneis foi priorizar os corredores de ônibus, ficamos na dúvida se o projeto foi tão criticado pela mídia e pela população usuária do transporte individual justamente por não priorizar os automóveis.

\footnotetext{
${ }^{421}$ SERRA..., 2005.

${ }^{422}$ MANSO, 2005.

${ }^{423}$ Ibidem.

${ }^{424}$ GUSMÃO, 2005.
} 
Na gestão seguinte, 2005-2008 (atual), os planos de construção de corredores de ônibus caminham a passos lentos. A pouco mais de um ano do final do mandato da atual gestão, foram informados os corredores que seriam previstos e inaugurados até o final de 2008. Porém, não se formulou nenhuma lei ou plano neste sentido. O anúncio desses corredores foi acompanhado da informação sobre sua publicação em Diário Oficial de 04.09.2007 e também de que não estava previsto ainda se seriam construídos em faixa central ou à direita, tampouco quando seriam marcadas as audiências públicas que aprovariam o cumprimento dos projetos. O projeto todo parecia um tanto amador e descompromissado.

Quadro 4 - Município de São Paulo Corredores de ônibus previstos na gestão 2005-2008

\begin{tabular}{|l|l|l|}
\hline Corredor Exclusivo & $\begin{array}{l}\text { Extensão } \\
\text { em km }\end{array}$ & Trajeto \\
\hline $\begin{array}{l}\text { São Miguel, Celso } \\
\text { Garcia, Centro }\end{array}$ & 13 & $\begin{array}{l}\text { Av. Marechal Tito, Av. São Miguel, Av. Celso Garcia, Av. Rangel } \\
\text { Pestana, R. do Gasômetro }\end{array}$ \\
\hline Brás Leme & 4 & $\begin{array}{l}\text { cruzamento R. Voluntários da Pátria com Av. Brás Leme, R. Eduardo } \\
\text { Viana, conecta-se com corredor Inajar/Rio Branco/Centro }\end{array}$ \\
\hline Berrini & 18,7 & $\begin{array}{l}\text { inicio em frente ao shopping Morumbi (Lgo. Los Andes), R. Funchal, } \\
\text { R. Gomes de Carvalho, inclui construção do terminal V. Olímpia e } \\
\text { Águas Espraiadas }\end{array}$ \\
\hline Indianópolis/Sumaré & 18,7 & $\begin{array}{l}\text { Terminal Jabaquara, bairros de Vila Mariana, Pinheiros e Lapa, } \\
\text { conecta-se com corredor Inajar/Rio Branco/Centro }\end{array}$ \\
\hline Corifeu, Faria Lima & 14,4 & $\begin{array}{l}\text { Av. Corifeu de Azevedo Marques, ponte do Jaguaré, Av. Queiroz } \\
\text { Filho, Av. Fonseca Rodrigues, R. Pedroso Alvarenga, Av. Borg. Faria } \\
\text { Lima, termina na Av. Hélio Pelegrini }\end{array}$ \\
\hline
\end{tabular}

Fonte: http://g1.globo.com/Noticias/SaoPaulo/0,,MUL108142-5605-206,00.html - acesso em 27.01.2008 Elaboração da autora.

Tão logo foram planejados, também já não estão mais nos planos os corredores Brás Leme, Sumaré e Faria Lima, pois os comerciantes e moradores dos bairros atingidos protestaram e a prefeitura recuou. No centro da avenida Brás Leme há um jardim que seria destruído com a construção do corredor. Além disso, os manifestantes reclamaram do aumento da poluição e do trânsito nos bairros, caso os corredores fossem realmente implantados.

Quanto ao corredor São Miguel/Celso Garcia, está prevista sua construção apenas no segundo semestre de 2008, bem como o da Av. Berrini. Enquanto isso, a prefeitura pretende 
implantar "corredores virtuais", fechados com cones, nas vias Clélia, Cruzeiro do Sul, Teotônio Vilela e Robert Kennedy ${ }^{425}$. Enquanto o corredor da avenida Celso Garcia não se concretiza, desde o final de janeiro de 2008 foi instalado um "corredor virtual" em alguns trechos da avenida, na faixa de automóveis, para a passagem de uma linha expressa de ônibus que passa nos horários de pico da manhã (das 6h às $8 \mathrm{~h}$ ) e da tarde (das $17 \mathrm{~h}$ às 20h). Assim, o ônibus expresso poderá ultrapassar os outros ônibus que circulam na faixa segregada de coletivos, que ainda não é um corredor exclusivo. É sofrível verificar como as medidas paliativas estão virando regra nesta administração.

Em março de 2008, também foi inaugurada uma extensão de 230 metros na avenida Vereador José Diniz do corredor já inaugurado na gestão anterior, o Capelinha/Ibirapuera/Santa Cruz. Tendo em vista que este corredor já existia desde 2003 e que a quilometragem acrescentada foi exígua, podemos afirmar que, definitivamente, a contribuição desta gestão na expansão do sistema viário seria ínfima, não fossem as obras de continuidade dadas ao polêmico Fura-Fila, atual Expresso Tiradentes, que passou a ser considerado um corredor exclusivo de ônibus que ligará o centro da Capital à Zona Leste, na Cidade Tiradentes. Nesta última gestão destaca-se a sua inauguração.

Iniciado na gestão 1997-2000 com o nome de "Fura-Fila" e previsto para atuar como uma via elevada sobre a qual circulariam VLPs (Veículos Leves sobre Pneus) entre a região do Sacomã e o Centro da Capital, o projeto sofreu alterações na gestão seguinte, levando o nome de "Paulistão", e sendo novamente remodelado na gestão atual, quando foi nomeado de Expresso Tiradentes, mudando-se o projeto para que seja um corredor exclusivo elevado de ônibus até a Cidade Tiradentes. Em março de 2007, finalmente foi inaugurado o primeiro trecho, de 8 km, entre a estação Mercado, no Parque Dom Pedro II $^{426}$, e o terminal Sacomã,

\footnotetext{
${ }^{425}$ www.nossasaopaulo.org.br/portal/node/225 - acesso em 08.04.2008.

${ }^{426}$ Os ônibus passam em intervalos de três minutos nas estações e na via, que são elevadas, seguindo o mesmo trajeto das avenidas das Juntas Provisórias e do Estado.
} 
construído para este propósito e também para atender as linhas municipais da região do Sacomã e as intermunicipais que têm como destino os municípios do ABC Paulista. O Expresso Tiradentes será um corredor exclusivo de ônibus com 31,8 km de extensão e, quando concluído, ligará o Parque D. Pedro II à Cidade Tiradentes, na zona Leste da cidade. Está em obra o trecho que ligará o corredor até a Vila Prudente, com 2,8 km, no qual haverá integração com a linha 2 - Verde, do metrô, já referida anteriormente.

\section{Figura 5 - Trajeto atual do Corredor Expresso Tiradentes}

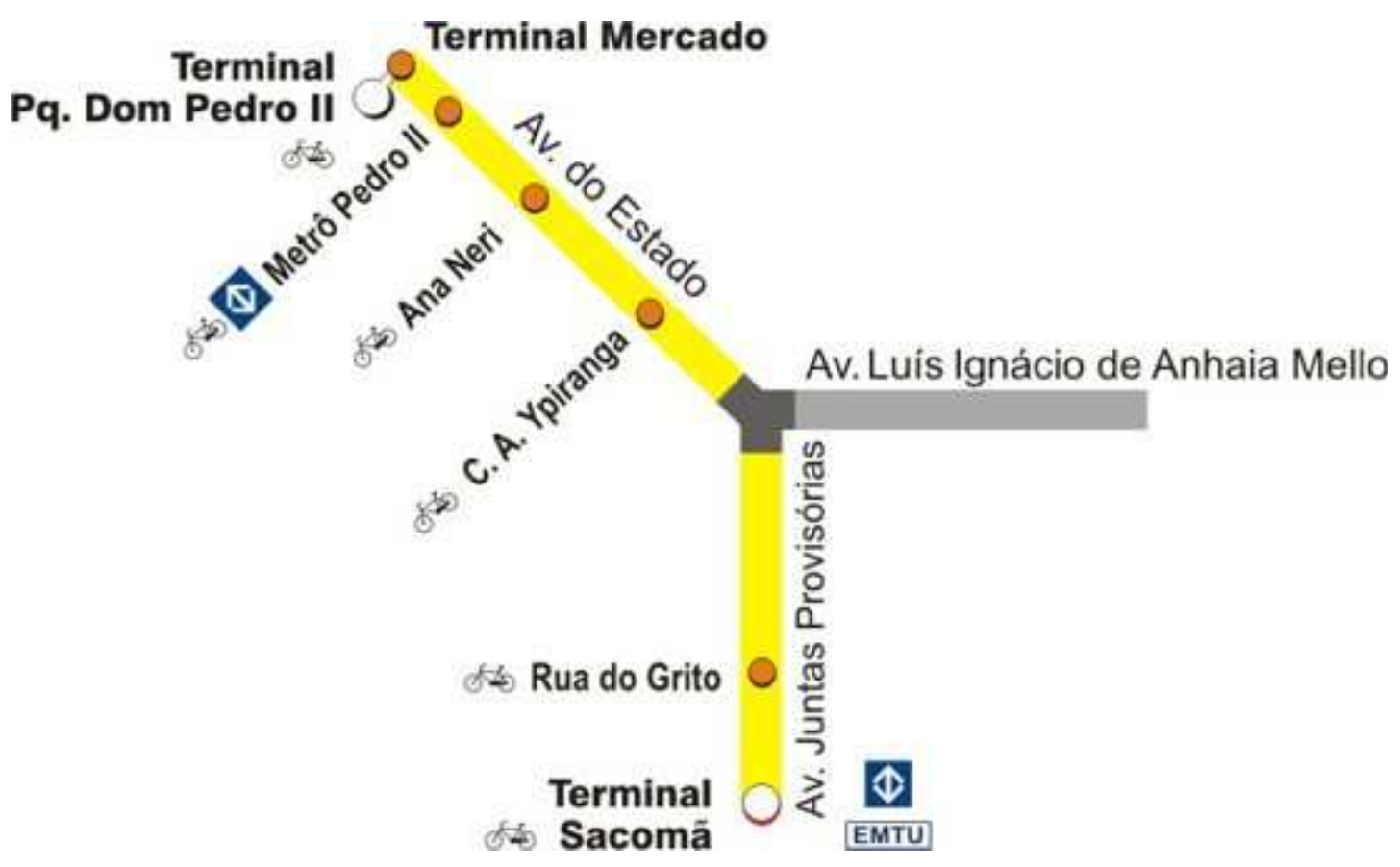

Fonte: http://www.emtu.sp.gov.br/tiradentes/imagens/tracado.jpg - acesso em 22.06.2008 

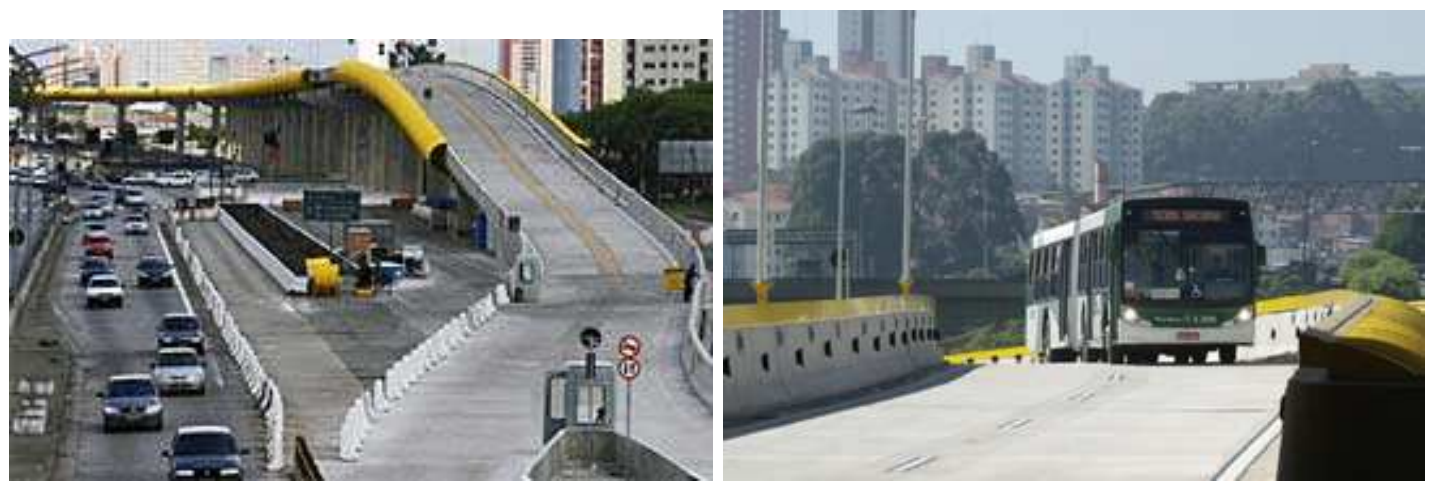

Fonte: http://g1.globo.com/Noticias/SaoPaulo/foto/0,,6242909,00.jpg http://www.daimlerchrysler.com.br/noticias/Abril/Expresso_Tiradentes/imagens/Expresso_Tiradentes_03.jpg acesso em 22.06.2008

Fotografias 55 e 56 - Município de São Paulo - Trechos do Expresso Tiradentes

As linhas provenientes da Capital foram seccionadas no terminal Sacomã, e os usuários passaram a utilizar o Bilhete Único, pagando a diferença entre os valores das tarifas municipal e intermunicipal. Os terminais do Expresso Tiradentes são providos de bicicletários para que os usuários possam deixar suas bicicletas e utilizar os ônibus.

Portanto, em matéria de construção de novos corredores exclusivos para ônibus no município de São Paulo, entre 1987 e 2007, sobressaíram-se as gestões de 1989-1992 e a de 2001-2004.

No âmbito intermunicipal, destacamos os corredores metropolitanos São-Mateus Jabaquara e Diadema-Brooklin, inaugurados em 1988 e 2000, respectivamente. A EMTU controla a operação do Corredor Metropolitano São Mateus/Jabaquara. Trata-se de

$133 \mathrm{Km}$ de vias exclusivas que abrangem cinco municípios da RMSP. O sistema conta com nove Terminais de Transferência, 111 paradas e uma frota de mais de 200 veículos. Transporta diariamente mais de 200 mil passageiros. Desde 1997 é objeto de uma Concessão operada pela empresa Metra - Sistema Metropolitano de Transportes Ltda. ${ }^{427}$

O Corredor Metropolitano constitui-se de trechos de vias segregadas e vias comuns, nos quais circulam ônibus a diesel e trólebus, sendo considerado de alta qualidade no deslocamento entre São Paulo e os municípios do ABC Paulista. Na Pesquisa de Imagem dos 
Transportes, realizada no final de 2007 pela ANTP, a avaliação positiva dos corredores metropolitanos diminuiu em relação a 2006, de 69\% para 53\%. Especialmente, o corredor São Mateus-Jabaquara obteve $66 \%$ este ano contra $80 \%$ ano em $2006^{428}$.

\section{Figura 6 - Rede de Corredores Metropolitanos EMTU São Mateus - Jabaquara / Diadema - Brooklin}

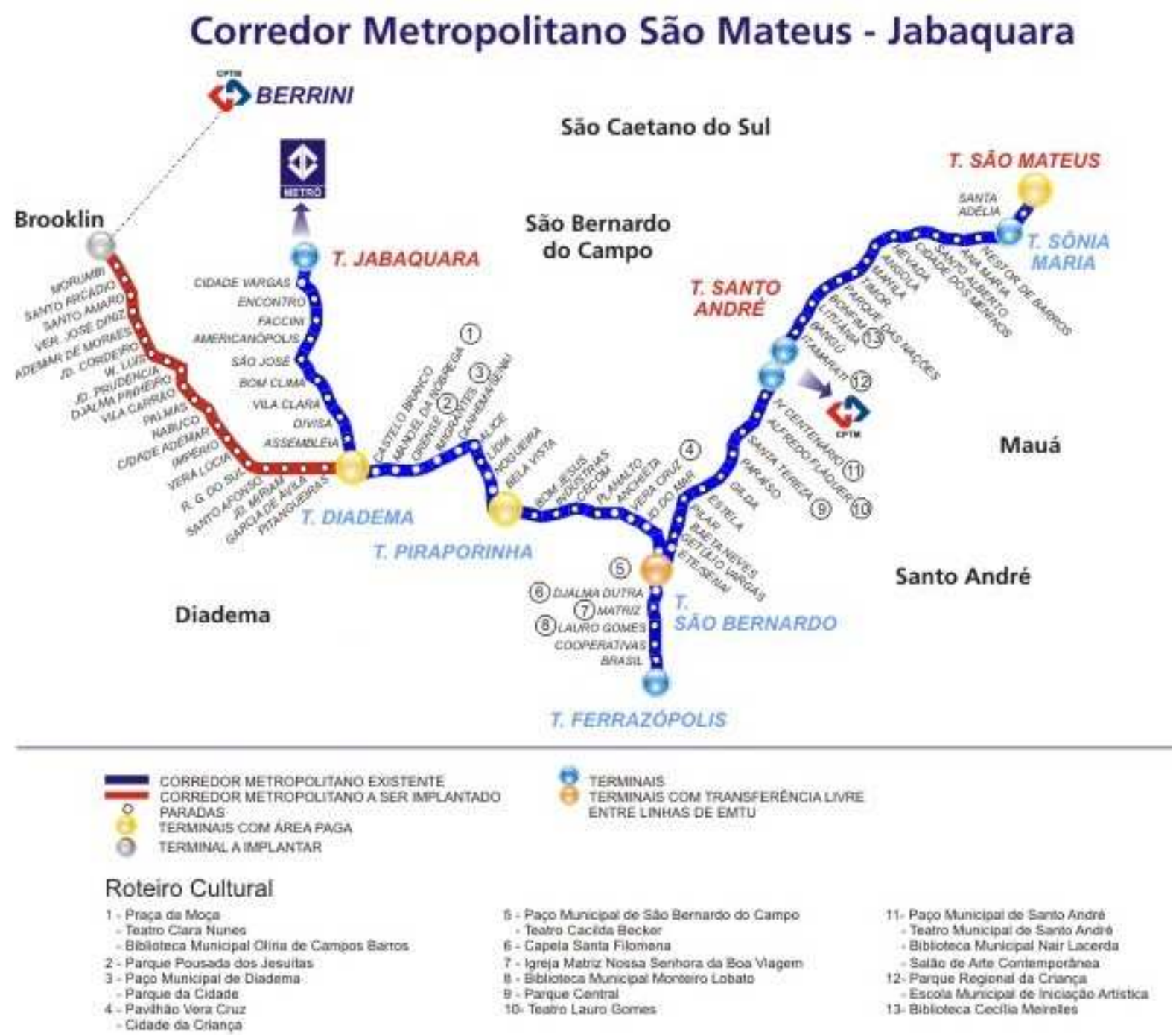

http://www.emtu.sp.gov.br/corredor_smt/corredor.html - 20.06.2008

428 A título de comparação, nos ônibus do sistema municipal de São Paulo, houve $42 \%$ de avaliação positiva, percentual menor do que o obtido na pesquisa de 2006 , de $48 \%$. Já o resultado da pesquisa em ônibus que operam em corredores exclusivos, a avaliação positiva melhorou de $57 \%$ para $64 \%$, apesar de estar abaixo da margem de erro. 


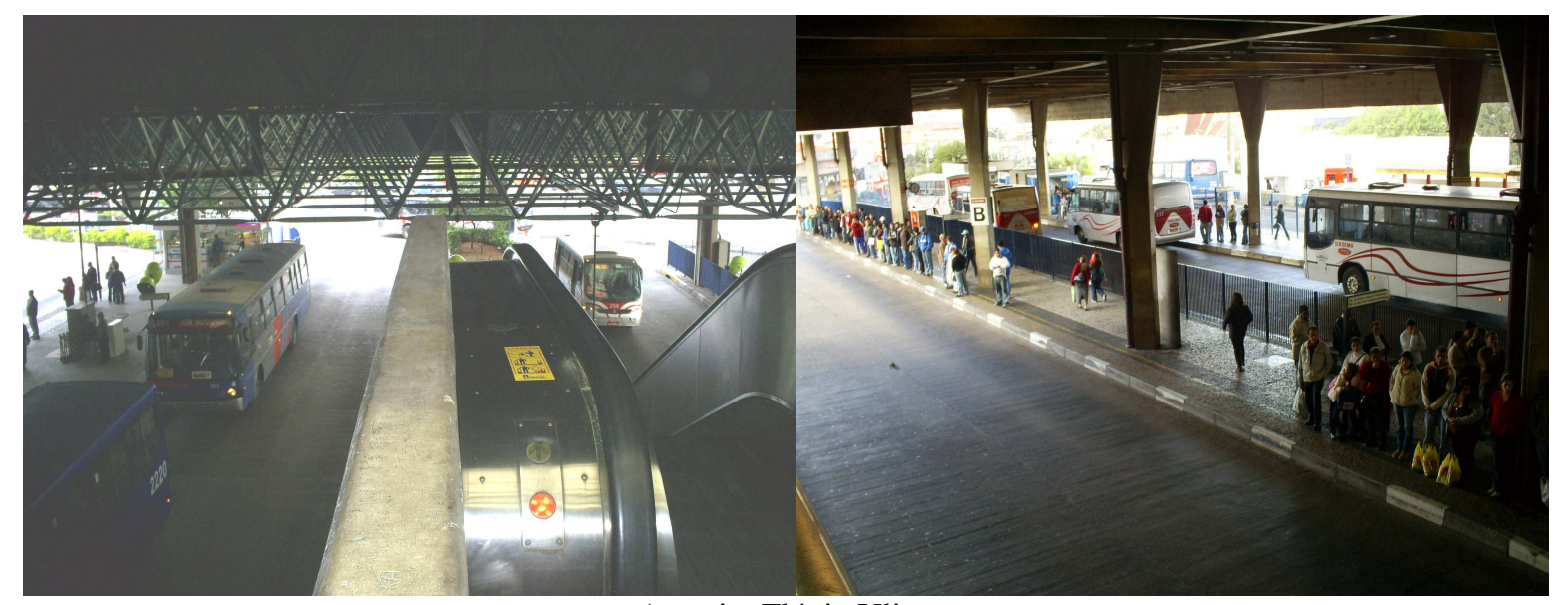

Autoria: Flávia Ulian

Fotografia 57 - Mun. de Diadema - Terminal Diadema/30/05/07 Fotografia 58 - Terminal Piraporinha/30/05/07

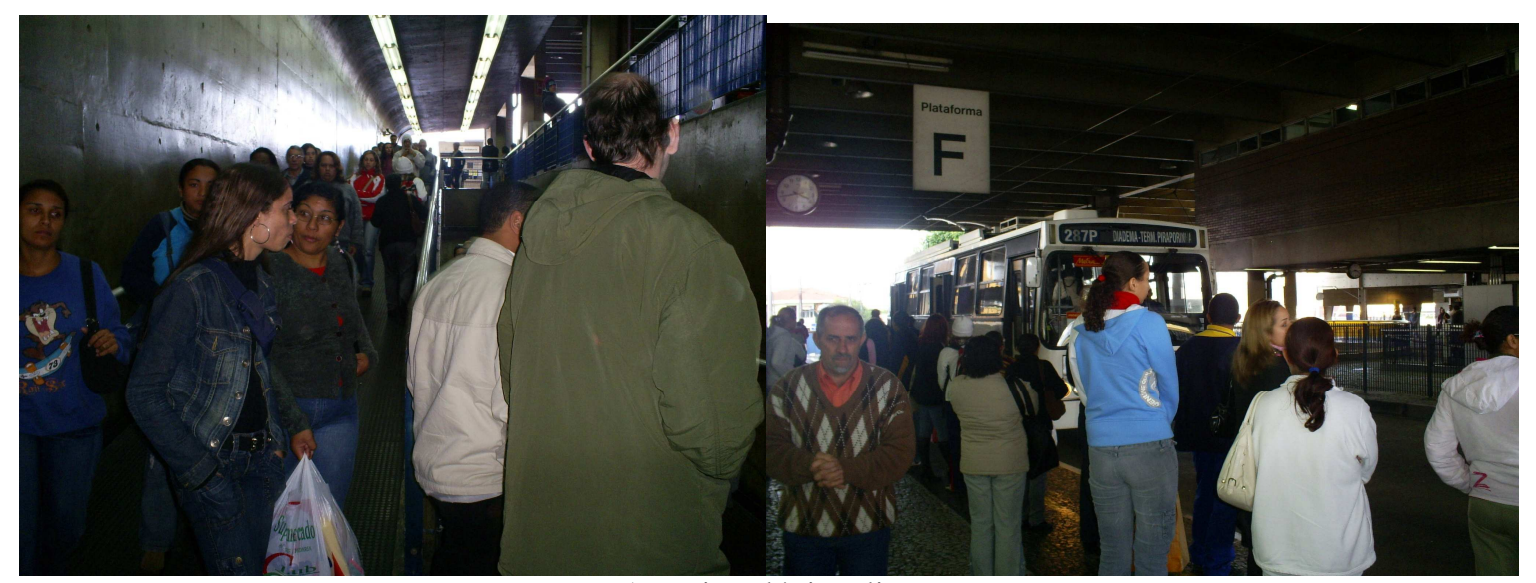

Autoria: Flávia Ulian

Fotografias 59 e 60 - Município de Diadema - Terminal Piraporinha / 30/05/07

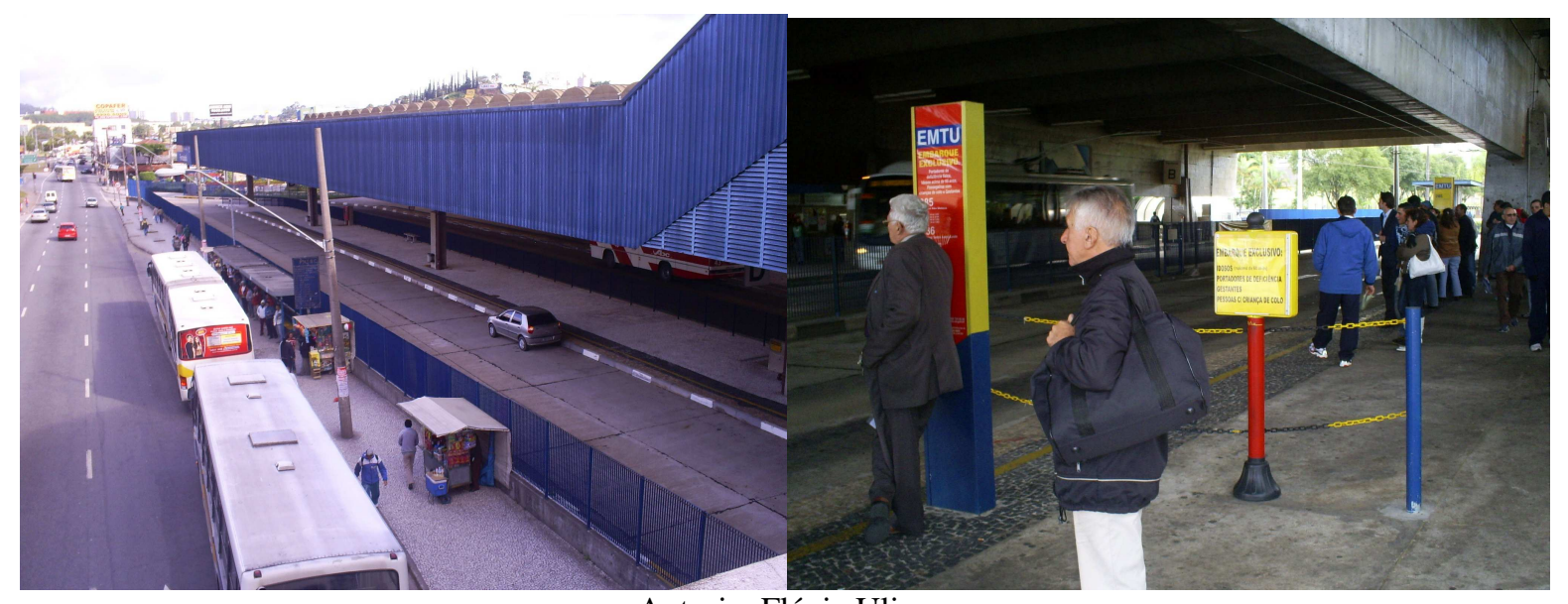

Autoria: Flávia Ulian

Fotografia 61- Município de São Bernardo do Campo Fotografia 62 - Terminal São Bernardo / 30/05/07 Terminal Ferrazópolis / 30/05/07 


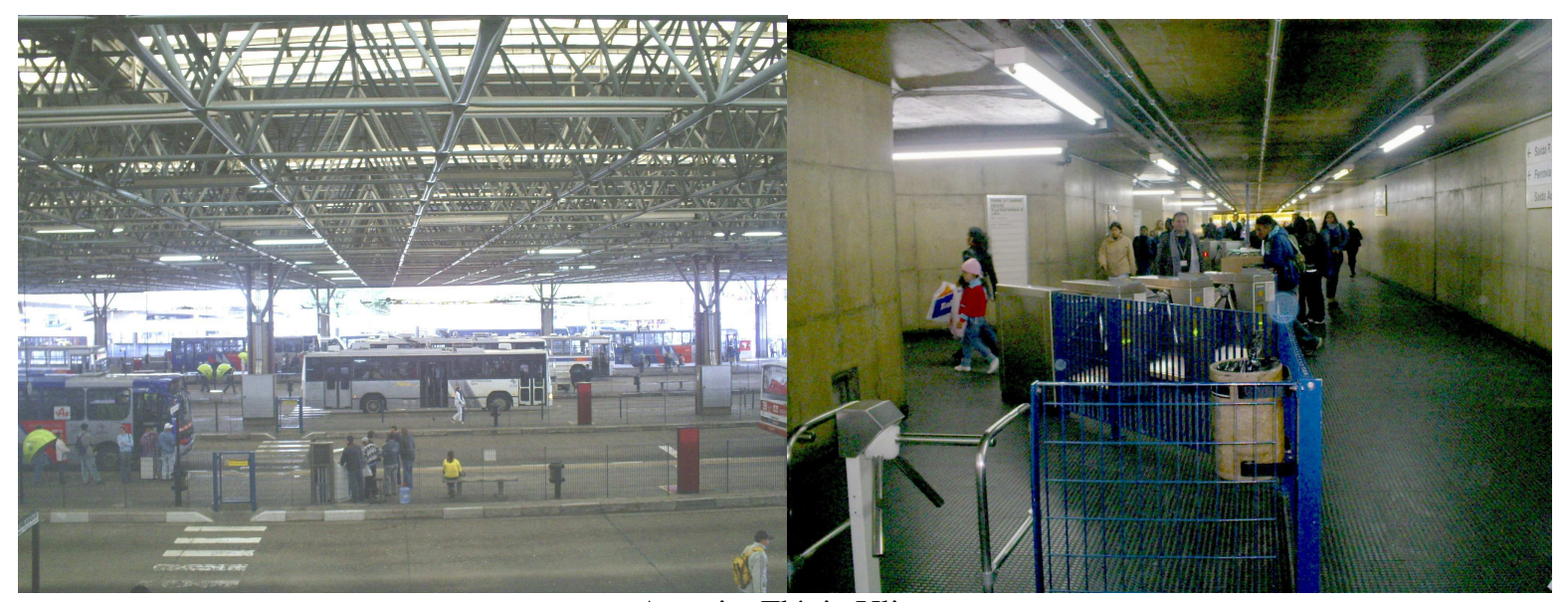

Autoria: Flávia Ulian

Fotografia 63 - Município de Santo André Terminal Santo André Oeste - Vista Geral / 30/05/07

Fotografia 64 - Terminal Santo André Oeste - Catracas localizam-se no subsolo / 30/05/07

Vale incluir nesta análise alguns depoimentos colhidos em visitas realizadas ao Corredor Metropolitano. Uma grande parte dos entrevistados não reclama exatamente do conforto dos veículos. O trólebus, que percorre o corredor São Mateus-Jabaquara, foi bastante elogiado: tem ar condicionado, música ambiente e é pouco ruidoso. Outro usuário do trólebus do corredor elogia o ônibus, que além das qualidades citadas acima, também não pega trânsito no corredor. Ele percebeu que em determinados horários, porém, a operadora retira veículos que iriam somente até Santo André e coloca outros que vão até São Mateus, ocasionando desconforto pela superlotação: aqueles que vão somente até Santo André lotam o ônibus e aqueles que vão até São Mateus ficam apertados pelo menos no trecho até Santo André. Trata-se de um problema de ajuste na logística. Logicamente, esta operação é feita para diminuir custos em horários nos quais, teoricamente, haveria menos passageiros. No entanto, nosso entrevistado percebeu também que, à noite, nos horários de saída das faculdades da região, não se colocam mais ônibus para rodar. O percurso fica, assim, mais demorado, pois os ônibus param em praticamente todos os pontos do corredor e, havendo fila para embarcar, o embarque atrasa. Além do cartão eletrônico Bilhete Ônibus Metropolitano (BOM) ${ }^{429}$, podese usar bilhetes vendidos exclusivamente nos terminais e em estabelecimentos comerciais

\footnotetext{
${ }^{429}$ O Cartão BOM armazena créditos, existindo na versão escolar, vale-transporte, especial, sênior e comum.
} 
localizados no entorno do corredor, mas não nos ônibus, o que causa problemas aos usuários que, sem bilhete, tomam o ônibus fora dos terminais, à noite.

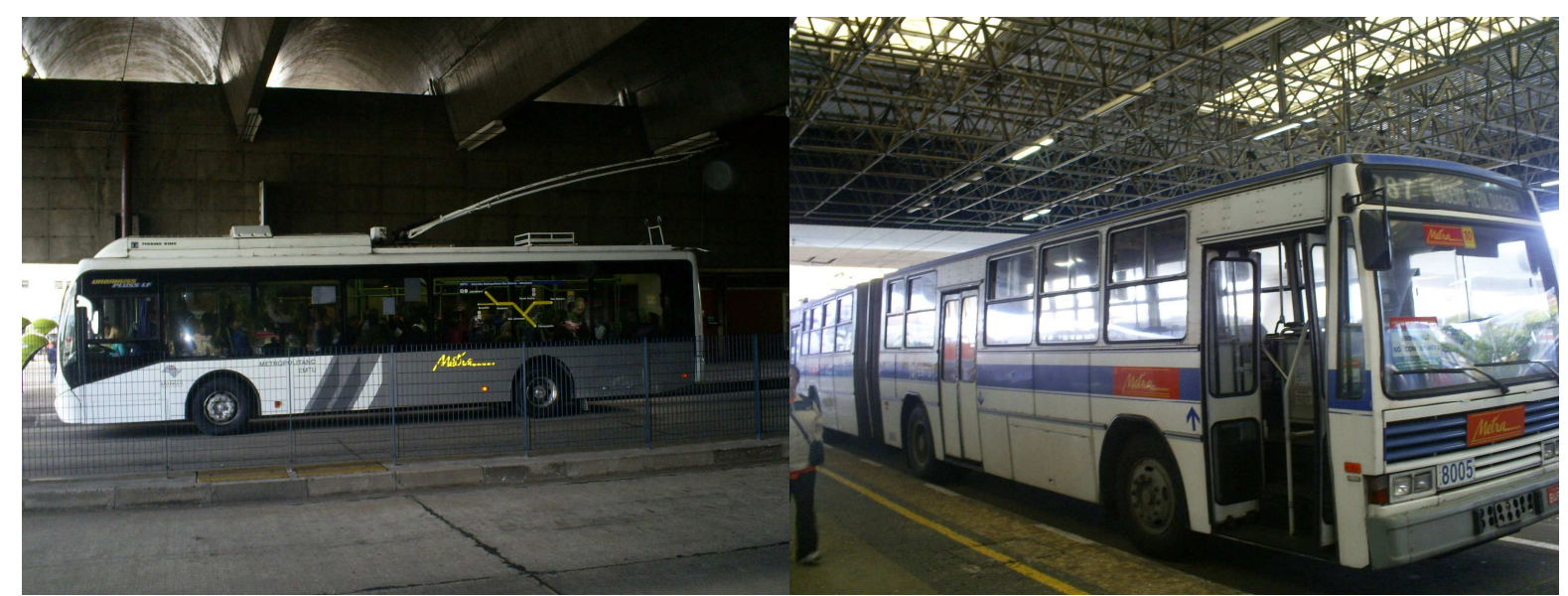

Autoria: Flávia Ulian

Fotografia 65 - Trólebus da concessionária Metra / 30/05/07

Fotografia 66 - No Corredor Metropolitano circulam também ônibus a diesel da Metra, menos confortáveis / 30/05/07

A extensão do corredor Diadema-Brooklin foi inaugurada em agosto do ano $2000 \mathrm{com}$ serviços de microônibus. Até hoje não opera com ônibus regulares porque, segundo dados fornecidos por um funcionário da Metra, não houve ainda um acordo entre a concessionária Metra e a SPTrans para que, no município de São Paulo, os ônibus de outras companhias concessionárias gerenciadas pela SPTrans possam trafegar. Além disso, um usuário do corredor São Mateus-Jabaquara, com quem conversamos, nos informou que o corredor Diadema-Brooklin não pode ser usado porque a Metra não possui ônibus com porta do lado esquerdo, necessária para circular pelo referido corredor.

O PITU, quanto ao transporte sobre pneus, prognosticou o Sistema Metropolitano, planejando a implantação de corredores de ônibus da EMTU em $300 \mathrm{~km}$ de corredores exclusivos. A consolidação do Rodoanel, com a construção de $121 \mathrm{~km}$ em pista dupla, também consta no PITU 2020. 
Quanto aos corredores de ônibus metropolitanos, trata-se de um sistema de média capacidade em sistema de troncalização, formado por corredores de ônibus metropolitanos. Seu ponto de partida é o corredor metropolitano São Mateus-Jabaquara. O Plano, detalhado na obra publicada pela STM e EMTU, "Transporte Metropolitano - Ações do governo no transporte intermunicipal por ônibus na RMSP”, de 1999, mostra uma preocupação com o atendimento da demanda, demonstrando seriedade no atendimento dos fluxos internos de cada sub-região da RMSP, bem como entre as sub-regiões, e entre estas e a Capital. Muitos terminais de integração seriam construídos, outros reformados. Vários quilômetros de corredores em via segregada também estavam no projeto. Praticamente nada foi feito nesses quase dez anos, comprometendo, portanto, a circulação da população usuária de ônibus intermunicipal na área metropolitana, e reforçando nossa crítica a um planejamento metropolitano que se faz fragmentado em relação às municipalidades.

Passaremos, na seqüência, a aprofundar um outro ponto do PITU, referente ao Rodoanel.

\section{Rodoanel Mário Covas}

Está em fase de implantação, com apenas um trecho construído, a auto-estrada que interligará as rodovias de acesso à RMSP, atendendo às necessidades de viagens perimetrais.

De acordo com a Dersa, a idéia de uma via perimetral que circundasse o núcleo central da Região Metropolitana de São Paulo remonta à segunda metade do século XX.

Segundo Barroso ${ }^{430}$, “projetos anteriores de 'rodoanéis' tiveram uma obsolescência do traçado em função dos mesmos haverem sido sucessivamente absorvidos pela cidade em expansão", conforme já aludido neste trabalho. O esboço de anel rodoviário de 1952 acabou

\footnotetext{
${ }^{430}$ BARROSO, 2004, p. 15.
} 
dando origem às avenidas marginais dos rios Tietê e Pinheiros. "Trinta anos depois, com essas duas vias já totalmente congestionadas, começaram a ser construídos o Minianel Viário

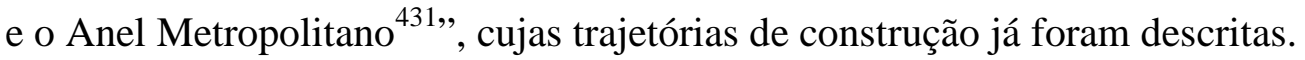

De acordo com o sítio da Secretaria de Transportes do governo do Estado de São Paulo, o atual projeto do Rodoanel Mario Covas (SP-21) é "um empreendimento urbano que tem a função de desviar e distribuir o tráfego de passagem para o entorno da Região Metropolitana de São Paulo - RMSP."432 Grande parte do Rodoanel está sendo construída dentro do perímetro urbano dos municípios que cruza. Ao final de sua construção, interligará dez rodovias que chegam a São Paulo - Régis Bittencourt, Raposo Tavares, Castello Branco, Anhangüera, Bandeirantes, Fernão Dias, Dutra, Ayrton Senna, Imigrantes e Anchieta. O objetivo é eliminar o tráfego de passagem, tornando o trânsito da cidade mais ágil para os transportes coletivo e individual. No entanto, como também cresce o número de veículos e de deslocamentos, é bem provável que ele venha a se tornar obsoleto tão logo seja concluído.

Para efeito de obras, o Rodoanel Mário Covas está dividido em quatro trechos: Norte, Sul, Leste e Oeste, com uma extensão total de aproximadamente $170 \mathrm{~km}$, constituindo-se em via expressa com controle total dos acessos, que se darão pelas vias radiais principais por ele interceptadas e sempre em desnível. Os empreendimentos lindeiros somente terão acesso ao Rodoanel caso não haja alternativas por vias locais. Será composto de duas pistas com três a quatro faixas de tráfego por sentido, mais acostamento, com distância de 20 a $40 \mathrm{~km}$ do Centro de São Paulo.

A Secretaria de Transportes do governo do Estado de São Paulo planeja que

Até 2020, o anel peri-urbano deverá ganhar mais 2,3 milhões de habitantes - 31\% a mais do que a população de 7,5 milhões de habitantes em 2000. Já na Região Metropolitana espera-se um crescimento populacional de $24 \%$ no mesmo período ou 4,5 milhões de pessoas - sobre uma população de 17,9 milhões de habitantes em 2000. No mesmo período, o Rodoanel ocasionará uma indução à ocupação acumulada inferior a $0,1 \%$.

\footnotetext{
${ }^{431}$ www.dersa.com.br /rodoanel/especial/index.html - acesso em 02.01.2007.

432 www.transportes.sp.gov.br/v20/rodoanel.asp - acesso em 02.01.2007.
} 
O Rodoanel age no sentido de substituir as ocupações de baixa qualidade ambiental (especialmente ocupações irregulares de terrenos) por outras de melhor qualidade (empreendimentos formais, condomínios etc.). Isso porque onde existe acesso ao Rodoanel há expressiva valorização da terra, substituindo a ocupação de baixa qualidade ambiental por empreendimentos legais, sujeitos a licenciamento ambiental. $^{433}$

Este trecho evidencia que o propósito da ocupação da região cortada pelo Rodoanel não são as moradias populares, nem os empreendimentos do circuito inferior da economia. As “ocupações de baixa qualidade ambiental (especialmente ocupações irregulares de terrenos)", diz o trecho citado, não serão toleradas. Devido à valorização da terra, os planejadores esperam atrair "empreendimentos formais e condomínios", mostrando a quem circula pelo Rodoanel a pujança da região metropolitana. Verifica-se que a estruturação da metrópole se dá, mais uma vez, propulsionada por uma via rodoviária, e é evidente a quem ela se destina. No entorno do Rodoanel há dois fatores indutores de expansão e adensamento urbano: setor de transportes e setor imobiliário. "A apropriação imobiliária tem um papel central na produção capitalista do espaço, pois sua atividade cria uma mercadoria fundamental: o espaço

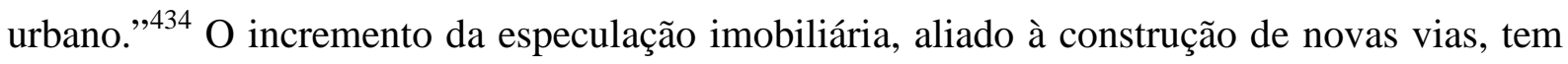
sido um fato recorrente no período estudado.

Barroso $^{435}$ explica que as novas fronteiras da produção imobiliária são os anéis metropolitanos e as periferias metropolitanas, quando um novo ciclo de especulação se inicia e o espaço geográfico é um valor de uso e satisfaz necessidades humanas. É condição de produção e reprodução social. No ano de anúncio do início das obras, 1997, ocorreu uma arrancada no número de pedidos por novos loteamentos na região do entorno do local onde seria construído o Rodoanel ${ }^{436}$. "A perspectiva de contar com uma via de trânsito fácil à porta

\footnotetext{
${ }^{433}$ www.transportes.sp.gov.br/v20/rodoanel_aae_inducao.asp- acesso em 02.01.2007.

${ }^{434}$ BARROSO, 2004, p.99.

435 Ibidem.

${ }^{436}$ Ibidem.
} 
de condomínios verdes passou a ser o melhor apelo comercial dos novos empreendimentos." 437

Estima-se que, no final de sua construção, “o Rodoanel absorverá cerca de 50\% do tráfego comercial com origem/destino fora da Região Metropolitana, proporcionando uma economia de custos em transportes da ordem de R $\$ 2$ bilhões anuais." ${ }^{438}$

O primeiro trecho construído, Oeste, foi concluído em outubro de 2002 e o segundo trecho foi iniciado em setembro de 2006. De acordo com o Dersa, a conclusão do trecho Oeste aliviou o trânsito do Butantã e dos bairros adjacentes à Cidade Universitária no município de São Paulo. Este trecho "interliga a região sul do País (Rodovia Régis Bittencourt), o oeste do Estado de São Paulo (rodovias Raposo Tavares e Castelo Branco), a região norte do Estado (rodovia Anhangüera) e a importante região de Campinas (rodovia dos Bandeirantes) ${ }^{, 439}$. Estas rodovias seriam responsáveis por cerca de $50 \%$ da carga total que entra na RMSP ${ }^{440}$.

\begin{abstract}
Ali, além da redução dos níveis de poluição, inclusive sonora, a saída de parte dos caminhões abriu espaço para o transporte coletivo e individual, especialmente nos congestionados corredores das Avenidas Francisco Morato e Eliseu de Almeida. Nesses corredores a velocidade média dos veículos, sobretudo dos ônibus, aumentou consideravelmente.Com a entrada em operação do Trecho Oeste do Rodoanel Mário Covas, o trânsito do transporte de cargas das Avenidas Marginais de São Paulo foi aliviado em quase $30 \%$. O significado econômico dessa mudança pode ser avaliado com base na situação atual, em que o desperdício de tempo nos longos e permanentes congestionamentos dessas vias é estimado em 1,7 bilhão de horas por ano $^{441}$
\end{abstract}

No entanto, há controvérsias. Reportagem do Jornal da Serra de setembro de 2002 revela que "O gigantismo da cidade gera e induz seu tráfego, e o Rodoanel será de pequena valia contra este fato" ${ }^{442}$. Na reportagem, é noticiado que dados fornecidos pelo próprio Poder Público - Dados da Pesquisa de Origem-Destino/1977 Região Metropolitana de São Paulo,

\footnotetext{
${ }^{437}$ ESTADO DE SÃO PAULO, 20.03.1998 apud BARROSO, 2004, p.106.

${ }^{438}$ www.transportes.sp.gov.br/v20/rodoanel_aae trafego.asp - acesso em 02.01.2007.

439 BARROSO, 2004, p.7.

${ }^{440}$ Ibidem.

${ }^{441}$ www.dersa.com.br/rodoanel/especial/index.html - acesso em 02.01.2007.

442 www.jornaldaserra.com.br/jsrodoanel/rodotrafego/ rodotrafegopage.htm - acesso em 02.01.2007.
} 
Síntese de Informações Domiciliares da Linha de Contorno, concluem que o aglomerado urbano gera seu próprio tráfego e este é dominante. O Rodoanel, então, teria pouca incidência no alívio do tráfego na malha viária existente. A reportagem informa ainda que, dos aproximadamente 400.000 veículos que trafegam todos os dias pela marginal do Tietê, apenas 384 caminhões que circulam nos horários de pico não têm vínculo com a cidade, e que grande parte dos veículos que circulam pelas marginais, vindos principalmente de outros Estados, tem algum tipo de ligação com a Região Metropolitana. "A maioria dos caminhões que infernizam os motoristas, por exemplo, entra na cidade para realizar entregas e não vai continuar passando apenas pelo Rodoanel." ${ }^{\text {443 }}$ Além disso, a velocidade dos ônibus teria aumentado por causa do corredor de ônibus ${ }^{444}$ e não em função Rodoanel. O Trecho Oeste do anel viário beneficia as localidades de Alphaville e Tamboré (Rodovia Castelo Branco) e a Granja Viana I e II (Rodovia Raposo Tavares), facilitando suas ligações com a Metrópole Interna ${ }^{445}$. Os espaços beneficiados são ocupados por população de renda média-alta e alta.

Barroso $^{446}$ critica a postura do Dersa, que trata o Rodoanel como obra viária localizada fora da área urbanizada, como um anel de contorno, questionando se seria mesmo externo à mancha urbana: "O Trecho Oeste atravessa áreas intra-urbanas densamente povoadas e possibilita a ocupação próxima a alguns dos últimos remanescentes urbanos da biosfera da Mata Atlântica." ${ }^{, 47}$. Com acessos abertos para os municípios por onde o Rodoanel passa, realiza as expectativas do setor imobiliário e adensa “conurbações não previstas e até mesmo indesejáveis." ${ }^{448}$. Seria uma rodovia-avenida utilizada para deslocamentos dentro do espaço metropolitano com surgimento de fixos intra-urbanos à beira da estrada, reestruturando novas

\footnotetext{
${ }^{443}$ www.jornaldaserra.com.br /jsrodoanel/rodotrafego/rodotrafegopage.htm - acesso em 02.01.2007.

444 O referido corredor integra o Passa-Rápido Campo Limpo/Rebouças/Centro, ainda não completamente implementado, mas que, nas avenidas Rebouças, Eusébio Matoso e Francisco Morato, já vem funcionando desde 2004.

${ }^{445}$ BARROSO, 2004.

446 Ibidem.

${ }^{447}$ Ibidem, p.47.

${ }^{448}$ Ibidem, p.49.
} 
localizações e fluxos. Importante lembrar que entendemos o projeto do Rodoanel como parte do já mencionado plano de construção da cidade da classe média.

\section{Mapa 6 - Região Metropolitana de São Paulo Rodoanel}

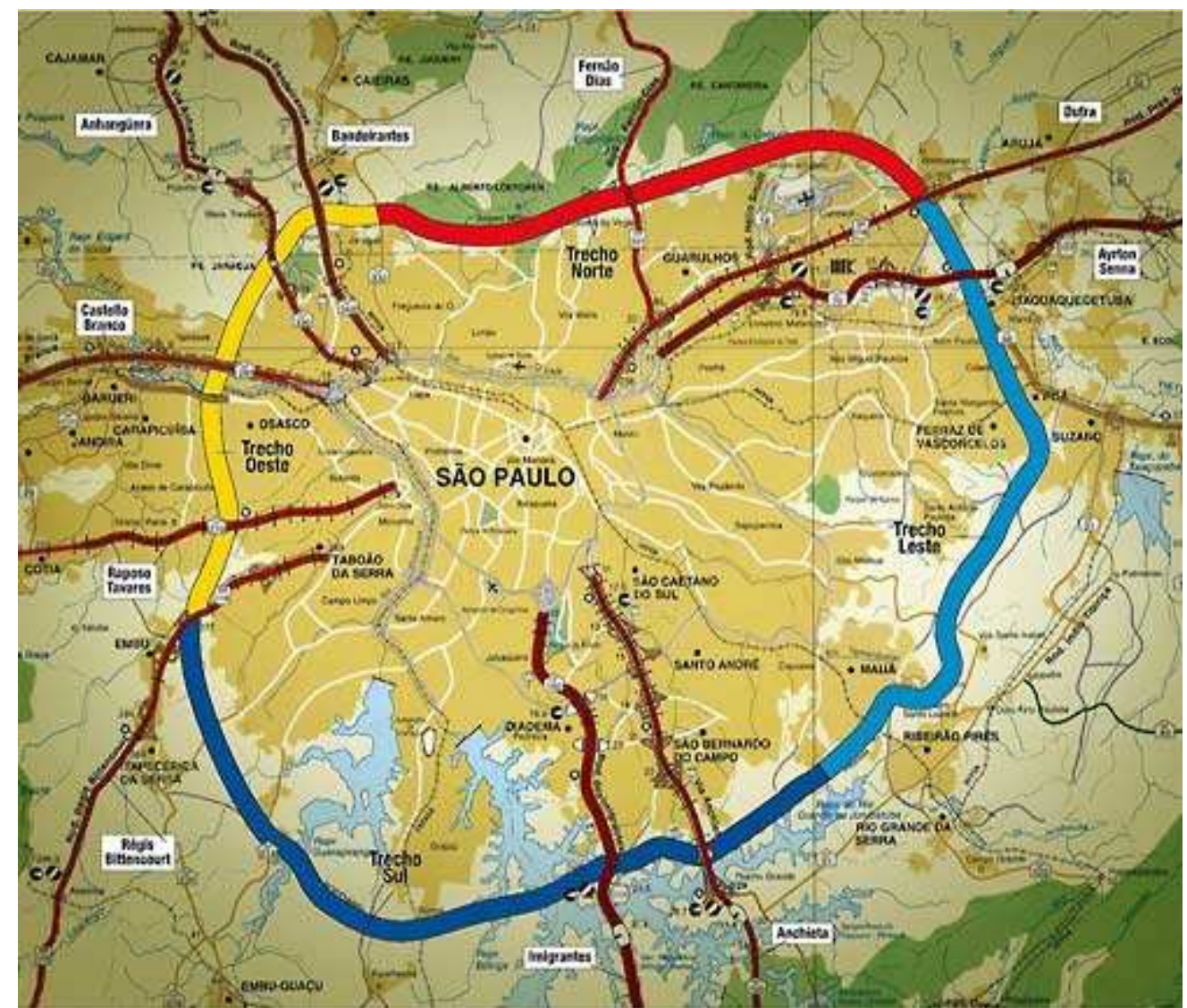

Fonte: http://www.dersa.com.br/rodoanel/imagens/album/mapa.html - acesso em 21.06.2008

$$
-\mathrm{x}-
$$

Este item procurou apresentar e discutir o sistema viário da RMSP e seu papel na estruturação da metrópole paulistana. Analisamos algumas políticas direcionadas à infraestrutura rodoviária, tanto quanto ao transporte individual como ao coletivo. Passaremos a uma apresentação muito rápida, no próximo item, sobre alguns aspectos que ainda ficaram pendentes acerca das políticas para o sistema viário e trânsito da RMSP. 


\subsection{2 - Políticas para o Sistema Viário e Trânsito}

O gerenciamento dos transportes e do trânsito na RMSP é realizado pela STM, secretaria estadual que faz parte da área de infra-estrutura. Há três coordenadorias técnicas na STM: a Coordenadoria de Planejamento e Gestão, responsável pelo PITU para as regiões metropolitanas e projetos derivados; a Coordenadoria de Relações Institucionais, responsável pela articulação com os municípios das regiões metropolitanas do Estado e planejamento e integração de comunicação e marketing com as empresas vinculadas; e a Coordenadoria de Transporte Coletivo, responsável pelo estabelecimento de políticas para o transporte metropolitano de passageiros.

O PMGSP 1994-2010, já referido anteriormente, apresentou propostas para o transporte coletivo sobre pneus, além daquelas mencionadas para os transportes sobre trilhos: implementar corredores de ônibus em linha segregada, não determinando exatamente os locais; melhorar o modo ônibus com maior oferta de veículos e faixas privativas de ônibus, apesar de não sugerir a racionalização da frota e nem indicar os locais da instalação das faixas segregadas; consolidar a integração multimodal e tarifária entre os diversos modos de transporte público, o que começou com o Bilhete Único, iniciativa da Prefeitura dez anos depois, e não do Estado; criar formas de reduzir o uso do automóvel, instalando estacionamentos junto a terminais de transporte coletivo e normatizando o uso do automóvel, com restrição de horários e lugares. Quanto à restrição de horários e lugares para o tráfego de automóveis, foi implementado o rodízio estadual, em 1997, aprovado para o prazo de dois anos e substituído por lei municipal ${ }^{449}$. Mais algumas diretrizes referentes ao controle do

\footnotetext{
$449 \mathrm{O}$ rodízio municipal atua de segunda a sexta-feira, das $7 \mathrm{~h}$ às $10 \mathrm{~h}$ e das $17 \mathrm{~h}$ às $20 \mathrm{~h}$. Seu objetivo é deslocar
} parte das viagens realizadas nos horários de pico para o resto do dia. O rodízio municipal está restrito ao Centro 
tráfego merecem ser mencionadas, como a de descentralização do controle de físcalização do tráfego das vias locais pelos municípios da RMSP. Vale também comentar que o Plano propunha ampliar os serviços de informações sobre as condições de circulação na área urbana e nos troncos rodoviários; "Aumentar o rigor no teor e na aplicação das normas de habilitação para direção de autos, motos e veículos similares"450, o que veio a ser implementado pelo Código de Trânsito Brasileiro, promulgado em janeiro de 1998; desenvolvimento de programa de melhoramento de operação e segurança de tráfego em pontos críticos; escalonamento de horários das atividades comerciais e de serviços; programas de educação para o trânsito, de adequação da infra-estrutura de monitoramento da rede viária, de prevenção em épocas de inundações e outros.

O Sistema Viário de Interesse Metropolitano (SIVIM) foi um programa criado pela EMTU em 1997 com vistas a realizar "um levantamento de informações sobre os pontos críticos do sistema viário para propor intervenções como construção e pavimentação de vias, adequação da sinalização e circulação nas áreas de transporte, trânsito etc."451 O programa classificou, em 2000, 370 vias e, em 2005, atualizou o levantamento apresentado que hoje soma cerca de $2.800 \mathrm{~km}$ nos 39 municípios que compõem a RMSP. O objetivo é complementar os planos existentes para obter indicadores de avaliação do sistema viário e propostas eventuais de intervenções e obras para a melhoria do Sistema.

A questão da mobilidade na cidade não está somente relacionada às políticas de transporte intra-urbanas, mas ainda aos planos nacionais do governo relacionados ao incentivo à indústria automobilística e planos de estabilização monetária. Neste último aspecto, Mello ${ }^{452}$ evidencia a importância do "Plano Real", de julho de 1994, que viabilizou, através da

Expandido da Capital. Às segundas-feiras estão impedidos de circular os carros com placas com finais $1 \mathrm{e} 2$, às terças-feiras, com finais 3 e 4, e assim por diante. O rodízio retira da frota cerca de $20 \%$ dos veículos em circulação.

${ }^{450}$ SÃO PAULO, 1994a, p.197.

${ }^{451} \mathrm{http}: / / \mathrm{www} . e m t u . s p . g o v . b r /-$ acesso em 27.01.2007.

${ }^{452}$ MELLO, 2000. 
estabilização da economia, a solidez dos preços dos combustíveis, o aumento da produção de automóveis aliado à redução das alíquotas de importação feitas pelo governo federal na gestão 1990-1993, que “jogou nas ruas da capital milhares de novos automóveis, o que levou ao acirramento das já difíceis condições de circulação." ${ }^{, 43}$ Quanto ao incentivo à indústria automobilística, a redução do Imposto sobre Produtos Industrializados (IPI) realizada na gestão federal de 2002-2005, tornou os carros mais baratos, isto porque a indústria automobilística é uma das bases da economia nacional, independentemente de o trânsito estar ruim ou não nas metrópoles brasileiras. Portanto, vale acrescentar a afirmação de Mello $^{454}$ : “Convém não esquecer, contudo, que as condições do transporte urbano e a deterioração da qualidade de vida nas cidades resultam de condições construídas".

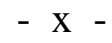

Na seqüência, conheceremos as condições referentes ao sistema de ônibus e lotação, meios de transporte coletivo rodoviários.

\footnotetext{
${ }^{453}$ MELLO, 2000, p.224.

${ }^{454}$ Ibidem, p.224, grifo da autora.
} 


\title{
3.3.3 - Políticas de Transporte Coletivo Rodoviário: Ônibus e Lotação
}

Este item aborda o serviço de ônibus e de lotação da RMSP. A opção pelo maior detalhamento do município de São Paulo deve-se, mais uma vez, ao fato de ser o município central da RMSP e de apresentar a maior demanda e número de viagens. O texto traz ainda informações sobre o sistema de ônibus intermunicipal e de fretados que atuam na região metropolitana.

\section{O Sistema de Ônibus}

Logo no início do período em análise desta Tese, a gestão da Prefeitura do Município de São Paulo 1989-1992 buscou municipalizar o transporte coletivo. A CMTC ${ }^{455}$ seria encarregada da arrecadação e pagamento das "empresas prestadoras de serviço com base em índices de quilometragem rodada, qualidade do serviço prestado e idade da frota" ${ }^{\natural 56}$. Havia a intenção de, sob este novo formato, diminuir a subvenção da Prefeitura para o setor, tentando mostrar que, sob o sistema anterior,

\begin{abstract}
as empresas estavam tendo um volume de lucro inversamente proporcional à qualidade do serviço prestado, uma vez que, ao serem remuneradas por passageiro transportado, interessava aos empresários manter em circulação um menor número de ônibus, com maior lotação ou mesmo com superlotação, diminuindo custos e aumentando lucros ${ }^{457}$.
\end{abstract}

Entre denúncias de corrupção e gasto excessivo, a Prefeitura estabeleceu um teto para a remuneração diária às empresas contratadas de forma a compatibilizar o limite anual previsto na Lei Orçamentária e o critério de remuneração diária estabelecido em contrato, com relação à receita primária advinda da arrecadação da tarifa. Isso significa dizer que as

\footnotetext{
455 A Cia. Municipal de Transportes Coletivos - CMTC - foi formada em 1947.

${ }^{456}$ MELLO, 2000, p.144.

${ }^{457}$ Ibidem, p. 145.
} 
empresas passaram a receber com base nos custos de operação, utilizando-se, para efetuar seu pagamento, as tarifas arrecadadas e subsídios autorizados. A CMTC exigia um grande investimento do poder público, já que, por remunerar as empresas operadoras pelo serviço prestado, exigia uma forte política de subsídio à tarifa do transporte urbano e também gastos com a sua própria manutenção.

Apesar de estável nos primeiros anos, o novo sistema começou a dar problemas relacionados ao desbalanceamento de rentabilidade entre as áreas, deficiência de fiscalização e pressões inflacionárias. Alguns operadores começaram a adotar práticas de redução de custos que afetaram a qualidade de serviço, a confiabilidade e a acessibilidade. Estes aspectos e também "os conflitos em torno das tarifas colocaram o sistema em uma posição desfavorável, como um dos piores problemas aos olhos da população [...]”458.

Crescia, já no início dos anos 90, o transporte clandestino, realizado, então, por ônibus de ex-motoristas do sistema oficial, e também por empresas dos municípios vizinhos, que “estavam encontrando espaço para operar clandestinamente em São Paulo, concorrendo com as linhas regulares." ${ }^{459}$ Visando ao combate do transporte clandestino, a Prefeitura propôs legalizá-lo mediante a criação da modalidade "ônibus-lotação", mas a condição de que se usassem veículos do tipo rodoviário (com uma porta) com tarifa superior não agradou os clandestinos, que se opuseram à prestação deste serviço. Em 1992, houve a legalização de parcela dos ônibus clandestinos via cooperativas. Foi criado pelo Decreto $\mathrm{n}^{\mathbf{0}} 33.593$, de 12 de agosto de 1993, um sistema complementar de ônibus, no qual a Prefeitura visava ao enquadramento dos ônibus clandestinos, que, neste ano, somavam cerca de 2.300 veículos,

\footnotetext{
${ }^{458}$ VASCONCELOS, 2000, p.143.

${ }^{459}$ MELLO, 2000, p.149.
} 
nomeando o sistema de "Bairro a Bairro"460 . Em 1997, segundo dados do Departamento de Transporte Público da SMT (DTP), havia 850 veículos cadastrados neste sistema ${ }^{461}$.

Ainda na gestão municipal de 1989-1993, procurando atrair o usuário do automóvel ao uso do ônibus, o Plano Trienal de Tráfego e Trânsito (PTTT), previu a implantação de linhas de ônibus seletivo para retirar das áreas centrais 150 mil veículos particulares. O seguinte trecho de Mello ${ }^{462}$ explica o processo de implantação dos "ônibus especiais" e seu fracasso:

\begin{abstract}
As empresas que participaram das licitações escolheram as linhas e chegaram a realizar pesquisa junto ao público alvo, a classe média. Deu-se prioridade às linhas que ligavam bairros mais distantes às regiões de escritórios e comércio, como Centro, Avenida Paulista e Faria Lima. Apesar de sua boa concepção original, o projeto não teve desenvolvimento satisfatório, o que foi atribuído ao pouco investimento da CMTC/SMT na divulgação das linhas e de seus itinerários e ao hábito cultural de utilização do automóvel.
\end{abstract}

Além dos fatores citados por Mello ${ }^{463}$, deve-se acrescentar que os ônibus especiais eram como os outros: ruidosos, com freadas bruscas que desconcertam os usuários e desconfortáveis para quem está acostumado ao conforto de seu próprio veículo. A tarifa superior impedia que fosse utilizado por grande parte da população, que o mantinha mais vazio do que os outros ônibus, mas mesmo assim não encorajava o seu uso por proprietários de automóveis particulares. Para que um programa de troca do automóvel pelo ônibus desse certo, seria necessário que o gasto e a duração das viagens fossem menores ou iguais ao uso do carro, que houvesse conforto, que se viajasse sentado e, por fim, que fossem implantados estacionamentos em áreas onde os usuários deixariam os carros para tomarem os ônibus especiais. Tudo isso estava previsto no PTTT, mas não foi implementado.

A CMTC gozava de visão positiva por parte dos usuários, mas iniciou seu ciclo de decadência, ligado a pressões corporativas e trabalhistas em relação a empregos e salários, à

\footnotetext{
460 Aos poucos, muitas das linhas servidas pelos ônibus deste sistema acabaram transformando-se em ônibus regulares do Subsistema Local do Sistema Interligado, criado em 2001.

${ }^{461}$ CIA. DO METROPOLITANO DE SÃO PAULO, $1997 \mathrm{~b}$.

${ }^{462}$ MELLO, 2000, p. 151.

${ }^{463}$ Ibidem.
} 
ineficiência e a denúncias de corrupção. Vasconcelos ${ }^{464}$ reforça que houve piora nas condições da CMTC no final do período da administração municipal de 1989-1993,

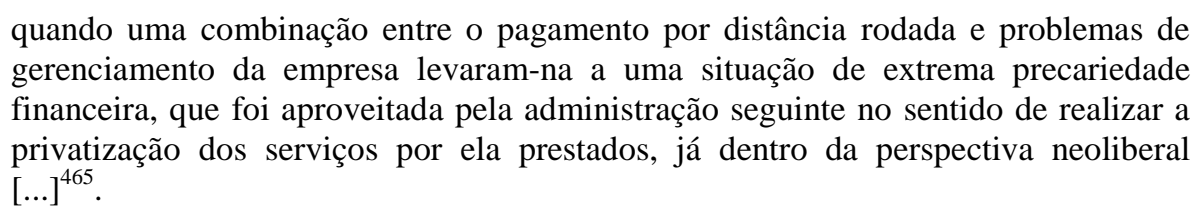

Em 1993, com a mudança de gestão da Prefeitura do Município de São Paulo, o número de ônibus em circulação foi reduzido em $10 \%$ e o pagamento das empresas voltou a ser feito pela tarifa arrecadada e não mais por quilômetros rodados.

Neste ano, "o quadro funcional da CMTC foi reduzido de 27.129 para 14.644 funcionários, registrando-se 12.485 demissões. A frota operacional também foi reduzida: de 2720 para 1661 veículos." ${ }^{466}$ Em 1994, o número de funcionários chegou a 2.700. Em 1995, foi criada a SPTrans, subordinada à SMT, cuja finalidade é gerir o sistema de transporte da cidade, finalizando a operação de transporte público em ônibus por empresa pública no município de São Paulo. Foram transferidos para a SPTrans todo o patrimônio e pessoal considerados necessários para seu funcionamento. A nova empresa atuaria como "contratante de serviços de transporte de passageiros, por intermédio de licitações [...] e atuando também no planejamento, programação, fiscalização e emissão de passes." ${ }^{467}$, configurando, na realidade, um modelo de terceirização.

Neste período, as mudanças econômicas estruturais no nível internacional e regional e a transição para uma economia de serviços na metrópole mudaram a demanda do transporte e novos nichos de mercado foram abertos. São os tempos de reestruturação produtiva. O transporte informal, que sempre tivera um papel secundário, passou a ser conveniente para um número crescente de usuários. A falta de fiscalização, a má imagem do transporte regular e a

\footnotetext{
${ }^{464}$ VASCONCELLOS, 2000.

${ }^{465}$ Ibidem, p. 143.

${ }^{466}$ MELLO, 2000, p.154.

${ }^{467}$ Ibidem.
} 
liberação da importação de vans viabilizaram o transporte informal, apoiado pela mídia, pelos usuários e parte da classe política. A seguinte afirmação de Vasconcelos ${ }^{468}$ reflete esta consideração: "O governo federal fingiu que não viu que as vans eram ilegais para o transporte público segundo a lei brasileira e os fabricantes multinacionais inclusive começaram a dar suporte legal à formação de cooperativas de operadores."

Em 1999, havia um número estimado de mais de 15 mil lotações operando em São Paulo. Os 11 mil ônibus regulares em operação foram perdendo passageiros, ameaçando haver grande desemprego no transporte regular.

Vasconcelos ${ }^{469}$ estima que "A perda de demanda foi de cerca de $20 \%$ em todo o sistema no primeiro instante [...]". Voltaremos a esse assunto adiante.

Tabela 18 - Município de São Paulo Evolução dos Passageiros transportados pelo sistema de ônibus municipal Anos escolhidos

\begin{tabular}{|l|c|}
\hline ANO & $\begin{array}{c}\text { PASSAGEIROS TRANSPORTADOS } \\
\text { NO SISTEMA DE ONIBUS MUNICIPAL }\end{array}$ \\
\hline 1987 & 1.937 .867 .128 \\
\hline 1990 & 2.023 .602 .389 \\
\hline 1994 & 1.821 .650 .804 \\
\hline 1997 & 1.611 .024 .762 \\
\hline 2000 & 1.113 .041 .936 \\
\hline 2001 & 1.166 .539 .679 \\
\hline 2002 & 1.180 .723 .330 \\
\hline 2003 & 1.201 .545 .033 \\
\hline 2004 & 1.677 .520 .087 \\
\hline 2005 & 2.507 .174 .899 \\
\hline 2006 & 2.661 .110 .194 \\
\hline 2007 & 2.729 .245 .250 \\
\hline
\end{tabular}

Fonte: www. Sptrans.com.br - acesso em 19.01.2008 Organização da autora.

A Tabela 18 mostra que o total de passageiros transportados pelo sistema de ônibus municipal foi da ordem de 1,9 bilhão de passageiros em 1987. Esta quantidade subiu para pouco mais de 2 bilhões no ano de 1990, mas decresceu a partir de 1994, caindo para 1,8

\footnotetext{
${ }^{468}$ VASCONCELLOS, 2000, p.144.

${ }^{469}$ Ibidem.
} 
bilhão neste ano, e depois para 1,6 bilhão em 1997, 1,1 bilhão em 2000, conforme referido nos parágrafos anteriores. Com a implantação do Bilhete Único, o número de passageiros transportados subiu abruptamente para 2,5 bilhões em 2005, 2,6 bilhões em 2006, terminando em 2007 com 2,7 bilhões de passageiros no sistema municipal de ônibus.

Em suma, no período estudado (1987-2007), verificou-se um crescimento da demanda diária por ônibus no sistema do município de São Paulo da ordem de 70\%, graças, em grande parte, ao Bilhete Único.

O sistema de ônibus funciona com a SPTrans emitindo ordens de serviço de operação para cada linha, definindo trajetos, horários de operação e frota necessária. Em 2006, as empresas operaram com uma frota aproximada de 14.703 ônibus e 990 linhas utilizados por uma média de 218.160.451 passageiros por mês. Estes dados, se comparados ao período anterior à implantação do Bilhete Único, mostram que o número de passageiros praticamente duplicou, pois em 2003, por exemplo, a média mensal de passageiros era de 100.128.752, e em dezembro de 2007 foram registrados 222.138.856 passageiros, ou seja, mais do que o dobro. Para entendermos estas transformações, deveremos compreender as políticas municipais em relação ao sistema de ônibus a partir de 2001.

O sistema sofreu várias transformações na gestão da prefeitura 2001-2004, quando foi instituído o Sistema Interligado por Lei Municipal $\mathrm{n}^{\circ}$. 13.241, de 12 de dezembro de 2001, caracterizado por ser uma rede de oito áreas integradas com sistema de bilhetagem eletrônica que propicia deslocamento mais rápido com racionalização do uso dos meios de transporte na cidade. O Plano Diretor Estratégico do Município de São Paulo, aprovado em 2002, traz na Seção II, intitulada "Elementos Estruturadores", texto explicativo da rede viária estrutural e da rede estrutural de transporte coletivo público. Esta última dá suporte físico ao Sistema Integrado de Transporte Coletivo. 


\section{Figura 7 - Subsistema Estrutural e Subsistema Local do Sistema Interligado}

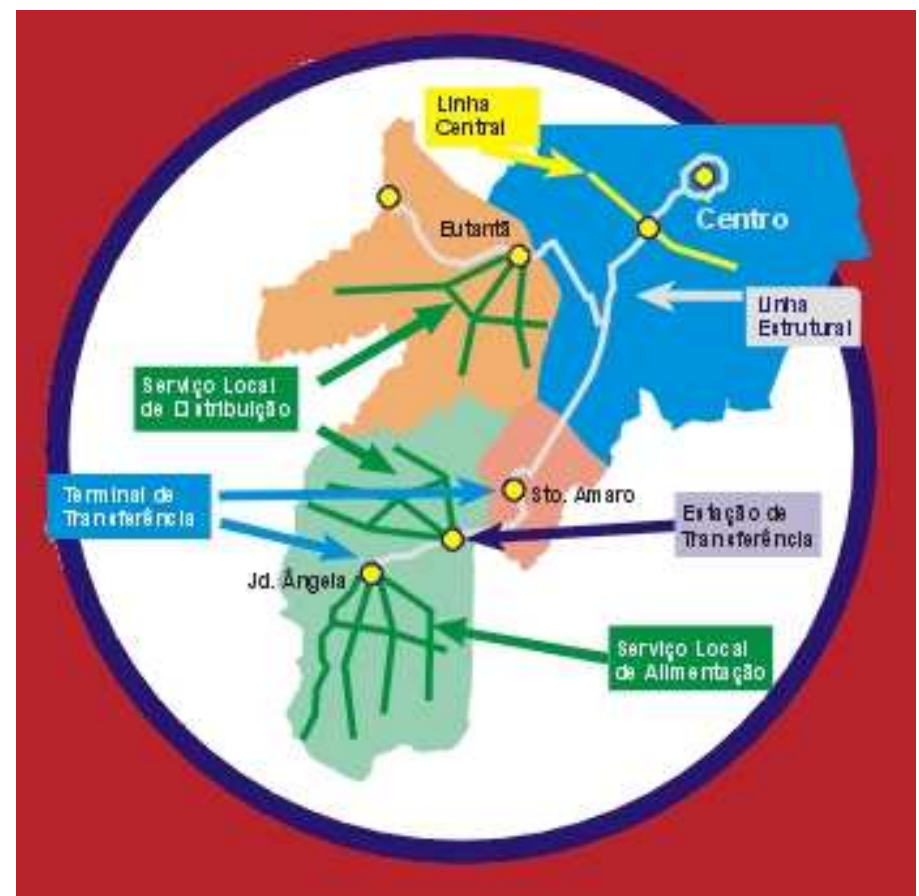

Fonte: www..sptrans.com.br - acesso em 27.05.2005

O sistema é composto de Subsistema Estrutural, em que veículos de médio e grande porte, sejam eles articulados, biarticulados ou comuns, operam em linhas que cobrem demandas elevadas e integram diversas regiões às áreas centrais da cidade. Este subsistema corresponde aos principais eixos viários da cidade, para os quais convergem as linhas saídas dos bairros. O Subsistema Local é operado por ônibus comuns e veículos de menor porte, como micro e mini-ônibus, que alimentam a malha estrutural e atendem deslocamentos internos nos sub-centros, configurando-se em serviços de trajeto curto prestados no interior dos bairros ${ }^{470}$.

Outra característica deste sistema de ônibus é quanto aos corredores de ônibus denominados de "Passa-Rápidos", já referidos em item anterior, que são eixos prioritários

\footnotetext{
${ }^{470}$ www.sptrans.com.br - acesso em 27.05.05.
} 
para os ônibus com faixa à esquerda, sendo que a mudança de um ônibus para outro pode ser feita nos terminais e estações de transferência. Haveria fiscalização eletrônica para substituir grades e muretas nos corredores. Já aludimos anteriormente que as faixas exclusivas à esquerda, com paradas no canteiro central, fazem com que a circulação dos coletivos, que também têm portas à esquerda, não seja interrompida pelos carros que entram e saem das garagens ou fazem conversões à direita ${ }^{471}$.

A proposta da divisão em dois subsistemas, Estrutural e Local, foi uma das principais transformações decorrentes da reorganização do sistema de transporte de São Paulo. Até então, a maioria das linhas convergia para o centro da cidade, forçando parte da demanda a passar pelo centro, mesmo que fosse a um ponto localizado na mesma zona da cidade. $\mathrm{O}$ nome Interligado deriva da proposta de segmentar e interligar os serviços ${ }^{472}$.

O sistema funciona com a entrada do passageiro em um veículo do Subsistema Local, no seu próprio bairro, que o leva até uma avenida por onde circulam as linhas maiores, do Subsistema Estrutural. A partir daí, o passageiro pode ir ao centro da cidade, pelo próprio Subsistema Estrutural, ou alcançar outro bairro da região, tomando um novo veículo do Subsistema Local ${ }^{473}$. Este sistema garante, também, racionamento de veículos, quer dizer, a empresa pode diminuir a quantidade de veículos em circulação, pois aproveita os veículos do sistema estrutural para transportar pessoas de diversos pontos que se "encontram" no terminal de transferência, que funciona como um $h u b$ de transporte.

O município de São Paulo foi dividido em nove macrorregiões, para a finalidade do projeto Interligado, que, em 2007, abarcava 1.327 linhas. Os ônibus de cada macrorregião foram pintados com uma cor específica, o que funciona como uma identidade visual para o passageiro reconhecer a região de procedência dos veículos, sejam eles ônibus, microônibus

\footnotetext{
${ }^{471}$ www.sptrans.com.br - acesso em 27.05.05.

${ }^{472}$ Ibidem.

${ }^{473}$ Ibidem.
} 
ou mini-ônibus. Na região central do município, os veículos seriam estampados por imagens do centro velho de São Paulo.

Figura 8 - Município de São Paulo Áreas de Divisão para Operação do Sistema Interligado
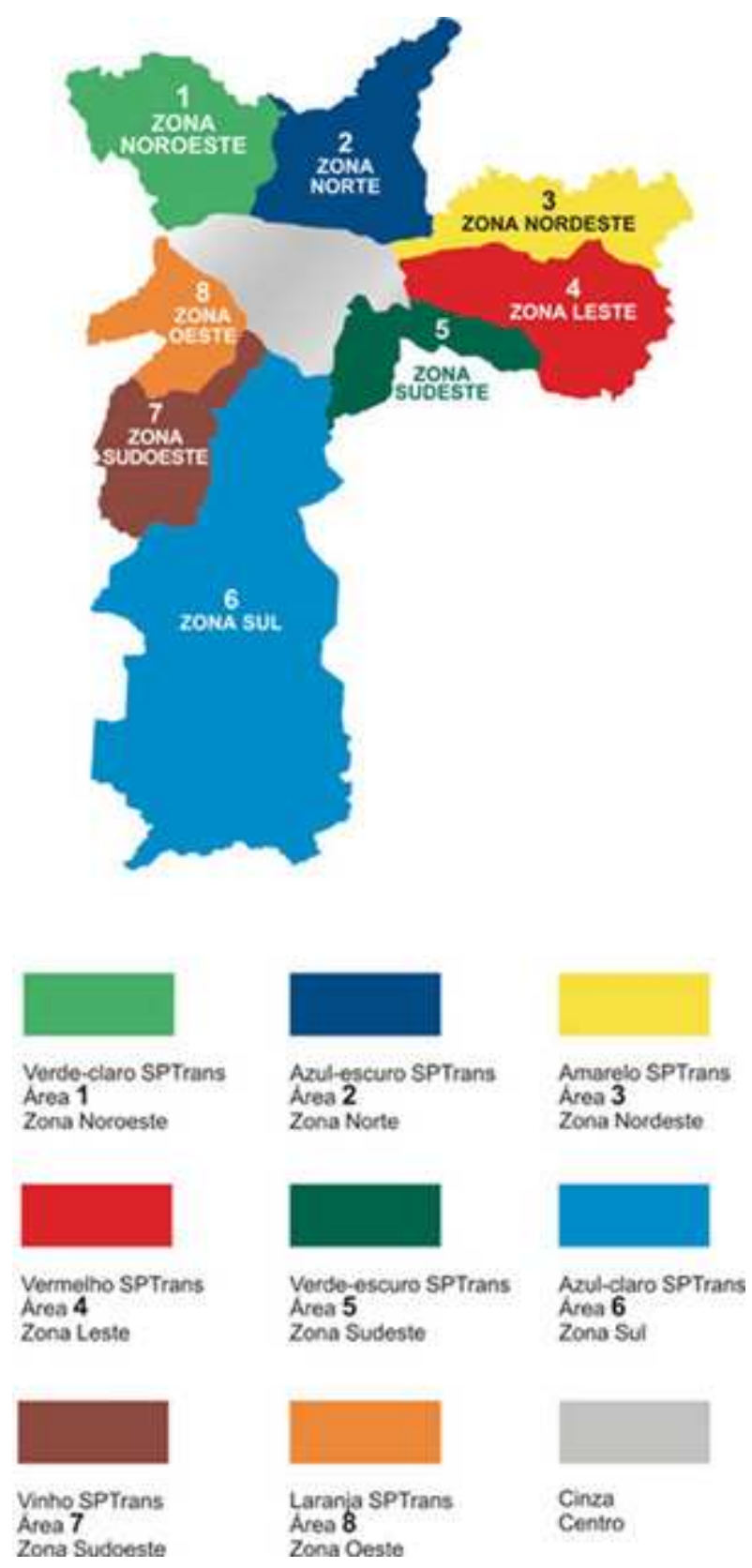

Fonte: www..sptrans.com.br - acesso em 27.05.2005 
Quanto à distribuição das linhas das macrorregiões para as empresas contratantes, as linhas dos subsistemas estrutural e local e dos equipamentos de acesso e transferência que compõem o Interligado nas oito regiões fora do centro passaram por licitação. A área central não fez parte da licitação, sendo que as atividades ali devem envolver todos os operadores do sistema $^{474}$.

Dados da Pesquisa O-D 1997, analisados pela SMT-SP, mostraram que 30\% de todas as viagens realizadas no município de São Paulo permanecem na mesma região de origem, comprovando que as atividades econômicas encontram-se dispersas pela área urbana. A pesquisa revelou ainda que $60 \%$ das viagens rumam proporcionalmente para sub-centros mais próximos e para a região central do município. A SMT-SP afirma que há grandes modificações na distribuição das viagens da população a partir do momento em que houve a criação de novas centralidades nos centros dos bairros dos diversos municípios que compõem a RMSP, conforme já foi aludido na primeira parte desta Tese.

Desta forma, é importante que haja linhas de transporte coletivo inter-regionais. No entanto, a área central do município de São Paulo é também pólo de atração de viagens da população dos outros municípios da RMSP. As linhas de ônibus que vêm de outros municípios com direção ao centro da capital, à medida que ingressam na região central, assumem "um papel distribuidor das viagens internas semelhantes ao das pequenas linhas de bairro." ${ }^{475}$ Quando os ônibus de longo percurso, em seu trajeto rumo ao centro, se aproximam do ponto de chegada, já desembarcaram parte considerável de seus passageiros. Cerca da metade destes usuários tem como destino os pólos regionais da Lapa, Penha, Santo Amaro e Pinheiros. "A reformulação do transporte coletivo sobre pneus passa, portanto, pela necessidade de reaproveitamento destes lugares vagos nos veículos que entram no centro

\footnotetext{
${ }_{475}^{474}$ http://portal.prefeitura.sp.gov.br/secretarias/transportes/ - acesso em 10.01.2008.

475 Ibidem.
} 
expandido [...]" "476. Daí a criação do Subsistema Local, que conecta os bairros, a partir de ônibus e/ou microônibus, com o Subsistema Estrutural, que recolhe as pessoas que efetivamente irão até o ponto final, diminuindo, desse modo, a quantidade de ônibus, o que beneficia o trânsito. Observamos este sistema em funcionamento em diversos municípios visitados por nós nos trabalhos de campo.

Há vias localizadas em pontos estratégicos da cidade de São Paulo, posicionadas em lugares por onde passa grande número de linhas estruturais e locais onde se localizariam estações de transferência ${ }^{477}$ do sistema Interligado.

Os terminais de ônibus maiores, para onde convergem as linhas estruturais e locais, têm sido dotados de tecnologia capaz de monitorar as chegadas e partidas de veículos, detectando problemas operacionais e tentando solucioná-los. São, por isso, chamados de terminais inteligentes, e pretendem ser mais do que um ponto de baldeações de uma linha para outra. O sistema Interligado também conta com Centrais de Operação das Concessionárias (COCs), que também monitoram veículos e promovem soluções para eventuais ocorrências. Há ainda comunicação entre estas Centrais e órgãos como a SPTrans, CET e Metrô para que, em conjunto, haja soluções gerais com relação à operação dos ônibus coletivos e do trânsito de uma forma geral. A SMT-SP afirma que

A tecnologia dos "terminais inteligentes" está implantada em 12 dos 22 terminais municipais. Fazem parte desta lista seis construções recentes (Parelheiros, Jardim Ângela, Lapa, Pirituba, Varginha e Guarapiranga), e seis adaptações em obras mais antigas na cidade (Bandeira, João Dias, Capelinha, Cidade Tiradentes, Santo Amaro e AE Carvalho). ${ }^{478}$

\footnotetext{
${ }^{476} \mathrm{http}: / /$ portal.prefeitura.sp.gov.br/secretarias/transportes/ - acesso em 10.01.2008.

477 Estas estações seriam necessárias para que nelas se fizesse a cobrança da passagem. Diversamente, com a cobrança no interior do ônibus, há demora para que ele saia do ponto, impedindo que os demais coletivos que também estão no corredor prossigam viagem. Este fenômeno vem ocorrendo em razão de não se ter dado prosseguimento no projeto das estações de transferência, previstas no Plano de Transportes 2001-2004. Algumas delas devem receber pelo menos 500 passageiros no horário de pico da manhã, e portanto necessitariam dispor de infra-estrutura e equipamentos urbanos compatíveis com a demanda. Estima-se que $40 \%$ das transferências ocorram em terminais, no pico da manhã, e outros $40 \%$ aconteçam nas estações de transferência, sendo apenas os $20 \%$ restantes realizados ao longo dos demais pontos de ônibus da cidade (Ibidem).

${ }^{478}$ Ibidem.
} 
De acordo com a SMT-SP, os terminais em projeto, Grajaú e São Miguel, também terão a tecnologia inteligente acima descrita. Em 2007, encontravam-se em funcionamento os seguintes terminais de ônibus, com suas respectivas localizações:

\section{Quadro 5 - Município de São Paulo Terminais de ônibus e sua localização}

\begin{tabular}{|c|c|}
\hline Terminal & Localização \\
\hline A.E. Carvalho & Av. Imperador, 1.401 \\
\hline Amaral Gurgel & R. Amaral Gurgel sob o Elevado Costa e Silva s/n \\
\hline Aricanduva & Av. Aricanduva, 86 - Penha \\
\hline Bandeira & Pça. Da Bandeira, s/n - Centro \\
\hline Capelinha & Estr. de Itapecerica, 3.222 - Capão Redondo \\
\hline Carrão & Av. 19 de Janeiro, $884^{\text {a }}$ - Vila Carrão \\
\hline Casa Verde & R. Baía Formosa, 80 - Casa Verde \\
\hline Cidade Tiradentes & R. Sara Kubitscheck, 165 - Cidade Tiradentes \\
\hline Grajaú & Av. Belmira Marin com Giovanni Bononcinni \\
\hline Guarapiranga & Av. Guarapiranga com Estrada do M Boi Mirim \\
\hline Jardim Ângela & Estr. M Boi Mirim com r. Marcelino Coelho \\
\hline Jardim Britânia & R. Pierre Renoir s/n (em frente ao $\mathrm{n}^{\circ}$ 92) \\
\hline João Dias & Av. João Dias, 3.589 - Jd. Monte Azul \\
\hline Lapa & Pça. Miguel Dell Erba com Viad. Com. Elias Nagib Blein \\
\hline Parelheiros & Estr.da Colônia com r.Gentil Chunck Rochel \\
\hline Parque D. Pedro II & Av. do Exterior, s/ n - Pq. D. Pedro II \\
\hline Penha & Av. Cangaíba, 130 - Penha \\
\hline Pirituba & R. Doutor Felipe Pinel, s/n \\
\hline Princesa Isabel & Al. Glete, 433 - Campos Elíseos \\
\hline Santo Amaro & Av. Padre José Maria, 400 - Santo Amaro \\
\hline São Miguel & R. Idioma Esperanto com av. Dr. José Artur Nova \\
\hline Varginha & Av. Paulo G. Reimberg com av. Luís Supertri \\
\hline V. Nova Cachoeirinha & Av. Inajar de Souza, s/n - V.N. Cachoreirinha \\
\hline Vila Prudente & R. Trocari, s/n - Vila Prudente \\
\hline
\end{tabular}

Fonte: http://portal.prefeitura.sp.gov.br/secretarias/transportes/ - acesso em 10.01.2008

Porém, esta sistemática só seria possível com a bilhetagem eletrônica, instituída em 2004 no município de São Paulo, com o Bilhete Único, um cartão que armazena valores para o pagamento de passagens de ônibus, microônibus e vans, usado tanto nos meios como nos terminais de transferência. Até então, pagava-se uma tarifa a cada troca de linha. Os terminais de integração eram a única possibilidade de baldeação gratuita, mas poderiam tornar o percurso mais longo. O Bilhete Único é passado por um validador no terminal ou no próprio 
meio de transporte, sendo descontados os créditos no valor da tarifa existente no cartão. Assim que foi implantado, o usuário poderia usar quantos meios quisesse num intervalo de duas horas. A partir de 2006, transformações foram instituídas ${ }^{479}$, e, então, foi limitada a quantidade de quatro ônibus a serem utilizados pelo passageiro dentro das duas horas, mediante cadastramento do usuário. Inicialmente, o uso do Bilhete Único era limitado aos meios rodoviários. A partir de 2005, passou a ser utilizado também no sistema metroviário, porém, paga-se um valor maior pela tarifa ${ }^{480}$, e não é dado o direito de usar o metrô novamente, mesmo no período de duas horas, valendo seu uso somente para mais quatro ônibus, no período de duas horas. $\operatorname{Rosa}^{481}$ calcula que houve um aumento de $50 \%$ do uso do ônibus após a entrada do Bilhete Único, em 2005, em relação a 2003. Porém, este ganho de passageiros não significou muito mais passageiros pagantes. $\mathrm{O}$ autor calculou em $5 \%$ apenas o aumento da receita. Portanto, a Prefeitura aumentou o subsídio repassado às empresas. Um funcionário da SPTrans nos informou que

\begin{abstract}
A remuneração das empresas é realizada com base no passageiro transportado. Cada uma das oito áreas operacionais tem valores diferenciados de remuneração por passageiros transportados, com base em planilha de custos. A passagem paga em dinheiro pelo usuário fica em poder da operadora, como adiantamento. A diferença é paga posteriormente pela SPTrans ${ }^{482}$.
\end{abstract}

A SPTrans ${ }^{483}$ registrou um índice de aprovação de $80 \%$ do sistema tarifário temporal do Bilhete Único, sendo um importante instrumento de inclusão social. Além disso, as pessoas que residem muito longe conseguiram ter mais chances de se empregar em áreas com maior disponibilidade de empregos porque os empregadores gastam menos com o transporte de seus funcionários, fazendo uso da tarifa temporal. Rosa ${ }^{484}$ comenta que após a implantação

\footnotetext{
${ }^{479}$ A Prefeitura divulgou através da mídia que estas mudanças ocorreram devido a fraudes que vinham ocorrendo com o uso do Bilhete Único.

${ }^{480}$ Este assunto já foi abordado no item referente ao modo metroviário.

${ }^{481}$ ROSA, 2006.

${ }^{482}$ Informação fornecida por funcionário da SPTrans em entrevista concedida a nós em 05.05.2008.

${ }^{483}$ SPTRANS, 2005 apud Rosa, 2006.

${ }^{484}$ Ibidem.
} 
do Bilhete Único, verificou-se ser seu benefício irreversível e que deverão ser tomadas outras formas de compensação para sanar o desequilíbrio financeiro, que tem transformado o sistema em alvo de críticas. O autor salienta que o bilhete eletrônico

\begin{abstract}
permite outras facilidades na operação de sistemas nas quais as tarifas podem ser alteradas por diversos fatores (valores diferentes em relação à distância percorrida, diferenciação quanto ao dia útil e final de semana, diferenciação quanto ao horário pico ou de vale, diferentes tarifas quanto aos diversos tipos de usuários, bonificação em forma de desconto para o usuário freqüente, tarifas reduzidas para usuários de baixa renda etc.), ensejando uma ampliação futura de sua aplicação. ${ }^{485}$
\end{abstract}

Teoricamente, o Sistema Interligado e o uso da bilhetagem eletrônica são coerentes com a realidade da metrópole, retirando ônibus e linhas muito longas, quebrando-as nos terminais e racionalizando a quantidade de ônibus que circula. O Sistema Interligado não cobre todo o município de São Paulo. A questão é que, com a mudança de gestão, a prefeitura atual (2005-2008) não ampliou os Passa-Rápidos e ainda diminuiu sua fiscalização. O que se vê constantemente são carros circulando pelos corredores de ônibus. A CET passou por um processo de sucateamento, com operadores sem rádio e poucos guinchos para remover veículos quebrados ${ }^{486}$. A culpa pelo excesso de ônibus e trânsito nos corredores recai sobre o excesso de passageiros e o Bilhete Único, ou seja, a população,é prejudicada e também culpada pela superlotação dos ônibus. Em artigo na Folha de São Paulo de 20.03.08, o exsecretário de Transportes do município de São Paulo da gestão 2001-2004 afirmou: “O que esperar dessa situação? Apenas que mais pessoas comprem carro ou moto, aumentando os congestionamentos e alimentando um círculo vicioso em que os ganhos de produtividade que se obtêm nas empresas são perdidos na circulação." ${ }^{487}$

\footnotetext{
485 ROSA, 2006, p.53.

${ }^{486}$ Reportagem da Folha de São Paulo de 13.04.2008 afirma que a CET tem deficiências básicas que não permitem viabilizar a melhoria do tráfego na cidade. A existência de poucos semáforos inteligentes é um item bastante criticado, pois os antigos não permitem ajustes de acordo com o fluxo dos cruzamentos. Outro item criticado é que os funcionários 'marronzinhos' não dispõem de rádios "para avisar sobre ocorrências que atrapalham a fluidez, sendo orientados a ligar a cobrar de celular pessoal ou orelhão." (IZIDORO, 2008, p.13). ${ }^{487}$ ZARATTINI, 2008.
} 
A Pesquisa O-D 1997 mostrou a situação de privilégio em que se encontra o transporte individual, que contabiliza metade dos deslocamentos motorizados da metrópole, contribuindo decisivamente para uma diminuição da velocidade das viagens. As viagens por modo coletivo, em 1997, eram 2,3 vezes mais demoradas e duas vezes mais caras do que os deslocamentos por automóvel ${ }^{488}$.

O uso dos ônibus sempre foi superior ao uso dos outros modos de transporte coletivo. A Tabela 19 mostra que, entre 1977 e 2002, houve diminuição do percentual de viagens em ônibus em relação ao total de viagens motorizadas, na RMSP. As viagens em ônibus passaram de praticamente a metade das viagens motorizadas, em 1977, para cerca de um terço, em 2002 O fato pode estar relacionado à perda de passageiros para o sistema de ônibus clandestinos e de lotações, para o sistema de metrô, e ainda ao aumento do número de viagens em automóveis particulares. Cabe lembrar que, nas integrações ônibus-metrô, as viagens são computadas para o modo metrô, já que, na hierarquia entre os modos de transporte utilizada pela Pesquisa O-D, para viagens com o uso de dois ou mais meio de transporte, o metrô está acima do ônibus. ${ }^{489}$

\section{Tabela 19 - Região Metropolitana de São Paulo Evolução das viagens motorizadas diárias em Ônibus 1977-1987-1997-2002}

\begin{tabular}{|l|c|c|c|c|c|c|c|c|}
\hline & \multicolumn{2}{|c|}{1977} & \multicolumn{2}{c|}{1987} & \multicolumn{2}{c|}{1997} & \multicolumn{2}{c|}{$\mathbf{2 0 0 2}$} \\
\hline & $\mathrm{X} 1.000$ & $\%$ & $\mathrm{X} 1.000$ & $\%$ & $\mathrm{X} 1.000$ & $\%$ & X 1.000 & $\%$ \\
\hline VIAGENS EM ÔNIBUS & 8.659 & 54,12 & 8.077 & 43,08 & 7.929 & 38,45 & 8.310 & 33,97 \\
\hline $\begin{array}{l}\text { TOTAL DE VIAGENS } \\
\text { MOTORIZADAS }\end{array}$ & 15.999 & 100,0 & 18.750 & 100,0 & 20.619 & 100,0 & 24.466 & 100,0 \\
\hline
\end{tabular}

Fonte: CIA. DO METROPOLITANO DE SÃO PAULO. Aferição da Pesquisa O-D 1997, 2002. Organização da autora.

Muitos dos demais municípios da RMSP também operam sistemas próprios de ônibus, como pode ser visualizado na Tabela 20.

\footnotetext{
${ }^{488}$ SÃO PAULO, s.d.

${ }^{489}$ Conforme já salientamos, de acordo com a Cia. do Metropolitano de São Paulo (2002), a hierarquia entre os meios de transporte se dá da seguinte maneira: metrô - trem - transporte fretado - transporte escolar - ônibus lotação - táxi - pessoa dirigindo automóvel - passageiro de automóvel - motocicleta - bicicleta - outros e a pé.
} 
Tabela 20 - Região Metropolitana de São Paulo Sistema de ônibus municipal em 1997 e 2003

\begin{tabular}{|c|c|c|c|c|c|c|c|c|c|c|}
\hline \multirow[t]{2}{*}{$\begin{array}{l}\text { MUNICÍPIOS E } \\
\text { SUB-REGIÕES }\end{array}$} & \multicolumn{2}{|c|}{$\begin{array}{c}\text { Serviço de } \\
\text { transporte } \\
\text { municipal por } \\
\text { ônibus }\end{array}$} & \multicolumn{2}{|c|}{$\begin{array}{c}\text { Empresas de } \\
\text { onibus em } \\
\text { operação }\end{array}$} & \multicolumn{2}{|c|}{$\begin{array}{l}\text { Linhas } \\
\text { regulares } \\
\text { de ônibus }\end{array}$} & \multicolumn{2}{|c|}{$\begin{array}{l}\text { Ônibus e/ou } \\
\text { trólebus em } \\
\text { operação }\end{array}$} & \multicolumn{2}{|c|}{$\begin{array}{c}\text { Passageiros } \\
\text { transportados por } \\
\text { ônibus (x1.000) }\end{array}$} \\
\hline & 1997 & 2003 & 1997 & 2003 & 1997 & $\begin{array}{c}200 \\
3\end{array}$ & 1997 & 2003 & 1997 & 2003 \\
\hline \multicolumn{11}{|l|}{ CENTRO } \\
\hline São Paulo & sim & sim & 52 & (1) & 829 & 592 & 10.723 & 14.793 & 1.611 .025 & 1.201 .341 \\
\hline \multicolumn{11}{|l|}{ OESTE } \\
\hline Barueri & sim & sim & 2 & 1 & 21 & 20 & 116 & 113 & 19.073 & 11.422 \\
\hline Carapicuíba & sim & (1) & 3 & (1) & 27 & (1) & 164 & $(1)$ & 24.596 & (1) \\
\hline Cotia & $\operatorname{sim}(2)$ & $\operatorname{sim}$ & 1(2) & 1 & $19(2)$ & 32 & $29(2)$ & 37 & $4.572(2)$ & 6.509 \\
\hline Itapevi & $\operatorname{sim}$ & $\operatorname{sim}$ & 1 & 1 & 13 & 23 & 35 & 40 & 6.119 & 5.756 \\
\hline Jandira & $\operatorname{sim}$ & $\operatorname{sim}$ & 1 & 1 & 8 & 11 & 25 & 27 & 4.449 & 2.918 \\
\hline Osasco & $\operatorname{sim}$ & $\operatorname{sim}$ & 3 & 3 & 39 & 43 & 285 & 312 & 45.125 & 45.837 \\
\hline $\begin{array}{c}\text { Pirapora do Bom } \\
\text { Jesus }\end{array}$ & não & não & 1(3) & (1) & 1(3) & (1) & 1(3) & (1) & $14(3)$ & (1) \\
\hline Santana do Parnaíba & não & sim & $2(2)$ & 2 & $2(2)$ & 9 & $5(2)$ & 28 & $690(2)$ & 2.424 \\
\hline $\begin{array}{c}\text { Vargem Grande } \\
\text { Paulista } \\
\end{array}$ & (1) & $\operatorname{sim}$ & (1) & (1) & (1) & (1) & (1) & (1) & (1) & $(1)$ \\
\hline \multicolumn{11}{|l|}{ SUDOESTE } \\
\hline Embu & $\operatorname{sim}$ & $\operatorname{sim}$ & 2 & 2 & 7 & 6 & 37 & 9 & $5.721(1)$ & (1) \\
\hline Embu-Guaçu & $\operatorname{sim}$ & Não & 2 & (1) & 7 & (1) & 17 & (1) & 30 & (1) \\
\hline Itapecerica da Serra & $\operatorname{sim}$ & sim & 2 & 2 & 9 & 7 & 32 & 20 & $1.575(2)$ & 900 \\
\hline Juquitiba & sim & sim & 1 & 2 & 7 & (1) & 9 & (1) & 576 & $(1)$ \\
\hline $\begin{array}{l}\text { São Lourenço da } \\
\text { Serra }\end{array}$ & $\operatorname{sim}$ & $\operatorname{sim}$ & 1 & 1 & 1 & 1 & 1 & 1 & 39 & 36 \\
\hline Taboão da Serra & $\operatorname{sim}(2)$ & $\operatorname{sim}$ & $4(2)$ & 2 & $11(2)$ & 10 & $54(2)$ & 78 & $7.546(2)$ & 6.742 \\
\hline \multicolumn{11}{|l|}{ SUDESTE } \\
\hline Diadema & sim & sim & 3 & 2 & 29 & 25 & 141 & (1) & $22.282(2)$ & $(1)$ \\
\hline Mauá & $\operatorname{sim}$ & $\operatorname{sim}$ & 2 & 2 & 41 & 47 & 140 & 153 & 18.241 & 24.446 \\
\hline Ribeirão Pires & $\operatorname{sim}$ & $\operatorname{sim}$ & 2 & 2 & 26 & 39 & (1) & 47 & 9.144 & 7.296 \\
\hline Rio Grande da Serra & $\operatorname{sim}$ & $\operatorname{sim}$ & 1 & 1 & 7 & 5 & $7(2)$ & 8 & 1.428 & 2.219 \\
\hline Santo André & $\operatorname{sim}$ & $\operatorname{sim}$ & 7 & 7 & 37 & 52 & 312 & 394 & 64.686 & 54.584 \\
\hline $\begin{array}{c}\begin{array}{c}\text { São Bernardo do } \\
\text { Campo }\end{array} \\
\end{array}$ & $\operatorname{sim}$ & $\operatorname{sim}$ & 3 & 1 & 51 & 57 & 280 & 335 & 60.497 & 53.184 \\
\hline São Caetano do Sul & $\operatorname{sim}$ & $\operatorname{sim}$ & 3 & 3 & 7 & 7 & 51 & 58 & 8.007 & 5.361 \\
\hline \multicolumn{11}{|l|}{ LESTE } \\
\hline Biritiba Mirim & $\operatorname{sim}(2)$ & $\operatorname{sim}$ & 1(2) & 1 & $4(2)$ & 12 & $6(2)$ & 10 & $256(2)$ & (1) \\
\hline $\begin{array}{c}\text { Ferraz de } \\
\text { Vasconcelos }\end{array}$ & $\operatorname{sim}$ & $\operatorname{sim}$ & 1 & 1 & 6 & 11 & 30 & 30 & 1.775 & 3.605 \\
\hline Guararema & $\operatorname{sim}$ & $\operatorname{sim}$ & 2 & 2 & 3 & 11 & $12(3)$ & 14 & $56(4)$ & 1.692 \\
\hline Itaquaquecetuba & $\operatorname{sim}$ & $\operatorname{sim}$ & 1 & 1 & 17 & 16 & 85 & 83 & 1.269 & 9.277 \\
\hline Mogi das Cruzes & $\operatorname{sim}$ & $\operatorname{sim}$ & 1 & 1 & 60 & 60 & 91(3) & 155 & $18.545(3)$ & 14.739 \\
\hline Poá & $\operatorname{sim}$ & $\operatorname{sim}$ & 1 & 1 & 4 & 4 & 9 & 11 & 960 & 944 \\
\hline Salesópolis & não & não & (1) & (1) & (1) & (1) & (1) & (1) & (1) & (1) \\
\hline Suzano & sim & sim & 1 & 1 & 21 & 31 & 86 & (1) & 7.664 & (1) \\
\hline \multicolumn{11}{|l|}{ NORDESTE } \\
\hline Arujá & $\operatorname{sim}$ & $\operatorname{sim}$ & 1 & 1 & 9 & (1) & 15 & (1) & (1) & $(1)$ \\
\hline Guarulhos & sim & sim & 5 & 4 & 50 & 81 & 530 & 522 & 61.779 & 59.979 \\
\hline Santa Isabel & $\operatorname{sim}$ & $\operatorname{sim}$ & 1 & 1 & 9 & 9 & 14 & 14 & 635 & 1.196 \\
\hline \multicolumn{11}{|l|}{ NORTE } \\
\hline Caieiras & sim & sim & 1 & 1 & 11 & 12 & 39 & 38 & $3.600(2)$ & 5.764 \\
\hline Cajamar & $\operatorname{sim}$ & $\operatorname{sim}$ & 1 & 1 & 3 & 4 & 750 & 1.117 & (1) & $\begin{array}{l}2.625(5) \\
\text { continua }\end{array}$ \\
\hline
\end{tabular}




\begin{tabular}{|c|c|c|c|c|c|c|c|c|c|c|}
\hline \multirow{2}{*}{$\begin{array}{l}\text { MUNICÍPIOS E } \\
\text { SUB-REGIÕES } \\
\text { Francisco Morato }\end{array}$} & \multicolumn{2}{|c|}{$\begin{array}{c}\text { Serviço de } \\
\text { transporte } \\
\text { municipal por } \\
\text { ônibus }\end{array}$} & \multicolumn{2}{|c|}{$\begin{array}{c}\text { Empresas de } \\
\text { ônibus em } \\
\text { operação }\end{array}$} & \multicolumn{2}{|c|}{$\begin{array}{l}\text { Linhas } \\
\text { regulares } \\
\text { de ônibus }\end{array}$} & \multicolumn{2}{|c|}{$\begin{array}{c}\text { Ônibus e/ou } \\
\text { trólebus em } \\
\text { operação }\end{array}$} & \multicolumn{2}{|c|}{$\begin{array}{c}\text { Passageiros } \\
\text { transportados por } \\
\text { ônibus }(\mathbf{x} 1.000)\end{array}$} \\
\hline & sim & sim & 1 & 1 & 18 & 19 & 60 & 70 & 8.313 & 8.048 \\
\hline Franco da Rocha & sim & $\operatorname{sim}$ & 1 & 1 & 17 & 22 & 86 & 67 & 11.373 & 8.779 \\
\hline Mairiporã & $\operatorname{sim}$ & $\operatorname{sim}$ & 1 & 1 & 23 & 23 & 15 & 39 & 1.554 & 1.800 \\
\hline
\end{tabular}

Fonte: Fundação Seade - Programa de Informação dos Municípios Paulistas

(http://www.seade.gov.br/produtos/imp/index.php - acesso em 12.01.2008); SPTrans (http://www.sptrans.com.br - acesso em 19.01.2008) / Elaboração da autora.

- (1) dado não disponível

- (2) dado referente ao ano de 1995, por falta de dados em 1997

- (3) dado referente ao ano de 1999, por falta de dados em 1997

- (4) dado referente ao ano de 1992, por falta de dados em 1997

- (5) dado referente ao ano de 2006, por falta de dados em 2003

A Tabela 20 nos aponta que, dos 39 municípios da RMSP, 35 possuíam sistema de ônibus municipal em 1997 e 2003, sob regime de concessão/permissão ${ }^{490}$, havendo uma companhia que gerencia o sistema. No caso do município de São Paulo, a SPTrans gerencia as empresas (viações) que têm a concessão das linhas. Em muitos casos, as empresas permissionárias e as concessionárias são gerenciadas pelo próprio órgão público municipal, como secretaria, diretoria ou divisão de transportes. Dependendo do tamanho e população do município, verificamos que há de 1 a 3 viações atuando. No caso de Santo André, há sete. O município de São Paulo contava com 52 empresas (viações) em 1997, mas não há dados sobre o ano de 2003.

Dependendo também da demanda e tamanho dos municípios, há uma quantidade maior ou menor de linhas regulares de ônibus. Quanto à frota de ônibus e/ou trólebus em operação, verifica-se que houve aumento entre 1997 e 2003 em 15 municípios. Em 10 municípios, praticamente não houve alteração da frota em operação e em quatro houve diminuição do número de veículos em operação. Há ausência de dados em dez municípios.

\footnotetext{
${ }^{490}$ A empresa permissionária tem a permissão de realizar determinados trajetos ou determinadas linhas. Já a concessionária obtém o direito de operação em área exclusiva.
} 
A quantidade de passageiros transportados sofreu transformações na maioria dos municípios da RMSP entre 1997 e 2003, tendo diminuído bastante em 12 municípios, como São Paulo ${ }^{491}$, Barueri, Itapevi, Jandira, Itapecerica da Serra, Taboão da Serra, Ribeirão Pires, Santo André, São Bernardo do Campo, São Caetano do Sul, Mogi das Cruzes e Franco da Rocha, e tendo diminuído sensivelmente em 3 municípios: Francisco Morato, São Lourenço da Serra e Poá. Já em 9 municípios, houve aumento da quantidade de passageiros transportados, caso dos municípios de Mairiporã, Caieiras, Santa Isabel, Ferraz de Vasconcelos, Rio Grande da Serra, Mauá, Santana do Parnaíba, Osasco e Cotia; em alguns municípios há uma discrepância muito grande entre os dados de 1997 e 2003, como em Guararema e Itaquaquecetuba. Os demais municípios não apresentam os dados em um dos anos enfocados, nem em anos próximos, então não pudemos fazer comparações.

Tecnologicamente, o sistema de transporte coletivo por ônibus pode ser dividido em duas frentes de atuação que se completam: o sistema de ônibus a diesel e gás natural e o sistema de trólebus. O ônibus com célula a combustível de hidrogênio vem sendo testado e iria começar a operar ainda como protótipo em 2008, no Corredor Metropolitano São MateusJabaquara.

Esta questão não é objetivamente o foco de nossa pesquisa, no entanto, ela está incluída quando se discute a questão do conforto do usuário de ônibus. Os ônibus a diesel são menos confortáveis que os trólebus por serem mais barulhentos e trepidarem mais. A questão ambiental também é relevante, já que os trólebus, movidos a energia elétrica, poluem muito menos.

Os depoimentos obtidos nos trabalhos de campo mostram que a qualidade do sistema melhorou muito desde nossa pesquisa realizada no Mestrado, no final dos anos 1990. Porém, ainda há muito a ser aperfeiçoado. Ao conversar com um trabalhador que mora em Santo

\footnotetext{
491 Já foi aludido na Tabela 18 que, a partir de 2004, a quantidade de passageiros cresceu. No entanto, optamos por trabalhar, na Tabela 20, com o ano de 2003 por ele congregar os dados dos demais municípios da RMSP.
} 
Amaro, no município de São Paulo, que usa três ônibus para chegar ao seu trabalho, na região do Sacomã, no mesmo município, o uso do Bilhete Único foi elogiado. O primeiro ônibus que toma é de seu bairro para o Terminal João Dias. Lá, pega o segundo ônibus, com destino a Ana Rosa. Desce no Terminal Vila Mariana e aí toma o terceiro ônibus, para o Terminal Sacomã. Pela manhã, gasta de 40 a 50 minutos. Para voltar, no final da tarde, de uma hora até uma hora e quarenta minutos, dependendo do trânsito. Com chuva, já demorou duas horas e meia entre o Sacomã e o Terminal João Dias. Ele acha que alguns ônibus são novos e confortáveis, porém há ainda veículos muito velhos e inseguros. Contou-nos ele que, certa vez, a porta de um ônibus abriu de repente, podendo causar acidentes. Ele acha que muitos motoristas não têm paciência e são imprudentes, não esperam todos desembarcarem. Este trabalhador considerou que "tem mesmo esse lado chato, é uma rotina meio ruim"

Trabalhadora que usa a linha Parque das Américas, da Empresa de Auto-Ônibus Santo André (Viação EAOSA), em Santo André, observou que o ônibus em si é confortável e limpo, mas a sua demora para chegar ao ponto é impressionante, além de não cumprir nenhum horário. Um veículo já quebrou o freio em uma de suas viagens, tendo o motorista feito uma manobra perigosa para poder segurar o ônibus. Queixou-se ainda do fato de os motoristas dirigirem muito rápido.

Outra questão presente nas entrevistas foi a da necessidade de se pegar muitos ônibus para se percorrer o trajeto necessário ao deslocamento entre a casa e o trabalho: "São três ônibus para ir e três para voltar. Já estou acostumado, já está na minha cabeça que tenho de pegar os três ônibus. À tarde, depois do trabalho, é muito cansativo. Dependendo do horário demora uma hora, se atrasar, uma hora e meia" ${ }^{493}$.

No Terminal Jabaquara, município de São Paulo, conversamos com uma mulher que trabalha no setor de serviços no centro de São Paulo e reside no Grajaú, Zona Sul do

\footnotetext{
492 Informação pessoal, 30/05/07.

${ }^{493}$ Informação pessoal, 30/05/07.
} 
município. Era um final de tarde chuvoso e a usuária estava há uma hora na fila, sendo que iria enfrentar mais duas horas no percurso até sua residência. Neste Terminal, os usuários organizam-se em várias filas em um único ponto. No da linha Grajaú via Sesc, já havia quatro filas. Normalmente, não há cortadores de fila, segundo a entrevistada. Há muitas filas porque quando os usuários percebem que vão ficar de pé no ônibus, começam uma nova fila. Se a pessoa tem pressa e não se importa de ir de pé, pode entrar na fila anterior. Segundo a trabalhadora entrevistada, os ônibus são muito velhos e os motoristas não respeitam os passageiros. Ela desabafa:

De manhã são 50 minutos, saio cedo, é rápido. Para voltar, são duas horas e meia. Estou ficando doente por causa deste ônibus, é muito desgastante. Na avenida Interlagos tem alagamentos. Depois que o ônibus chegar, o motorista vai descansar, e nós não podemos entrar no ônibus, pelo menos para sentar. É um absurdo, deveria haver um outro motorista para já adiantar o trajeto ${ }^{494}$.

Na mesma tarde chuvosa, no Terminal Jabaquara, verificamos que o ponto da linha Terminal Varginha estava lotado, com seis filas. Informaram-me que, com trânsito bom, até o Terminal Varginha o trajeto demora uma hora e meia, e com trânsito ruim, duas horas. Para aquele Terminal, só há esta linha de ônibus. Do Terminal Varginha, uma entrevistada que trabalha no setor de serviços pegaria outro ônibus.

\footnotetext{
Se passar de duas horas, tenho que pagar este segundo ônibus, pois extrapola o horário do Bilhete Único. Pela manhã, saindo às $6 \mathrm{~h} 30$ tem menos gente no ônibus, mas nunca consigo um lugar para sentar. Nesta linha, os ônibus são novos e se fossem mais vazios, seriam mais confortáveis. $\mathrm{O}$ trajeto entre minha casa e o trabalho é mais cansativo que o próprio dia de trabalho ${ }^{495}$.
}

Muitos usuários reprovam a necessidade de realizar baldeações em terminais, pois consideram que prolonga o tempo de viagem. Em Barueri, o sistema é como o Interligado de São Paulo. Trabalhadora e moradora do município de Barueri é obrigada a realizar baldeação no Terminal porque não há ônibus direto de seu bairro até Alphaville, onde trabalha. Apesar

\footnotetext{
${ }^{494}$ Informação pessoal, 30/05/07.

${ }^{495}$ Informação pessoal, 30/05/07.
} 
de ser relativamente próximo, a trabalhadora reclama, pois acha um transtorno precisar fazer baldeação no Terminal, considerando perda de tempo. No primeiro ônibus, que sai de seu bairro até o terminal, o trajeto dura apenas dez minutos. Mas ao chegar ao Terminal, o segundo ônibus sai de 30 em 30 minutos e, se o perder, ela terá de esperar o próximo por meia hora. Na volta para casa, o ônibus que pega no terminal até sua residência é demorado. Como são operados pela viação Benfica, que é a única no município, a entrevistada acha que a empresa acaba diminuindo a quantidade de ônibus para economizar, sabendo que não há concorrência.

Moradora do Parque do Lago, próximo ao Jardim Ângela, na Zona Sul do município de São Paulo que trabalha na Aclimação, no mesmo município, informa que pega ônibus em seu bairro às 5 h45 até a avenida Santo Amaro, onde pega outro ônibus para o Terminal Ana Rosa. Ela afirmou que o primeiro já vem lotado de outro bairro. Apesar de ter freqüência de 15 em 15 minutos, como há muita demanda, todos os ônibus são muito cheios. Esta linha vem direto até o Terminal Ana Rosa, assim como a que pega na avenida Santo Amaro, porém como a primeira linha dá mais voltas, a trabalhadora opta por trocar de ônibus, o que é possível graças ao Bilhete Único. O trajeto, com um ônibus apenas, leva duas horas e meia. Se fizer a baldeação e tomar o segundo ônibus, é um pouco mais rápido.

Ela nos contou que o ônibus que pega na avenida Santo Amaro demora e é muito lotado. No trajeto, passa pela avenida Eng. Luis Carlos Berrini, onde muitos passageiros descem. Além de os veículos desta linha serem muito velhos, não são seguros, muitas vezes têm janelas quebradas, são muito desconfortáveis e por causa de serem muito cheios, não se consegue sentar. A trabalhadora desabafa, explicando que, no corredor de ônibus da avenida M’Boi Mirim, há fiscais

para darem apoio aos passageiros, mas não dão apoio nenhum, ficam segurando os ônibus para não saírem com a porta aberta, e acaba atrasando os ônibus que estão atrás. É um exagero ficar segurando o ônibus. Para fechar a porta tem que socar todo mundo que nem numa lata de sardinha para o ônibus poder sair. As pessoas ficam irritadas, quebraram o vidro do ônibus, queriam quebrar o ônibus inteiro. Isso atrasa 
muito os ônibus. A solução seria colocar mais ônibus e tirar as latas velhas. Os ônibus do centro são melhores, mas os da nossa periferia são piores. Por quê? Os que moram no centro são melhores que os que moram na periferia? ${ }^{496}$.

A pergunta ecoa, que resposta posso dar a esta entrevistada? Muitos perguntam se meu trabalho vai ajudar a melhorar a vida sofrida nos longos deslocamentos em ônibus cheios e demorados.

Ouvimos depoimentos também de moradores dos demais municípios da RMSP em relação aos sistemas municipais de ônibus. Usuárias dos ônibus de Suzano, trabalhadoras do setor de serviços, comentaram que os veículos da Viação Suzano que fazem o trajeto do centro para os bairros passam aproximadamente a cada 30 minutos, e que algumas vezes vêm mais rápido. O sistema tem melhorado bastante, com ônibus mais confortáveis e mais linhas, mas tudo é novidade, pois há algum tempo o serviço não era bom. O terminal de ônibus está sendo reformado.

Em Rio Grande da Serra, escutamos reclamação em relação ao sistema daquele município. Os ônibus são velhos, sujos e lentos, além de demorarem a passar. Uma trabalhadora que entrevistamos no Terminal Ribeirão Pires e que reside em Rio Grande da Serra e trabalha no município de São Paulo, usa o trem e, ao invés de descer em Rio Grande da Serra e tomar um ônibus municipal daquele município, prefere descer em Ribeirão Pires e tomar um ônibus intermunicipal, que é muito mais seguro, em uma linha com veículos novos. Muitos comentários sobre o sistema de ônibus municipal de Ribeirão Pires nos fizeram entender que os trabalhadores que dele se utilizam podem contar com um bom sistema, com ônibus confortáveis, rápidos e seguros. Por outro lado, uma trabalhadora do setor de serviços que usa a Viação Ribeirão Pires reclamou que os ônibus têm constantes problemas de manutenção e quebram com frequiência. Além disso, a demora na espera pelo ônibus é muito

\footnotetext{
${ }^{496}$ Informação pessoal, 28/05/07.
} 
cansativa. Ela acredita que o trajeto que faz em uma hora de ônibus seria reduzido a 20 minutos de automóvel.

Em Itaquaquecetuba, conversamos com trabalhadora do setor de serviços que reclamou da demora dos ônibus, que são até confortáveis, mas chegam a demorar uma hora para chegar no ponto. Além disso, os ônibus não conseguem atender ao município todo, que tem cerca de 50 bairros.

A mesma reclamação veio de outra trabalhadora do setor de serviços que aguardava um ônibus na Estrada de Santa Isabel, em Itaquaquecetuba. Ela aguarda o ônibus neste local, pois se for até o centro de Itaquaquecetuba, talvez não consiga entrar no ônibus, que fica muito cheio. Nos finais de semana, os ônibus demoram mais ainda, e ela já chegou a ficar uma hora e vinte minutos no ponto. Ela percebeu que quando o motorista vê que os passageiros não conseguirão mais entrar no ônibus, ele nem pára no ponto. Os usuários têm de esperar mais uma hora por outro ônibus. Esta entrevistada reclama que, curiosamente, quando trabalhava em São Paulo, o ônibus intermunicipal utilizado era mais rápido do que os ônibus municipais de sua cidade. Agora que o trajeto é mais curto, demora mais. Constatamos o descaso com a qualidade do transporte das operadoras deste município.

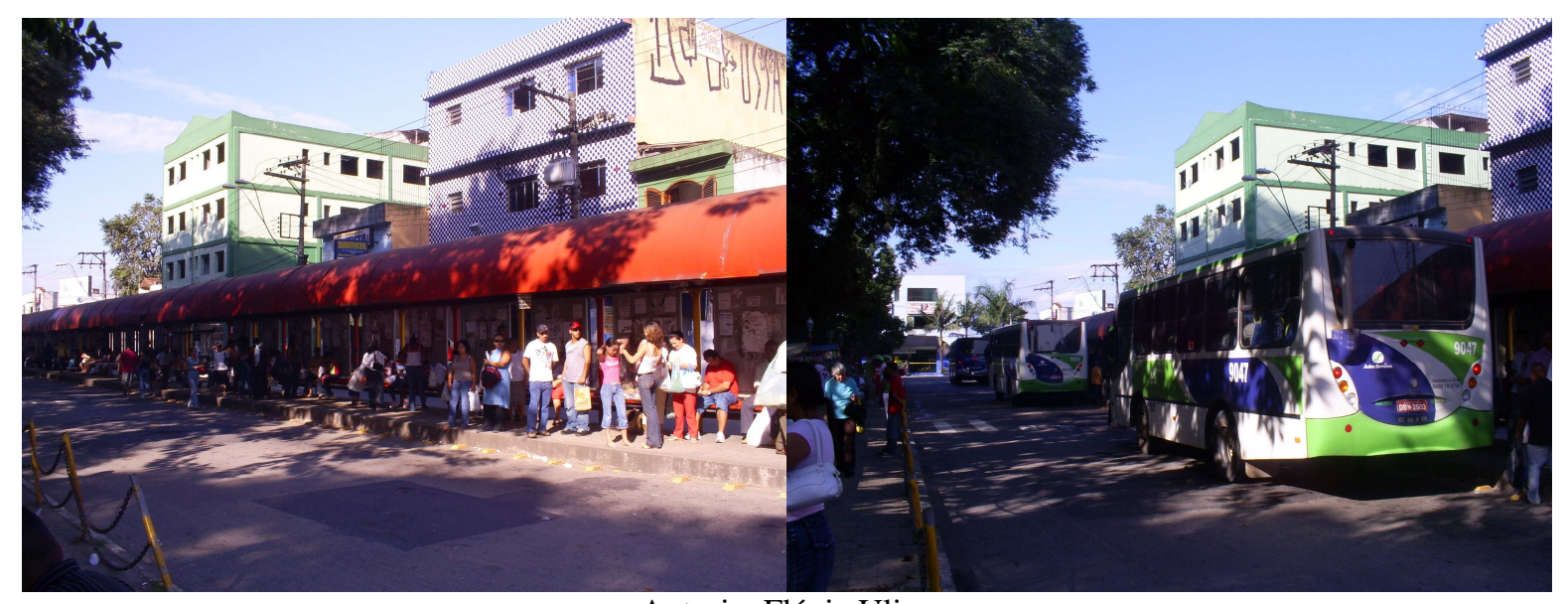

Autoria: Flávia Ulian

Fotografias 67 e 68 - Município de Itaquaquecetuba - Terminal urbano de ônibus no centro / 21/03/07 
Em São Bernardo do Campo, também ouvimos queixas: "o ônibus municipal que vai do bairro ao centro é demorado, esta linha é lenta, o ônibus não é confortável, é razoavelmente limpo, não é seguro porque os motoristas não respeitam os limites de velocidade e são obrigados a acelerar para cumprir o horário"497.

Como não estamos realizando pesquisa quantitativa, não intencionamos tirar conclusões sobre os sistemas de ônibus a partir dos depoimentos que colhemos. Mas, após a realização de todos os trabalhos de campo, pudemos ter uma visão geral da percepção dos usuários com quem conversamos sobre os sistemas de transporte dos municípios da RMSP. Constatamos que alguns fatores que molestam os usuários são a demora pela espera nos pontos, o trajeto demorado em função do trânsito lento, o desconforto do veículo acrescido da sua má condução pelo motorista. Citação utilizada em nossa Dissertação de Mestrado continua contemporânea, ao final de nosso período de estudo, entre 1987 e 2007: “ “As principais reclamações dos usuários de ônibus são o longo tempo de espera no ponto, a demora no trajeto e o pequeno número de linhas oferecidas pelas empresas que operam nesse setor.' (Folha de São Paulo, 07.06.1996)",498.

Em Santo André, ouvimos críticas ao sistema de ônibus municipal daquele município. Trabalhadora que reside em São Paulo e trabalha em Santo André usa o corredor metropolitano entre o Terminal São Mateus, em São Paulo, até o Terminal Santo André. Neste trajeto o ônibus é muito confortável e limpo, apesar de demorar uma hora e dez minutos, devido à longa distância percorrida. No entanto, do Terminal Santo André, toma um ônibus municipal desconfortável, com bancos duros e de limpeza razoável. Como é perto, não fica muito tempo no ônibus, que é, além de tudo, demorado e sempre lotado.

\footnotetext{
${ }^{497}$ Informação pessoal, 30/05/07.

${ }^{498}$ ULIAN, 1999, p.102.
} 
Em Moji das Cruzes, trabalhadora do setor de serviços que reside em um sítio comenta que o ônibus que usa sai de três em três horas, mas cumpre os horários programados, só atrasando quando os motoristas faltam. O problema são os ônibus sempre lotados.

Moradora de Carapicuíba que trabalha em hospital em Cotia, disse que, apesar do bairro em que mora ser vizinho do bairro do hospital no qual trabalha, por serem municípios diferentes não há ligação por ônibus entre os bairros, sendo necessário o deslocamento até o centro de Carapicuíba para, daí, tomar outro ônibus para Cotia. Ela afirmou ainda que o sistema de ônibus de Carapicuíba é muito bom, eficiente e rápido, e os ônibus são novos. Há também ônibus que saem de Carapicuíba para o bairro de Pinheiros, em São Paulo, mas como há muita demanda, os ônibus são muito cheios, pois em Carapicuíba não há empregos e a população se desloca para trabalhar em São Paulo.

\section{O Sistema de Ônibus Intermunicipal Regular}

O transporte intermunicipal da RMSP é operado pela EMTU, uma sociedade anônima de economia mista e de capital fechado controlada pelo Governo do Estado de São Paulo, subordinada à STM. A EMTU foi criada em 1977.

A necessidade de uma empresa que coordenasse o transporte coletivo intermunicipal surgiu a partir do processo de metropolização, intensificado na segunda metade do século XX. Até então, os ônibus rodoviários interurbanos controlados pelo DER (Departamento de Estradas de Rodagem) faziam o transporte entre as cidades. Os serviços de transporte urbano eram restritos aos sistemas municipais. A conurbação entre os municípios e a transformação de alguns deles em municípios chamados dormitórios, onde habita grande parte da mão-deobra que diariamente necessita se deslocar para os municípios mais industrializados e 
providos de maior quantidade de serviços, como São Paulo, Osasco, Guarulhos e ABC Paulista, trouxe a necessidade do transporte público para seus deslocamentos diários ${ }^{499}$.

A EMTU gerencia dois sistemas de transportes sobre pneus: o regular e o de fretamento. O Sistema Regular foi regulamentado pelo Decreto $\mathrm{n}^{\circ} 24.675 / 86$ e oferece transporte metropolitano coletivo de passageiros por ônibus. É subdividido em dois tipos de serviços: o comum e o seletivo. Ambos são compostos por conjuntos de linhas ligando pelo menos dois municípios que fazem parte da região metropolitana. Porém, enquanto o Serviço Comum é atendido por ônibus urbanos comuns, com transporte de passageiros sentados e em pé, o Serviço Seletivo é atendido por ônibus do tipo rodoviário, com transporte apenas de passageiros sentados ${ }^{500}$. Assim, no Serviço Comum é usado um ônibus comum, com duas ou três portas, cobrador e catraca, e no Serviço Seletivo, ônibus de uma porta, mais luxuoso, com poltronas reclináveis, sendo, portanto, de tarifa superior. Ambos serviços são regulares, isto é, seguem horários pré-estabelecidos.

De acordo com a EMTU, cerca de $70 \%$ das 612 linhas intermunicipais metropolitanas têm como destino a cidade de São Paulo ${ }^{501}$. A Tabela 21 mostra os dados básicos do sistema de ônibus gerenciado pela EMTU:

Tabela 21 - Região Metropolitana de São Paulo Dados sobre o sistema de ônibus EMTU-SP, 2006

\begin{tabular}{|c|c|c|c|c|c|}
\hline Discriminação & Regular & Orca & Corredor & Aeroporto & Total \\
\hline Passageiros/dia & 1.185 .850 & 24.368 & 212.465 & 5.044 & 1.427 .727 \\
\hline Frota operacional & 3.646 & 150 & 215 & 23 & 4.034 \\
\hline Viagens/dia & 38.997 & 1.201 & 4.194 & 298 & 44.690 \\
\hline Quilometragem percorrida & 966.296 & 28.420 & 53.292 & 9.985 & 1.057 .993 \\
\hline
\end{tabular}

Fonte: EMTU - Relatório Gerencial, outubro, 2006.

Disponível em: http://www.emplasa.sp.gov.br/portalemplasa/EncontrosMetropolitanos/IME/Transporte.pdf $\underline{27 / 01 / 2008}$

\footnotetext{
${ }^{499}$ www.emtu.sp.gov.br - acesso em 12.01.08.

500 www.emtu.sp.gov.br/regular/ - acesso em 27.01.2007.

501 Ibidem.
} 
O conceito geral do modelo de sistema de média capacidade da EMTU oferece uma rede única e interligada por meio de corredores e faixas exclusivas para ônibus, além de terminais, abrangendo todo o serviço metropolitano. Adotou-se um modelo como o já descrito em relação ao município de São Paulo (Sistema Interligado) e que também vem sendo adotado por várias prefeituras da RMSP: uma "rede de linhas troncais e alimentadoras conectadas em terminais e estações de transferência localizados nos vários municípios, em pontos favoráveis à organização da rede de transporte" ${ }^{\text {502 }}$, sem ônus de transferência para os usuários com destinos próximos. Este projeto grandioso, porém, ainda não foi implantado em toda a mancha urbana.

Para a implantação deste projeto, a RMSP foi dividida em cinco ${ }^{503}$ áreas de operação, além da Capital, para a concessão dos serviços intermunicipais metropolitanos. Para a gestão do sistema, foram assinados os respectivos contratos com as concessionárias de quatro áreas de operação. O município de São Paulo é uma área comum a todas as áreas de concessão.

O Sistema Orca, também gerenciado pela EMTU, é composto por linhas municipais operadas por empresas individuais que atuam, cada uma, com um único veículo coletivo de pequeno porte, como microônibus e vans de até 20 lugares. Este sistema funciona como se fosse uma extensão do sistema sobre trilhos, ligando estações de Metrô a estações de Trem Metropolitano, como é o caso da ligação pela Ponte Orca entre a estação de Metrô Vila Madalena e a estação de trem Cidade Universitária; ou ainda ligando a estação Jabaquara de Metrô ao Jardim Zoológico de São Paulo. Não é cobrada tarifa no sistema Orca, desde que o

\footnotetext{
502 SÃO PAULO, 1999, p.25.

${ }^{503}$ A Área 1 é composta pelos municípios de Juquitiba, São Lourenço da Serra, Embu-Guaçu, Itapecerica da Serra, Embu, Taboão da Serra, Vargem Grande Paulista e Cotia que ocupam território $1.500 \mathrm{~km}^{2}$. A Área 2 é composta pelos municípios de Cajamar, Caieiras, Itapevi, Jandira, Carapicuíba, Osasco, Barueri, Santana de Parnaíba, Pirapora do Bom Jesus, Francisco Morato e Franco da Rocha, ocupando uma superfície de $968 \mathrm{~km}^{2}$. A Área 3 é composta pelos municípios Guarulhos, Arujá, Mairiporã e Santa Isabel que ocupam território de 1.098 $\mathrm{km}^{2}$. A Área 4 é composta pelos municípios de Ferraz de Vasconcelos, Itaquaquecetuba, Poá, Mogi das Cruzes, Guararema, Biritiba Mirim, Salesópolis e Suzano que ocupam território $2.135 \mathrm{~km}^{2}$. A Área 5 compreende os municípios de Diadema, São Caetano do Sul, São Bernardo do Campo, Santo André, Mauá, Ribeirão Pires e Rio Grande da Serra, distribuídos em área de $841 \mathrm{~km}^{2}$ (http://www.emtu.sp.gov.br/regular/ - acesso em 27.01.2007).
} 
usuário pegue uma senha dentro do sistema de trens metropolitanos ou de metrô, isto é, o usuário deve ter obrigatoriamente pagado a passagem de trem ou metrô para usar o microônibus da Orca.

Entrevista realizada com usuária da Ponte Orca no trajeto estação Vila Madalena, da linha 2-Verde do Metrô, à estação Cidade Universitária, da linha C da CPTM, mostra como o cidadão pode ser respeitado em seu deslocamento ao ser oferecido conforto e eficiência. Observamos isso ao conversar com esta trabalhadora do setor de serviços que reside em Osasco e trabalha na avenida Paulista. Ela realiza diariamente o seguinte trajeto: toma um ônibus municipal no bairro onde reside, em Osasco, que faz um rápido trajeto de cerca de dez minutos até a estação Osasco. Lá, pega o trem na linha C até a estação Cidade Universitária. Sem precisar pagar mais tarifas, pega o miniônibus da Orca até a estação de metrô Vila Madalena, e então, pega a linha 2 - Verde de metrô até a estação Brigadeiro. Desde o primeiro ônibus que tomou em Osasco até a estação Brigadeiro, o trajeto leva aproximadamente uma hora e quinze minutos. Os quatro meios de transporte utilizados foram elogiados pela entrevistada, desde o ônibus do sistema municipal de Osasco, passando pela linha C da CPTM, o miniônibus da Orca e o metrô. Segundo ela, todos os meios são confortáveis e na maioria das vezes ela pode se sentar. Especialmente a Ponte Orca chama a atenção, pois ninguém vai em pé e, por ser um veículo pequeno, pode cortar o trânsito por vias menores, menos congestionadas.

Na RMSP, a EMTU controla ainda a operação do Corredor Metropolitano São Mateus/Jabaquara, através da concessionária Metra, que opera os terminais e os ônibus deste corredor, já referido neste texto.

A EMTU também implantou o Sistema Aeroporto, um serviço de linhas seletivas e suburbanas de ônibus, operado pelo Consórcio Internorte de Transporte, que partem de 
diversos pontos da Capital com destino ao Aeroporto Internacional de São Paulo, em Guarulhos $^{504}$.

O Bilhete Único ainda não opera no sistema gerenciado e operado pela EMTU. De acordo com a EMTU/SP, a empresa adota a Bilhetagem Eletrônica no Sistema Metropolitano por Ônibus na RMSP, em conjunto com o CMT (Consórcio Metropolitano de Transportes). O CMT é composto por cerca de 45 empresas de ônibus que operam nos municípios da RMSP, sendo responsável pela emissão do BOM, um cartão eletrônico que armazena os créditos eletrônicos.

Os congestionamentos vêm aumentando muito. A facilidade para a compra de automóvel com financiamentos de longo prazo contribui para o aumento do número de veículos em circulação, o que agrava os congestionamentos, tornando as viagens de ônibus mais longas e cansativas. Grande parte dos ônibus intermunicipais transitam "por vias radiais que diariamente registram os maiores picos de congestionamento - Francisco Morato, na zona oeste; trecho inicial da rodovia Raposo Tavares, na zona sudoeste; Marginal do rio Tietê, na

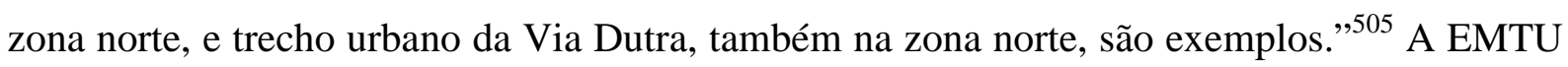
informa, ainda, que por conta do Programa Índice de Qualidade do Transporte da EMTU/SP a empresa tem procurado realizar ações específicas de melhoria do serviço nas linhas com pior avaliação por parte dos usuários. Porém, até o Corredor Metropolitano teve piora nesta avaliação, o que não teria relações com os congestionamentos, já que a maior parte do trajeto é percorrida em corredor com canaleta exclusiva para os ônibus.

Apresentamos a seguir depoimentos de usuários de ônibus do sistema intermunicipal gerenciado pela EMTU.

\footnotetext{
${ }^{504}$ www.emtu.sp.gov.br/regular/ - acesso em 27.01.2007.

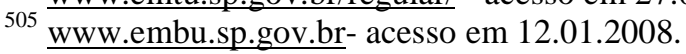


Professora em Biritiba Mirim que mora em Moji das Cruzes usa o ônibus intermunicipal diariamente e acha o serviço muito bom. Em Biritiba Mirim não há sistema de ônibus municipais, apenas os escolares, que são municipais.

Em Francisco Morato, uma entrevistada que mora neste município e trabalha na Barra Funda, em São Paulo, pega um ônibus ou táxi em seu bairro até a estação de trem em Morato, pois o táxi custa menos do que o ônibus, já que trabalham em sistema de lotação, pagando R\$ 1,50 cada passageiro. Além disso, o ônibus é muito demorado, apesar de confortável. Outra entrevistada de Francisco Morato prefere ir direto de ônibus intermunicipal desde seu bairro, em Francisco Morato, até a Barra Funda para não pagar o trem, apesar de demorar duas horas no trajeto. Além disso, o ônibus não é lotado como o trem.

Na linha Itapevi Cohab, o cobrador do ônibus informou que há muitos ônibus, mas que não dão conta de atender a toda a população no horário de pico, quando circulam lotados. $\mathrm{O}$ trajeto dos ônibus intermunicipais acompanham a linha de trem entre Osasco e Itapevi, mas os ônibus avançam além da estação Itapevi, chegando até as Cohabs, localizadas em bairros afastados e distantes. Apesar da discussão já realizada neste trabalho sobre as novas centralidades metropolitanas, o cobrador afirmou que os ônibus são cheios, de manhã, em direção a Osasco, e à tarde, em direção a Itapevi, ou seja, desempenham a função de transporte de trabalhadores que saem dos municípios dormitórios de Itapevi, Jandira e Carapicuíba em direção a Osasco, onde há empregos.

Trabalhador do setor de serviços em São Caetano do Sul que usa a linha intermunicipal Santo André - Príncipe de Gales, que saía do Terminal Ana Rosa, em São Paulo, descreve o ônibus como limpo, confortável, eficiente e não sente nenhum desgaste no seu cotidiano. Na ocasião de seu depoimento, estavam todos na iminência da inauguração do Terminal Sacomã, quando esta linha intermunicipal sairia de lá. Neste caso, os usuários terão de pegar outras linhas para se dirigirem ao Terminal e de lá realizar a baldeação para tomar o 
intermunicipal. Esta transformação deixava o entrevistado desgostoso, pois sabia que o tempo do trajeto iria aumentar, como realmente aconteceu.

Um outro entrevistado que usa linha de ônibus intermunicipal proveniente de São Caetano do Sul para Mauá relatou ter presenciado três ou quatro acidentes por causa de freios quebrados nos ônibus.

Trabalhadora de shopping centerr em Santo André, usuária de ônibus intermunicipal de Mauá a Santo André, da viação EAOSA, reclama não da qualidade do veículo, que não é cheio nem desconfortável, mas da demora. O que desgasta, no cotidiano de uso desta linha, é ter de esperar pelo ônibus. Em dada ocasião, chegou a esperar uma hora e meia por ele. Ela contou que quando algum motorista falta, não há outro para substituí-lo, o que causa grande espera pelos ônibus.

Houve críticas de passageiros que aguardavam, no Terminal Ribeirão Pires, o ônibus Baruel, para Suzano. Esta linha, além de demorada, em determinados horários chega ter 40 minutos de espera pelo ônibus, e nos finais de semana, uma hora de espera, os ônibus são lotados e desconfortáveis.

Trabalhadora do município de Carapicuíba que reside em Barueri reclamou da viação Benfica. Segundo ela, esta empresa monopoliza o transporte intermunicipal desta sub-região, cobrando preço alto pela qualidade que oferece aos usuários, pois os ônibus são superlotados. Os sistemas municipais, tanto de Barueri quanto de Carapicuíba, são ótimos, na visão da entrevistada. O problema seriam os ônibus intermunicipais, muito cheios e demorados.

Damos seqüência à discussão sobre os sistemas de ônibus abordando o Sistema de Fretamento que, na RMSP, também é gerenciado pela EMTU e operado por viações particulares. 


\title{
O Sistema de Fretamento
}

O outro sistema gerenciado pela EMTU é o Sistema de Fretamento, que se constitui de um serviço de transporte coletivo privado, regulamentado pelo Decreto $n^{\circ}$. 19.835/82, cuja característica básica é a cobrança periódica para execução do serviço, prestado mediante contrato prévio $^{506}$. O serviço é oferecido por meio de veículos de médio e grande porte (ônibus, microônibus ou vans) e contratado por grupos de funcionários de uma empresa ou pela própria empresa, que terceiriza o benefício para seus empregados. Um grupo de pessoas que moram na mesma região e trabalham num bairro ou cidade distante de casa também pode se interessar por contratar um serviço de fretamento ${ }^{507}$.

De acordo com Soares et alli ${ }^{508}$, o serviço de fretamento é de difícil monitoração e controle:

\begin{abstract}
cadastramento e inspeção de frota têm sido as medidas possíveis aos órgãos gestores. Demanda, operação, itinerários, pontos de embarque e desembarque etc. não são controlados de modo sistemático e planejado. De outra parte, uma desregulamentação poderia ensejar malefícios tão grandes como aqueles provocados pelo transporte clandestino.
\end{abstract}

Em nível metropolitano, as empresas devem ser registradas na STM, que regulamenta o serviço de fretamento e tem como órgão gestor e fiscalizador a EMTU. Em 2001, a Prefeitura de São Paulo regulamentou em nível municipal o serviço de fretamento.

Soares et alli $^{509}$ afirmam que, de acordo com suas pesquisas, o serviço é bem aceito por seus usuários, apontando, no ano de 2000, percentual entre excelente e bom de 97\%, superior ao do metrô (96\%) e inferior apenas ao do automóvel (98\%).

O Sistema de Fretamento teria surgido no processo de industrialização, nos anos 50, especialmente na região do ABC Paulista. Muitas fábricas estavam localizadas em locais não

${ }^{506}$ www.emtu.sp.gov.br/regular/ - acesso em 27.01.2007.

${ }_{507} \mathrm{http}$ ://portal.prefeitura.sp.gov.br/secretarias/transportes/organizacao/ 0017 - acesso em 27.01.2007.

${ }^{508}$ SOARES et. alli, 2005.

509 Ibidem. 
servidos pelas ferrovias nem pelo incipiente sistema de ônibus. Numerosos empregados que trabalhavam em turnos e horários diversificados necessitavam de transporte, já que os sistemas de transporte público não atendiam horários tão adversos. Então, as indústrias contrataram empresas privadas para realizar os serviços de transporte para seus funcionários. Com o passar do tempo, este serviço foi incorporado aos benefícios pagos pelo empregador. Atualmente, em muitos casos, o serviço de ônibus fretado faz parte dos acordos trabalhistas entre patrões e empregados ${ }^{510}$.

\section{Tabela 22 - Região Metropolitana de São Paulo Frota cadastrada de fretamento Evolução anual - anos escolhidos}

\begin{tabular}{|c|c|}
\hline Ano & Veículos cadastrados \\
\hline 1992 & 3.402 \\
\hline 1997 & 5.399 \\
\hline 2001 & 6.256 \\
\hline 2005 & 7.622 \\
\hline
\end{tabular}

Fonte: SOARES et alli, 2005.

Organização da autora.

Conforme podemos aferir pela Tabela 22, em média, a frota de ônibus fretados vem aumentando. Em 2005, 65\% desta frota era composta por ônibus, sendo o restante ocupado por vans e microônibus. O setor de empresas de fretamento estima haver 570 mil usuários por dia na RMSP. Atualmente, a SPTrans informa que há 8 mil ônibus fretados circulando na RMSP, sendo 3.700 deles registrados na própria capital paulista. O serviço teria se expandido na última década para transportar grupos organizados que realizam grandes deslocamentos da residência ao trabalho ou à universidade ${ }^{511}$.

Comparando-se a frota do serviço de fretamento à frota do serviço regular intermunicipal gerenciado pela EMTU, Soares et alli" ${ }^{512}$ observaram que "no período 1992-

\footnotetext{
${ }^{510}$ SOARES et alli, 2005.

${ }^{511}$ IZIDORO, 2007.

${ }^{512}$ SOARES et alli, op. cit.
} 
2005, a frota de Fretamento na RMSP cresceu 124\%, enquanto a frota do Sistema Regular Intermunicipal cresceu 28,7\%.” Isto quer dizer que houve maior crescimento da quantidade de ônibus fretados nas ruas do que dos ônibus regulares intermunicipais. Os autores apontam o transporte clandestino como um fator que impactou o serviço regular de transporte, mas não o serviço de fretamento. Pensamos que este fato se deve à demanda do transporte regular ser diferenciada da demanda do transporte fretado, de maior poder aquisitivo.

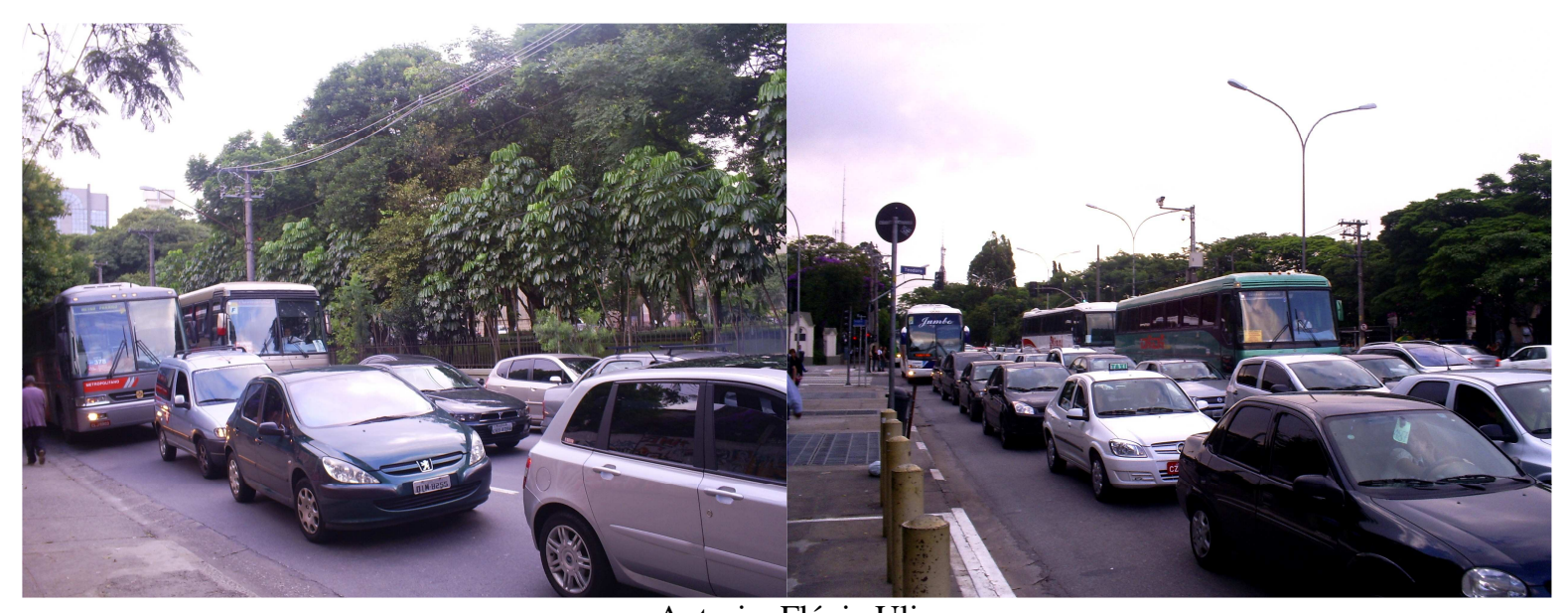

Autoria: Flávia Ulian

Fotografia 69 - Município de São Paulo - Ônibus fretado e intermunicipal da EMTU disputam espaço na rua Teodoro Sampaio / 31/01/08

Fotografia 70 - Município de São Paulo - Ônibus fretados e automóveis disputam espaço na avenida Dr. Arnaldo / 31/01/08

Os estudos de Soares et alli ${ }^{513}$ concluem que o serviço de fretamento foi a única modalidade de transporte coletivo que cresceu nos últimos 15 anos na $\operatorname{RMSP}^{514}$. A propaganda para conquistar usuários para o sistema de fretamento vem sendo feita com o uso de argumentos que tentam persuadir o potencial cliente de que, com o uso de ônibus fretados, o passageiro pode descansar, ler, dormir e até fazer amigos durante o deslocamento ${ }^{515}$. Como são confortáveis, muitas pessoas optam por este serviço como uma "alternativa à falta de

\footnotetext{
${ }^{513}$ SOARES et alli, 2005.

${ }_{515}^{514}$ Cabe lembrar que os autores realizaram seus estudos antes do início da vigência do Bilhete Único.

515 www.fretado-sp.com.br/ - acesso em 10.01.2008.
} 
qualidade do transporte coletivo comum e para quem aceita deixar o automóvel em casa." Muitos ônibus, inclusive, têm banheiro, ar condicionado, aparelhos de TV e DVD.

Para que uma nova linha seja oferecida, é necessário que pelo menos vinte pessoas interessadas pelo mesmo roteiro e horário formulem um pedido junto a uma empresa. O sítio http://www.fretado-sp.com.br/, por exemplo, se propõe a receber as informações de possíveis interessados. A partir daí, a empresa que prestará o serviço requer ao DTP a nova linha. Somente são transportadas pela linha as pessoas inscritas naquele roteiro, que fazem o pagamento mensal pelo serviço. Segundo a reportagem da Folha de São Paulo de 12.11.2007, as paradas freqüentes e desordenadas dos ônibus provocam congestionamentos da hora do embarque e desembarque ${ }^{517}$. Soares et alli ${ }^{518}$, no entanto, observam que "Se é verdade que ele atrapalha o trânsito, principalmente na hora do estacionamento/embarque, não é menos verdade que é um transporte coletivo, que ocupa menos espaço na via pública do que o automóvel."

Os veículos fretados não podem usar as vias com corredores de ônibus à esquerda, exceto em trechos com mais de três faixas de rolamento, porque os veículos utilizados dispõem apenas de porta à direita para embarque e desembarque. Nestes corredores, não podem também usar a faixa da direita, pois provocaria o estrangulamento da avenida, com ônibus nas duas faixas laterais. Esta restrição tem causado morosidade no deslocamento pelo sistema. A SPTrans, que administra o serviço na capital paulista, é favorável ao serviço de fretamento, pois se trata de um sistema em que cada ônibus tira 15 automóveis da rua ${ }^{519}$.

No cotidiano dos trabalhadores que se deslocam de ônibus fretado, conversamos com uma trabalhadora do setor comercial que nos informou que mora no ABC Paulista e trabalha em São Paulo. Ela apanha um ônibus fretado que demora cerca de uma hora e meia para

\footnotetext{
${ }^{516}$ IZIDORO, 2007.

517 Ibidem.

${ }^{518}$ SOARES et alli, 2005.

${ }^{519}$ IZIDORO, op. cit.
} 
chegar ao destino final. Apesar do conforto, eficiência, segurança e limpeza do meio de transporte, considera seu deslocamento desgastante pela longa distância, trânsito e ruídos tanto do trânsito como do próprio motor do ônibus.

Outro passageiro entrevistado, trabalhador de uma indústria em São Bernardo do Campo, utiliza o ônibus fretado pela empresa, que sai próximo de sua casa com o destino final dentro da própria empresa. O trajeto leva em torno de 40 minutos. O ônibus é bastante confortável e não pega trânsito, pois o seu horário de trabalho é das 21 h30 às 6 h00. O entrevistado relatou que "por ser um ônibus fretado de uma boa empresa não tenho de que me queixar,"520.

\title{
O Sistema de Lotação
}

Podemos definir a lotação como

\begin{abstract}
um modo de transporte coletivo de pequena capacidade, operado atualmente por veículos utilitários do tipo 'perua', tendo como características principais a existência de ponto inicial e final, e um itinerário básico pré-determinado. Funciona, dependendo de cada região, primordialmente nos horários de pico da manhã e tarde, como complemento do sistema ônibus. ${ }^{521}$
\end{abstract}

No município de São Paulo, em sua origem, a SMT teria criado as linhas de lotação como forma particular de operação do sistema táxi. Até 1990, não era permitido pela legislação o uso de veículos utilitários na operação das linhas de lotação. No entanto, desde 1991 verificou-se grande número de peruas 'Kombi' operando o sistema de forma irregular, principalmente nas áreas centrais e junto às estações de metrô ${ }^{522}$.

O Decreto $\mathrm{n}^{\mathrm{o}} .31 .347$ de 20 de março de 1992 criou a modalidade ônibus-lotação: "Esta primeira legislação, provavelmente em virtude das rigorosas exigências estabelecidas

\footnotetext{
${ }^{520}$ Informação pessoal, 30/05/07.

${ }^{521}$ CIA.DO METROPOLITANO DE SÃO PAULO, 1997b, p.15.

522 Ibidem.
} 
pelo poder público, e frente às dificuldades encontradas no diálogo com os representantes dos operadores deste serviço, termina sendo aplicada apenas a um reduzido número de linhas." Utilizam-se, desde o início da década de 1990, quando foi aberta a importação de veículos estrangeiros, "vans" importadas do tipo Besta e Topic, já que, devido à concorrência, os operadores visam a oferecer ao passageiro produto de melhor qualidade e a vantagem de levar mais passageiros por viagem (cerca de 14 passageiros).

As lotações, portanto, cresceram em número a partir da informalidade, quando saíram do papel secundário para tornarem-se convenientes a um volume cada vez maior de pessoas. No caso das vans, inicialmente, foram apoiadas por parte dos usuários, pela imprensa e por políticos, "muitos deles ligados direta ou indiretamente ao novo negócio." 524 Assim como aconteceu em outros países em desenvolvimento, o autor relata que os donos das vans começaram uma reação violenta:

Começaram bloqueando a circulação de ônibus perto dos pontos de ônibus e disputando seus passageiros [...]. Mais tarde, começaram a queimar ônibus nas vias, como reação à fiscalização. Quando ocorreu o primeiro acidente fatal com uma das vans, a opinião pública começou a mudar, embora relutante aos maus serviços prestados pelo transporte regular. Com o aumento dos operadores ilegais, conflitos começaram a aparecer e grupos foram formados, para controlar rotas e áreas, muitos incluindo pessoas ligadas ao setor de segurança pública, formalmente encarregadas de fiscalizar o transporte ilegal. A entrada no negócio começou a ser submetida a pagamento e pessoas armadas começaram a controlar esta entrada e a operação cotidiana. O ciclo 'selvagem' descrito acima havia começado em São Paulo [... $]^{525}$.

Os conflitos referidos pelo autor nos anos 1990 entre os chamados "perueiros" e a administração municipal são muito parecidos com o que hoje vemos com relação aos motoqueiros. Com o crescimento de atos violentos no chamado "ciclo selvagem", a fiscalização cresceu e foi apoiada pela população. Até o início dos anos 2000, os governos municipal e estadual haviam adotado posturas conflituosas em relação à problemática. A

\footnotetext{
${ }^{523}$ CIA.DO METROPOLITANO DE SÃO PAULO, 1997b, p.5.

${ }^{524}$ VASCONCELOS, 2000, p.144.

${ }^{525}$ Ibidem.
} 
partir desta década, passaram a atuar em conjunto, "fazendo refluir a violência; muitas vans foram retiradas das vias, mas um grande grupo continuou operando nas áreas periféricas." ${ }^{, \ldots 6}$

As lotações estão presentes em quase toda a região metropolitana, sendo a Zona Leste do município de São Paulo a melhor servida, em grande parte, ainda na informalidade. As lotações partem normalmente de estações de metrô, trens e terminais de ônibus. Nas regiões mais densamente povoadas, próximas a conjuntos habitacionais, o volume dos serviços de lotação aumenta e, conseqüentemente, o número de usuários do sistema. A proliferação desses serviços deve-se, além da deficiência do sistema de transportes por ônibus, aos níveis crescentes de desemprego, já que a função de motorista e a de cobrador das lotações acabam empregando um grande número de pessoas. Os percursos realizados pelas lotações são relativamente curtos, o que permite aos operadores do sistema a realização de até 10 viagens por período (manhã ou tarde). ${ }^{527}$

As lotações são um meio de transporte que a população pode utilizar não só em períodos críticos, como greves dos meios de transporte coletivos, mas também como uma alternativa ao uso do automóvel particular, táxi ou meios de transporte coletivos que estão cheios e são muito demorados, ou também porque não servem adequadamente todos os lugares da cidade, como atesta a seguinte afirmação: “o sistema de lotação tem atendido satisfatoriamente os bairros situados em áreas de difícil acesso, sem calçamento, com vias estreitas e declividade acentuada, onde normalmente os ônibus têm dificuldade de acesso, manobras ou estacionamento. ${ }^{, 528}$.

O estudo supra citado sugeriu a criação de terminal de peruas de lotação, operando com veículos leves, pequenos, junto a algumas estações de metrô onde se identifica grande uso do sistema. Sugere ainda dar mais

\footnotetext{
${ }^{526}$ VASCONCELOS, 2000, p.144.

${ }^{527}$ CIA.DO METROPOLITANO DE SÃO PAULO, $1997 \mathrm{~b}$.

${ }^{528}$ Ibidem, p.6.
} 
atenção à lotação como alternativa de transporte coletivo de pequena capacidade, numa época em que se incentivam a utilização de transporte solidário (carona), o uso do ônibus e do metrô, ou o sistema de rodízio de veículos, visando a diminuir os problemas decorrentes da utilização do veículo particular como meio de transporte. ${ }^{529}$

Entendemos que a lotação transporta um número muito menor de pessoas do que um ônibus, porém, maior do que um automóvel. Muitas vezes, os empresários de ônibus justificam que, como os ônibus andam vazios em determinados períodos do dia, diminuem a frota em circulação. As empresas de ônibus colocaram nas ruas microônibus para ganhar a concorrência com as lotações. Muitas linhas de ônibus que operam com prejuízo foram transferidas às lotações, levando os ônibus para as regiões com maior demanda de transporte.

O sistema de lotações parece ser necessário para complementar o sistema de ônibus, bastante deficiente em diversas áreas da região metropolitana. Talvez, se fosse incentivado e regularizado o transporte por lotações com o uso de combustíveis alternativos, como o gás natural, muito menos poluente, o número de veículos particulares nas ruas diminuísse e, ao mesmo tempo, melhorasse a qualidade ambiental.

Datam de 1995 os primeiros dados disponíveis relativos à existência de serviço de lotação regularizado e o respectivo número de linhas, bem como sobre a existência de serviço de lotação não cadastrado entre os municípios da RMSP. Para sermos coerentes com os dados gerais desta pesquisa, norteados pela Pesquisa O-D de 1997, optamos por analisar especialmente os dados referentes a este ano e, apenas quando não disponíveis, apresentaremos dados de anos próximos a ele. Na década de 2000, os dados referentes às lotações foram somente coletados em 2003.

${ }^{529}$ CIA.DO METROPOLITANO DE SÃO PAULO, 1997b, p.13. 
Tabela 23 - Municípios e sub regiões da RMSP Serviço de Lotação 1997 e 2003

\begin{tabular}{|c|c|c|c|}
\hline & 1997 & 2003 & 2003 \\
\hline $\begin{array}{l}\text { MUNICÍPIOS E } \\
\text { SUB-REGIÕES }\end{array}$ & $\begin{array}{l}\text { Existência de serviço de } \\
\text { lotação regularizado } \\
\text { Número de linhas }\end{array}$ & $\begin{array}{c}\text { Existência de serviço de } \\
\text { lotação regularizado } \\
\text { Número de linhas }\end{array}$ & $\begin{array}{l}\text { Existência de serviço de } \\
\text { lotação não cadastrado }\end{array}$ \\
\hline \multicolumn{4}{|l|}{ CENTRO } \\
\hline São Paulo & $\operatorname{sim}-231$ & não & dado não disponível \\
\hline \multicolumn{4}{|l|}{ OESTE } \\
\hline Barueri & Não & não & dado não disponível \\
\hline Carapicuíba & Não & dado não disponível & dado não disponível \\
\hline Cotia & não (1995) & $\operatorname{Sim}-30$ & não \\
\hline Itapevi & Não & não & não \\
\hline Jandira & Não & não & não \\
\hline Osasco & Não & não & dado não disponível \\
\hline $\begin{array}{c}\text { Pirapora do Bom } \\
\text { Jesus }\end{array}$ & Não & não & $\operatorname{sim}$ \\
\hline $\begin{array}{c}\text { Santana do } \\
\text { Parnaíba }\end{array}$ & Não & não & $\operatorname{sim}$ \\
\hline $\begin{array}{c}\text { Vargem Grande } \\
\text { Paulista }\end{array}$ & Não & $\operatorname{sim}-2$ & $\operatorname{sim}$ \\
\hline \multicolumn{4}{|l|}{ SUDOESTE } \\
\hline Embu & $\operatorname{Sim}-14$ & $\operatorname{Sim}-11$ & não \\
\hline Embu-Guaçu & Não & Sim -71 & não \\
\hline Itapecerica da Serra & Sim -10 & Sim -18 & não \\
\hline Juquitiba & Sim -2 & $\operatorname{sim}-1$ & não \\
\hline $\begin{array}{c}\text { São Lourenço da } \\
\text { Serra } \\
\end{array}$ & Não & não & não \\
\hline Taboão da Serra & não (1995) & $\operatorname{sim}-8$ & não \\
\hline \multicolumn{4}{|l|}{ SUDESTE } \\
\hline Diadema & Não & não & não \\
\hline Mauá & Não & não & não \\
\hline Ribeirão Pires & Não & não & não \\
\hline $\begin{array}{l}\text { Rio Grande da } \\
\text { Serra }\end{array}$ & Não & não & não \\
\hline Santo André & Não & não & não \\
\hline $\begin{array}{c}\text { São Bernardo do } \\
\text { Campo }\end{array}$ & Não & não & não \\
\hline São Caetano do Sul & Não & não & não \\
\hline \multicolumn{4}{|l|}{ LESTE } \\
\hline Biritiba Mirim & Não & não & não \\
\hline $\begin{array}{c}\text { Ferraz de } \\
\text { Vasconcelos }\end{array}$ & Não & não & não \\
\hline Guararema & Não & não & não \\
\hline Itaquaquecetuba & Não & não & $\operatorname{sim}$ \\
\hline Mogi das Cruzes & Não & $\mathrm{Sim}-20$ & não \\
\hline Poá & Não & não & não \\
\hline Salesópolis & Não & não & não \\
\hline Suzano & Não & dado não disponível & dado não disponível \\
\hline \multicolumn{4}{|l|}{ NORDESTE } \\
\hline Arujá & Não & não & não \\
\hline Guarulhos & Não & Sim -40 & $\operatorname{sim}$ \\
\hline Santa Isabel & Não & $\operatorname{sim}-5$ & $\operatorname{sim}$ \\
\hline \multicolumn{4}{|l|}{ NORTE } \\
\hline Caieiras & Não & não & não \\
\hline Cajamar & Não & não & $\begin{array}{r}\text { dado não disponível } \\
\text { continua }\end{array}$ \\
\hline
\end{tabular}


continuação

\begin{tabular}{|c|c|c|c|}
\hline & $\mathbf{1 9 9 7}$ & $\mathbf{2 0 0 3}$ & $\mathbf{2 0 0 3}$ \\
\hline $\begin{array}{c}\text { MUNICÍPIOS E } \\
\text { SUB-REGIÕES }\end{array}$ & $\begin{array}{c}\text { Existência de serviço de } \\
\text { lotação regularizado } \\
\text { Número de linhas }\end{array}$ & $\begin{array}{c}\text { Existência de serviço de } \\
\text { lotação regularizado } \\
\text { Número de linhas }\end{array}$ & $\begin{array}{c}\text { Existência de serviço de } \\
\text { lotação não cadastrado }\end{array}$ \\
\hline Francisco Morato & Não & sim - & sim \\
\hline Franco da Rocha & Não & não & não \\
\hline Mairiporã & Não & não & sim \\
\hline RMSP & & & \\
\hline
\end{tabular}

Fonte: http://www.seade.gov.br/produtos/imp/index.php - 12.01.2008 - Sistema de Informação dos Municípios Paulistas (IMP)

Elaboração da autora.

Obs. Não há dados disponíveis sobre a existência de serviços de lotação não cadastrados em 1997, apenas em 2003.

Analisando-se os dados da Tabela 23, verificamos que, de modo praticamente generalizado, não havia serviço de lotação regularizado na RMSP em 1997, além de também não haver dados disponíveis sobre os serviços de lotação não cadastrados. Os municípios onde este serviço já era regularizado neste ano eram: São Paulo, com 231 linhas; Itapecerica da Serra, com 10 linhas; Embu, com 14 linhas e Juquitiba, com 2 linhas.

Já em 2003 a situação é diferente, pois há dados sobre praticamente todos os municípios, com exceção de Carapicuíba e Suzano. São dez os municípios que apresentam serviço de lotação regularizado: Cotia (30 linhas), Vargem Grande Paulista (2 linhas), Itapecerica da Serra (18 linhas), Embu (11 linhas), Embu-Guaçu (71 linhas), Juquitiba (1 linha), Mogi das Cruzes (20 linhas), Guarulhos (40 linhas), Santa Isabel (5 linhas) e Francisco Morato (3 linhas). Em 2003, a Tabela 23 mostra que não havia serviço de lotação regularizado no município de São Paulo porque neste período a gestão da prefeitura 2001-2004 transformou este sistema no Subsistema Local do Sistema Interligado, substituindo as vans por mini-ônibus e micro-ônibus.

Chama a atenção a grande quantidade de linhas de lotação em Embu-Guaçu, em número de 71 , em detrimento das informações com relação ao transporte por ônibus deste município, apresentada na Tabela 20. A informação é que havia, em 1997, apenas 7 linhas de ônibus, não havendo dado disponível em 2003. 
Quanto à informação da existência de serviço de lotação não cadastrado em 2003, ela é positiva em apenas sete municípios, o que nos parece duvidoso, pois a população sabe da existência deste serviço e o usa de forma velada.

Como mostram os dados da Tabela 24, o sistema de lotações não era praticamente utilizado até o ano de 1997, quando passa de 25 mil viagens diárias em 1987 para 199 mil viagens diárias em 1997, e triplicou para 630 mil viagens diárias em 2002. Em relação ao total de viagens motorizadas, porém, seu percentual de uso ainda era pequeno em 2002 (2,58\%), apesar do crescimento.

\section{Tabela 24 - Sub-Regiões da Região Metropolitana de São Paulo Evolução das viagens diárias em Lotação 1987-1997-2002}

\begin{tabular}{|c|c|c|c|}
\hline & \multicolumn{3}{|c|}{$\begin{array}{c}\text { VIAGENS EM } \\
\text { LOTAÇÃO } \\
\text { (x1.000) }\end{array}$} \\
\hline $\begin{array}{c}\text { MUNICÍPIOS E } \\
\text { SUB-REGIÕES }\end{array}$ & 1987 & 1997 & 2002 \\
\hline CENTRO & 18 & 143 & 495 \\
\hline OESTE & 2 & 4 & 14 \\
\hline SUDOESTE & 0 & 18 & 39 \\
\hline SUDESTE & 1 & 15 & 30 \\
\hline LESTE & 2 & 2 & 8 \\
\hline NORDESTE & 2 & 15 & 38 \\
\hline NORTE & 0 & 2 & 6 \\
\hline RMSP & 25 & 199 & 630 \\
\hline
\end{tabular}

Fonte: CIA. DO METROPOLITANO DE SÃO PAULO. Aferição da Pesquisa O-D 1997, 2002. Organização da autora.

Como podemos aferir pela tabela acima, entre 1987 e 1997 houve um significativo acréscimo de viagens realizadas por este sistema, e mais ainda entre 1997 e 2002 . No total da RMSP, elas passaram de 25 mil para 630 mil viagens diárias, ou seja, um aumento de cerca de 25 vezes. No município de São Paulo, as viagens utilizando-se as lotações aumentaram cerca de 27 vezes. Na sub-região Oeste (Barueri, Carapicuíba, Cotia, Itapevi, Jandira, Osasco, Pirapora do Bom Jesus, Santana do Parnaíba, Vargem Grande Paulista), aumentaram sete vezes. Na sub-região Sudoeste (Embu, Embu-Guaçu, Itapecerica da Serra, Juquitiba, São 
Lourenço da Serra, Taboão da Serra), os dados de 1987 eram zerados, passando para 39 mil deslocamentos diários em lotação. Na Sudeste (Diadema, Mauá, Ribeirão Pires, Rio Grande da Serra, Santo André, São Bernardo do Campo, São Caetano do Sul), também houve um aumento incrível de 1.000 para 30.000 viagens em lotação por dia. Na Leste (Biritiba Mirim, Ferraz de Vasconcelos, Guararema, Itaquaquecetuba, Mogi das Cruzes, Poá, Salesópolis, Suzano), as viagens quadruplicaram, e na sub-região Nordeste (Arujá, Guarulhos, Santa Isabel), aumentaram 19 vezes. Por fim, na sub-região Norte (Caieiras, Cajamar, Francisco Morato, Franco da Rocha, Mairiporã), triplicaram os deslocamentos por lotação.

Com as alterações nos sistemas de ônibus e de cadastramento das lotações, porém, é bem provável que na próxima Pesquisa O-D, ainda em andamento, estes dados tenham sofrido novas alterações.

O item subseqüente trata do modo não motorizado de transporte a pé. Sendo ele bastante significativo nos deslocamentos realizados na metrópole. Pretendemos, com sua análise, encerrar a abordagem dos modos de transporte de passageiros na RMSP. 


\title{
4 - Transporte Não-Motorizado: o Modo a Pé
}

As Pesquisas O-D contabilizam o modo a pé como modo principal quando a distância percorrida da origem ao destino é superior a 500 metros ou 5 quadras. Porém, quando o motivo for trabalho ou escola, a viagem é registrada independentemente da distância ${ }^{530}$.

De acordo com Scarlato ${ }^{531}$,

\begin{abstract}
Dentre alguns dos fatores que permitem explicar o crescimento do transporte a pé, podemos apontar a impossibilidade de acesso ao automóvel por parte da população de baixa renda, assim como o aumento do custo das passagens e sua participação em gastos com o transporte. Esses fatos estão relacionados também com o aumento dos cortiços e favelas nas áreas centrais. Morar nesses tipos de habitação permite que os trabalhadores se desloquem a pé entre a residência e o local de trabalho, economizando, assim, o dinheiro a ser gasto com o transporte.
\end{abstract}

Esta afirmação é amparada pelos dados sobre a renda familiar mensal da população que anda a pé, conforme pode ser aferido pela Tabela 25:

\section{Tabela 25 - Região Metropolitana de São Paulo Percentual de Viagens Diárias a Pé por Renda Familiar Mensal 1987 e 1997}

\begin{tabular}{|c|c|c|c|c|c|c|c|}
\hline Ano & \multicolumn{5}{|c|}{ Renda - em reais de outubro de 1997} & \\
\hline & Até 250 & 250 a 500 & 500 a 1.000 & 1.000 a 1.800 & 1.800 a 3.600 & Mais de 3.600 & Total \\
\hline $\mathbf{1 9 8 7}$ & 55,44 & 51,14 & 43,10 & 32,22 & 22,98 & 12,72 & 36,22 \\
\hline $\mathbf{1 9 9 7}$ & 56,47 & 48,88 & 41,37 & 33,96 & 22,60 & 13,66 & 34,39 \\
\hline
\end{tabular}

Fonte: CIA. DO METROPOLITANO DE SÃO PAULO. Aferição da Pesquisa O-D 1997, 2002.

Elaboração da autora.

A Tabela 25 confirma que a maior parte das viagens realizadas a pé, tanto em 1987 quanto em 1997 (55,40\% e 56,47\%) foi realizada por pessoas com renda familiar mensal de até $\mathrm{R} \$ 250,00$. A diferença destes valores para $100 \%$ seria a população que usa transporte motorizado, dado este não mostrado na tabela. No intervalo de rendimentos familiares

\footnotetext{
${ }^{530}$ CIA. DO METROPOLITANO DE SÃO PAULO, 2007.

${ }^{531}$ SCARLATO, 1998, p.451.
} 
mensais de $\mathrm{R} \$ 250,00$ a $\mathrm{R} \$ 500,00$, praticamente a metade dos deslocamentos foram realizados a pé $(51,14 \%$ e 48,88\%, respectivamente em 1987 e 1997). Até mesmo na faixa de rendimentos familiares mensais de $\mathrm{R} \$ 500,00$ a $\mathrm{R} \$ 1.000,00$, é alto o percentual de viagens a pé (43,10\% em 1987 e 41,37\% em 1997). Ele diminui conforme aumenta a renda familiar mensal, chegando a pouco mais de $10 \%$ para pessoas com renda familiar mensal acima de $\mathrm{R} \$ 3.600,00$.

Os dados de 2002 não estão na tabela porque foram usados intervalos de renda diferenciados nesta pesquisa. A Aferição da Pesquisa O-D 1997, realizada em 2002, mostrou que $62,37 \%$ das viagens realizadas por pessoas cuja renda familiar mensal era de até $\mathrm{R} \$ 400,00$ foi realizado a pé. Para a faixa de rendimentos familiares mensais entre $\mathrm{R} \$ 400,00 \mathrm{e}$ $\mathrm{R} \$ 800,00$, o percentual é de $51,24 \%$, ou seja, quase a metade dos deslocamentos realizados por pessoas incluídas nesta faixa de renda foi feita a pé. Novamente, o percentual vai diminuindo conforme aumenta a faixa de rendimentos, até a maior faixa, composta por pessoas cuja renda familiar mensal é maior que $\mathrm{R} \$ 6.000,00$, na qual somente $14,74 \%$ dos deslocamentos desta faixa foram realizados a pé. Conforme já referimos, a diferença entre os percentuais apresentados na tabela e $100 \%$ é o volume de viagens em transporte motorizado.

$\operatorname{Rosa}^{532}$ menciona em seu trabalho os "desabrigados com teto", indivíduos que se deslocam de sua casa para o trabalho, mas não retornam todos os dias para economizar o dinheiro da passagem.

$\mathrm{Na}$ opinião do Engenheiro Luciano Luz, da CPTM, entrevistado por nós em 26.02.2008, é equivocado interpretar que o alto percentual de viagens a pé se dá porque as pessoas não têm o dinheiro da passagem. Ele explicou que, na Pesquisa O-D, de acordo com a

${ }^{532}$ ROSA, 2006. 
hierarquia ${ }^{533}$ utilizada para contabilidade das viagens, o modo a pé é o último. Assim, quando o passageiro vai a pé até a estação de metrô, o deslocamento que ele fez foi contabilizado no modo metrô, e não no modo a pé. Do mesmo modo, as idas a pé até o ponto de ônibus, ou estação de trem, não são contabilizadas como viagens a pé. Quando não havia o Bilhete Único e o usuário pegava apenas um ônibus, sendo o restante do percurso realizado a pé para que ele não pagasse a tarifa do outro ônibus, este deslocamento a pé não era computado, pois o deslocamento através do ônibus ou outro modo motorizado era contabilizado como modo principal, uma vez que qualquer modo motorizado é superior ao modo a pé na hierarquia da contagem dos deslocamentos. Atualmente, sabe-se que muitos dos deslocamentos anteriormente feitos a pé para economizar o valor do segundo ônibus não são mais desse modo, pois o Bilhete Único resolveu esta questão, mas também não haviam sido contabilizados nas pesquisas como deslocamentos a pé.

Portanto, quando se contabiliza o modo a pé, está se afirmando que todo o deslocamento foi realizado a pé, da origem ao destino. Nesse caso, sim, pode ser que se faça o deslocamento a pé para economizar o dinheiro da passagem. Não há, porém, pesquisas neste sentido, ou seja, não se sabe o universo desta realidade. As pesquisas têm mostrado que mais de $70 \%$ dos deslocamentos a pé são realizados por outros motivos, dentre eles o deslocamento até a escola, que sozinho representava a metade dos deslocamentos a pé da $\mathrm{RMSP}^{534}$. Isto porque em grande parte as pessoas buscam escolas próximas às suas casas para facilitar os deslocamentos de seus filhos até elas. Aí, o deslocamento a pé também não se dá por economia, mas por conveniência.

533 Conforme já foi aludido neste texto, a hierarquia da Pesquisa O-D segue a seqüuencia: metrô - trem transporte fretado - transporte escolar - ônibus - táxi - dirigindo automóvel - passageiro de automóvel - moto bicicleta - outros - à pé. O modo principal é o modo de maior hierarquia entre os utilizados na mesma viagem.

${ }^{534}$ CIA. DO METROPOLITANO DE SÃO PAULO, 2002. 
$\mathrm{Na}$ metrópole do transporte motorizado, o papel conflitante entre o motorista e o pedestre é, de acordo com Vasconcellos ${ }^{535}$, singular na realidade brasileira, já que, embora “o Código Nacional de Trânsito estabeleça claramente a prioridade do pedestre sobre o veículo nas interseções (art.175), ela é ‘brasileiramente’ negada na prática pelo exercício cotidiano do poder da força e da negação da cidadania: quem está a pé é inferior e, portanto, deve esperar." O autor também comenta sobre a banalização dos atropelamentos na sociedade do automóvel. Os acidentes são considerados "como produto natural da forma de desenvolvimento urbano, econômico e cultural, ocorrido no Brasil.",536

\section{Tabela 26 - Região Metropolitana de São Paulo Número de passageiros transportados a pé (em milhares/dia)}

\begin{tabular}{|c|c|c|}
\hline $\mathbf{1 9 8 7}$ & $\mathbf{1 9 9 7}$ & $\mathbf{2 0 0 2}$ \\
\hline 10.650 & 10.813 & 14.194 \\
\hline
\end{tabular}

Fonte: CIA. DO METROPOLITANO DE SÃO PAULO.Aferição da Pesquisa O-D 1997, 2002. Organização da autora.

As Pesquisas O-D apontam que os índices de viagens a pé cresceram 66\% entre 1987 e 2002. O percentual de deslocamentos a pé da RMSP gira, no período estudado, em torno dos $37 \%$ de todos os deslocamentos realizados na metrópole diariamente. Só este dado seria suficiente para que a região fosse melhor estruturada para os pedestres. O desrespeito às faixas de pedestre, as conversões que priorizam o veículo motorizado durante a vigência do sinal verde aos pedestres, a duração do sinal verde inadequada à travessia de avenidas largas, a ausência de calçadas, e muitos outros fatores que priorizam o veículo ao pedestre deveriam ser problemas sanados pelas políticas de transportes metropolitanos. 
No período por nós estudado, entre 1987 e 2007, verificamos que o transporte coletivo, pelo menos até 1995, esteve "imerso num quadro de paralisia - de estagnação para a ferrovia, lentíssimo crescimento do metrô e retrocesso no atendimento por ônibus",537. Mello ${ }^{538}$ observa que “o transporte urbano de passageiros não foi enfocado como serviço público de consumo coletivo, mas instrumentalizado, em maior ou menor grau, como ferramenta, como alavanca de crescimento do setor privado e, portanto, como instrumento de reprodução do capital."

A partir do final do período estudado por Mello ${ }^{539}$, o ano de 1995, até o final do período por nós estudado, o ano de 2007, a situação sofreu grande reversão no que tange à quebra no período de estagnação. No entanto, as observações realizadas nos estudos da autora acerca das políticas de transporte serem utilizadas "como alavanca de crescimento do setor privado", não deixam dúvidas de que, neste aspecto, não houve nenhuma reversão.

O capítulo que ora finalizamos apresentou que intensas mudanças na forma e na função dos sistemas de transporte de passageiros ocorreram em tempos de reestruturação produtiva na RMSP. A estrutura, conforme alentado no parágrafo anterior, não se reverteu no sentido de manutenção de seus objetivos: a acumulação de capital às custas da mobilidade das pessoas.

Podemos relacionar os circuitos superior e o inferior da economia urbana com o transporte urbano. O circuito superior constitui-se no transporte moderno "que responde ao consumo moderno, à aceleração dos ritmos de troca, aos fluxos articulados a forças de transformação cuja gênese situa-se além da cidade." ${ }^{540}$. O circuito inferior é o transporte que articula o local e que se subordina "às necessidades do circuito moderno, na medida em que

\footnotetext{
${ }^{537}$ MELLO, 2000, pp.211-212.

${ }^{538}$ Ibidem, p.212.

${ }^{539}$ Ibidem.

${ }^{540}$ Ibidem, p. 220 .
} 
seus recursos servem primordialmente para potencializar a acumulação [...]"541. Para a autora, os recursos alocados para o setor de transportes que retornam ao circuito moderno da economia são os que mais aparecem como bons investimentos aos olhos da população: obras grandiosas viárias que atraem os usuários de automóveis são uma delas. Aliaremos todas estas reflexões ao que apresentaremos na terceira e última parte de nossa pesquisa: a mobilidade dos passageiros na RMSP em tempos de reestruturação produtiva, quando fazemos a análise dos índices de mobilidade, dos meios de transporte mais utilizados e da duração das viagens na RMSP.

${ }^{541}$ MELLO, 2000, p.220. 


\section{Parte III - A Mobilidade dos Passageiros na RMSP em Tempos de Reestruturação Produtiva}

O modo de vida urbano compreende uma multiplicidade de relações sociais. A metrópole oferece possibilidades da realização da mobilidade e o cotidiano das pessoas pode compreender uma rede de relações sociais imbricadas. Contudo, a metrópole também isola os indivíduos, muitos deles imobilizados por imposições sociais. Relacionamos esta questão com a noção de tempo rápido, proposta por $\operatorname{Santos}^{542}$, que se contrapõe ao tempo lento. O tempo rápido é o "das ações que animam os objetos técnicos"543. O autor afirma que o "tempo rápido não cobre a totalidade do território nem abrange a sociedade inteira." ${ }^{544}$. Expõe também que aqueles que têm mobilidade na cidade podem "percorrê-la e esquadrinhá-la" pouco:

\footnotetext{
Sua comunhão com as imagens, freqüentemente prefabricadas, é a sua perdição. Seu conforto, que não desejam perder, vem, exatamente, do convívio com essas imagens. Os homens 'lentos', para quem tais imagens são miragens, não podem, por muito tempo, estar em fase com esse imaginário perverso e acabam descobrindo as fabulações ${ }^{546}$.
}

O autor continua nos lembrando que esses homens lentos, alheios ao meio técnicocientífico informacional, destinado aos ricos e às classes médias, são aqueles que olham para o futuro. São os pobres que sonham com a satisfação e imaginam a abundância. São os homens lentos que caminham e usam o lento transporte coletivo.

Foi concedida à classe média brasileira uma tecnologia mais veloz: o automóvel, e “o usuário do transporte coletivo permaneceu preso à mesma alternativa tecnológica, não apenas

\footnotetext{
${ }^{542}$ SANTOS, 1997.

${ }^{543}$ Ibidem, p. 211.

544 Ibidem.

${ }^{545}$ Ibidem, p.260.

${ }^{546}$ Ibidem, p.260-261.
} 
pela sua impossibilidade concreta de mudar de modo de transporte, mas também pela relativa estagnação tecnológica [...] do transporte coletivo: os ônibus [...]" ${ }^{, 547}$. Mello ${ }^{548}$ entende que, ao ter uma ação regressiva em relação à provisão de transporte coletivo na RMSP, o Estado confirmou a estratificação social e os valores simbólicos de identificação social que associam a pobreza ao transporte coletivo, especialmente ao trem e, também, em parte, ao ônibus, cumprindo "um papel na reprodução da pobreza, participando ativamente de seu agravamento." ${ }^{549}$. Já ao atuar positivamente na infra-estrutura de circulação viária, agiu de forma positiva à reprodução da riqueza, ou pelo menos àquele estrato social que apresenta condições de adquirir um ou mais automóveis para conseguir reproduzir o estilo de vida da classe média, tido como o majoritário e mais importante da metrópole ${ }^{550}$. A estrutura levou mais em conta o tempo rápido na construção de uma forma urbana destinada a alguns segmentos sociais, aos homens móveis e velozes.

A diminuição do índice de mobilidade ${ }^{551}$ na RMSP vinha acontecendo desde 1977, quando o índice médio de mobilidade era de 2,08 viagens por habitante. Este índice diminuiu em 1987 (2,06), e mais ainda em 1997 (1,87), voltando a subir em 2002 (2,11 viagens por habitante). Ele aumenta conforme cresce a renda familiar mensal. Além disso, percebemos que a faixa mais alta de rendimentos, em 1987, tinha mais do que o dobro de mobilidade em relação àquela mais baixa, o mesmo fato ocorrendo em 1997, apesar da queda da mobilidade total neste ano. Entendemos que os altos índices de congestionamento de caminhões, motocicletas, automóveis e ônibus contribuem ativamente para a queda do índice de mobilidade em todos os níveis sociais, inclusive nos de maior rendimento.

\footnotetext{
${ }^{547}$ VASCONCELLOS, 1999, p.236.

${ }^{548}$ MELLO, 2000.

${ }^{549}$ Ibidem, p.219.

${ }^{550}$ MELLO, 2000; VASCONCELLOS, 2000.

${ }^{551} \mathrm{O}$ índice de mobilidade corresponde ao número de viagens realizadas por habitante, ou seja, quantas viagens são realizadas por habitante em um determinado período.
} 
Historicamente, o menor índice de mobilidade é menor nas faixas salariais mais baixas, como mostra a Tabela 27:

Tabela 27 - Região Metropolitana de São Paulo Índice de mobilidade por renda familiar mensal em 1987 e 1997

\begin{tabular}{|l|c|c|}
\hline \multicolumn{1}{|c|}{ RENDA } & $\begin{array}{c}\text { ÍNDICE DE MOBILIDADE } \\
\text { TOTAL 1987 }\end{array}$ & $\begin{array}{c}\text { ÍNDICE DE MOBILIDADE } \\
\text { TOTAL 1997 }\end{array}$ \\
\hline Até $\mathrm{R} \$ 250,00$ & 1,33 & 1,16 \\
\hline De $\mathrm{R} \$ 250,00$ a $\mathrm{R} \$ 500,00$ & 1,63 & 1,47 \\
\hline De $\mathrm{R} \$ 500,00$ a $\mathrm{R} \$ 1.000,00$ & 1,95 & 1,76 \\
\hline De $\mathrm{R} \$ 1.000,00$ a $\mathrm{R} \$ 1.800,00$ & 2,31 & 2,07 \\
\hline De $\mathrm{R} \$ 1.800,00$ a $\mathrm{R} \$ 3.600,00$ & 2,65 & 2,34 \\
\hline $\mathrm{R} \$ 3.600,00$ e mais & 3,08 & 2,64 \\
\hline MEDIA & 2,06 & 1,87 \\
\hline
\end{tabular}

Fonte: CIA. DO METROPOLITANO DE SÃO PAULO. Aferição da Pesquisa O-D 1997, 2002.

Organização da autora.

A Aferição da Pesquisa O-D 1997, realizada em 2002, trouxe-nos dados mais detalhados acerca do índice de mobilidade e sua relação com a faixa de renda, como podemos observar na Tabela 28.

Tabela 28 - Região Metropolitana de São Paulo Índice de mobilidade por modo principal e renda familiar mensal, em 2002

\begin{tabular}{|l|c|c|c|c|c|}
\hline \multicolumn{1}{|c|}{ Renda } & Índice de & mobilidade & por modo & \multicolumn{2}{c|}{ principal } \\
\hline & COLETIVO & INDIVIDUAL & MOTORIZADO & A PE & TOTAL \\
\hline Até $\mathrm{R} \$ 400,00$ & 0,43 & 0,15 & $\mathbf{0 , 5 8}$ & 0,95 & $\mathbf{1 , 5 3}$ \\
\hline De R \$ 400,00 a R\$ 800,00 & 0,59 & 0,27 & $\mathbf{0 , 8 6}$ & 0,91 & $\mathbf{1 , 7 7}$ \\
\hline De R \$ 800,00 a R\$ 1.600,00 & 0,75 & 0,57 & $\mathbf{1 , 3 2}$ & 0,79 & $\mathbf{2 , 1 1}$ \\
\hline De R \$ 1.600,00 a R \$ 3.000,00 & 0,76 & 1,16 & $\mathbf{1 , 9 2}$ & 0,60 & $\mathbf{2 , 5 2}$ \\
\hline De R \$ 3.000,00 a R $6.000,00$ & 0,57 & 1,76 & $\mathbf{2 , 3 3}$ & 0,46 & $\mathbf{2 , 7 9}$ \\
\hline R\$ 6.000,00 e mais & 0,37 & 2,47 & $\mathbf{2 , 8 4}$ & 0,49 & $\mathbf{3 , 3 3}$ \\
\hline MEDIA & 0,63 & 0,70 & $\mathbf{1 , 3 3}$ & 0,78 & $\mathbf{2 , 1 1}$ \\
\hline
\end{tabular}

Fonte: CIA. DO METROPOLITANO DE SÃO PAULO. Aferição da Pesquisa O-D, 2002.

Organização da autora.

Em todos os modos de transporte, os índices de mobilidade mais baixos correspondiam à menor faixa de renda, com exceção do modo a pé, o que mostra claramente que a população de menor rendimento só possui maior mobilidade quando não precisa pagar por ela, ou seja, quando caminha. A população da RMSP que se encontra nesta faixa de rendimento familiar mensal perfazia, no ano da pesquisa, $17 \%$ da população total. 
A faixa de rendimentos seguinte, de $\mathrm{R} \$ 400,00$ a $\mathrm{R} \$ 800,00$ (24,5\% da população), também apresentava índice de mobilidade inferior à média, e já notamos a diminuição do índice de mobilidade a pé nesta faixa de renda, mas ainda superior à faixa de renda anterior, no modo motorizado. Ambas, que juntas correspondiam, na época da pesquisa, a 41,5\% da população da RMSP, apresentam baixíssimos índices de mobilidade no modo motorizado individual $^{552}$.

A faixa de rendimentos entre $\mathrm{R} \$ 1.600,00$ a $\mathrm{R} \$ 3.000,00$, cujo percentual equivale a 19\% dos habitantes da RMSP, no entanto, já tem praticamente o dobro de mobilidade no modo individual que a faixa anterior, de $\mathrm{R} \$ 800,00$ a $\mathrm{R} \$ 1.600,00$ (27,5\% da população). Em todas as faixas de renda, o índice de mobilidade no modo motorizado é superior ao do modo a pé. Na média do modo individual, o índice de 0,70, supera o modo coletivo, de 0,63.

O tempo de deslocamento usado para o transporte, na maioria das vezes, é tido como um tempo perdido pelo usuário. Os habitantes de uma metrópole necessariamente perdem mais tempo no transporte do que aqueles que residem em cidades menos populosas e menores. Para minimizar essa perda, seria importante que os meios de transporte coletivos fossem, ao menos, confortáveis e que não trouxessem tanto desgaste ao trabalhador. Existe a necessidade urgente de regulamentação de horários dos ônibus para que as pessoas possam se programar melhor nos seus percursos, sabendo o horário em que o ônibus vai passar e o tempo aproximado de duração do percurso. Pensamos que se os terminais inteligentes, referidos anteriormente, tiverem realmente tão alto grau de tecnologia como foi divulgado, certamente poderão sanar este problema. Logicamente, dado o tamanho da metrópole, há imprevistos que usualmente provocam atrasos. Seria necessário, assim, que as empresas tivessem veículos e motoristas sobressalentes para cobrir os eventuais atrasos dos ônibus para

\footnotetext{
552 O modo motorizado individual compõe-se de motorista de automóvel, passageiro de automóvel, táxi,
} caminhão, moto e outros. 
que os usuários que eventualmente já estão aguardando o veículo no terminal não tenham de aguardar a chegada daquele determinado ônibus para que o subseqüente saia. Mesmo que a demora seja inevitável pelas longas distâncias a serem percorridas, o transporte em ônibus precisa melhorar muito sua qualidade, diminuindo os solavancos e os ruídos e proporcionando assentos confortáveis a quem vai passar, em muitos casos, até mais de duas horas no veículo.

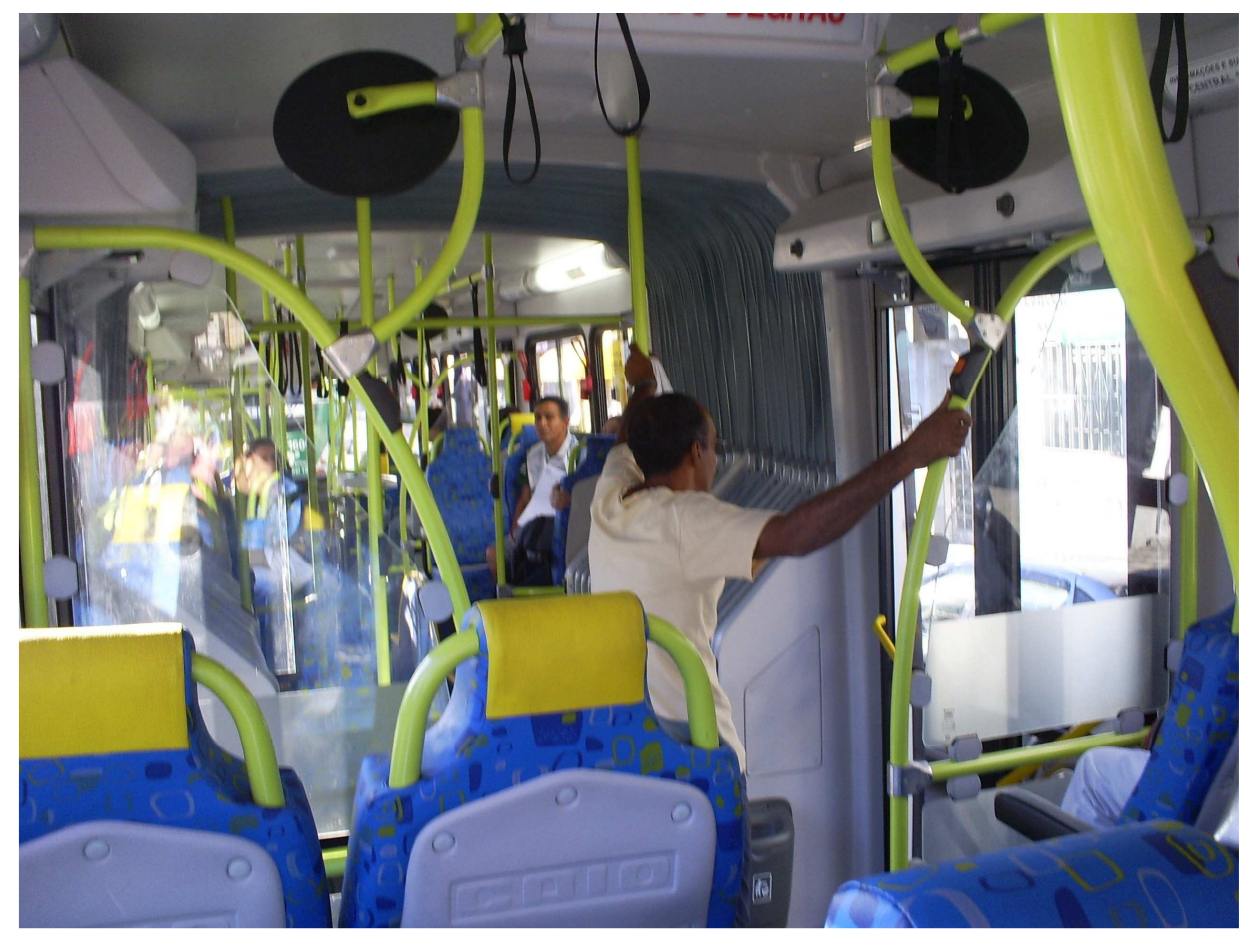

Autoria: Flávia Ulian

Fotografia 71 - Município de São Paulo - Interior de ônibus novo a diesel da Viasul / 21/03/07

A análise da Tabela 29 nos permite conhecer a duração das viagens em cada modo principal $^{553}$, realizadas nos deslocamentos entre a residência e o trabalho.

\footnotetext{
${ }^{553}$ Cf. nota 533 .
} 
Tabela 29 - Região Metropolitana de São Paulo

Número de viagens diárias produzidas por modo principal e sua duração

por motivo de trabalho, em 1997

\begin{tabular}{|c|c|c|c|c|c|c|c|c|c|c|c|c|c|c|c|c|c|c|}
\hline $\begin{array}{l}\text { MODO } \\
\text { PRINCIPAL } \\
\text { DAVIAGEM }\end{array}$ & 0-14 min. & $\begin{array}{l}15-29 \\
\text { min. }\end{array}$ & $\begin{array}{l}30-44 \\
\text { min. }\end{array}$ & $\begin{array}{l}45-59 \\
\text { min. }\end{array}$ & 1h-1h14 & $\begin{array}{l}\text { 1h15- } \\
1 \mathrm{~h} 29\end{array}$ & $\begin{array}{l}1 \mathrm{~h} 30- \\
1 \mathrm{~h} 44\end{array}$ & $\begin{array}{l}1 \mathrm{~h} 45- \\
1 \mathrm{~h} 59\end{array}$ & $\begin{array}{l}2 \mathrm{~h}- \\
2 \mathrm{~h} 14\end{array}$ & $\begin{array}{l}2 \mathrm{~h} 15- \\
2 \mathrm{~h} 29\end{array}$ & $\begin{array}{l}2 \mathrm{~h} 30- \\
2 \mathrm{~h} 44\end{array}$ & $\begin{array}{l}2 \mathrm{~h} 45- \\
2 \mathrm{~h} 59\end{array}$ & $\begin{array}{l}3 \mathrm{~h}- \\
3 \mathrm{~h} 14\end{array}$ & $\begin{array}{l}3 \mathrm{~h} 15- \\
3 \mathrm{~h} 29\end{array}$ & $\begin{array}{l}3 \mathrm{~h} 30- \\
3 \mathrm{~h} 44\end{array}$ & $\begin{array}{l}3 \mathrm{~h} 45- \\
3 \mathrm{~h} 59 \\
(4 \mathrm{~h})\end{array}$ & $\begin{array}{l}4 \mathrm{~h} \text { e } \\
\text { mais }\end{array}$ & TOTAL \\
\hline Ônibus & 49.863 & 391.252 & 849.416 & 469.238 & 759.678 & 282.993 & 433.191 & 120.145 & 217.365 & 39.814 & 98.967 & 15.524 & 38.848 & 3.203 & 9.165 & 190 & 3.609 & 3.782.461 \\
\hline Ônibus fretado & 4.276 & 40.621 & 87.176 & 76.597 & 79.132 & 37.504 & \begin{tabular}{|l|}
29.723 \\
\end{tabular} & 12.473 & 14.815 & 1.434 & 2.456 & 419 & 2.435 & 24 & 0 & 0 & 0 & 388.085 \\
\hline $\begin{array}{l}\text { Dirigindo } \\
\text { automóvel }\end{array}$ & 713.599 & 848.626 & 927.899 & 268.121 & 365.586 & 78.406 & 115.217 & 18.213 & 44.404 & 6.334 & 9.186 & 1.289 & 8.179 & 560 & 1.372 & 52 & 906 & 3.407 .949 \\
\hline $\begin{array}{ll}\text { Passageiro de } \\
\text { automóvel }\end{array}$ & 168.844 & 177.032 & 172.213 & 48.041 & 53.570 & 11.387 & 25.520 & 3.684 & 11.972 & 521 & 2.531 & 1.164 & 2.972 & 0 & 157 & 0 & 33 & 685.903 \\
\hline Táxi & 276 & 14.278 & 7.086 & 2.792 & 1.968 & 470 & 290 & 69 & 934 & 0 & 0 & 0 & 0 & 0 & 0 & 0 & 0 & 33.163 \\
\hline Lotação/Perua & 4.761 & 13.249 & 22.969 & 8.558 & 10.968 & 2.414 & 3.732 & 462 & 1.663 & 0 & 378 & 0 & 72 & 0 & 0 & 0 & 0 & 69.226 \\
\hline Metrô & 2.792 & 31.970 & 133.124 & 103.808 & 181.034 & 105.969 & 193.776 & 68.711 & 98.081 & 22.576 & 41.907 & 8.823 & 23.764 & 2.184 & 5.927 & 817 & 6.705 & 1.046 .364 \\
\hline Trem & 1.025 & 7.368 & 15.549 & 38.600 & 81.381 & 49.908 & \begin{tabular}{|l|}
103.356 \\
\end{tabular} & 43.502 & 71.523 & 16.021 & 28.740 & 6.252 & 18.547 & 1.079 & 1.968 & 884 & 2.102 & 487.805 \\
\hline Motocicleta & 24.578 & 38.268 & 33.086 & 6.493 & 6.121 & 990 & 1.373 & 206 & 0 & 0 & 95 & 0 & 0 & 0 & 0 & 0 & 0 & 111.278 \\
\hline Bicicleta & 38.025 & 31.795 & 25.919 & 7.738 & 3.991 & 590 & 1.180 & 739 & 342 & 0 & 197 & 0 & 0 & 0 & 0 & 0 & 0 & 110.516 \\
\hline A pé & 1.588 .094 & 680.441 & 301.355 & 29.294 & 37.016 & 5.729 & 5.797 & 840 & 3.458 & 1.161 & 697 & 143 & 1.538 & 0 & 0 & 0 & 0 & 2.655 .563 \\
\hline TOTAL & 2.601.133 & $\begin{array}{l}2.274 .900 \\
\end{array}$ & 2.575.792 & 590.749 & 1.580 .445 & 576.360 & $\mathbf{9 1 3 . 1 5 5}$ & 269.044 & 464.557 & 87.861 & 185.154 & 33.614 & 96.355 & $\mathbf{7 . 0 5 0}$ & 18.589 & 1.943 & 13.355 & 12.778.313 \\
\hline
\end{tabular}

Fonte: CIA. DO METROPOLITANO DE SÃO PAULO. Pesquisa O-D, 1997.

Elaboração da autora 
Os dados da Tabela 29 não estão completos, pois omitimos dois modos que não julgamos pertinentes, ou que não teriam exatamente importância na análise feita neste momento: transporte escolar e outros modos. Optamos por nos restringir apenas aos modos mais significativos para o entendimento da qualidade dos deslocamentos dos trabalhadores sob o ponto de vista de sua duração. Além disso, os dados não levam em conta a distância entre as residências e os locais de trabalho.

O modo principal mais utilizado para o deslocamento ao trabalho era, em 1997, o ônibus, com 3.782.461 viagens diárias. Em segundo lugar, o automóvel particular com o trabalhador dirigindo o automóvel. Neste modo, ocorreram 3.407.949 deslocamentos diários em 1997. Neste ano, bastante significativo também foi o número de deslocamentos diários realizados a pé, como modo principal: 2.655.563. Na seqüência, temos os modos metrô, automóvel particular com o trabalhador sendo passageiro, trem, ônibus fretado, motocicleta, bicicleta, lotação/perua.

Quanto ao tempo de deslocamento por motivo de trabalho, destacaram-se os intervalos de 0 a 14 minutos, com 2.601 .133 viagens realizadas neste tempo e o intervalo entre 30 e 44 minutos, com 2.575.792 viagens. Em terceiro lugar, aparecia o intervalo de 15 e 29 minutos, com 2.274.900 viagens, e em quarto lugar, entre 1 hora e 1 h14 minutos (1.580.445). Traduzindo estas quantidades de deslocamentos em números percentuais, podemos dizer que o maior percentual deles, entre 0 a 14 minutos, corresponde a 20,35\% dos deslocamentos. $20,15 \%$ das viagens ocorriam com duração entre 30 e 44 minutos, 17,80\% em intervalos entre 15 e 29 minutos e $12,36 \%$ entre $1 \mathrm{~h}$ e $1 \mathrm{~h} 14$ minutos.

Os modos de transporte com o maior número de deslocamentos entre 0 e 14 minutos, ou seja, que são rápidos no transporte entre a casa e o local de trabalho, tendo em vista o tamanho da metrópole paulista, são, em primeiro lugar, o modo a pé, em segundo o trabalhador dirigindo automóvel, e em terceiro, o trabalhador como passageiro de automóvel. 
Já no intervalo entre 15 e 29 minutos, sobressai-se o trabalhador dirigindo automóvel, em segundo, a pé, e em terceiro, o modo ônibus.

Analisando-se do ponto de vista do modo de transporte, verificamos que, nos modos ônibus e ônibus fretado como modo principal, as maiores quantidades de deslocamentos para o trabalho levaram entre 30 e 44 minutos, e em segundo lugar, de 1 hora a 1 h14 minutos. No modo em que o trabalhador dirige o automóvel, também se sobressaiu em primeiro lugar a duração de 30 a 44 minutos, em primeiro lugar, em segundo lugar, entre 15 e 29 minutos. Quando o trabalhador é passageiro de automóvel ou vai de táxi ao trabalho, a maior quantidade de deslocamentos ocorreu no intervalo de 15 a 29 minutos e, em segundo lugar, de 30 a 44 minutos. No modo lotação/perua como modo principal, aconteceu o contrário: a maior quantidade de viagens demorou de 30 a 44 minutos, e em segundo lugar, de 15 a 29 minutos. Já os modos metrô e trem aparecem como muito demorados: tanto num como noutro modo, maior quantidade de pessoas apresentou deslocamentos entre $1 \mathrm{~h} 30$ e $1 \mathrm{~h} 44$ minutos, e em segundo lugar, entre 1 hora e $1 \mathrm{~h} 14$ minutos. As quantidades de deslocamentos entre 2 horas e 2h14 minutos com o uso destes modos também são expressivas. Os modos bicicleta e a pé são mais usados em deslocamentos rápidos, sobressaindo-se aqueles que duraram entre 0 e 15 minutos, em primeiro lugar, e entre 15 e 29 minutos, em segundo lugar.

À primeira vista, parecem ser o trem e o metrô os modos principais com maior duração das viagens por motivo de trabalho. A Tabela 30 nos ajuda a entender melhor quais os modos principais mais lentos e os mais rápidos.

Tabela 30 - Região Metropolitana de São Paulo Percentual de viagens diárias produzidas por modo principal e sua duração por motivo de trabalho, em 1997

\begin{tabular}{|l|c|c|c|c|c|c|}
\hline MODO PRINCIPAL & & \multicolumn{5}{|c|}{ TEMPO DE DURAÇÃO DA VIAGEM } \\
\hline & & $\mathbf{0 - 5 9}$ min. & 1h-1h59 & $\mathbf{2 h - 2 h 5 9}$ & $\mathbf{3 h - 3 h 5 9}$ & + de 4h \\
\hline Ônibus & 100,0 & 46,52 & 42,19 & 9,82 & 1,35 & 0,09 \\
\hline Ônibus fretado & 100,0 & 53,76 & 40,92 & 4,92 & 2,11 & $\begin{array}{c}0 \\
\text { continua }\end{array}$
\end{tabular}




continuação
\begin{tabular}{|l|c|c|c|c|c|c|}
\hline MODO PRINCIPAL & & \multicolumn{5}{|c|}{ TEMPO DE DURAÇÃO DA VIAGEM } \\
\hline & & $\mathbf{0 - 5 9}$ min. & $\mathbf{1 h - 1 h 5 9}$ & $\mathbf{2 h - 2 h 5 9}$ & $\mathbf{3 h - 3 h 5 9}$ & $\mathbf{+}$ de $\mathbf{4 h}$ \\
\hline Dirigindo automóvel & 100,0 & 80,93 & 16,94 & 1,79 & 0,29 & 0,02 \\
\hline Passageiro de automóvel & 100,0 & 82,53 & 13,72 & 2,36 & 0,45 & 0 \\
\hline Táxi & 100,0 & 88,74 & 8,43 & 2,81 & 0 & 0 \\
\hline Lotação/Perua & 100,0 & 71,55 & 25,38 & 2,94 & 0,1 & 0 \\
\hline Metrô & 100,0 & 25,89 & 52,51 & 16,37 & 3,12 & 0,64 \\
\hline Trem & 100,0 & 12,82 & 57,02 & 25,11 & 4,6 & 0,43 \\
\hline Motocicleta & 100,0 & 92,04 & 7,80 & 0,08 & 0 & 0 \\
\hline Bicicleta & 100,0 & 93,63 & 5,88 & 0,48 & 0 & 0 \\
\hline A pé & 100,0 & 97,87 & 1,85 & 0,20 & 0,05 & 0 \\
\hline
\end{tabular}

Fonte: CIA. DO METROPOLITANO DE SÃO PAULO. Pesquisa O-D, 1997.

Elaboração da autora.

Mais de $90 \%$ das viagens cujos modos principais são a pé, bicicleta e motocicleta foram realizados em menos de uma hora. Neste tempo, também foram realizadas cerca de metade das viagens em ônibus fretado e ônibus. Apenas um quarto das viagens realizadas com o metrô como modo principal foram feitas em menos de uma hora. Menor ainda é o percentual de viagens realizadas por trem em menos de uma hora. Em contraposição, cerca de $80 \%$ dos deslocamentos de até uma hora foram realizados por automóvel como modo principal, tanto quando o trabalhador dirige, quanto nas ocasiões em que é passageiro.

Entre uma e duas horas de duração, no entanto, foi realizada praticamente a metade dos deslocamentos quando o metrô é o modo principal. Não há contradição entre estes dados e o senso comum de que o Metrô é um sistema rápido. Certamente as viagens mais longas com o uso do metrô como modo principal ocorreram em conjunto com outros modos de transporte, como o trem, o ônibus ou a lotação, e mesmo juntamente com o modo a pé. No entanto, sendo o primeiro da hierarquia utilizada pela Pesquisa O-D, aparece como modo principal, escamoteando os outros modos incluídos no mesmo trajeto.

O trem também participa de alto percentual de deslocamentos como modo principal em deslocamentos que levam entre uma e duas horas. Rosa $^{554}$ realizou uma pesquisa baseada na Pesquisa de Acesso e Difusão (AD) da CPTM em 2005 e verificou que há uma 
concentração maior de usuários do trem metropolitano com duração da viagem maior do que 60 minutos. $\mathrm{O}$ autor afirma que

Visto que o trem metropolitano, nas áreas mais extremas de suas linhas, tem viagens com tempos de percurso em torno de 60 minutos para atingir as zonas centrais da RMSP (Centro do Município de São Paulo, por ex.), poderíamos, de certa forma, inferir que os usuários deste modo estariam segregados espacialmente, por conta dos deslocamentos com tempos demasiadamente longos para atingirem as oportunidades $^{555}$.

Ainda neste intervalo de duração, participam cerca de $40 \%$ dos deslocamentos de ônibus e de ônibus fretado como modo principal. Já o automóvel é responsável apenas por cerca de $17 \%$ dos deslocamentos que se realizam entre uma e duas horas.

Conforme vai aumentando o tempo de deslocamento, diminui o percentual de viagens realizadas. O único destaque para viagens que duram entre duas e três horas ocorre quando o trem é o modo principal, com um quarto dos deslocamentos neste tempo de duração.

O estudo dos tempos de reestruturação produtiva da metrópole paulistana fez com que Ferrari $^{556}$ fizesse a seguinte afirmação:

Eram substituídos ônibus de transporte de operários - homens e mulheres portadores da mercadoria viva da força de trabalho - por caminhões transportando hora-a-hora mercadorias já produzidas. Substituição que tornava a malha urbana um inferno; em meio, ainda, a um ar irrespirável de cidades cada vez mais violentas. Imediaticidade que vai sendo percebida como resultado de relações intrínsecas dos imperativos econômicos e políticos mais globais, e resultante da implantação de um tempo real dentro das fábricas. Isto é, o just in time extravasava os muros da fábrica. As cidades apareciam como o lócus ampliado da produção, entendendo-se que nelas ocorria a circulação, uma face crucial do processo produtivo.

Como em tempos fordistas construiu-se um espaço urbano fordista e um estilo de vida fordista, com a reestruturação da produção para o just in time, as vidas das pessoas adquirem o ritmo da fábrica em tempo real. Como uma imposição da nova estrutura metropolitana que se constrói, os deslocamentos na metrópole crescem dia após dia. As pesquisas que têm sido

\footnotetext{
${ }^{555}$ ROSA, 2006, p.106.

${ }^{556}$ FERRARI, 2003, p. 15.
} 
feitas sobre os deslocamentos realizados na metrópole deveriam servir de base para o planejamento de transportes desta metrópole.

Comparando-se os dados das viagens realizadas diariamente na RMSP, verificamos que houve um crescimento, entre 1987 e 2007, em praticamente $100 \%$ das viagens realizadas por trem metropolitano, $70 \%$ nos deslocamentos realizados pelo metrô e pelos ônibus municipais (município de São Paulo) ${ }^{557}$.

No entanto, como sempre foi leviano, o poder público deixou uma herança "tosca", e os problemas que os cidadãos enfrentam para se deslocarem no cotidiano estão se tornando piores a cada dia. É necessário que se consolide uma infra-estrutura de transportes que possa integrar as atividades dispersas no território metropolitano, criando pólos articuladores locais que têm sido construídos, conectando os sistemas de ônibus que, em alguns casos, são intermodais, para garantir a integração sócio-espacial da população metropolitana ${ }^{558}$. Porém, a velocidade de sua implementação não tem sido no ritmo just in time e ainda está muito aquém das necessidades da população.

Ferrari $^{559}$ argumenta que a reestruturação produtiva vem sendo promovida pelo capital e Estado: "A tensão entre a racionalidade da produção capitalista no interior das fábricas e o aparente caos urbano está ligado por nexos sutis e uma unidade contraditória entre trabalho, capital e poder do Estado [...]"560. A autora acredita não ser possível separar esta unidade. Além disso, o caos, na realidade, é "a própria ordem anárquica do mercado capitalista."561, gerado pela velocidade rápida de rotação do capital que impõe uma circulação de mercadorias dinâmica promovida, por exemplo, pelo acelerado ritmo do just in time.

\footnotetext{
557 CIA. DO METROPOLITANO DE SÃO PAULO, 2002; www.metro .sp.gov.br/empresa/numeros/indicadores/indicadores.shtml $\quad-$ acesso em 27.05.2008; www.cptm.sp .gov.br/e_companhia/gerais.asp - acesso em 27.05.2008; www.sptrans.com.br/new05/conteudos/ indicadores /passageiros/ - acesso em 27.05.2008).

${ }^{558}$ MEYER et alli, 2004.

${ }^{559}$ FERRARI, 2004.

${ }^{560}$ Ibidem, p.61.

561 Ibidem.
} 
Sobre a malha viária urbana, recaem os efeitos desta dinamização, que devem ser enfrentados pelo poder político-institucional de âmbito local, [ou seja, a tese da autora é que] os planejamentos $\square$ ust in time aplicados a fornecedores $\mathrm{e}$ consumidores dos conglomerados industriais extrapolam o interior das fábricas, invadindo a malha urbana, saturando as ruas, impondo os efeitos da circulação em tempo real a todos $[\ldots]^{562}$.

A estrutura urbana just in time se contrapõe à taylorista-fordista. A coexistência destas duas estruturas urbanas é gerenciada pela administração pública. As metrópoles são, na visão da autora, configurações sócio-espaciais representativas do momento histórico da acumulação fordista e da industrialização, desequilibrando produção, moradia, transporte, meio ambiente e cultura. Pensamos que o sistema de transportes mal preparado para transportar a sociedade industrial fordista torna-se ainda pior para dar conta de transportar a sociedade em ritmo just in time. De acordo com o Engenheiro Luciano Luz, da CPTM, em entrevista concedida a nós no dia 26.02.2008, o pico ${ }^{563}$ da manhã sempre foi menor do que o da tarde, mas em 2007 observou-se que este último superou o pico da manhã. No intervalo dos horários de pico da manhã e tarde, também houve acréscimo de passageiros, daí ter dobrado o número de passageiros que usam os trens metropolitanos, entre 1997 e 2007 . Houve momentos em que os operários estavam no "chão da fábrica", hoje, no entanto, estão no "chão urbano". É evidente no espaço urbano o reflexo da produção em tempo real, com mudanças dos fluxos de pessoas e mercadorias. Ferrari ${ }^{564}$ afirma que as cidades foram "reduzidas a um nó que deve ser desatado - dia-a-dia - por seus habitantes e pelo poder municipal para atendimento das metas de projetos de produtos just in time e circulação em tempo real impostos pelo aumento da velocidade de rotação do capital." Apesar de toda a sociedade funcionar em torno do cumprimento das metas estabelecidas pelo capital e dos problemas e custos serem socializados, a apropriação das soluções e dos lucros continua privada ${ }^{565}$.

\footnotetext{
${ }^{562}$ FERRARI, 2004, p.61.

${ }^{563}$ Os horários de pico são aqueles com maiores quantidades de fluxos.

564 Ibidem, p.63.

565 Ibidem.
} 
Forma, infra-estrutura de transportes; função, deslocamentos; estrutura, políticas de transporte, no longo processo de estruturação e reestruturação da metrópole paulistana. Procuramos abarcar todos os elementos pertinentes aos sistemas de transportes terrestres urbanos a fim de compreender a mobilidade dos passageiros na RMSP em tempos de reestruturação produtiva. A discussão do índice de mobilidade e duração das viagens por motivo de trabalho realizada neste último capítulo contribuiu para que a problemática central formulada nesta Tese fosse respondida, encerrando, por hora, nosso trabalho de pesquisa. Contudo, sabemos que o trabalho de pesquisa é infindável e a temática aqui abordada já está repleta de novidades. 


\section{Considerações Finais}

Procuramos, nesta Tese, investigar os deslocamentos e a rede de transporte de passageiros na metrópole paulistana no período de 1987 a 2007. A pesquisa foi norteada buscando responder à problemática central de que a reestruturação produtiva induz a uma redefinição do sistema de transportes terrestres tanto no que se refere à infra-estrutura quanto aos deslocamentos realizados por passageiros. Podemos afirmar, após a conclusão desta Tese, que a redefinição do padrão produtivo também redefiniu o padrão da circulação de passageiros na RMSP.

Os fluxos das pessoas e a infra-estrutura do transporte metropolitano apresentaram, no período em análise, grandes transformações que, ao se refletirem no território, remodelando sua configuração, foram responsáveis por uma parte da reestruturação por que vem passando a metrópole em tempos de reestruturação da produção.

O novo ordenamento urbano observado na paisagem metropolitana a partir da ampliação do sistema viário em geral configura uma nova metrópole regulada pela intensificação dos fluxos de mercadorias e de passageiros. A partir da década de 1990, a reengenharia da produção alterou os fluxos e provocou novas demandas por transportes, configurando novos arranjos espaciais na metrópole.

Entendendo a mobilidade como a capacidade dos indivíduos realizarem deslocamentos, ou ainda o atributo de fazerem-se movimentar, e a acessibilidade como a facilidade do indivíduo poder deslocar-se para participar de uma atividade qualquer, o que depende da disponibilidade de meios de transporte para tal, percebemos que, se não há acessibilidade satisfatória, o indivíduo tem limitadas suas oportunidades de tomar parte de um conjunto de atividades. A mobilidade não é acessível a todos de forma igual, apesar da 
metropolização estar associada comumente à maior mobilidade. Definitivamente, a circulação intra-metropolitana não é igualmente usufruída por todos no espaço urbano. Para absorver este fenômeno em sua totalidade, analisamos nesta Tese, detalhadamente, estas duas funções urbanas, a mobilidade e a acessibilidade, através de seus três elementos principais: o sistema viário (elemento fixo), os percursos (fluxos) e os veículos (meios de transporte).

Este exame nos possibilitou compreender o que Vasconcellos ${ }^{566}$ havia escrito sobre ser a circulação o conjunto de práticas de consumo do espaço viário e, portanto, estar susceptível a variações relacionadas às condições sociais, econômicas e políticas dos indivíduos. A localização menos acessível das moradias daqueles indivíduos com menos recursos financeiros os impele a uma segregação espacial, que limita as condições de mobilidade da população metropolitana, evidenciada pela ocupação das periferias mais distantes dos postos de trabalho. As camadas pobres da população metropolitana que habitam, nas palavras de Maricato $^{567}$, a chamada "cidade oculta, disfarçada e dissimulada" despendem longas horas de seus dias rumo à cidade hegemônica para o provimento de suas necessidades básicas.

A construção do espaço e da configuração territorial urbana na RMSP, a partir do período da reestruturação produtiva, foi pesquisada à luz da Geografia como ciência social comprometida com a interpretação dos fenômenos que se desenrolam no espaço urbano produzido pela lógica do capital que regula as formas de deslocamento distanciando o ser humano de uma perspectiva humanista de sobrevivência.

Sob a linha metodológica de análise da realidade pautada sobre os fenômenos empíricos, de dados estatísticos e conhecimento teórico dos fatos que ocorrem na RMSP no que tange às suas atividades econômicas, utilizamo-nos das quatro categorias do método geográfico de análise do espaço: forma, função, estrutura e processo. A pesquisa realizada nos proporcionou, através do estudo das infra-estruturas de transporte ferroviário, metroviário

\footnotetext{
566 VASCONCELLOS, 1999.

${ }^{567}$ MARICATO, 1996.
} 
e rodoviário, o conhecimento da forma. São passíveis de visualização na paisagem os sistemas de objetos que determinam que os deslocamentos aconteçam.

A análise dos fluxos realizados de acordo com os dados das Pesquisas O-D nos proporcionou o entendimento da função, analisada em relação ao motivo por trabalho, à renda, à duração, ao conforto, à eficiência e outros nos diferentes meios de transporte. Os fluxos compõem o sistema de ações do espaço geográfico.

As políticas que determinam a infra-estrutura viária e influem na qualidade dos fluxos de passageiros compuseram a dimensão da categoria de análise estrutura, absolutamente fundamental para que pudéssemos fazer a crítica ao sistema de transporte de passageiros da RMSP no que se refere à sua eficiência, conforto, segurança e outros itens que possam qualificá-lo. Além disso, a estrutura nos permite compreender o funcionamento dos sistemas de objetos e de ações.

O processo histórico permeou toda a pesquisa.

À luz da subjetividade expressa nas entrevistas realizadas, nos foi possível construir uma nova visão de nosso problema de pesquisa. Além das entrevistas que refletem o cotidiano dos homens e sua compreensão sobre o sistema de transportes, o fato de termos realizado as pesquisas de campo, observando e utilizando o próprio sistema de transporte coletivo, nos possibilitou o contato direto com nosso objeto de pesquisa. Teria sido impossível qualquer conclusão científica sobre o sistema de transporte de passageiros da RMSP apenas através da bibliografia e dos dados estatísticos. Vivenciar o cotidiano dos sujeitos na realização de seus deslocamentos através do espaço metropolitano nos proporcionou captar a realidade geográfica para além do discurso, o que torna a tarefa de codificar esta experiência em palavras ainda mais exigente.

A RMSP, nossa área de estudo, composta de 39 municípios habitados por cerca de 19,6 milhões de habitantes, consolidou-se na metade do século XX como metrópole industrial 
e a partir dos anos 90, também como metrópole de serviços engendrados pelos desdobramentos do setor industrial em tempos de reestruturação produtiva.

Entre 1960 e 1980, a RMSP consolidou um processo industrial calcado nos moldes fordistas da produção industrial capitalista. Sua função de pólo central da economia nacional consolidou-se, concentrando o emprego industrial, atraindo fluxos migratórios e desenvolvendo novos padrões culturais e hábitos de consumo difundidos por uma classe média que nela se formou devido aos altos índices de crescimento econômico da década de $1970^{568}$. Porém, os anos 1990 marcaram a reafirmação de um novo período que se iniciava no final da década anterior: os tempos de reestruturação produtiva. As transformações da forma social de produção industrial originam alterações da forma espacial da cidade. As marcas da reestruturação produtiva são a desconcentração territorial das atividades produtivas, a desintegração vertical da indústria, a terceirização das unidades de produção, a terciarização, a flexibilização e a precarização das relações de trabalho.

Na Segunda Divisão Internacional do Trabalho, o Brasil apresentou bom desempenho econômico com o incremento da industrialização nacional seguido por um período de desaceleração econômica. Na década de 1990, em um contexto recessivo, a política econômica brasileira adotou medidas que visavam a estimular a competitividade industrial, a produtividade e a inovação tecnológica. Por isso, muitas empresas brasileiras adotaram medidas para a reestruturação da produção, que levaram, entre outros, à terceirização de atividades e diminuição do emprego industrial.

Estamos passando por uma revolução no capitalismo tão profunda e significante quanto à da transição da produção artesanal para a industrial. É importante para os capitalistas a redução da força e dos processos de trabalho, sua substituição, estruturação e divisão. Uma classe de trabalhadores industriais semi-habilitados para o trabalho industrial geograficamente

\footnotetext{
${ }^{568}$ ARAÚJO, 2001.
} 
concentrada e socialmente homogênea está sendo cada vez mais substituída por força de trabalho social e geograficamente dispersa.

As técnicas aprimoraram-se com enorme rapidez e o espaço construído por esse "novo" trabalho se transforma muito rapidamente. A resposta do capital aparece na revolução tecnológica e na reestruturação produtiva, com a remodelagem dos sistemas de administração das empresas e a implantação do toyotismo. Novas práticas de gestão do trabalho foram introduzidas de forma heterogênea setorial e regionalmente, sendo sua difusão realizada gradualmente, havendo adoção de práticas toyotistas ao mesmo tempo em que princípios fordistas/tayloristas com padronização e rígida divisão de trabalho ainda imperavam.

Utilizando estratégias defensivas de reestruturação produtiva, o empresariado brasileiro, no decorrer da década de 1990, tentou enfrentar um quadro de incertezas macroeconômicas, enxugando a produção e terceirizando serviços.

A metrópole subordinou-se, então, a novas formas estruturantes da formação sócioespacial capitalista do final do século XX. O ordenamento urbano que se dá em função da redefinição do sistema de transportes é inerente a esta nova formação sócio-espacial e em tempos de reestruturação produtiva torna-se, nas palavras de Lencioni ${ }^{569}$, "um novo fato urbano metropolitano". Irradiadora e atrativa de fluxos, a centralidade metropolitana apresenta internamente pólos de convergência de fluxos, configurando-se como uma metrópole polinucleada. Este fenômeno, associado à dispersão e à descontinuidade da mancha urbana, é responsável pelo engrandecimento dos fluxos urbanos, em tempos de reestruturação produtiva.

A observância da evolução das viagens por motivo de trabalho entre 1987 e 1997, ao mostrar decréscimo do número de deslocamentos realizados por motivo de trabalho na indústria e aumento daqueles realizados por motivo de trabalho no setor de serviços, denuncia 
a diminuição de empregos no setor secundário e crescimento de vagas no setor terciário. Porém, a vacância no setor industrial não pôde ser suprida totalmente pelas ofertas de emprego no setor de serviços devido à entrada de tecnologias que substituíram a mão-de-obra humana, e também da aplicação da terceirização e outras formas de gerenciamento das empresas, o que eliminou cargos das estruturas organizacionais. O crescimento do desemprego também é refletido pela diminuição de $2,41 \%$ das viagens por motivo de trabalho como um todo, ocorrida entre 1987 e 2002.

As fronteiras entre os setores secundário e terciário são cada vez mais fluidas. A "desconstrução" do modelo empresarial fordista e a reorganização das relações entre as firmas, com a externalização de atividades (terceirização) induzem ao crescimento de numerosos serviços que antes eram incluídos nas grandes empresas. Na realidade, o crescimento do setor terciário da metrópole paulistana está profundamente encadeado com as atividades de produção industrial.

A verificação dos dados analisados na Tese nos permitiu apreender que, na RMSP, é o município de São Paulo que mais vagas oferece no mercado de trabalho, além de também oferecer melhores remunerações do que os demais municípios da região. Isto explica, em parte, o intenso fluxo de passageiros entre as sub-regiões da RMSP e a Capital. O crescimento de ocupados que trabalham em municípios diferentes de onde residem cresceu na década de 2000, corroborando para o aumento de deslocamentos intra-metropolitanos entre 1997 e 2002.

Os sistemas de transporte urbano de passageiros da RMSP constituíram importante fator na estruturação da urbanização metropolitana. O mercado imobiliário é, em grande parte, responsável pelo uso coletivo do espaço urbano, o que leva à valorização de determinados espaços em detrimento - e desvalorização - de outros. A infra-estrutura de transportes é, em grande parte, determinante nesta valorização do espaço. A instalação da população migrante nas periferias da metrópole paulistana, em terrenos pouco valorizados, aliada à precária 
distribuição dos meios de transporte no espaço urbano, leva à exclusão sócio-espacial dos indivíduos.

O Estado, ao se limitar na providência de infra-estrutura de transportes, é conivente com a construção de um modelo econômico concentrador de renda e de um espaço segregador. As políticas de transporte de massa na metrópole paulistana, estabelecidas historicamente, não lograram atender as necessidades de deslocamentos da população como um todo. Pelo contrário, o provimento de infra-estrutura de transportes para as classes médias não foi negligenciado pelas políticas de transporte. O planejamento urbano invariavelmente tem caráter político e a urbanização se dá muito mais de acordo com o mercado de terras e de capitais do que de acordo com os planos urbanos. Ao analisar o processo de concentração de renda dos anos 60 e 70, podemos associar o acesso da classe média ao transporte individual ao processo de chegada de migrantes de outros Estados brasileiros acompanhado pelo crescimento da periferia. Assim, houve crescimento do transporte individual e o apoio do Estado a este crescimento favorecendo a expansão do sistema viário, o que seria interessante para a economia do país, já que a indústria automobilística constitui-se um dos pilares da economia nacional. Paralelamente a isto, houve o abandono do transporte coletivo sobre trilhos. Ao crescer a fluidez do transporte individual, os ônibus são beneficiados, mas por pouco tempo, pois o excesso de automóveis logo satura o sistema viário.

O transporte individual criou um modelo de cidade com crescimento horizontal ilimitado, onde há a promessa de mobilidade e acessibilidade propiciada por um ciclo de subvenção do sistema viário. Verifica-se, na RMSP, crescentes dificuldades de garantir infraestrutura para viabilizar a mobilidade e a acessibilidade no interior do espaço metropolitano dadas às deficiências das políticas de transportes públicos. O trabalho de $\mathrm{Mello}^{570}$ nos mostrou que as conseqüências imediatas desse desajuste são, no campo social, as

\footnotetext{
${ }^{570}$ MELLO, 2000.
} 
desigualdades da mobilidade e acessibilidade proporcionada aos cidadãos; no âmbito do espaço urbano, a constante destruição dos tecidos internos metropolitanos; além do custo ambiental.

$\operatorname{Rosa}^{571}$ afirma que a queda da demanda pelo transporte coletivo em detrimento do aumento do interesse pelo individual justifica-se a partir do momento em que, no caso dos ônibus, tornam-se menos atraentes para a população por vários fatores, mas principalmente pela lentidão. O sistema viário está congestionado pelo excesso de automóveis e há poucas vias exclusivas para ônibus. Há maior facilidade para a aquisição de motos e automóveis, formando-se um quadro negativo para o sistema de ônibus, cuja queda da demanda no início dos anos 2000 acabou levando ao aumento das tarifas, sem resolver, no entanto, o problema da queda constante de sua velocidade. Então, como num círculo vicioso, a demanda caiu ainda mais.

A retrospectiva da composição da infra-estrutura viária metropolitana e a pontuação de planos que visavam à ampliação do sistema viário na RMSP foram passos necessários para a compreensão da metrópole contemporânea. Logicamente não foi possível, nesta Tese, destacar toda a evolução das ferrovias e do arruamento, tampouco todos os planos viários da metrópole, tendo em vista que não daríamos conta desta tarefa, até mesmo porque seria necessário realizarmos um outro projeto de pesquisa com este objetivo. No entanto, para entendermos a forma e a função, necessitamos conhecer a estrutura e o processo, ou seja, a compreensão da infra-estrutura e dos fluxos de passageiros perpassa pela noção de que foram concebidos a partir da elaboração de políticas que vêm se desenvolvendo há algumas décadas. Desta maneira, pontuamos, em nosso trabalho, algumas políticas. Nas duas décadas analisadas por esta pesquisa, destacaram-se, no âmbito dos planos de transportes, o PMGSP/1994 e o PITU 2020/2025. Estes planos tiveram o mérito de iniciar a recuperação da malha ferroviária 
metropolitana depois de décadas de abandono. Entre 1987 e 2007, a demanda do sistema ferroviário duplicou, passando de cerca de 890 mil para 1.600 mil viagens diárias e o Plano de Expansão 2007-2010, que integra o PITU 2025, prevê que em 2010 a demanda alcance 2.365 mil usuários. Para tanto, está prevista a aquisição de dezenas de novos trens, reforma de tantos outros, além de modernização das linhas, estações e operação. Estas medidas são prementes, na medida em que o crescimento da demanda ainda não foi suprido pelas ações realizadas até o momento.

As políticas de expansão da rede metroviária superaram a visão de que este sistema deveria chegar às periferias da metrópole, afirmando-se como uma rede que vai se concentrar no centro da metrópole, onde há maior adensamento populacional, mais infra-estrutura urbana, mais empregos, possibilitando um maior aproveitamento deste sistema de transporte, de alto custo de implantação. Sob esta óptica, os sistemas de ônibus e de trem metropolitano são, então, aqueles que devem interligar o metrô aos bairros afastados do município de São Paulo, e aos demais municípios da RMSP. Os Planos PITU 2025 e o estudo da Rede Essencial do Metrô propõem, com esta mentalidade, interligar as quatro linhas de metrô já existentes e terminar a construção da quinta linha (Linha 4-Amarela), concentrando-o nas áreas onde houve mais investimentos em infra-estrutura e que, portanto, têm ocupação de solo mais densa, maior quantidade de empregos e de moradia.

Enquanto a industrialização paulista desenvolveu-se às margens da ferrovia na primeira metade do século $\mathrm{XX}$, o desenvolvimento industrial ocorrido na metrópole paulistana a partir da década de 1950 apoiou-se na infra-estrutura rodoviária em expansão, quando vimos instalarem-se inúmeras indústrias às margens de rodovias que dão acesso à área metropolitana, colocando-as em comunicação com a metrópole e assegurando as relações extra-metropolitanas. É notável a atuação do transporte rodoviário na estruturação da 
metrópole. Sendo a ferrovia estanque, a sua ligação com os bairros através dos ônibus possibilitou a expansão de municípios, que viriam formar o que hoje chamamos de RMSP.

A intervenção no sistema viário e os planos de transporte efetivados a partir da metropolização de São Paulo perpetuaram a construção da metrópole tendo em vista a supremacia do automóvel. Quanto mais aumentava a quantidade de automóveis particulares, mais havia a necessidade de modificações no sistema viário. E quanto mais se ampliou o sistema viário voltado para a maior fluidez dos automóveis, mais o seu uso foi incentivado, e logo as novas obras viárias já se mostravam insuficientes para os fluxos crescentes. A especulação imobiliária que se faz na cidade em tempos de reestruturação produtiva, em que vemos a intensificação da financeirização do capital, produz um espaço urbano tornado, cada vez mais, espaço de circulação de pessoas, mercadorias e capital.

A otimização da circulação através do sistema viário permeou dezenas de planos e modelos de planejamento de transportes idealizados e até mesmo implementados na RMSP. Cabe lembrar que a gestão metropolitana é fundamental, tendo em vista que a resolução de problemas individuais pelo município pode não ter o efeito esperado se não estiver concatenada a outros municípios metropolitanos.

A maior parte do tratamento das vias da RMSP para uso prioritário do ônibus representou a intenção de facilitar a circulação destes veículos nas vias já existentes, não fazendo parte de um plano efetivo, que visasse à priorização do transporte coletivo. Poucas foram as iniciativas previstas em planos neste sentido no período em análise. Salientamos o Corredor Metropolitano Jabaquara-São Mateus e os Corredores com Canaleta Exclusiva do município de São Paulo. Se tivessem sido implementados todos os corredores metropolitanos previstos no Plano do Sistema Metropolitano, preconizado pelo PITU 2020, certamente o sistema de ônibus estaria servindo melhor a população. No entanto, circulando por vias muitas 
vezes sem tratamento específico para os ônibus e disputando espaço com outros veículos, este sistema tem sido mal avaliado pela opinião pública.

Conforme nos ensinou Santos ${ }^{572}$, São Paulo, ao estruturar-se como metrópole, passou a concentrar atividades que demandam mais acessibilidade. A metrópole buscou disponibilizar a acessibilidade, construindo uma vasta rede de transportes urbanos e regionais. Ao mesmo tempo, foi se construindo enquanto metrópole, atraindo empresas do circuito superior, e também, mesmo que à revelia, as atividades do circuito inferior. O autor salientou, ainda, que o circuito moderno pode criar o crescimento, mas não o desenvolvimento, e pensamos que é o que acontece em São Paulo, que cresceu enormemente em estatísticas de população, de produção industrial, mas também em níveis de pobreza, o que não supõe que tenhamos atingido o pleno desenvolvimento.

Os meios de reprodução da força de trabalho, na sociedade urbana contemporânea localizam-se, via de regra, fora da unidade familiar-habitacional. As atividades que as pessoas necessitam realizar para garantir seu sustento levam-nas a realizarem deslocamentos no espaço urbano para dirigirem-se aos seus locais de trabalho. As pessoas precisam, de alguma forma, consumir a circulação, que por sua vez é um dos meios de reprodução fornecidos, ou pelo menos organizados pelo Estado. Vasconcellos ${ }^{573}$ referiu-se a um novo estilo de vida criado pelo desenvolvimento do urbano capitalista. Com a expansão da cidade, caracteriza-se uma segregação social do espaço e crescem as distâncias e os tempos de viagem.

Os sistemas de transporte analisados nesta Tese compreenderam os modos ferroviário, metroviário, rodoviário e a pé.

No modo rodoviário, foram analisados os sistemas de ônibus regulares, de fretamento, este muito favorável, pois atende o potencial usuário do automóvel e uma parcela dos usuários do sistema de transporte público; e o sistema das lotações. Este último, tendo se desenvolvido

\footnotetext{
572 SANTOS, 2004.

${ }^{573}$ VASCONCELLOS, 1999.
} 
na clandestinidade, no final dos anos 1990, quando foi aberta a importação de veículos utilitários estrangeiros, na onda de demissões engendrada pela reestruturação da produção industrial, tornou-se um serviço conveniente a um grande número de pessoas. Tanto usuários desgostosos com o sistema de transporte público, quanto políticos ligados diretamente ou não ao novo negócio, e até mesmo uma parcela dos desempregados, que usaram seus fundos de garantia e indenizações na compra de veículos utilitários, muitos foram os que apoiaram o serviço de lotações. A perda de passageiros foi evidente no sistema de ônibus, e não sendo possível regularizar todas as lotações, até o início dos anos 2000 houve conflitos decorrentes do embate entre elas, empresários de ônibus e municipalidades. Atualmente, regularizou-se grande parte do serviço de lotações. No caso do município de São Paulo, ele foi utilizado pelo subsistema local do Sistema Interligado, operando com microônibus ao invés de veículos utilitários. Mesmo assim, o sistema ainda persevera de forma clandestina nas periferias dos municípios metropolitanos, atendendo bairros de difícil acesso ao sistema de ônibus, ou que a ele não interessa.

A terceira parte de nossa pesquisa discutiu a mobilidade de passageiros na RMSP no sentido de ratificar o que havia sido exposto na parte precedente: que a estrutura levou mais em consideração determinadas camadas sociais, privilegiando-as com tecnologias de transporte mais velozes, das quais o automóvel é símbolo. E para seu império, o território tem sido dotado de formas modernas, como túneis, viadutos e uma novíssima ponte estaiada na área mais cara da cidade de São Paulo, onde apenas automóveis têm permissão para circular.

Em contraposição, os homens lentos continuarão no lento transporte coletivo, ou a pé. O índice de mobilidade na RMSP, em 2002, flagrou que quem ganhava até $\mathrm{R} \$ 400,00$ possuía, no transporte coletivo, quase seis vezes menos mobilidade do que quem ganhava mais de $\mathrm{R} \$ 6.000,00$, no uso do transporte individual. A caracterização dos homens lentos é perfeita neste contexto. 
Além do índice de mobilidade, nossa pesquisa também analisou a duração das viagens diárias produzidas por modo principal na metrópole paulistana. Concluímos que o modo mais lento é o trem metropolitano. Unindo lugares distantes da metrópole acaba sendo o mais demorado. Outra questão é que o intervalo dos trens era longo, os menores intervalos ainda não tinham entrado em vigor em 1997. A nova Pesquisa O-D que está sendo realizada a partir dos dados de 2007, com certeza trará inovações neste sentido.

O segundo lugar em deslocamentos mais longos em 1997 era o metrô, mas deve sua posição à articulação com outros modos, algo que os dados não informaram. Ou ainda, à transferência de linhas dentro do próprio sistema, o que prolonga o tempo das viagens.

Já os ônibus, morosos em grande parte no tempo de espera, e também no decorrer do próprio deslocamento, como mostram diversos depoimentos colhidos, ocupava o terceiro lugar em duração dos trajetos na pesquisa realizada.

Em contrapartida, estão os modos individuais: quando o trabalhador dirige o automóvel, quando é passageiro de automóvel, quando usa táxi, motocicleta e bicicleta ou vai a pé. Nestes, o tempo de deslocamento é muito mais curto. Já que não temos conhecimento, pela pesquisa, das distâncias percorridas, calculamos que isso acontece em grande medida porque, nos modos individuais, o passageiro não precisa aguardar pelo meio de transporte.

No decorrer de toda a nossa pesquisa, verificamos que, nas duas décadas estudadas, ocorreram intensas transformações sócioespaciais na metrópole paulistana, tanto em sua forma, revelada na paisagem metropolitana, quanto na função, em que os fluxos assumiram papel de destaque maior. As vias e os terminais de transporte, enfim, toda a infra-estrutura de transporte mostra-se com incrível evidência na paisagem. Os fluxos atingiram intensidade extraordinária. As transformações na produção e no trabalho foram responsáveis por uma reorganização dos fluxos de pessoas e mercadorias absolutamente inovadoras. Concluímos 
que a terceirização de atividades industriais e dos serviços, bem como seu crescimento, estão vinculados ao crescimento dos deslocamentos intra-metropolitanos.

A Pesquisa de Imagem dos Transportes, realizada no final de 2007 pela Associação de Transportes Públicos, refletiu maior uso dos ônibus, metrô e trem por ocasião da entrada do Bilhete Único em 2005, de maior parcela da população de baixa renda. O aumento da demanda pressionou a oferta do sistema de transporte, cuja lotação excessiva impactou nos níveis de satisfação dos usuários. A explosão do uso de todas as modalidades de transporte coletivo a partir do Bilhete Único atesta que havia uma demanda reprimida pelo custo das passagens. De acordo com os dizeres contidos em muitos ônibus que circulam pela RMSP "Direito do cidadão, dever do Estado", pensamos que o transporte coletivo deveria ser mais subsidiado. Mas os tempos de reestruturação produtiva são também tempos neoliberais, presumindo-se que, ao Estado, cabe apenas gerenciar e organizar, e à iniciativa privada, cabe operar e lucrar.

Em tempos de reestruturação produtiva, verificamos a diminuição das atividades industriais e o crescimento de novas modalidades de serviços. Isto significa que, com a terceirização de tantas atividades que, em tempos fordistas, se concentravam na fábrica, multiplicaram-se as empresas prestadoras de serviços produtivos. Além disto, muitos outros serviços distributivos e sociais aumentaram e se disseminaram pelo espaço urbano. Com novas atribuições, a metrópole paulistana vem, desde o final dos anos 1980 até os dias de hoje, sofrendo uma reorganização. De acordo Meyer et alli ${ }^{574}$, a tendência atual é a diluição da forma urbana convencional com o estabelecimento de uma nova ordem urbana que nasce da dispersão das atividades no território. Assim, a metrópole é definida simultaneamente pela organização das atividades produtivas e não produtivas, e por seus deslocamentos diários. Isto quer dizer que o planejamento de transportes metropolitano precisa ser calcado em padrões de

\footnotetext{
${ }^{574}$ MEYER et alli, 2004.
} 
deslocamento que vêm se renovando, pelo menos, nos últimos 20 anos. Meyer et alli ${ }^{575}$ ressaltam que é fato que o padrão pendular de deslocamentos urbanos não predomina mais. No entanto, concluímos, ao vivenciar a realidade geográfica metropolitana, que, seguramente, os movimentos pendulares ainda não podem ser completamente desconsiderados.

As viagens estão mudando, e há uma tendência ao crescimento dos deslocamentos em horários variados. O transporte público que temos hoje ainda não se adequou a essas mudanças. O aumento dos fluxos de automóveis em decorrência do crescimento da classe média, o crescimento dos fluxos em decorrência da ampliação da terciarização e da terceirização, acrescidos à expansão do crédito para o financiamento de motos e veículos, provocaram uma perfeita explosão de veículos e fluxos na RMSP após 1990.

A Geografia, como ciência que busca o conhecimento da espacialidade, investiga o movimento, os eventos que acontecem no espaço e que, portanto, o fazem existir. Sendo a realidade geográfica expressa pela interação entre os fixos, ou sistema de objetos, e os fluxos, ou sistema de ações, entendemos que a pesquisa realizada sobre o Sistema de Transportes Terrestres de Passageiros na RMSP em tempos de Reestruturação Produtiva foi uma contribuição considerável para os estudos de Geografia Urbana.

A reestruturação produtiva significou nada mais do que a incorporação de novas técnicas ao trabalho e à gerência, que engendraram alterações na organização do espaço. Fazendo uso de categorias analíticas, procuramos compreender esta nova organização do espaço metropolitano sob o viés das infra-estruturas de transporte e dos deslocamentos dos passageiros. A espacialidade da metrópole paulistana, resultado dos processos produtivos que se acumularam através do tempo, assume uma nova conformação motivada pela intensificação de fluxos de pessoas e mercadorias imposta pela redefinição do padrão produtivo e pela intensificação do setor terciário, típicos da atual fase do sistema do capital.

\footnotetext{
${ }^{575}$ MEYER et alli, 2004.
} 
Ensejamos, através do estudo das vias férreas, metroviárias e rodoviárias, das modalidades de transporte que circulam por estas vias na RMSP, e ainda dos deslocamentos de passageiros, concluir que, desde a origem da estruturação da metrópole paulistana, a mobilidade e a acessibilidade foram, ao mesmo tempo, princípios e resultantes do processo de metropolização, fato que pode ser verificado pelo estudo histórico da relação entre a expansão da mancha urbana e a estrutura viária. Tendo importante participação em todas as etapas do processo de estruturação da metrópole, a mobilidade desempenhou um papel indutor tanto no início da metropolização quanto no atual período, quando a RMSP passa por intensas transformações decorrentes do processo de reestruturação da produção.

Finalizamos parafraseando Milton Santos ${ }^{576}$ : "Por uma outra circulação". Pensamos que o período estudado nesta pesquisa marca uma transição em marcha, certos de que a problemática atual dos transportes na RMSP não é irreversível, e uma outra circulação é possível. 


\section{Referências}

\section{Livros, Periódicos, Publicações, Teses e Dissertações}

ACCA, Rogério dos Santos. A dinâmica industrial recente da metrópole paulista: das ilusões pós-industriais a novas perspectivas sobre o desenvolvimento metropolitano. Dissertação de Mestrado apresentada ao Departamento de Sociologia da Faculdade de Filosofia, Letras e Ciências Humanas da Universidade de São Paulo. Orientador: Prof. Dr. Glauco Arbix. São Paulo, 2004. 190 p.

ANTUNES, Ricardo. Os sentidos do trabalho. Ensaio sobre a afirmação e a negação do trabalho. São Paulo, Boitempo: 2003. 258 p.

ARAÚJO, Maria de Fátima Infante. Reestruturação produtiva e transformações econômicas Região Metropolitana de São Paulo. São Paulo Perspec., v. 15, no. 1. São Paulo, jan./mar. 2001. Disponível em http://www.scielo.br/scielo.php?script=sci_arttext\&pid=S0102$\underline{88392001000100004 \& \operatorname{lng}=\mathrm{pt \& nrm}=\mathrm{iso}}$ - acesso em 22.06.2007.

ARBIX, Glauco \& ZILBOVICIUS, Mauro (org.) De JK a FHC. A reinvenção dos carros. São Paulo: Scritta, 1997. 522 p.

ARROYO, Mônica. São Paulo e os fluxos internacionais de mercadorias: a espessura de uma região metropolitana. In: CARLOS, Ana Fani A. e OLIVEIRA, Ariovaldo U. (org.).

Geografias de São Paulo: representação e crise da metrópole. São Paulo, Contexto: 2004. Vol 2. p. 85-103.

Mercosul: novo território ou ampliação de velhas tendências? In:

SCARLATO, Francisco C., SANTOS, Milton, SOUZA, Maria Adélia A. de, ARROYO, Mônica (orgs.). O novo mapa do mundo. Globalização e espaço latino-americano. São Paulo: Hucitec-Anpur/Annablume: 1994.

BARAT, Josef. A evolução dos transportes no Brasil. Rio de Janeiro, Fund. IBGE, 1978. 358 pp.

Transportes e industrialização no Brasil no período 1885-1985: o caso da indústria siderúrgica. Rio de Janeiro: Biblioteca do Exército: 1991. 136 pp.

BARROSO, José Roberto Góes. Cenários e implicações sócio-espaciais do Rodoanel Mário Covas. Dissertação de Mestrado apresentada ao Departamento de Geografia da Faculdade de Filosofia, Letras e Ciências Humanas da Universidade de São Paulo. Orientador: Prof. Dr. Francisco Capuano Scarlato. São Paulo, 2004.

BELUSSI, Fiorenza \& GARIBALDO, Francesco. Variety of Pattern of the Post-Fordist Economy: why are the 'Old Times' still with us and the 'New Times' yet to come? In: GRINT, Keith (ed.). Work and Society: a Reader. Cambridge: Polity Press, 2000. 
BEYNON, Huw. O sindicalismo tem futuro no século XXI? In: SANTANA, Marco Aurelio e RAMALHO, José Ricardo (Orgs.) Além da Fábrica: trabalhadores, sindicatos e a nova questão social. São Paulo: Boitempo, 2003. pp. 44 a 71.

BÍBLIA SAGRADA, Gamma Editorial/Rio de Janeiro: Paulinas, s.d.

BRAVERMAN, Harry. Trabalho e capital monopolista. Trad. Nathanael C. Caixeiro. $3^{\text {a }}$. ed. Rio de Janeiro, Guanabara: 1987. 379 pp.

CACCIAMALI, Maria Cristina \& BRITTO, André. A flexibilização restrita e descentralizadora das relações de trabalho no Brasil. In: CHAHAD, José Paulo Zeetano \& CACCIAMALI, Maria Cristina (org.) Mercado de Trabalho no Brasil. Novas práticas trabalhistas, negociações coletivas e direitos fundamentais no trabalho. São Paulo: LTR, 2003. pp. 125 a 155 .

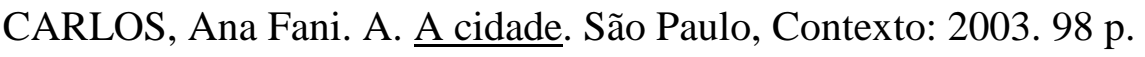

Espaço-tempo na metrópole. São Paulo, Contexto: 2001. 368 pp.

CARMO, Paulo Sérgio do. A ideologia do trabalho. São Paulo, Moderna: 2005. 143 p.

CASTELLS, Manuel. A questão urbana. Trad. Arlene Caetano. Rio de Janeiro, Paz e Terra: 2000. $590 \mathrm{p}$.

CHAHAD, José Paulo Zeetano \& CACCIAMALI, Maria Cristina (org.) Mercado de Trabalho no Brasil. Novas práticas trabalhistas, negociações coletivas e direitos fundamentais no trabalho. São Paulo: LTR, 2003. Introdução. pp. 9 a 37.

CHAHAD, José Paulo Zeetano. As modalidades especiais de contrato de trabalho na CLT e a flexibilidade do mercado de trabalho brasileiro. In: CHAHAD, José Paulo Zeetano \& CACCIAMALI, Maria Cristina (org.) Mercado de Trabalho no Brasil. Novas práticas trabalhistas, negociações coletivas e direitos fundamentais no trabalho. São Paulo: LTR, 2003. pp. 41 a 77.

CHAHAD, José Paulo Zeetano \& ZOCKUN, Maria Helena. A terceirização do trabalho no Brasil: um estudo de caso. In: CHAHAD, José Paulo Zeetano \& CACCIAMALI, Maria Cristina (org.) Mercado de Trabalho no Brasil. Novas práticas trabalhistas, negociações coletivas e direitos fundamentais no trabalho. São Paulo: LTR, 2003. pp. 105 a 124.

CIA. DO METROPOLITANO DE SÃO PAULO (CMSP). O Metrô de São Paulo: 1987 1991. Tecnologia e humanização. São Paulo, METRÔ, março de 1991. 156 pp.

Pesquisa Origem-Destino 1977: Região Metropolitana de São Paulo, Síntese das Informações. São Paulo, METRÔ, 1980.

Pesquisa Origem-Destino 1987: Região Metropolitana de São Paulo, Síntese das Informações. São Paulo, METRÔ, 1990. 80 pp. il.

Relatório da Diretoria de Operação. São Paulo, METRÔ, 1997a. 
METRÔ, 1997b. 16 pp.

Alternativos e lotação: sua operação junto às estações de metrô. São Paulo, Pesquisa Origem-Destino 1997: Região Metropolitana de São Paulo, Síntese das Informações. São Paulo, METRÔ, 1998. CD-ROM.

Aferição da Pesquisa Origem-Destino 2002: Região Metropolitana de São Paulo, Síntese das Informações. São Paulo, METRÔ, 2002. CD-ROM.

Relatório Operacional 2002. São Paulo, METRÔ/STM, 2003. CD-ROM.

. Relatório Operacional Metrô de São Paulo 2004. São Paulo, METRÔ/STM,

2005. CD-ROM.

2006a. CD-ROM.

Relatório Operacional Metrô de São Paulo 2005. São Paulo, METRÔ/STM, . Metrô de São Paulo. Rede Essencial. Trechos Prioritários. Ago. 2006b. 100

pp.

Relatório Operacional Metrô de São Paulo 2006. São Paulo, METRÔ/STM, 2007. CD-ROM.

COMIN, Álvaro \& AMITRANO, Claudio. Economia e emprego: a trajetória recente da Região Metropolitana de São Paulo. Novos Estudos CEBRAP, São Paulo, no. 66: 53-76, jul. 2003.

CORREA, Roberto Lobato. Espaço, um conceito-chave da Geografia. In: CASTRO, Iná. E. de, GOMES, Paulo C.C., CORREA, Roberto L. (org.) Geografia: conceitos e temas. São Paulo, Bertrand do Brasil: 2004. pp. 15-48.

COSTA, Wanderley Messias da. O processo contemporâneo de industrialização: um estudo sobre a expansão da produção industrial em território paulista. Dissertação de Mestrado apresentada ao Departamento de Geografia da Faculdade de Filosofia, Letras e Ciências Humanas da Universidade de São Paulo. Orientador: Prof. Dr. Armando Correa da Silva. São Paulo, Março 1982.

DAMIANI, Amélia Luisa. Urbanização crítica e situação geográfica a partir da metrópole de São Paulo. In: CARLOS, Ana Fani A. e OLIVEIRA, Ariovaldo U. (org.). Geografias de São Paulo: representação e crise da metrópole. São Paulo, Contexto: 2004. p. 19-58.

DEMO, P. Metodologia Científica em Ciências Sociais. São Paulo: Atlas, 1985. 255 pp.

DEUS, João Batista de. O Sudeste Goiano e a desconcentração industrial. Coleção CentroOeste de Estudos e Pesquisas. Brasília, Ministério da Integração Nacional, Universidade Federal de Goiás, 2002. 243 p.

DICIONÁRIO ESCOLAR DA LINGUA PORTUGUESA. Ministério da Educação e Cultura, Departamento Nacional de Educação, 1963. 
DRUCK, Maria da Graça. Terceirização: (des)fordizando a fábrica. Um estudo do complexo petroquímico. São Paulo, Boitempo: 2001. 271 p.

ELETROPAULO S.A. A cidade da Light - 1899-1930. Superintendência de Comunicação/Departamento de Patrimônio Histórico. São Paulo, Eletropaulo, 1990. 2 volumes. $260 \mathrm{pp}$.

FERRARI, Terezinha. Cidade, trabalho e técnica. O mito da produção em tempo real. São Paulo, 2003. Tese de Doutorado. Pontifícia Universidade Católica - SP. 276 p.

. Reestruturação técnico-produtiva do capital e poder local. Lutas Sociais, São Paulo, 11/12: 60-71, 2004.

GEIGER, Pedro P. A urbanização brasileira nos novos contextos contemporâneos. In: GONÇALVES, Maria Flora (org.) O novo Brasil urbano. Impasses / Dilemas / Perspectivas. Porto Alegre: Mercado Aberto, 1995. p. 23-40.

GORZ, André. Metamorfoses do trabalho: crítica da razão econômica. São Paulo, Annablume, 2003. 248 p.

HARVEY, David. A condição pós-moderna. Uma pesquisa sobre as origens da mudança cultural. Trad. Adail U. Sobral e Maria Stela Gonçalves. São Paulo: Loyola, 2005a. 349 p. A produção capitalista do espaço. Trad. Carlos Szlak. São Paulo:

Annablume, 2005b. 251 p. O novo imperialismo. São Paulo: Loyola, 2004. 201 pp.

HIRST, Paul \& THOMPSON, Grahame. Globalização em questão. A economia internacional e as possibilidades de governabilidade. Trad. Wanda Caldeira Brand. Petrópolis: Vozes, 1998. $364 \mathrm{pp}$.

JANNUZZI, Paulo de Martino; MATTOS, Fernando A. Mansor de \& PAULINO, Luis Antônio. Empregos, força de trabalho e desemprego na Região Metropolitana de São Paulo: cenários prospectivos. Cadernos da FACECA, PUC, Campinas, vol. 14 (1): 19-38, jan-jun 2005.

KLINK, Jeroen Johannes. A cidade-região. Regionalismo e estruturação no Grande ABC Paulista. Rio de Janeiro, DP\&A: 2001. 225 pp.

KOVARICK, Lucio. A espoliação urbana. $2^{\text {a }}$. ed. São Paulo, Paz e Terra, 1993. 204 p.

LANGENBUCH, Juergen. A estruturação da Grande São Paulo. Estudo de Geografia Urbana. Rio de Janeiro, Fundação IBGE: 1971. 354 p.

LEMOS, Amália Inês Geraiges de. Cotia e sua participação no conjunto da faixa periférica da metrópole paulistana. Dissertação de Mestrado apresentada ao Departamento de Geografia da Faculdade de Filosofia, Letras e Ciências Humanas da Universidade de São Paulo.

Orientador: Prof. Dr. Pasquale Petrone. São Paulo, Março 1972. 193 p. 
. Metropolização e modernidade. As metrópoles da América

Latina. In: SCARLATO, Francisco Capuano; SANTOS, Milton; SOUZA, Maria Adélia A. de; ARROYO, Mônica (orgs.). O novo mapa do mundo. Globalização e espaço latinoamericano. São Paulo, Hucitec-Anpur/Annablume: 1994. pp.181-186.

. São Paulo: metrópole financeira da América do Sul. In:

CARLOS, Ana Fani A. e OLIVEIRA, Ariovaldo U. (org.). Geografias de São Paulo: representação e crise da metrópole. São Paulo, Contexto: 2004. Vol 2. p. 105-121.

Um exemplo de processo de metropolização recente na periferia da Grande São Paulo: o município de Itaquaquecetuba. Tese de Doutoramento apresentada ao Departamento de Geografia da Faculdade de Filosofia, Letras e Ciências Humanas da Universidade de São Paulo. Orientador: Prof. Dr. Pasquale Petrone. São Paulo, Fev. 1980. 203 p.

LENCIONI, Sandra. A emergência de um novo fato urbano de caráter metropolitano em São Paulo. Particularidade de seu conteúdo sócio-espacial, seus limites regionais e sua interpretação teórica. Boletim Paulista de Geografia (AGB), São Paulo, n. 82: 45-64, set. 2005.

Reestruturação urbano-industrial: centralização do capital e desconcentração da metrópole de São Paulo: a indústria têxtil. Tese de Doutoramento apresentada ao Departamento de Geografia da Faculdade de Filosofia, Letras e Ciências Humanas da Universidade de São Paulo. Orientadora: Profa. Dra. Ana Fani Alessandri Carlos. São Paulo, 1991.

Reestruturação urbano-industrial no Estado de São Paulo: a região da metrópole desconcentrada. In: SANTOS, Milton; SOUZA, Maria Adélia A. de, SILVEIRA, Maria Laura (org.) Território, globalização e fragmentação. $5^{\text {a }}$. ed. São Paulo, HUCITEC /Annablume, 2002. pp. 198-210.

LOJKINE, Jean. O papel do estado na urbanização capitalista. In: FORTI, Reginaldo (org.). Marxismo e urbanismo capitalista. São Paulo: Ciências Humanas, 1979. 166 pp.

MARICATO, Ermínia. Metrópole, legislação e desigualdade. Estudos Avançados, v.17, nº 48. São Paulo, maio/agosto 2003. p. 151-166. .Disponível em http://www.scielo.br/scielo. php? script=sci_arttext\&pid=S0103-40142003000200013\&lng=en\&nrm=iso - acesso em 24.06.2007.

Metrópole na periferia do capitalismo: ilegalidade, desigualdade e violência. São Paulo: Hucitec, 1996. 141 p.

MARTINS, Heloísa Helena T. de Souza. Os dilemas do movimento sindical em face da terceirização. In: MARTINS, Heloísa Helena T. de Souza \& RAMALHO, José Ricardo. Terceirização: diversidade e negociação no mundo do trabalho. São Paulo, HUCITEC-CEDINETS, 1994. pp. 13-40.

MARX, Karl. O capital.Coleção Os Pensadores, São Paulo, 1988. 
MELLO, Karla Reis Cardoso. Transporte urbano de passageiros: as contradições do poder público. Tese de Doutoramento apresentada ao Departamento de Geografia da Faculdade de Filosofia, Letras e Ciências Humanas da Universidade de São Paulo. Orientador: Prof. Dr. Francisco Capuano Scarlato. São Paulo, 1998. 237 pp.

Transporte urbano de passageiros: as contradições do poder público. São Paulo, Café Ed. Express, 2000. 259 p.

MÉSZÁROS, István. Para além do capital. Trad. Paulo César Castanheira e Sérgio Lessa. São Paulo: Boitempo Ed.: 2002. 1102 pp.

MEYER, Regina Maria Prosperi; GROSTEIN, Marta Dora \& BIDERMAN, Ciro. São Paulo Metrópole. São Paulo, Edusp/ Imprensa Oficial de São Paulo: 2004. 290 pp. il.

MORAES, Antônio Carlos Robert. Território e história no Brasil. São Paulo, Annablume/HUCITEC, 2002. 198 p.

MUNCK, Ronaldo. Labour and Globalisation: the new 'Great Transformation'. London: Zed Books, 2001.

NEGRI, Barjas. Concentração e desconcentração industrial em São Paulo (1880-1990). Campinas, UNICAMP: 1996. 242 pp.

NOVO DICIONÁRIO BÁSICO DE LÍNGUA PORTUGUESA FOLHA/AURÉLIO. Rio de Janeiro, Nova Fronteira, 1994/1995.

OFFE, Claus. Capitalismo Desorganizado. São Paulo: Brasiliense, 1994. 322 pp.

OLIVEIRA, Francisco de. O Estado e o urbano no Brasil. Espaço \& Debates, $n^{\circ} .6$ jun/set, 1982.

PASSARELLI, Silvia Helena. O diálogo entre o trem e a cidade: o caso de Santo André. Dissertação de Mestrado apresentada à Faculdade de Arquitetura e Urbanismo da Universidade de São Paulo. Orientador: Prof. Dr. Murilo Marx. São Paulo, 1994. 160 p.

PERO, Valéria. Terciarização e qualidade do emprego: uma análise da Região Metropolitana de São Paulo no início dos anos 90. Instituto Latinoamericano de Desenvolvimento Econômico e Social. Fundação Friedrich Ebert no Brasil. São Paulo, jul. 1995.

PRATES, Rodolfo Coelho. Reestruturação da Metrópole Paulista: o processo de descentralização industrial. Dissertação de Mestrado apresentada ao Departamento de Geografia da Faculdade de Filosofia, Letras e Ciências Humanas da Universidade de São Paulo. Orientador: Prof. Dr. Wanderley Messias da Costa. São Paulo, 2001. 177 p.

POCHMANN, Márcio. O emprego na globalização. A nova divisão internacional do trabalho e os caminhos que o Brasil escolheu. São Paulo, Boitempo: 2002. 151 p.

ROSA, Silvio José. Transporte e exclusão social: a mobilidade da população de baixa renda da Região Metropolitana de São Paulo e trem metropolitano. Dissertação de Mestrado 
apresentada ao Departamento de Engenharia de Transportes da Escola Politécnica da Universidade de São Paulo. Orientador: Prof. Dr. Jaime Waisman. São Paulo, 2006. 161 p.

RÉMY Jean \& VOYÉ, Liliane. A cidade: rumo a uma nova definição? Porto, Afrontamento: 1994. $167 \mathrm{p}$.

RIFKIN, Jeremy. $\mathrm{O}$ fim dos empregos. O declínio inevitável dos níveis de empregos e a redução da força global de trabalho. São Paulo, Makron Books:1995. 348 pp.

SANTOS, Milton. A natureza do espaço. Técnica e tempo, razão e emoção. São Paulo, HUCITEC, 1997. 308 p.

. A urbanização brasileira. São Paulo, HUCITEC: 1993. 157 p.

. Espaço e Método. São Paulo, Nobel, 1985. 88p.

. Metamorfoses do espaço habitado. 4. ed. São Paulo, HUCITEC, 1996a.

$124 \mathrm{p}$.

Metrópole corporativa fragmentada. O caso de São Paulo. São Paulo, Nobel/Secretaria do Estado da Cultura, 1990. 117 p.

- O espaço dividido. Os dois circuitos da economia urbana dos países subdesenvolvidos. Trad. Myrna T. Rego Viana. São Paulo, Editora da Universidade de São Paulo: 2004. 440 p.

Rio de Janeiro, Record: 2000. 174 p.

. Por uma outra globalização. Do pensamento único à consciência universal.

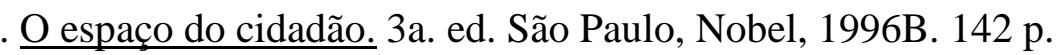

. Por uma economia política da cidade: o caso de São Paulo. São Paulo, Hucitec:Educ Ed. PUC-SP: 1994. 145 p.

Por uma Geografia Nova. São Paulo, HUCITEC: 1980. 236 p.

. Por uma outra globalização. Do pensamento único à consciência universal. Rio de Janeiro, Record: 2000. 174 p.

SANTOS, Milton \& SILVEIRA, Maria Laura. O Brasil. Território e sociedade no início do século XXI. Rio de Janeiro, Record, 2006. 473 p.

SÃO PAULO. Estado. PITU. Plano Integrado de Transportes Metropolitanos 2020. São Paulo, CPTM, EMTU, METRÔ, Secretaria dos Transportes Metropolitanos, C-D Rom, s.d.

Plano metropolitano da Grande São Paulo 1994/2010. São Paulo, EMPLASA e Secretaria de Planejamento e Gestão, 1994a.

Por dentro da Grande São Paulo. São Paulo, EMPLASA e Secretaria de Planejamento e Gestão, 1993a. 
. Sumário de Dados da Grande São Paulo: 1977. São Paulo,

EMPLASA, 1978.

EMPLASA, 1979.

Sumário de Dados da Grande São Paulo: 1978. São Paulo,

EMPLASA, 1980.

. Sumário de Dados da Grande São Paulo: 1979. São Paulo,

. Sumário de Dados da Grande São Paulo: 1980. São Paulo,

EMPLASA, 1981.

. Sumário de Dados da Grande São Paulo: 1981. São Paulo,

EMPLASA, 1982.

EMPLASA, 1983.

. Sumário de Dados da Grande São Paulo: 1982. São Paulo,

. Sumário de Dados da Grande São Paulo: 1983. São Paulo,

EMPLASA, 1984.

. Sumário de Dados da Grande São Paulo: 1984. São Paulo,

EMPLASA, 1985.

EMPLASA, 1986.

Sumário de Dados da Grande São Paulo: 1985. São Paulo,

EMPLASA, 1987.

. Sumário de Dados da Grande São Paulo: 1986. São Paulo,

Sumário de Dados da Grande São Paulo: 1987. São Paulo,

EMPLASA, 1988.

. Sumário de Dados da Grande São Paulo: 1988. São Paulo,

EMPLASA, 1989.

. Sumário de Dados da Grande São Paulo: 1989. São Paulo,

EMPLASA, 1990.

Sumário de Dados da Grande São Paulo: 1990. São Paulo,

EMPLASA, 1991.

. Sumário de Dados da Grande São Paulo: 1991. São Paulo,

EMPLASA, 1992.

Sumário de Dados da Grande São Paulo: 1992. São Paulo,

EMPLASA, 1993b. 
Sumário de Dados da Grande São Paulo: 1993. São Paulo,

EMPLASA, 1994b.

EMPLASA, 1995.

. Sumário de Dados da Grande São Paulo: 1994. São Paulo,

EMPLASA, 1996.

. Sumário de Dados da Grande São Paulo: 1995. São Paulo,

Sumário de Dados da Grande São Paulo: 1996. São Paulo,

EMPLASA, 1997.

. Sumário de Dados da Grande São Paulo: 1997. São Paulo,

EMPLASA, 1998.

Transporte Metropolitano. Ações do governo no transporte intermunicipal por ônibus na RMSP. São Paulo, SMT/EMTU: 1999. 156 p. il.

SCARLATTO, Francisco Capuano. A indústria automobilística no capitalismo brasileiro e suas articulações com o crescimento espacial da metrópole paulista. Dissertação de Mestrado apresentada ao Departamento de Geografia da Faculdade de Filosofia, Letras e Ciências Humanas - USP. São Paulo, 1981. 142 p.

(org.) Geografia do Brasil. São Paulo, EDUSP: 1998. pp. 381 a 463.

SCHOPPA, René Fernandes. 150 anos de trem no Brasil. 30 de Abril de 1854 a 2004. São Paulo: Formato e Modelo Gráfica e Ed. Ltda.: 2004. 196 p.

SEADE. Pesquisa de condições de vida na Região Metropolitana de São Paulo. Principais resultados. São Paulo: Fundação SEADE, dez. 1992.

SENNETT, Richard. A corrosão do caráter. Trad. Marcos Santarrita. São Paulo: Record, 2005. 204 p.

SOJA, Edward W. Geografias pós-modernas. A reafirmação do espaço na teoria social crítica. Trad. Vera Ribeiro. Rio de Janeiro, Jorge Zahar: 1993. 324 p.

SOUZA, Marcelo José Lopes de Souza. O território: sobre espaço e poder, autonomia e desenvolvimento. In: CASTRO, Iná. E. de, GOMES, Paulo C.C., CORREA, Roberto L. (org.) Geografia: conceitos e temas. São Paulo, Bertrand do Brasil: 2004. pp. 77-116.

SOUZA, Maria Adélia Ap. de. O novo Brasil urbano: integração ou fragmentação? In: GONÇALVES, Maria Flora (org.) O novo Brasil urbano. Impasses / Dilemas / Perspectivas. Porto Alegre: Mercado Aberto, 1995. p. 65-72.

ULIAN, Flávia. Transporte e cidadania na cidade de São Paulo. Inserção e Exclusão no Espaço Urbano. São Paulo, 1999. Dissertação de Mestrado, Departamento de Geografia da Faculdade de Filosofia, Ciências e Letras da Universidade de São Paulo. 192 pp. 
VASCONCELLOS, Eduardo Alcântara de. Circular é preciso, viver não é preciso. A história do trânsito na cidade de São Paulo. São Paulo: Annablume/Fapesp: 1999. 326 p.

Transporte urbano, espaço e eqüidade. Análise das políticas públicas.

São Paulo, Annalume, 2001. 218 p.

Transporte urbano nos países em desenvolvimento. Reflexões e propostas. São Paulo, Annalume, 2000. 282 p.

VELTZ, Pierre. Mundialización, ciudades y territorios: la economia de archipelago. Barcelona, Ariel, 1999. 254 pp.

WAKISAKA, Tânia. Zoneamento de uso e ocupação do solo e produção do espaço urbano em São Paulo. Dissertação de Mestrado apresentada à Faculdade de Arquitetura e Urbanismo - USP. Orientação: Profa. Dra. Maria Adélia Ap. de Souza. São Paulo, 1991. 238 pp.

WATERMAN, Peter. The new social unionism: a new union model for a new world order. In: MUNCK, Ronaldo \& WATERMAN, Peter. Labour Worldwide in the Era of Globalization: alternative union models in the new World order. London, Macmillan Press, 1999.

\section{Reportagens e Jornais e Revistas}

BRISOLA, Fabio. A gigante da Marginal. Disponível em http://www.estadao.com.br lestadaodehoje/20070819/not_imp37190,0.php , 18.10.2007. Acesso em 08.04.2008.

CREDÊNDIO, José Ernesto. Nova ponte vai criar corredor exclusivo para carros e motos em SP. Disponível em http://www1.folha.uol.com.br/folha/cotidiano/ult95u344648.shtml , 11.11.2007. Acesso em 08.04.2008.

FRANÇA, Valéria. Não dá para tomar ônibus. Jornal da Tarde, Caderno Cidade, 29.03.2008. $3 \mathrm{~A}$

GALVÃO, Vinícius Queiroz \& GALLO, Ricardo. Centro expandido perde 'uma Santos' em 11 anos. Folha de São Paulo, Caderno Cotidiano, 18.02.2008. C1, C3.

GUSMÃO, Marcos Buarque de. O mico da Rebouças. Vejinha Online. 19.01.2005.

Disponível em http://veja.abril.com.br/vejasp/190105/cidade.html. Acesso em 10.04.2008.

GRADILONE, Cláudio. Canteiro de Obras. Disponível em: http://vejasaopaulo.abril.com.br /revista/vejasp /edicoes/2034a/m0142830.html. Acesso em 10.03.08.

IZIDORO, Alencar. Kassab barra ônibus fretado em corredor. Folha de São Paulo, 12.11.2007, pp. C1-C3, caderno Cotidiano.

SP prioriza trânsito, mas 'esquece' CET. Folha de São Paulo, 13.04.2008a, pp. C13, C14, C16, caderno Cotidiano. 
IZIDORO, Alencar; SANGIOVANNI, Ricardo. Velocidade cai em corredores de ônibus de SP. Folha de São Paulo, 24.03.2008, p. C1, Caderno Cotidiano.

IZIDORO, Alencar; SEABRA, Cátia; SPINELLI, Evandro. Pacote de trânsito prioriza os corredores de ônibus. Folha de São Paulo, 19.03.2008, p.C1, Caderno Cotidiano.

IZIDORO, Alendar; SPINELLI, Evandro; PEQUENO, João. Metrô de SP é mais lotado que o de Tóquio. Folha de São Paulo, 21.04.2008b, pp. C4, C5, C6, caderno Cotidiano.

JUNQUEIRA, Caio. Comissão vê falha em túnel da Rebouças e anuncia interdição de faixas. Folha Online, 13.01.2005. Disponível em http://www1.folha.uol.com.br/folha/cotidiano /ult95u104160.shtml. Acesso em 10.04.2008.

MÃE consegue salvar filha, mas é atropelada por trem. Folha de São Paulo, 11.02.2008, p. C6, caderno Cotidiano.

MANSO, Bruno Paes. Pressa fez preço dos túneis dobrar. O Estado de São Paulo, 05.05.2005. Disponível em http://clipping.planejamento.gov.br/Noticias.asp?NOTCod=192488. Acesso em 10.04.2008.

MARCHESINI, Adriele. Número de lançamentos imobiliários sobe $70 \%$ na Região Metropolitana. Disponível em http://web.infomoney.com.br/templates/news /view.asp?codigo=919564\&path=/suasfinancas/imoveis/compra. Acesso em 10.03.2008a.

. Com preço $8 \%$ maior, SP tem $65 \%$ dos lançamentos imobiliários da

RMSP. Disponível em http://web.infomoney.com.br/templates/news /view.asp?codigo=922399\&path=/suasfinancas/imoveis/compra. Acesso em 10.03.2008b.

RIGI, Camilla. Via expressa para ônibus vai ocupar faixa de automóveis na Celso Garcia. $\underline{\mathrm{O}}$ Estado de São Paulo, 29.01.2008, p. C1, Caderno Metrópole.

SALLES, Ygor. Indústria de SP fecha 2007 com criação de 104 mil vagas. Folha de São Paulo, 17.01.2008, p. B8, caderno Dinheiro.

SALOMON, Marta. Oferta de trabalho está desequilibrada. Folha de São Paulo, 08.11.2007, p. B1, caderno Dinheiro.

SANGIOVANNI, Ricardo \& CREDENCIO, José Ernesto. Protesto contra ônibus lento fecha via por 6 h. Folha de São Paulo, 08.03.2008, p. C1, caderno Cotidiano.

SANGIOVANNI, Ricardo \& PINHO, Márcio. SP deve atingir hoje a marca de 6 milhões de veículos. Folha de São Paulo, 21.02.2008, p. C4, caderno Cotidiano.

SCHROEDER, Renato. V de Voraz. Morar. Revista da Folha. 28.09.2007. pp.34-36.

SERRA anuncia comissão para revisar túnel da Rebouças. Folha Online, 06.01.2005.

Disponível em http://www1.folha.uol.com.br/folha/cotidiano/ult95u103839.shtml. Acesso em 10.04.2008. 
SOARES, Luiz Américo; LEITE, Raimundo Clauberto Soares; PEREIRA, Arnaldo Luís Santos. Fretamento: esfinge ou monalisa? Panorama do Sistema de Fretamento nas regiões metropolitanas do Estado de São Paulo. São Bernardo do Campo, maio de 2005. Disponível em http://www.emtu.sp.gov.br/artigos/menu.htm?arq=11 - acesso em 25.01.2008.

SOARES, Alexssander. SP pára de pagar túnel da Rebouças. Disponível em http://www.estado.com.br/editorias /2006/07/28/cid-1.93.3.20060728.32.1.xml. Acesso em 10.04.2008.

SOFIA, Julianna. Baixa qualificação puxa alta do emprego. Folha de São Paulo, 06.01.2008, p. B1, caderno Dinheiro.

UNIÃO estuda investir no metrô de SP. Folha de São Paulo, 18.03.2008, p. C1, caderno Cotidiano.

ZARATTINI, Carlos. O caos no transporte e a cidade tucana. Folha de São Paulo, 20.03.2008, p. A3, Caderno Brasil.

\section{Sítios pesquisados (por ordem cronológica)}

http://www.smt.sp.gov.br -27.05 .05$

http://www..sptrans.com.br -27.05 .2005$

http://www.unisantos.com.br/ metropms/metropoles/rmsp.htm - 06.01.2007

http://www.seade.gov.br/produtos/500anos/index.php?tip=esta - 07.01.2007; 08.01.2007

http://www.transportes.sp.gov.br/v20/rodoanel.asp - 02.01.2007

http://www.transportes.sp.gov.br/v20/rodoanel_aae_inducao.asp - 02.01.2007

http://www.transportes.sp.gov.br/v20/rodoanel_caracteristicas.asp - 02.01.2007

http://www.transportes.sp.gov.br/v20/rodoanel_aae_trafego.asp - 02.01.2007

http: //www. transportes. sp. gov. br/v20/ infraestrutura rodoviario.asp - 02.01.2007

http://www.dersa.com.br/rodoanel/especial/index.html - 02.01.2007

http://www.jornaldaserra.com.br/jsrodoanel/rodotrafego/rodotrafegopage.htm - 02.01.2007

http://www.abpfsp.com.br/ferrovias.htm - 10.01.2007

http://pt.wikipedia.org/wiki/Rodovia_Raposo_Tavares - 26.01.2007

http://www.otaboanense.com.br/2006/not_1501.htm - 26.01.2007

http://www9.prefeitura.sp.gov.br/sempla/md/mostra_tabela.php?cod_subtema=tra\&nome_tab =transportes $7 \&$ partes $=1-27.01 .2007$

http://www.emtu.sp.gov.br/regular/ - 27.01.2007

http://www.emtu.sp.gov.br/fretamento/-27.01.2007

http://www.emtu.sp.gov.br/aeroporto/index.htm - 27.01.2007

http://www.emtu.sp.gov.br/orcazoo/ - 27.01.2007

http://portal.prefeitura.sp.gov.br/secretarias/transportes/organizacao/0017 - 27.01.2007

http://www.seade.gov.br/produtos/paep/pdfs/analiseregional.pdf - 04.03.2007

http://www.mte.gov.br/sal_min/EVOLEISM.pdf - 23.06.2007

http://www.emplasa.gov.br/ - 30.06.2007

http://www.blogtecnisa.com.br/ - 24.09.2007

http://www.emplasa.sp.gov.br/portalemplasa/infometropolitana/rmsp/rmsp_dados.asp 16.11.2007 
http://www.soleis.com.br/salario_minimo.htm - 17.11.2007

http://www.fretado-sp.com.br/ - 10.01.2008

http://www.osasco.sp.gov.br/ - 12.01.2008

http://www.carapicuiba.sp.gov.br/- 12.01.2008

http://www.barueri.sp.gov.br- 12.01.2008

http://www.cajamar.sp.gov.br- 12.01.2008

http://www.santanadeparnaiba.sp.gov.br- 12.01.2008

http://www.piraporadobomjesus.sp.gov.br- 12.01.2008

http://www.vargemgrandepaulista.sp.gov.br- 12.01.2008

http://www.itapevi.sp.gov.br- 12.01.2008

http://www.jandira.sp.gov.br- 12.01.2008

http://www.taboaodaserra.sp.gov.br- 12.01.2008

http://www.itapecerica.sp.gov.br- 12.01.2008

http://www.embu.sp.gov.br- 12.01.2008

http://www.embuguacu.sp.gov.br- 12.01.2008

http://www.juquitiba.sp.gov.br- 12.01.2008

http://www.santoandre.sp.gov.br- 12.01.2008

http://www.saobernardo.sp.gov.br- 12.01.2008

http://www.saocaetanodosul.sp.gov.br- 12.01.2008

http://www.diadema.sp.gov.br- 12.01.2008

http://www.seade.gov.br/produtos/imp/index.php - 12.01.2008 - Sistema de Informação dos

Municípios Paulistas (IMP)

http://www. sptrans.com.br -19.01 .2008$

http://www9.prefeitura.sp.gov.br/spMovimento/dadosgerais/viagensdiarias.php - 22.01.2008

http://www.antp.org.br/ANTPNot.aspx?AspXPage=g\%5FCD4D4122F8C44A109105EC5C1

347FF87:\%2540ID\%3D365 - 25.01.2008

http://www.emplasa.sp.gov.br/portalemplasa/EncontrosMetropolitanos/IME/Transporte.pdf 27.01.2008

http://www.metro.sp.gov.br/empresa/relatorio/2006/rametro2006.pdf - 03.02.2008

http://www.cptm.sp.gov.br/e_companhia/gerais.asp - 06.02.2008

http://pt.wikipedia.org/wiki/\%C3\%8Dndice_de_Desenvolvimento_Humano - 23.02.2008

http://www.ibge.gov.br/home/estatistica/indicadores/trabalhoerendimento/pme/pmemet 2. shtm $-24.02 .2008$

http://www1.folha.uol.com.br - 24.02.2008

http://www.pitu.stm.sp.gov.br/ - 24.02.2008

www.pitu.stm.sp.gov.br/download.php?file=documentos/revisaodoplano.pdf - 24.02.2008

http://www.seade.sp.gov.br/produtos/ped/pedv98/jan08/janeiro2008.pdf) - 27.02.2008

http://www.metro.sp.gov.br/expansao/rede_essencial/rede_essencial_01.shtml-02.03.2008

http://www.metro.sp.gov.br/expansao/plano_expansao_2007_2010/plano_expansao_2007_20

10.asp - 03.03.2008

http://www1.folha.uol.com.br/folha/brasil/ult96u21244.shtml - 01.04.2008

http://www.cptm.sp.gov.br/e_noticias/webnoticias/one_news.asp?IDNews=4327 - 03.04 .2008

http://www.metro.sp.gov.br/expansao/sumario/ppp/ppp.shtml - 06.04.2008

http://www.metro.sp.gov.br/empresa/numeros/indicadores/indicadores.shtml\#demanda -

06.04.2008

http://www.workpedia.com.br/sub\%FArbio.html - 08.04.2008

http://elt0n.wordpress.com/2007/02/12/maquete-da-futura-ponte-sobre-o-rio-pinheiros-sp/ 08.04 .08

http://www.prefeitura.sp.gov.br/portal/a_cidade/noticias/index.php?p=20495 - 08.04.2008

http://www.nossasaopaulo.org.br/portal/node/225 - 08.04.2008 
http://www.prefeitura.sp.gov.br/portal/a_cidade/noticias/index.php?p=17351 - 08.04.2008 http://portal.prefeitura.sp.gov.br/secretarias/planejamento/plano_diretor/0004/portal/secretaria s/planejamento/plano_diretor/titulo3/0006 - 10.04.2008

http://www.detran.sp.gov.br/frota/frota_jan.asp - 12.04.2008

http://www.metro.sp.gov.br/expansao/rede_essencial/rede_essencial_06.shtml - 18.06.2008

http://lume.fau.usp.br/tikiwiki/tiki-index.php?page=São\%20Paulo\%20Metrópole\#attachments $-18.06 .2008$

http://www.cptm.sp.gov.br/E_IMAGES/geral/Mapa_popup.asp - 20.06.2008

http://www.metro.sp.gov.br/expansao/rede_essencial/rede_essencial_05.shtml - 20.06.2008

http://www.cetsp.com.br/internew/informativo/pico/reesinte.gif - 22.06.2008

http://www.vitruvius.com.br/arquitextos/arq000/imagens/452_06.jpg - 22.06.2008

http://www.vitruvius.com.br/arquitextos/arq000/imagens/452_07.jpg - 22.06.2008

http://www.urbanistas.com.br/sp/wp-content/uploads/sampaist/estaiada1.jpg - 22.06.2008

http://elt0n.files.wordpress.com/2007/02/image004.jpg - 22.06.2008

http://www.emtu.sp.gov.br/tiradentes/imagens/tracado.jpg - 22.06.2008

http://g1.globo.com/Noticias/SaoPaulo/foto/0,6242909,00.jpg - 22.06.2008

http://www.daimlerchrysler.com.br/noticias/Abril/Expresso_Tiradentes/imagens/Expresso_Ti

radentes_03.jpg - 22.06.2008

http://www.sampaonline.com.br/postais/estacaoberrini.jpg - 24.06.2008 
Apêndice A 

Tabela 31 - Região Metropolitana de São Paulo - Sub- Regiões e Municípios da Vínculos Empregatícios por Setor - 2005

\begin{tabular}{|c|c|c|c|c|c|c|c|c|c|c|c|}
\hline $\begin{array}{l}\text { MUNICÍPI } \\
\text { OS E } \\
\text { SUB- } \\
\text { REGIÕES }\end{array}$ & $\begin{array}{l}\text { Total de } \\
\text { Vínculos }\end{array}$ & $\begin{array}{c}\text { Vínculos na } \\
\text { Agropecuária }\end{array}$ & $\begin{array}{l}\text { Participação dos } \\
\text { vínculos na } \\
\text { Agropecuária no } \\
\text { total dos } \\
\text { vínculos do } \\
\text { município }(\%)\end{array}$ & $\begin{array}{l}\text { Vínculos na } \\
\text { Indústria }\end{array}$ & $\begin{array}{c}\text { Participação } \\
\text { dos vínculos } \\
\text { na Indústria } \\
\text { no total dos } \\
\text { vínculos do } \\
\text { município (\%) }\end{array}$ & $\begin{array}{c}\text { Vínculos } \\
\text { no } \\
\text { Comércio }\end{array}$ & $\begin{array}{c}\text { Participação } \\
\text { dos vínculos } \\
\text { no Comércio } \\
\text { no total dos } \\
\text { vínculos do } \\
\text { município } \\
(\%)\end{array}$ & $\begin{array}{c}\text { Vínculos } \\
\text { nos } \\
\text { Serviços }\end{array}$ & $\begin{array}{c}\text { Participação } \\
\text { dos vínculos } \\
\text { nos Serviços no } \\
\text { total dos } \\
\text { vínculos do } \\
\text { município (\%) }\end{array}$ & $\begin{array}{c}\text { Vínculos } \\
\text { na } \\
\text { Construção } \\
\text { Civil }\end{array}$ & $\begin{array}{c}\text { Participação } \\
\text { dos vínculos } \\
\text { na } \\
\text { Construção } \\
\text { Civil no total } \\
\text { dos vínculos } \\
(\%)\end{array}$ \\
\hline CENTRO & 3.684.599 & 3.954 & & 521.237 & & 641.834 & & 2.374.400 & & 143.174 & \\
\hline São Paulo & 3.684 .599 & 3.954 & 0,11 & 521.237 & 14,15 & 641.834 & 17,42 & 2.374 .400 & 64,44 & 143.174 & 3,89 \\
\hline OESTE & 467.968 & 941 & & 105.135 & & 83.140 & & 266.521 & & 13.231 & \\
\hline Barueri & 173.559 & 143 & 0,08 & 31.640 & 18,23 & 25.716 & 14,82 & 111.827 & 64,43 & 4.233 & 2,44 \\
\hline Carapicuíba & 28.782 & 13 & 0,05 & 5.008 & 17,40 & 6.038 & 20,98 & 16.730 & 58,13 & 993 & 3,45 \\
\hline Cotia & 48.957 & 320 & 0,65 & 15.299 & 31,25 & 11.862 & 24,23 & 19.981 & 40,81 & 1.495 & 3,05 \\
\hline Itapevi & 17.195 & 14 & 0,08 & 4.881 & 28,39 & 3.175 & 18,46 & 8.358 & 48,61 & 767 & 4,46 \\
\hline Jandira & 11.930 & - & - & 5.406 & 45,31 & 1.708 & 14,32 & 4.303 & 36,07 & 513 & 4,30 \\
\hline Osasco & 118.645 & 233 & 0,20 & 29.133 & 24,55 & 25.268 & 21,30 & 61.348 & 51,71 & 2.663 & 2,24 \\
\hline $\begin{array}{l}\text { Pirapora do } \\
\text { Bom Jesus }\end{array}$ & 3.338 & 9 & 0,27 & 657 & 19,68 & 288 & 8,63 & 2.359 & 70,67 & 25 & 0,75 \\
\hline $\begin{array}{c}\text { Santana do } \\
\text { Parnaíba }\end{array}$ & 56.948 & 65 & 0,11 & 10.105 & 17,74 & 7.617 & 13,38 & 37.929 & 66,60 & 1.232 & 2,16 \\
\hline $\begin{array}{l}\text { Vargem } \\
\text { Grande } \\
\text { Paulista }\end{array}$ & 8.614 & 144 & 1,67 & 3.006 & 34,90 & 1.468 & 17,04 & 3.686 & 42,79 & 310 & 3,60 \\
\hline SUDOESTE & 118.066 & 379 & & 28.722 & & 21.692 & & 64.463 & & 2.810 & \\
\hline Embu & 34.680 & 77 & 0,22 & 8.420 & 24,28 & 4.289 & 12,37 & 21.352 & 61,57 & 542 & 1,56 \\
\hline $\begin{array}{l}\text { Embu- } \\
\text { Guaçu }\end{array}$ & 6.623 & 66 & 1,00 & 3.321 & 50,14 & 1.234 & 18,63 & 1.904 & 28,75 & 98 & 1,48 \\
\hline $\begin{array}{c}\text { Itapecerica } \\
\text { da Serra }\end{array}$ & 18.939 & 92 & 0,49 & 3.282 & 17,33 & 6.289 & 33,21 & 8.818 & 46,56 & 458 & 2,42 \\
\hline Juquitiba & 6.635 & 70 & 1,06 & 475 & 7,16 & 910 & 13,72 & 4.958 & 74,72 & 222 & 3,35 \\
\hline
\end{tabular}




\begin{tabular}{|c|c|c|c|c|c|c|c|c|c|c|c|}
\hline $\begin{array}{l}\text { MUNICÍPI } \\
\text { OS E } \\
\text { SUB- } \\
\text { REGIÕES }\end{array}$ & $\begin{array}{l}\text { Total de } \\
\text { Vínculos }\end{array}$ & $\begin{array}{l}\text { Vínculos na } \\
\text { Agropecuária }\end{array}$ & $\begin{array}{l}\text { Participação dos } \\
\text { vínculos na } \\
\text { Agropecuária no } \\
\text { total dos } \\
\text { vínculos do } \\
\text { município }(\%)\end{array}$ & $\begin{array}{l}\text { Vínculos na } \\
\text { Indústria }\end{array}$ & $\begin{array}{l}\text { Participação } \\
\text { dos vínculos } \\
\text { na Indústria } \\
\text { no total dos } \\
\text { vínculos do } \\
\text { município }(\%)\end{array}$ & $\begin{array}{l}\text { Vínculos } \\
\text { no } \\
\text { Comércio }\end{array}$ & $\begin{array}{c}\text { Participação } \\
\text { dos vínculos } \\
\text { no Comércio } \\
\text { no total dos } \\
\text { vínculos do } \\
\text { município } \\
(\%)\end{array}$ & $\begin{array}{l}\text { Vínculos } \\
\text { nos } \\
\text { Serviços }\end{array}$ & $\begin{array}{c}\text { Participação } \\
\text { dos vínculos } \\
\text { nos Serviços no } \\
\text { total dos } \\
\text { vínculos do } \\
\text { município (\%) }\end{array}$ & $\begin{array}{l}\text { Vínculos } \\
\text { na } \\
\text { Construção } \\
\text { Civil }\end{array}$ & $\begin{array}{c}\text { Participação } \\
\text { dos vínculos } \\
\text { na } \\
\text { Construção } \\
\text { Civil no total } \\
\text { dos vínculos } \\
(\%)\end{array}$ \\
\hline $\begin{array}{c}\text { São } \\
\text { Lourenço da } \\
\text { Serra } \\
\end{array}$ & 10.002 & 65 & 0,65 & 655 & 6,55 & 1.284 & 12,84 & 7.921 & 79,19 & 77 & 0,77 \\
\hline $\begin{array}{l}\text { Taboão da } \\
\text { Serra } \\
\end{array}$ & 41.187 & 9 & 0,02 & 12.569 & 30,52 & 7.686 & 18,66 & 19.510 & 47,37 & 1.413 & 3,43 \\
\hline SUDESTE & 624.536 & 151 & & 227.927 & & 99.696 & & 279.957 & & 16.805 & \\
\hline Diadema & 89.059 & 4 & 0,00 & 52.569 & 59,03 & 12.097 & 13,58 & 22.360 & 25,11 & 2.029 & 2,28 \\
\hline Mauá & 46.101 & 14 & 0,03 & 21.955 & 47,62 & 9.082 & 19,70 & 14.127 & 30,64 & 923 & 2,00 \\
\hline $\begin{array}{c}\text { Ribeirão } \\
\text { Pires } \\
\end{array}$ & 19.009 & 21 & 0,11 & 6.612 & 34,78 & 2.961 & 15,58 & 9.124 & 48,00 & 291 & 1,53 \\
\hline $\begin{array}{c}\text { Rio Grande } \\
\text { da Serra } \\
\end{array}$ & 2.993 & 2 & 0,07 & 1.192 & 39,83 & 266 & 8,89 & 1.173 & 39,19 & 360 & 12,03 \\
\hline Santo André & 142.001 & 38 & 0,03 & 34.161 & 24,06 & 30.605 & 21,55 & 73.272 & 51,60 & 3.925 & 2,76 \\
\hline $\begin{array}{c}\text { São } \\
\text { Bernardo do } \\
\text { Campo } \\
\end{array}$ & 221.219 & 69 & 0,03 & 92.251 & 41,70 & 30.421 & 13,75 & 95.143 & 43,01 & 3.335 & 1,51 \\
\hline $\begin{array}{c}\text { São Caetano } \\
\text { do Sul } \\
\end{array}$ & 104.154 & 3 & 0,00 & 19.187 & 18,42 & 14.264 & 13,70 & 64.758 & 62,18 & 5.942 & 5,71 \\
\hline LESTE & 191.548 & 5.054 & & 61.844 & & 34.979 & & 82.343 & & 7.338 & \\
\hline $\begin{array}{c}\text { Biritiba } \\
\text { Mirim }\end{array}$ & 2.779 & 1.205 & 43,36 & 194 & 6,98 & 580 & 20,87 & 800 & 28,79 & - & - \\
\hline $\begin{array}{c}\text { Ferraz de } \\
\text { Vasconcelos }\end{array}$ & 12.933 & - & - & 7.308 & 56,51 & 1.932 & 14,94 & 3.550 & 27,45 & 143 & 1,11 \\
\hline Guararema & 4.384 & 394 & 8,99 & 1.403 & 32,00 & 852 & 19,43 & 1.230 & 28,06 & 505 & 11,52 \\
\hline $\begin{array}{c}\text { Itaquaque } \\
\text { cetuba }\end{array}$ & 29.154 & 84 & 0,29 & 14.188 & 48,67 & 5.575 & 19,12 & 9.135 & 31,33 & 172 & 0,59 \\
\hline $\begin{array}{l}\text { Mogi das } \\
\text { Cruzes }\end{array}$ & 60.736 & 2.223 & 3,66 & 14.571 & 23,99 & 13.993 & 23,04 & 26.611 & 43,81 & 3.338 & 5,50 \\
\hline Poá & 41.434 & 20 & 0,05 & 5.878 & 14,19 & 3.974 & 9,59 & 29.170 & 70,40 & 2.392 & $\begin{array}{c}5,77 \\
\text { continua }\end{array}$ \\
\hline
\end{tabular}




\begin{tabular}{|c|c|c|c|c|c|c|c|c|c|c|c|}
\hline $\begin{array}{l}\text { MUNICÍPI } \\
\text { OS E } \\
\text { SUB- } \\
\text { REGIÕES }\end{array}$ & $\begin{array}{l}\text { Total de } \\
\text { Vínculos }\end{array}$ & $\begin{array}{c}\text { Vínculos na } \\
\text { Agropecuária }\end{array}$ & $\begin{array}{c}\text { Participação dos } \\
\text { vínculos na } \\
\text { Agropecuária no } \\
\text { total dos } \\
\text { vínculos do } \\
\text { município (\%) }\end{array}$ & $\begin{array}{l}\text { Vínculos na } \\
\text { Indústria }\end{array}$ & \begin{tabular}{|c|} 
Participação \\
dos vínculos \\
na Indústria \\
no total dos \\
vínculos do \\
município (\%)
\end{tabular} & $\begin{array}{c}\text { Vínculos } \\
\text { no } \\
\text { Comércio }\end{array}$ & $\begin{array}{l}\text { Participação } \\
\text { dos vínculos } \\
\text { no Comércio } \\
\text { no total dos } \\
\text { vínculos do } \\
\text { município } \\
\text { (\%) }\end{array}$ & $\begin{array}{l}\text { Vínculos } \\
\text { nos } \\
\text { Serviços }\end{array}$ & $\begin{array}{c}\text { Participação } \\
\text { dos vínculos } \\
\text { nos Serviços no } \\
\text { total dos } \\
\text { vínculos do } \\
\text { município (\%) }\end{array}$ & $\begin{array}{c}\text { Vínculos } \\
\text { na } \\
\text { Construção } \\
\text { Civil }\end{array}$ & $\begin{array}{c}\text { Participação } \\
\text { dos vínculos } \\
\text { na } \\
\text { Construção } \\
\text { Civil no total } \\
\text { dos vínculos } \\
\text { (\%) }\end{array}$ \\
\hline Salesópolis & 1.771 & 432 & 24,39 & 41 & 2,32 & 410 & 23,15 & 869 & 49,07 & 19 & 1,07 \\
\hline Suzano & 38.357 & 686 & 1,79 & 18.261 & 47,61 & 7.663 & 19,98 & 10.978 & 28,62 & 769 & 2,00 \\
\hline$\underset{E}{\text { NORDEST }}$ & 259.321 & 678 & & 105.980 & & 46.557 & & 99.285 & & 6.821 & \\
\hline Arujá & 13.245 & 146 & 1,10 & 6.151 & 46,44 & 1.983 & 14,97 & 3.905 & 29,48 & 1.060 & 8,00 \\
\hline Guarulhos & 237.914 & 114 & 0,05 & 97.355 & 40,92 & 43.413 & 18,25 & 91.400 & 38,42 & 5.632 & 2,27 \\
\hline Santa Isabel & 8.162 & 418 & 5,12 & 2.474 & 30,31 & 1.161 & 14,22 & 3.980 & 48,76 & 129 & 1,58 \\
\hline NORTE & 80.623 & 113 & & 2.274 & & 11.788 & & 44.142 & & 2.306 & \\
\hline Caieiras & 13.698 & 7 & 0,05 & 5.918 & 43,20 & 2.453 & 17,91 & 4.285 & 31,28 & 1.035 & 7,56 \\
\hline Cajamar & 40.568 & 50 & 0,12 & 10.737 & 26,47 & 2.306 & 5,68 & 27.023 & 66,61 & 452 & 1,11 \\
\hline $\begin{array}{l}\text { Francisco } \\
\text { Morato }\end{array}$ & 5.894 & - & - & 219 & 3,72 & 1.821 & 30,90 & 3.744 & 63,52 & 110 & 1,87 \\
\hline $\begin{array}{c}\text { Franco da } \\
\text { Rocha }\end{array}$ & 9.496 & 13 & 0,14 & 2.985 & 31,43 & 2.517 & 26,51 & 3.651 & 38,45 & 330 & 3,48 \\
\hline Mairiporã & 10.967 & 43 & 0,39 & 2.415 & 22,02 & 2.691 & 24,54 & 5.439 & 49,59 & 379 & 3,46 \\
\hline RMSP & 5.426 .661 & 11.260 & 0,21 & 1.073 .119 & 19,77 & 939.686 & 17,32 & 3.211.111 & 59,17 & 191.485 & $\mathbf{3 , 5 3}$ \\
\hline
\end{tabular}

Fonte: Fundação Seade - Informações dos Municípios Paulistas - Organização da autora 
